\title{
GREEK BIRDS
}




$$
\begin{array}{r}
3^{2} 62 \\
18
\end{array}
$$




$$
2-6
$$



GLOSSARY OF GREEK BIRDS 


\section{Eondon}

HENRY FROWDE

Oxford University Press Warehouse Amen Corner, E.C.

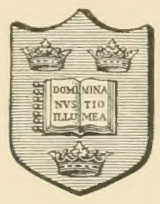

Mew Dork

MACMILLAN \& Co., 66 FIFTH AVENUE 



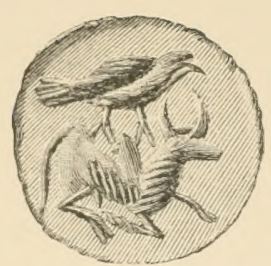

FiG. I.

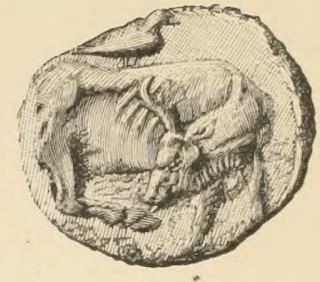

Fig. 2.

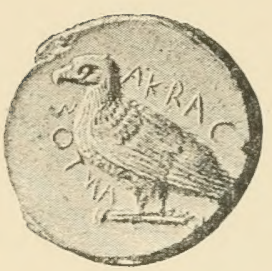

FIG. 3 .

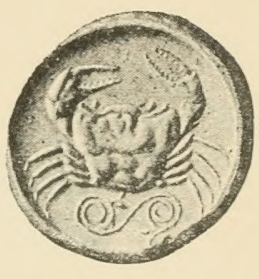

Fig. 4 .

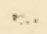

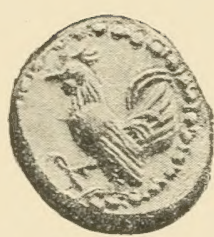

FIG. 5 .

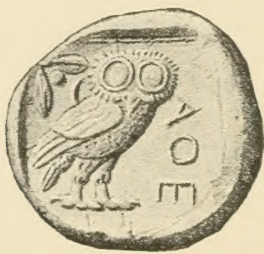

FIG. 6. 


\section{ILLUSTRATIONS.}

Fig. I. AN ARchaic Gem, PRobably PARThian (Paris Coll., 1264, 2 ; cf. Imhoof-Blumer und Keller, Pl. xxi, 14).

Fig. 2. Tetradrachm of Eretria (B. M. Cat., Central Gr., Pl. xxiii, I).

Both these subjects represent a bird on a bull's (or cow's) back, in my opinion the pleiad in relation to the sign Taurus (vide infra, p. 31). In Fig. 2 the bull is turning round, to symbolize the tropic ; in Fig. $I$ it is in the conventional kneeling attitude of the constellation Taurus, as Aratus describes it (Ph. 5I 7) -

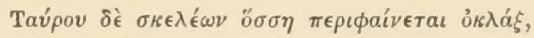

or in Cicero's translation-

'Atque genu flexo Taurus connititur ingens.'

Compare also, among other kindred types, the coins of Paphos, showing a bull with the winged solar disc on or over his back (Rev. Num., r883, p. 355 ; Head, H. Numorum, p. 624 , \&c.).

Figs. 3, 4. A COIN of Agrigentum, with EAgle AND CRAB (Head, H. Numorum, p. 105). Aquila, which is closely associated with Capricorn (cf. Manil. i. 624), sets as Cancer rises: it may figure, therefore, as a solstitial sign.

Fig. 5. Coin of Himera, Before B.C. 842 , With THE Cock (Head, H. Numorum, p. 125; cf. infra, p. 26).

Fig. 6. Athenian Tetradrachm, with Owl, Olive-twig, and CRESCENT Moon (Head, p. 3i2; cf. infra, p. 46).

Fig. 7 (on title). Decadrachm of Agrigentum. Cf. Aesch. Agam. I IO-120 (vide infra, p. 8). The reverse of the coin shows Cancer associated with the solar Quadriga. 



\section{A GLOSSARY OF}

\section{GREEK BIRDS}

\section{I'ARCY WENTWORTH THOMPSON}

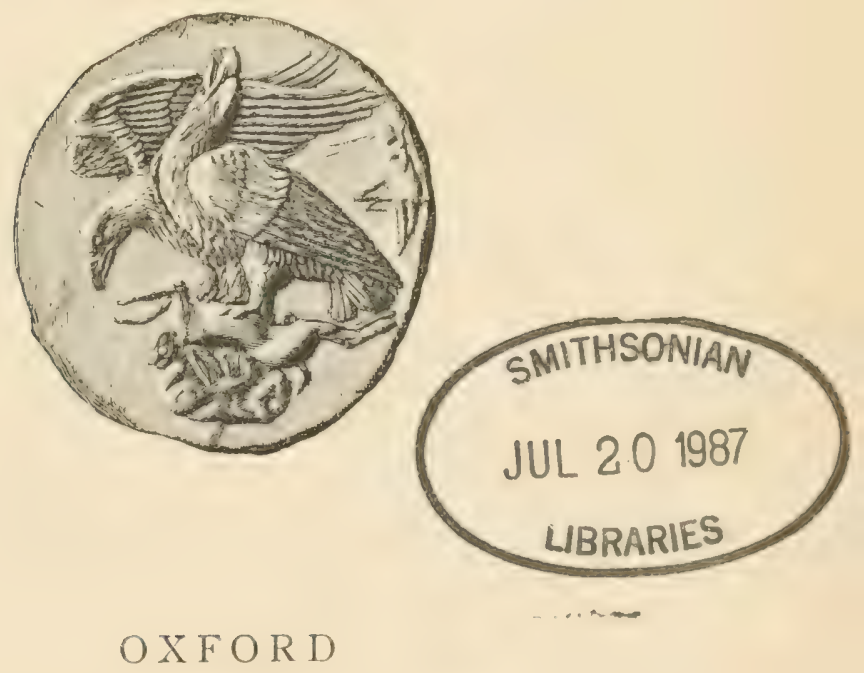

, AT THE CLARENDON PRESS 


\section{Oxford}

PRINTED AT THE CLARENDON PRESS HY HORACE HART, PRINTER TO THE UNIVERSITY 


\section{$T \Omega|\sqcap A T P|$}

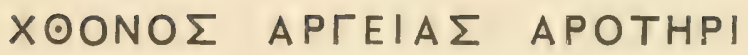

KAPПON $\Omega N$ ПOTE EЕПEIPE

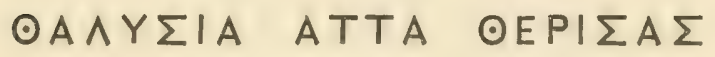

$A \sqcap O \Delta I \Delta \Omega M I$ 
RES ARDUA, VETUSTIS NOVITATEM DARE, NOVIS AUCTORITATEM, OBSOLETIS NITOREM, OBSCURIS LUCEM, FASTIDITIS GRATIAM, DUBIIS FIDEM.--PLINY.

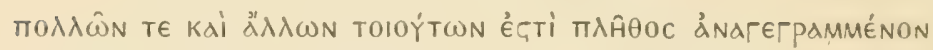

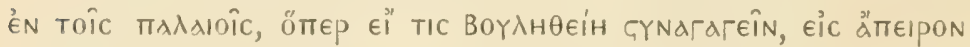

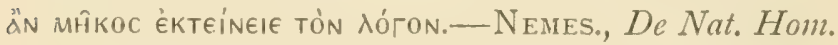




\section{PREFACE}

THIS book contains materials for research in greater measure than it presents the results of it; and, accordingly; it is not my purpose to preface it with an extended summary of the many wide gencralizations to which the asscmblage of fact and legend here recorded may seem to lead. This book indeed includes only a small part of the notes I have gathered together since I began years ago, as an undergraduate, ignorant of the difficulties of the task, to prepare the way for a new edition of the Natural History of the Philosopher. Three points, however, in my treatment of the present subject deserve brief explanation here.

Instead of succeeding in the attempt to identify a greater number of species than other naturalist-commentators, dealing chicfly with the Aristotelian birds, have done, I have on the contrary ventured to identify a great many less. This limitation on my part is chicfly due to the circumstance that I have not ventured to use for purposes of identification a large class of statements on which others have more or less confidently relied. A single instance may serve to indicate the statements to which I allude. In the Historia Animalium (especially in the Ninth Book, great part of which seems to me to differ in character and probably in authorship from all but a few isolated passages of the rest of the work), in the works of such later writers as Pliny, Aelian and Phile, and scattered here and there in earlier literary allusions, we find many instances recorded of supposed hostility or friendship between different animals. When we are told, 
for example, that "uvos is hostile to ikar Ois and to the Horse, that $\pi \iota \pi \omega$ is hostile to $\pi \circ \iota \kappa \iota \lambda i s$, to $\kappa o \rho v \delta \omega v$, to $\chi \lambda \omega \rho \in u^{\prime} s$ and to Epwosos, that one Hawk is hostile to the Raven and another to the Dove, and one Eagle to the Goose or to the Swan, we try at first to use these statements as best we can in unravelling the probable identification of the respective species. But when we find, for instance, among the rest that the Owl is hostile to the Crow, and when we recognize in that statement the ancient Eastern fable of the War of the Owls and Crows, we are tempted to reject the whole mass of such statements and to refuse them. entry into the domain of Zoological Scicnce. While former commentators have, with greater or less caution, rejected many fables, they have often rashly accepted many others. And I fear for my part that $I$ in turn, while rejecting a much greater number, have perhaps also erred in ascribing a fabulous or mystical meaning to too few.

For many such statements, and for others equally unintelligible in the terms of Natural History, I offer a novel and, at first sight, a somewhat startling explanation: to wit, that very many of them deserve not a zoological but an astronomical interpretation.

In the spring of $x 89+$ I read to the Royal Society of Edinburgh a paper (which I have not yet printed) on 'Bird and Beast in Ancient Symbolism'. In that essay I sought to demonstrate the astronomic symbolism of certain ancicnt monuments, especially of the great bas-relief of $\mathrm{Cy}$ bele in the Hermitage Muscum ${ }^{1}$; secondly, of the beast and birdemblems of classical coinage ${ }^{2}$; and lastly, of certain fables or myths of the philosophers and poets.

2 This monument, a figure of which is accessible in Miss J. E. Harrison's Aythology of Ancient Athens, represents, according to my view, the ancient tropics of Leo and Aquarius, with Taurus and Leo in symbolic combat in the frieze below.

2 The identical theory, in so far as it applies to numismatic emblems, was promulgated a few months afterwards by M. Jean Svoronos in a learned and scholarly paper, to be found in the Bulletin de Correspondance Hellinique for I894; but the theory was not so novel as M. Svoronos and I supposed it to be. In connexion with coins or gems, it is explicitly and admirably stated by Gorius, De 
Many illustrations of this theory of mine will be found in the pages of this Glossary ${ }^{1}$. Suffice it to say here, in bricfest illustration, that the Farle which attacks the Swan and is in turn defeated by it, is, according to my view, the constellation Aquila, which rises in the East immediately after Cygnus, but, setting in the West, goes down a little while before that more northern constellation; that Haliactus and Ciris are the Sun and Moon in opposition, which rise and set alternately, like the opposite constellations of Scorpio and Orion with which the poet compares them.

Among many other opinions and testimonies to the same effect, let us listen to the words of a Father of the Church : ' The ancients believed that the lesends about Osiris and Isis, and all other mythological fables [of a kindred sort], have reference either to the Stars, their configuration, their risings and their settings, or to the wax and wane of the Moon, or to the cycle of the Sun, or to the diurnal and nocti-diurnal hemispheres ${ }^{2}$ '

The proof and the acceptance of such a theory as this are linked with considerations far-reaching in their interest. The theory has its bearing on our new knowledge of the orientation of temple-walls; it helps to cxplain what Quintilian meant when he said that acquaintance with Astronomy was essential to an understanding of the Pocts; the wide-spread astronomic knowledge which it presupposes may account for the singular interest in and admiration of the didactic poem of Aratus, the poem translated by Germanicus and Cicero and quoted by St. Paul; and the whole hypothesis points to a broad distinction between two great orders of Myth.

Myths are spontaneous or literary, natural or artificial. Some come to us from the Childhood of Religion and the Childhood of the World; dream-pictures as it were from the half-opening eyes of awakening intelligence. archaic traces of the thoughts and ways of primitive and simple men; these

Gemmis Astriferis, 1750 ; and a kindred but exaggerated development, in regard to legrend, of the same hypothesis forms the method of Dupuis.

${ }^{1}$ Cf. pp. 8, 28, 31, 63, 107, 12 1, 132, 192, \&c.

${ }^{2}$ Euseb. Pr. Ev, iii. c. 4. 
are the folk-lore tales and customs that are presented to us by the school of Mannhardt. But others, and these for the most part are astronomic myths, belonging to a relatively later age, were artificially invented of the wise, to adorn, preserve. or conceal their store of learning; they had their birth in cultured homes of decp religion, of treasured science, of exalted poetry. Both orders of Myth come to us with the glamour of antiquity, and each has for us a diverse but perennial interest:

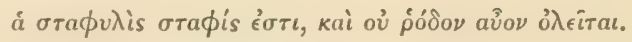

The distinction between these two orders of Myth was pointed out long ago by an ancient critic $^{1}$; he drew the distinction clearly, but the tales of folk-lore, puerile in his eyes, found no echo of sympathy in the old scholar's heart. IVe, on the other hand, have learned nowadays to say with the poet:

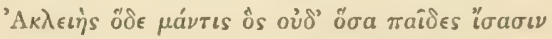
Oîं $\epsilon_{0}^{2}$

The great Signs of the Heavens are as old as our knowledge of the months and years, and about them poet-watchers of the stars wove an imperishable web of imagery. Of this kind are the Voyage in quest of the Golden Fleece ${ }^{3}$, and the Twelve Labours of the Hero-God ${ }^{4}$; and I have attempted to show how into the same fabric are woven tales of Aetos and Haliaetos, of Halcyon and Ciris, of Stymphalian perhaps also

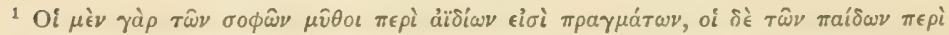

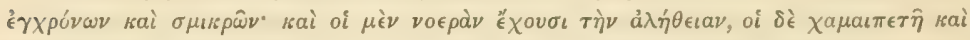

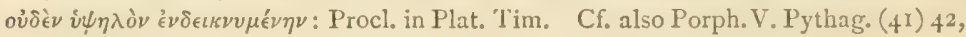
Iambl. V. Pythag. 23, and other commentators on the Pythagorean Symbols.

2 Apoll. Rh. iii. 930.

3 'Auf die Argonauten hatte ich immer ein Zutrauen.... Es liegen herrliche Motive darin, und gewiss liessen sich noch manche daraus entwickeln': Goethe to Schiller, Letter 496 .

t An English scholar very recently propounded the view that the Hind with the Golden Horns was a reindeer !-

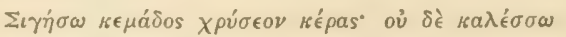

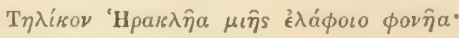

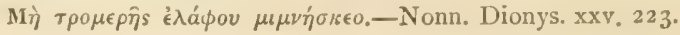


of Diomedian and Memnonian Birds, of Pleiad-Doves and Singing Swans. All these come to us from the Land beyond the Rainbow: they are divellers in Fairyland.

Akin to this enterprise of tracing allusions to the ancient science of the Stars in art and legend, in neglected phrases and statements, of the Greeks, is the effort I have made to ascribe to non-Aryan languages names used by Ilellenic writers for many legendary as well as for many real Birds. The Master told his pupils that the gods whom men worshipped under other names were, in the childhood of religion, the Sun, the Moon, and the Stars of Heaven, to which many barbarians still bowed down ${ }^{1}$; and he told them also that one who should seek to explain by Greek all the words of Greek should surely go astray, for that many words in daily use were borrowed from barbaric speech ${ }^{2}$.

The astronomic science that the ancients loved and understood, as do the wise men of China and Arabia to this day, was not the gift of Grece alone, but was the accumulated gain of ages of antecedent civilization by the River of Egypt and the Four Rivers of Chaldaea; and Eastern imagination veiled in mysterious allegory the ancient treasures of Eastern lore.

If the quest after non-Aryan words and the attempt to trace the esoteric meaning of fables to a science which had its origin on alien soil are to be justified, we must cease to believe in a gulf between the Greeks and their Eastern contemporaries and predecessors. That gulf, if gulf there was, was crossed again and again. It was crossed by the migrations of races, by the tramp of armics, by the sails of commerce; by the progress of religions. by the influence of art, by the humble footsteps of philosophers, secking wisdom like Dervish-pilgrims of the Eastern or Wandelnde Studenten of the Western world.

1 Plat. Cratyl., p. 397.

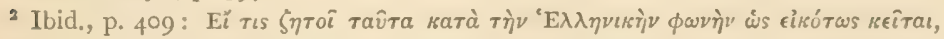

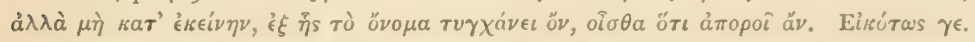
The doctrine of 'Loan-words' thus adumbrated in the Cratylus, is now, within certain limits, a commonplace of philology; but we do not know where the quest for such Loan-words may end. 
As the White Doves came from Babylon or the Meleagrian IBirds from the farther Nile, so over the sea and the islands came Eastern legends and Fastern names. And our Aryan studies must not blind us to the presence in an Aryan tongue of these immigrants from Scmitic and Egyptian specch, or from the nameless and forgotten language that was spoken by the gods.

D. W. T. 


\section{A \\ GLOSSARY OF GREEK BIRDS}

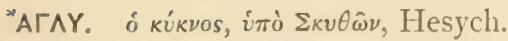

'Aro'p. cietós, kúrpııı, Hesych.

Bochart (Hieroz. II. c. xi, coll. 79, 80) shows good reason for supposing that ảerós here should read yépavos, and that ảyóp is merely Heb. רעม, a crane (Jerem. viii. 7; Is. xxxviii. 14). Cf. Lewysohn, Zool. d. 'Talmuds, p. 169.

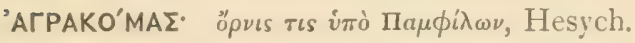

'ATPEY' $\Sigma$. An unknown bird. It is like a Blackbird, black, musical, and a mimic, Ael. viii. 24. The description is somewhat suggestive of the Indian Mynah, but it is in the main mystical. Vide S. v. katpeús.

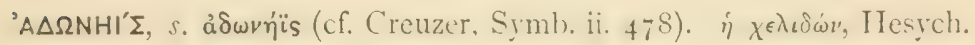

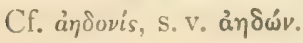

'AEI' $\Sigma K \Omega \Psi$, vide S. V. $\sigma K \omega \dot{\psi} \psi$.

'AE^^O' $\Sigma$, an unknown bird, Hesych.

'AEPOKO'PAE, vide S.V. Kópał.

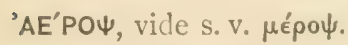

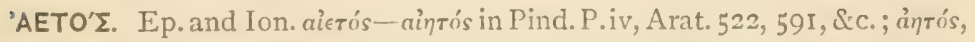
Arat. 315 ; aißerós, for aifetós, Hesych. Dim. détı̊єús, Ael.vii. 47, Aesop, Fab. I. a'erós is said to be 'the flyer,' 'the Bird,' from root af or vi,

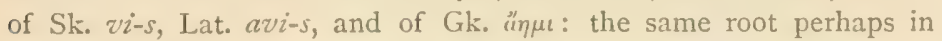

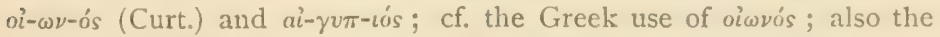

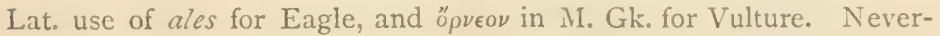
theless, the absence of Eagle-names similar to cietós in other Indo- 


\section{AETOE (continued)}

European languages is so striking, that I suspect for it a non-Aryan root.

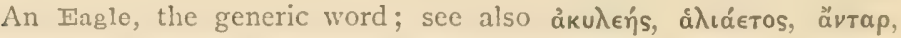

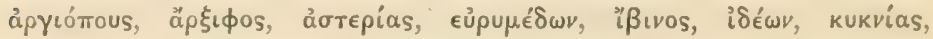

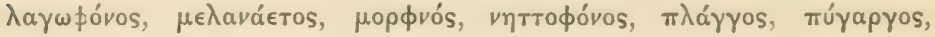
хрuбáєtos, \&c.: v. Arist. H. A. viii. 3, 592 b, ix. 32, 618 b, 619a; on the species of Eagles cf. Cuvier ad Plin. x. 3, ed. Grandsaigne, whose identifications, however, like those of Sundevall (Thierarten des Aristoteles, Stockholm, 1863, also in Swedish, K. Akad. Wetensk. Stockholm, I862), are in my opinion to be received with caution. Besides the Osprey, Pandion Haliaètus, and the Short-toed Eagle, Circaëtus gallicus, the following true Eagles are regular inhabitants of Greece, $A$. Chrysaetus, A. heliaca, A. naevia, A. Bonelli, A. pennata, and Haliaetus albicilla. Though occasional passages may be descriptive of the habits of one rather than another of these species, there is no evidence of any of these having been recognized as distinct: such names as å $\lambda \iota \iota^{\prime} \epsilon \tau o s, \mu \in \lambda a \nu$ átтos and $\lambda a \gamma \omega \phi$ óvos have a mystical or symbolic rather than a descriptive or specific meaning. On the confusion of the Eagles with the Vultures, vide infra. Eagles are common in Greece, though (Xen. Venat. v. 24) absent from many of the islands, for want of hills. On the Eagle in classical art and mythology cf. O. Keller, Thiere d. cl. Alterthums, pp. 236-276, 430-452.

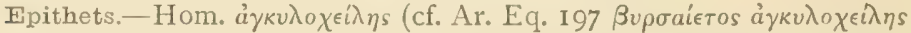

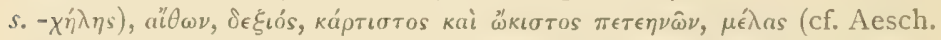

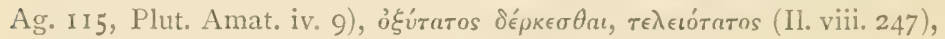

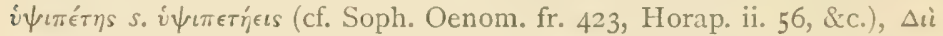

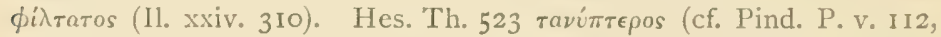
Il. xxiv. 317, Orphic. Lith. 124). Pind. P. i. 6, v. 48, Isthm. vi à $\rho$ òs

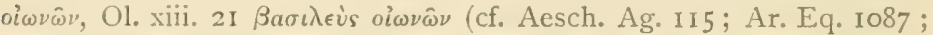
Ael. ix. 2; Nic. Ther. 448; Callim. Hymn. Jov. 68; Ovid, Met. iv. 362 ; the Eagle was an Egyptian symbol for the king, according to Horap. ii. 56, and was worshipped as a royal bird by the Thebans, Diod. Sic. i. 87,9$)$; a royal emblem also at Babylon, Philostr. Imagg. $386 \mathrm{~K}$.

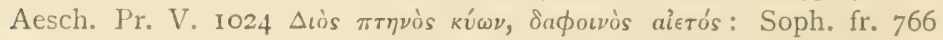

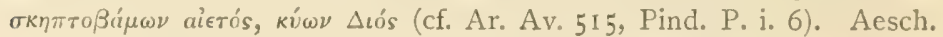

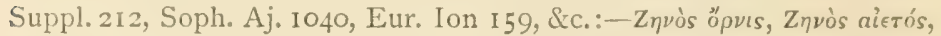

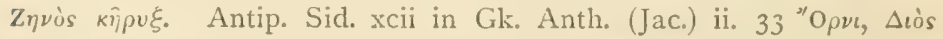

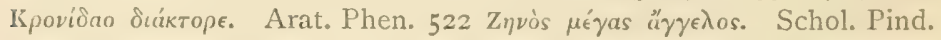

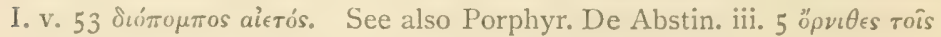

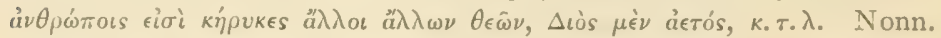

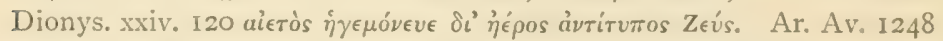

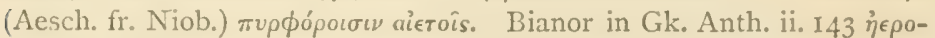

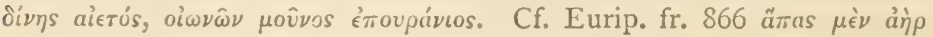


AETOE (continucd).

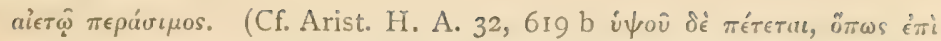

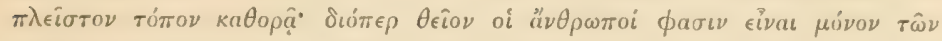

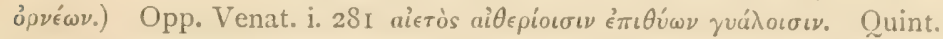

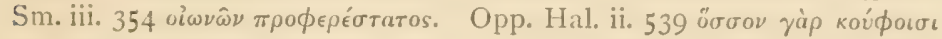

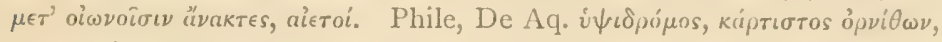

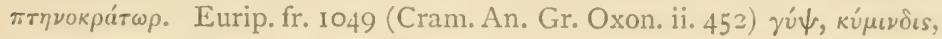

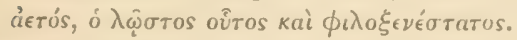

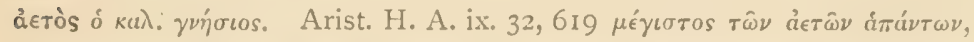

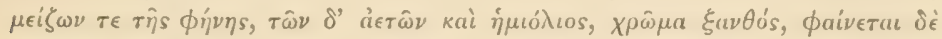
ỏ̀

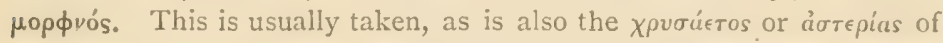
Acl. H. A. ii. 39, to mean the Golden Eagle, Aq. Chrysaetus (L.); the former birds are however said by both authors to be very rare, whereas the Golden Eagle is the commonest eagle in Greece (Heldreich). Aristotle's statement as to its size is modified by Pliny (H. N. x. 3, media magnitudine). The passage is obscure and mythical, as shown

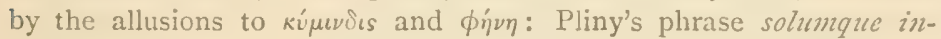
corruptae originis is a literal but perhaps incorrect translation of

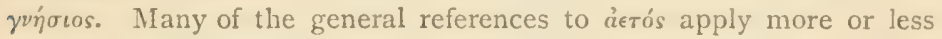
closely to Aq. Chrysaetus, e. g. Arist. H. A. ix. 32, 619, its nesting

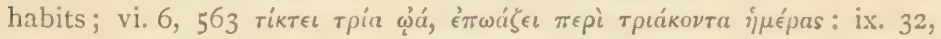

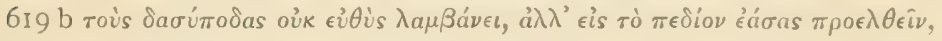
this last statement being, however, very obscure: Ael. ii. 39, \&c., \&c. On the other hand accounts of the capture of snakes and stories of

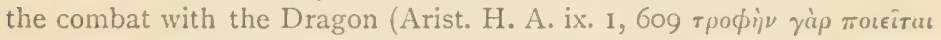

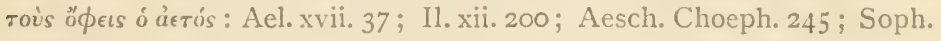
Antig. I10-126; Nonn. Dion. x1. 476; Nic. Theriac. 448; Aes. Fab. 120; cf.Virg. Aen. xi.751 ; Hor. Carm. iv. 4 ; Ovid, Met. iv. 712 ; Flav. Vopisc. De Aurel. iv), are based on the habits of Circaëtus gallicus, the Shorttoed Eagle, which feeds on reptiles, and partly also of the Lämmergeier. In Imhoof-Blumer and Keller's Thierbilder we have coins of Chalcis in Euboea showing an Eagle with the snake in its beak, and also (pl. v. 9) a similar coin of Cyrene in which the bird's head is evidently a Lämmergeier's.

The Vultures were frequently confused under the name cierós, e.g.

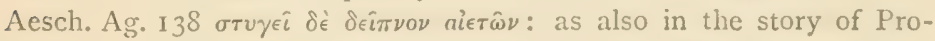
metheus, e.g. Hes. Th. 523; Aesch. Pr. V. 1022 ; Pr. Sol. ap. Cic. Q. Tusc. ii. Io; Apoll. Rh. ii. 1254, 1263, iii. 85 ; Lucian, Prom. 20 (i. 203); D. Deor. i. I (i. 205), \&rc., \&.c.; and as in the story of the death of Aeschylus, Ael. vii. 16, Plin. x. 3, Valer. Max. ix. 12. 2, Didyn. Chalc. ed. Ritter, I 845, pp. $84 \&$ c., Hesych. Onomast. c. I6, where the deтós was evidently a Lämmergeier, on whose propensity to feed on tortoises v. Tristram, Fauna of Palestine, p. 94, see also Ibis, 1859, p. I77 ; cf. Aes. 


\section{AETOE (continued).}

Fab. 419; Babr. 115. (On the mythical character of the Aeschylus legend cf. Teuffel, Rh. Mus. ix. 148, I854; Piccolomini, Sulla morte favolosa di Eschilo, Pisa, 1883; Keller, op. c. pp. 257, 444.)

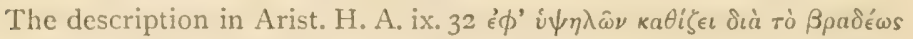

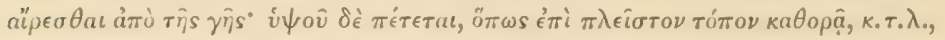

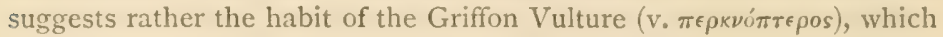
is also the 'Eagle' alluded to in like terms in Job xxxix. 28 ; cf. also Ael. ii. 26, Horap. i. II, ii. 56. The Griffon Vulture is the royal bird of the East, the standard of the Assyrian and Persian armies (Xen. Cyr. vii. I. 4, cf. Is. xlvi. II, Habakkuk i. 8 ; whence probably the Roman Eagle), and the Eagle-headed God Nisroch (2 Kings xix. 37) of the Assyrians (cf. Tristram, Fauna of Palestine, p. 95 ; see also Hammer, Hist. Osman. i. p. 50, Creuzer's Symbolik, iii. pp. 649, 756, \&c.). The crested Eagles of Assyrian sculpture (cf. Pocock's Descr. of the East, II. pl. xvi; Wood's Baalbec, pl. xxxiv), are merely a further development of the solar emblem, and it is unnecessary to suppose (as does Hogg, Ann. and Mag. N. H. (3) xiii. I864, p. 520) that they are copied from an actual crested species.

The Persians, reverencing the Eagle, admired the aquiline nose and

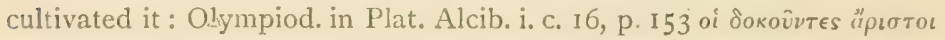

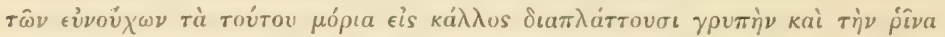

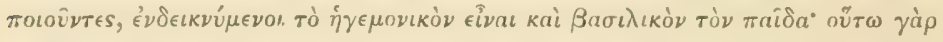

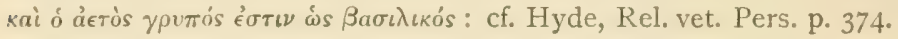

A fine description of the Eagle's flight in Apuleius, Florid. i.

Myth and legend.- The story of Prometheus, vide supra.

The story of Ganymede. Strato in Gk. Anth. iii. p. 82 ; Anon. ibid.

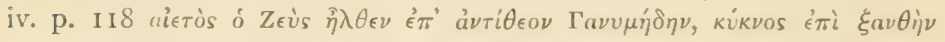

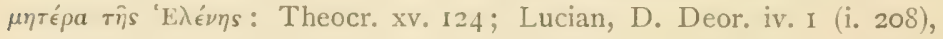
Hor. Car. iv. 4. The statue of Leochares, Plin. H. N. xxxiv. 19, 29. On coins of Chalcis, Dardanos, Ilia, \&c. The story referred to the constellation Aquila, Hygin. P. Astr. ii. 16, Germanic. Phen. 317, Manil. Astron. v. 486, \&c.

The story of Leda: the Swan pursued by an Eagle; Eurip. Hel. 17-22. The Eagle in combat with the Swan, freq., e.g. Il. xv. 692, Arist. ap. Ael. V. H. i. 14, Phile xv. 10, Statius Theb. iii. 524, viii. 675, ix. 858, \&c. On coins of Mallos in Cilicia, and Camarina (Eckhel, Doctr. Numm. i. I. 201, Imhoof-Blumer and Keller, pl. vi. I6, I7, Scc.).

The Eagle with Dolphin on coins of Sinope, and other towns, especially on the Black Sea and Hellespont, is taken by Keller as symbolic of the fish-trade (op. c. p. 262): the Dolphin here has also been referred to the Eastern emblem of Eros (cf. Weber, Hist. of Ind. Litcr. $1882, \mathrm{p} .257$ ), but is more probably simply the constellation 


\section{AETOE (continucd).}

adjacent to Aquila (cf. Manil. Astron. i. 353). See for other views, Welcker, Der Delphin und der Hymnus des Arion, Rhein. Mus. i. pp. 392-400, I 833 .

The myth of Nisus and Scylla or Ciris, Virgil (?) Ciris, Hygin. Fab. 198, Ovid, Met. viii. I46, \&c. (a Semitic solar myth, O. Keller, 1.c. p. 259); see also E. Siecke, De Niso et Scylla in aves mutatis, Berlin, I 884 , vide s. v. áגıáetos.

The transmigration of Agamemnon, Plato, Rep. x. p. 620; of King Periphas of Attica, Anton. Lib. Met. vi; Ov. Met. vii. 399 (cf. Th. Panofka, Zeus und Aegina, Berlin 1836); of King Merops of Cos, Anton. Lib. Met. xv. Cf. the ceremony at the consecration of a dead Emperor:

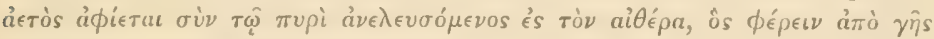

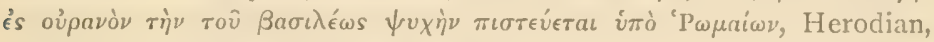
iv. 2. I I ; cf. Dio Cass. 1vi. 42, lxxiv. 5.

The Eagle as a portent ( $\dot{\alpha}_{0} \tau \epsilon \lambda \epsilon$ เótaros) in connexion with the founding of the Ptolemaic dynasty, Suid. s. v. Aáyos: of the Phrygian dynasty by Gordius, Arrian, Anab. ii. 3, Ael. xiii. I ; of the Persian by Achaemenes, Ael. xii. 21 ; with the birth of Alexander, Justinus xii. 16. 5.

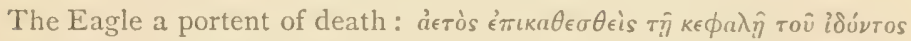

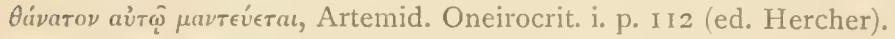

On the Eagle in augury cf. Il. viii. 247 , xii. 200 , Od. ii. $146, x x .242$, Aesch. Ag. II5, Ar. Vesp. 15, \&.c. : doubtless also referred to, though unnamed, in such passages as Orph. Lith. 45, Aesch. Sept. c. T. 24, Pr. V. 486: still more frequent in Latin, e.g. Liv. i. 24 ; Cic. De Divin. i. 47 , ii. 48 ; Sueton. Octav. 94, 96, 97 ; Valer. Max. i. 4. 6, Plut. Brutus xxxvii. \&c. See Hopf, Thierorakel, pp. 87 et seq.; Spanheim in Callim. Hymn. Jov. 69.

On Eagles in the Mithraic mysteries, Porphyr. De Abst. iv. I6. How the Etruscans understood the language of eagles, ibid. iii. 4.

An Eagle's nest with seven eggs (!), as a portent, Plut. Marius, xxxvi. An Eagle's nestling in symbolism and dream-prophecy, Horap. ii. 2 (cf. Leemans in loc.).

The mythical genealogy of the Eagle: Arist. De Mirab. 835 a, i. (6o)

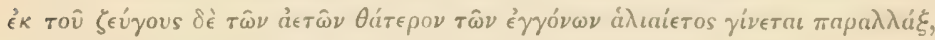

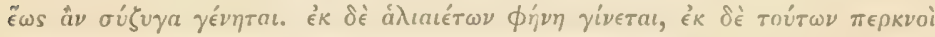

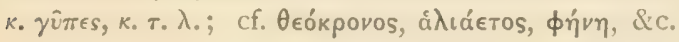

How фív rears its young, Arist. H. A. ix. 32, 619, Antig. Hist. Mirab. $4(52)$, cf. Plin. x. 3 .

How the Eagle feeds and defends its young, and is affectionate towards them, Ael, ii. 40, Opp. Ven. II 5, Arist. H. A. ix. 32, 6 Ig (cf.

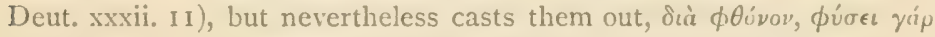

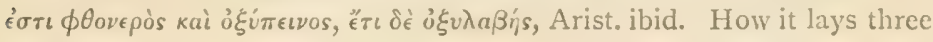




\section{AETOE (continued).}

eggs, hatches two, and rears one, Musaeus ap. Arist. vi. 6, 563, Plin.

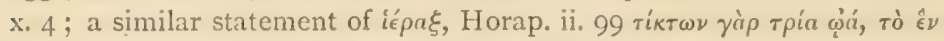

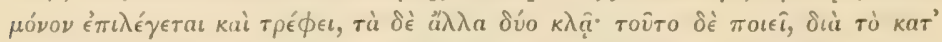

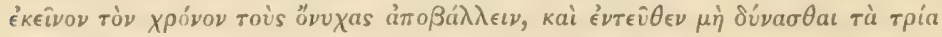

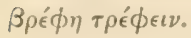

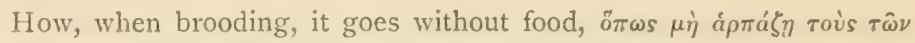

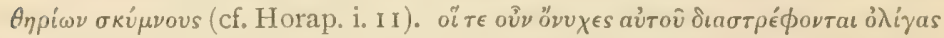

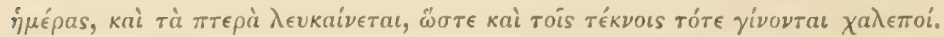

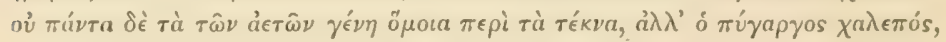

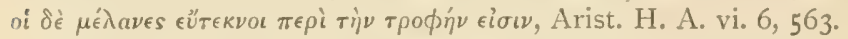

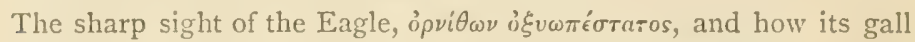
mingled with honey is an ointment for the eyes, Ael. i. 42 ; Plin. xxix. 38,

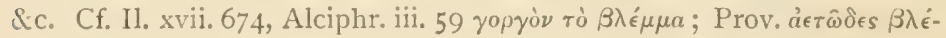
$\pi \epsilon \iota v$, Lucian Icarom. I4 (ii. 769), Hor. Sat. i. 3. 26, \&c. How the Eagle's offspring look straight at the sun, and the bastards, being by this test discovered, are cast out, Ael. ii. 26, cf. Arist. H. A. ix. 34, 620, Antig. Mirab. 46 (52), Lucan ix. 902, Lucian, Pisc. 46 (i. 613), Sil. Ital. x. 107, Petron. Sat. I 20, Claudian III. Cons. Hon. Praef. I2, Plin. x. (3) 4, Dion. De Avib. i. 3, Apul. Florid. i. 2, Basil. Hexaem. viii. 6. I 77, Eust. Hexaem. viii. 6. 952, S. August. Mor. Manich. xvi. 5o, Julian. Imp. Epp. I6 (386 C), 40 (418 d), Eunod. Ep. i. 18, id. Carm. ii. 150, Phile i. I4. Cf. Chaucer, P. of Fowles, 33I 'the royal egle ... that with his sharpe look perceth the sun.' On the Egyptian origin of this fable, see Keller, op. c. p. 268, and cf. Horap. i. 6, II. The Solar Myth is also oriental, and in the Rig-veda the sun is frequently compared to a Vulture or Eagle hovering in the air.

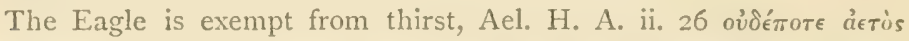

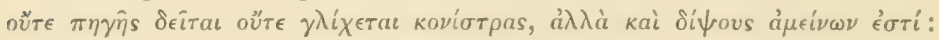
cf. Arist. H. A. viii. I 8, 60I b; but perishes of hunger (also an Egyptian

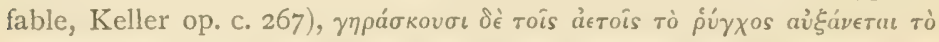

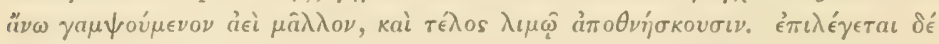

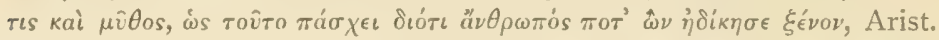
H. A. ix. 32, 6I9. Cf. Antig. 46 (52), Horap. ii. 96 (where the Eagle is said to be for that reason an Egyptian symbol for an old and starving man), Epiphan. ad Physiol. c. 6, Plin. x. I4.

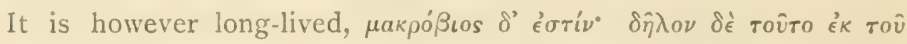

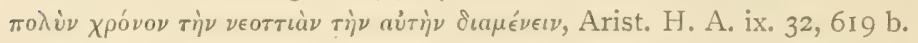

It fèeds on grass, Ael. ix. Io ( $\mu$ ó by бí $\mu$ фито, Ael. vi. 46, Phil. De An. Pr. 668, and in sickness eats tortoises as a remedy, Dion. De Av. i. 3.

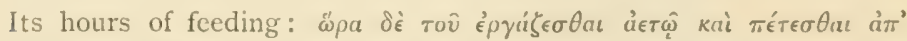

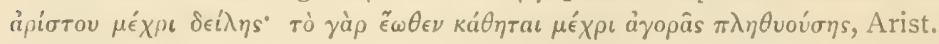
H. A. ix. 32,6 ig. 
AETOE (continued).

Its feathers are incorruptible, Ael. ix. 2, Plut. Q. Conv. i. 10, Plin. $x$. (3) 4 ; its right wing buried in the ground is an insurance against hail, Geopon. i. 14, 2.

How it walks with its toes turned in, to keep its claws sharp, Plut. De Curios. I2.

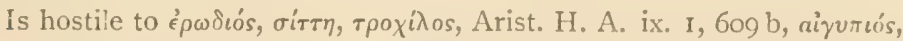

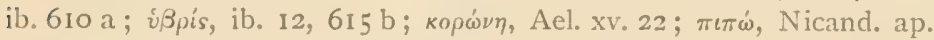

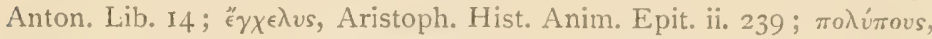
Ael. vii. I I, as well as to $\delta \rho \dot{i}^{\prime} \omega \nu$, Arist. ix. I, 609 (cf. Ael. ii. 26, Plut. Od. et Inv. iv. p. 650), and кúкvos, ib. I2, 6 5 b, by which last it is con-

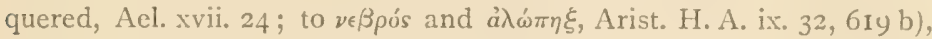

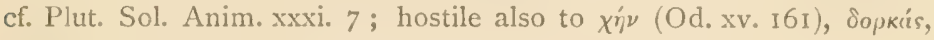

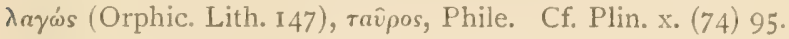

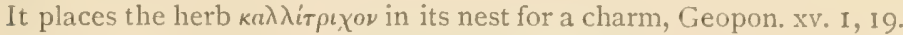
The Eagle a symbol of the Nile, Diod. Sic. i. 19. 2. Cf. Eustath. in

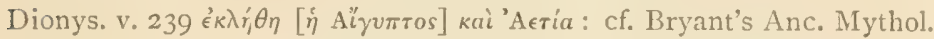
i. pp. 19, 378. A symbol of the year, Artemid. Oneirocr, ii. 20, as the Vulture is also said to be by Horap. i. II ; of elevation, Horap. i. 6 ; of the sun on the equator, Clem. Alex. Strom. v. 567. For the explanation of these hieroglyphs, into which the emblem of the Vulture enters as a phonetic element, see Lauth, Sitzungsber. Bay. Ak. I876, p. 8 r.

A king who lives remote from and disdainful of his people is pre-

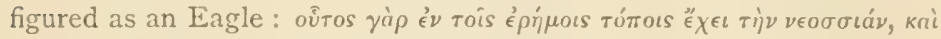

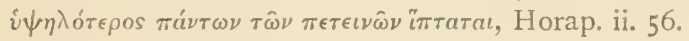

The white Eagle of Pythagoras, Iambl. V. Pyth. xxviii. I42, Ael. V. H. iv. 17, was probably a symbol for the town of Croton, on whose coins an eagle is displayed (cf. Brit. Mus. Cat. Coins, i. c. 20, also Creuzer, Symb. ii. 602, footnote). How Pythagoras lured an Eagle at Olympia, Iambl. V. Pyth. xiii. 62, Porph. V. Pyth. 25, Plut. Numa viii.

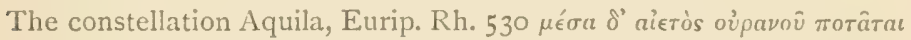
(cf. Petavii Var. Diss., lib. v. c. 14) ; Arat. Phen. 313, Hygin. iii. 15, \&c. The constellation Aquila is frequently referred to in Latin; e.g. Ov. F. v. 732 grata Iovi fulvae rostra videbis avis; [viii. Kal. Jun. Rostra aquilae oriuntur chronice.] Ib. vi. 194 si quaeritis astra, Tunc oritur magni praepes adunca Iovis; [Kal. Jun. Aquila oritur chronice.] Cf. Columella xi. 2 ; Germanic. Phaen. 692 redit armiger uncis Unguibus, ante omnes gratus tibi, Iuppiter, Ales; cf. ib. 6ro, \&c. On the mythology of the Eagle in connexion with the constellation Aquila, see also Eratosth. c. 29, Hygin. P. Astr. ii. 16, for, int. al., the stories of the metamorphosis of Ethemea, of the Eagle that brought Venus' slipper to Mercury (cf. Strabo xvii. So8, Ael. V. H. xiii. 33), the eagle that portended victory to Jore in his combat with the Titans, \&.

The complicated mythology of the Eagle baffles analysis. It is 


\section{AETOE (continued).}

sometimes evidently a solar emblem, as is Zqvòs öpves in Aesch. Suppl.

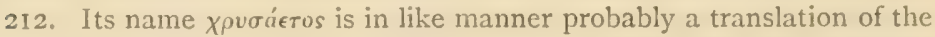
'golden hawk' of Egyptian Horus. In its combat with the Hare, the Swan, the Bull, the Dragon, and so forth, these latter are probably symbolic of their stellar name-sakes, and in such cases, the hostile Eagle is, in the main, a stellar and not a solar emblem. The following are the principal facts in connexion with the constellation Aquila which seem to bear on the mythology of the Eagle. It rose nearly together with the Dolphin, and shortly after, and as it were in pursuit of, the Swan and the Serpent of Ophiuchus: it set as the Lion rose, whose leading star Regulus was also called $\beta a \sigma i \lambda i \sigma k o s$, the Hare and the Dogstar rising simultaneously; it set together with Aquarius, known also as Ganymede the cup-bearer, and it was close beside and rose together with the Arrow of Sagittarius. It is not far distant from the constellation Lyra, which last constellation is also known as the Vulture; it and the Eagle are known respectively to later writers (and to the Arabs) as Aquila or Vultur cadens and volans or $\gamma^{i} \psi \kappa a \theta \dot{\eta} \mu \epsilon \nu o s$ and $\pi \in \tau \dot{\mu} \mu \epsilon \nu o s$, nesr-el-wâki and nesr-el-tâir, whence our modern names Vega and Altair applied to their two principal stars. (See for Arabic and other references, Ideler, Sternnamen, pp. 67, 106, \&c.; also Grotius' Aratus, Notae ad Imagg. pp. 54, 60, \&c., \&c.) Aquila rose together with the latter stars of the Scorpion, but Lyra or the Vulture, rising a little earlier, seems to have been the true paranatellon of that sign : accordingly it is probably not the true Eagle but the Vulture or Aquila cadens, which, substituted for the unlucky Scorpion, figures with the other three cardinal signs of Leo, Taurus, and Aquarius, in the familiar imagery of

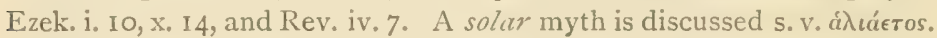
The combat with the Hare is interesting from its representation on a famous decadrachm of Agrigentum, as well as for the equally mystical

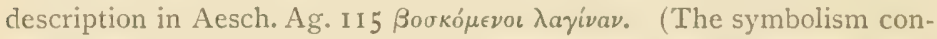
nected with the Hare seems to me to be peculiarly complicated and difficult, and all tentative hypotheses are more than commonly liable to be overthrown.) The Eagle with the Serpent or Dragon occurs not only in classical coinage (Chalcis, Agrigentum, Gortyna, Siphnos, \&c.), but also on Persian and Egyptian sculptures. The Eagle with the lightning (ảeròs mupфópos) or thunderbolt (ministrum fulminis, cf. Plin. x. 3, Serv. in Aen. i. 398, Sil. Ital, xii. 58 adsuetis fulmina ferre Unguibus) occurs on coins of Elis, Catana, Megalopolis, \&c. Philo's phrase

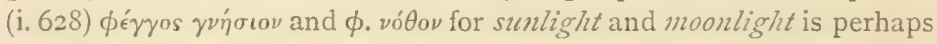

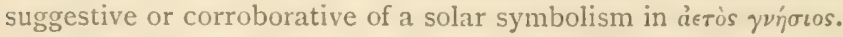

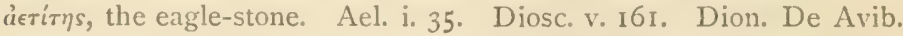

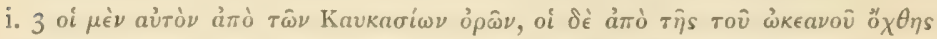

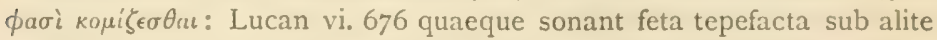
saxa; Plin.x. 3, xxx. (I4) 44, xxxvi. (2 I) 39, xxxvii. (I I) 72, Horap. ii, 49, 
AETOE (continued).

Phile 736, Geopon. xv. 1, 30, Solinus, c. 37, Philostr. V. Apollon. ii. 14, Stobaeus 98, Priscian in Perieges. p. 393. Cf. Physiol. Syrus, where

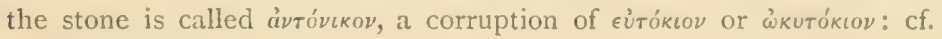
Eustath. Hexaëm. p. 27, Epiphan. De Duodecim Gemmis, \&.c., ed. Romae, I743, p. 30, Marbod. Lapidarium, 339-39r (King's Ant. Gems, p. 404). See also, for mediaeval and other references, Boch. Hieroz. ii. 3I2-3I6, and N. and Q. (8) v. 5IS, I894. The Eagle with its stone, an Egyptian symbol of security, Horap. ii. 49.

Proverb and Fable.-Fable of Fox and Eagle, Archiloch. fr. 86-88 (IIO), Aes. Fab. 5; Ar. Av. 652. Hence according to Rutherford

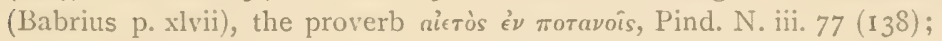

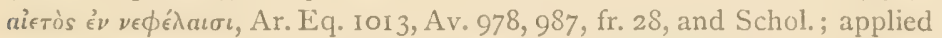
by the oracle to the Great King (cf. Ezek. xvii. 3), Schol. in Ar. Eq. IoIo;

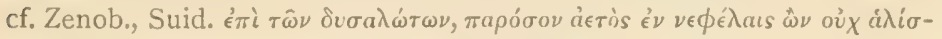
кєรaı : for other explanations, see Steph. Thes.

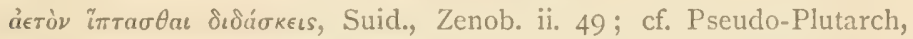

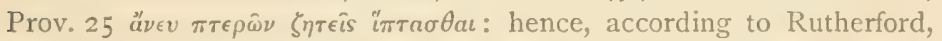
the fable of the Eagle and Tortoise, Babr. cxv, Aes. 419 ; cf. Diog. L., ii. 17,10 .

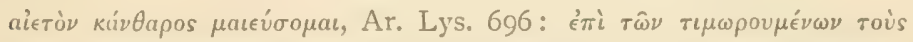

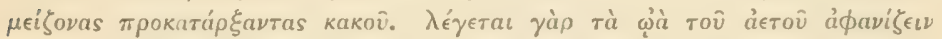

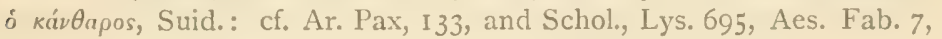
Keller, op. c. p. 269.

The oracle of Aëtion, Herod. v. 92.

Fable of Eagle shot with its own feathers, Aesch. Myrm. fr. 123, cf. Schol. in Ar. Av. 808, Aes. Fab. 4. The Eagle and the Archer, Bianor, Gk. Anthol. ii. p. 143.

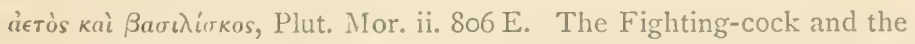
Eagle, Babr.v; the Eagle and Lion in partnership, Babr. xcix; the Eagle mindful of benefits, Aes. 6, 92, 120, Ael. xvii. 37, whence the

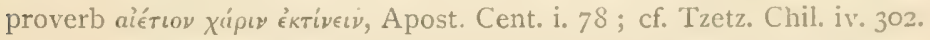

The tame Eagle of Pyrrhus, Ael. ii. 40 ; the Eagle that saved Tilgamus of Babylon, Ael. xii. 21 ; that saved Aristomenes, Paus. iv. I8. 5 : cf. Antip. Sidon. xcii in Gk. Anthol. ii. 33: see also Ael. vi. 29, Plin. x. (5) 6: cf. Marx, Gr. Märchen, I889, pp. 29-50.

On Hawking with trained Eagles in India, Ctesias, fr. I I (ed. Müller), Ael. iv. 26 ; in Thrace, Ael. ii. 42 ; cf. also Leo Africanus and Tzetzes Chiliad. iv. 134. On Eagles trained for Falconry, see (e.g.) Scully, Contr. to the Ornith. of E. Turkestan, Stray Feathers, vi. p. 123, I876; also Yule's Marco Polo, Schlegel's Fauconnerie, \&.c.

Representations of Eagles.-On Babylonian processional sceptres, Herod. i. 195. On the sceptre of the Persian kings, Xen. Cyrop. vii. 
AETOE (continued).

I. 4 (cf. Keller, op. c. pp. 240, 435). On the sceptre of Zeus at Olympia, Paus. v. II. I (copied on a late coin of Elis); and at Megalopolis, id.

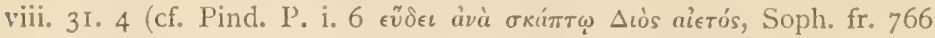
$\sigma \kappa \eta \pi \tau o ß a ́ \mu \omega \nu$ aítrós, Schol. in Ar. Av. 510); on pillars before the altar of Zeus Lycaeus, in Arcadia, id. viii. 38. 5 ; on the Omphalos at Delphi

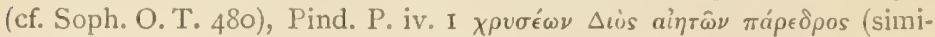

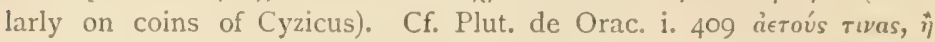

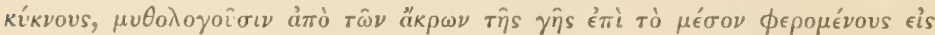

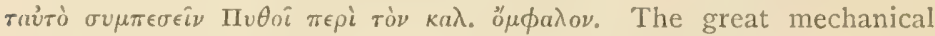
Eagle with outspread wings on the altar at Olympia, Paus. vi. 20. 12. On the shield of Aristomenes at Messene, Paus. iv. I6. 7 (cf. account of shield in Eurip. fr. Meleag. iv, and on the shield of Aeacus, Zi vo

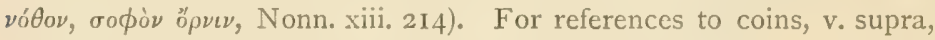
passim.

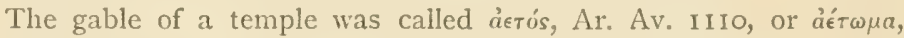

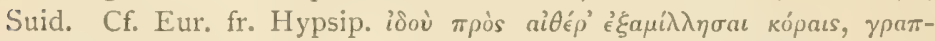

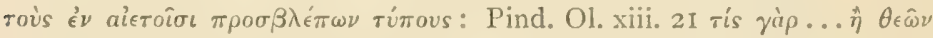

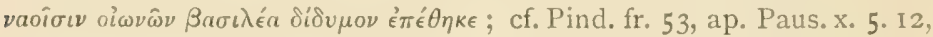
and Bergk's note; Tacit. H. iii. 71 ; Bekker Anecd. p. 348.3 ḋeтой

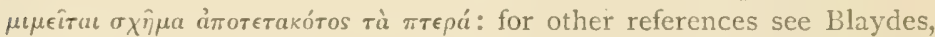
in Ar. Av. I 106. Compare the Sacred Hawk or Eagle, or the winged solar disc, on Egyptian gables, \&c., and on Mithraic monuments. See Brönsted, Voy. en Grèce, ii. 154; Welcker, Alte Denkmäler, i. 3. A conventional ornament on the gable even of modern buildings in the Greek style, still represents the degenerate emblem of the Eagle's wing.

See also, besides the special references to the other Eagle-names

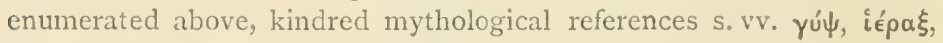
$\pi \epsilon \rho \kappa \nu o ́ \pi \tau \epsilon \rho \circ, \phi \eta ́ v \eta$.

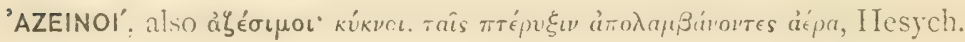

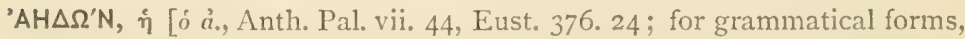
see Bergk. Philol. xxii. p. 10, Ahrens in Kuhn's Zeitschr. iii. p. 81, \&c.] Also ảnoovis (Eur. Rhes. 550, Theocr. viii. 38, freq. in Gk. Anthol., \&c.),

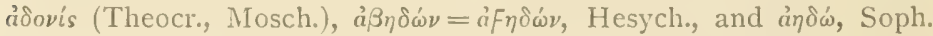

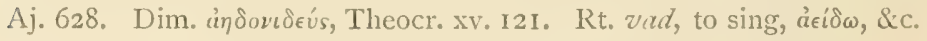

The Nightingale, Motacilla luscinia, L., Daulias luscinia, auctt. Mod. Gk. ảंóńn, applied to various Warblers.

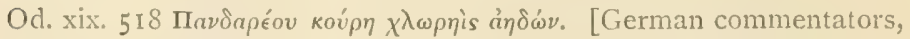
translating $\chi \lambda \omega \rho \eta$ is green, have made many needless conjectures as to some other bird being here alluded to ; cf. Groshans, p. 5 ; Buchholz, pp. 123-125. On the word $\chi \lambda \omega$ pis see also G. E. Marindin and W. W. Fowler, Class. Rev. 1890, pp. 50, 231, and in particular Steph. 


\section{$\mathrm{AH} \triangle \Omega \mathrm{N}$ (continued).}

Thes. (ed. I $82 \mathrm{I}$ ), coll. I284-5. The general significance is perhaps 'the nightingale, that clepeth forth the fresshe leves newe,' Chaucer, P. of

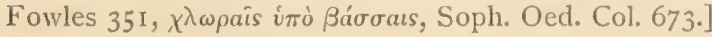

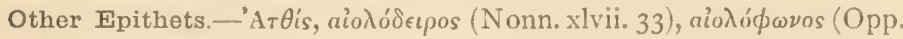

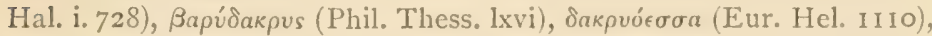

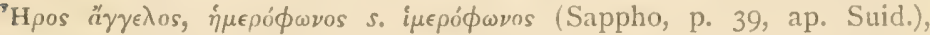

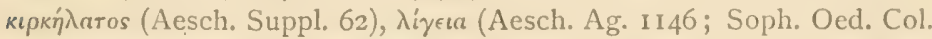

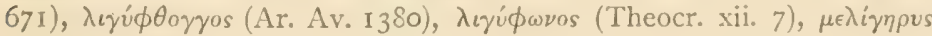
(C. I. G. 6261 ; Gk. Anthol. iv. pp. 231, 273; cf. Theocr. Ep. iv. 12),

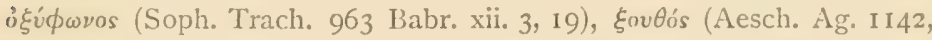

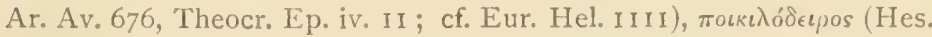

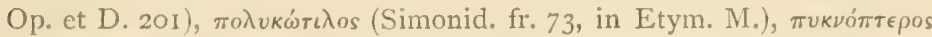

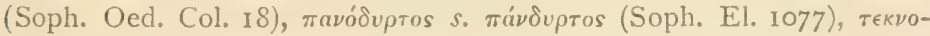

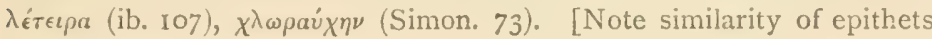

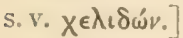

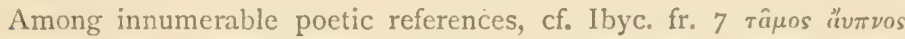

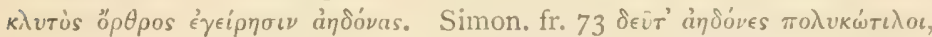

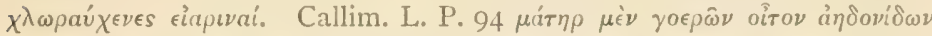
"

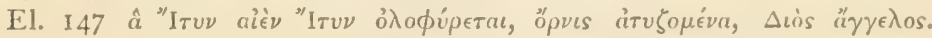

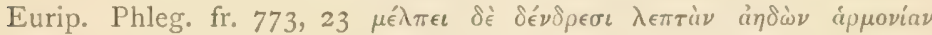

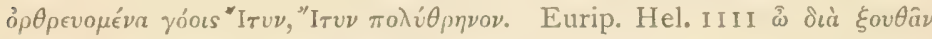

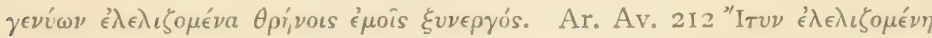
(cf. Hor. Car. iv. 2. 5 Ityn flebiliter gemens, Catull. lxv. I4 Daulias absumpti fata gemens Ityli). Soph. Aj. 628 oiktpâs yóov öpvitos rỉjoûs,

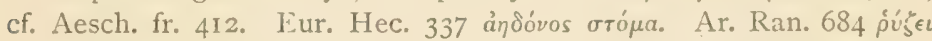

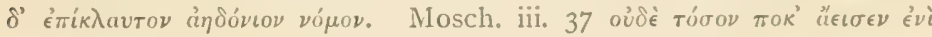

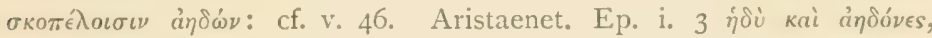

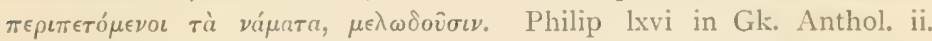

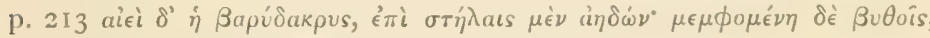

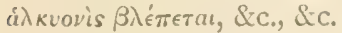

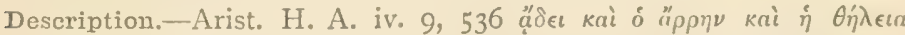

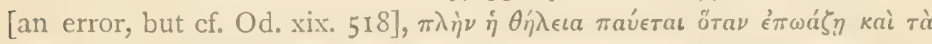

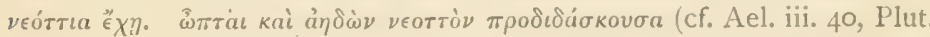

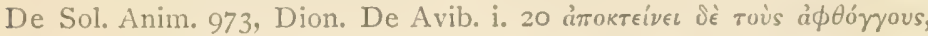

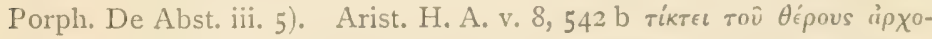

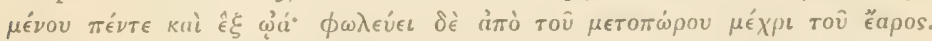

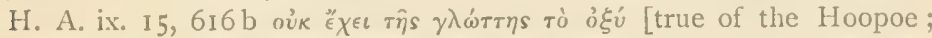
$a \eta \eta \dot{\omega} \nu$ is an interpolation here, Aub. and Wimm., cf. Plin. x. 43 (29), but compare the version in Apollod. iii. I4]. H. A. ix. 49 B, 632 b

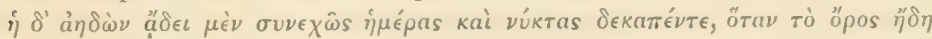

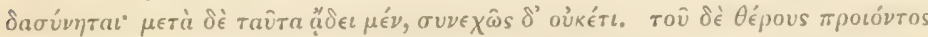

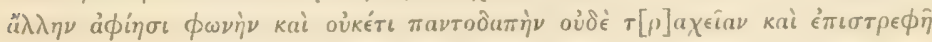


$\mathrm{AH} \triangle \Omega \mathrm{N}$ (contimued).

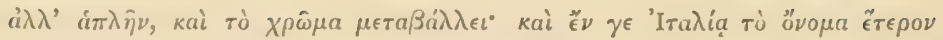

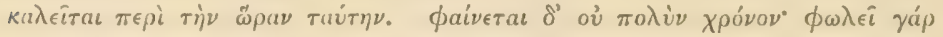
(cf. Ael xii. 28; Plin. N. H. x. 29, Clem. Alex. Paedag. x): the above

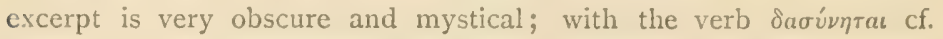
Etym. M. s.v. $\Delta a v \lambda i$ s, also Aesch. fr. 27 (ibi cit.), and Paus. x. 4, 7.

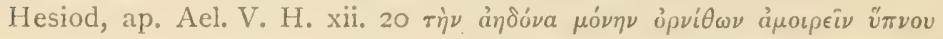

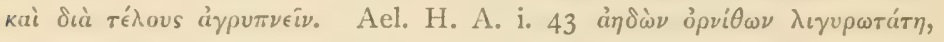

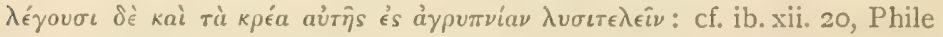

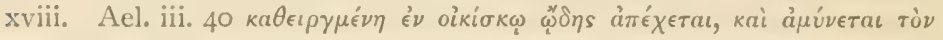

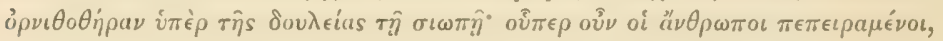

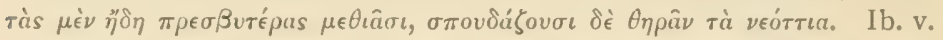

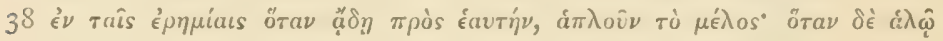

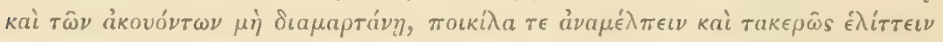

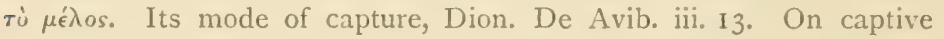
Nightingales, see also Nemesian, Ecl. ii, De Luscinia. A white or albino specimen, Plin. 1. c.

The locus classicus for the Nightingale's song is Plin. x. (29) 43, cf. Ar. Av. 209; see also Dion. De Avib. i. 20, Phile xviii, \&c.

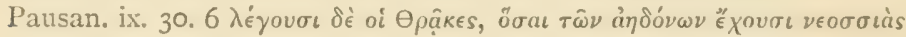

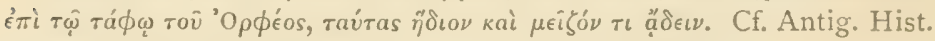
Mirab. 5, Myrsili Methymn. fr. 8 (vol. iv. p. 459, Müller).

The Nightingale which sang over the infant Stesichorus, as a presage of poetry, Plin. X. 43 (29). The transmigration of Thamyras (? Thammuz), Plato, Rep. x. 620.

On talking Nightingales, Plin. N. H. x. 59 (42).

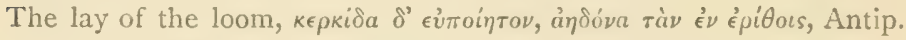
Sid. xxii, Gk. Anthol. ii. I I, cf. id. xxvi; cf. Ar. Ran. I316.

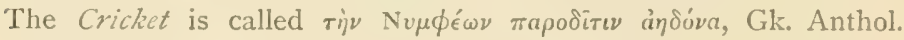
iv. 206.

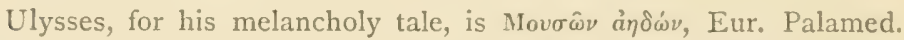

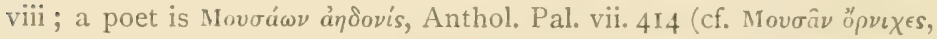
Theocr. vii. 47); a bad poet is ảnóóv ingale the shivers), Phryn. Com. Inc. $\mathrm{i}$.

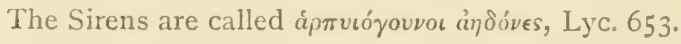

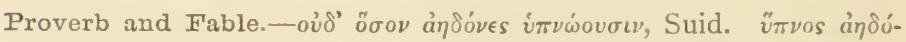

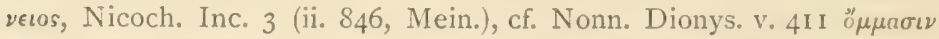

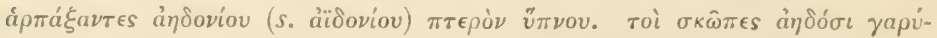

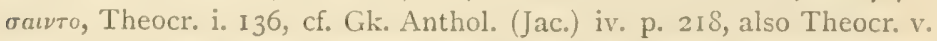

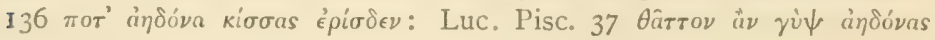
$\mu \mu \dot{r}_{\text {бatro. }}$

Fable of the Hawk and the Nightingale, Hes. Op. et D. 203, cf. Aes. Fab. 9, Plut. Mor. I58 B. The Nightingale and the Swallow, 
$\mathrm{AH} \triangle \Omega \mathrm{N}$ (continued).

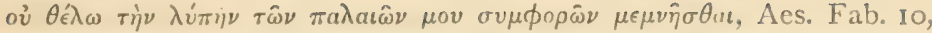
cf. Babr. xii. Vox et praeterea nihil, Plut. Apophth. Lacon. 123 A ti $i$ as

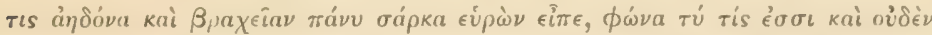

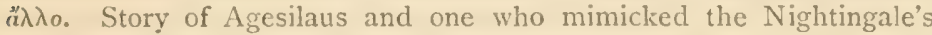

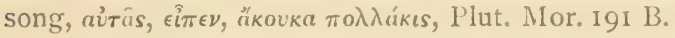

On the myths of Itylus, Philomela, Procne, and in general on the melancholy strain of the Nightingale, cf., int. al., Theocr. xv. I2I; Pherecydes, fr. p. I36 (ed. Sturtz); Ar. Av. 203, 665, and Scholia; Paus. i. 41. 8; Boios ap. Ant. Lib. xi ; Hygin. Fab. 45 (309, 212); Apollod. iii. I4. 8; Virg. Georg. iv. 510, Ecl. vi. 79; Martial x. 51, xiv. 75 ; Ovid, Met. vi. 424, Am. ii. 6. 7; Catull. lxv. I4; Carm. de Philomela, \&c., \&c. See also (int. al.) Hartung, Relig. und Myth. d. Gr. iii. p. 33; Duntzer in Kuhn's Ztschr. xiv. p. 207; E. Oder in Rh. Mus. f. Philol. (N. S.) xliii. p. 540 et seq.; Keller op. c. pp. 304-320; Pott in Lazarus and Steinthal's Zeitschrift, xiv. p. 46, I883; J. E. Harrison, J. Hellen. Studies, viii. 439-445, I887, M. of Anc. Athens, p. Ixxxiv.

The Nightingale's song, as Coleridge discovered, is not melancholy. It was a spirit of religious mysticism that 'First named these notes a melancholy strain, And many a poet echoes the conceit.' I believe the innumerable references to the melancholy lay of aisovis or ain $\delta \omega \nu$, and to the lament for "I $\tau$ s, to be for the most part veiled allusions to the worship of Adonis or Atys; that is to say, to the mysterious and melancholy ritual of the departing year, when women 'wept for

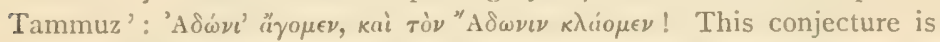

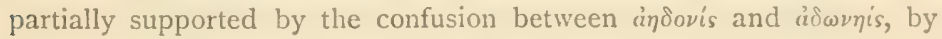
the mythical relations between the Nightingale and the Swallow, and by the known connexion of both with the rites of Adonis. Compare

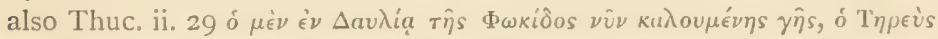

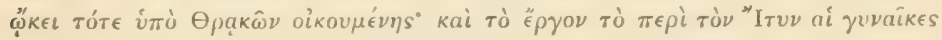

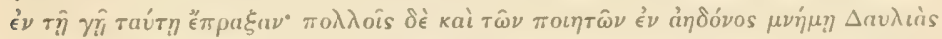

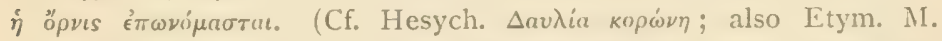

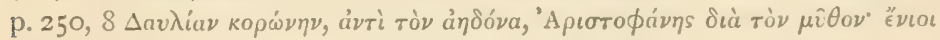

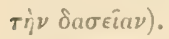

In the above passage from Thucydides the commentators take ai yvvaikes to refer to Procne and Philomela; it seems to me to mean simply that in that spot the women-folk practised the rites of Adonis. It is noteworthy that Dodwell found an archaic village-festival, or feast of tabernacles, taking place at Daulis, when he visited the locality at the season of the vernal equinox (cf. Ezek. viii, \&c.). The passage

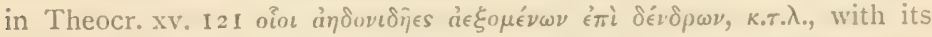
context, is important in this connexion. As I have attempted to bring anjó $\boldsymbol{\omega}$, Itys or Itylus, and possibly even Thamyras into relation with 


\section{$\mathrm{AH} \triangle \Omega \mathrm{N}$ (continued).}

Adonis, Atys, and Thammuz respectively, so I am tempted to see a connexion between a fourth Adonis-name, Duzi or Dazu, and the

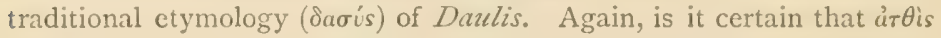
å $\delta \dot{\omega} \nu$, a late and rare epithet in Greek (Nonn. Dionys. xlvii. 32, cf. ibid. xliv. 265), means really the Attic nightingale; or may we not here also have an Atys-name? Lastly, a reference to a Molochsacrifice is indicated in Hesychius under the heading $\Lambda i \beta u s \tau \in a \dot{\eta} \delta \dot{\omega} \nu^{*}$ ai

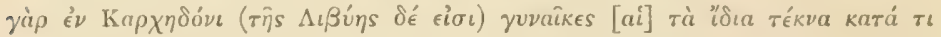

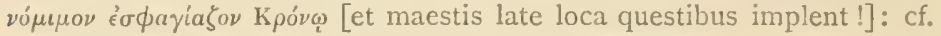
Soph. in Andromeda, fr. I32, ap. Hesych. s. v. koupiov.

Philomela and Procne are frequently confused, cf. Serv. ad Ecl. vi. 78. In all Greek authors, Philomel is the name of the Swallow, and Procne of the Nightingale (Ar. Av. 665). The Latins generally reverse this; but Varro De L. L. and Virg. Ecl. vi adhere to the Greek version of the story (W. H. Thompson, ad Plat. Gorg. fr. 6, p. I8o). ản $\delta \dot{\omega} \nu$ and ${ }^{3} \lambda \kappa v \dot{\omega} \nu$ are also apt to be confused, e. g. Arist. H. A. viii. 3, $593 \mathrm{~b}$, where

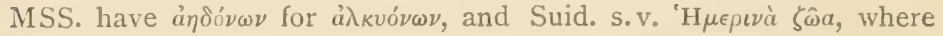

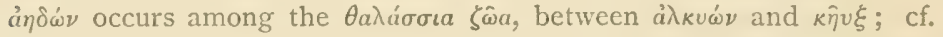
Boch. Hieroz. ii. 218. In the version of the Itylus-Myth given by Boios, ap. Anton. Lib. II, the mother of Aëdon is transformed into the bird $a ̉ \lambda \kappa v \omega \dot{\nu}$.

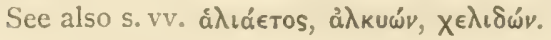

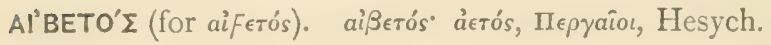

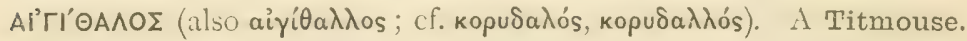

Three sorts are indicated, Arist. H. A. viii. 3, $592 \mathrm{~b}$ ó $\mu \dot{\epsilon} \nu \sigma \pi \iota \zeta i \tau \eta s \mu \boldsymbol{e}^{-}$

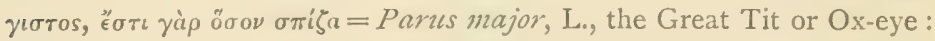

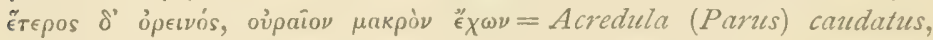
the Long-tailed Tit (which occurs in Northern Greece, v. d. Mühle

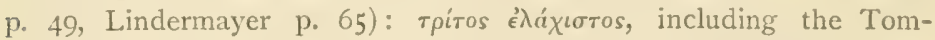
Tit and its allies, of which, according to Heldreich (p. 39) P. ater, coeruleus and palustris are rare in Greece ; $P$. lugubris, Nath., is commoner and now shares the same popular name $k \lambda \epsilon i \delta \omega v a ̂ s$ with the Great

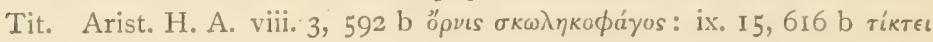
cià $\pi \lambda \epsilon i \sigma \tau a$ (the Long-tailed Tit is known to lay very numerous eggs) :

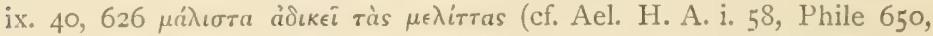
Geopon. xv. 2, 18). According to Alex. Mynd, ap. Athen. ii. p. 65,

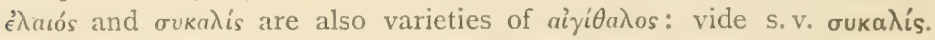

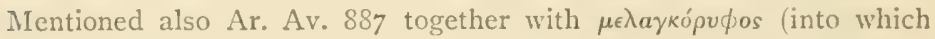

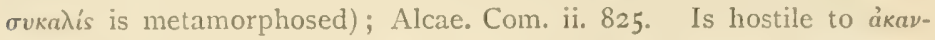
$\theta v \lambda \lambda$ is, Plut. De Od. et Inv. iv. 537 B. The metamorphosis of Timandra, Anton. Lib. Met. v; and of Ortygius, Met. xx. Is con-

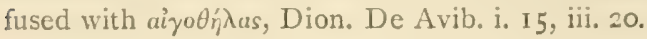




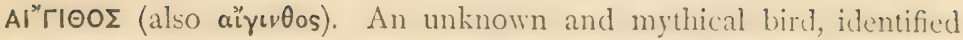
by the older commentators (e.g. Belon) with the Linnet.

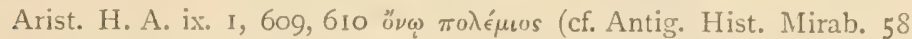
(63) ; Ael. H. A. v. 48 ; Dion. De Avib. i. 12; Phile 696; Plin. x. 95).

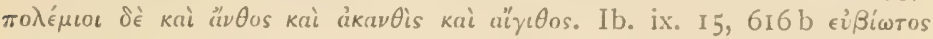

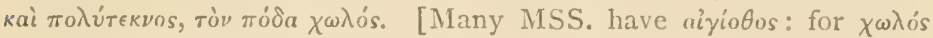
some texts read $\omega \chi \chi \rho^{\prime}$, or $\chi \lambda \omega$ pós, the latter Albertus Magnus, but cf.

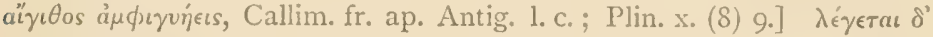

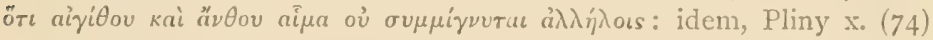
95 (who calls it avis mimima), Ael. H. A. x. 32, and Phile 432, the

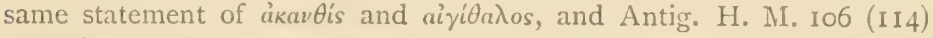

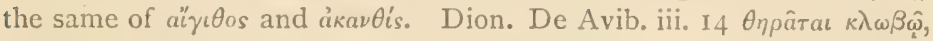

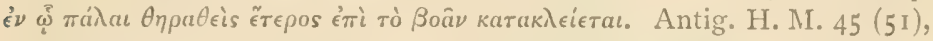

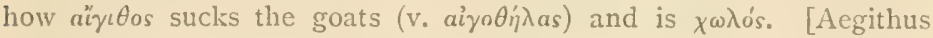
solo nomine huic nostrae aetati cognitus, P. Hardouin, Annott. ad

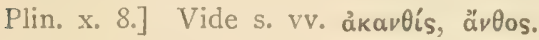

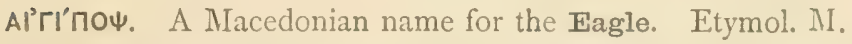

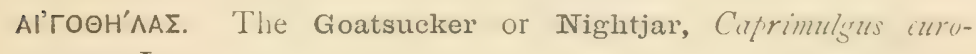
paeus, I.

The name is probably corrupt, and the mythical attribute of the bird due to a case of 'Volksetymologie.'

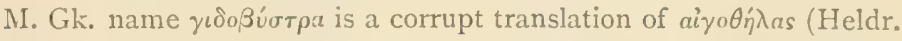

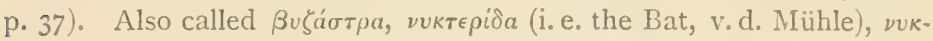

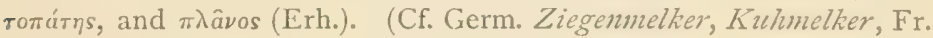
tette-clièrre, \&c.)

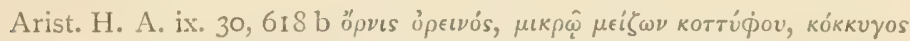

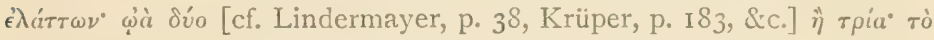

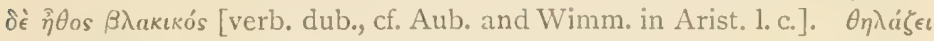

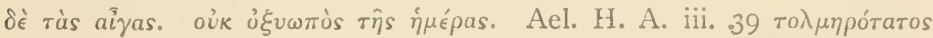

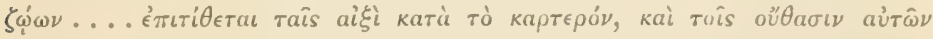

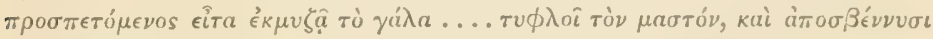

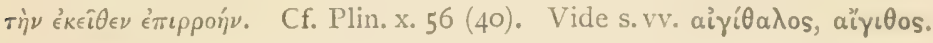

A'rOKE'фA^OE. Probably a kind of Owl: perhaps the Horned or Long-eared Owl, Strix otus, L., or its small ally Ephialtes scops, K. Bl. The latter is the Asio of Plin, x. (23), xxix. $3^{8}$, which name in its Italian diminutive form is Shelley's 'Sad Aziola.'

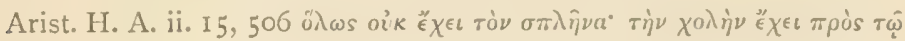

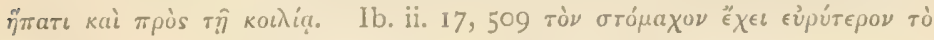
кїт.

Gesner (p. 62) mentions Capriceps as an unknown bird. Neither Sundevall nor Aubert and Wimmer pronounce an opinion on it: the 


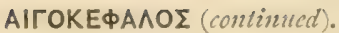

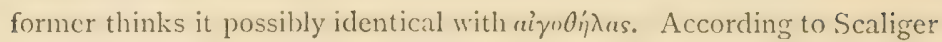
p. $25 \mathrm{I}$, ai is mentioned along with $\gamma \lambda a \dot{\xi} \xi$, and the name suggests a Homed Owl (sic Scaliger, Lidd. and Sc., \&c.). For other suggestions, see Newton, Dict. of Birds, p. 365, s. v. Godzit.

\section{Al'ГYпाо' $\Sigma$. A Vulture.}

Etymology very doubtful. The analogy of Lämmergeier suggests a compound of ait or ofis (Curt.) and $\gamma \dot{v} \psi$, but the word is probably much more primitive and ancient. I suspect that most of the remarkably numerous bird-names beginning with al- (many of which are peculiarly difficult to identify, a circumstance suggesting their generic rather than specific character), contain an element akin to avi-s, Sk. vi-s (v. áerós), and in this case that $\gamma^{\prime} \psi$ is the shortened or derived form. The dialectic form alyitro $\psi$ is interesting in this connexion.

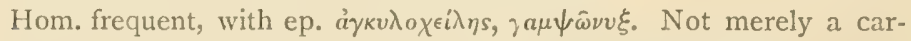
rion-eater (as in Hes. Sc. 405-412), but attacks live birds (I1. xvii. 460,

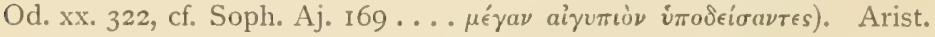

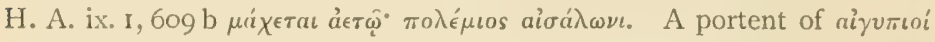
in chase of ip Is feared by $\tau \rho \omega \gamma \lambda i \tau \eta s$, Phile 692. Sometimes distinguished from $\gamma \dot{\psi} \psi$,

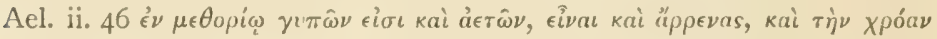

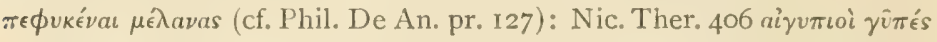

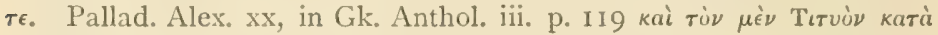

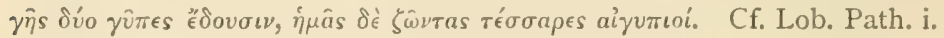
p. 87.

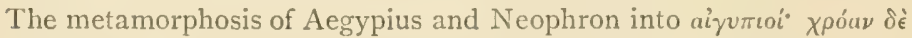

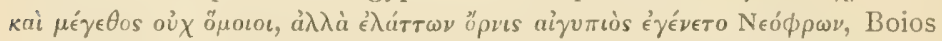
ap. Anton. Lib. Met. $\mathrm{v}$; the smaller species here alluded to is the White or Egyptian Vulture, the Neophron percnopterus of modern

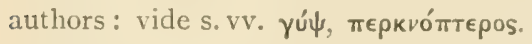

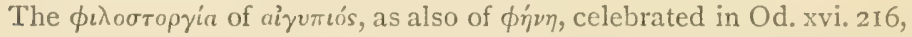
Aesch. Ag. 49, Opp. Hal. i. 723, \&c., is connected with the Egyptian association of the Vulture with the goddess of Maternity (cf. Horap. i. II).

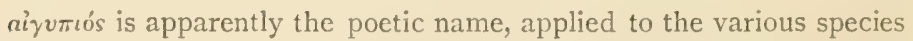
which frequent the battle-field, and on the other hand applied to an Eagle in such passages as Il. xvii. 460. That the word is an old and

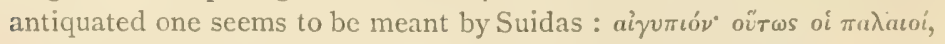
à $\lambda \lambda^{\prime}$ oủ $\gamma \hat{v} \pi \alpha . \quad$ Cf. Bekk. An. 354. 28, Rutherford, New Phryn. p. 19.

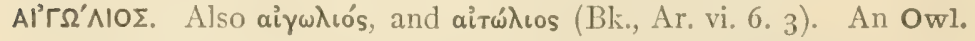

Arist. H. A. viii. 3, 592 b, a nocturnal rapacious bird, mentioned with

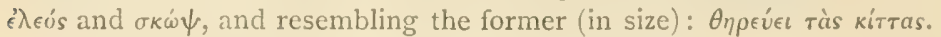


AIT $\Omega \wedge \mid O \Sigma$ (continued).

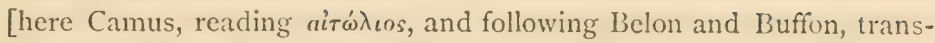
lates Milvus niger, the Black Kite].

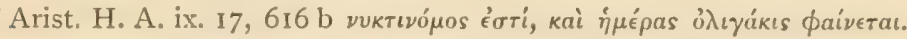

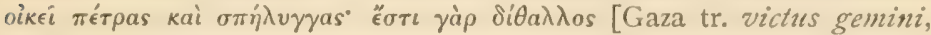

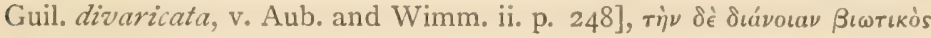

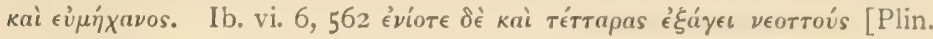
x. $79(60)]$.

The metamorphosis of Aegolius, Boios ap. Anton. Lib. Met. 19.

If $\delta i \theta a \lambda \lambda$ os means particoloured, aijwi $\lambda_{\text {os }}$ is clearly the White or Barn Owl, Strix flammea, L., as Littré (ad Plin.) takes it to be; it however does not catch birds, and is said to be scarce in Greece (v. d. Mühle, Lindermayer). Gesner transl. by ululu, and identifies it with the Tawny Owl. Sundevall librates between the Tawny and the Barn Owl; A. and W. incline to the former. See aiyoké $\phi \alpha \lambda \circ$,

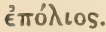

AI"OYIA. A poetic word, of uncertain or indefinite meaning.

Probably a large Gull, e.g. Lanus marinus, the Black-backed Gull (Sundevall), or L. argentatus, the Herring Gull (Krüper), the former being rare in Greece. Netolicka's hypothesis of the Merganser, and that of Groshans that it was a Diver or Grebe, do not tally with Aristotle: Schneider's identification with the Skua, Lestris parasiticus, fails, inasmuch as the latter does not dive (vide Buchholz, op. c. pp. I I2, I13) nor does it breed in the Mediterranean. The Herring Gull is abundant during the winter and breeds about the middle of April: the Common Tern (Sterna anglica) lays about the same time (Krüper) but in the lagoons and not on the cliffs.

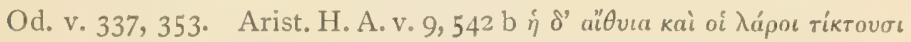

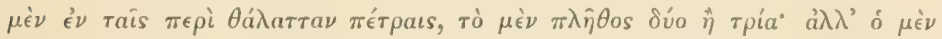

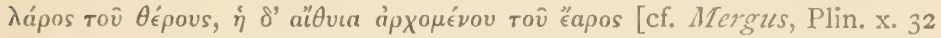

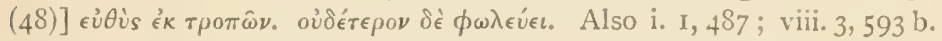

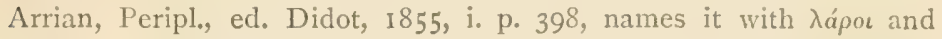

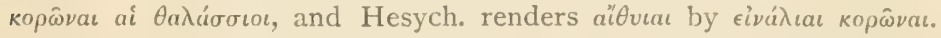

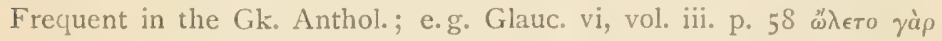

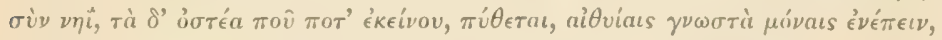
cf. Marc. Arg. xxxi, ibid. ii. p. 250; Callim. xci; Leon. Tar. xci, Gk.

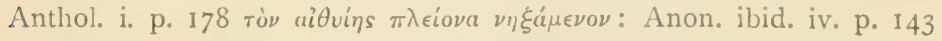

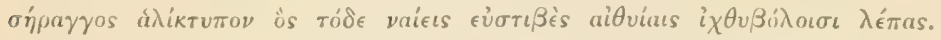
Phile, De Anim. Pr. 680, is hostile to $\pi \epsilon \lambda a \rho \gamma^{\prime}$ s and $\kappa \rho^{\prime} \xi$. Is said to be deaf and dumb, Aristoph. Hist. Anim. Epit. i. I4I.

The metamorphosis of Hyperippa, daughter of Munychus, Nicander ap. Anton. Lib. Met. 14.

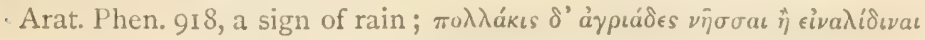


AlOYIA (continued).

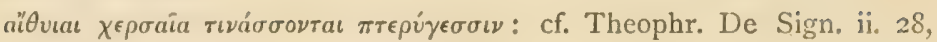
Virg. Georg. i. 362.

A long but unsatisfactory description in Dion. De Avib. ii. 5.

A title or epithet of Athene, Paus. i. 5. 3, i. 4 I. 6.

Said to be the name of a horse in Mnasalc. xiii. Gk. Anthol. i. p. 125.

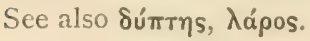

Al" 三. An unknown bird. Arist. H. A. viii. 3, $593 \mathrm{~b}$ : mentioned

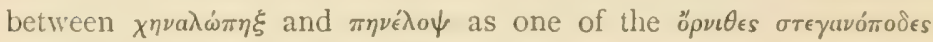
ßари́тєро (omitted in several MSS.).

According to Belon the Plover (Vanellus cristatus) was so called in Greece in his time: the interpretation cannot hold. Sundevall conjectures al $\xi$ to be one of the smaller Geese (? Anser leucopsis), and to be derived from the goat-like cry. Perhaps as aiyoké $\phi a \lambda o s$ suggests the Homed Owl, so al $\xi$ here suggests the Horned Grebe, Podiceps auritus, Lath., a common bird in Greece in winter.

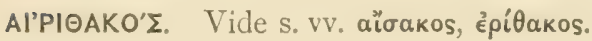

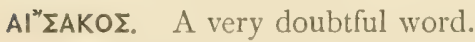

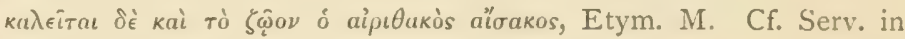
Aen. iv. 254, v. 128.

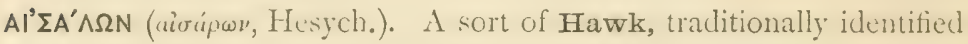
with the Merlin, Falco aesalon, L. (Gesner, \&c.).

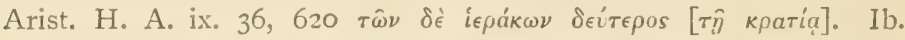

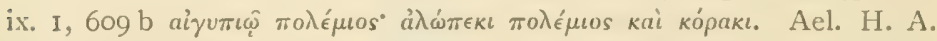

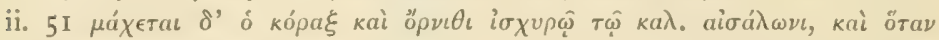

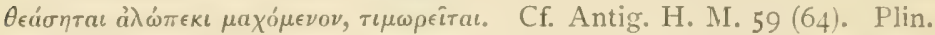
N. H. x. (74) 95 Aesalon vocatur parva avis, ova corvi frangens, cuius pulli infestantur a vulpibus. Invicem haec catulos eius ipsamque vellit: quod ubi viderunt corvi, contra auxiliantur velut adversus communem hostem. (Some editors read aesalona for epileum, Plin. N. H. x. 9.)

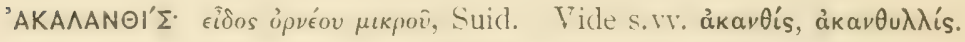

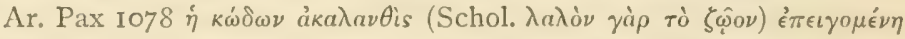

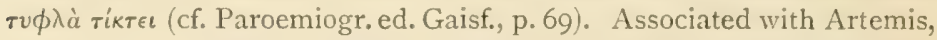
Ar. Av. 87r. One of the nine Emathidae, daughters of Pieros, was

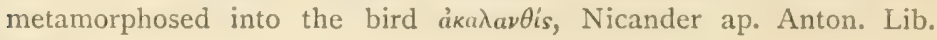
Met. ix.

'AKANOI' $\Sigma$. A small bird, usually identified with the Linnet, Fringilla camnabina, L., or the Goldfinch, $F$. carduelis, L., on the ground of

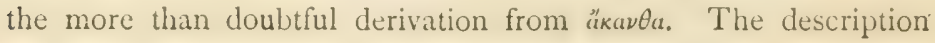




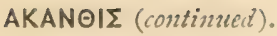

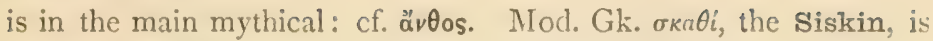
perhaps akin (Bikélas).

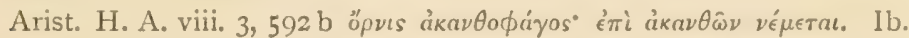

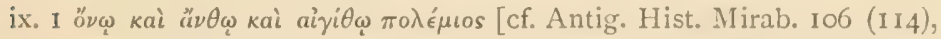

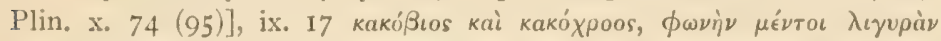

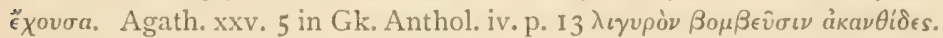
Theocr. 7. I4I : the Scholia in Theocr. make akavtis synonymous with

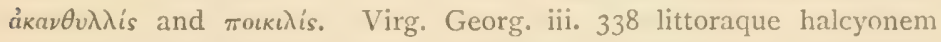
resonant, et acanthida [al. acalanthida] dumi ; cf. Serv. in Virg. alii lusciniam esse volunt, alii vero carduelem, quae spinis et carduis pascitur.

In Anton. Lib. Met. vii, the daughter of Autonous and Hippodamea is called 'A $\alpha \nu \theta$ 's and 'A $\alpha \nu \theta v \lambda \lambda$ is indifferently; note also that her mother was metamorphosed into kopvoós. Hesych. and Aelian

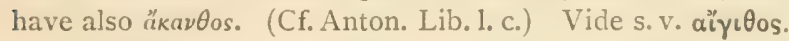

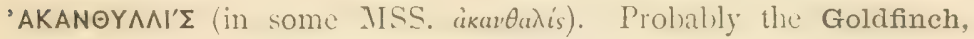
Fringilla carduelis, L.

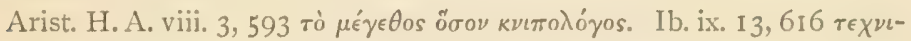

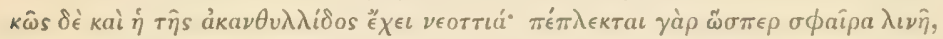

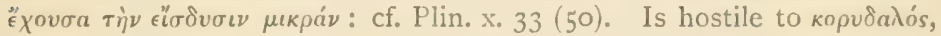
Ael. iv. 5, Phile, De An. Pr. 683. Mentioned also Eubul. fr. iii. 268,

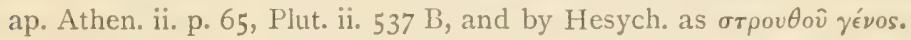

The description in Arist. H. A. ix. 13 has suggested to scientific commentators (Sundevall, p. I16, \&c.) the nest of the Long-tailed or Pendu-

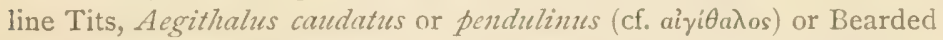
Tit, Calamophilus biarmicus; but the neat round nest of the Goldfinch

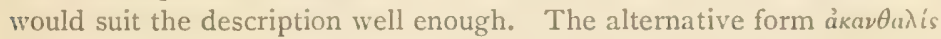
is evidently identical with $a^{\prime} \alpha \lambda a \nu \theta i s$, and so supports the identity of the

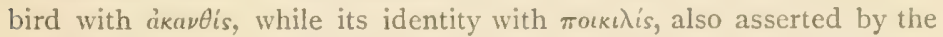
Schol. in Theocr., is strengthened by the statements of hostility to

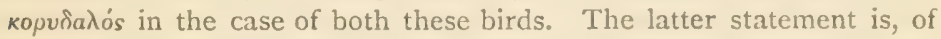

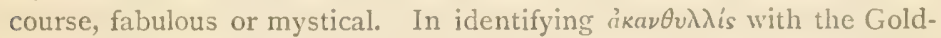
finch, I only mean that such an identification was probably adopted by

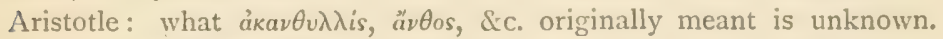
See also ai̧îa

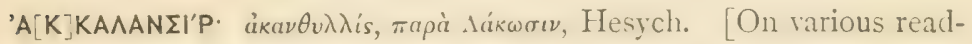
ings cf. Valkenaer, Adon. p. 278 ; Ahr. Dor. ii. 69.]

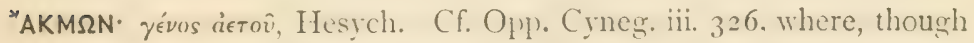
“kpoves are cited as zolves, the description closely resembles that of the mystical eagles in Aesch. Ag. I I I-I 20. 


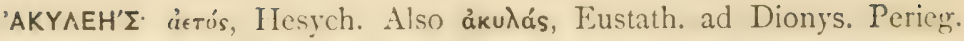
381. Perhaps akin to aquila; cf. Umbrian (Tab. Eugub.), angla s. ankla.

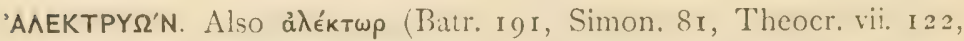

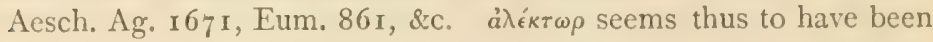
an old form, retained in tragedy; cf. Rutherford, New Phryn. p. 307$)$.

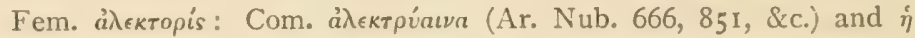

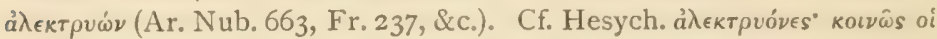

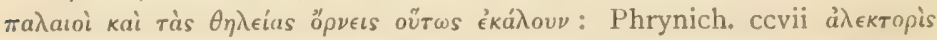

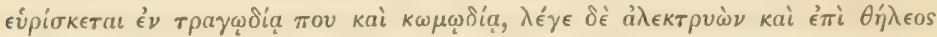

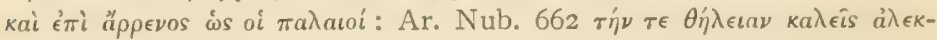

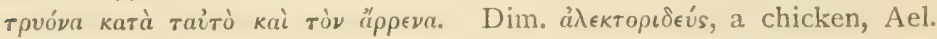

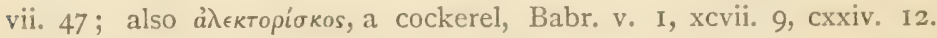

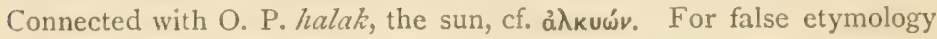

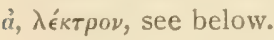

The Common or Domestic Fowl, Gallus gallinacens, L. Often mentioned simply as ópvis, a 'fowl' [especially a hen, Athen. ix. 373

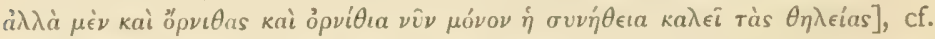

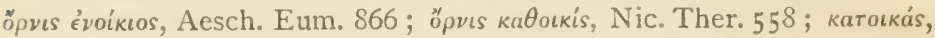

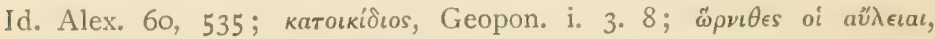

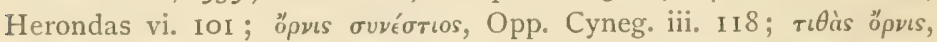
Alpheus Mityl. in Gk. Anth., ii. p. II 8, cf. Arat. Progn. 960 (228), \&c., \&c.

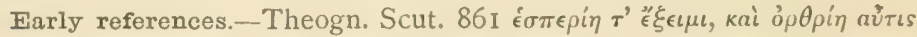

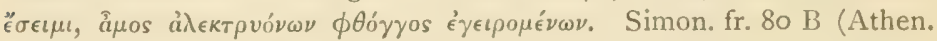

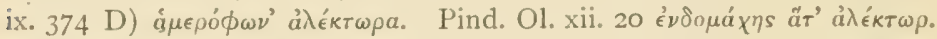

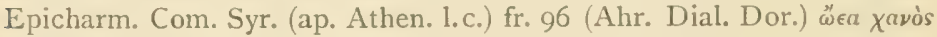

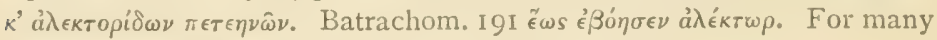
fragments, see Athen. 1.c.

Description.-Arist. H. A. v. 13, 544, De Part. ii. 657 b, De Gen. iii.

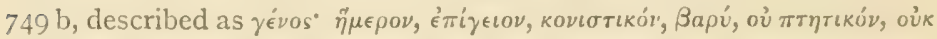

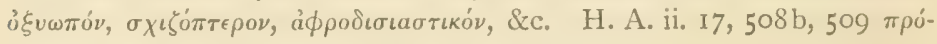

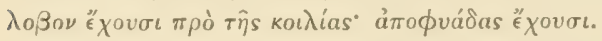

Comb and spurs. Ar. Av. 487, 1366, Arist. H. A. ii. 12, 504 b čvta $\tau \hat{\omega} \nu$

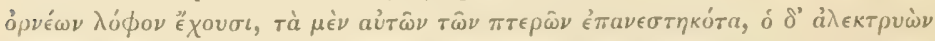

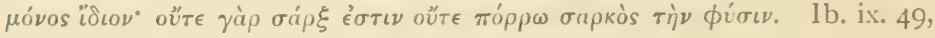

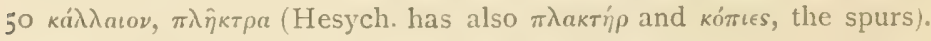

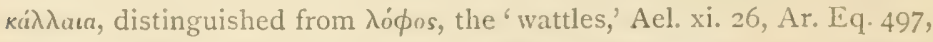

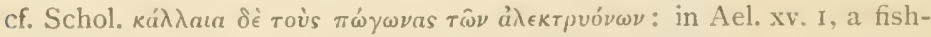

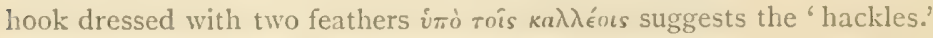

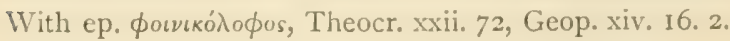




\section{A^EKTPY $\Omega N$ (continued).}

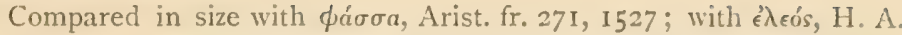
viii. 3. $592 \mathrm{~b}$; with the largest of the Woodpeckers, H. A. ix. 9, 614 b;

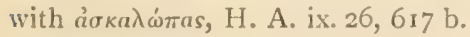

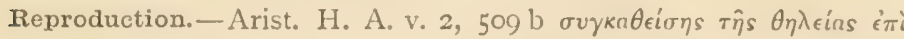

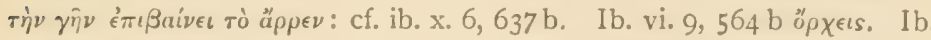

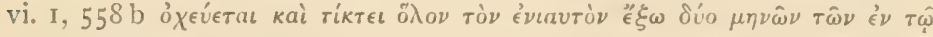

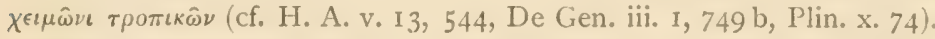

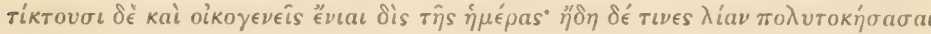

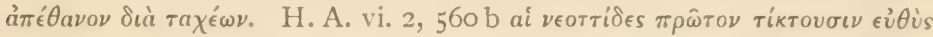

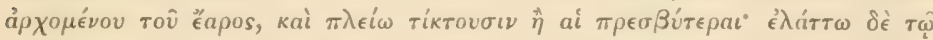

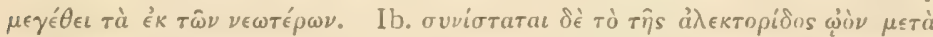

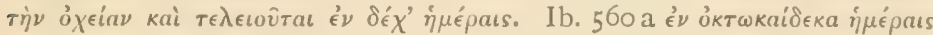

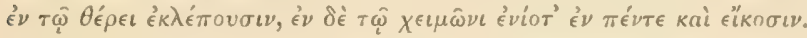

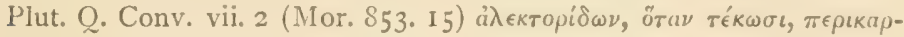
$\phi \iota \sigma \mu o ́ s$, cf. Plin. x. 4 I (57).

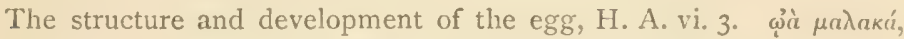

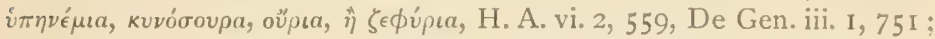

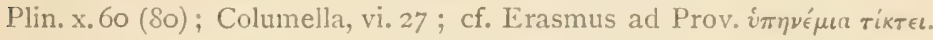

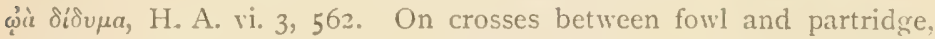
De Gen. ii. 7, 749 b. How Pea-hen's eggs are put under a sitting hen, H. A. vi. 9,564 b. How the hen takes the chicks under her wing, H. A. ix. 8, 613 b; cf. Alpheus Mityl. xii, in Gk. Anthol. ii. p. I $8 \chi^{\epsilon-}$

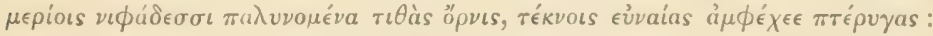

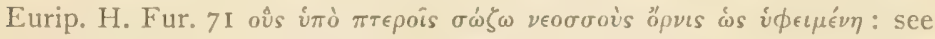
also Plutarch. De Philost. (Mor. 599. 4) ; Opp. Cyneg. iii. II9. How a cock sometimes, after the hen's death, rears the brood, and ceases to crow, H. A. ix. 49, 63I b, Plin. x. (55) 76. H.A. ix. 8, 614 4 'v roís iєpois,

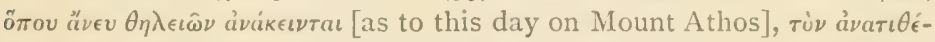

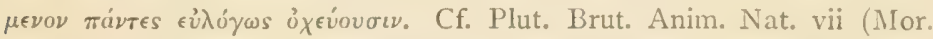

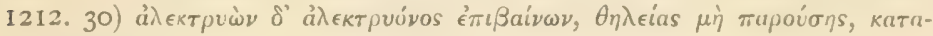

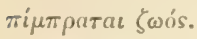

On eggs in medicine, Diosc. ii. 44, Galen. De Fac. Simp. Med., Plin. xxix. (3) 11, \&c. The longer eggs produce male birds, and are the better to eat, Hor. Sat. ii. 4.12, Plin. x. 74 (52).

On artificial incubation in Egypt, Arist. H. A. vi. 2, 559 b, Diod. Sic. i. 74. Geopon. xiv. 8. I. On capons, Arist. H. A. ix. 49, 63I b ; cf. Plin. x. (2I) 24, \&c. Varro, R. R. iii. 9, \&c. On the whole management of fowls, Geopon. xiv. 7-17.

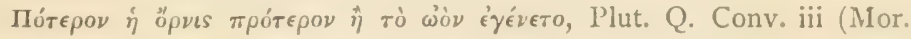
770. 13).

The Crowing Cock.-Among innumerable poetic and other references, cf. Theogn., Simonid., Batrachom., supra. Cratin. ap. Athen. 374 D

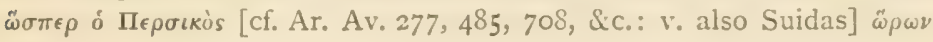




\section{A^EKTPY $\Omega N$ (continued).}

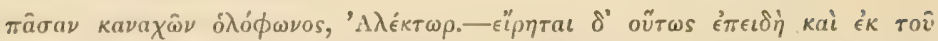

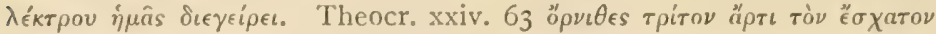

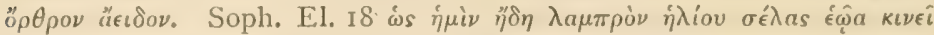

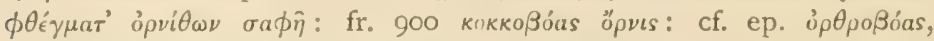

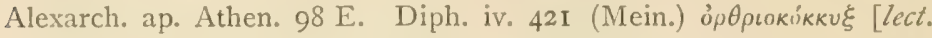
dub.] $a^{3} \lambda \epsilon \kappa \tau \rho v \omega \dot{\nu}$. Probably alluded to also Soph. Anten. 2, fr. I4I

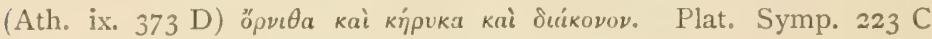

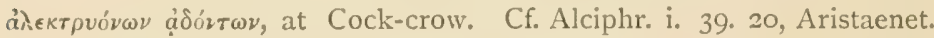

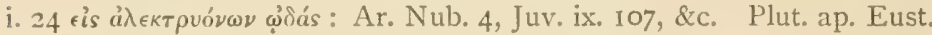

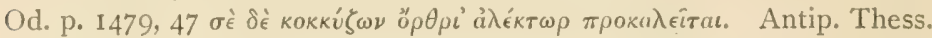

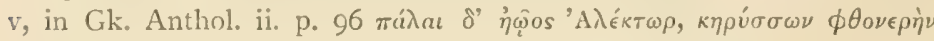

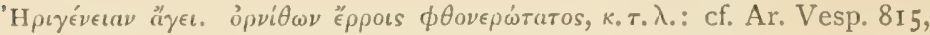
Anyt. xi, in Gk. Anthol. i. p. 132, Virg. Aen. viii. 456, \&c. Arist. De

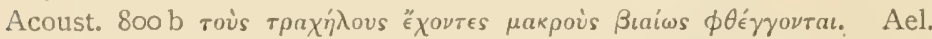

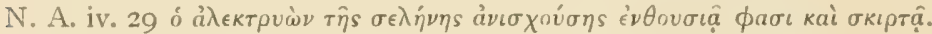

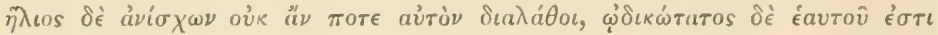
тұлıкáoe. Cf. Arist. H. A. iv. 9, 536. Lucian, Gallus, \&c. With ep. ஸ́рó $\mu a \nu \tau \iota s$, Babr. cxxiv. II.

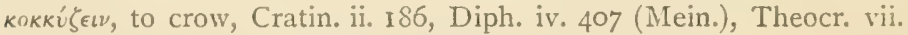

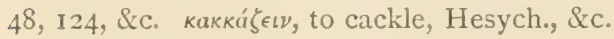

Why the Cock crows : by an affinity for the sun, or rejoicing in heat and light, Heliodor. i. 18. See also Schol. Ar. Av. 830, Cic. De Div. ii. 26. According to Theophrastus (Ae]. iii. 38) in moist localities Cocks don't crow. Paus. v. 25. 9, on the shield of Idomeneus, as a

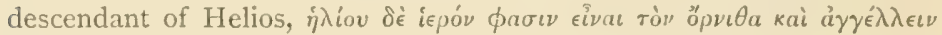
civı́vaı $\mu \epsilon ́ \lambda \lambda$ ovros тoù iุiníov. See also Schol. Diog. L. viii. 34, Plaut. M. Gl. iii. 1. 96, Mart. xiv. 223, Isidor. De N. R. c. 3, \&c., \&c.

How to prevent Cocks crowing, by means of a collar of sarmentum wood, Plin. xxiv. 25.

On hearing a Cock crow, or an ass bray, it is a matter of common prudence to spit, Joh. Chrysost. in comm. ep. S. P. ad Ephes. iv. I2 (vol. xi. p. 93, Montef.): this reference to the ass is used to explain ")

On Fighting Cocks, Aesch. Eum. 866; Plato, Legg. vii.789; Theocr. xxii. 72 ; cf. Opp. Cyneg. ii. I89; cf. Schol. in Ar. Eq. 494, Ach. I65

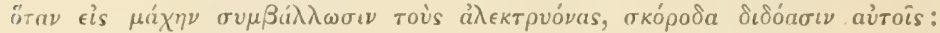
Lucian, Anarch. 37 (2.918), \&c. (See also Xen. Symp. iv. 9, and cf. $\phi v \sigma \iota \gamma \gamma o^{\prime} \mu a \imath$, from $\phi \dot{v} \sigma \iota \xi \xi$, garlic. The annual cock-fight at Athens,

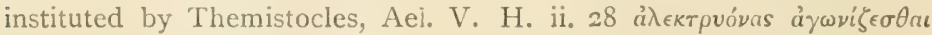

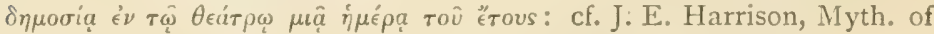
Anc. Athens, p. 278; also at Pergamus, Plin. x. 2I (25). The cockfight was depicted on the High-priest's chair in the Dionysiac theatre (Boetticher, Harrison, \&c.) ; represented also in the Festival Calendar 
$A \wedge E K T P Y \Omega N$ (continued).

of Panaria (iorgopiko at Atixens, as taking place in the month Poseideon, about the end of December (Boetticher, Philologus, xxii. p. 397, I865). As an attribute of January, on a Calendar of the time of Constantius; Graevii Thes. Ant. Rom. viii. 96, Creuzer, Symb. iii.6r6. Ael. N. A.

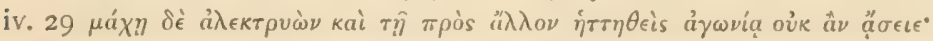

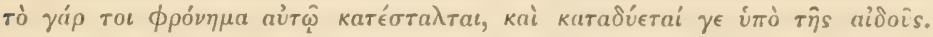

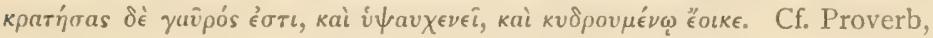
Galli victi silent, canunt victores, Cic. De Divin. ii. 26 ; cf. Ar. Av. 70

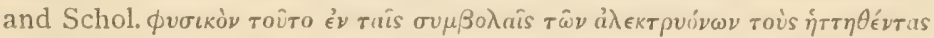

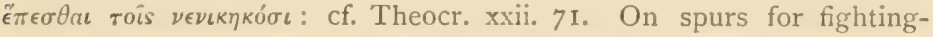
cocks, $\pi \lambda \hat{\eta} \kappa \tau \rho a$, кé $\nu \tau \rho a$, cf. Ar. Av. 760 , and Schol. The table with raised edges, $\tau \eta \lambda i a$, on which Cocks or Quails were pitted against one another (still used in the East), Aeschin. viii. 221, Alciphr. iii. 53, Poll. ix. 108: also $\pi i \nu a \xi$, Plut. Mor. 65 c. It was a matter of duty and of education

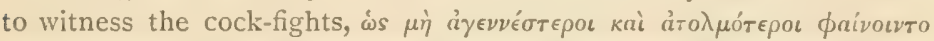

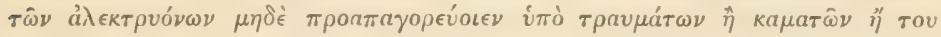

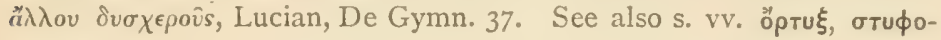
кó $\mu \pi$ ros.

On the marks of courage, Arist. Physiogn. 2, 806b; Plin. x. (56) 77 ; Geopon. xiv. I6.

The fighting-breed of Tanagra, Pausan. ix. 22. 4 (vide infra).

How the Cock fights his own father, Ar. Nub. I427, \&c., cf. Av. 758, 1364 .

How a hen that has defeated the Cock in combat, crows and assumes the plumage of the male, Arist. H. A. ix. 49, 63I b, cf. Ael. v. 5 ; Terent. Phorm. iv. 4. 30 gallina cecinit. On wide-spread superstitions connected with the Crowing Hen, vide Hopf, Thierorakel, pp. I64, I65.

On the pugnacity of the Cock, cf. also Pind. Ol. xii. 20. Aesch.

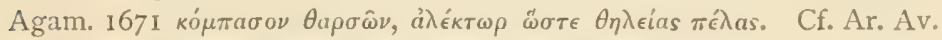

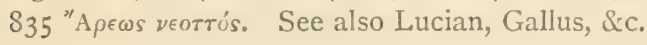

Placed as a symbol of battle on the head of Athene's statue in the Acropolis at Elis, Pausan. vi. 26. 23.

Varieties and Breeds.-Adrian Fowls, Arist. H. A. vi. I, $558 \mathrm{~b} \mu$ нкраi

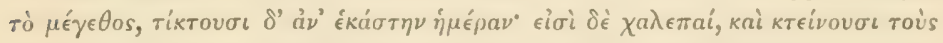

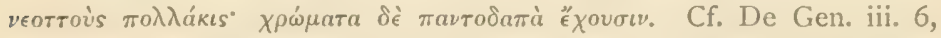
Chrysipp. ap. Athen. vii. 285 E, Plin. x. 75 (53), Hecat. fr. 58, ap. Steph. Byz.

Illyrian Fowls, that lay twice or thrice a day, Arist. De Mirab. I28, 842 b ; cf. H. A. vi. I, 558 b.

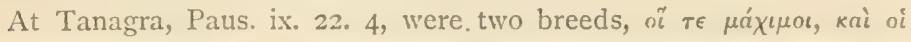

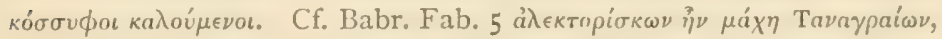

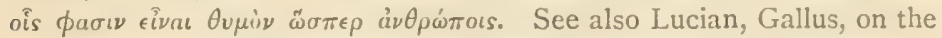

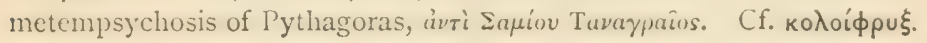




\section{$A \wedge E K T P Y \Omega N$ (continued).}

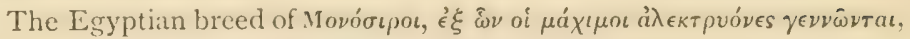
and on their exemplary patience as sitters, Geopon. xiv. 7. 30.

A silent breed at Nibas, near Thessalonica, Ael. xv. 20.

On the breeds of fowls, galli tanagrici, medici, chalcidici, \&ic., see also Varro, De R. R. iii. 9. 3 ; Colum. viii. 27 and 31 ; Plin. x. (21) 24 , (56) 77 .

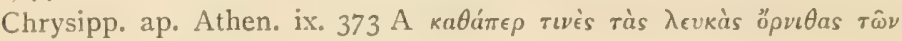

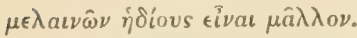

The fatted fowls of the Delians, and Roman laws and practices regarding the same; Plin. x. 50, cf. Columella viii. 2, Varro iii. 9, Cic. Academ. iv.

The large fowls of Ctesias, fr. 57. 3, Ael. xvi. 2, were Impeyan Pheasants; cf. Cuvier in Grandsaigne's Pliny, vii. p. 409, and Yule's Marco Polo, i. p. 242.

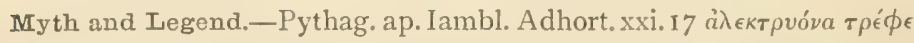

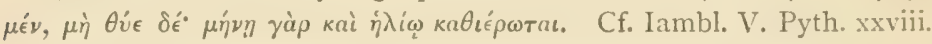
I $47,150, \& c$.

A white Cock sacred to the Moon, Pythag. ap. Diog. L. viii. S. I9,

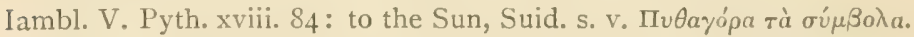

A white or yellow Cock sacrificed to Anubis, Plut. de Is. lx.

The Cock sacred to Athene, Paus. vi. 26. To Hermes, Lucian, Gallus (cf. Montfaucon, i. pl. lxviii, lxxi, Graev. Thes. A. R. V. 7 I 8 A,

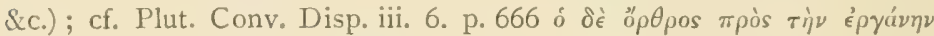

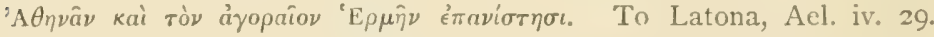
Sacrificed to Mars, Plut. Inst. Lacon. (Mor. 238 F.). Sacred to Demeter, and therefore not eaten at Eleusis, nor by the initiates of Mithra; Porphyr. De Abst. iv. 16. Sacrificed to Nephthys and Osiris on the $13^{\text {th }}$ of Boedromion, and to Hercules and Thios on the 29 th of Munychion, C. I. G. 523, Marm. Oxon. ii. 21, pp. 15, 17.

Dedicated to Aesculapius, Plat. Phaed. I18. See also Artemid. v. 9

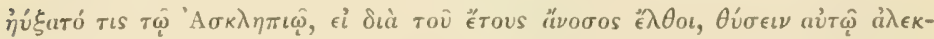
трuóva: also Porphyr. Vit. Pythag. 36, Herondas, Ascl. iv. 12. On the fowl in medicine, Nic. Ther. 557, Cels. v. 27, Diosc. Ther. 19 and 27, Galen and Pliny passim.

Sacrificed to the Household gods, Juv. xiii. 233 Laribus cristam promittere galli ; cf. ibid. xii. 96 .

The Cuthic deity Nergal (2 Kings, xvii. 30) is said to have been represented as a Cock : for which reason Rabbinical writers, according to Gesenius, connect the name with לוגר, tharnegol, a Cock, which word old-fashioned etymologists found hid in Tanagra.

An image dedicated to the Twin Brethren, Callim. xxiv, in Gk. Anthol. i. p. 218 ; cf. Pausan. vi. 26.

How fowls were kept in the temples of Hercules and Hebe, $\epsilon^{\nu} \nu \hat{\eta}$ 


\section{$A \wedge E K T P Y \Omega N$ (continued).}

Ev่p'́r $\eta$, Mnaseas ap. Ael. xvii. 46 ai $\mu \dot{\nu} \nu$ oủ

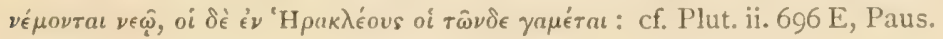
ii. 148 .

Ael. N. A. ii. 30, how a new-purchased cock, if carried thrice round the table, does not seek thereafter to escape. Ib. iii. 3 I, how the lion fears the cock, and how the latter frightens the basilisk to death: for which reason travellers in Libya take a cock along with

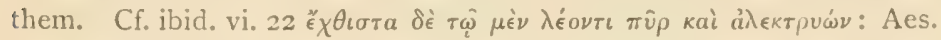
Fab. 323; Plut. De Inv. iv (Mor. 650, 5), Sol. Anim. xxxii (Mor. I20I, 23). Hence also the use of a Cock to destroy the Lion-weed, $\dot{\eta} \lambda \epsilon \cos _{\nu}$ $\tau \in \cos \pi o ́ a=o j \rho \circ \beta a ́ \gamma \chi \eta$, Geopon. ii. 42.3. A confusion is possibly indicated here with the Galli, priests of Cybele; according to Varro, De R. R. c. 20 (Nonius, s. v. mansuetum), when the Galli saw a lion, tympanis ... fecerunt mansuetum: for other important references see Mayor's note to Juv. viii. I76. Note further that a mystical name for the Sun was $\lambda \epsilon \epsilon^{\prime} \nu$, and that those who participated in the rites of Mithra were called Lions; Porphyr. De Abst. iv. I6. Niclas, the learned editor of the Geoponica (ed. I78I), and certain other historians quoted by him, finding that a lion in Bavaria evinced no terror at the sight of a Cock, but killed and ate the bird, still remained faithful to the old tradition, asserting that that lion's spirit must have been broken by captivity: scimus quam vim habeat consuetudo; cum diu in galli vicinia detentus esset, quid mirum, si eum ferre didicerit, \&c. !

Paus. ii. 34. 2 ; at Methana (Troezene) a Cock with white wings was torn in two by two men as a charm to protect the vines from the wind si $\psi$, cf. J. G. Frazer, Folk-lore, i. 163, I890. See on Sacrifices of the Cock, Sir J. G. Dalyell's Darker Superstitions of Scotland, I835; Sir S. Baker, Nile Sources, pp. 327, 335, \&c., \&c.

On ả^єктрионаутєі́, see Lucian's Gallus, De Dea Syr. xlviii, Cic. De Div. ii, Plin. x. (21) 24 ; cf. Mém. Acad. Inscr. vii. 23, xii. 49; Hopf, Thierorakel, pp. $161-163$.

How some cannot abide a cock or a hen, Plut. fr. viii. Io (I2. 23).

The Cock as a weather-prophet, Ael. vii. 7, Plut. Mor. 129A, Theophr. De Sign. i. 17, Arat. Progn. 960 (228), Geopon. i. 3, 8.

How the flesh of a fowl absorbs molten gold, Plin. xxix. 25.

Is hostile to àtrayás, Ael, vi. 45.

\section{Proverb and Fable.}

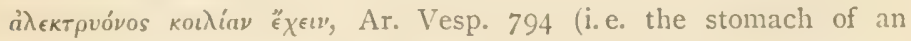
ostrich, to swallow pebbles), cf. Suid.

ả入

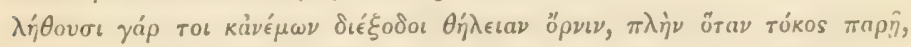
Soph. fr. 424 . 


\section{A^EKTPY $\Omega N$ (continued).}

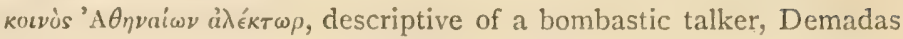
ap. Athen. iii. 99 D.

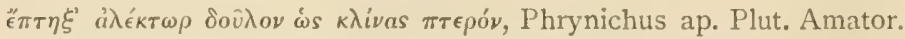

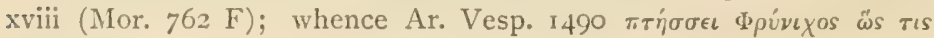

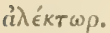

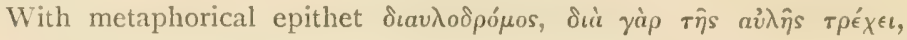
Artemid. iv. 24 ; cf. Ar. Av. 291.

Fable of the Eagle which carried off the Cock crowing over his victory, Aesop, Fab. 2I. The Weasel and the argumentative Cock, ib. 14. The Cock and Thieves, ib. 195. The Cock and Dog, as wayfarers, ib. 225. The two Cocks and the Partridge, ib. 22. See also Babrius and Aesop passim.

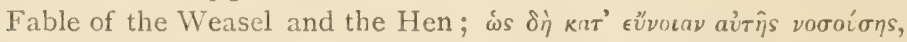

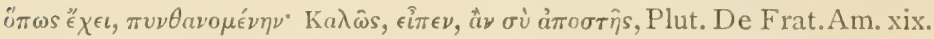

How the plumage of the Cock outshines the raiment of Croesus in

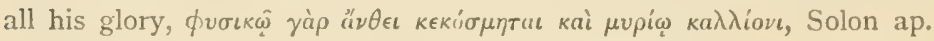
Diog. L. i. 2. 4 .

Representations. - The oldest Coins with the Cock are those of Himera and Dardanus (Imhoof-Bl. and K. pl. v. 38-42) and of Carystus (B. M. C., Central Greece, p. roo, pl. xviii), all of the early fifth century. They recall the Indian Gallus Sonneratii (cf. J. P. Six, in Imhoof-B1. p. 35), or rather the Gallus fermgineus or bankiva of Northern India. Cf. also Blyth's note (Ibis, I867, p. I57) on fowls sculptured on the Lycian marbles (c. 600 B. C.). See also Conze, Ann. de l'Inst., I870, p. 280 , on a Cock represented on an ancient relief of Dionysus and Semele (?), B. C. 580-540. In regard to Himera, it is noteworthy that Pindar's twelfth Olympian Ode, in which the Cock is mentioned, was addressed to Ergoteles, an inhabitant of Himera (cf. Buckton, N. and Q. (4) iii. I3I).

The Cock with the Lion is early and frequent on coins of Asia Minor: with Athena on coins of Leucas, Corinth, Dardanus; also on coins of Ithaca, Zacynthus, Argos, \&c.

On a statue of Athene, Paus. vi. 26 (v. supra); on a statue of Apollo, to indicate sunrise, Plut. De Pyth. Orac. xii. 574 (Mor. 488. 30). On the shield of Idomeneus, Paus. v. 25 (v. supra).

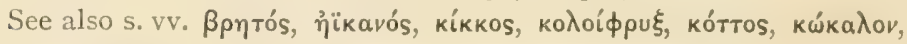

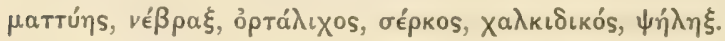

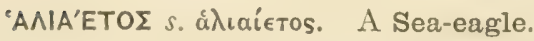

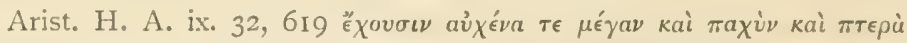

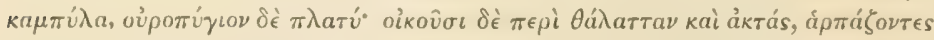

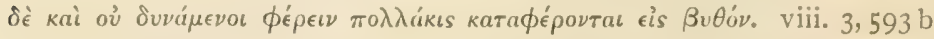

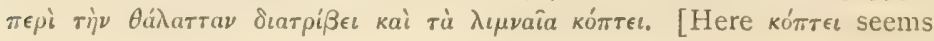




\section{ANIAETOE (continued).}

meaningless and may be an interpolation; $c f$ the next reference.]

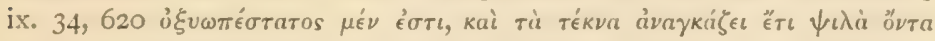

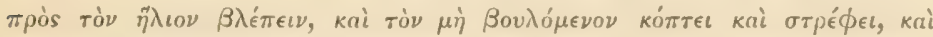
оंтоте́

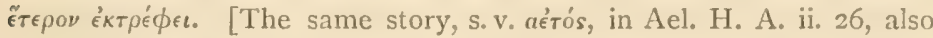

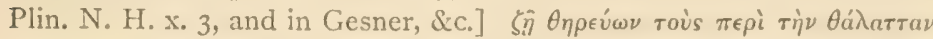

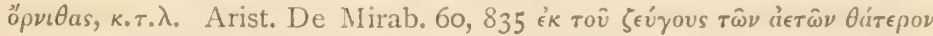

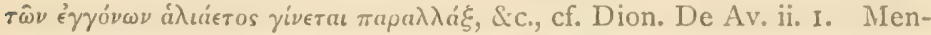

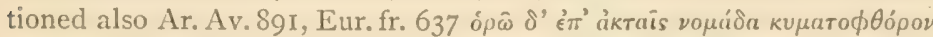

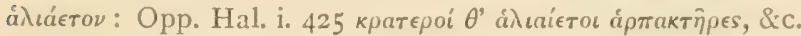

See also Nonn. Dion. xlii. 53I, where åtáєtos, associated with

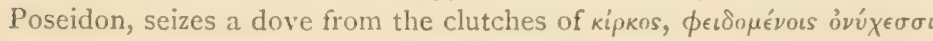

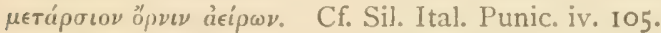

A good omen to fishermen, Dion. De Avib. ii. I.

On the fabled metamorphosis of Nisus or Pandareus see Ovid, Met. viii. 146, xii. 560; Boios ap. Anton. Lib. c. xi; Hygin. Fab. 98; Virg.(?) Ciris 536, and Keller, op.c. p. 259.

Arist. H. A. ix. 32, 6Ig is apparently descriptive of the Osprey,

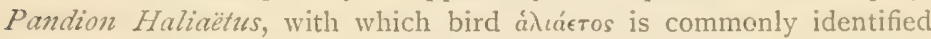
by mediaeval and modern commentators; but the description of the chase after sea-birds (ix. 620) applies rather to Aquila naevia, or Hal. albicilla (Sundevall). A Sea-eagle is very frequently alluded

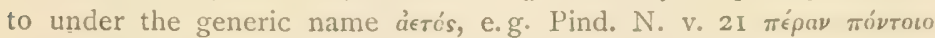

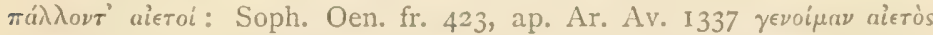

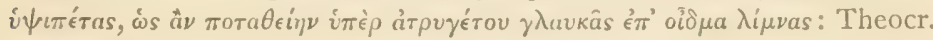
xiii. 24 .

An Eagle with a fish is frequent on coins, e. g. Acragas (Imhoof-Bl. and K. pl. iv. 3I), Sinope (ibid. v. II, I2), and many other towns especially in the Black Sea and Hellespont (Keller, op.c. p. 262).

In all the above references, as in most passages relating to the Eagle, a mystical and symbolic meaning outweighs the zoological. The poem of Ciris is of great importance for the understanding of the myth. It is noteworthy how many birds, or names associated with birds, occur, with more or less obscure significance, in this poem; to wit, Procne, the Daulian maids, Pandion, the Anser Ledae, Haliaetus or Nisus, and lastly Ciris. I accept the theory that we have here to do with an elaborate Sun and Moon myth. The golden or purple lock in Nisus' hair (cui splendidus ostro Inter honoratos medio de vertice canos Crinis inhaerebat, Ov. Met. viii. 8, cf. Ciris 122, Apollod. ii. 4. 5), recalls, on the one hand, the Samson-legend (as we are expressly told by Tzetzes in Lyc, 648), and on the other, the crest of the solar $\epsilon_{\pi \circ} \psi$ or picus, both of which birds appear in the version of the legend given by Boios. The name Nisus is akin to nesher, nisr, an eagle (vide 


\section{AAIAETOE (continued).}

S. V. ảetós), and Nisus or 'A $A$ cíєtos plunges, like the setting Sun, into

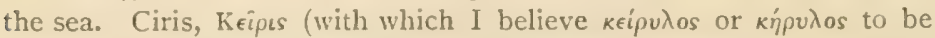
connected), or Scylla is the Moon (cf. Porphyr. De Abst. iii. 17), which, as the watery goddess, appears in some forms of the legend as a fish. The last lines of the poem Ciris are of peculiar importance, where the mutual pursuit and fight of Haliaetus and Ciris are described, and compared with the alternate appearance and disappearance of the opposite constellations of Scorpio and Orion: Quacunque illa levem fugiens secat aethera pennis, Ecce inimicus atrox magno stridore per auras Insequitur Nisus: qua se fert Nisus ad auras, Illa levem fugiens raptim secat aethera pennis: it is the Moon in opposition, the Moon at the full, which (strictly speaking, at the sacred season of the equinox) sets and rises as the Sun rises and sets. Cf. also Cornutus, p. $72 \mathrm{~L}$

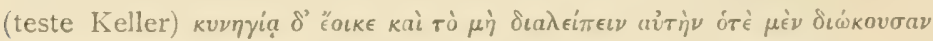

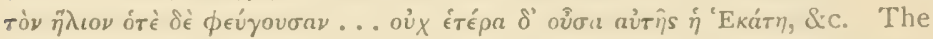
full understanding of the stories of andóv, Procne, Philomela, and the whole Tereus-legend, depends on the further elucidation of this myth. Were it not for the comparison drawn with Scorpio and Orion, we might be rather disposed to refer the description to the Moon in the last quarter, stationed in advance of and as it were in flight before the Sun. The same four lines occur in Virg. Georg. i. 406-409, where I venture to think they are out of place and keeping.

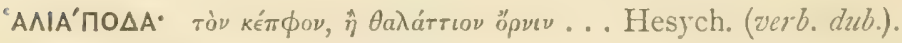

'A^IחOPфYPI' $\Sigma$. A bird, doubtless the Halcyon.

Ibyc. fr. S (13) ap. Athen. ix. 388 D, according to Hermann and Schneidewin. Others read $\lambda a \theta \imath \pi \circ \rho \phi u p i \delta \epsilon s, v$. Bergk, P. Lyric. Gr. iii.

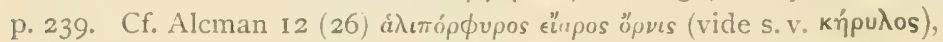
whence Tennyson 'The sea-blue bird of March' (on which, see Whitley Stokes and others, Academy xxv. I884; also Tennyson in Nature Notes, i. p. 93, ii. p. 173, where the Laureate alters the epithet). I am not inclined to admit that $a \dot{\lambda} \iota \pi \rho^{\prime} \phi v p o s$ means sea-blue, nor that it is anything so simple as a mere colour-epithet; cf. å $\lambda$ เáєtos.

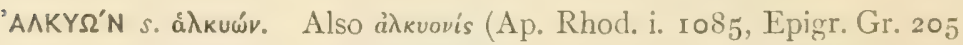

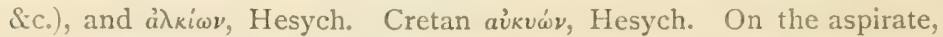
see Förstemann, Curt. Zeitschr. iii. 48. Not from ã $\lambda$ s : cf. Lat. alc-edo.

Probably connected with O. P. halak or harac the Sun, and so akin to $a^{\lambda} \lambda \epsilon \kappa \tau \rho \nu \dot{\omega} \nu$ and $\dot{\eta} \lambda \epsilon \kappa \tau \rho o \nu$, also to ${ }^{\circ} \mathrm{H} \rho \alpha \kappa \lambda \bar{\eta} s$ and to many other proper names, e.g. Alc-inous.

The Haleyon, a symbolic or mystical bird, early identified with the

Kingfisher, Alicio isfrita, L. The Kingfisher is called, in Mod. 
$A \wedge K Y \Omega N$ (continued).

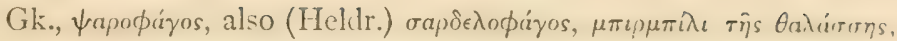

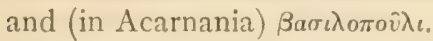

First mentioned in Simon. fr. 12 (ap. Arist. H.A. v. 8, 542 b, Poet. Lyr. Gr., Bergk p. 874, vide infra); Alcman 26 (12), ap. Antig. Mirab. 27;

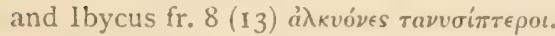

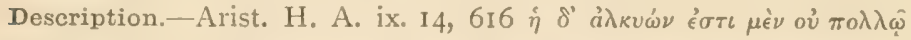

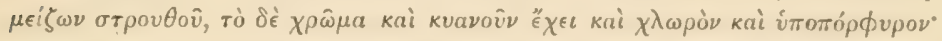

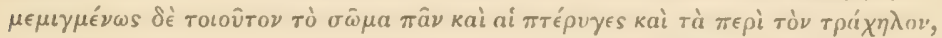

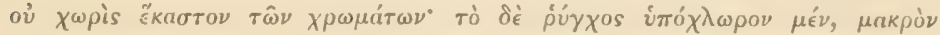

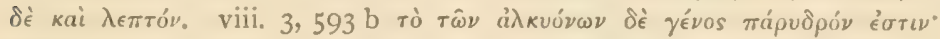

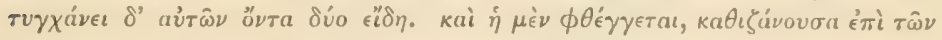

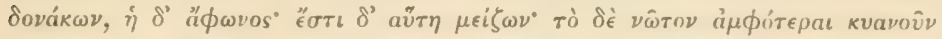

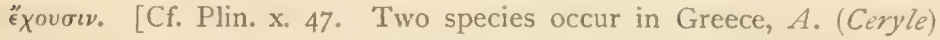

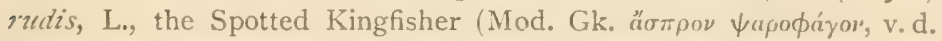
Mühle), principally near the coast, and $A$. ispida, the Common Kingfisher. Sundevall points out that $A$. rudis has not tò $\nu \hat{\omega} \tau o \nu$ kuavoûy, and suggests $A$. smymensis, which does not now occur in Greece (Krüper) but in Asia Minor. Neither of these birds can sing, any more than the common Kingfisher, and the attempt is hopeless to identify the second Aristotelian species with either. The whole matter is confused and mystical.]

On the 'song' of the Halcyon, cf. Tymnes ii (Gk. Anthol. i. p. 256)

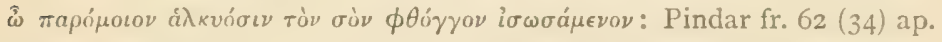

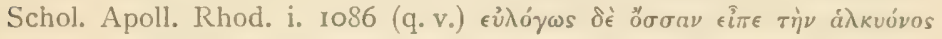

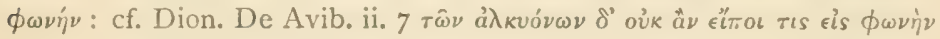

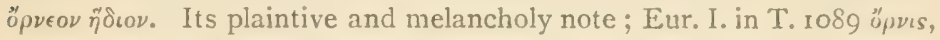

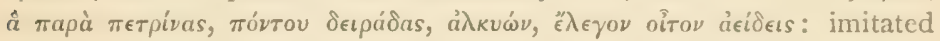

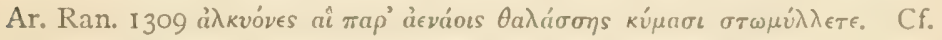

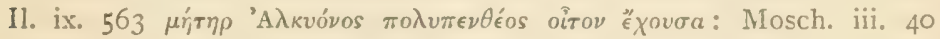

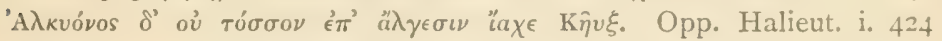

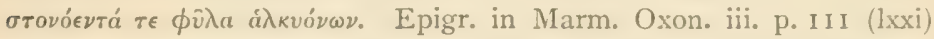

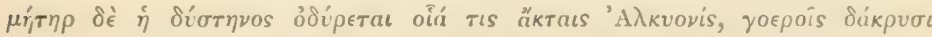
$\mu \nu \rho o ́ \mu \epsilon \nu a$. See also Lucian in Alcyone, Philostr. Imagg. $362 \mathrm{~K}$, Plut. Utr. Anim., Ov. Met. xi, Trist. v. I. 60, Her. xviii. 81, \&c., \&c.; cf.

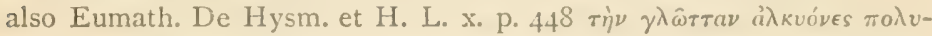

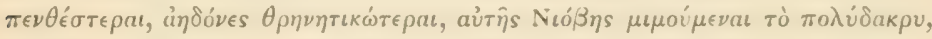

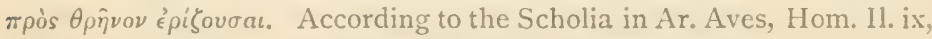

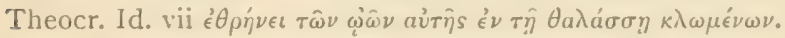

How the females carry the old males on their backs, Ael. vii. I7; cf. Plut. Utr. Anim., Antig. Hist. Mirab. 27. Cf.also Alcman (ap. Antig. 1.c.)

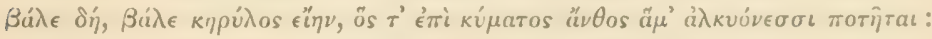

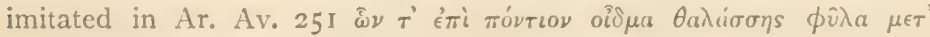

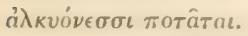




\section{$A \wedge K Y \Omega N$ (contimued),}

Beloved of the Sea-nymphs, Theocr. vii. 59, cf. Virg. Georg. i. 399.

Associated with Pallas, Antip. Sidon. xxvi, Gk. Anth. ii. p. 12 i $\sigma \tau \omega \nu$

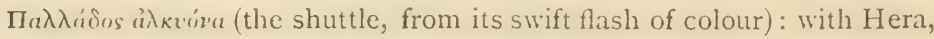
Pindar fr. 1 . c.

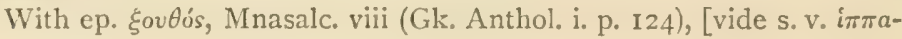
$\lambda \in K r \rho v \omega \dot{\omega}]$.

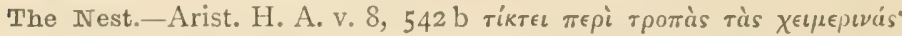

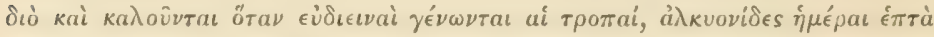

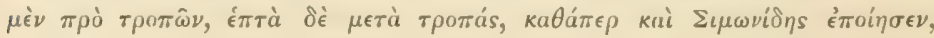

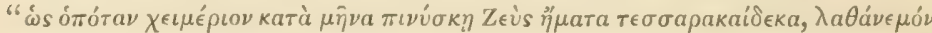

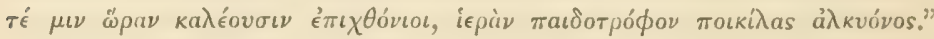

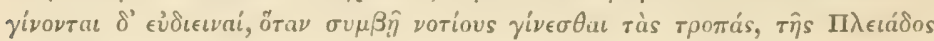

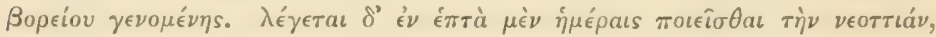

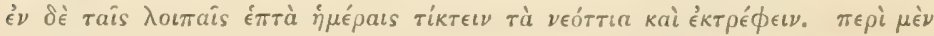

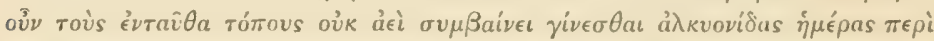

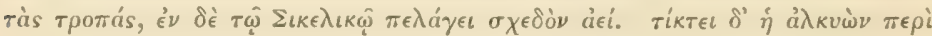

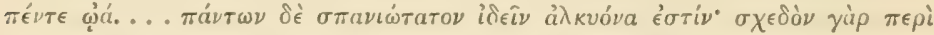

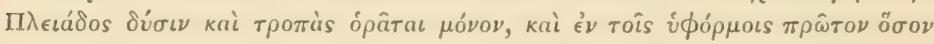

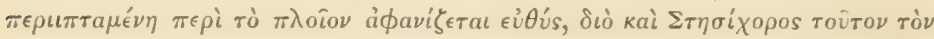

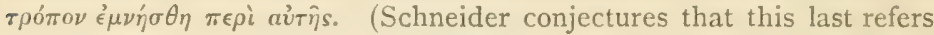
to an Argonautic legend, cf. Apoll. Rhod. i. 1085 and Schol.) The Nest

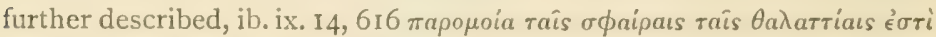

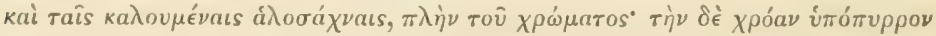

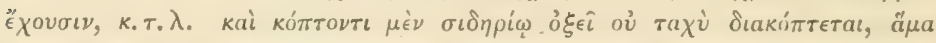

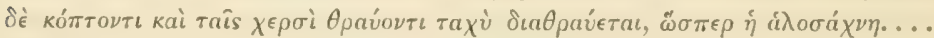

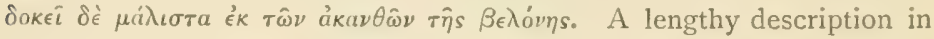
Ael. H. A. ix. I7 : see also Dion. De Avib. ii. 7; Plin. x. (32) 47, (33) 49; Plut. De Sol. Anim. xxxv; Aes. Fab. 29, \&c. Cf. also Callim. xxxi (Gk.

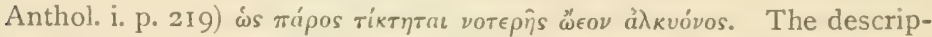

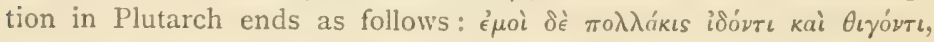

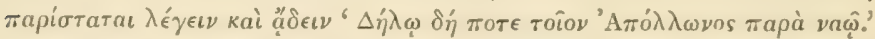

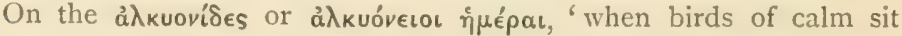

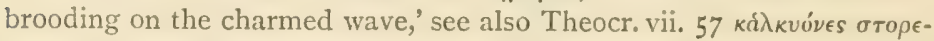

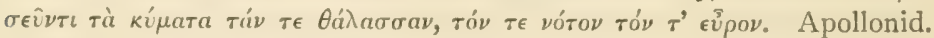

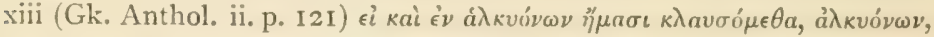

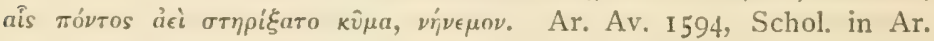
Ran. 1344, Ael. i. 36, Philoch. 180, Plut. Sol. Anim, p. 983 , Quaest. Graec. pp. 1809, I810, Apoll. Rhod. i. I086, Plin. x. (32) 47, xviii. (26) 62, xxxii. (8) 27, Aul. Gell. iii. Io, Sil. Ital. xiv. 275, Plaut. Poen. I45, Casina, prol. 26, Diosc. iv. I36, Alciphr. i. I, Lucian Halc. 2, Ovid Met. xi. 745, Colurn. xi. 2, Dion. De Avib. ii. 7, Carm. De Philom. 383. On the number of the Halcyon days, see, in addition to the above, Suidas, according to whom Simonides made them eleven (v. supra), Dema- 
A^KY $\Omega N$ (continued).

goras seven, and Philochorus nine. See also references in Bochart, Hieroz. ii. 861 .

On the myth of Alcyone and Ceyx, cf. 11. ix. 563 (where the bird is not mentioned, but cf. Heyne, in loc.), Lucian, Halcyon. 2, where Alcyone and Ceyx descend from the Morning Star, Ovid, Met. xi. 410, Apollod. I. vii. 4, Serv. ad Virg. Georg. i. 399, Lutat. ad Stat. Theb. ix. 36r, Tzetz. ad Lyc. p. 69, \&z.

The myth of the Halcyon days is unexplained. The above statements have no zoological significance: the Kingfisher neither breeds at four months old, nor lays five eggs (but rather six or seven), nor nests in the winter season, nor on the sea. I conjecture that the story originally referred to some astronomical phenomenon, probably in connexion with the Pleiades, of which constellation Alcyone is the principal star. In what appears to have been the most vigorous period of ancient astronomy (not later than 2000 B.C., but continuing long afterwards to influence legend and nomenclature), the sun rose at the vernal equinox in conjunction with the Pleiad, in the sign Taurus: the Pleiad is in many languages associated with bird-names (cf. Engl. 'henand-chickens,' see also s. v. $\mu$ épo $\psi$ ), and I am inclined to take the bird on the bull's back in coins of Eretria, Dicaea, and Thurii for the associated constellation of the Pleiad. (Note, as a coincidence, the relation of Alcyoneus to the heavenly Bull in Pind. I.v. 47 ; ubi Schol. ßочßótay

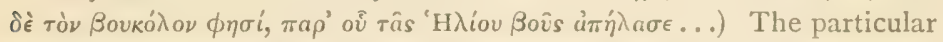
bird thus associated with Taurus may vary; on some of the abovementioned coins, where it is certainly not a Kingfisher, it is taken by Canon Tristram (Ibis, I893, p. 215) to be a Tern; to me it seems rather to be the Swallow, figuring as the bird of spring; (on the cognate symbolism of the Dove, see S. v. $\pi \epsilon \in \epsilon \iota \alpha$ ). The Halcyon is said by Canon Tristram (1. c.) to have been the sacred bird of Eretria; I cannot find a direct statement of the fact. Suidas definitely asserts that the Pleiades were called ' $\Delta \lambda \kappa$ кóves. At the winter solstice, in the same ancient epoch, the Pleiad culminated at night-fall in mid-heaven,

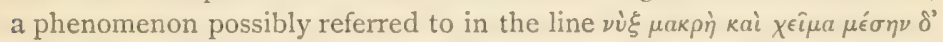

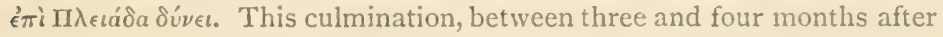
the heliacal rising of the Pleiad in Autumn, was, I conjecture, symbolized as the nesting of the Halcyon. Owing to the antiquity and corruption of the legend, it is impossible to hazard more than a very guarded conjecture; but that the phenomenon was in some form an astronomic one I have no doubt. [It might for instance refer more directly to the Sun, which anciently began its annual course at the spring equinox when in conjunction with the Pleiads, and which at the winter season, when in the lowest part of its course, might be said to brood upon the sea, only beginning its ascent a week after the actual 
$A \wedge K Y \Omega N$ (continued).

tropic (cf. Ptolemy, ap. Petav. iii. 54, Kal. Jan.: Sol elevari incipit)]. The risings and settings of the Pleiads and of the Dogstar were apparently the chief landmarks of the ancient year, and in this con-

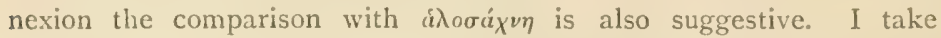
'i $\lambda n \sigma(i \chi \nu \eta)$ to be a corruption, by 'Volksetymologie,' of the Egyptian $\sigma o \lambda \epsilon \chi^{\prime}{ }^{\prime}$, the Dog-star. Cf. Chalcid. in Timaeum Plat. f. cxxiv, ed. Fabr., Cum hanc eandem stellam àoтрокívov quidam, Aegyptii vero $\sigma o \lambda \epsilon \chi^{\prime}$ v vocant (v. Jablonsk. in Steph. Thes, and cf. Leemans in Horap. i. 3). The common Egyptian name for the Dog-star is Sothi,

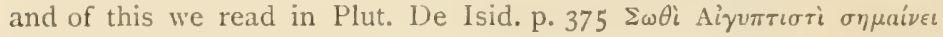

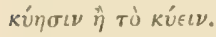

The birds anciently associated with the season of the vernal equinox are, with the exception of the Nightingale, associated with St. Martin in modern times; viz. the House-martin or Martlet (cf. $\chi \epsilon \lambda \iota \delta \omega \nu$ ), the Harrier (cf. кipkos), Fr. oiseau St. Martin, and the Kingfisher, Fr. martin-pêcheur. It is precisely the same birds, with the addition of the solar Hoopoe and Woodpecker, and with the substitution of

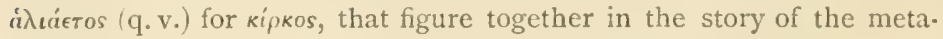
morphosis of Pandareus; Boios ap. Anton. Lib. Met. xi.

In the calendars ascribed to Geminus (?), Columella and Ptolemy (?), the Halcyon days are placed in the end of February or beginning of March. I cannot account for this discrepancy, which is clearly at variance with the older tradition; unless indeed the phrase had lost its meaning and was simply transferred to the season of the migration of birds.

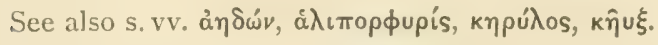

Note.-On the mystical element in the stories of $\alpha^{\prime} \lambda \kappa v \dot{\omega} \nu$ and $a^{\prime} \eta \delta \dot{\omega} \nu$

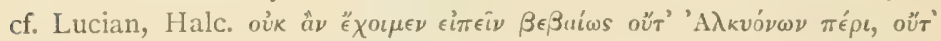

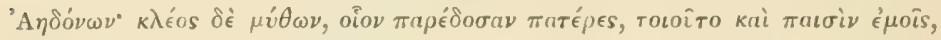

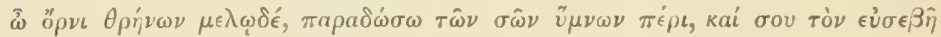

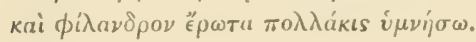

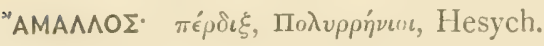

'AMmEnI's. An unknown bird. Ar. Av. 304. Cf. Poll. vi. 52.

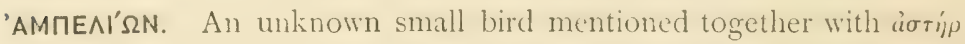
(q.v.), with epithet коифótatos. Taken as identical with a $\mu \pi \epsilon \lambda$ is:

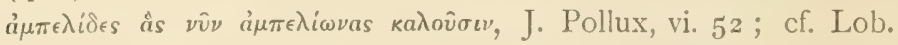
Prol.p. 49. In Mod. Gk. ả $\mu \pi \lambda$.

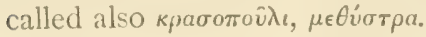

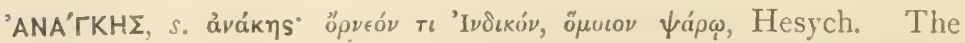
name is strongly suggestive of the Arabic and Syrian Anka or 


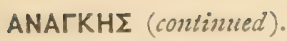

Onka, which is said to be identical with Simurgh, the magical bird of the Persians, and which is believed further to come into relation with Athene "O $\gamma \kappa a$; cf. Von Hammer-Purgstall, Wien. Jahrb. d. Lit. xcvii. I26, Creuzer, Symb. iv. 397, Boch. Hieroz. ii. SI2, 852 . Vide s. v. ökvos.

"ANeor. An unknown small bird. The name does not occur in Nod. Gk., and like so many of the bird-names mentioned in a non-scientific or fabulous sense, is probably an exotic.

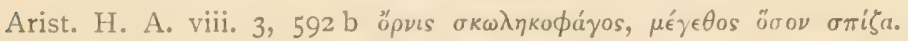

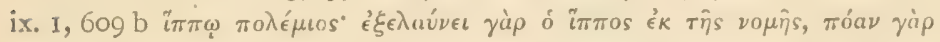

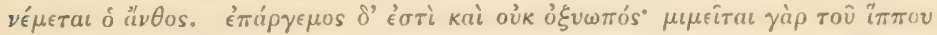

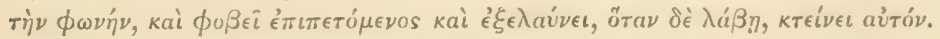

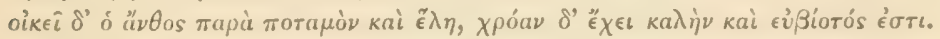

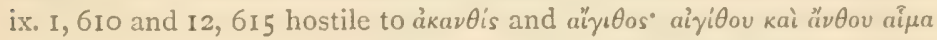

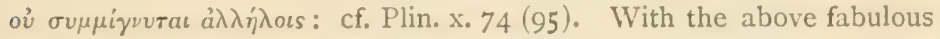

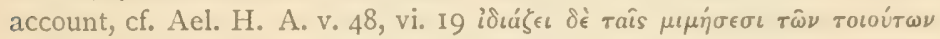

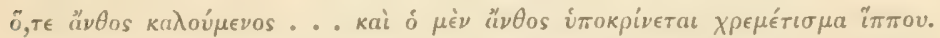
Also Plin. x. (47) 52 ; see also Boios ap. Anton. Lib. c. 7, where Anthus is a son of Autonous and Hippodameia, killed by his father's horses, and metamorphosed into the bird ${ }^{\prime} \nu 00 \mathrm{~s}$. In Phile 705 it is the fish avtias that is said to be hostile to the horse.

Note.-As indicative of the mythical, fabulous, and probably exotic

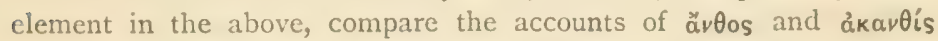

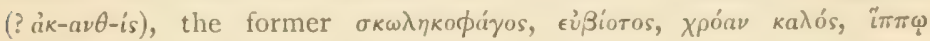

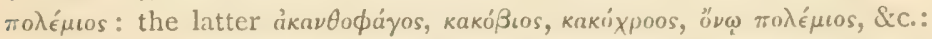

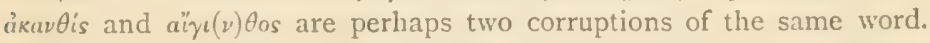
Though the bird cannot be identified, and though it is more than doubtful whether it was ever known to the Greeks, yet Sundevall's identification of "ü 0 os as the Yellow Wagtail, Motacille flava, L., deserves to be recorded. This hypothetical identification is based on the brilliant colour (which according to v.d. Mühle is more brilliant in Greece even than in N. Europe) and on the localitics frequented. The Yellow WVagtail frequently consorts with the cattle at pasture, feeding on flies; it may indeed have become associated with the above fable, the origin of which, however, is doubtless more deep-seated and obscure.

'ANOMAIA. I hird assnciated with Alheme, [xsilly the Night-Heron.

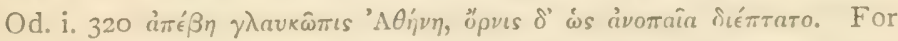
various explanations and Scholia, see Steph. Thes. (ed. 182I), Lidd. and Sc., S.c. According to Rumpf, De aedibus Homericis, ii. p. 32, Giessen, 1857, Netolicka, Naturh. aus Hom. p. II, Buchholz, Hom. 
ANOMAIA (continued).

Realien, p. 126, the Swallow, from its passing in and out through the

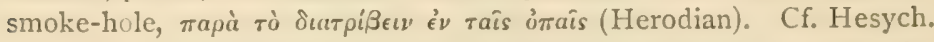

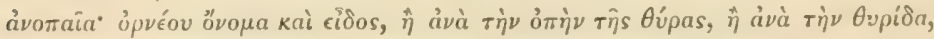

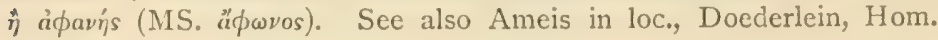
Gloss, \&ic.

Bochart, Hieroz. ii. 337, suggests (not for the first time, for the statement is made in early Hebrew dictionaries) a connexion with Hebr. $7 \Xi 25$ anaphah, which he supposed to be a species of eagle, partly perhaps to make it fit in with the interpretation, common in his time, of a vomaia. But according to Lewysohn (Zool. d. Talmuds, p. I09), with whom Tristram agrees, anaphah is rightly translated Heron (Lev. xi. 19), which seems to me to lend support to the hypothesis that a'voraia is identical with it. Cf. épwớós, Il. x. 274.

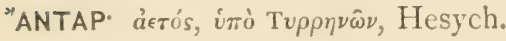

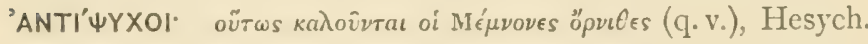

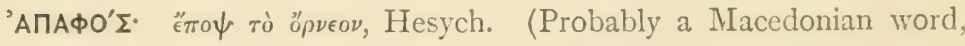
Schmidt in Hesych.; or more likely Egyptian, vide infra, s. v. ध̈

"AחOYs. A bird of the swallow kind. Probably including the Swift, Cypselus apus, L., and Hirundo rupestris, Scop., the Cliff

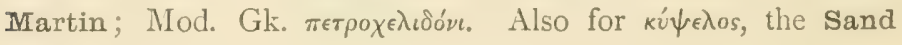
Martin.

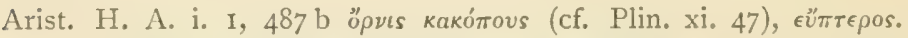

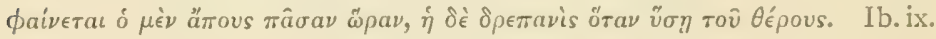

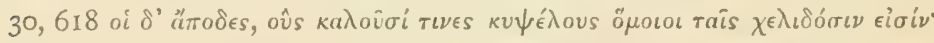

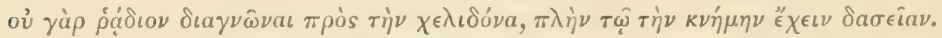

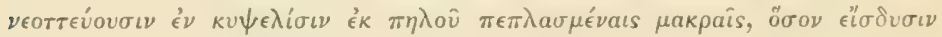

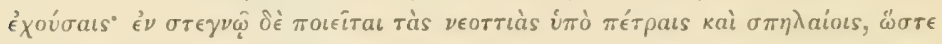

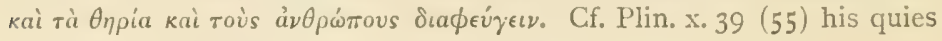
nisi in nido nulla, \&c.

The name is traditionally identified with the swift, Cypselus apus, L. As regards the former passage (which is doubtfully authentic) it appears that $H$. rupestris is the only bird of the Swallow kind which is a permanent resident in Greece (Krüper p. 255, \&c.), though Erhard (p. 46) says that Swifts winter in the Cyclades. The second passage is corrupt, and contains two different accounts of the nest (cf. Sundevall p. I30). H. rupestris builds solitarily, on the face of

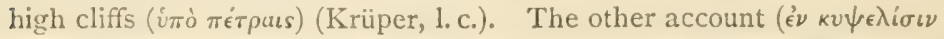

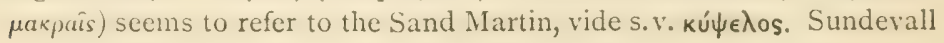




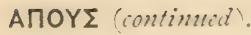

takes ämous to be the Swift: Aubert and Wimmer (p. III) take it to be the House Martin (Hirundo urbica L.). The name $\pi \in \tau \rho o \chi \in \lambda$ เón applies in Mod. Gk. both to H. rupestris and to the Swift (Heldreich).

"APAKOs. An Etruscan word for a Hawk. äракоs" iśpak, Tuppquó, Hesych. Said to be a Lydian word, Jablonsk, in Steph. Thes. Cf. $\beta a ́ p \beta a \xi$.

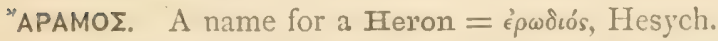

'APrIo'noy s, s. ápyimous. A Macedonian name for the Eagle, Ireych.

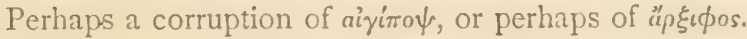

'APHTIA' $\triangle E \Sigma^{\prime}$ OPNIOEE. Fiabulous birds, which shot forth their feathers like arrows: doubtless an astronomical emblem. Apoll. Rhod. ii. $1035^{-1052 . ~ C f . ~ K i n g ' s ~ A n t . ~ G e m s ~ p . ~} 330$.

'APNEYTH'P. [Cf. Lat. urinator, a diver, Sk. vâri, water (Curt.).] Supposed to mean a diving bird, diver or grebe (Colymbus).

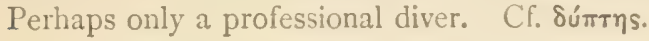

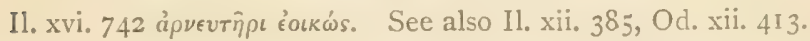

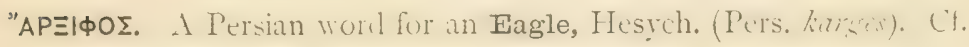
åpүเómous.

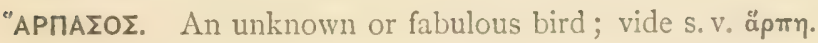

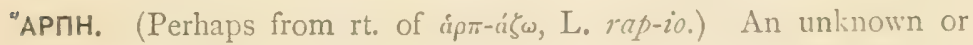
fabulous bird.

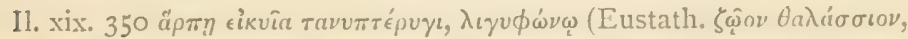

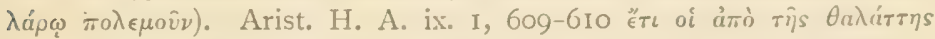

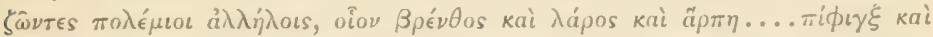

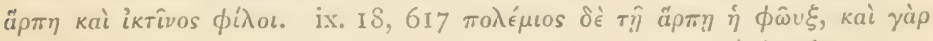

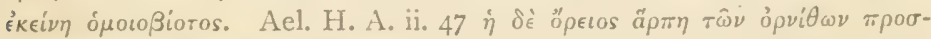

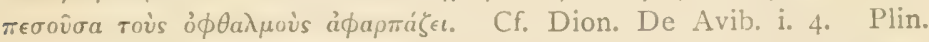
x. 95 (74) Dissident harpe et triorches accipiter. Harpe et milvus contra triorchem communibus inimicitis. The wife and son of Cleinis

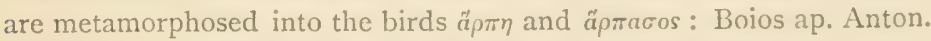
Lib. Met. 20. According to Hesych., å $\rho \pi \eta$ is Cretan for ikrivos.

Places ivy, kíroos, in its nest for a charm, Ael. i. 35, Phile 729, Geopon. xv. I.

The word is poetical. Dionysius (1. c.) refers to the Lämmergeier. Some mediaeval commentators (e.g. Gesner) take Harpe and Milvus (ikтivos) to be identical in Arist. and Plin. 11. cc., as does also Tzetzes,

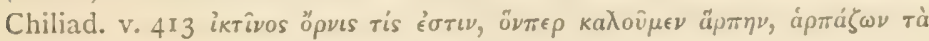


APחH (continued).

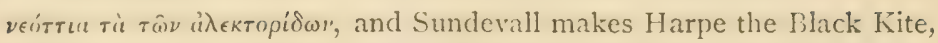
Milvus ater, or M. parasiticus. Aubert and Wimmer suspect á $\rho \pi \eta$ to be a large Gull (Larus). For other hypotheses, vide Buchholz p. I37.

'A BHNOI' öp

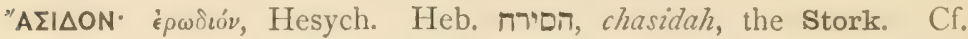
Boch. Hieroz. ii. $3^{21-326 .}$

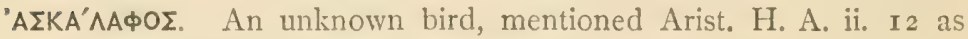
possessing colic coeca (ámoфváors).

Usually translated Owl, from the story of the Metamorphosis of Ascalaphus, Ovid, Met. v. 539 Foedaque fit volucris, venturi muncia luctus, Ignavus bubo, dirum mortalibus omen. Cf. Apollodor. ii. p. 107

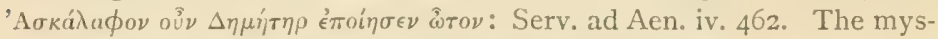
tical aspect of the story is briefly indicated by Creuzer, Symbolik, iv. 378. [Quaenam sit avis, neque ex Aristotele neque ex Plinio aut ex Aeliano deprehendere potuimus. Sed Ovidius inter fabulas ostendit esse bubonis speciem : Scaliger in Arist.]

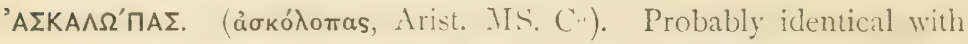

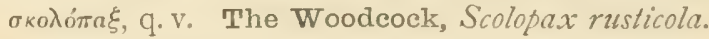

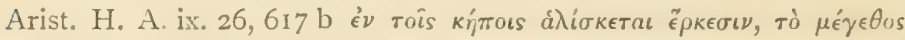

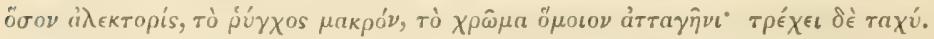

The Woodcock according to v. d. Mühle and Lindermayer is very abundant in Greece in November. Aubert and Wimmer rather identify årà

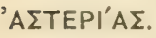

I. An Eagle $=\chi$ pvбáєтos, Ael. ii. 39. In Arist. H. A. ix. $3^{6}$,

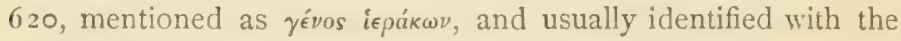
Goshawk.

Cf. Scaliger in Arist. p. 249: ảotepía vertit Theodosius stellarem ... årepíu igitur puto nostrum asturcm: ut enim punctis quibusdam tanquam stellis totus pictus in pectore. This identification, though adopted by Sundevall, is inacceptable. airtepias is said to be the largest of the eagles, and to feed on fawns, cranes, and in Crete, bulls;

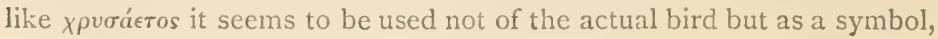
probably astronomical.

II. A bird of the Heron kind, supposed, for a similar and equally unsatisfactory reason, to be the Bittern, Ardea stellaris, L.

It is only mentioned in connexion with an Egyptian myth, probably relating to the Stork; and the name itself is in all probability foreign

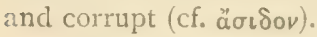




\section{AITEPIAE (continnted).}

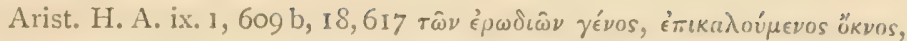

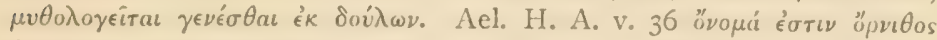

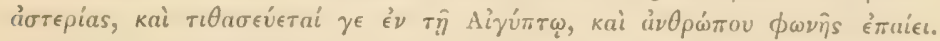

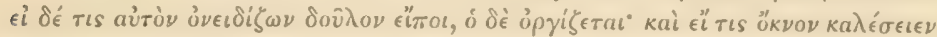

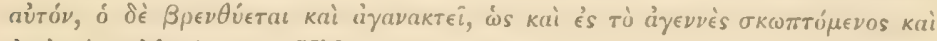

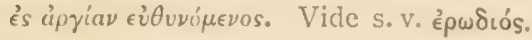

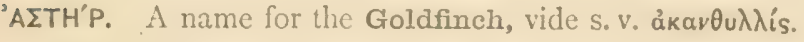

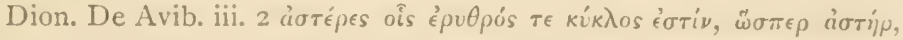

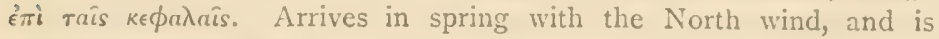
caught with bird-lime.

'AsTPATANI'NOE. An unknown small birl, mentioned alengr with the foregoing, with epithet raxús. Perhaps a synonym of àrtíp: Belon (cit. Bikélas) has It. stragalino $=$ Goldfinch, but, according to Giglioli, the word is not known in any modern Italian dialect.

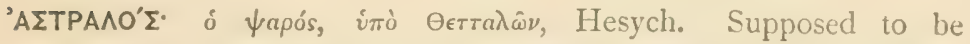
akin to L. stur-mu-s (Curt.), L, paru-s (Fick), O. H. G. sprâ, \&c.

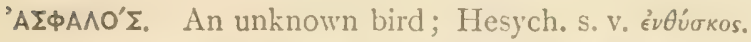

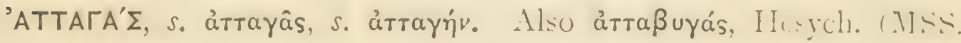

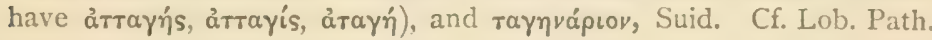
i. p. 142. Athen. $388 \mathrm{~B}$ notes the accent as an exception, and the

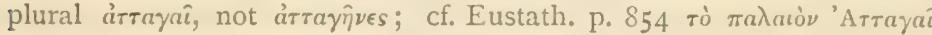

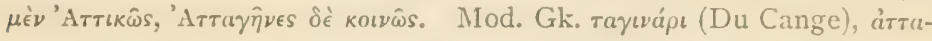

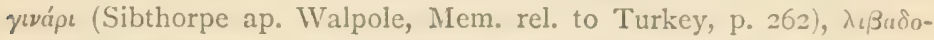

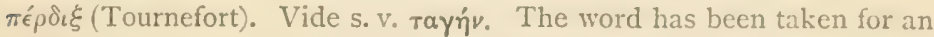
Egyptian one, from the phrase 'Arrayas Aiyurtius, Clem. Alex. Paed. ii. I. p. I40 ; cf. Sturzius De Dial. Aeg. p. 86, ap. Steph. Thes. p. clxxiii.

The Francolin, Tetrao francolinus, L. See Lilford, Ibis, I862, p. $35^{2}$.

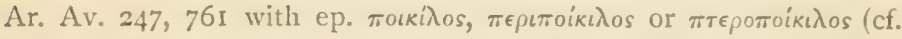

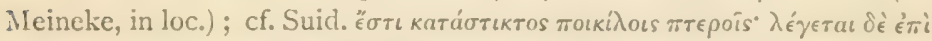

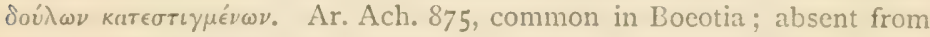
Crete, praeterquam in Cydoniatarum regione, Plin. x. $58\left(\delta_{3}\right)$. Arist.

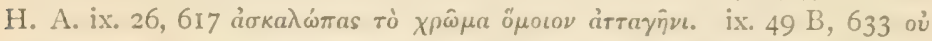

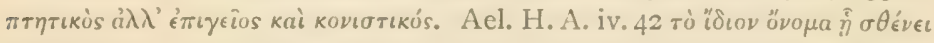

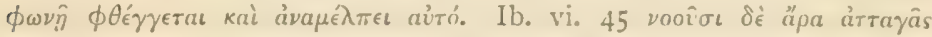

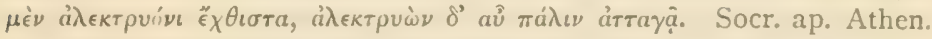
ix. $387 \mathrm{f}$, how the arrayas in Egypt said in times of famine rpis rois кaknúpyous kaká (vide Casaub. in Athen. ii. p. 420, ed. 1600); cf. Ael

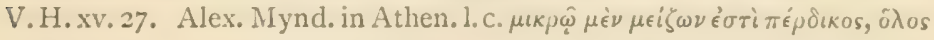


ATTATAE (continued).

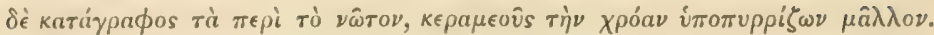

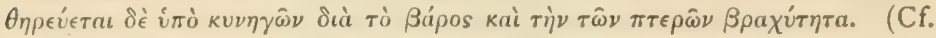

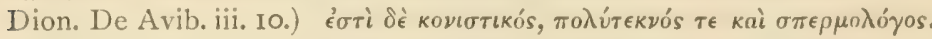

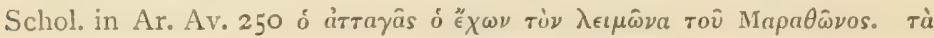

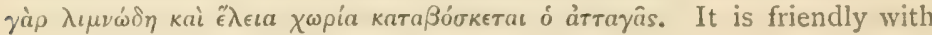
the stag, Opp. Cyneg. ii. 404.

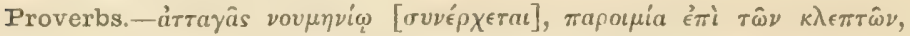

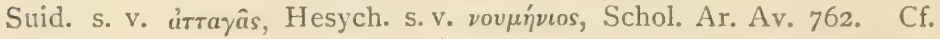
Timon ap. Diog. L. ix. 16. 6, Paroem. Gr. i. p. 307, ii. pp. I6, 2 I 2 (Scaliger

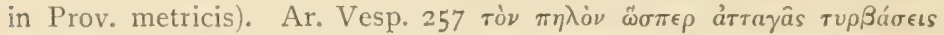

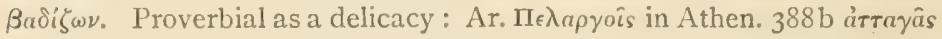

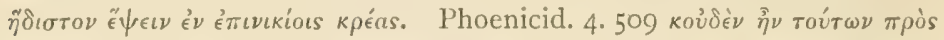

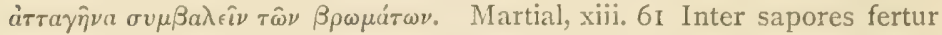
alitum primus, Ionicarum gustus attagenarum. Cf. Ovid, F. vi. 175, Hor. Epod. ii. 54 ; Plin. x. 48 ; Apicius, De Re Coquin. vi. 3 ; Aul. Gell. Noct. Att. vii. 16, \&c. Mentioned also, Hippon. fr. ap. Athen. 1. c.

The Francolin does not now occur in Greece or Italy, though it is found in Crete, Cyprus, Sicily, Malta, and on the southern shores of the Black Sea (Lindermayer p. 125). On this account, Sundevall and

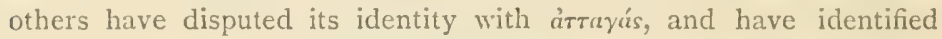
the latter with various birds, especially Perdix cinerea, the Common (or Northern) Partridge; C. T. Newton, Cont. Rev. 1876, p. 92, taking it to be Pterocles alchata, a species of Sand-grouse. The descriptions, especially that of Alex. Myndius, point distinctly to the Francolin, and even Lindermayer does not doubt that the name is to be so interpreted, and that the bird was formerly abundant. The record by Sibthorpe of the modern Greek name, which I cannot find in more recent writers, suggests that the bird has only lately disappeared from Greece. According to Danford (Dresser, Birds of Europe, vii. p. 124) it is fast disappearing in Asia Minor also: likewise in Cyprus (Guillemard, The Field, Sept. 1 $\delta 92$ ). The general disappearance of the Quail in recent years from England is a parallel case.

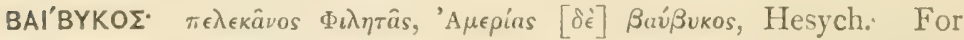
other readings, v. Steph. Thes. ii. coll. 40, 4I, and Schmidt's Hesych. i. pp. $35^{2}, 3^{66}$.

BAIH'O. An Egyptian name for a Hawk.

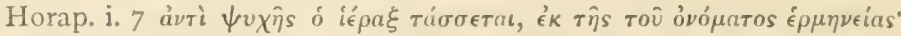

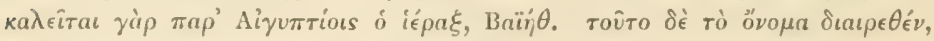

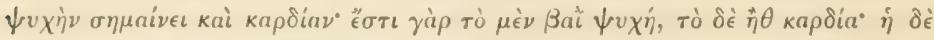

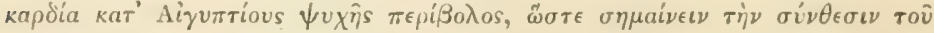

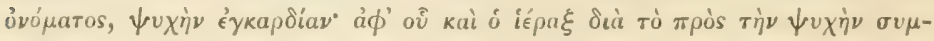


BAIHO (continued).

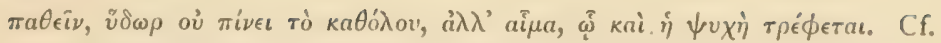
Leemans in Horap. p. 151, and in particular Lauth, Sitzungsber. Bayer. Akad., 1876, p. 78 ; the hawk enters as a phonetic or alphabetic element into the hieroglyphic spelling of $b a i ̈$ or $b a$, and in the second place becomes associated with the symbolic meaning of the word. I suspect that $\beta$ aiß $\beta$ vos is closely allied, especially as a bird like a pelican is figured instead of a hawk in an alternative spelling of the syllable ba. The Egyptian representation of the Soul as a Hawk is also mentioned

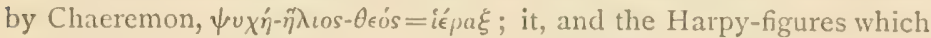
represent the disembodied soul are interesting in connexion with Plat. Phaedr. p. 246 ; cf. Jomard, Descr. de l'Eg. Antiq. vol. ii. pp. 366, 38r, Bunsen, Egypt's Place in History, v. I35, R. Brown, jun., Dionys. Myth. i. 340, \&.c.

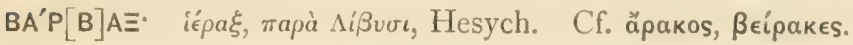

BAPI'THI. An unknown small bird. Dion. De Avib. iii. 2.

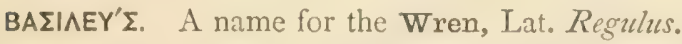

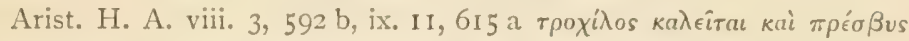

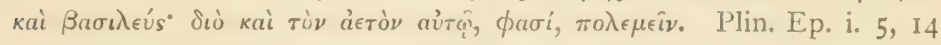
regults omnium bipedum nequissimus; cf. Plin. H. N. viii. 37 . See also Carm. de philomela v. 42 Regulus atque merops et rubro pectore progne Consimili modulo zinzinulare sciunt. Vide s. vv. $\beta \alpha \sigma i \lambda i ́ \sigma k o s$,

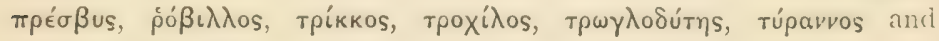
especially oै $\rho \times \iota \lambda$ os.

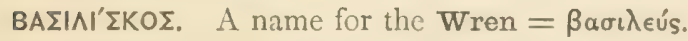

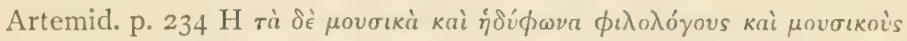

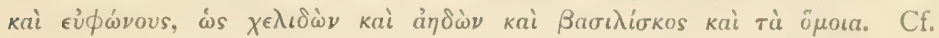

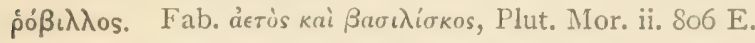

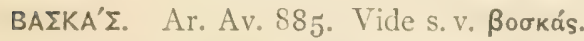

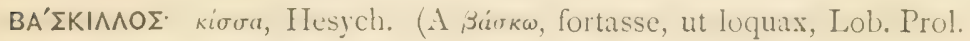

p. I 20.)

BATI' $\Sigma$. An unknown bird.

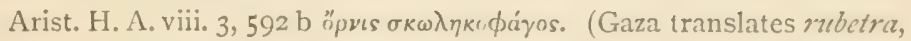
as if from $\beta$ íros, a name like our 'brambling,' and apparently supposed the bird to be the Stonechat, the traquet of Belon, to which bird, Saxicola mbetra; L., his name is still applied.)

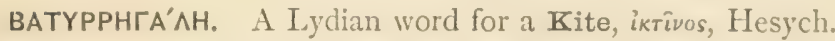

BEI'PAKE: ¿épakes, Hesych. Possibly for Fı́pakes.

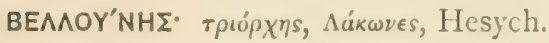




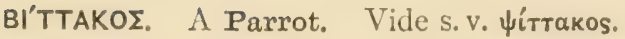

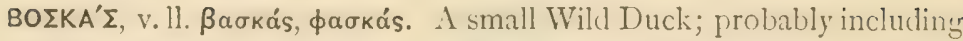
the Teal (Anas crecca) and Garganey (A. querquedula), both common in Greece; and in Athenaeus also a larger species.

ßaбkás, Ar. Av. 885 .

Bookás, Arist. H. A. viii. 3, $593 \mathrm{~b}$ mentioned among the heavier

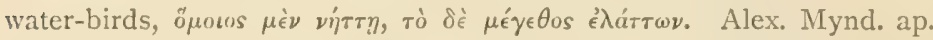

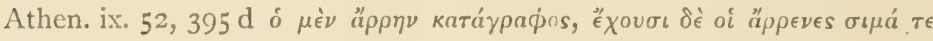

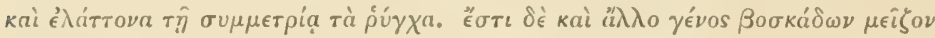

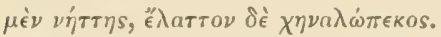

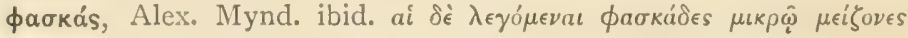

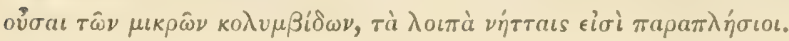

BOY $\triangle Y^{\prime} T H \Sigma$. An unknown small bird, mentioned Dion. De Avib. iii. 2, with epithet $a \dot{\sigma} \theta \epsilon \dot{\eta} s$.

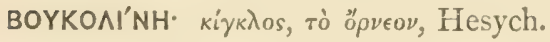

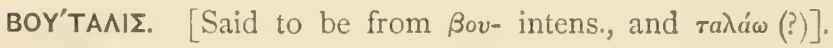

The Nightingale, in Aesop 235.

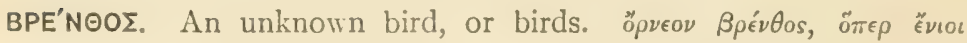

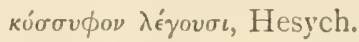

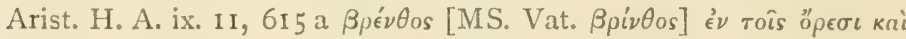

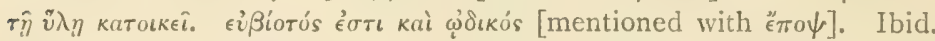

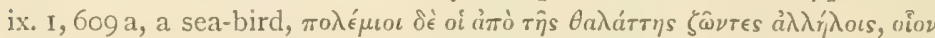

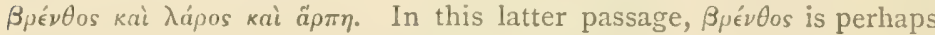
a later interpolation; cf. branta, the Brent Goose.

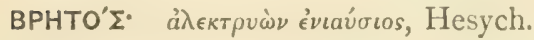

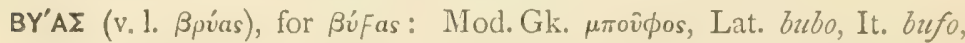
Sp. buho, O.H.G. uiwo, Germ. uhu. [Cf. Lith. bub-auti, to shriek, Fick i. 685 , ii. 620 .]

An Owl, especially the Eagle Owl, Strix bubo, L., Bubo maximus, Bonap.

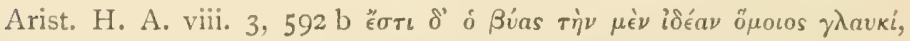

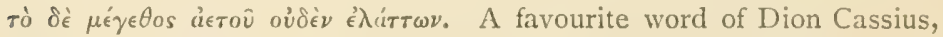
usually as a bird of evil omen, e.g. lvi. 29 Búas $\epsilon^{\prime} \beta v \xi \epsilon$, also xl. 17, 47, xlii. 26, 1. 8, liv. 29, lvi. 45, \&c. Cf. Bubo, Virg. Aen. iv. 462, and Serv. in loc., Plin. x. (12) 16, Ovid, Met.v. 550, vi. 431, x. 453, xv.791, Seneca, Herc. F. 686, \&c.

The Owl, bubo, in medicine and magic, Plin. xxix. 26 and 38 ; its egg also is valuable, but difficult to obtain: quis enim, quaeso, ovum 
BYAE (continued).

bubonis unquam videre poterit, quum ipsam avem vidisse prodigium sit ?

The Eagle Owl is not rare in Greece (v.d. Mühle, Lindermayer), and is still called $\mu \pi$ rov $\phi o s$ or yoûße.

BY'ZA = Búas. Nic. ap. Anton. Lib. ro, where the daughters of

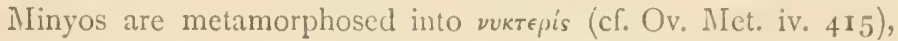

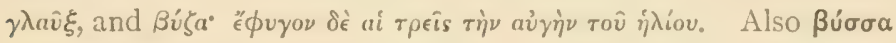

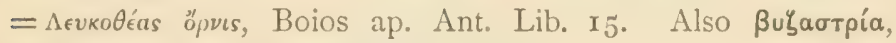

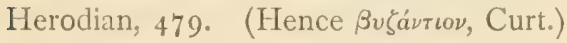

BY'TOAN rò $\psi$ qápa, Hesych.

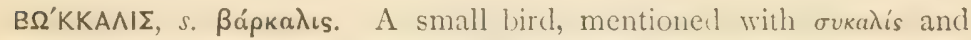
others in a list of presents to the Indian king, Ael. xiii. 25.

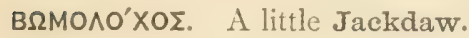

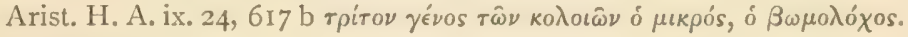
See кoגotós.

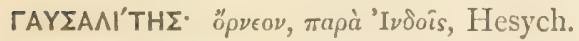

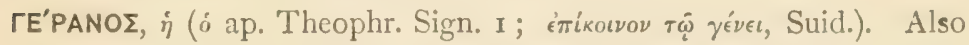

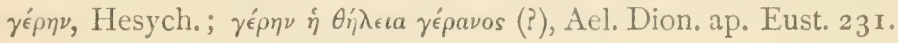
35 ( 175 ); cf. Lob. Prol. p. 49.

Etymology doubtful: according to Curtius, from rt. gar, to cry. Cf. Lith. garny, Bret. garan, O. H. G. chranuh, Germ. Kranich, Kran, Armen. Kr'mnk, Eng. crane: without the $n$ in L. grus, Lith. ger-ve, O. Sl. geraw', Russ. zurawl (v. Edl., \&c.).

The Crane. Ardea grus, L., Grus cinereus, auctt. Mod. Gk. yepavós, yєрán (Heldr.). The Crane is in Greece a bird of passage only, chiefly seen on its journey northward in the spring (cf. Strab. i. 2. 28): it breeds further north, in Macedonia (hence grues Strymoniae, Virgil, Seneca, Martial, Claudian, \&c.; s. Bistoniae, Antip. Sidon. cv, Lucan, \&c.) and on the Danube (Krüper, p. 267 ). In Hom. yépavos doubtless includes the Stork also, the latter bird not being mentioned, though equally common in the Troad (Schliemann, Ilios, p. I I 3 ).

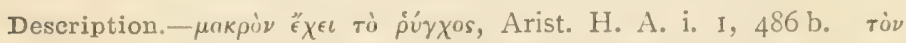

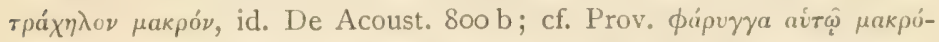

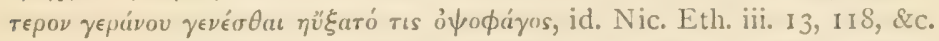
An uncomplimentary description, Athen. iv. I3I E. In colour, $\tau \epsilon \phi \rho a ́$

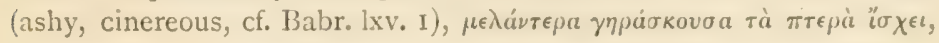




\section{TEPANOE (continued).}

Arist. H.A. iii.12, 5 19, cf. De Gen.v. 5, 785, Plin.x. 42 (29), Solin. c. IO. Its noisy cry, Arist. De Acoust. 800 ; frag. 24I, p. I52 a : cf. Il. iii. 3, Antip. Sidon. xvii, Q. Smyrn. xiii. I04, Ar. Av. 7 I0, Virg. Aen. x. 265, Mart. Ep. xxx; Lucret. iv. 182 ; in Carm. De Philom. grus gruit; S.c. With ep. $\beta \omega \lambda$

A smaller species in the Balearic Islands, called Vipio, Plin. x. 49 (69).

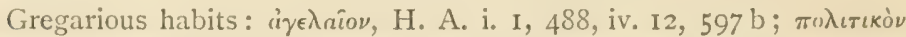

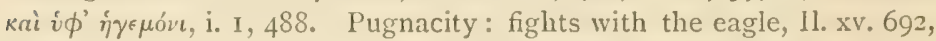
Q. Smyrn. xiii. 104, Ael. iii. 13; and with its own kind, H. A. ix. 12,

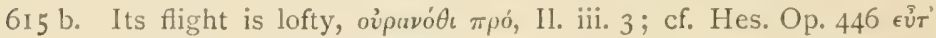

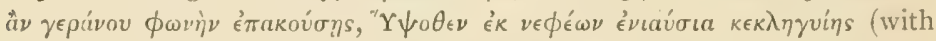

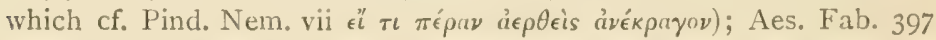

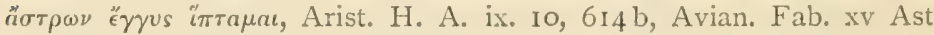
ego deformi sublimis in aëra penna, Proxima sideribus numinibusque feror; Ael. iii. 14, Plin. x. 23, Isidor. Origin. xii. 7 ; see also Horap. ii. 98, where a watcher of the stars is said to be symbolized in Egypt

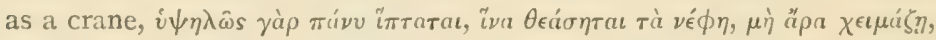

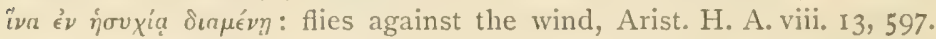

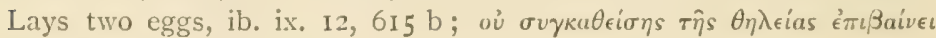
тò äppev, ib. v. 2, 539 b.

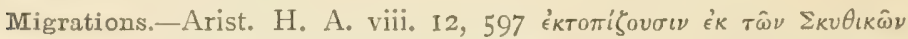

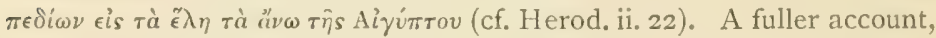
how they alight before foul weather, how they have in front a leader, kri

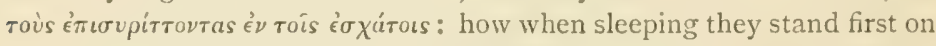
one leg and then on the other: how while they rest the leader keeps watch, Arist. H. A. ix. 10, 614 b: cf. frag. 241, 1522 a, Antig. H. Mirab. 46; and how their discipline taught men the rules of government, Ael. iii. I4.

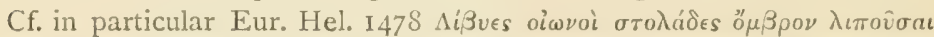

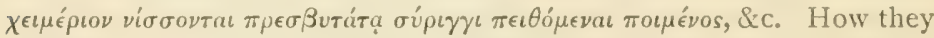
fly aloft in the form of a triangle, with the old in front, the young in the middle, Ael. iii. I3, Plut. De Sol. Anim. Mor. 967 C, 979 A, Dion. De Av. ii. 17, iii. II. The distance they traverse, crossing the Euxine between the promontories of Criumetopon and Carambis, Plin. x. 30 : from Thrace to the river Hebrus, Ael. ii. I ; cf. Diog. Perieg. I55 ait

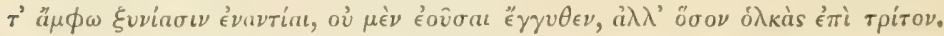

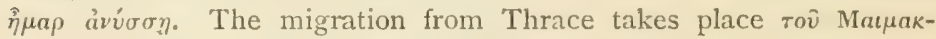

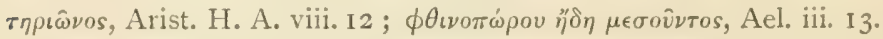

The flock was supposed to represent a $\Delta$ or other letters ; cf. Philostr.

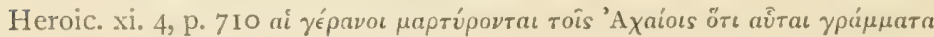

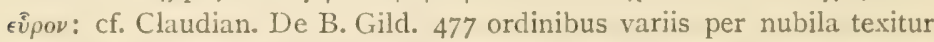
ales Littera, pennarumque notis inscribitur aer ; Lucan v. 712, Martial ix. I4, xiii. 75, \&c., \&c. See also Bochart, Hieroz. ii. p. 78, G. J. Voss, 


\section{TEPANOE (continued).}

De Arte Gramm. i. 25, Mayor in Cic. Nat. Deor. ii. 49, Hemsterh. ad Lucian, i. 305, \&c., \&c. ; cf. Cicero, De Nat. Deor. 1. c., Martial xiii. 75.

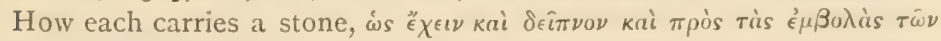
ả $\nu \epsilon \omega \nu$ є̃ $\rho \alpha$, Ael. ii. I, cf. Antip. Sidon. cv, Ar. Av. I137, I429, Nonn.

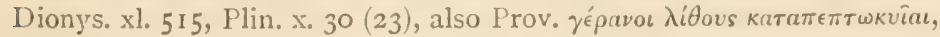
of provident men, Suid.; and how the same is a touchstone for gold, Ael. iii. 13. [In Plin. xxxvii. 72, the stone yepavisıs is said to be so called from resembling the hue of the crane's neck.] How the oldest crane, having encircled the flock, dies and is buried, Ael. ii. 1. How they post sentinels, who hold aloft a stone for wakefulness' sake, Ael. iii. I3, Plut. Sol. Anim. x, xxix, Plin. x. 30, Phil. De An. Pr. xi. The stone still figures in heraldry as the crane and her 'vigilance.' The crane an Egyptian symbol of vigilance, Horap. ii. 94. It observes the

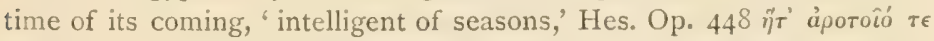

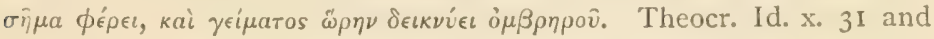

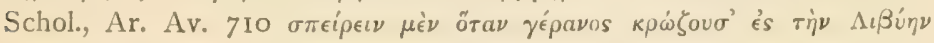
$\mu \in \tau a \chi \omega \rho \hat{\eta}$.

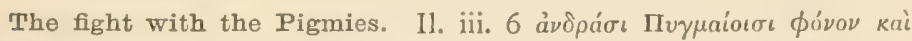

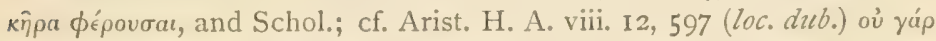

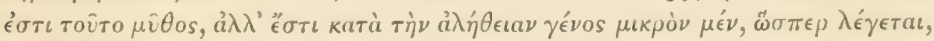

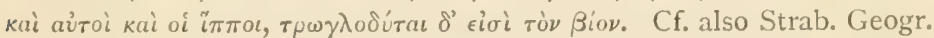
i. 2.28, p. 35, xv. 1. 57, p. 7 I I ; Ctesias, Photii Biblioth. p. 68; Opp. Hal. i. 620; Philostr. Imagg. ii. p. 375, Heroic. 1.c., Babrius xxvi; Apoll. Vit. iii. 50, p. 136, \&c. Frequent in Latin; Plin. H. N. iv. I8, vii. 2, x. 23 (3o); Ovid, Met. vi. 90; F. vi. 176 nec quae Pygmaeo sanguine

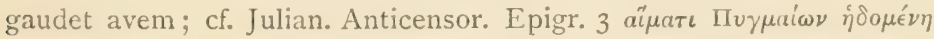

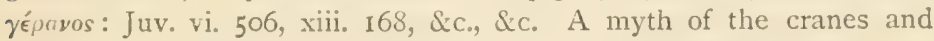

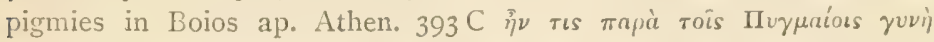

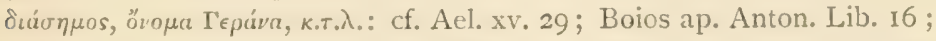
Eustath. in Iliad. I444. I4; Ovid. Met. 1. c. The legend of the Pigmies appears in India in the story of the hostility between the Garuda bird

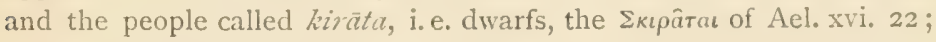
cf. Megasthenes ap. Plin. vii. 2. It is quite possible that this fable has an actual foundation in the pursuit of the ostrich by a dwarfish race.

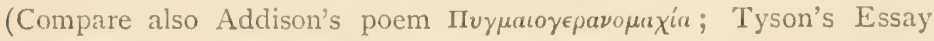
concerning the Pygmies, \&c.

The Cranes of Ibycus : the avengers of crime. Schol. Ar. Thesmoph.

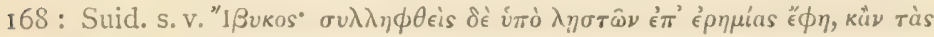

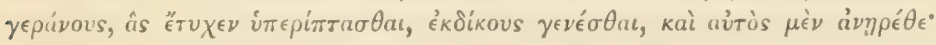

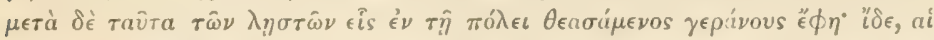

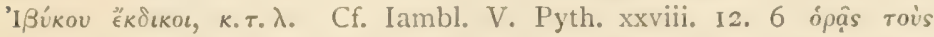

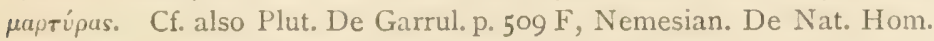
c. 42 , Eudoc. p. 247 , Zenob. i. 37, Apostol. ii. I4, Diogen. i. 35, H. Steph. 


\section{TEPANOE (continued).}

Animadv. ad Adagia Erasmi, p. 10; Stat. Silv. v. 3. I 52 volucrumque precator Ibycus. Evidently alluded to also in Ar. Av. I427. See also Welcker's interesting article, Die Kraniche des Ibykos, Rhein. Mus. i. pp. 4OI-4I3, I 833 .

A weather-prophet.-A sign of early winter, or of storm, éà $\pi \rho \omega \hat{\imath}$

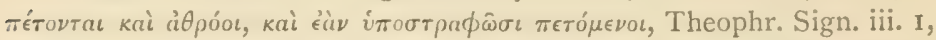
Geopon. i. 3. 12 ; cf. Hes. Op. et D. 629, and the imitation of the line

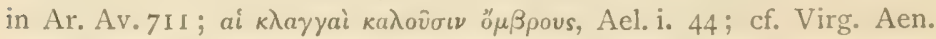
x. 265, Georg. i. 35 I, 373, (cf. Milton, "With clang despise the ground, under a cloud In prospect '). How mariners return to port if they see the cranes flying the contrary way, Ael. iii. I4, cf. vii. 7. A sign of

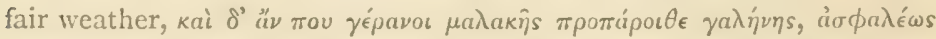

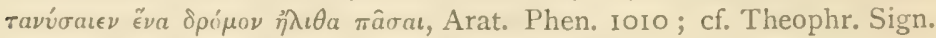

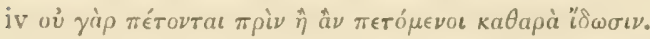

The crane was not molested, Lucill. 66 (Gk. Anthol. iii. p. 42) ovjocis $\pi \rho o ̀ s ~ \gamma \epsilon$ ánous $\pi \hat{\lambda} \lambda \epsilon \mu$ s: cf. Ael. ii. I ; see however Babr. 13.

Mentioned as food, Plat. Polit. p. I 14, Athen. p. 131, Plut. De Esu Carn. ii : Plin. x. 30, Hor. Sat. ii. 8, 86, Epod. ii. 35, Apic. vi. 2. Its brain used as an aphrodisiac, Ael. i. 44. How captured, by means of a beetle inside a dry gourd, Dion. De Avib. iii. II. Grues mansuefactae, Plin. H. N. x. 23 .

Their plumes carried in front of the shield by certain Eastern tribes, Herod. vii. 70 ; cf. iv. 175 .

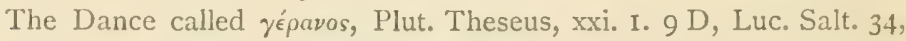
J. Poll. iv. 20 (IOI). Perhaps described in Callim. Delian Hymn,

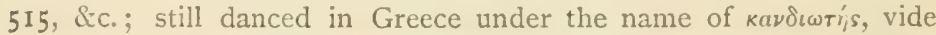
Guys, Voy. littér., lettre xiii ; represented in Leroy, Ruines des plus beaux monuments de la Grèce (2nd ed.), p. 22, pl. x (Ricard, Vies de Plut. i. p. I37, I829). The dictionaries usually say that the dance mimics the flight of the cranes, which is incorrect: the dancing of Cranes may be seen in the opening of the year in any zoological garden.

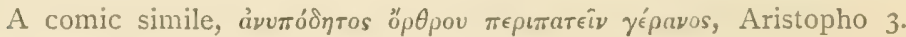
36I (Mein.).

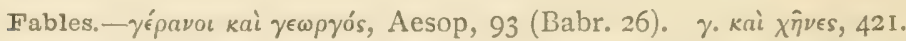

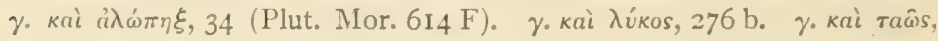
397 (Babr. 65).

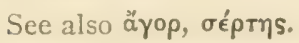

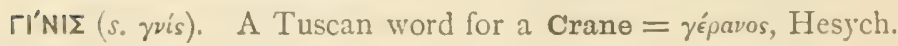

TAAY'KION. A kind of Duck.

Perhaps the Golden-eye, Anas clangula, L., Clangula glaucion, Lonap., which winters in considerable numbers in all the waters of Greece 
ГAAYKION (icntinuil).

(Lindermayer, p. 163); at least some species of duck with pale yellow

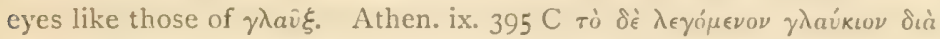

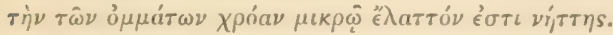

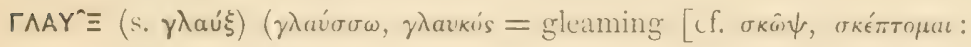
v. Edl. p. 37 ]).

The Iittle Owl, Athene noctua, auctt. Mlod. Gk, коvкочßata.

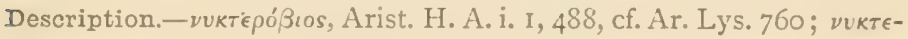

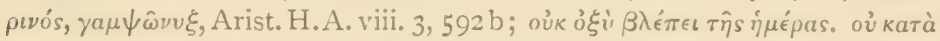

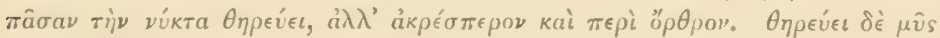

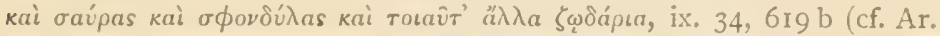

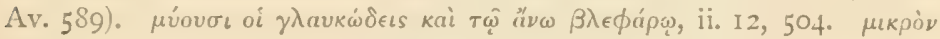

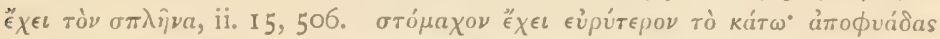

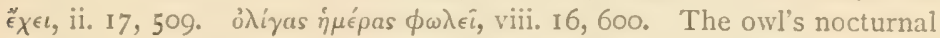

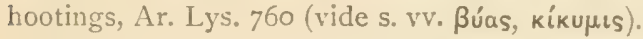

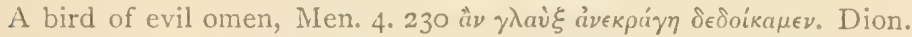

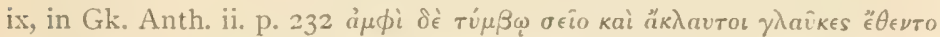
yóov: Ael. x. 37 (foretelling Pyrrhus' death); see also Pallad. De Re

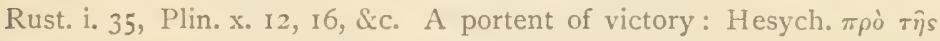

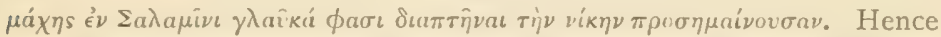

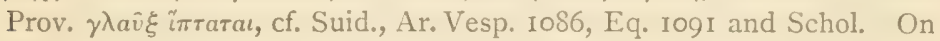
the Owls released by Agathocles to encourage his soldiers, see Diod. Sic. xx. II, 3 .

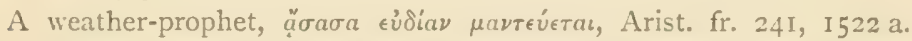
Cf. Theophr. Sign. iv, Ael. vii. 7, Arat. 999, Geopon. i. 2. 6, Virg. Georg. i. 403 .

The hostility to it of small birds, Arist. H. A. ix. I, 6og, Luc. Harm. I

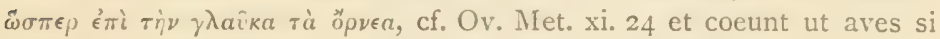
quando luce vagantem Noctis avem cernunt; Plin. x. (17) 19, \&c.

Capture of small birds by means of the owl, Arist. H. A. ix. I, 609

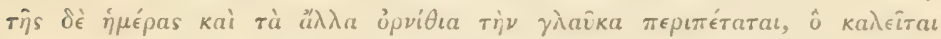

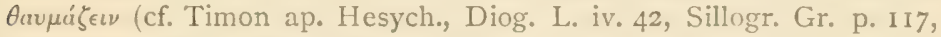

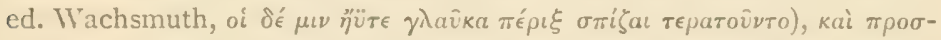

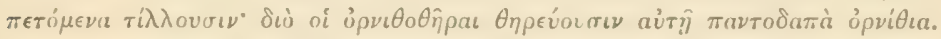
Cf. Arist. H. A. ix. 22, 617 b, Ael. i. 29, Phil. De An. Pr. 468, Dio Chrys. xii. I; an Egyptian version, Horap. ii. 5I. Full account in Dion. De

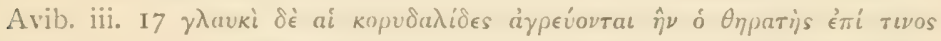

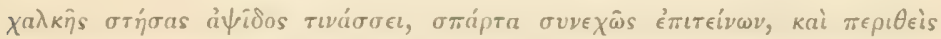

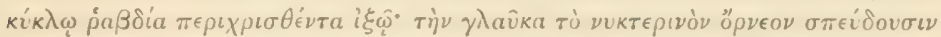

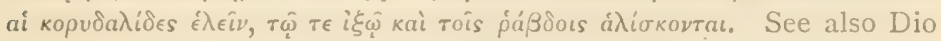
Prusiensis, Orat. 72 and I2, quoted in Schneider's Ecl. Phys. i. 48.

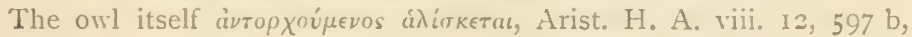
fr. 276,1527 b. 
ГАAY $\equiv$ (continued).

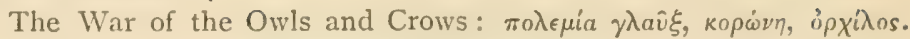

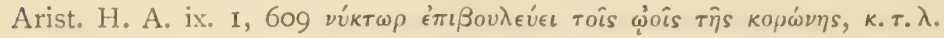
Ael. iii. 9, Antig. Mirab. 57 (62), Plut. Od. et Inv. iv (Mor. 537 C). The story is oriental, and is one of the chief tales in the Mahabharata. Cf. Indian Antiq. March, I882, p. 87; also, 'The Night of Slaughter,' by Sir Ed. Arnold. The account in Julian. Imp. Orat. iv. I 49 suggests that the story is simply a parable of the Sun and Moon; vide infra.

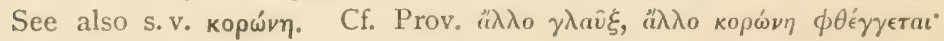

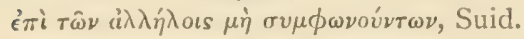

Milks the ewes like a goatsucker: uses a bat's heart to keep away ants from its nestlings, Dion. De Avib. i. I 5.

Sacred to Demeter, Porph. De Abst. iii. 5.

No Owls in Crete. Ael. v. 2, xvii. Io, Arist. De Mirab. 124 (130), $83(84)$, Plin. x. 29 (4I).

Fables of the very wise Owl, Aes. 105, 106, from Dio Chrysost. xii, 1xxii. A fabled metamorphosis, Nicand. ap. Anton. Lib. Io; s. v. $\beta u ́$ ha : see also Boios ap. Ant. Lib. I5.

The allusion to the Owl in Ar. Av. 358 is unexplained: it contains some obscure reference to the sacred $\chi \dot{r} \rho a$ and probably to the feast

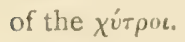

$\gamma \lambda \alpha u \hat{\xi}$ can scarcely be said to be a generic term, except in the sense that the Little Owl, as the commonest species, is taken as typical of the rest. It is still extremely common about Athens (cf. Ar. Av. 3or

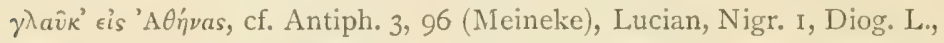
Vit. Plat., Cic. ad Quint. ii. 16, \&c.; Propert. ii. 20, 5 nocturna volucris funesta querela, Attica), as indeed it is, in one or other of its local forms, all round the Levant. It is the bird of Athene (cf. Ar. Av. 516, Eq. 1092, \&c., \&c.), doubtless in her primitive character of the Goddess of Night; the epithet $\gamma \lambda a v \kappa \omega t \pi \iota s$ is quite obscure, but I fancy we have it used in a very ancient sense when applied to the moon, e.g.

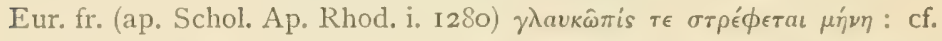
Emped. ap. Plut. ii. 934 C; cf. also $\gamma \lambda a v k \omega$, a name for the Moon, Schol. Pind. Ol. vi. 76 (cit. Fick, Beitr. Indog. Spr. xx, p. 156, I894). On Athene as a moon-goddess, cf. Porph. ap. Euseb. P. E. iii. II; Creuzer, Symb. iii. 380 , \&c. It was represented on Athenian coins

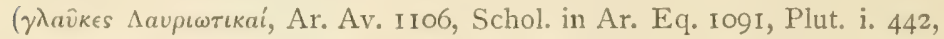
Philochori fr. p. 83, Suid., Hesych.), and is still the city's badge. On a very ancient colossal Owl from the Parthenon, see Friederichs,

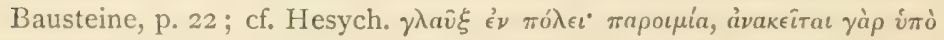

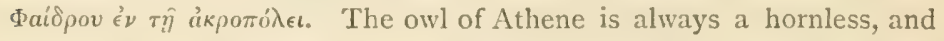
never a horned or eared species (cf. Blumenbach, Sp. Hist. Nat. Ant. p. 20, Göttingen, 1808).

A dance called $\gamma \lambda a \hat{\xi} \xi$, Athen. xiv. 629 f.; also $\sigma \kappa \dot{\omega} \psi$, q. v. 


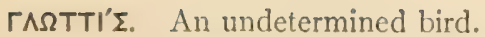

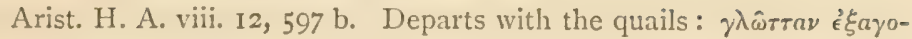

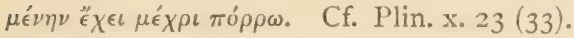

Supposed by Sundevall (op.c. p. 129) to be identical with "iv Wryneck, on account of the protrusible tongue; as also by Niphus, in Arist., v. Camus, ii. 383 ; the Wryneck however winters in Greece (Lindermayer p. 4I). Belon identified it with the Flamingo, Gesner, followed by Linnaeus, from a confusion with Ger. or Sw. Glutt, with the Greenshank, in connexion with which latter bird the name survives

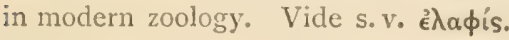

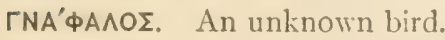

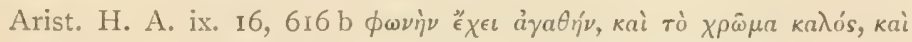

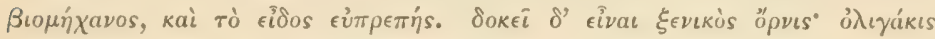

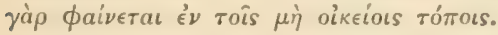

Gesner suggests the Bohemian Waxwing, Ampelis garmulus, L.,

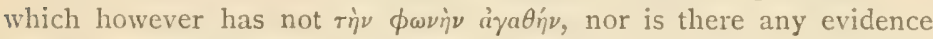
of the Waxwing reaching Greece. Probably the foreign name of a foreign bird.

rOINE'EE· кópakes, Hesych. Perhaps for $[F]$ oiva's, q. v.

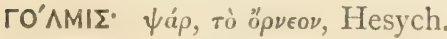

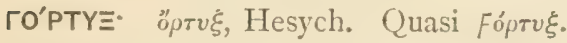

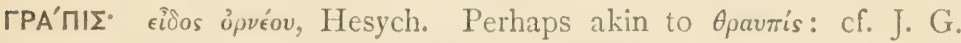
Schneider in Arist. H. A. viii. 5. 4, p. 590.

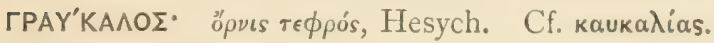

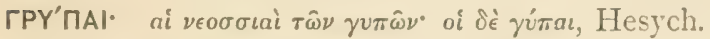

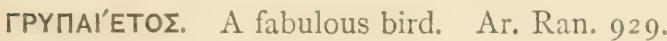

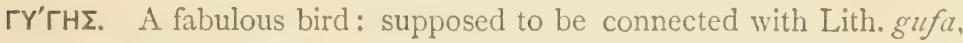
guzuly's, a Stork.

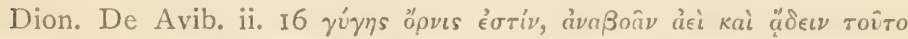

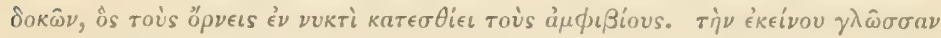

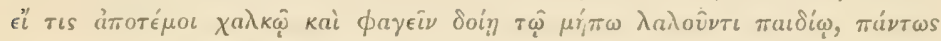

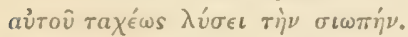

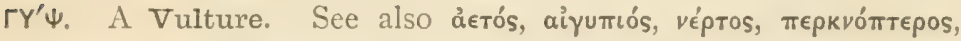

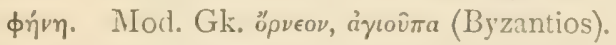

Frequent in Homer, usually with the idea of feeding on carrion, Il. iv. 237 , xi. I62, xvi. 836 , xxii. 42 ; Od. xxii. 3o, \&c. Cf. Eur. Tr. 595

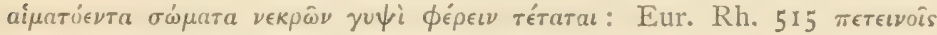

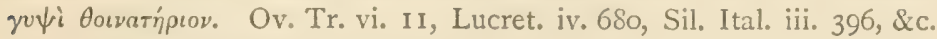
Used metaphorically, Eur. Andr. 75. 


\section{$\Gamma Y \Psi($ continued).}

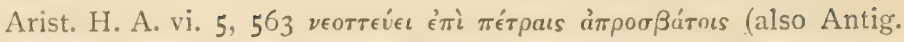

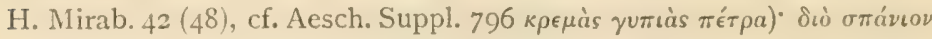

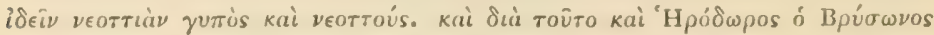

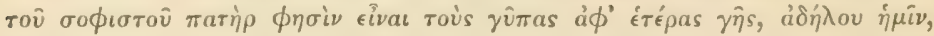

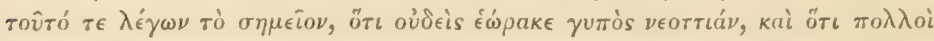

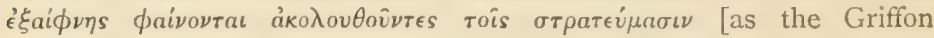
Vulture did at Sebastopol], cf. Ael. ii. 46, Basil. Hexaëm. viii ‘́ors âv

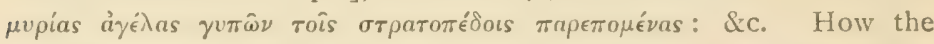

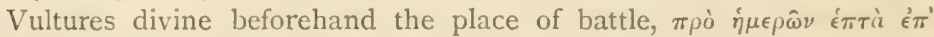

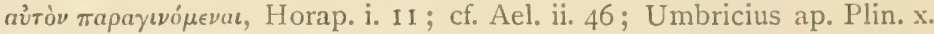
(6) 7 ; Plaut. Truc. ii. 3. 16, Martial, Ep. 62, 6.

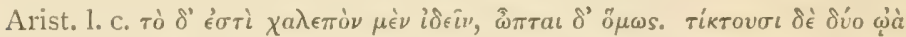
oi yûtes (cf. Plin. x. 7). Cf. H. A. ix. II, 615, which latter passage has

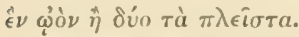

On the mythical generation of vultures, how they are all females, are impregnated by the East wind, lay no eggs, and bring forth their young alive and feathered, see Ael. ii. 46, Arist. De Mirab. (6c) 835 a, I, Horap. i. I I, Dion. De Avib. i. 5, Phile, De An. Pr. 121, Plut. Quaest. de Us. Rom. 93 (Mor. 286 A, B), Ammian. Marcell. xvii, Tzetz. Chil. xii. 439, Euseb. Pr. Ev. iii. I2, and innumerable other references in Patristic literature. On the mythical genealogy of the vultures, see also

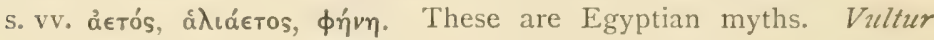
fulvus was sacred to Maut, the Goddess of Maternity, cf. Deut. xxxii.

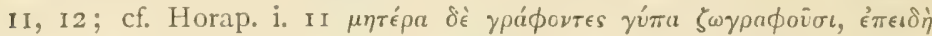

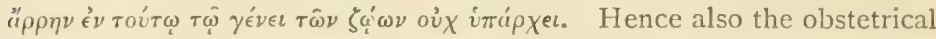
value of a Vulture's feather, Plin. xxv. ( I4) 44. The Common Egyptian Vulture or Pharaoh's Hen, Neophron percnopterns, was sacred to Isis,

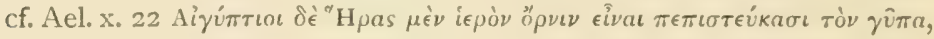

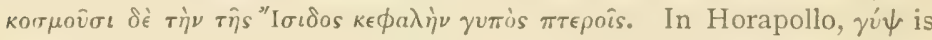
always feminine. The Vulture being sacred in Egypt, was an unclean bird among the Jews; cf. Еैто $\psi$

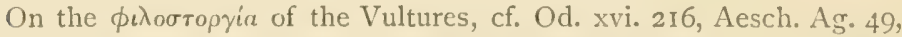

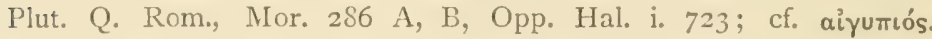
The Vulture is stated to feed its young with its own flesh or blood, a myth afterwards transferred to the Pelican; Horap. i. I1, cf. Georg.

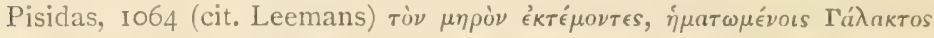

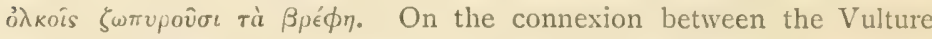
and the Pelican, see s.v. $\beta a เ \eta \dot{\theta}$. The stories of the Vulture's tenderness and affection coincide with the resemblance between the Hebrew words

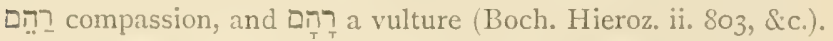

How a Vulture's feather, if burnt, drives serpents from their holes, Ael. i. 45, Plin. xxix. (4) 24. How the pomegranate is fatal to vultures, Ael. vi. 46. How the odour of myrrh is fatal to Vultures, Ar. De 
$\Gamma Y \Psi$ (continued).

Mirab. (147) 845 a, 35, Ael. iii. 7, iv. 18, Geopon. xiii. 16, xiv. 26, Theophr. De C. Pl. vi. 4, Clem. Alex. Paedag. ii. 8 ; and why, Dion. De Avib. i. 5. Doves do not fear the Vulture, Ael. v. 50; the hawk is hostile to it, Ael. ii. 42. Most of the above mythical attributes of the Vulture are summed up by Phile, c. iii De Vulture.

The stories of Prometheus and Tityus, Od. xi. 577 ; Aen. vi. 595; Lucret. iii. 997 ; Ov. Met. iv. 456; Val. Fl. Argon. vii. 357, \&c. See also S.v ảetós.

How the Persians exposed their dead to the Vultures, Herod. i. I 40.

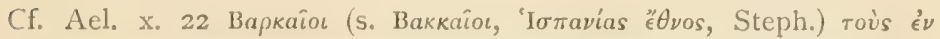

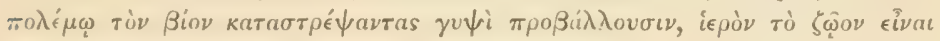

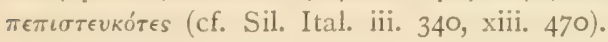

The augury of Romulus, Plut. Romulus ix, Quest. Rom. 93, Dio Cass. xvi. 46, Dion. Hal. i. p. 73, Ael. x. 22, Liv. Hist. i. 7, \&c.; of Augustus, Sueton. Aug. c. 95. The prophecy of Vettius, drawn from the vultures of Romulus, as to the duration of Rome, Censorin. xiv.

The Vulture is sacred to Hercules, Plut. Mor. $286 \mathrm{~A}$; is associated with Pallas, Eur. Tr. 594. The Vulture and Scarab together, according to their order and position, represented Neith or Phtha, Athene or Hephaestus, Horap. i. I2 ; cf. Creuzer, Symb. iii. 338 , and Lauth op. cit.

In the system of Egyptian hieroglyphics the Vulture and the Beetle are associated or contrasted with one another. This relation bears upon certain statements made by Greek writers. The beetle, kán $\theta_{\text {upos, }}$ is devoid of females (Ael. x. I 5) as the Vulture is of males; it is killed, as is the Vulture, by the odour of myrrh (Ael. i. 38, vi. 46, Phile I20, 1215); it shares with the 'Eagle' the gift of the renewal of youth (Arist. H. A. viii. I7, 601). For further details concerning Egyptian Vulture-myths and for many references to other sources of information, see Horap. ed. Leemans, pp. I7I-I9I; and for the connexion between the statements of Horapollo and the phonetic value of the Vulturesymbol, see Lauth, Sitzungsber. Bayer. Akad. I876, pp. 8I-83.

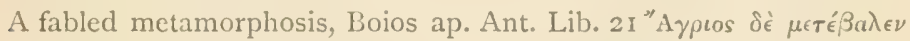

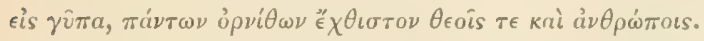

A medicinal application, Dioscor. ii. cap. De stercore: $\gamma u \pi$ òs ä $\phi o \delta o s$

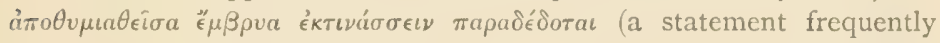
made by the Arab Doctors, Bochart). For other medicinal uses of the vulture's liver, heart, and feathers, see Plin. xxix. (4) 24, (6) 38 , Galen iv. \&, Sext. Platon. ii. 2, Quint. Seren. c. 47, \&.c.

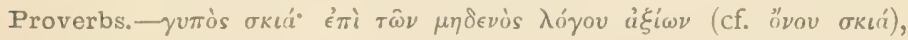
Suid.; the proverb may refer, on the other hand, to the shadow of coming events, in allusion to the Vulture's fabled prescience (vide

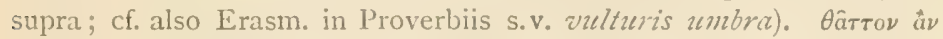

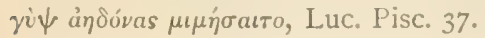




\section{$\Gamma \gamma \Psi$ (continued).}

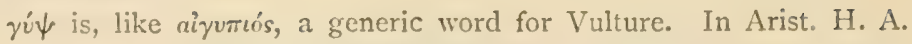

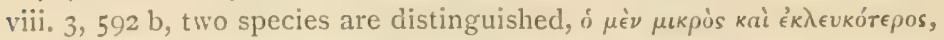

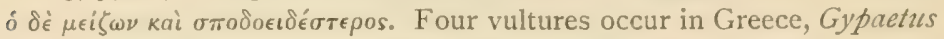
barbatus, the Lämmergeier, Vultur fulvus, the Griffon Vulture, V. cinereus, the Black or Cinereous Vulture, and Neophron percnopterus. Sundevall and others have tried to apportion among these four the

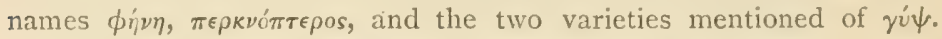
But I think it certain that here the small white Neophron is meant as the one variety, and that the larger darker sort includes the other three. The true Vultures were usually spoken of as dark-coloured or black; e. g. Plin. x. 6 vulturum praevalent nigri, cf. Phile I30; Juv. Sat. xiii vulturis atri poena; Senec. in Thyeste, visceribus atras pascit effossis aves.

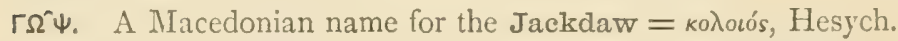

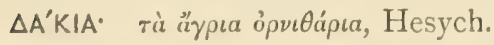

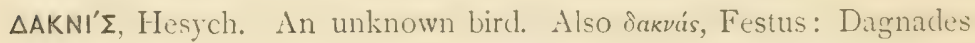
sunt avium genus, quas Aegyptii inter potandum cum coronis devincire soliti sunt, quae vellicando morsicandoque et canturiendo assidue non patiuntur dormire potantes.

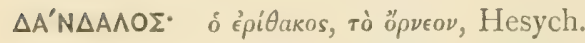

$\triangle E I^{\prime} P H \Sigma$. A name for the Sparrow in Elis. Nicander ap. Athen. ix. 392 a.

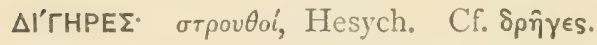

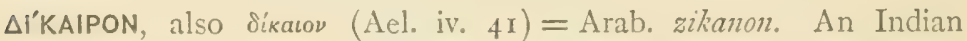
'bird' as large as a Partridge's egg, whose dung causes a painless death like sleep; Ctesias p. 3 I3, Ael. iv. 4I, Phile, De Anim. Propr. $33\left(3^{2}\right)$, v. 76 I. The 'bird' was the Dung-beetle, Scarabaeus sacer, L., Arab. zikanon; the 'dung' was probably confounded with charas, a resinous preparation of Indian hemp. Vide Valentine Ball, Indian Antiq. xiv. p. 3 Iо, I885; also Proc. R. I. Acad. (2) ii.

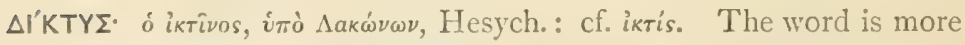
than doubtful as a bird-name, and is applied to a Libyan animal by Herod. iv. 192.

$\triangle P A K O N T I \Sigma$. An unknown or fabulous bird, into which one of the nine Emathidae, daughters of Pierus, was metamorphosed; Nicand. ap. Anton. Lib. Met. c. 9. 


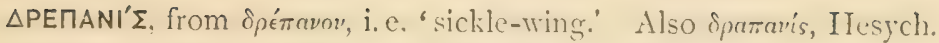

Arist. H. A. i. I, 487 b. A bird similar to ämovs and $\chi \epsilon \lambda \iota \delta \omega \nu, \epsilon u ̈ \pi \tau \epsilon \rho \circ$,

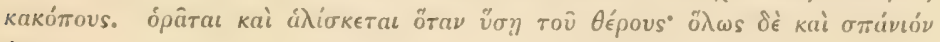

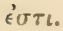

Probably the larger Alpine Swift, Cypselus mella, L., and also perhaps the Common Swift, $C$. apus, both conspicuously 'sicklewinged.' On the other hand, Aub. and Wimm. p. I I I, also Bochart ii. 62, as well as Gaza and Scaliger, say the SandMartin: v. кú $\psi \in \lambda$ os. Cf. Plin. x. (33) 49, xi. 47 (107), xxx. (4) I 2. The brief account indicates that the bird is comparatively scarce, and that its period of residence in the country is short; both circumstances telling in favour of a Swift as against the Sand-Martin.

Spemavis is translated $\kappa \epsilon \gamma \chi x$ is by Hesychius.

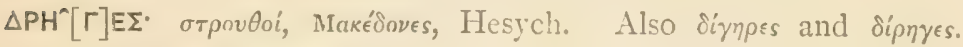

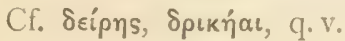

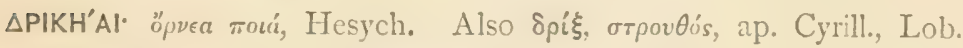

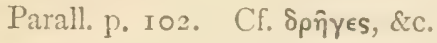

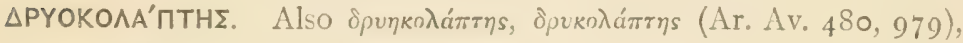

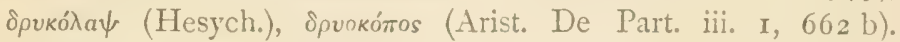
Cf. Sk. därvāghäta (Keller).

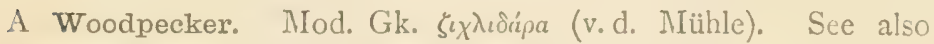

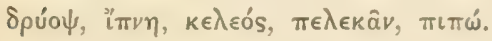

Arist. H. A. viii. 3, 593, vide s. v. $\pi \iota \pi \omega ́$. Ib. ix. 9, 6I4, a full and

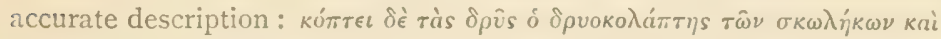

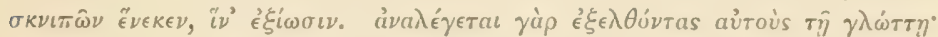

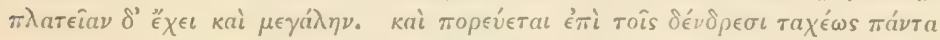

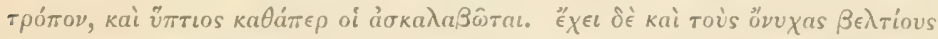

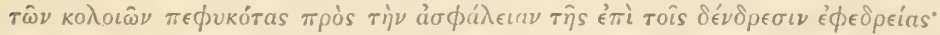

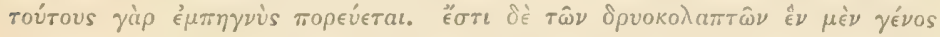

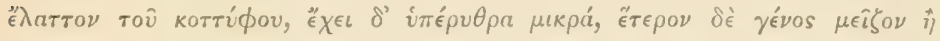

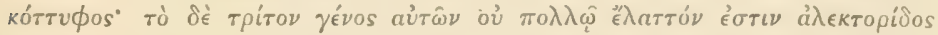

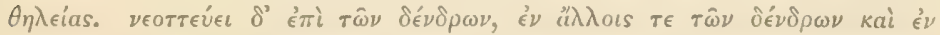

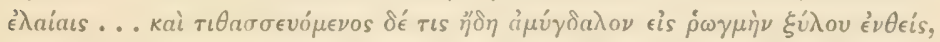

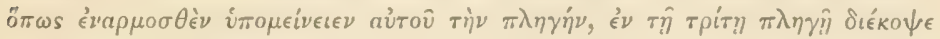

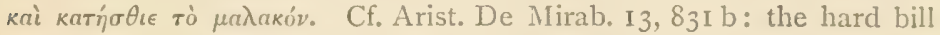
of the woodpecker, Arist. De Part. iii. r, 662 b.

Four well-defined species occur in Greece. (a) the Great Black Woodpecker, Picus Murtius, which evidently answers to the last and largest variety mentioned above; (i) the Green Wvodpecker, I'. iniliti, 


\section{$\triangle$ PYOKOAAחTHE (continued).}

with its close ally, $P$. canus; $(c, d)$ the Greater and Lesser Spotted Woodpeckers, P. major and minor. The Green Woodpecker is described under the name $\kappa \epsilon \lambda \epsilon o ́ s$, and accordingly Sundevall and others make the remaining two of the three Aristotelian varieties to be the Greater and Lesser Spotted Woodpeckers respectively. But as $P$. viridis, whether it had another name or not, would certainly

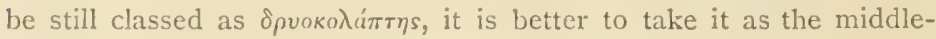
sized sort, uniting the Greater and Lesser Spotted Woodpeckers as the last and least variety.

The Woodpecker is not in Greek, as it is in Latin (e. g. Ov. Met. xiv. 32 I, F. iii. 37, 54, Virg. Aen. vii. I91, Plin. x. 18 (20), Plut. Q. Rom. xxi. 268 F, Romulus iv; Aug. Civ. Dei, xiii. 15), a bird of great mythological importance, though the Dryopes were probably, like the descendants of Picus, a Woodpecker-tribe. It figures in the oriental Samir-legend

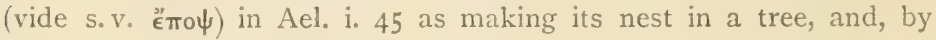
virtue of a certain herb, removing a stone with which one shall have blocked up the entrance; cf. Plin. x. (18) 20, xxv. 5 ; Plut. p. 269 ; Dion. De Avib. i. I4; and is accordingly spoken of as a rival power to є̈то廿 in Ar. Av. 480 . Cf. Alb. Magnus, De Mirab. I6or, p. 225. See also Baring-Gould, Myths of the Middle Ages, p. 397. The Woodpecker and the Hoopoe come into relation also in the version of the Tereusmyth given by Boios ap. Anton. Lib. Met. $x I$, where the brother of

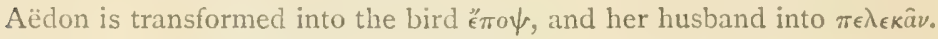

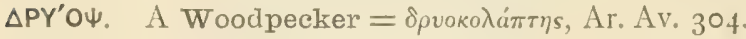

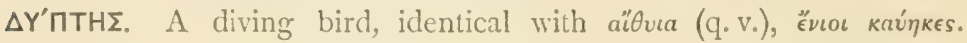
Etym. MI.

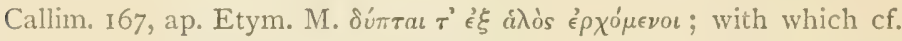

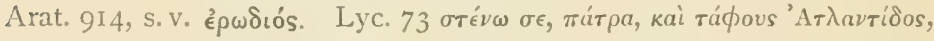

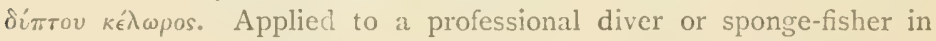
Opp. Hal.ii. 436, and possibly also, therefore, in the preceding reference. Cf. åpvยutíp.

$\triangle Y_{T I}{ }^{n}$ I. An unknown water-bird. Dion. De Avib. ii. 13, iii. 24.

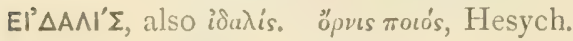

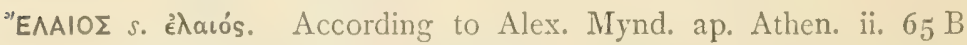

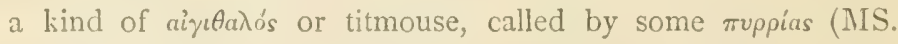

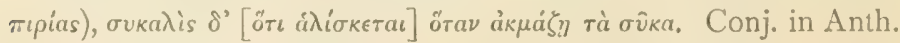

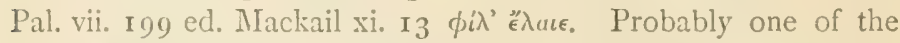
many Warblers which frequent the olive-gardens, e.g. Salicaria olivetorum, Strickl., and S. clacica, Linderm. (v. Lindermayer, pp. $88-92)$. 
"ENANOE = ikTivos, Hesych.

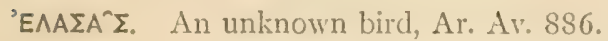

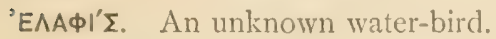

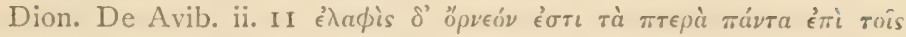

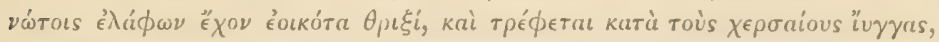

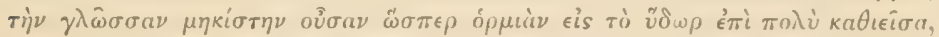
$\kappa . \tau . \lambda$. The hair-like feathers on the back suggest, if anything, a Heron or Egret. A gem in the British Mluseum represents a Heron or Stork, with the antlers of a Stag; v. Torr, Rhodes, pl. I, Imhoof-Bl. and K., pl. xxvi. 59.

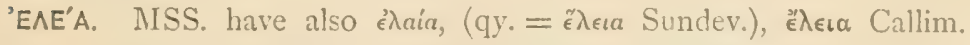

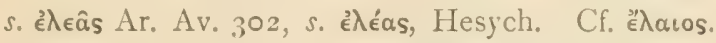

A small bird, probably the Reed-Warbler, Salicaria arundinacea, Selby, and allied species.

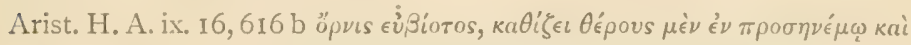

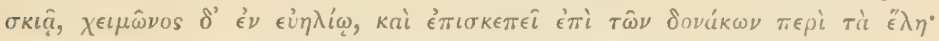

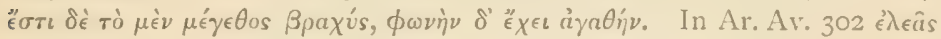
may or may not be the same bird. Callim. ap. Schol. Ar. Av. $302 e^{\prime \prime} \lambda \epsilon \iota$

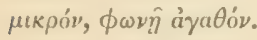

The Reed-Warbler is a permanent resident in Greece, and is very common in all marshy places (Krüper, \&·c.).

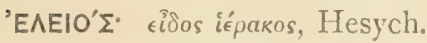

Sch. conjectures $\tilde{\epsilon} \lambda \epsilon \cos$ palustris in Arist. H. A. ix. $36, \mathrm{I}$, and for

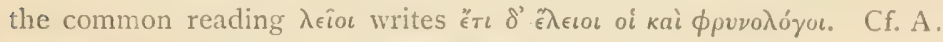
and W. ii. p. 264. Vide s. v. $\epsilon \pi \iota \lambda \epsilon i$ os.

'EAEO' $\Sigma$. A kind of Owl.

Arist. H. A. viii. 3, $592 \mathrm{~b}$; mentioned with, and said to resemble,

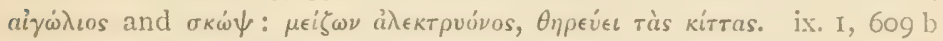

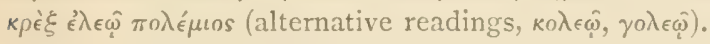

The size accords with that of the Tawny Owl, Symium Aluco, L., which is common in Greece and is not definitely ascribed to any other classical name. Scaliger so identifies it, taking éneís from the owl's cry, cf. $\epsilon^{\prime} \lambda \epsilon \lambda \epsilon \hat{v}$, \&c., also Lat. uluelc. Sundevall reads $\dot{\epsilon} \lambda \epsilon \dot{s}^{\prime}$ s. $\tilde{\epsilon} \lambda \epsilon \cos =$ palustris, supporting this vicw by the mention of Crex in the context, and identifies the bird with Strix brachyolus, L., the Short-eared or NIarsh Owl. But both etymological suggestions are

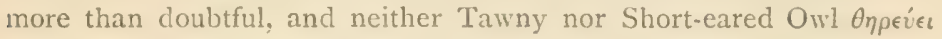
tìs kirtas. Artemidor. iii. 65, Zonar. c. 684.

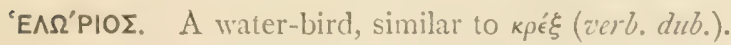

Clearch. ap. Athen, viii. $332 \mathrm{E}$ (Casaubon), where later editors read

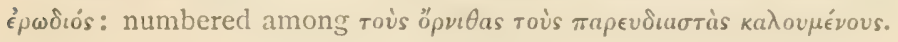




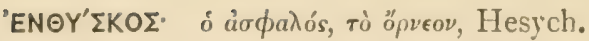

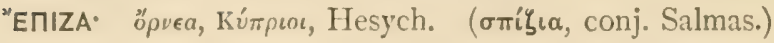

'EחIAAI' $\Sigma$. An unknown small bird.

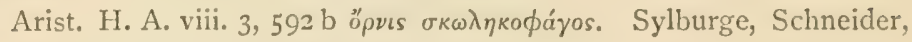

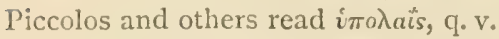

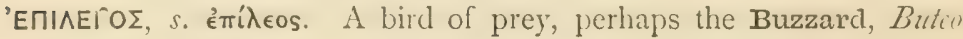
vulgaris, Bechst.

Plin. H. N. x. 9 epileum Graeci vocant qui solus omni tempore apparet, caeteri hieme abeunt (vide s. v. aíá́ $\lambda \omega v$ ). This passage, following on a reference to Buteo, and stating a fact recorded by

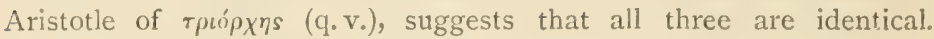
Perhaps connected with, or a mere variant of, $\epsilon^{\prime} \lambda \epsilon$ เós or $\lambda \epsilon \hat{\epsilon} o s$, q. v.

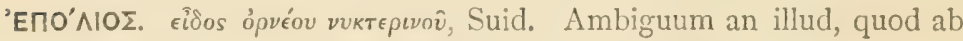
Aristotele air $\omega \lambda$ iós, H. St. Thesaur. App. p. $942 \mathrm{E}$.

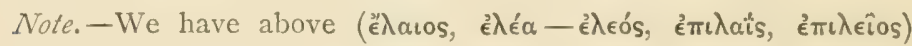
a succession of bird-names all very similar, whose meaning and deriration are alike obscure.

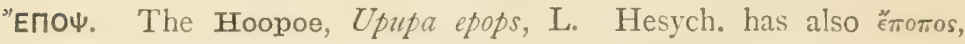

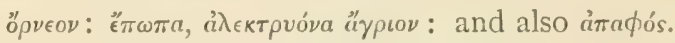

Mod. Gk. $\tau \zeta a \lambda o \pi \epsilon \tau \epsilon \iota v$ ós or $\tau \sigma a \lambda o \pi \epsilon \tau \epsilon \iota \nu o ́ s$ (Erhard, Heldreich), ảyptn-

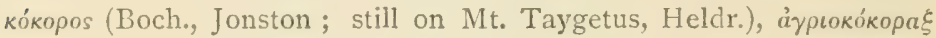

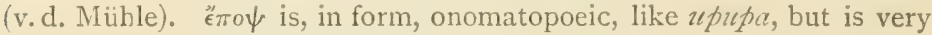

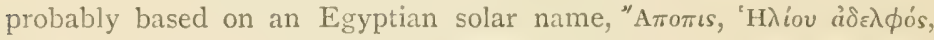
Plut. De Is. xxxvi ; with which cf."Era

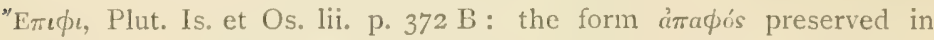
Hesychius is identical with the name used by the Syriac Physiologist.

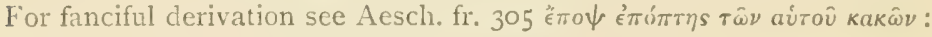
cf. Hesych.s.v. See also s.vv. коикои́фа, тои́тоs.

First mentioned by Epicharm. ap. Athen. ix. 39I D (fr. I I6, Ahrens)

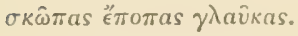

Description.-Arist. H. A. i. 488 b öprus öpetos, cf. ix. II. 615 a (vide Boch. Hier. ii. p. 343 for similar interpretation of Heb. or Arab. dukiphat,

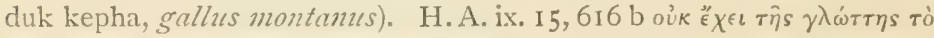

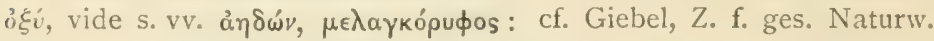

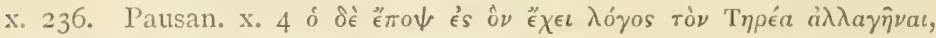

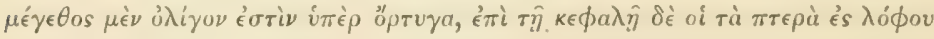

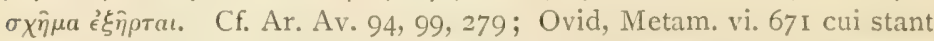
in vertice cristae, Prominet immodicum pro longo cuspide rostrum, Plin. x. (65) $36 \mathrm{cum}$ fetum eduxere abeunt. Is destructive to bees, Phil. De An. 712. 


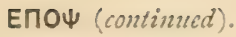

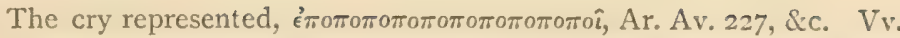

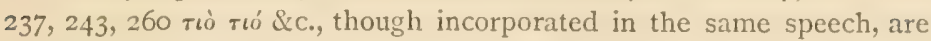
evidently from the nightingale and other birds behind the scenes: кเккаßâे, v. 26I, is the owl's hoot.

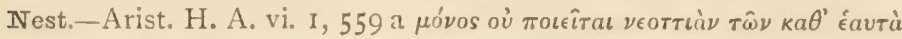

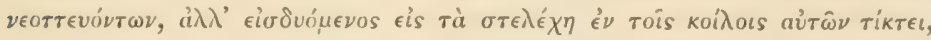

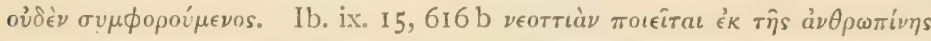
кómpov. According to Heldreich (p. 38) the Hoopoe is a spring and autumn migrant through Greece, but does not now breed there: it however seems to breed in Macedonia and perhaps in Epirus (Krüper).

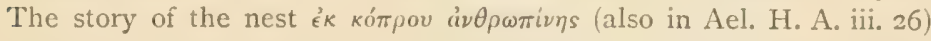
arises (I) from the Hoopoe's habit of seeking its insect food among dung (avis obscoeno pastu, Plin. H. N. x. 29; cf. Fr. coq puant, Germ. Kothhahn, Stinkhahn, Mistvogel, \&c.), and (2) from the nest having an evil smell from the accumulation within of excrement, and perhaps also from a peculiar secretion of the birds (see for scientific references, Aub. and Wimm. i. p. 91).

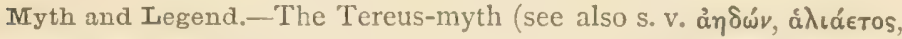
$X \in \lambda(\delta \omega \dot{v})$ Aesch. fr. 297, in Arist. H. A. ix. 49 B, 633 a (more probably from the lost Sophoclean tragedy of Tereus, cf. Schol. Ar. Av. 284,

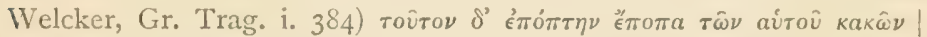

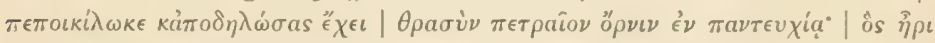

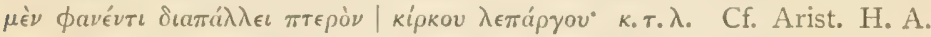

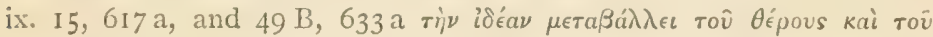

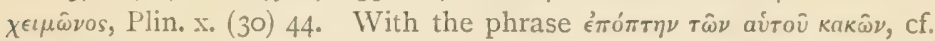

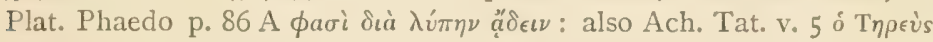

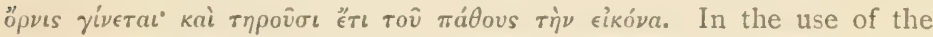
word $\epsilon$ '́t $\pi \tau \eta s$, we have not merely a fanciful derivation of $\epsilon_{\pi \circ} \psi$, but also an allusion to the mysteries.

In this very obscure story we have frequent indications of confusion between Hoopoe and Cuckoo, and the 'metamorphosis' is in part connected with the resemblance between the Cuckoo and the Hawk; cf. Arist. vi. 7, Theophr. H. P1. ii. 6, Geopon. xv. 1, 22, Plin. H. N. x. 8, II. See also Lenz, Zool. d. Gr. u. R. p. 318. For the relations between Hoopoe and Cuckoo, der Kuckuk und sein Küster, v. Grimm, D. M. p. 646, Grohmann, Aberglaube aus Böhmen, Leipzig, I864, p. 68, \&c. On the metamorphosis of the Cuckoo into a Hawk in English and German Folk-lore, see Swainson, Provincial Names of British Birds, p. 113 .

How the Hoopoe first appeared at 'Tereus' tomb in Megara, Paus. i. 41, 9. The Tereus-myth also in Aesch. Suppl. 60, Apollod. iii. 14, Ach. Tat. v. 5, Ovid, Metam. vi, \&c. 


\section{ЕПО廿 (continued).}

On the Tereus-myth, and the mythology of the Hoopoe in general, see in particular E. Oder, Der Wiedehopf in d. gr. Sage, Rhein. Mus. (N. F.), xliii. pp. 54I-556, I888.

A weather-prophet, Horap. ii. 92 éà $\pi \rho \dot{~ r o v ̂ ~ k a i ́ p o v ~ r a ̂ \nu ~ a ̉ \mu \pi \epsilon ́ \lambda \omega \nu ~}$

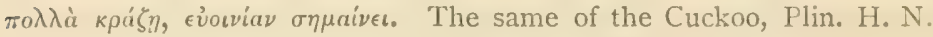
xviii. 249, Hor. Sat. i. 7, 30. With ep. čا

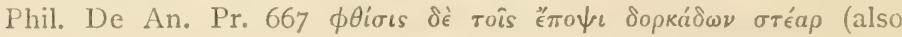

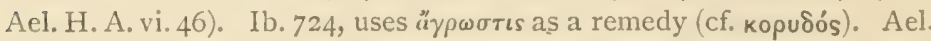

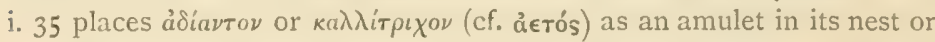
heals itself when injured, Horap. ii. 93 ; also written áriavtov, Geopon. XI. I, I9.

How the Hoopoe by means of a certain herb (the same ádiavrov) liberates its imprisoned young, Ael. iii. 26, cf. Ar. Av. 654, 655. The

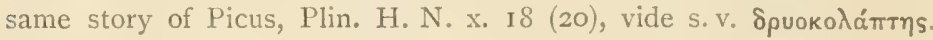
This is a version of the well-known Samir-legend (the 'open Sesame' of the Forty Thieves), and is told also of the Hoopoe in connexion with Solomon (Boch. Hieroz. ii. 347). See also Buxdorf, Lex. Talmud. col. 2455: on similar German superstitions see Meier, Schwab. Sagen, Nr. 265. On Indian versions of the story of the Hoopoe which sheltered Solomon from the sun, see W. F. Sinclair, Ind. Antiquary, 1874 : also ib. 1873 , p. 229, Curzon's Monast. of the Levant, c. xii, \&c. The story of the Indian Hoopoe, Ael. xvi. 5, which buried its father in its

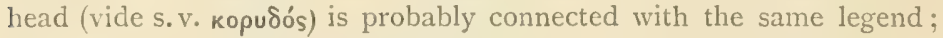
see Lassen, Ind. Alterth. 2nd ed. i. p. 304. The statement (Ael. 1. c.)

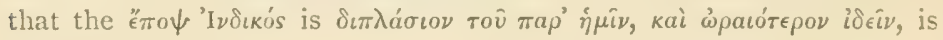
purely fabulous.

Filial affection of the Hoopoe, Ael. x. I6, vide S. v. коuкоúфa,

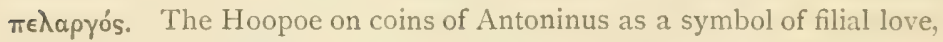
Eckhel, Doctr. numm. vi. 53I, Creuzer, Symbolik, ii. p. 64, Zoega, Numm. Eg. Imp. pl. x. I, Seguin. Scl. Numism. p. 152.

The evil smell of the Hoopoe suggests a connexion with Pitumnus in the story of Pilumnus and Pitumnus or Sterculinius; Serv. Aen. ix. 4 fratres fuerunt dii; horum Pitumnus usum stercorandorum invenit agrorum, Oder, op. c. p. 556 : cf. Jordan-Preller, Röm. Myth. i. 375.

The Hoopoe was a sacred bird in Egypt, as it still is among the Arabs (cf. Creuzer, l. c., Denon pl. 119, 8, \&.c., \&.c.). From its rayed crest it was a solar emblem, and it is in part as such that it comes into relation with kipkos, the sacred hawk of the solar Apollo. The woodpecker, with its red or golden crest (cf. Ov. Met. xiv. 394) becomes in like manner a solar emblem, and there is a curious parallel in the connexion between Circe and the metamorphosis of Picus. As a solar emblem also, the Hoopoe figures in the version of the Phoenix-myth 


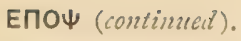

in Ael. xvi. 5. To a like source is traceable the Samir-legend, and possibly also the obscure origin of the Tereus-myth. From its sanctity in Egypt it became an unclean bird among the Jews, Lev. xi. 19, Deut. xiv. I \&, where its name תפיכוד dukifhat (cf. коukoúф $\alpha$ ) is rendered Laproing, as being the crested bird with which the translators were most familiar (cf. Newton, Dict. of Birds, p. 505).

In the Birds of Aristophanes we have many veiled aliusions to the mythology of the Hoopoe. The confusion with ко́кки (vide s. v. коuкoúфa) is indicated throughout; the fables of Tereus and Procne

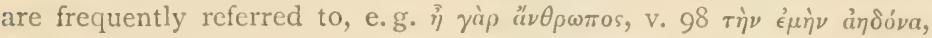

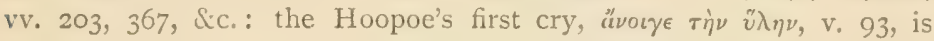
a reference to the Samir-legend; the kindred fable of kopvós appears in vv. $472-476$; the mysterious root in v. 654 is the magical a'siavtov:

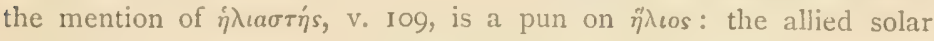

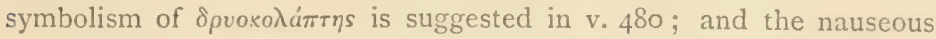
reputation of the nest is probably hinted at in the Hoopoe's pressing invitation to Peisthetairus, v. 64I, that he should enter in.

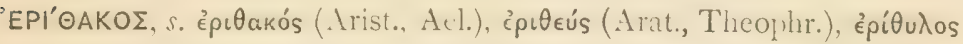
(Schol. ad Ar. Vesp.). The Robin, Erithacus rubecula, L.

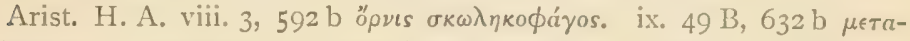

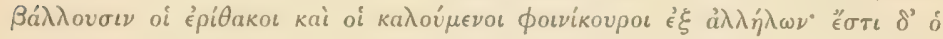

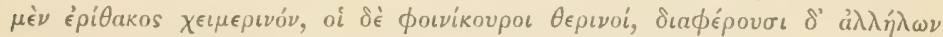

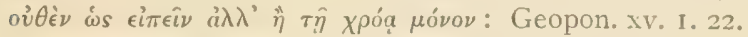

A weather-prophet, Arat. Phen. I025, Theophr. fr. vi. 3, $2 \chi_{\varepsilon \epsilon \mu \hat{\omega} \nu o s}$

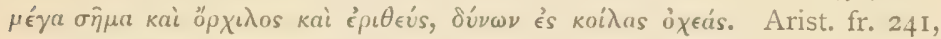

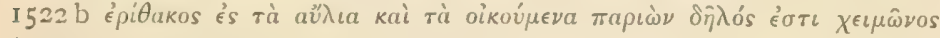

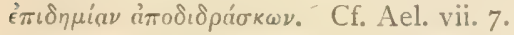

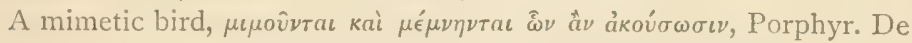
Abst. iii. 4 ('́piӨakos here is either an interpolation, or is used of some other bird).

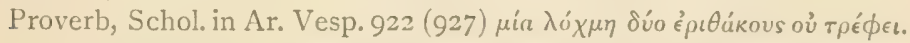

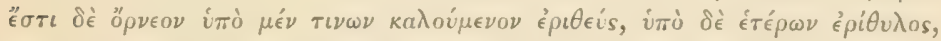

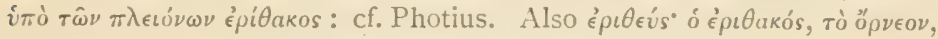

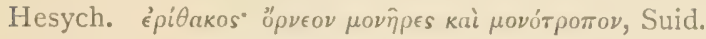

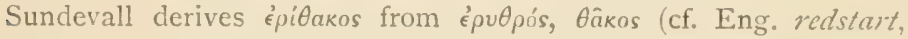
Germ. Rothsteiss), and identifies the bird in Arist. with the Redstart, Lusciola phoenicurus, L., in winter plumage: vide s.v. фoเvíkoupos. The derivation is far-fetched, and the identification is discountenanced by the fact that the Redstart does not, at least in Attica, remain through the winter (Krüper p. 245), during which season the Robin

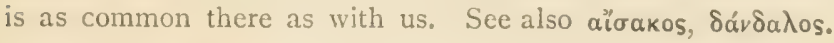

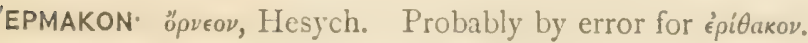




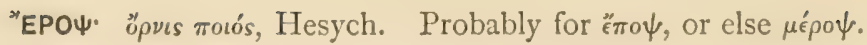

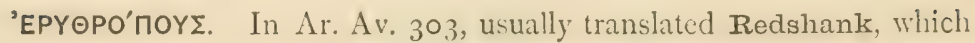
bird, Totanus calidris, L., is common in Greece in winter. Used as an epithet of $\pi \dot{\lambda} \lambda \epsilon \iota$, Arist. H. A. v. I 3,544 b.

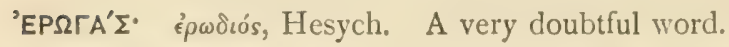

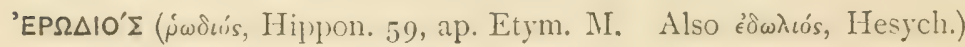
A Heron, L. ardea; etym. dub.

Various species are mentioned : $\delta \pi \epsilon ́ \lambda \lambda o s$, the common Heron, Ardea

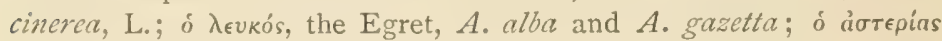
$\kappa a \lambda .$, A. (Botcumes) stellaris, L., the Bittern; Arist. H. A. ix. I, $609 \mathrm{~b}$;

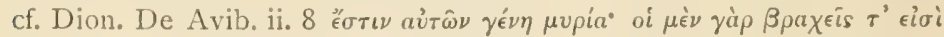

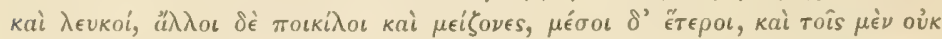

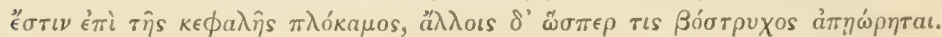
Plin. $x .60(79)$.

The above identifications of $\pi \hat{\epsilon} \lambda \lambda$ os and ảotepías (q.v.) are doubtful: the same words occur in relation to one another as proper names in Apoll. Rh. i. I76; cf. Pott in Lazarus and Steinthal's Zeitschrift, xiv. p. 43.

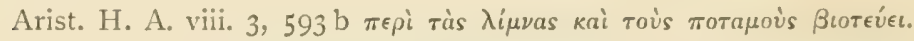

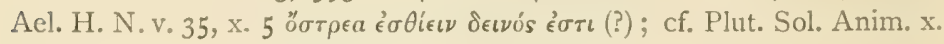
(Mor. 967 D). Its flight described, Arist. De Inc. Io, 7 Io a, fr. 24I, $1522 \mathrm{a}$.

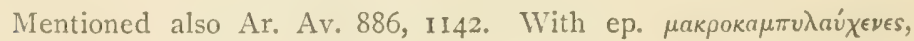
Epich. 49, ap. Athen. ix. 398 D.

Myth and Legend.-Sent by Athene, to Odysseus and Diomede, as a favourable augury, $11 . x \cdot 274$. Here from the nocturnal appearance of the bird and its loud cry, Netolicka (Naturh. a. Homer p. 10) and others suggest the Night-Heron, Ardea Nycticorax, L., which is

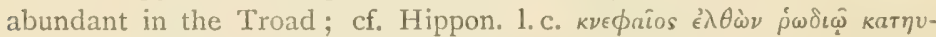

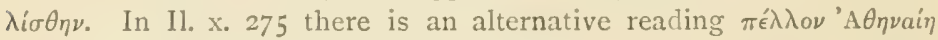
(Zopyrus, De Mileto Cond. iv (Schol. Venet.), cf. Groshans, Prodr. Faun. pp. 15, 16, Buchholz p. II9; for a discussion of important Scholia on this passage, and for notes on '́ $\rho \omega \delta$ óós in general, see J. G. Schneider,

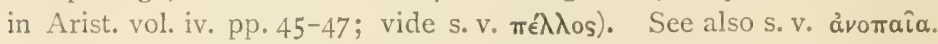

The Heron as a symbol of Athene on coins of Ambracia and Corinth (Imh.-Bl. and K. p. 3 S, pl. vi). Said also to be sacred to Aphrodite, Etym. M. A bird of good omen, Ael. x. 37, Plut. Mor. 405 D, especially the White Heron, Plin. xi. 37. A weather-prophet, Arat. Phaen. 913, 972, Athen. viii. $332 \mathrm{E}$ (where Casaub. reads $\dot{\epsilon} \lambda \omega$ '́os), Ael.vii. 7, Theophr. De Sign. i. 18 , ii. 28 , Virg. Georg. i. 363 , Lucan, v. 553 , Cic. Div. i. 8,

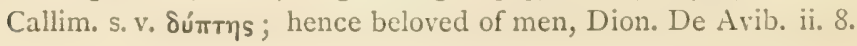




\section{EP $\Omega \triangle 1 O \Sigma$ (continued).}

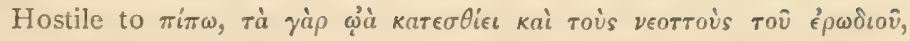

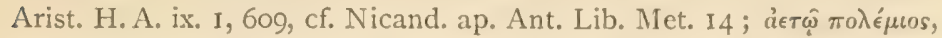

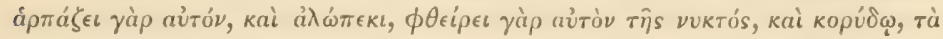

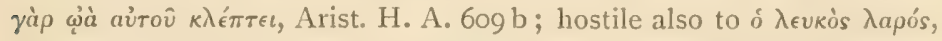
Ael, iv. 5, Phile, De An. 682, and to sorex, Plin. x. (74) 95. Friendly with кор $\omega \nu \eta$, Arist. H. A. ix. I, 6 10, Ael. v. 48.

Erodius, who tended the horses of his father Autonous, was turned into the bird épwóı́s, his father being metamorphosed into ökvos, and

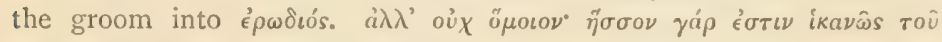
$\pi \epsilon \lambda \lambda$ : $:$ Boios ap. Ant. Lib. Met. 7.

Swallows a crab, ка́ркıроу, as a remedy, Phile 724 , or places one in its nest as a charm, Ael. i. 35, Geopon. xv. I. Noted, like the stork, for filial and parental affection, Ael. iii. 23.

On the painful generation of the Heron cf. Arist. H. A. ix. I, 609 b, Plin. x. (60) 79; hence a fanciful derivation of épwótós in Etym. M. and Eust. ad I1. x. 274. Vide infra, s. v. $\pi \epsilon ́ \lambda \lambda$ os.

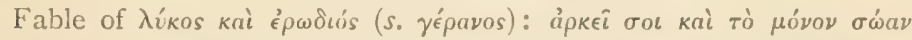

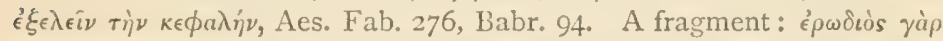

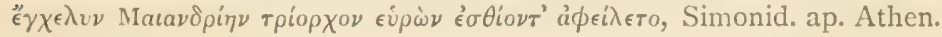
vii. 299 C.

Deprived by Neptune of the power of swimming, and why, Dion. De Avib. ii. 8. The Island of Diomedea, Ael. H. A. i. I ka

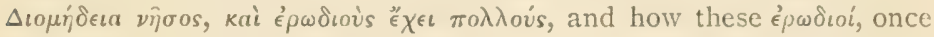
the comrades of Diomede, give welcome to Greek visitors; also Lycus ap. Antig. Mirab. 172 (I88), Anton. Lib. Met. 37, Phile, De Anim. Pr. 152. Cf. Ovid, Metam. xiv. 498, Aen. xi. 271 et Serv. in loc., Plin. x. 44 (61). Cf. also S. Augustin, De Civ. Dei, xviii. 16, Lachmund, De Ave Diomedea diss., Amstelod. (1672) I686. There is evident but obscure connexion between the story of the birds of Diomede, and the metamorphosis above alluded to: where the son of Autonous and. Hippodameia is killed by his father's horses, and his father and his servant

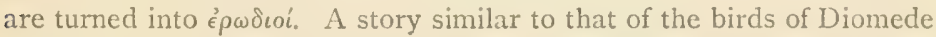
is wide-spread, and usually told of the Stork, cf. Alex. Mynd. ap. Ael. iii. 23; for Modern Greek references, see Marx, Gr. Märchen, I876, pp. 52, 55 .

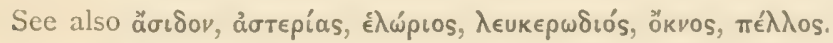

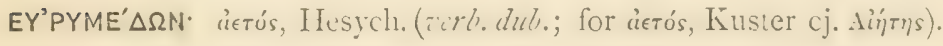

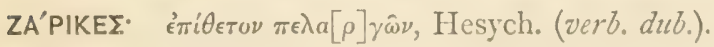

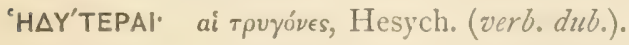

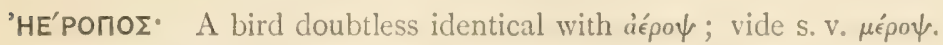
According to Boios ap. Ant. Lib. Met. I8, the boy Botres was 
HEPONOE (continued).

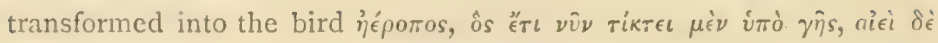
$\mu \in \lambda \epsilon \tau \hat{a} \hat{a} \pi \epsilon ́ \tau \epsilon \sigma \theta a \iota$.

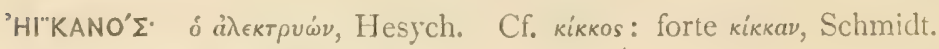

'HMIO'NION. öp

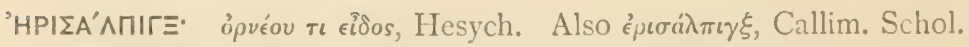
ad Ar. Av. 884 .

OEO'KPONOE. A fabulous bird.

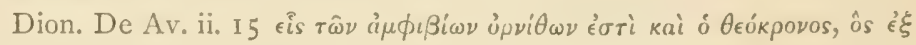

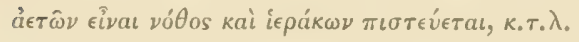

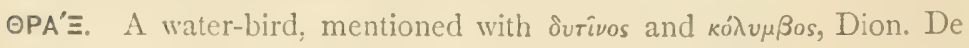
Avib. ii. I 3, iii. 24, q. v.

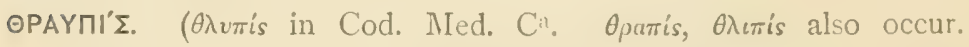

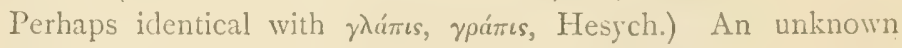
species of Finch. Cf. J. G. Schneider in Arist. l.c.

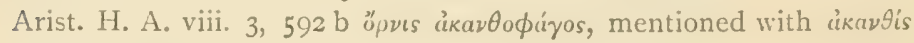

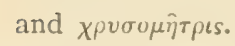

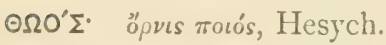

"IBINOE: áєtós, Hesych.

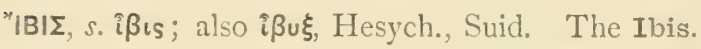

An Egyptian word, bahu : cf. hib or hip in copt. vers. Lev. xi. I7 for Flus' A. V. great orol; cf. Is. xxxiv. II ; tr. ibis in LXX and Vulg.); vide Scholtzii Lex. Aegypt., Oxon. 1775, p. 155. Another Egyptian name leheras still survives as Arab. el harciz, and is preserved in the following fragment: Albert. Magn. vi. p. 255 Avis autem, quae ab incolis Aegypti secundum Aristotelem ieheras (s. leheras) vocatur, et habet duos modos, et unus illorum est albus et alius est niger. Cf. Gesner, iii. p. 546 Avis (inquit Albertus, de ibide sentiens) quae ab Aegyptiis secundum Aristotelem leheras (s. ieheras) dicitur, secundum Avicennam Caseuz vocatur. Cf. Belletête, Annot. ad op. Savigny (infra cit.), p. 39.

Of the two species of Ibis, the Whits or Sacred Ibis, which was first recognized by Bruce (Travels in Abyss. v. p. 173, 1790) is Tantalus acthiopicus, Latham, Numenius Ibis, Savigny, or Ihis religiosa, Cuv. : the Abou Hannes or Father John of the Abyssinians (Bruce), and Abou Mengel or Father Sickle-bill of the fellaheen. The Sacred Ibis still regulariy visits Lower Egypt at the time of the inundation, coming from Nubia (cf. Newton, Dict. of Birds, s.v.). Before the time of Bruce's discovery, the name had been variously assigned to several 
$|B| \Sigma$ (continued).

birds: having been likened to a Stork by Strabo, it was identified with that bird by Belon, by Prosp. Alpin., Hist. Eg. Nat. p. I99, and by Caylus, Antiq. Eg. vii. p. 54, though such an identification was expressly rejected by (e.g.) Albertus Magnus (vi. p. 640 non est ciconia: quia rostrum longum quidem sed aduncum habet), and Vincent. Burgund., Bibl. Mund. i. p. I212; it was supposed to be a Curlew (fulcinellus) by Gesner (H. A. iii. 546) and Aldrovandi (Orn. iii. p. 312) and an Egret or White Heron by Hasselquist (Iter Palest. (2) cl. 2, no. 25), an identification adopted by Linnaeus (Syst. Nat. ed. x. p. I14); by Perrault (Acad. des Sc. Paris, iii. p. 58, pt. xiii) it was taken to be a much larger bird, the Tantalus ibis of Linnaeus (Syst. Nat. ed. xii); and yet others, e. g. Maillet (Descr. de l'Égypte, 4 to ii. p. 22) confounded it with the Egyptian Vulture or 'Pharaoh's Hen.' The White Ibis is figured on the Mosaic of Palestrina (cf. the coloured figures in the P'itture ant. di Petr. S. Bartholi) and in the Pitture ant. d' Erculaneo (ii. pll. 59, 60).

The Black Ibis of Herodotus, the Glossy Ibis of ornithologists, is Ibis falcinellus, Temm., Falcinellus igneus or Plegades falcinellus of more recent writers. It is confounded by L. \& Sc. with the Scarlet Ibis, an American bird. To it the Arab name el harciz is said especially to apply.

On both species, see Cuvier, Ann. du Mus. iv. pp. 103-135, I804; and especially the learned memoir of J. C. Savigny, Hist. nat. et mythol. de l'Ibis, Svo Paris, I805. On Ibis mummies, cf. T. Shaw, Levant, I738, pp. 422, 428, G. Edwards, Nat. Hist. I743-1764, Blumenbach, Phil. Trans. I794, and later writers.

The Sacred Ibis is said to nest in palm-trees, Ael. x. 29 rou's aì oúpous

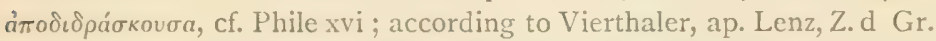
u. R.p. 379, it breeds in Sennaar, nesting on mimosa-trees, and building twenty to thirty nests on a tree: see also Heuglin, Ornith. Nord. Afrikas, p. 1138 .

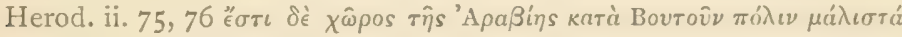

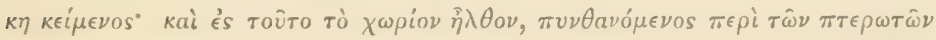

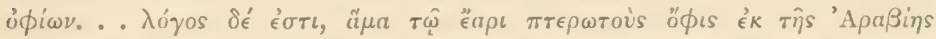

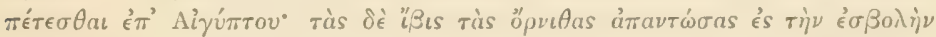

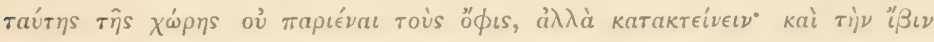

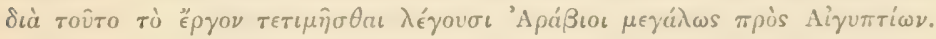

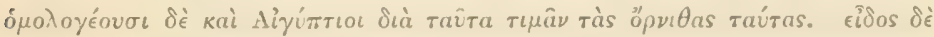

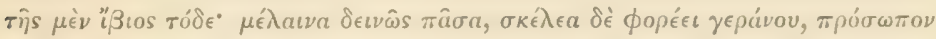

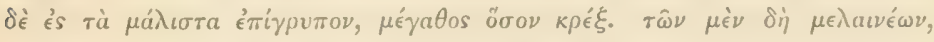

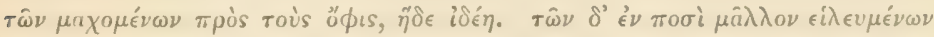

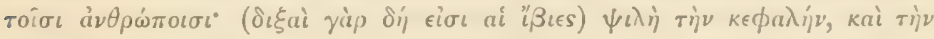

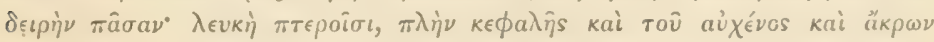


$\mid \mathrm{BI}$ (continued).

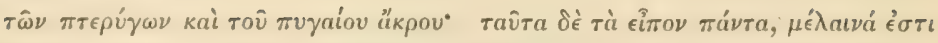

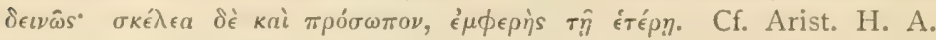

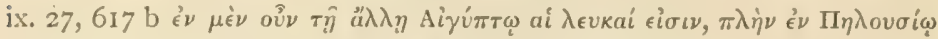

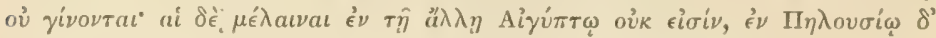
eiriv. Cf. Plin. x. (30) 45, Solin. xxxv. p. 95. On the geographical confusion implied in these accounts, vide J. G. Schneid. in Arist. vol. iv. pp. 493-496.

The annual fight between the Ibis and the flying serpents is also alluded to: Cic. Nat. D. i. IoI, Ael. ii. 38, Phile, De An. xvi, Solin. xxxv, Pomp. Mela iii. 9, Amm. Marcell. xx. 15, Isidor. i. p. 306, Albert. M. vi. p. 640, \&c.

The Ibis in conflict with a winged serpent on coins of Jubah II, and Cleopatra of Mauretania (Imhoof-Bl. and K. p. 37). The 'Winged Serpents' were probably the hot winds and sandstorms (cf. Diod. Sic. i. 128) of spring, which disappeared as the Etesian winds ('jpvitia

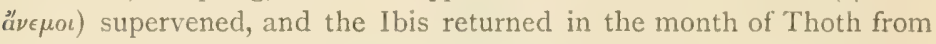
its migration, with the season of the inundations which freed Egypt from all her pests: cf. Savigny, op. cit. pp. 9I, I34, Pluche, Hist. du Ciel, i. I, p. 77 ; an interpretation of the Winged Serpents, more subtle than this, is however possible: cf. the öфıs iєpakópopфos, Philo ap. Euseb. Praep. Evang. i. p. 4I, Lydus De Menss. pp. 53, 137, Creuzer

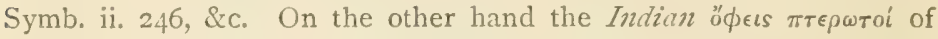
Megasthenes (ap. Ael. xvi. 4I) seem to have been real, not mythical, and were very probably 'Vampire' Bats, Pteropus medius, Temm. (Val. Ball). On the Ibis as a useful destroyer of ordinary serpents, see Cic. Nat. D. i. 36, ii. 50, Diod. Sic. i. 97, Strabo, Geogr. xvii. p. 823, Plin. N. H. x. 28 (40), \&c. How Moses brought it in cages of papyrus to destroy the serpents of the Ethiopian desert, Joseph. ii. IO. p. 127. How serpents are terrified by an Ibis' feather, Ael. i. 38 , Phile, De An. v. 7I5, or even paralyzed by it, Zoroast. in Geopon. xv. I, cf. ib. xiii. S, Theoph. Simoc. Quest. Phys. xiv. p. I9, \&c.; likewise the crocodile: an indolent and rapacious man symbolized by a crocodile

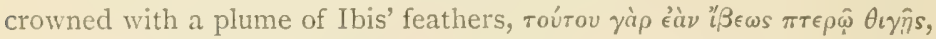

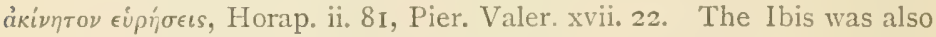
hostile to the scorpion, Ael. x. 29, including 'winged scorpions,' Phile, De Ibi : and is associated [obscurely] with the Scorpion on the small zodiac of Dendera, Savigny, op. cit. p. 131, Denon, Voy. pl. 130; cf. Kircher, Oedip. ii. pp. 207, 213. The Ibis also destroyed locusts and caterpillars, Diod. Sic.; it fed on fish, avoiding. strong currents, Physiol. Syr. c. xviii, Procop. Comm. in Levit. p. 344, Vincent. Burg. Specul. i. p. I212; and on the refuse of the markets of Alexandria, Strabo, 1. c. Its flesh was poisonous and fatal, Vinc. B. i. I2 I2, ii. I 489 ejus ova si quis comeditur, moritur; cf. Albert. M. xxiii. 24, Gesner, 
$\mid \mathrm{BI}$ (continued).

cap. De Ibi. How the basilisk springs from an egg, the product of poison eaten by the Ibis : ex aliquo quod illa peperit, ut putredinoso, magnum aliquid malum enascitur basiliscus, \&c., Theoph. Simoc. 1. c.; cf. Pier. Valer. p. I 75 .

It was foul-feeding and insatiable of poison, Ael. x. 29, Phile xvi; cf. Gesner v. 547 apud Graecos lexicorum conditores ibin ỏ $\phi \iota \phi c i ́ o \nu$

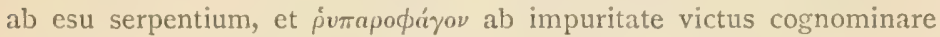
invenit. Nevertheless, it was in other respects cleanly (Ael. x. 29), and the Egyptian priests washed in water from which the. Ibis had

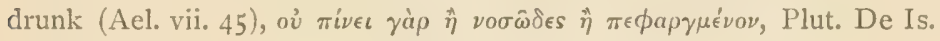
p. 381. It is killed by hyaena's gall, Ael. vi. 46, Phile 666.

Mentioned with name Avkov̂pyos, Ar. Av. I296. Compared with the Stymphalian birds, Paus. viii. 22, 5. Its tameness noted, Strabo, 1. c., Joseph. Antiq. Jud. p. 127, Amm. Marcell. p. 337.

Its name a term of reproach, Ovid, Ibis, v. 62 Ibidis interea tu quoque nomen habe: cf. Callim. Alciati embl. 87, in sordidos.

The Ibis was sacred to Isis, the Moon-Goddess: Ael. ii. 38 iє pà rîs

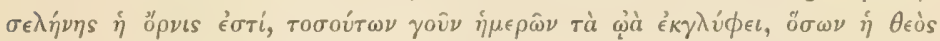

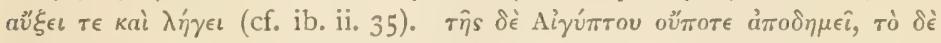

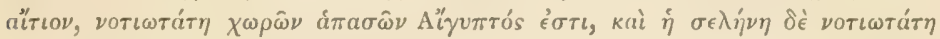

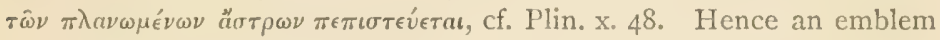
of Egypt, Pier. Valer. xvii. I8, Kircher, Oedip. iv. p. 324, and as such on coins and medals of Hadrian and Q. Marius. See also Phile xvi

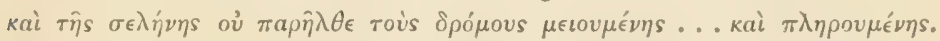

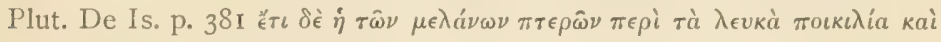

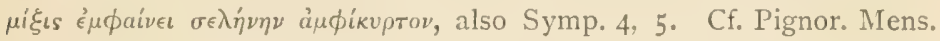
Isiac. Expl. p. 76; Wilkinson, Anc. Egyptians, (2) ii. pp. 217-224; Renouf, Hibbert Lectures I879, pp. I 16, 237. It is figured together with the new moon on the southern Temple of Jupiter Ammon at Karnak (Descr. de l'Égypte, Thèbes, ii. 261, pl. 52 ; Creuzer, ii. p. 208, \&.c.). On the connexion between Thoth and the Moon, discussed in explanation of the Ibis' relation to the latter, see Leemans in Horap. p. 247.

It represented the moon (as a hawk symbolized the solar Osiris) at Egyptian banquets of the gods, Clem. Alex. Stromat. v. 7. Its mode of generation was probably related to lunar superstitions: Ael. x. 29

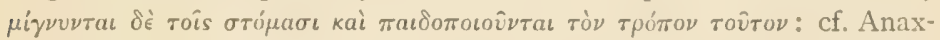
agoras ap. Arist. De Gen. iii. 6, 756 B, Schol. in Pl. Phaedr., Solin. xxxv, \&c. Its ashes prevent abortion, Plin. xxx. (I 5) 49.

The Ibis was sacred also to Thoth or Hermes: cf. Socr. ap. Pl. Phaedr.p. 274; Ael. x. 29; Plut. Symp. ix. 3; Diod. Sic. i. S; Horap. i. capp. 10, 36 ; Pier. Valer. xvii. 19; Kircher, Obel. Pamph. iv. 325, Oedip. i. I5, ii. 213, \&c. Thoth was the patron or emblem of Sirius, which star on the small zodiac of Dendera is represented close to a double- 


\section{$|B| \Sigma$ (continued).}

headed snake with ibis-heads; cf. Savigny, op. cit. p. 159, Kircher, Oedip. iii. p. 96, Sc. : on the same zodiac an ibis-headed man rides on Capricornus, under which sign Sirius rose anti-heliacally (Dupuis, Orig. de tous les cultes, v. I); in this connexion, cf. Timoch. 3. 590 $\pi \hat{\omega} s \hat{\imath} \nu \sigma \dot{\omega} \sigma \in \iota \in \nu$ ißıs $\hat{\eta} \kappa \dot{\omega} \omega \nu$. Thoth is figured as an Ibis, or with an ibis-head, Plut. Symp. ix, cf. Pherecydes, Hymn. Merc. ${ }^{3} \Omega$ 'E $p \mu \eta \bar{s}$

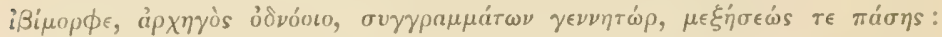
Hermes, pursued by Typhon, changed himself into an Ibis, Hygin. Astr. P. ii. c. 28 , Ant. Lib. Met. c. 28 , Ovid, Met. v. 33 I. Many of the bird's peculiarities, real or fabulous, are mystically associated with the same god: e.g. its dainty walk (Ael. ii. 38) with the inventor of the dance; its numerical constants (e.g. its intestine 96 cubits long, and its pace of one cubit, Ael. x. 29) with the inventor of arithmetic; the equilateral triangle or $\Delta$ that its beak and legs made (Plut. Is. et Osir. 381 ; or its legs alone, Pier. Valer. xvii. I8, xlvii) with the inventor of letters (cf. also Kircher, Obel. Pamphil. pp. 125-131), its knowledge of physic with the founder of the medical art. On the Ibis as the inventor of clysters, cf. Cic. N. D. ii. 50, I26, Plut. De Sol. Anim. p. 974 C тîs i $\beta \epsilon \omega s$

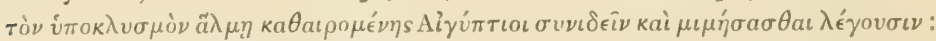
id. De Is. et Osir. p. 38I, Ael. ii. 35, x. 29, Phile xvi, Plin. viii. (27) 4I, x. 30, Galen, De Ven. Sect. i, \&c.; the same story of the Stork, Don Quixote, ii. p. 63 (edit. Lond. 1749) : cf. N. and Q. (4) ix. p. 216: see also Bacon, De Augm. v. 2. The opposed black and white of the Ibis' plumage, as sometimes of Mercury's raiment, suggested various symbolic parallels, the opposition of male and female, of light and darkness, of order and disorder, of speech and silence, of truth and falsehood: cf. Ael. x. 29, Schol. in Pl. Phaedr., Plut. De Is. 38 I D, Clem. Alex. Str.

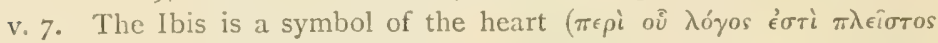

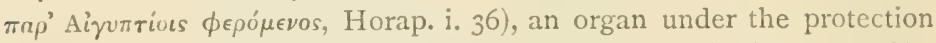
of Hermes; and the bird has a heart-shaped outline (Ael. x. 29 kapoias

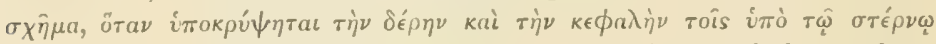
$\pi \tau \epsilon \rho$ is) as indeed its mummies have still; a weight as it issues from the egg equal to the heart of a new-born child (Plut. Symp. 670), or a heart of its own of exceptional size (Gaudent. Merula, Memorab. iii. c. 50); in this connexion we may compare the Eg. bahu with $b a$ or bai the soul (Lauth, op. cit.); cf. supra s.v. $\beta a \imath \eta \dot{\theta}$. The Ibis was emblematic of the ecliptic or zodiacal ring: åı $\theta \mu$ vo yà

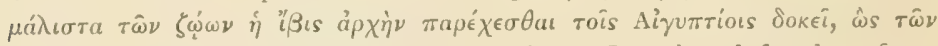

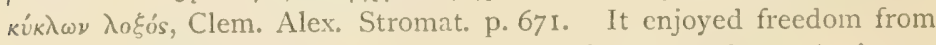
sickness, longevity, or even immortality (Apion ap. Ael. x. 29); it was buried at Hermopolis (Herod. ii. 67, Acl. 1.c.).

จ $1 \mathrm{BY} \equiv$. Hesych., Suid.; vide s. v. ¿ $\beta$ เs.

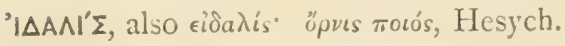




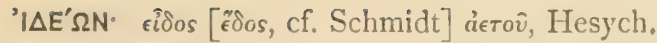

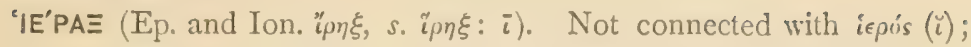
perhaps from root $F \bar{i}$ swift (cf. Naass, Indo-Germ. Forsch. i. p. I 59), but the etymology is quite obscure.

A Hawk. The generic term especially for the smaller hawks and

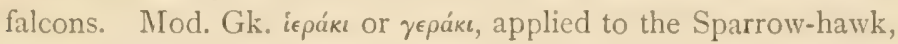
Kestrel, Hobby, \&c., and also to the Kite (Erhard). Dimin. iєракıঠєús, Eust. 753, 56; iєракібкоs, Ar. Av. III 2.

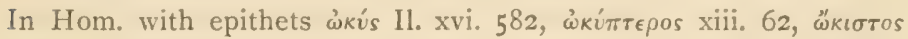

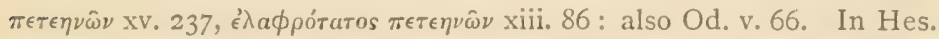

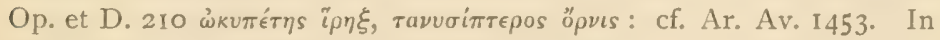

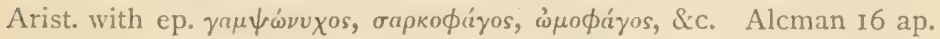
Athen. $373 \lambda \hat{v} \sigma a \nu \delta^{\prime}$ "̈ Eur. Andr. $114 \mathrm{I}$ of $\delta^{\prime}$ ơ

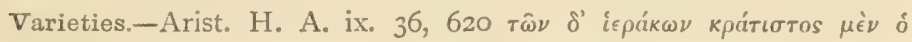

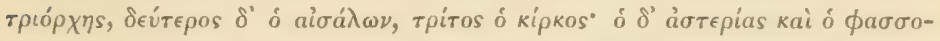

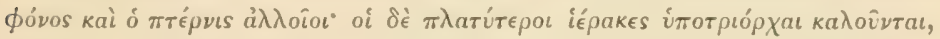

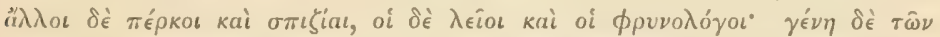

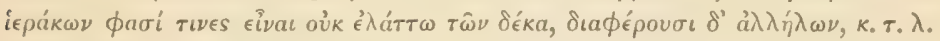
Cf. ib. viii. 3, 592 b. That there were ten species of hawks is asserted by Callimachus, Etym. M. Vide Callim. fr. p. 468, ibique Bentleii; cf. Schol. ad Ap. Rhod. i. 1049. For lists of the species, cf. Ar. Av. II78, Ael. xii. 4, Dion. De Avib. i. 6, Plin. x. 8, 9, 10. The Egyptian hawks were smaller, Arist. H. A. xii. 4. The various hawks migrate

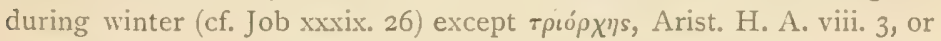
epileus, Plin. x. (8) 9.

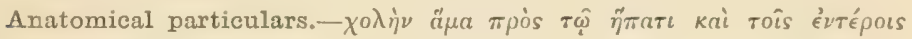

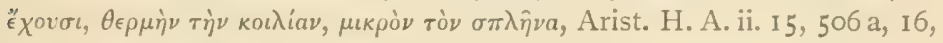
506b; De Part. iii. 7, 670a.

Breeding habits.-Arist. H. A. vi. 6, 563, incubates twenty days; ix. 1 I,

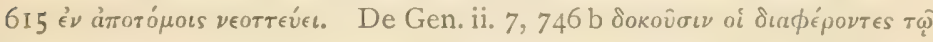

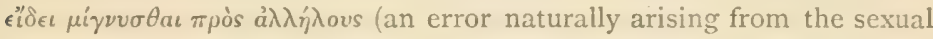
difference in size and plumage in many species). H. A. vi. 7,564

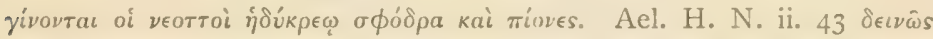

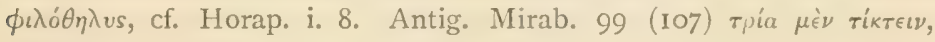

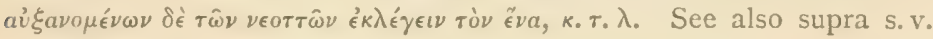
åetós, and cf. Horap. ii. 99.

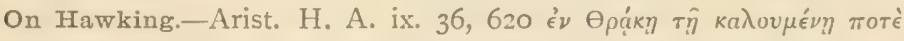

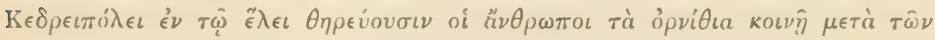
iє pák $\omega \nu$. Cf. De Mirab. vi. I1 8, 84I b, Ctesias in Phot. Excerpt. and ap. Ael. iv. 26, Ael. ii. 42, Antig. Hist. Mirab. [Amphipolis], 28 (34), Plin. H. N. x. S (10), \&c. The account in Dion. De Avib. i. 6, iii. 5, and 


\section{IEPA $\equiv$ (continued").}

probably also in Martial, Ep. xiv. 216, refers to bird-catching with a captive hawk, as with the owl. See also for much curious information, 'Iєракобóфıov, s. rei accipitrariae scriptores, ed. Paris, 16I2, and Leipzig, 1866, also Schlegel's Fauconnerie, \&c.

Metamorphosis with the Cuckoo--Arist. H. A. vi. 7, 562 b, Plut. Arat. cap. xxx, Tzetz. ad Lyc. 395 ; Geopon. xv. I. Theophr. De Pl. ii.

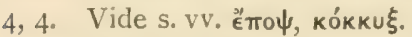

Myth and Legend.-Worship of Hawks in Egypt, Herod. ii. 65, 67;

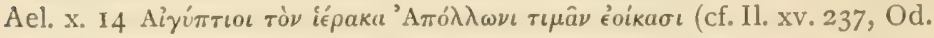

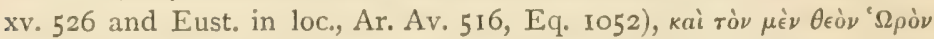

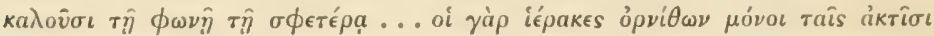

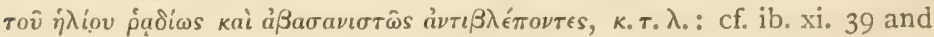
vii. 9, where the priests are called iєракоßобкоi ; cf. also Plut. Is. et Os.

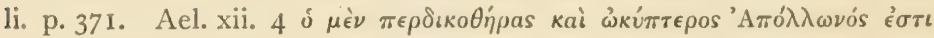

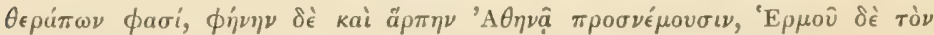

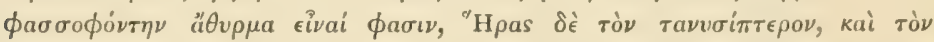

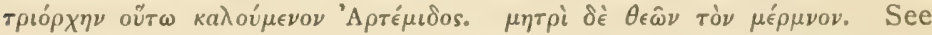
also Strabo, Geogr. xvii. I. 47, Horap. i. 8, Pier. Valer. Hierogl. xxi,

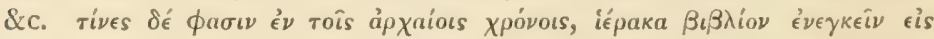

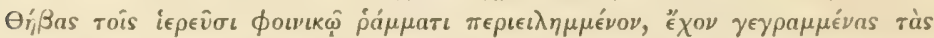

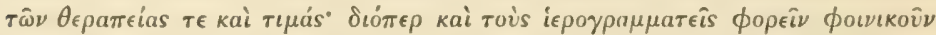

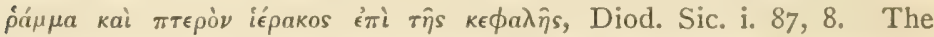

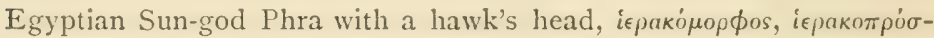
$\omega \pi$ s, Philo ap. Eus. P. E. 4I D, II6 D (i. Io, iii. I2), Horap. i. 6. In the Rig-Veda the sun is frequently compared to a hawk, hovering in the air. The hawk associated with fire-worship, Ael. x.24. A threelegged hawk sometimes seen in Egypt, Ael. xi. 39. Moult before the inundation, ib. xii. 4 ; live seventy years, $i b . x$. I4; the leg-bone has an attraction for gold, ib.; throw earth on an unburied corpse,

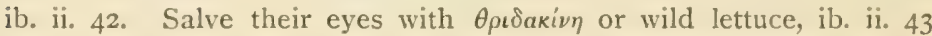
(also Dion. De Avib. i. 6); hence, as well as by reason of their sharp sight, the Hawk or Eagle in medicine constitute a remedy for diseases of the eye, Plin. xxix. (6) 38 , \&c.; as does the herb iє pákıov, Horap. i. 6 , Plin. xx. (7) 26, xxxiv. (II) 27 : it is seldom possible to trace any meaning in the mystical herbs associated with particular animals, and

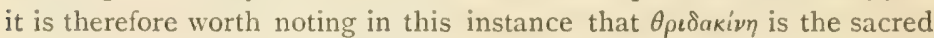
herb of Adonis. Are supposed by some to be bastard eagles, Ael. ii. 43; how a hawk caused the apprehension of a sacrilegious thief at Delphi, ib.; how the hawks in Egypt repair to certain Libyan islands to breed, having sent two messengers in front, ib. (cf. Plin. H. N. x. 8, Diod. Sic. i. 87); do not eat the heart, ib. ii. 42 ; hostile to the fox, the eagle, and the vulture, ib. Are exempt from thirst, Damasc. V. Isid. 97 (cf. s. v. a'єrós), but drink blood instead of water, Horap. i. 7. Their 
IEPA $\equiv$ (continued).

heart is eaten, to obtain prophetic powers, Porph. De Abst. ii. 48. A Hawk sitting on a tree a sign of rain, Theophr. Sign. fr. vi. 2, I 7

The Fable of the Hawk and the Nightingale, Hes. Op. et D. 201, Aes. fab. 9.

A metaphor of the Hawk and the Crows, Ar. Eq. I052.

The metamorphosis of Hierax, Boios ap. Anton. Lib. iii ; cf. that of Deucalion, Ov. Met. xi. 340.

The Hawk entered in Egypt into innumerable hieroglyphics, in which its image is, in the main, a phonetic element, the symbolic ideas being, for the most part, secondary (cf. supra, s. v. $\beta a\llcorner\eta \dot{\theta}$ ).

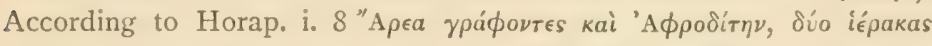

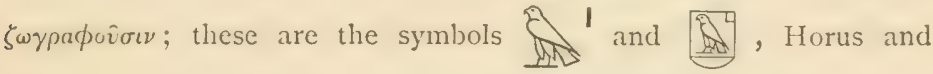
Hat-Hor, the latter being the oikos " $\Omega$ pov of Plutarch. According to

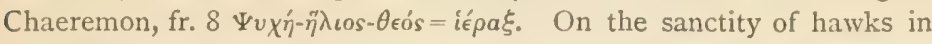
Egypt, and the solar symbolism associated with them there, see also (besides the references quoted above), Porph. De Abst. iii. 4 ; the Sun called í́ $\rho a \xi$, ibid. iv. 16, Plut. De Is. et Osir. c. 51, Eus. P. E. iii. 10, Clem. Alex. Strom. v. 7.

For other words and phrases in which the hieroglyph of the Hawk

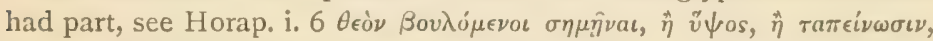

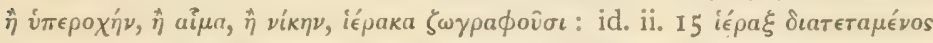

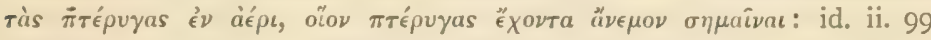

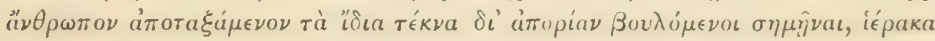

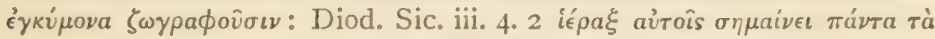

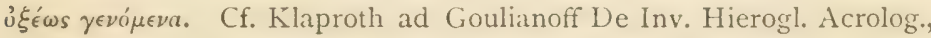
cit. Leemans in Horap. p. 150, and especially Lauth, Sitzungsber. Bayer. Akad., I 876, pp. 77-79.

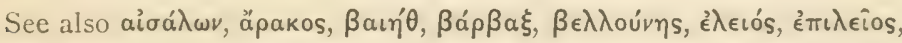

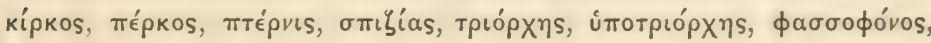
фpuvoגóyos, \&c.

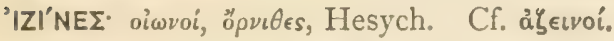

"IKTEPOE. A bird with fabulous attributes; according to Pliny, identical with galgulus, the Golden Oriole.

Plin. xxx. II (28) Avis icterus vocatur a colore, quae si spectetur,

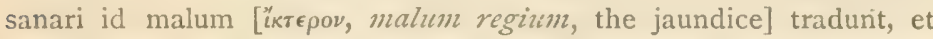
avem mori. Hanc puto Latine vocari galgulum (galbula, Mart. xiii. 68). Cf. Dion. De Avib. i. 27 ; Coel. Aurel. Chron. iii. 5 passio vocabulum sumpsit secundum Graecos ab animalis nomine, quod sit coloris fellei. Cf. Schneider, in Arist. H. A. ix. I2; and Suid., who derives

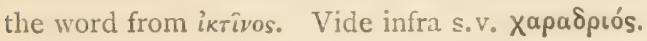




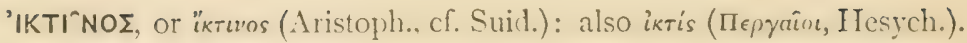
In plur. iktives (Ael. i. 35, ii. 47 ) or ikrives (Paus.). For other grammatical forms, see L. \& Sc., \&c. Derivation unknown; sometimes said to be connected with Sk. çyēna.

A Kite: including the Common Kite, Milvus regalis, Briss., M. ictimus, Sav., and the Black Kite, $\boldsymbol{M}$. ater, Gm. The Black Kite is still called iкrivos in the Cyclades, where it is the commoner species of the two (Erh.). The Common Kite is also

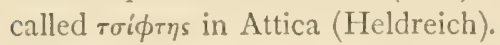

In minor references frequent, usually as a robber, e. g. Theogn. I26I,

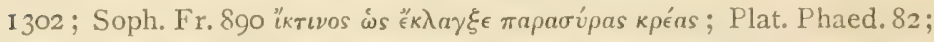
Men. 4, 329 (493) ; Plat. Com. 2, 695 (69) : Aristoph. fr. 2, I192 (71),

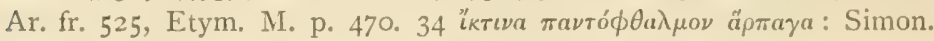

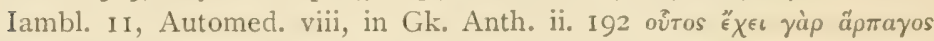

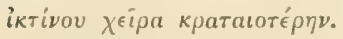

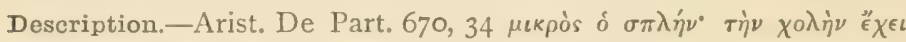

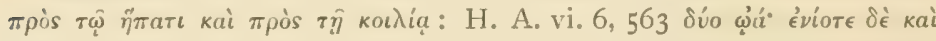

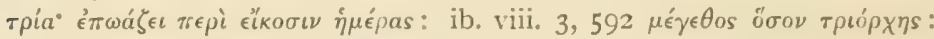

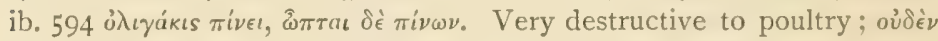

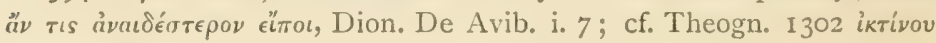

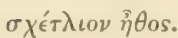

A migratory bird: it arrives before the swallow, at the spring shearing-time, Ar. Av. 714; in Egypt it does not migrate, Herod. ii. 22 ; it sometimes hibernates, Arist. H. A. viii. I6, 600 oi $\mu \dot{\epsilon} \nu \pi \lambda \eta \sigma i o \nu$

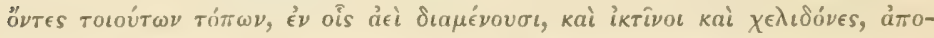

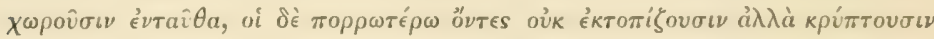

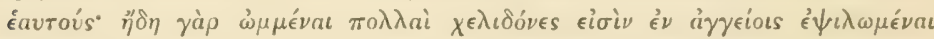

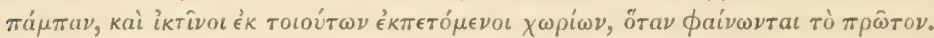
The common Kite is merely a bird of passage in Greece, a very few remaining to winter there (Krüper); the Black Kite is a rare visitor to the mainland of Greece. Both species are common, and breed, in Macedonia (Krüper, Elwes, \&c.).

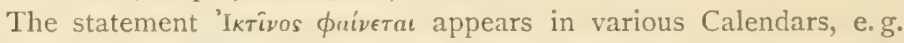
Geminus, Isag. in Arat. Phaen. co xvi, who dates its advent, according to Eudoxus thirteen days, to Euctemon eight, and to Callippus one day, before the vernal equinox. According to Grotius, Arat. Phaen. notae ad imagg. p. 55, Milvus, in Latin, refers to the constellation Cygnus; cf. Ov. F. iii. 793 Stella Lycaoniam vergit declivis ad Arcton Milvus. Haec illa nocte [xvi. Kal. April.] videnda venit; see also Plin. xviii. 6; but according to Ideler, Sternnamen, p. 77 , the dates given do not tally with this hypothesis, the heliacal rising of Cygnus being three months earlier; and he prefers to assume that the statements in the older Calendars referred to the bird of passage, and were mistakenly 
IKTINOE (continued).

attributed to a constellation by Ovid and Pliny. I am for myself inclined to think that Ovid did allude to the constellation, but that he did not mean (nor say) that on the date in question it rose with the sun; as a matter of fact it then rose at midnight, and was on the meridian when it disappeared at sunrise. 'I

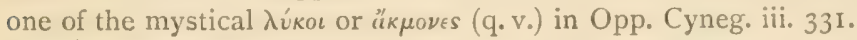

Myth and Legend.-Hostile to kópa $\xi$, Arist. H. A. ix. I, 609, Ael. iv. 5, Phile, De An. 688, Cic. De Nat. Deor. ii. 49; friendly to $\pi i \phi \iota \gamma \xi$ and $\tilde{a} \mu \pi \eta$, Arist. 1. C., Ael. v. 48. Use $\theta$ ṕos as a remedy, Phile 725 ; place '́á $\mu \nu \nu_{\nu}$ in the nest as a charm, Ael. i. 55 ; how a stick from a Kite's nest is a remedy for headache, Plin. xxix. (6) 36 , xxx. (4) I2; detest the pomegranate, poin, so that they never even alight on that tree, and why, Dion. De Avib. i. 7. Suffer at certain seasons from sore feet, Dion. 1. c., namely, at the time of the Solstice, Plin. x. (IO) I2 ; and

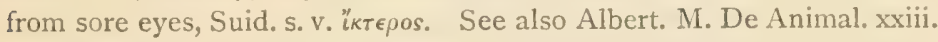

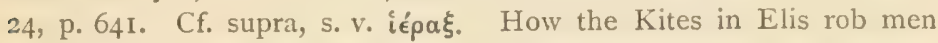
in the market-place (cf. Ar. Av. 1624), but never molest the if pó $\theta_{\text {utor, }}$ Ael. ii. 47, Arist. De Mirab. 123,842 a, Theopomp. ap. Apollon. Hist. Mirab. x, Pausan. v. I4, Plin. 1.c.; on the Kite as dangerous to

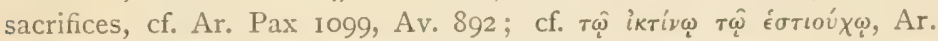
Av. 865. How the Kite was once a King, Ar. Av. 499. The story in Plin. 1. c., milvos artem gubernandi docuisse caudae flexibus, does not seem to occur in Greek. In Latin, Milvus is proverbial for its powers of flight and of vision; cf. Pers. Sat. iv. 26, Juv. ix. 25, Martial ix. Ep. 55 .

Fable of ikrivos that lost its voice trying to neigh, Aes. Fab. ed. Halm, 170, Babr. 73; Suid. ; cf. Julian in Misopogone, p. 366 (cit. Schneider in

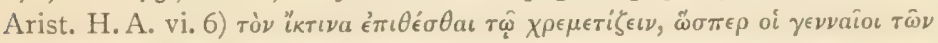

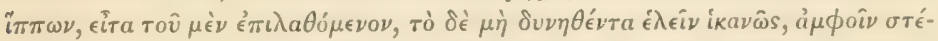

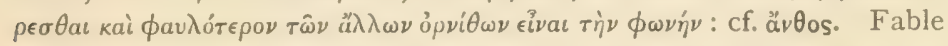

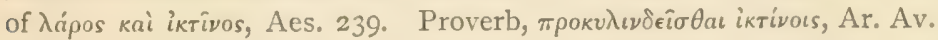

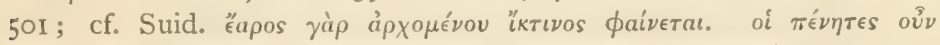

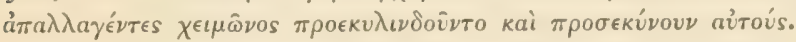

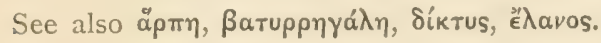

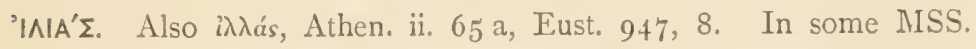

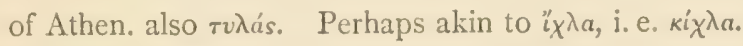

A kind of Thrush : for references, see $k i x \lambda \eta$.

Gesner, Belon, and others identify i $\lambda$ ıás as the Redwing, Turdus iliacus, L., on account of its small size (Arist. H. A. ix. 20,617). Sundevall points out that the expression $\tilde{\eta} T r o \nu \pi \circ \iota \kappa \iota \lambda \dot{\eta}$ (1. c.) is inapplicable. In Athen. ii. 65 a (c. 68) these words are omitted from a corresponding passage; and the account of the nesting habits of $\kappa i \chi \lambda \eta($ H.A. vi. I) 
IAIAE (continued).

are transferred to $i \lambda \lambda$ ás. Both the Redwing and the Fieldfare are now winter-migrants in Greece, and not very common (Krüper, Lindermayer, \&c.). The word was probably an old or dialectic form, meaning simply thrush, to which it was sought to apply a specific meaning in Aristotle.

'IMANTO'mOYs. A wading-bird; the name is now allotted to the Stilt.

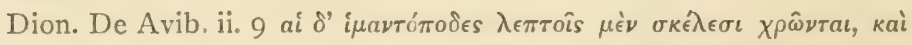

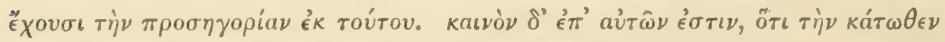

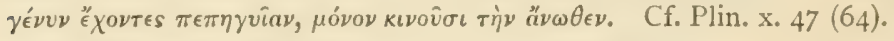

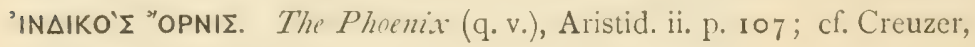
Symbolik, ii. p. 167 .

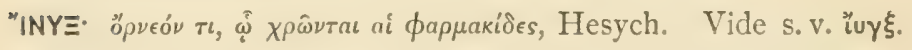

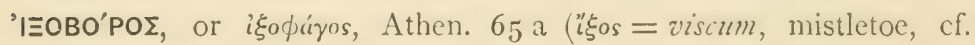
Ital. viscada, the Missel-thrush).

The Missel-thrush, Turdus r'iscizorus, L. Mod. Gr. kıрtapiva (v. d.

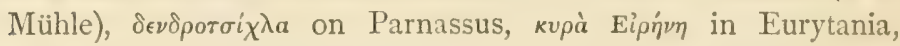

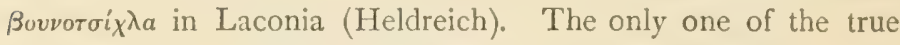
thrushes resident in Greece throughout the year (Krüper).

Arist. H. A. ix. 20, 617. Vide s. v. kix $\lambda \lambda_{\eta}$.

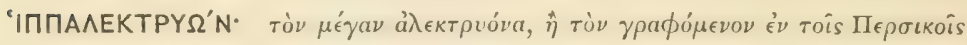

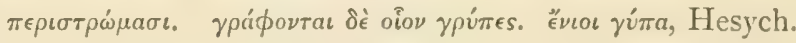

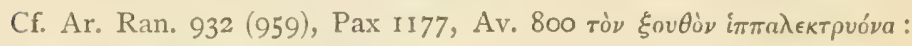
cf. Aesch. Myrm. fr. 130, \&c., \&c.

Note.-The epithet $\xi o v \theta$ ós is applied to various creatures, e. g. ả $\eta \delta \omega^{\prime}$,

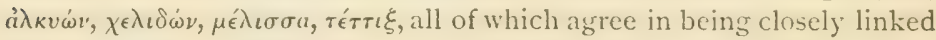
with religious symbolism. The meaning of the adjective is quite unknown. With the various conjectures of modern commentators cf.

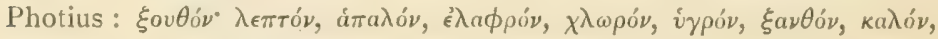

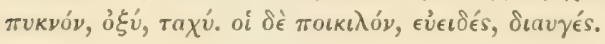

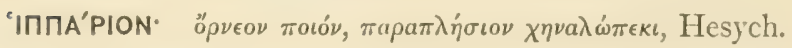

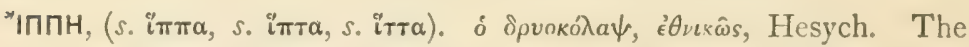
root is supposed to be $\imath \pi$, Lat. ic-o (Vaniček 82 ), cf. iros; and the word is taken to be identical with $\pi i \pi \omega$ (q. v.); but the itra suggests identity with oirt?.

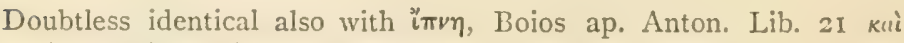

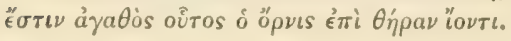




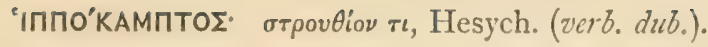

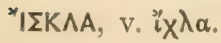

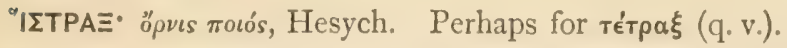

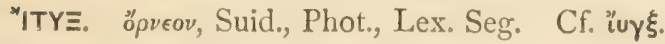

"IYr Th. 400 ; but more probably a word of foreign and unknown origin.

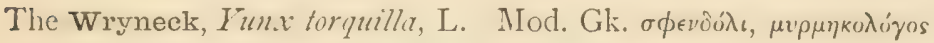

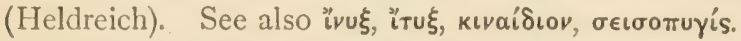

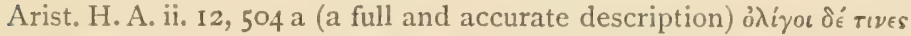

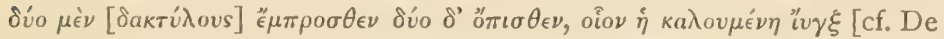

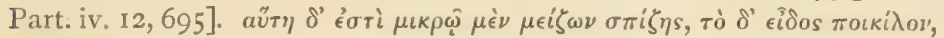

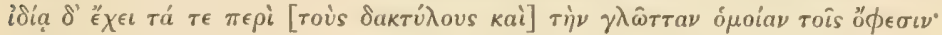

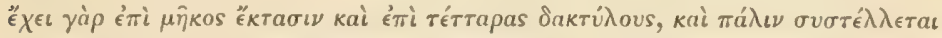

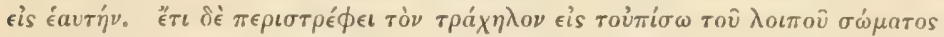

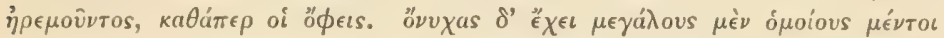

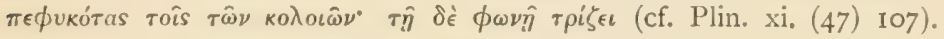

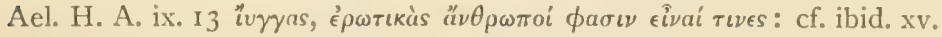

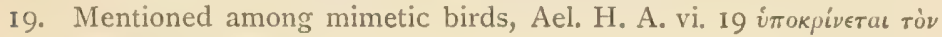

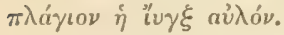

Superstition, interwoven with a phallic symbolism (cf. Dion. De Avib. i. 23), used the ${ }^{\prime} v \gamma \xi$ as a charm to bring back a strayed lover.

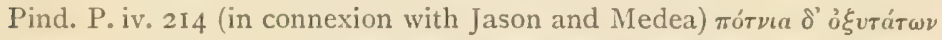

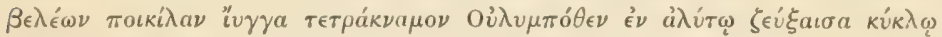

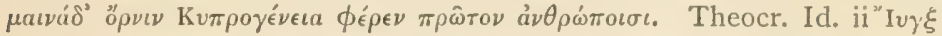

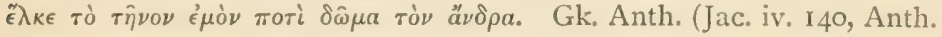

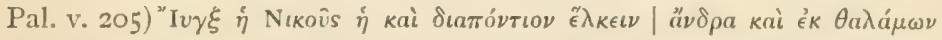

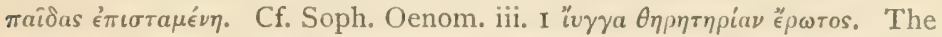
bird was bound upon a wheel and spun round, cf. Theocr. ii. 30;

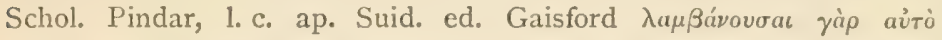

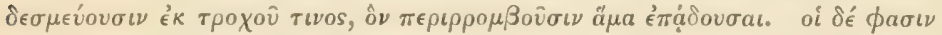

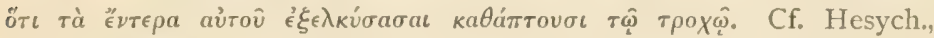
Suidas, Tzetzes in Lycophr. 310, Ael. H. A. ix. I3, \&c. In Pind. P. iv.

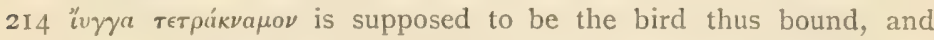

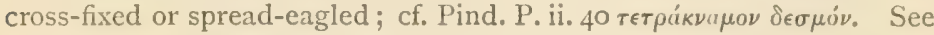
also King, Ant. Gems, i. $38 \mathrm{r}$.

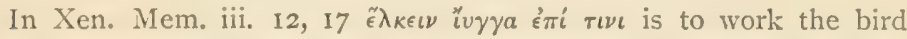
against some one (Schn.), and perhaps the word is here used for the wheel itself or for a charm in a more general sense; cf. Aristaenet.

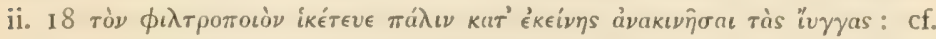

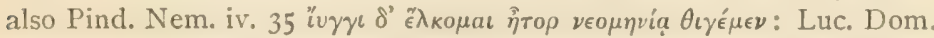

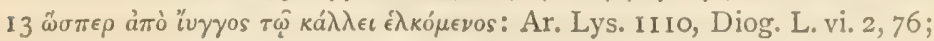




\section{IYГ $\equiv$ (contimued).}

Ael. xv. 19, Opp. Hal. iv. 132 ; still more loosely used in Ael. ii. 9, v. 40, xii. 46, xiv. I 5, \&c. Compare also Virgil's translation of Theocritus, Ducite ab urbe domum mea camina, ducite Daphnin. The magic wheel was properly called ṕó $\beta$ ßos, Theocr. ii. 30, Orphic. fr. xvii (Hermann) ap. Clem. Alex. Strom. p. I 5. 8, Luc. D. Meretr. iv. 5, \&c.;

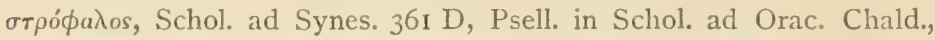
трохі́⿴коs, Tzetz. Chil. xi. 3 So (trochiscilus, Apul. De Mag. xxx), cf. Clem. Alex. Strom. v. 8, or ṕcós, Suid., and in Lat. rhombus, Mart. ix. 30, Propert. iii. 6, 26, rota, Plaut. Cistell. ii. 1. 4, or turbo, Hor. Epod. xvii. 7 . It was probably similar to, though not identical with, the ṕó $\tau \rho \circ \nu$, or tambourine of the Corybantes, and the bird was, like that instrument, associated with the worship of Rhea, Dion. De Avib. i. 23. According to Marcellus in Nonn. Dionys. ix. I16, the $\rho \circ \mu \beta o s$ was (and under the same name still is, in Italy) an instrument twirled round at the end of a thong, which means to say, I suppose, that it was a 'bull-roarer'; if

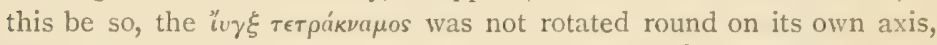
but spun at the end of a string, as we spin cockchafers. Concerning the magic wheel, see also Selden, De Diis Syr. i. I, 33.

The bird is represented on a vase in connexion with Dionysus, Brit. Mus. Vase Cat. No. I293; and the Pindaric epithet $\pi \circ \kappa^{\prime} \lambda \eta$ has been interpreted as a link in its Dionysiac character (cf. R. Brown, jun., Dionys. Myth, i. 339). In this connexion the name 'Iŕyzü for Dionysus (Hesych.), is very interesting. Another vase (No. 1356) represents Adonis holding out the bird to Aphrodite.

‘vy $\xi$ was also used metaphorically for love or desire, cf. Aesch. Pers. 989, Lyc. 310 and Schol. Heliodor. iv. I 5, \&c.

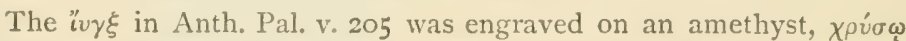

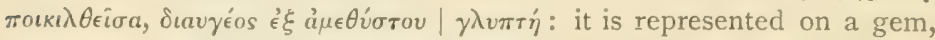
associated with Jason and the Golden Fleece (Imh.-Bl. and K. pl. xxi. 2 I, p. I3I) probably in illustration of Pind. Pyth. iv.

According to Nicander, ap. Anton. Lib. Met. 9, one of the nine Emathidae, daughters of Pierus, was metamorphosed into the bird ¿ı $\gamma \xi$.

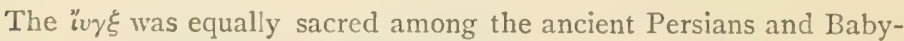
lonians, Marini Proclus, xxviii, cf. Hopf, Thierorakel, p. I44. See also the remarkable description of the Royal Judgement-seat at Babylon, Philostr. V. Apollon. i. 25, where however the precise meaning of " $v \gamma \xi$ is

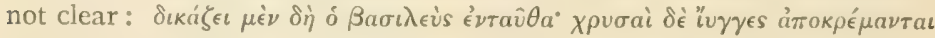

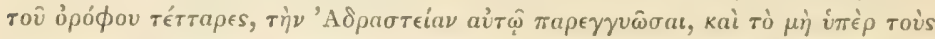

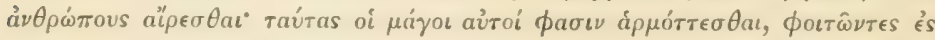

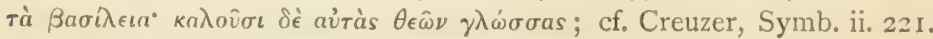
See also Pseudo-Zoroaster, fr. 54, ed. Cory. 
IYTE (continued).

Bury (J. of Hellen. St. vii. pp. I57-160) supposes, chiefly from Theocritus Id. ii, and Pindar Nem. iv, that the " $v \gamma \xi$ was originally a moon-charm or invocation to the Moon-Goddess ' $I \omega$, a theory supported by Mart. ix. 30, where rhombus is in like manner a moon-chamm, as also by such parallel passages as Virg. Ecl. viii. 69, and Tibull. i. 8. 21 . The "थช $\xi$ was undoubtedly thus used in lunar rites, but the bird does not cry ' $I \dot{\omega}$, ' $I \omega$, and the suggested derivation of its name and sanctity from such a cry cannot hold. It is interesting, however, to find that Io and " $\iota y \xi$ do come into relation with one another, the witch who by her spells had made Zeus enamoured of Io, being transformed by Juno into the bird " $i v \xi$, Niceph. in Schol. ad Synesium, p. 360 , Creuzer, Symb. iii. 249 ; see also Schol. Pind. I. c. It is thus quite possible that 'I $\dot{\omega}$ and 'vy $\xi$ are after all cognate, though the bird's cry had nothing to do with their etymology.

"थर $\xi$ and " $\beta$ is come into relation with one another, as both connected with moon-worship ; and the dialectic form of the latter, $\imath \beta v \xi$ (Hesych., ? ' $F \cup \xi)$ suggests perhaps an ancient confusion between the two names.

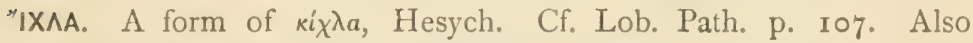

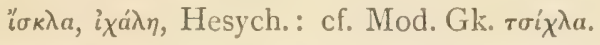

'IXNEY'M $\Omega$ N. An unknown or fabulous small bird; mentioned by Nicander ap. Anton. Lib. c. I4.

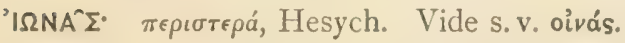

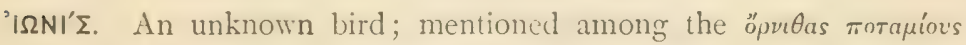

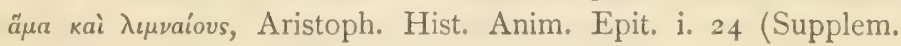
Aristot. i. r. p. 5, Berolini, I885).

KAKKA'BH, s. каккаßís. какка́з̧ Hesych. (Cf. Sk. Kukliubha.) A name for the Partridge.

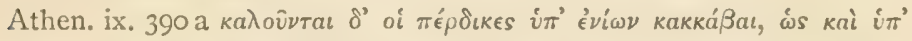

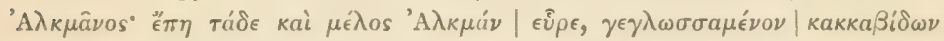

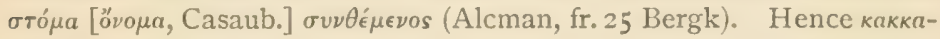

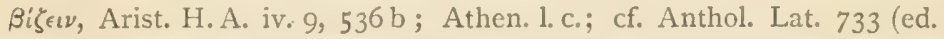
Riese) Interea perdix cacabat nidumque revisit. Cf. Stat. Sylv. ii. 4. 20 quaeque refert iungens iterata vocabula perdix. Vide s.v. $\pi \epsilon ́ p \delta$. $\xi$.

KA^AMO $Y^{\prime} T H \Sigma$. An unknown bird.

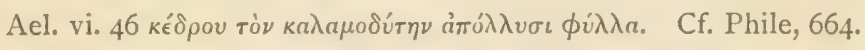

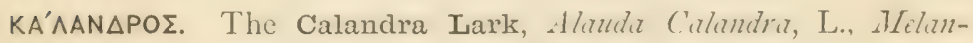
corypha calandra, auctt. The Chelaundre or Calendre of Chaucer, who distinguishes it from the lark or laverokke, Rom. of the Rose, 662, cf. v. 655. Skeat (in loc.) derives the word, 
KA^AN $\triangle \mathrm{PO \Sigma}$ (continued).

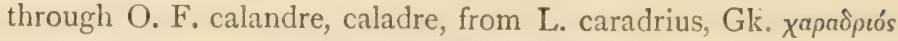

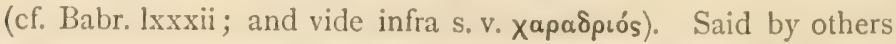
to be connected with L.caliendrum, a tufted head-dress, a top-knot.

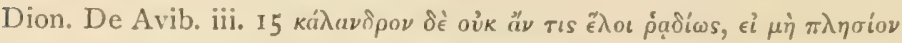

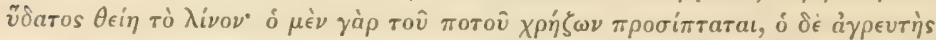

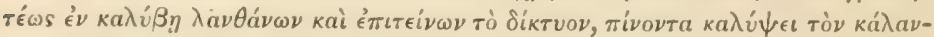
$\delta \rho v$. The same device is still used for the capture of small birds in Italy; cf. Frederick II, De Venat. p. 32 ; J. G. Schneider, Anm. z.d. Ecl. Phys. p. 4I ; see also Bechstein's 'Cage Birds,' \&c.

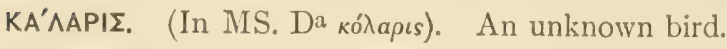

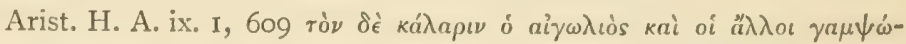

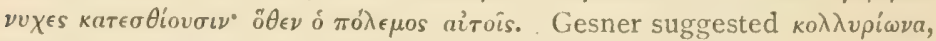

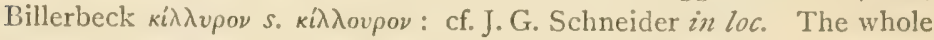
chapter is replete with difficulties, and, in my opinion, with signs of foreign influence or even of spurious origin.

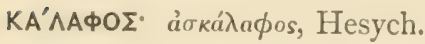

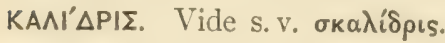

$K A^{\prime} \wedge \wedge \Omega N$. A name for the Cock.

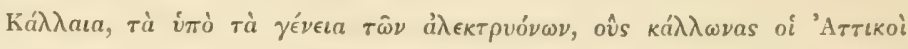

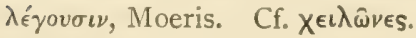

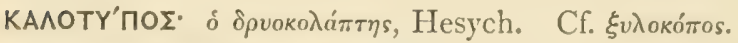

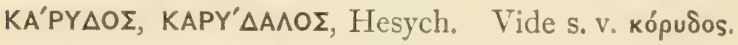

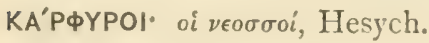

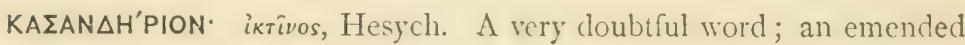
reading is $\kappa a ́ \sigma v \nu^{*} \theta \eta p i o v$ (Schmidt).

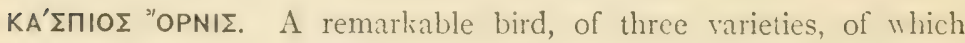
one croaks like a frog, one bleats like a goat, and the third barks like a dog. Full description in Ael. xvii. 33, 38 . It is not identified by Gesner.

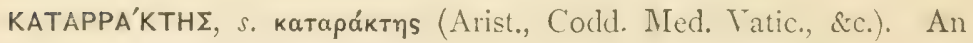
unknown bird; the references to which are so discordant as to suggest that the meaning was early lost, if indeed the name was ever applied to an actual species. It is the 'Cormorant, of the LXX.

Mentioned in Ar. Av. 886. In Soph. frr. 344, 641, applied to the Eagle and to the Harpies (cf. Hesych.), as катарракти́р is to кiркоs, Lyc. 


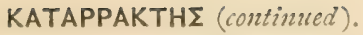

169. In Aristotle, said to be a sea-bird, but not web-footed: mentioned

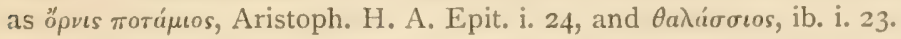

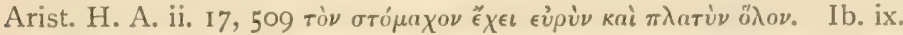

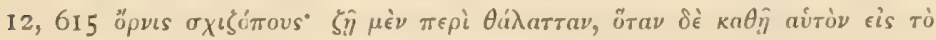

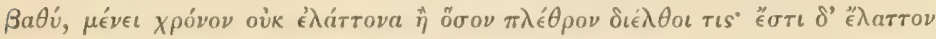
iє́pakos. From this account and from its mention in ii. 17, between

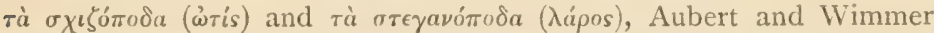
identify катарра́ктүs with Podiceps auritus, the Eared Grebe, Mod. Gk. карататаikıо (Erh. p. 48); Sundevall, on the other hand, with the Little Cormorant, Phalacrocorax or Graculus pygmaeus (vide koגoós, $\boldsymbol{\beta}$ ). Neither of these birds, however, suggests by its habits the name

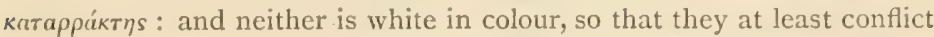
with the following excerpt from Dion. De Avib. ii. 2 $\omega$ s oi $\tau \hat{\omega} \nu \lambda \lambda^{\prime} \rho \omega \nu e^{\prime} \lambda a ́ \sigma-$

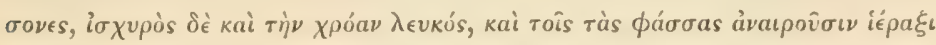

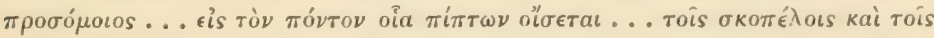

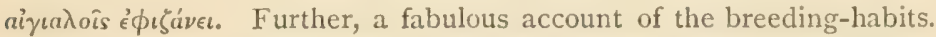

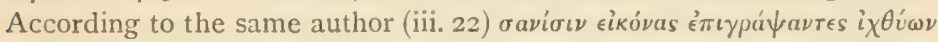

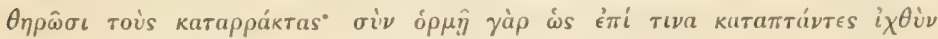

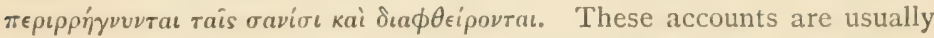
applied to the Gannet or Solan Goose, Sula bassuna (cf. Oedmann, Act. Acad. Stockh., vii. 1786, Schneid. in Arist. vol. ii. p. 88); but the size is incompatible with such an identification, and the bird is not a native of Greece. The account in Plin. x. (44) $5 \mathrm{I}$ is wholly fabulous, and

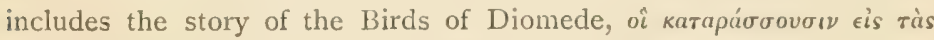

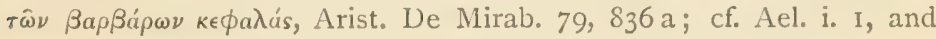

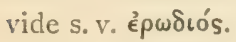

Gesner, who is followed in modern ornithological nomenclature and by the lexicographers, identified катарра́ктүs with the Skua, Lestris catarrhactes, L., a bird which does not occur in the Mediterranean.

KATPEY' $\Sigma$. An unknown or mystical bird.

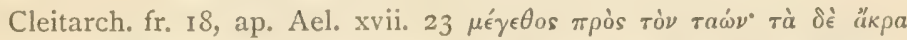

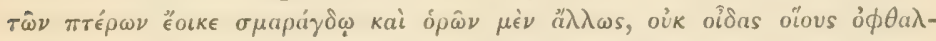

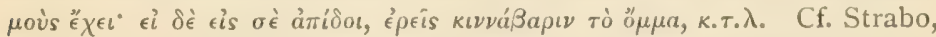

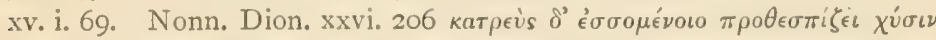

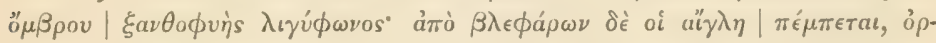

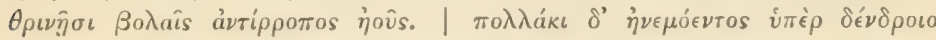

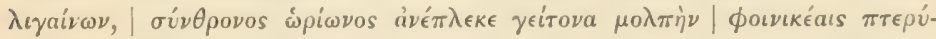

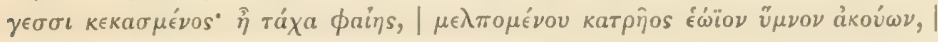

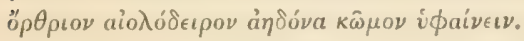

The description of the plumage in Aelian has suggested to some commentators the Manâl or Impeyan Pheasant, Lophopus impeyanus (cf. Val. Ball, Ind. Antiq., xiv. 305, 1885), which bird is very possibly 


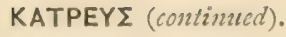

meant by the partridge larger than a vulture, Strabo, xv. I, 73, and by

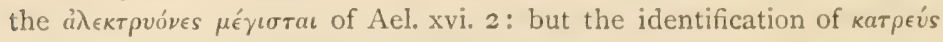
with that bird is precluded by the comparison of its voice with the Nightingale's, a statement which suggests comparison with Sk. Fittima, melodious. The various accounts are all fabulous or mystical, and

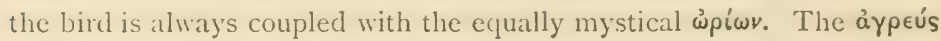

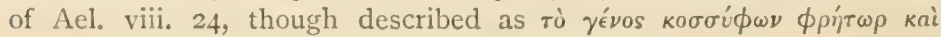
$\sigma v \gamma \gamma \epsilon \nu \eta^{\prime} s$, is probably akin.

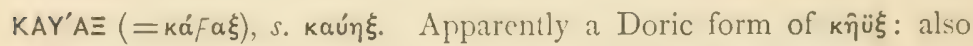
kaúns, Hippon. 5. Root unknown: a comparison with such words as Lith. kovas, Dutch kauuw, Eng. chough, is tempting, but unwarranted: cf. Fick, ii. 63. A diving sea-bird. kaúa $\xi$ $\lambda a ́ \rho o s$, Hesych.

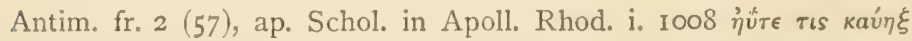

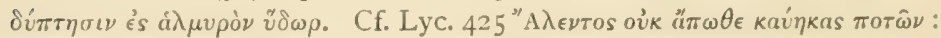

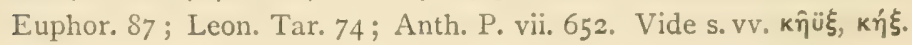

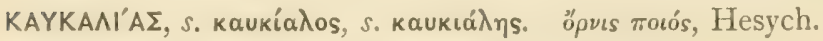

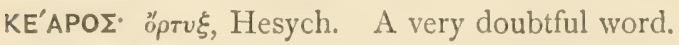

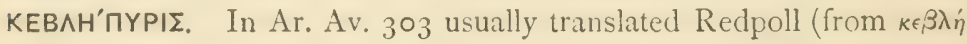
$=\kappa \epsilon \phi a \lambda \dot{\eta}$ ), which bird, Fringilla linaria, L., only occurs in Greece rarely, during severe winters. The meaning is unknown.

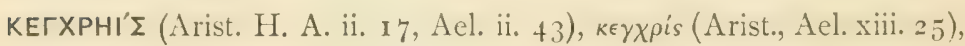
$\kappa \epsilon \rho \chi \nu \eta{ }^{\prime}$ or $\kappa \epsilon \rho \chi \nu \eta j s$ (Aristoph., Ael. xii. 3, Eubul. fr. ap. Athen. ii. ${ }^{6} 5$ e, Photius), ќ́ $\gamma \chi \rho \eta$ (Aristoph. H. A. Epit. i. 22, i. 28), кє́ $\rho \chi \nu \eta$, Hesych. Cf. also ке́рка乡̆, ке́ркvos.

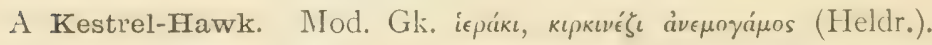
The Common Kestrel, Falco tinnunculus, L., is a permanent resident in Greece, and not rare; but the Lesser Kestrel, F. cenchris, Naum. or $F$. timmunculoides, Natt., a summer migrant, is in its season the commonest of Greek hawks; cf. G. St. Hilaire ap. Bory de St. Vincent, Moréc, Oiseaux, p. 29, pl. ii, iii: Aub. u. Wimm., Arist. De Gen., Introd. p. 28 ; Krüper, op. cit., p. I6 I ; and Lindermayer, p. I 4, who says 'Ich habe im Jahre 1848 von 5-7 Uhr Morgens an dem Thore der Akropolis I 4 Stücke erlegt, ohne mich von der Stelle zu bewegen.'

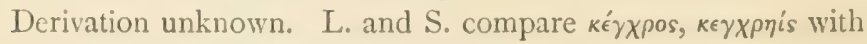
Lat. milium, mil 'uus; but derive the name from kép $\chi{ }^{\nu}$ os, 'hoarse': cf. Fr. cresserelle, O. F. quercerelle. Scalig. in Arist. p. 25 I 


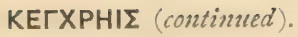

Quercerellam vocant Franci, non corrupta voce, quasi Cenchrellellam, ut ait Ruellius, sed quasi Querquerellam; nam Querquerum, lamentabile, dixerunt veteres; semper enim stridet et queri videtur. The derivation from к'́xy pos is also old, cf. Camus ii. p. 257 'parce qu'elle a le plumage couvert de petites taches comme de petites graines.'

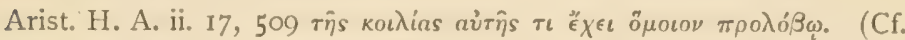
Gesner, p. 284 Dieses Vogels Magen ist dem Kropf gleich und gar

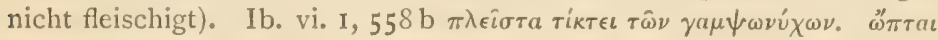

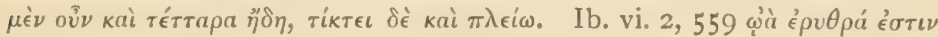

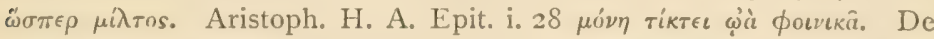

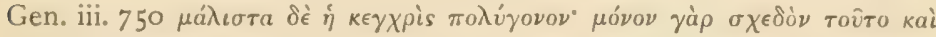

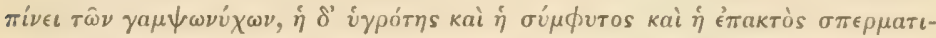

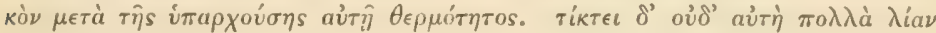

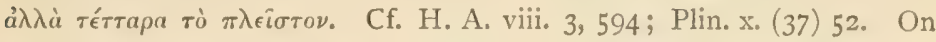

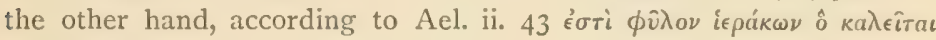

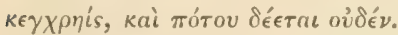

Mentioned also in Ar. Av. 304, 589, I 181 : Ael. xii. 4. One of the daughters of Pieros was transformed by the Muses into the bird кє $\gamma \chi$ pís, Nicand. ap. Anton. Lib. c. 9.

In Ael. xiii. 25, кє $\gamma \chi$ pis seems to refer to a different bird, being mentioned as a dainty with $\sigma v \kappa a \lambda i s$, and $\kappa \epsilon \rho \chi \nu \eta s^{\prime}$ is mentioned in a similar way by Eubul. ap. Athen. ii. $65 \mathrm{e}$.

KETXPI'THE. Apparently a sort of wild duck or goose, Dion. De Avib. iii. 23.

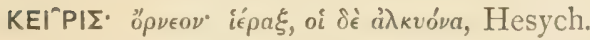

On the fabled metamorphosis of Ciris, Nisus, Pandion, \&c., vide

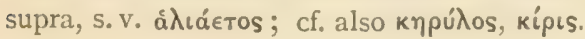

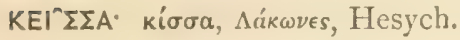

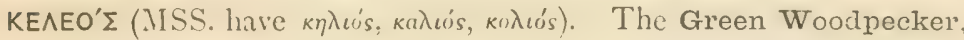

Picus viridis, L. (a scarce bird in Greece, Lindermayer). Mod.

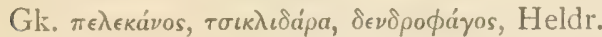

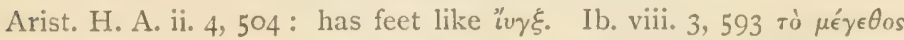

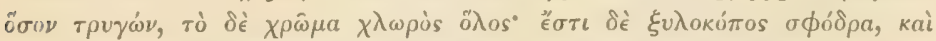

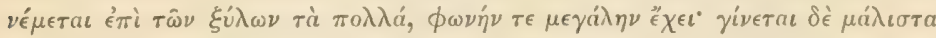

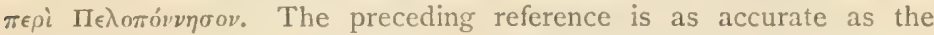

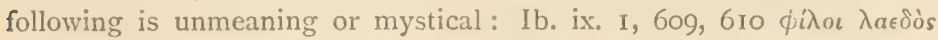

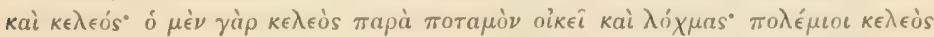

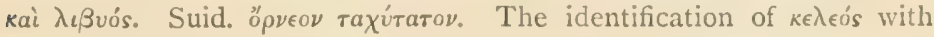




\section{KEAEOI (continued).}

the Green Woodpecker is said to have been first given by Gesner, cf. Schn. in Arist., vol. iii. p. 592.

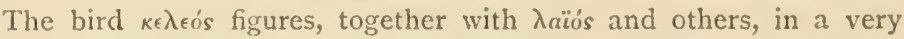
mystical story of Boios, ap. Anton. Lib. c. xix.

Celeus is also the name of a mystical king of Attica, in connexion with the story of Ceres and Triptolemus; this circumstance may be correlated with other Woodpecker-myths in Greek and Latin referred

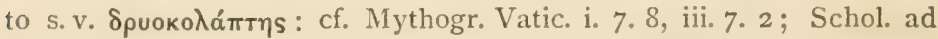
Greg. Nazianz. p. 48, ed. Gaisf., \&c. On other relations between Celeus and the Ceres-myth, cf. Hom. Hymn. Cer. 475; Ar. Ach. 48 ; Pausan. i. I4, 38, 39, ii. 14; Anton. Lib. c. xix; vide also Creuzer's Symbolik (ed. I836) i. I 52, iv. 368, 384.

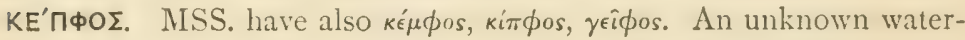

bird; usually, but without warrant, identified (after Schneider in Arist., and Promt. Lips. I 786, p. 50r) with the Stormy Petrel, Thalussidroma pelagica, L. According to Hesych., identical with кं' $\xi$. The accounts are fabulous, and the name is very probably foreign.

Arist. H. A. viii. 3, $593 \mathrm{~b}$, a sea-bird, mentioned with $\lambda$ ápos and

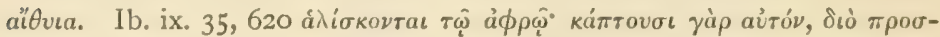

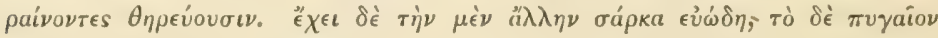

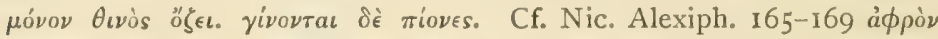

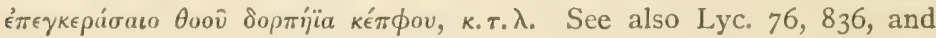

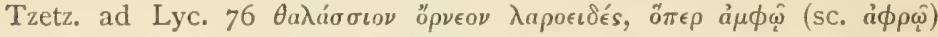

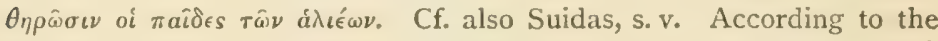

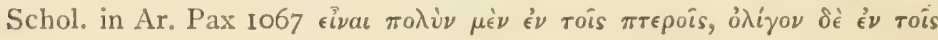

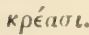

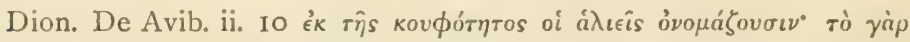

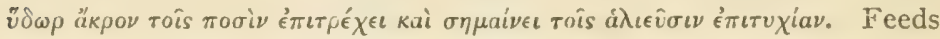
on small fish killed by tumnies and dolphins; sleeps seldom; afraid of

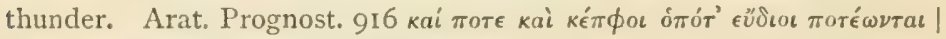

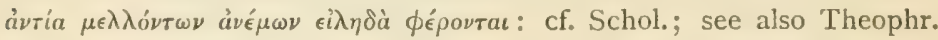
Fr. vi. 28 ; Symmach. (Schol. Ar. Pax 1067) p. 217 . See also Hesych.:

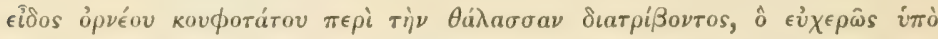

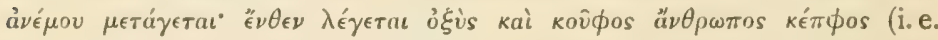

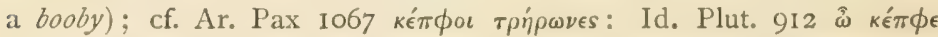

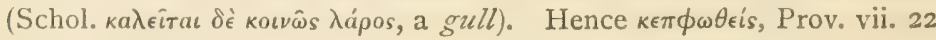
(ed. LXX); cf. Cic. Att. I3. 40.

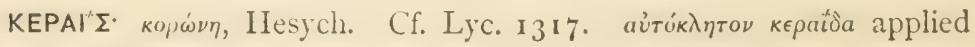
to Medea.

KE'PBEPOE. Nentioned as a bird-name in Anton. Lib., Net. c. xix; cf. s. v. $\lambda a \in \delta o ́ s$. 
KE'Polos. Perhaps the Tree Creeper, Corthia familiaris, I. Tide S. v. киเто入ó

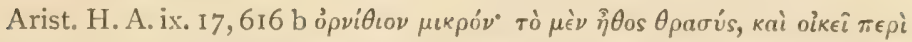

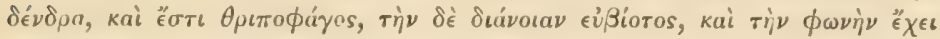
$\lambda a \mu \pi \rho a ́ v$.

The passage contains several birds difficult to identify. The description of $\kappa^{\prime} \theta_{p} \theta$ เos suggests the Tree Creeper, with which it is usually

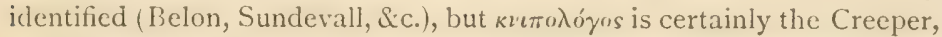
and the above description is not enough to reveal an indubitable synonym.

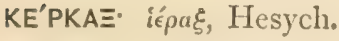

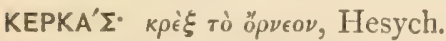

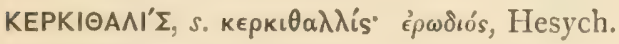

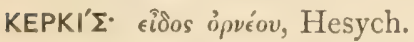

KEPKI' $\Omega$ N. (For a discussion of possible Sk. roots, see Temple, infra cit.). An Indian talking bird.

Ael. xvi. 3 ; is the size of a starling, particolotrred, docile, and learns to speak; it is impatient of captivity, and gets its name $\epsilon \pi \epsilon \epsilon \delta \dot{\eta}$

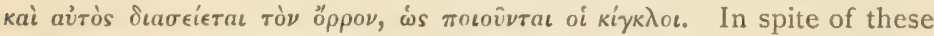
two discrepant statements, it is possible that Aelian refers to the Common Mynah, Acridotheres tristis, the Talking Mynah, Gracula religriosa, or allied species, Hind. sarak or shîrak; Temple, Ind. Antiq. 1882, p. 29r ; Val. Ball, ib. 1885, p. 305 ; cf. Lassen, Ind. Alterth. iii. p. 32 I (I 858$)$.

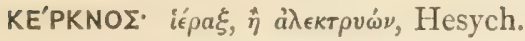

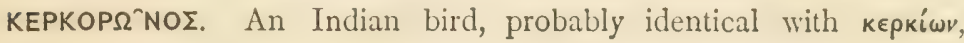
Ael. Xv. I 4 .

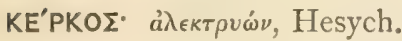

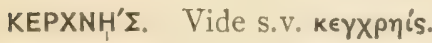

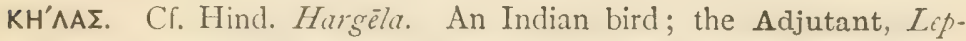
toptilus argala, L. See Val. Ball, Ind. Antiq. xiv. p. 305, I 885 .

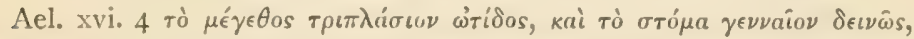

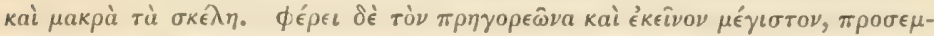

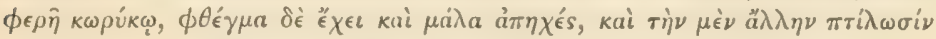

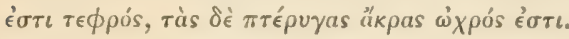

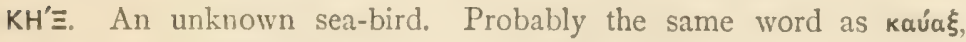

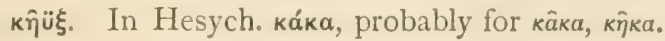

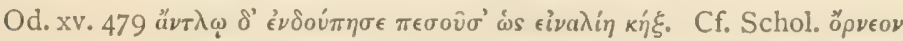




\section{$\mathrm{KH} \equiv$ (continued).}

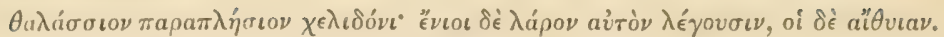

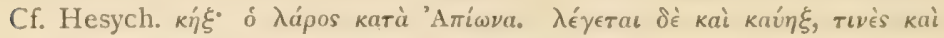

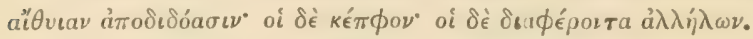

Usually identified with the Gannet, Sula bassana, L. (vide s. v. катарра́ктүs), which does not occur, sdve by the rarest chance, in Greece. Among other more than dubious hypotheses, Netolicka (Naturh. aus Homer, p. I4), with whom Buchholz, Körner, and others agree, suggests the Great Crested Grebe, Podiceps cristatus, L., whose

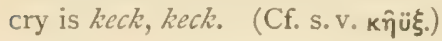

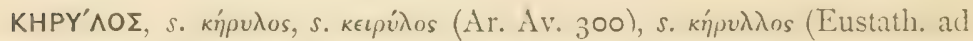
Hom.), s. kipvios (Hesych.). A doubtful, perhaps foreign, word, sometimes applied to the Halcyon, sometimes compared with it.

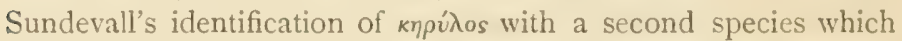
occurs in Greece, Alcedo (Ceryle) rudis, the Smyrna Kingfisher,

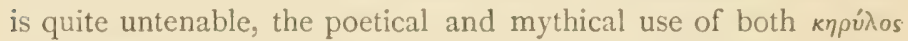
and a' $\lambda_{\kappa \nu \omega} \nu$ being opposed to so concrete an interpretation. The suggested connexion with Lat. coeruleus (O. Keller, Lat. Etym., I893, p. I5) is in equal degree improbable.

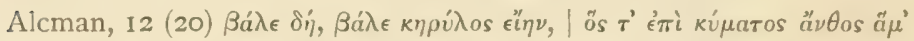

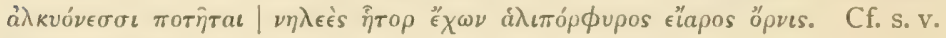

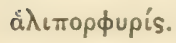

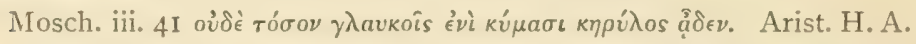

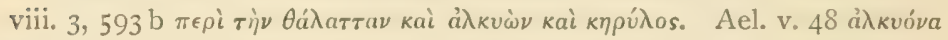

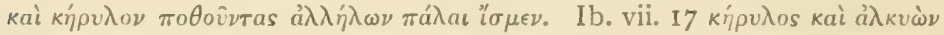

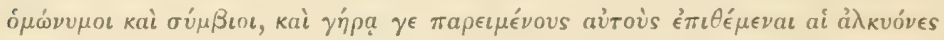

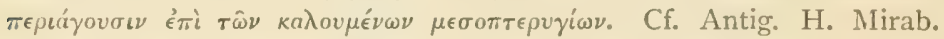

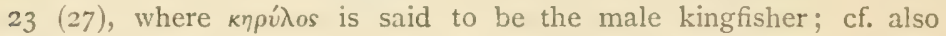

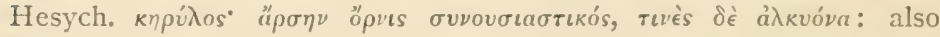
Tzetzes ad Lyc. 387; Schol. Ar. Av., Schol. Theocr. vii. 57 ; Eustath. ad Hom. Il. i. 558. In Clearch. ap. Athen. x. $332 \mathrm{E}$, numbered among

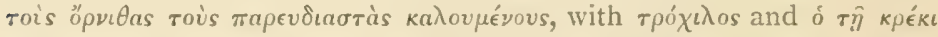

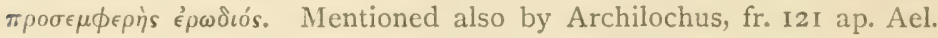

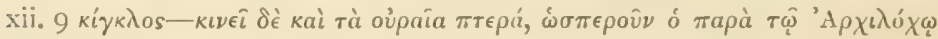
кípvios.

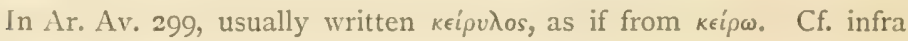
s. v. omopyìos.

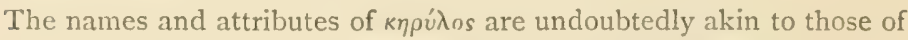
кeipts or Ciris; and it is interesting to note that, according to Hesychius, the name кєipıs applies either to a hawk or to the Halcyon.

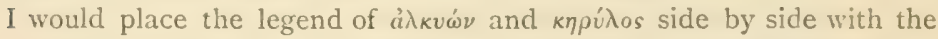

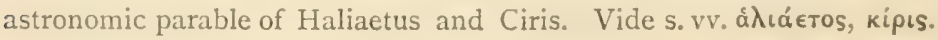




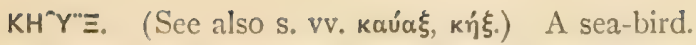

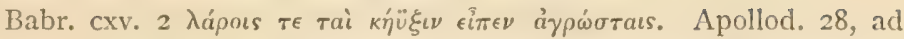
Lucian. i. 178 ; said by Schol. to be the male $a \dot{\lambda} \kappa v \omega \dot{\omega}$, and identical with

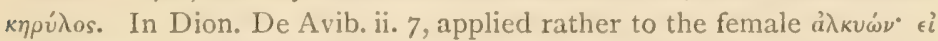

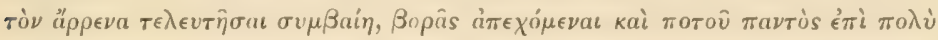

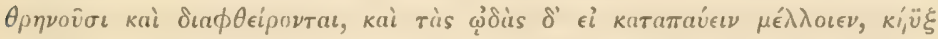

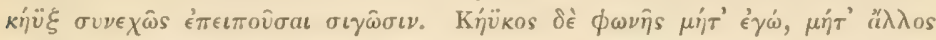

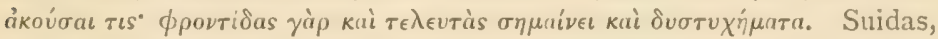

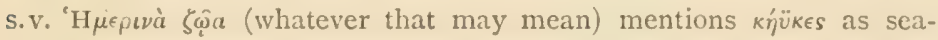
birds; together with ‘̇^vóves and änóves. On the fable of Ceyx, Alcyone, \&c., see Ovid. Met. xi. 269, \&c., \&c.; Ceyx comes into relation with Hercules and the Argonautic legends in Anton. Lib. c. xxvi; and the Hesiodic myth of Ceyx and Cycnus is of the same order. We may, I think, rest assured that $\kappa \hat{\eta} \ddot{u} \xi$ was not originally a concrete and specific bird-name, but a mystical term associated with

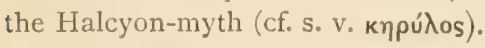

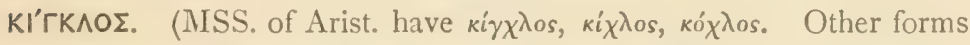

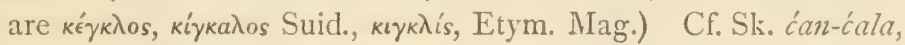
mobile (Burnouf, Dict. 237).

A Wagtail, Motacilla sp. According to Hesychius, Photius, and

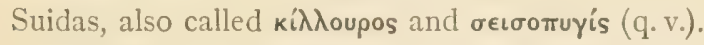

Arist. H. A. viii. 3, 593 b mentioned among the smaller aquatic birds with $\sigma$ Xouvi $\lambda$ os and múyapyos; is less than the latter, which is as large as

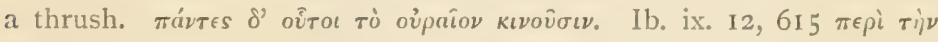

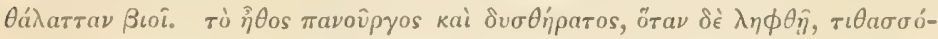

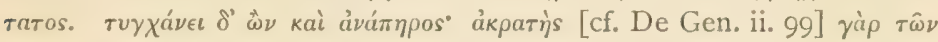

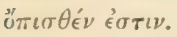

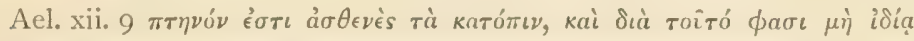

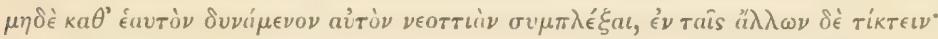

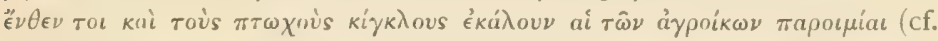
Menand. Thais 4, ap. Suid. and Phot. (4.132, Meineke) кík

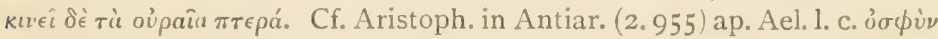

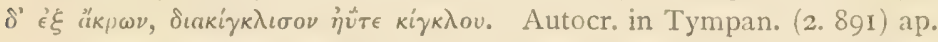

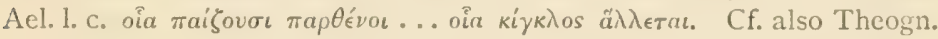

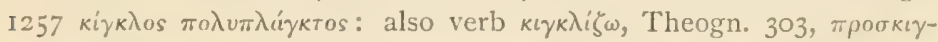

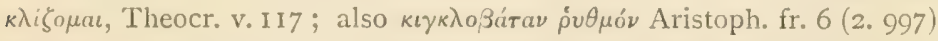

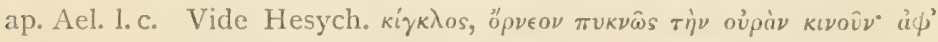

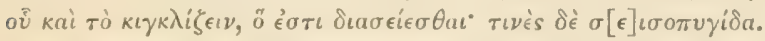

Sundevall takes $\kappa i \gamma \kappa \lambda$ os to be a Sandpiper, Tringa sp., chiefly, as it seems, because $\sigma$ Xoví $\lambda$ os is doubtless a name for the Wagtail, Motacilla. But I prefer to believe that кi $\gamma \kappa \lambda$ s is also a WVagtail, firstly because the movement is much more characteristic and noticeable in that bird than in the Sandpiper, secondly because of the statement as to its size, and 


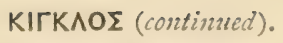

thirdly because of its asserted tameness in captivity. The statement in Aelian, about the nest (also ap. Phile, 492), may perhaps be explained by the fact that, according to Kriiper, the Wagtails in Greece all leave the plains in summer to breed, resorting to the hills, or in the case of $M$. melanocephala to the salt-marshes and lagoons. At the

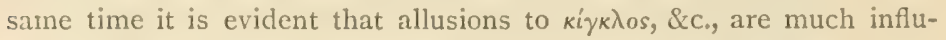
enced by notions and superstitions connected with the bird iuy $\xi$.

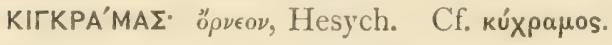

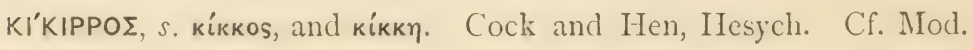
Gk. ко́ккораs.

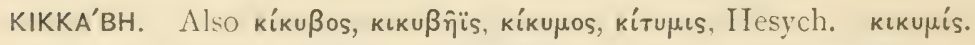

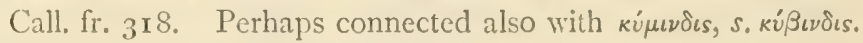

An Owl. Lat. cicuma (Festus).

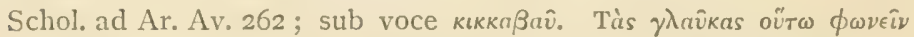

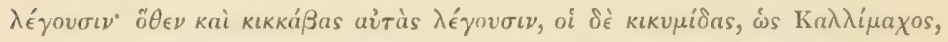

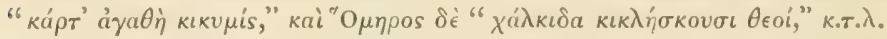

Cf. кочкоvßауіа, and койккоs, the modern Athenian popular names for $\gamma \lambda a \hat{v} \xi$. Vide s.v. коккоßа́pๆ.

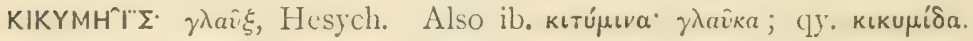

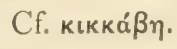

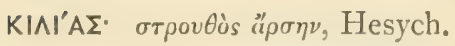

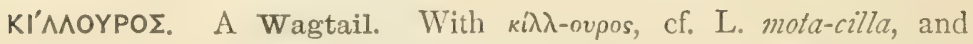
perhaps $\kappa i \gamma-k \lambda$-os. On the root, cf. Benfey's Zeitschr. viii. 1892.

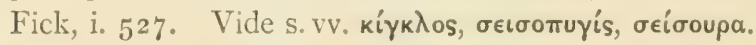

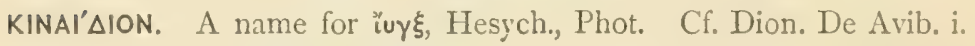
23 , Schol. in Theocr. ii. I 7 .

KIN $\triangle A \Psi O I^{\circ}$ ö $\rho \nu \in a$, Hesych.

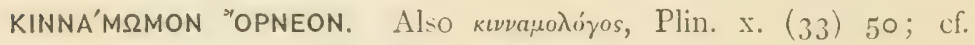
Solin. (33) 46 . The fabled Cinnamon Bird.

Herod. jii. III; how the Arab merchants left pieces of flesh which might break down by their weight the nests to which the birds carried them, and in which the cinnamon was found. In Arist. H. A. ix. 13, 616 , a variation of the same story, the nests being brought down with weighted arrows. Cf. Ael. ii. 34, xvii. 21 ; Antig. H. Mirab. c. 49; Phile De Pr. An. 28 (27); Plin. xii. (I9) 42 ; Sindbad the Sailor, \&c. Sometimes confused with the Phoenix; cf. Claud. Epist. ii. I5 Venit et extremo Phoenix longaevus ab Euro, Apportans unco cinnama rara pede; Ovid, Met. xv. 399 ; Stat. Silv. ii. 6. 87. 


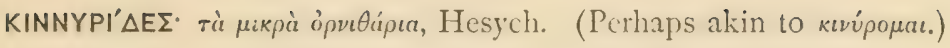

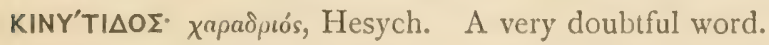

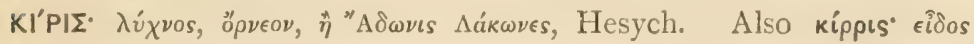

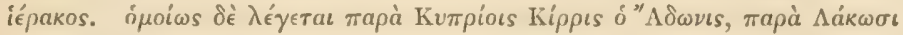

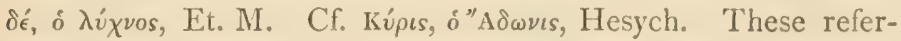
ences are important in connexion with the solar symbolism

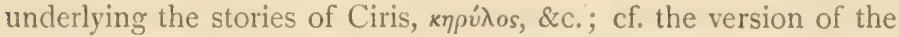
Ciris-myth, s. v. kippıs (s. kıрpis), Dion. De Avib. ii. I4.

KI'PKH. A poetic or mystical bird-mame; different from, and hostile to, кіркоs.

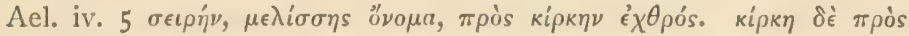

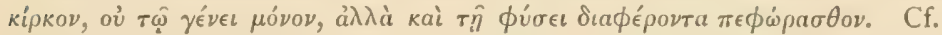
ib. iv. 58 .

KI'PKOs. A poetic and mystical name for a Hawk: the sacred Hawk of Apollo; in the main an astronomical, perhaps solar,

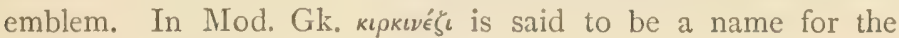
Kestrel (Heldr.), vide s. v. кєүхрךís.

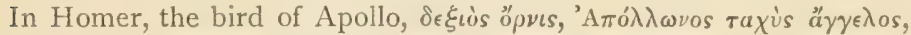

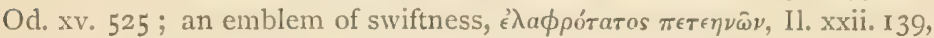

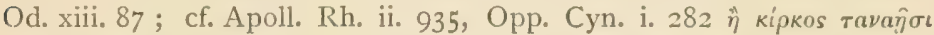
$\tau \iota \nu \alpha \sigma \sigma o ́ \mu \epsilon \nu o s ~ \pi \tau \epsilon \rho \operatorname{y\epsilon \sigma \sigma \iota v:~usually~as~an~enemy~of~the~Dove,~Il.~xxii.~}$

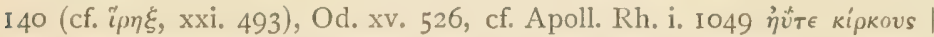

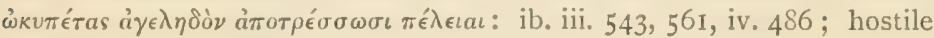

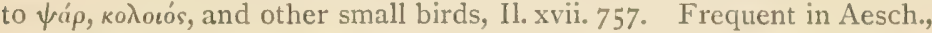

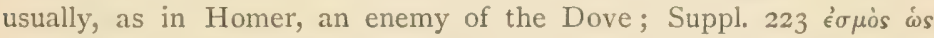

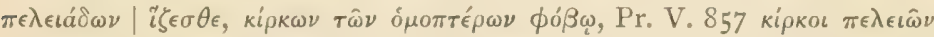
ov $\mu a \kappa p a ̀ \nu ~ \lambda \epsilon \lambda \epsilon \iota \mu \mu \epsilon \operatorname{coc}$ (note in this passage the association with Egyptian "Eraфos) ; mentioned in connexion with the Tereus-myth, as metamor-

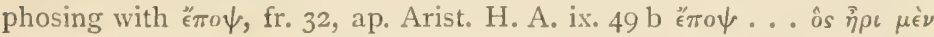

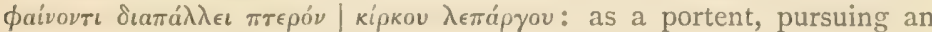

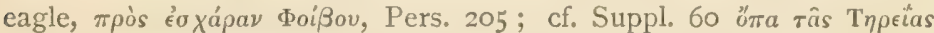

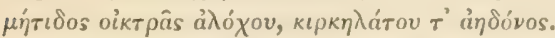

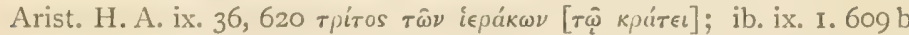

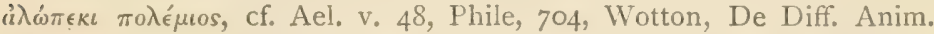
vii. 143 , \&c. In Plin. $\mathrm{x} .8$ circos occurs as an alternative reading for aggithus; cf. circus as the name of a gem, similis accipitri, Pun. xxxvii. 10 .

Mentioned as hostile to the Dove also in Ael. iii. 46, v. 50 ai $\delta \dot{e} \pi \epsilon \rho t-$

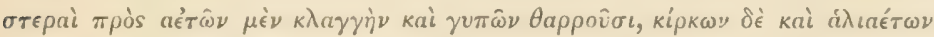

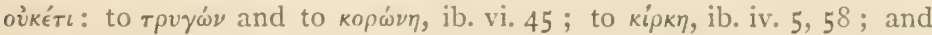

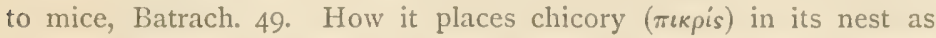

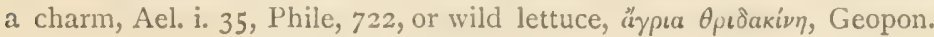




\section{KIPKOE (continued).}

xv. I. 19, with which it salves its eyes, Anatol. p. 297 (cf. lépa $\xi$ ); and is

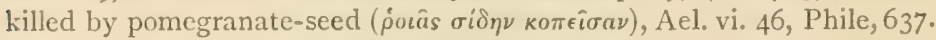

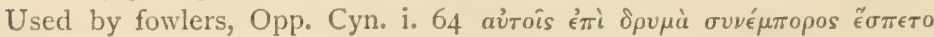
кіркок.

The bird is not identifiable as a separate species, and is so recognized by Scaliger and others. Neither the brief note as to its size in a corrupt passage of the ninth book of the History of Animals, nor the mystical references to its alleged hostilities and attributes in Aristotle, Aelian, and Phile, are sufficient to prove that the name indicated at any time a certain particular species. The word is poetical, and is chiefly used in relation to $\pi \hat{\epsilon} \lambda \epsilon \iota a$, or with reference to Apollo. The attempts on the part of commentators to assign кipкos to a particular species are all based on the epithet $\lambda \epsilon^{\prime} \pi a \rho \gamma o s$. Thus Sundevall suggests the Hen Harrier or Ringtail, Circus cyaneus, of which the male is blueish-grey: while Belon and others of the older naturalists, followed by Camus, assigned the name to the Moor Buzzard or Marsh Harrier, $C$. aeruginosus, which is only white beneath the tail. But the meaning of $\lambda \epsilon^{\prime} \pi \alpha \rho \gamma o s$ is in reality unknown; it will not bear using, nor is it likely to have been used, as a specific or diagnostic

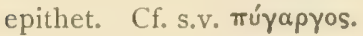

The chief allusions to кiркоs are obviously mystical, though the underlying symbolism, involving also the symbolic meanings of the Hoopoe, the Dove, the Crow, the Fox, the Pomegranate, \&c., is not decipherable. In this connexion, the passage in Opp. Cyn. iii. 293-339 is important and suggestive, but I refrain from putting forward a tentative hypothesis as to its meaning; we have here enumerated five kinds

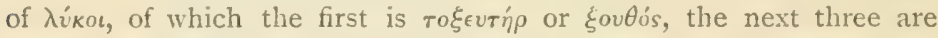

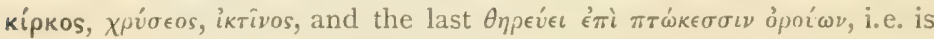
$\lambda a \gamma \omega \phi o ́ v o s$ (the last two are called äkroves, q.v.); of these five names the last four are all also names or epithets of hawks.

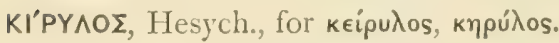

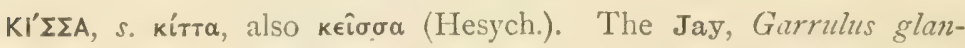

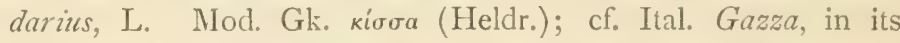
many dialectic forms. Perhaps one of the many bird-names connected with rt. kak, to cry, quasi kik-ja (v. Edl., p. 52); cf. Sk. kiki, a Jackdaw, with which Von Edlinger connects O. H. G. heh-aro, Germ. Häher, the Nutcracker. See also s.v. $\beta a ́ \sigma \kappa \iota \lambda \lambda \circ o$.

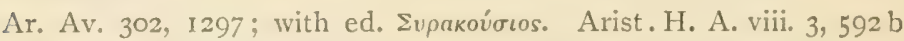

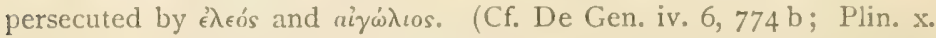

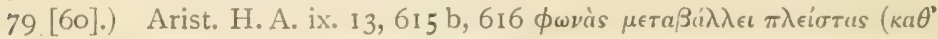

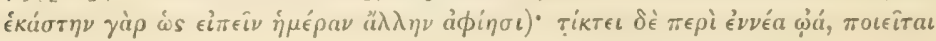




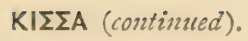

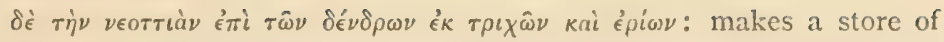

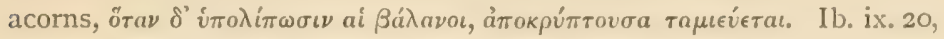

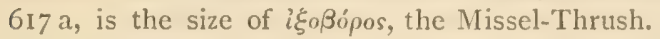

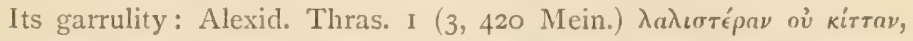

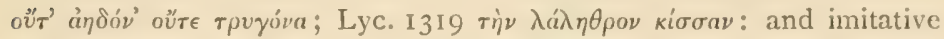
faculty, Ael. vi. 19, Plut. De Sol. Anim. p. 973 C, Dion. De Avib. i. 18,

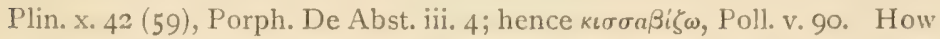
it is caught with a springe and bait of olive, Dion. De Avib. iii. I8. Mentioned also in frr. Antiph. 3. 145, Anaxand. 3. 185, Mnesim. 3. 570 (Meineke). According to Nicand. ap. Anton. Lib. c. 9, one of the Emathides, daughters of Pierus, was metamorphosed into the bird ki $\sigma \sigma a$; cf. Ovid, Met. v. 294, 663; Mart. Ep. xiv. 76; Pers. Prol.; Plin. x. 33.

Sundevall supposes the Magpie (which is very much rarer in Greece than the Jay) to have been meant, but the description tallies much better with the Jay, which still retains the name. The Magpie is now called караки́ka (Heldr.). In Italian, gazza, chéca, cecca, pica, \&c., apply both to the Magpie and to the Jay, as very possibly kior a also did in Greek. Pliny (x. 29) gives an accurate account of the Magpie, describing it as a variety of pica of recent advent to the neighbourhood of Rome.

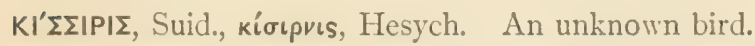

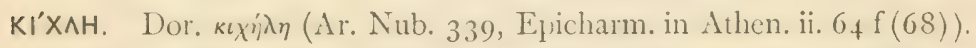

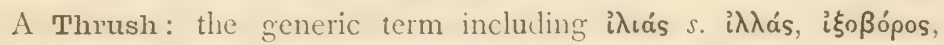
$\tau \rho$ ‘xás, q. $\mathrm{v}$. The root appears in Russ. kwickzol, a thrush, with which ouzel is perhaps cognate. Mod. Gk. $\tau \xi^{\prime \prime} \chi \chi \lambda a$. Cf. also ix $\lambda \alpha,{ }^{\circ} \sigma \mathrm{X} \lambda \alpha$.

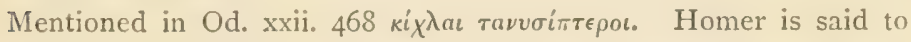
have received a present of kíx $\lambda$ a for reciting a certain poem, hence called 'E $\pi \iota \kappa \iota \chi \lambda$ ióøs: Menaech. ap. Athen. ii. 65 b.

Description.-Arist. H. A. viii. 3, 593 b, ix. 22, 617 b, is as large

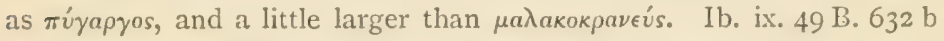

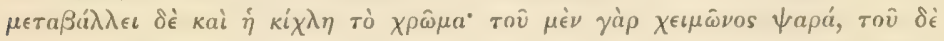

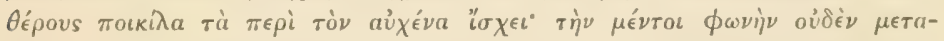
$\beta a ́ \lambda \lambda \epsilon \iota$. Cf. Ael. xii. 28. This would suggest a confusion of species : the more variegated birds being Fieldfares and Redwings; the latter are said to occur in large flocks in Spring (v.d. Mühle), though all alike have departed by Summer. Its song alluded to, Ar. Ach. III 6

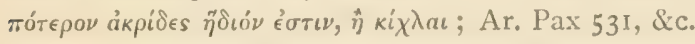

Nesting. -Builds in a spray of myrtle, $\theta \dot{c} \lambda \lambda \lambda_{o \nu} \mu \nu p \rho i v \eta s$, or places one in the nest for a charm, Ael. i. 35, Phile, De An. 723, Geopon. xv. 1, I9, Anatol. p. 298: cf. Fab. Aes. 194. A different account, Arist. H. A.

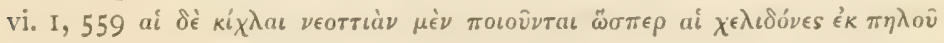




\section{$\mathrm{KIX \Lambda H} \mathrm{(contimued).}$}

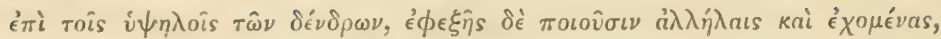

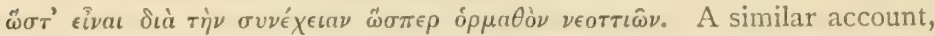
restricted to the variety $i \lambda \lambda$ ás, Alex. Mynd. ap. Athen. ii. 65 a $\hat{\eta} \nu$ ku $i$

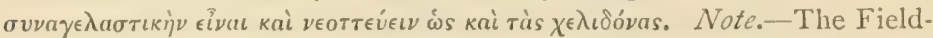
fare, T. pilaris, L., which breeds only in Northern Europe, is the only Thrush which nests in colonies. Sundevall takes the above passage (Arist. H. A. vi. I) to indicate that the Fieldfare formerly nested in Greece or at least in Macedonia. In Anth. Pal. ix. 373, Mackail (p. 358) takes $\kappa i \chi \lambda \eta$ to be either the Thrush or the Fieldfare, which latter however is a winter-migrant in Greece. (For other references

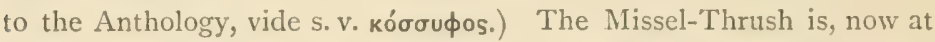
least, the only species, except the Blackbird, which remains to breed in Greece or Asia Minor.

Migration.-Arist. H. A. viii. 16, $500 \phi \omega \lambda \epsilon \hat{\imath}$, i. e. hibernates. Cf. Plin. x. 24 (35) Abeunt et merulae turdique. Sed plumam non amittunt nec occultantur; visi saepe ibi quò hibernum pabulum petunt: itaque in Germaniâ hyeme maxime turdi cernuntur.

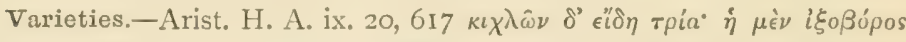

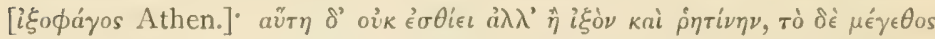

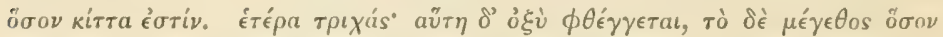

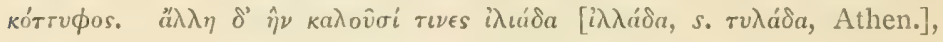

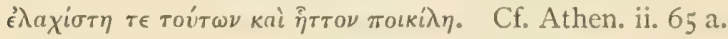

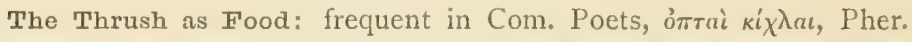

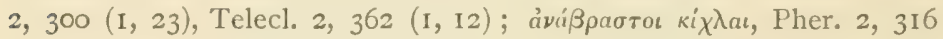

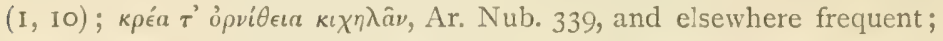

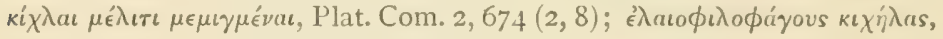
Epicharm. 281 L. ap. Athen. 1. c., \&c. \&c. Cf. Athen. ii. pp. 64, 65, Geopon. xiv. 24, Colum. De R. R. viii. Io, Varro, De R. R. iii. 5, Pallad. i. 26, Martial, Ep. xiii. 51, 92, Hor. Epist. i. 15, 41, Plin. x. 23 (30), \&c. \&c. Prescribed as a remedy for Pompey, and obtained from the

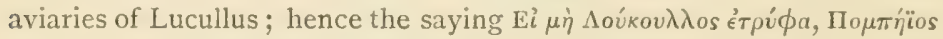
oủk â $\nu$ "̌ $\zeta \eta \sigma \epsilon$, Plut. i. 518 F, $620 \mathrm{~B}$, ii. $204 \mathrm{~B}, 786 \mathrm{~A}$. Capture by traps

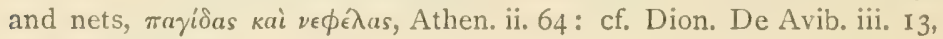
Pallad. xiii. 6, \&c.

A talking thrush, Plin. x. (42) 59.

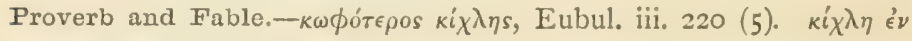
$\mu \nu \rho \sigma \iota \nu \bar{\nu} \iota$, Aes. Fab. 194.

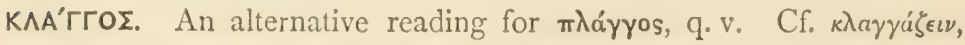
Lat. clangunt aquilae, Carm. De Philom., \&c.

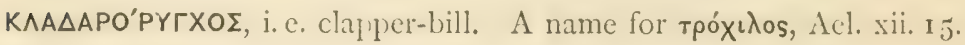

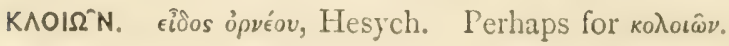




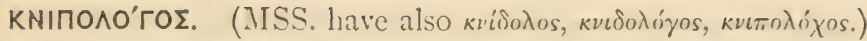

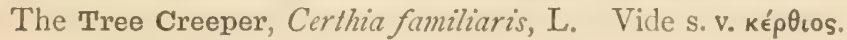

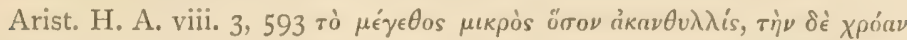

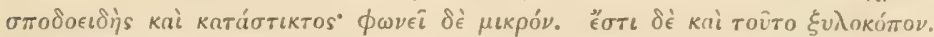
(Mentioned at the end of the list of Woodpeckers.) Gloger, Sundevall, Aubert u. Wimmer, and others, agree in the above identification. The word is used by Nicander, ap. Anton. Lib. c. I4, as an epithet or synonym of $\pi \iota \pi \dot{\omega}, q . v$.

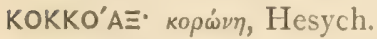

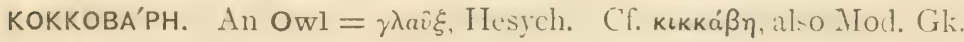
and Calabr. кочкоvßayia, Neap. cucuveggia, Alban. kukuvalike, all

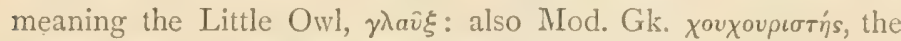
Tawny Owl, Sp. chucha; vide O. Keller, Lat. Etym. I 893, p. I I I. Bikélas cites, from Wagner's Carm. Gr. Med. Aevi, the form

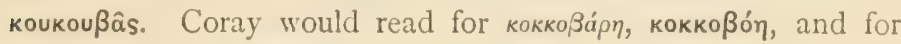

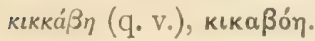

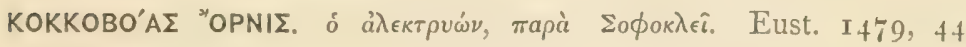
(Soph. fr. 900).

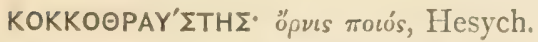

KO'KKY三. (f. Sk. kokilus, Lith. kukuti, O. II. G. gauh, Scot. grozuk, Ec.

The Cuckoo, Cuculus canorus, L. Mod. Gk. койккоs.

Full Description and comparison with iépa $\xi$, Arist. H. A. vi. 7, 563, 564 .

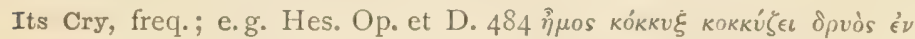

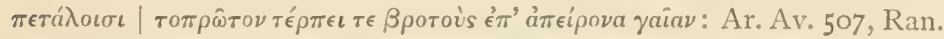

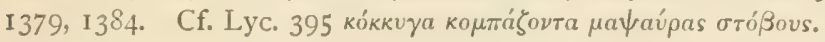

Note.-коккú $\zeta \epsilon \iota \nu$ is still more frequently used of the Crowing Cock;

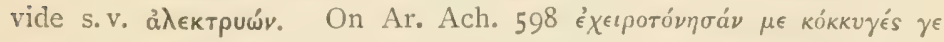

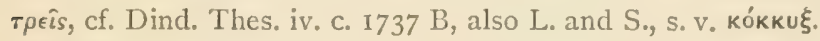

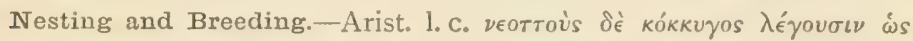

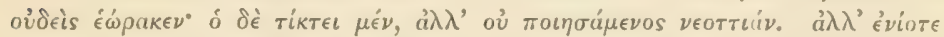

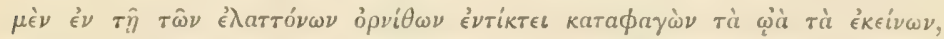

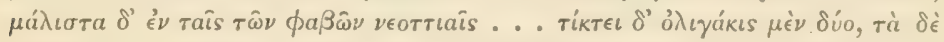

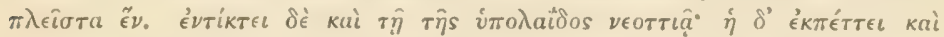

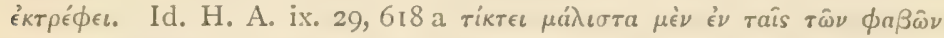

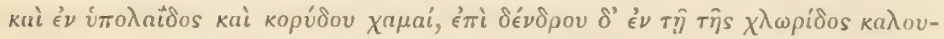

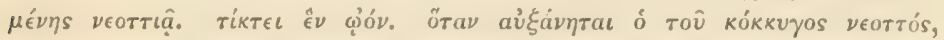

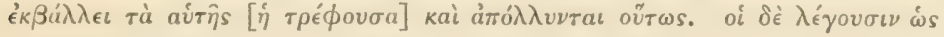

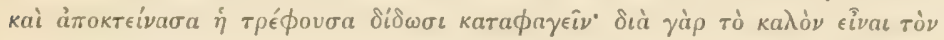

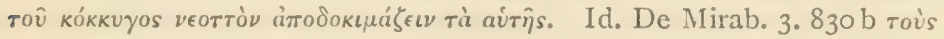

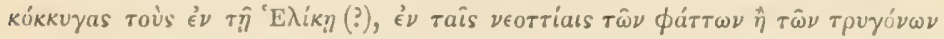




\section{KOKKY $\equiv$ (continued).}

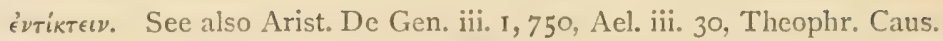
P1. ii. 18, 9, Dion. De Avib. i. 13, Plin. x. (9) 26, Phile, De An. Pr. xxiv.

A species that builds its own nest: Arist. H. A. vi. 7, 564 veorteviet

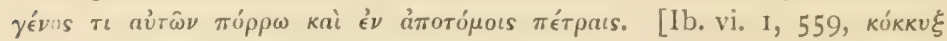

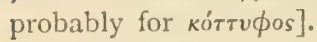

The Cuckoo is said by Kriiper (p. 184) to lay in Greece chiefly in the nest of Sylvia orphea, and also of the species of Saxicola. Coccystes glandarius, the Great Spotted Cuckoo, which also occurs in Greece, (Mod. Gk. kpâvos), lays in the nests of the Jackdaw, Magpie and Crow.

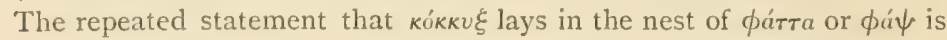
inexplicable, unless such a statement be of foreign origin and refer originally to some Oriental species; a little light is perhaps thrown upon the point by the circumstance that in certain Chinese legends the Dove and the Cuckoo are confounded together: vide infra s.v. $\pi \epsilon \rho$ ттєр⿱ . This discrepancy deprives of all value the attempted identifications of $i \pi o \lambda a i s$, wihch are based on its being some bird in whose nest the Common Cuckoo habitually lays its egg; see also S. v. $\pi a ́ \pi \pi$ os.

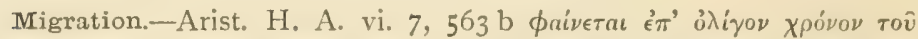

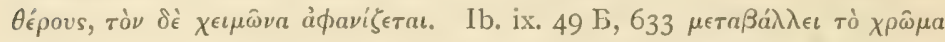

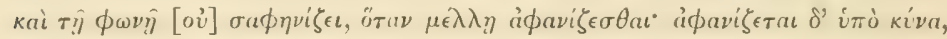

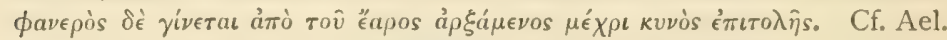

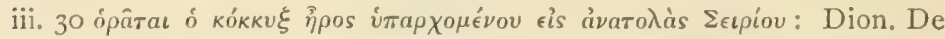

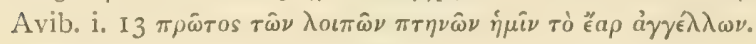

Metamorphosis with the Hawk, Arist. H. A. vi. 7, 563 b, ix. 49 B, 633 .

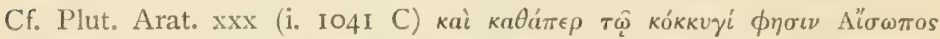

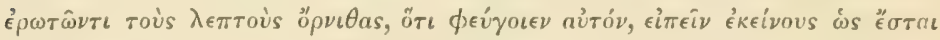

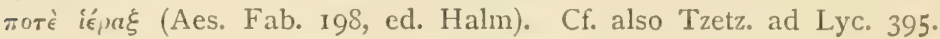
See also supra, s. vv. Еैто廿, кíркоs.

Other Myths and Legends.--How Jupiter, in the shape of a Cuckoo, sought Hera on Mount Thornax; and how for this reason the cuckoo figures on Hera's sceptre, Pausan. ii. 17, 4: cf. Schol. ad Theocr. xv. 64 ; hence the mountain was called őpos Koккúyıv, Pausan. ii. 36, I ; cf. Creuzer, Symb. iii. 248 ; cf. also the Teutonic Gauchisberg, Grimm, D. Myth. p. 646, \&c.

From its propinquity to Sparta, and from the circumstance of the Cuckoo having come in a cloud, Creuzer (1. c.) conjectures an allusion to the same story in Ar. Av. 8I4; cf. also the weather prophecy in Hesiod, 1. c.

How the Cuckoo was king over Egypt and Phoenicia, Ar. Av. 504. In these latter statements we have evidence of a confusion with the 


\section{KOKKY $\equiv$ (continued).}

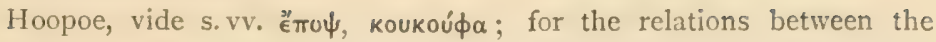
Cuckoo and the Hoopoc, Der Kuckuk und sein Küster, v. Grimm, 1. c.

On the mythology of the Cuckoo, see also (int.al.) Von Mannhardt, Zeitsch. f. d. Myth. iii. pp. 209-298; Hardy, Pop. Hist. of the Cuckoo, Folk-lore Record, pt. ii ; Hopf, Orakelthiere, p. I 52.

How the Amphisbaena, alone among serpents, appears before the Cuckoo is heard, i.e. in early spring, Plin. xxx. (10) 25; a magic remedy for fleas, Plin. 1.c.; a Cuckoo in a hare-skin, a remedy for sleeplessness, Plin. xxx. (1 5) 48 ; the Cuckoo as food, Plin. x. 9; cf. Arist. H. A. vi. 7, 564 (spurious passage).

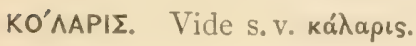

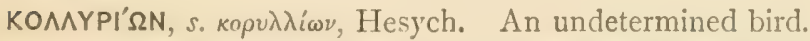

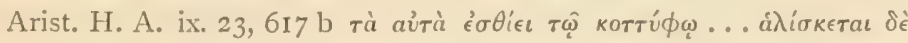

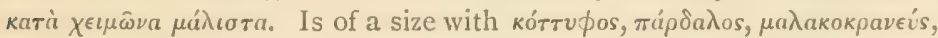
$\chi \lambda \omega$ pi $\omega \nu$.

Belon's unsupported hypothesis of the Slwike (Observ. ii. 98) is handed down in the modern scientific name of Lanius collurio. Buffon, quoted by Camus, ii. p. 238, says (Hist. Des Ois. ii. p. 7o) that

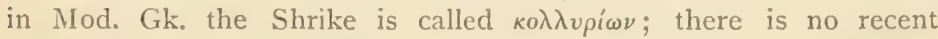
evidence of this. Gloger suggests with more probability, Turdus pilaris, L., the Fieldfare.

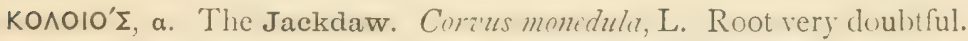

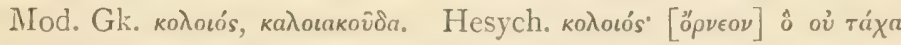

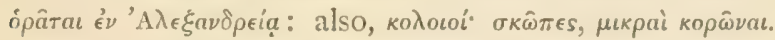

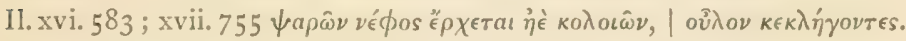

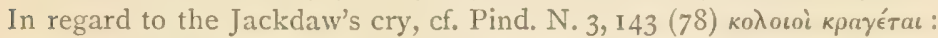
Antip. Sid. 47 ko

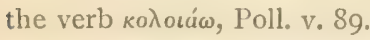

Frequent in Aristophanes; Av. passim, Ach. 875, Vesp. 129, Eq. 1020, \&c.

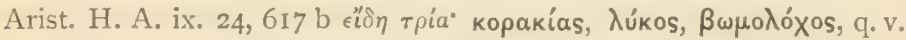

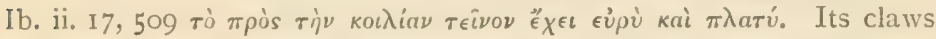

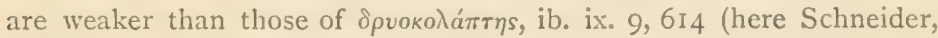
followed by Sundevall, would read for $\kappa o \lambda \circ \iota \hat{\omega} \nu, \kappa o \lambda \iota \hat{\omega} \nu$ s. $\kappa \epsilon \lambda \epsilon \hat{\omega} \nu)$. De

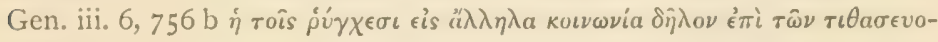

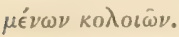

How the Jackdaw, a victim to sociality, is caught with a dish of oil, into which, looking at his own reflection, he falls; Ael. iv. 30, Athen. ix. 393 b, Dion. De Avib. iii. I9. Caught also with springes baited with an olive, Dion. ib. iii. I8.

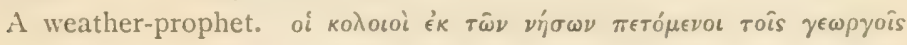




\section{KO^OIOE (continued).}

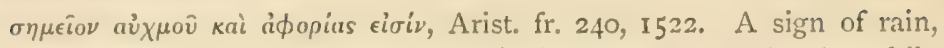

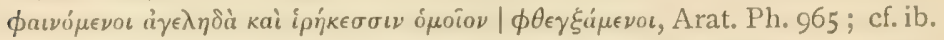

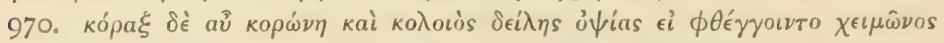

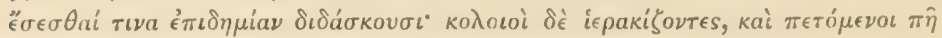

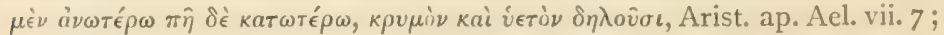
cf. Theophr. De Sign. vi. I ; Arat. I023, I026; Ovid, Amor. ii. 6, 34 pluviae graculus auctor aquae; Lucret. v. 1082.

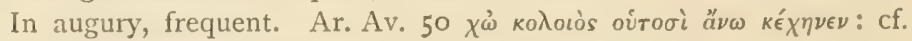
W. H. Thompson's note on Plat. Phaed. 249 D.

How the Jackdaws, destroying the grasshoppers' eggs, are cherished by the Thessalians, Illyrians, and Lemnians, Ael. iii. I2, Plin. xi. 29. How the Veneti bribe the Jackdaws to spare their crops, and how the Daws respect the compact, Ael. xvii. I6, Antig. Hist. Mir. I73 (189), Arist. De Mirab. ii. $9,84 \mathrm{I}$ b. On the construction of scare-crows, cf. Geopon. xiv. 25 .

Story of a Jackdaw enamoured of a certain youth, Ael. i. 6, xii. 37. The Jackdaw in medicine, Plin. xxix. (6) 36 , xxx. (I I) 30 , \&c. Uses laurel as a remedy, Plin. viii. 27.

Fables. - The Daws and the Husbandman, Babr. xxxiii. The Daw

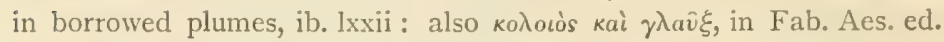

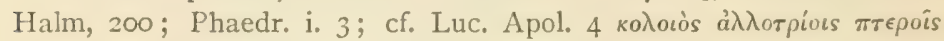

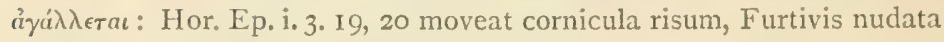
coloribus. See also Aes. Fab. 201, 202, 398.

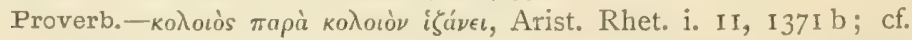

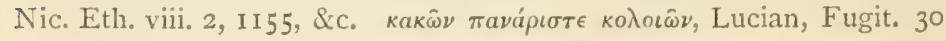

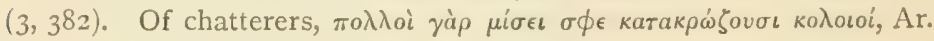
Eq. IO20.

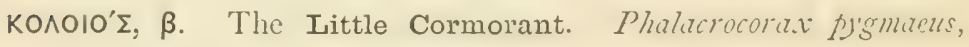

Bonap.; vide s. v. катарра́ктүs.

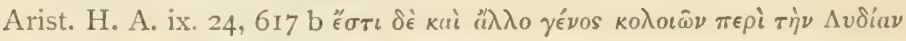

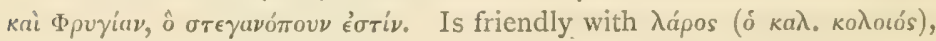
Ael. v. 48 .

Sundevall ingeniously suggests the above interpretation, the large or Common Cormorant, 'corvo marino,' being known as кópa

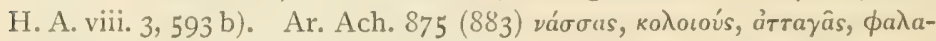
pías, \&c., is quoted by Athen. ix. $395 \mathrm{E}$ as a list of water-birds. Cf. s.v.

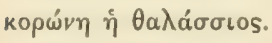

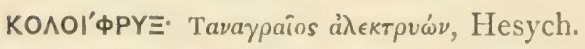

KO^OKTPY $\Omega^{\prime} N$. In Hesych,, supposed to be based on an ancient

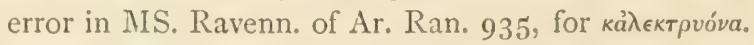

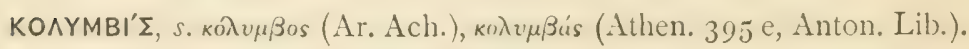
A water-bird; especially a Grebe. 


\section{KOАYMBII (continued).}

Ar. Av. 304, Ach. 875, brought to market from Boeotia. Mentioned among the water-birds in Arist. H. A. i. I, 487, viii. 3, $593 \mathrm{~b}$; Alex.

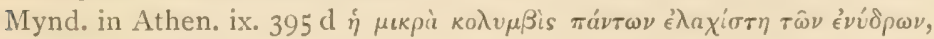

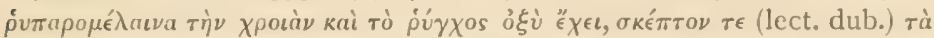

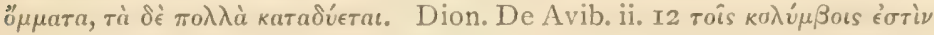

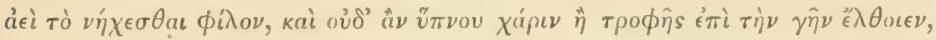

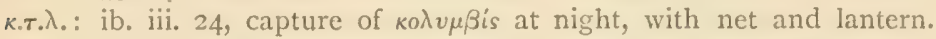
The above passage from Alex. Mynd., so far as it is intelligible, is a good description of the Little Grebe or Dabchick, Podiceps minor, L.,

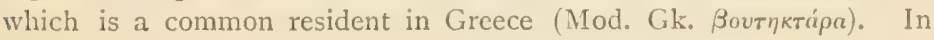
Arist. De Part. iv. 12 we find a minute account of the Grebe's foot, but without a name.

According to Nicand. ap. Anton. Lib. c. ix, one of the Emathides, daughters of Pierus, was metamorphosed into the bird кo $\lambda v \mu \beta$ ís.

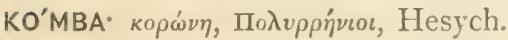

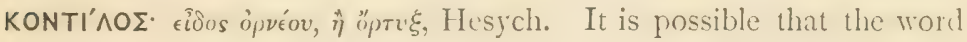
may be connected with kóvтos, and that it may relate to the game of óртөуокотіa, or quail-tapping.

KOPAKI'As. Also kopakivos (synonymous according to Hesych.).

A Chough. Pyrrhocorax alpims, the Alpine Chough, and Fregitus graculus, the Cornish Chough; both found in Greece, the latter

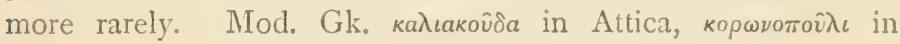
Laconia (Heldr.).

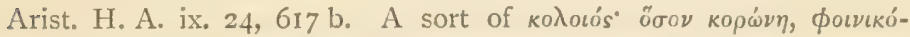

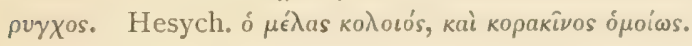

KO'PAE, $\alpha$. The Raven. Corvus corax, L. Cf. Sk. kar-âvas, L. cor-z'us, Sw. krå-ka, O. N. hrö-kr, A. S. hro-c, Eng.crow, rook, O. N. hra-fn,

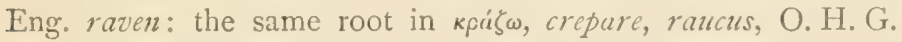

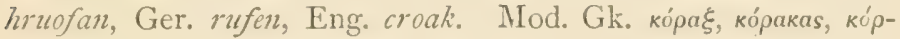

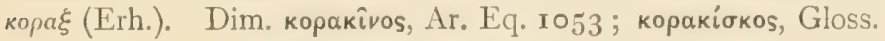

Not in Homer. Poet., frequent, with the idea of ravenous, carrionfeeding, e. g. Aesch. Suppl. 75I, Ag. 1473 ; Gk. Anthol. (Jac.) iv. 179

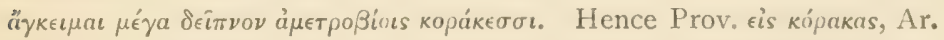
Vesp. 51, 852, Nub. 123, 133, 789, Pax 500, 1221, Thesmoph. 1226, \&c., Arist. fr. 454, 1552 b, Plut. ix. 415 , Lucian, Alex. $46(2,552)$; frequent also in the comic fragments. See also the long note of Photius; cf. also

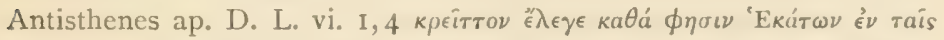

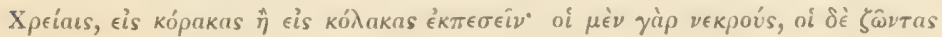

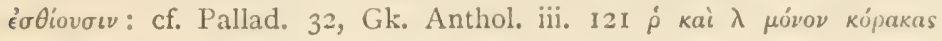




\section{KOPAE (continued).}

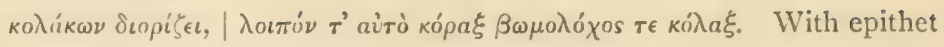
кยауо́ттероs, Eur. Andr. 862.

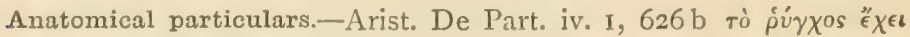

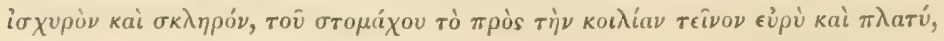

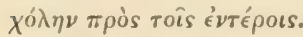

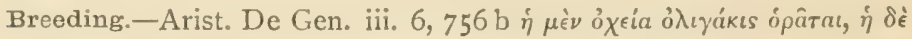

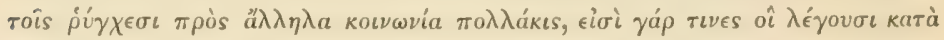

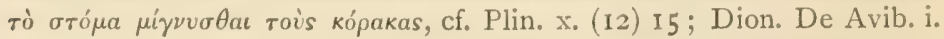

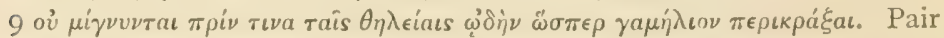
for life, Athen. ix. 506. Lays four to five eggs, Arist. H. A. ix. 31, 618 b. Incubates twenty days and cxpels the fledglings, ib. vi. 6, 563 b.; cf. Plin.

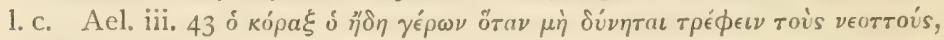

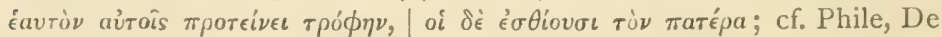
Anim. Pr. vi.

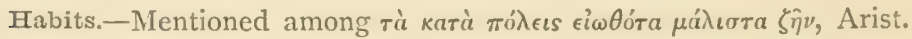

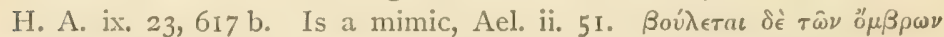

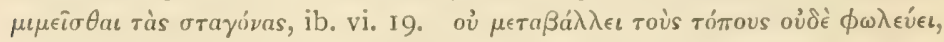
Arist. H. A. ix. 23, 617 b. How the Ravens pick out sheeps' eyes, Ar. Av. 582 .

Myth and Legend. - How there are never more than two Ravens

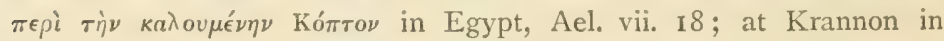
Thessaly, Arist. De Mirab. 126, 842 b, Plin. x. (12) 15 ; in Pedasia in Caria, Arist. De Mirab. 137,844 b. In this last instance they inhabit the temple, and one has a white throat. Perhaps the kópakes here were

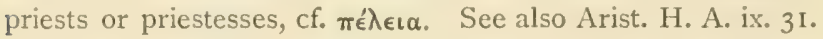

On the кópakes or корákıа, as a grade in the Mithraic hierarchy, cf. Porphyr. De Abst. iv. I6, Hieronym. ad Laet. 7, Diodor. i. 62, Inscr. Grüter. p. 1087. 4, \&c.; cf. Montfaucon, ii. p. 377, Creuzer's Symbolik i. p. 253, Münter ad Jul. Firmic. v. p. 20, \&c. Creuzer (i. p. 43I) correlates the Indian myth of Brahma appearing in one of his incarnations as a Raven, and compares in turn this latter story (ii. p. 655) with that in Herod. iv. 15. The Raven of Odin is, perhaps, also cognate.

The Raven as a messenger of Apollo. Hesiod, fr. 125 (142) ap.

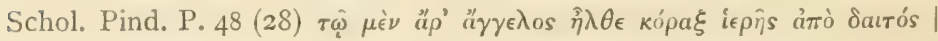

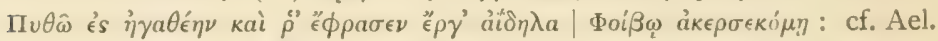

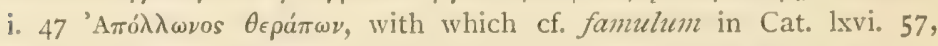

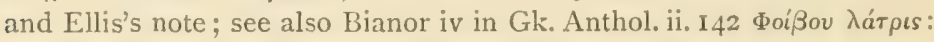
Ael. i. 47, 48, vii. 18, Porph. De Abst. iii. 5, Stat. Silv. ii. 4 Phoebeius ales, \&c.

Hence with the laurel-emblem, on coins of Delphi. Hence also Stat. Theb. iii. 506 comes obscurus tripodum; Petron. Sat. c. 122 delphicus ales. 
KOPA $\equiv$ (continued).

The legend of Coronis (Paus. ii. 26, 6), mother of Aesculapius : the raven sent for water by Apollo, and punished for dallying by the way; hence the raven, alone of birds, does not bring water to its young: Dion. De Avib. i. 9, Phil. De An. Pr. vi : cf. Callim. fr. nuper edit., Gompertz, Mitth. a. d. Rainersammlung, 1893, Kenyon, Class. Rev. I 893, p. 430. See further, Ael. i. 47 ; also Ovid, F. ii. 249, where Corvus in the same story appears as a constellation; according to Hyginus; Poet. Astron. c. xl, the raven waited to devour some ripening figs, and the punishment of everlasting thirst is correlated with the juxtaposition of the constellations Corvus and Crater, which latter the Hydra guards (Ovid, F. ii. 243 Continuata loco tria sidera Corvus et

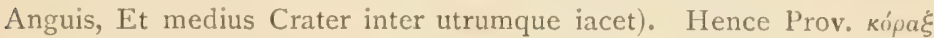

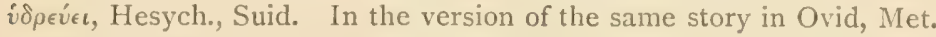
ii, the raven was originally white (v. 536) Nam fuit haec quondam niveis argentea pennis Ales, ut aequaret totas sine labe columbas; a worldwide legend : cf. Hygin. Fab. 202, Gower, Conf. Amant. iii, \&c.

On the name Coronis in connexion with Moon-symbolism, cf. Pott in Lazarus and Steintheil's Zeitschr., xiv. p. J8, I 883 .

It is skilled in augury, Ael. i. 48 ; cf. Aes. Fab. 212, Plin. x. (12), I 5 , Cic. Divin. i. 39, Ovid, Met. ii. 534, Plaut. Aulul. iv. 3, I, Id. Asin. ii. 1, 12, Hor. Car. iii. 17, Stat. Theb. iii. 506, Petron. Sat. 122, Valer. Max. i. c. 4 , Festus, 197, \&c.

How ravens conducted Alexander to the Temple of Jupiter Ammon, and subsequently gave warning of his death, Plut. V. Alex. c. 27.

How the ravens flocked to Delphi, and despoiled the gifts of the Athenians, before the Sicilian disaster, Pausan. x. I $5,5$.

How ravens guided the Boeotians to the site of a new city, Photius, S. v. és kópakas.

How all the ravens departed from Athens and the Peloponnese on the defeat of Medius at Pharsalus, Arist. ix. 31, 618 b : cf. Plin. x. 15; see Schneider in loc., and ad Xen. Hellen. ii. 3, 4, further Diodor. xiv. 82 , and Strab. xi. p. 591. Some similar incident seems to be alluded

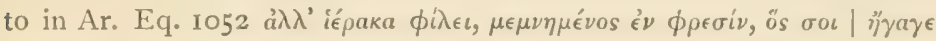

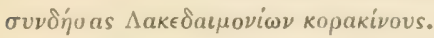

How in Egypt the ravens beg of those sailing by in boats, and if denied, cut the cordage, Ael. ii. 48. Places ä $\gamma \nu$ in its nest as a charm,

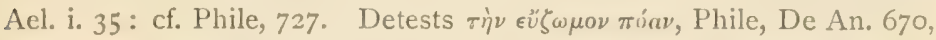

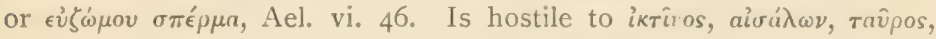
övos, Arist. H. A. ix. I, 609 b, Ael. v. 48, Phile, 388, 705, and to $\chi \lambda \omega \rho \epsilon i$ ', Phile, 690. A raven and an ass together on a coin of Mindaon, Imh. Bl., and Kell., p. 32, pl. 24 (the constellation Corvus set shortly after Cancer, with which latter the Ass is associated). The hare detests the voice of the raven, Ael, xiii. I I (and the constellation Lepus sets soon 


\section{KOPAE (continued).}

after the rising of Corvus, as does also Taurus). The raven is friendly to the fox, Arist. H. A. ix. I, 609 b. The raven's eggs dye the hair and the teeth black, Ael. i. 48, Phile, De An. vi, Plin. xxix. (6) 34. The raven in medicine, Plin. xxix. (4) I3, \&c. After killing a chameleon, the raven uses a leaf of laurel as an antidote to the reptile's venom, Plin. viii. (27) $4 \mathrm{I}$.

For an account of the various Raven-myths discussed in connexion with the astronomic symbolism of the constellation Corvus, see Hygin. Poet. Astron. xl, Fab. ccii, German. c. xl, Eratosthen. c. xli, Theon. p. I5I, Vitruv. ix. 7, Ovid. 1. c., Dupuis, Orig. de tous les cultes, vi. p. $457, \& \mathrm{c}$.

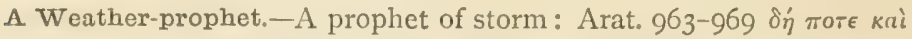

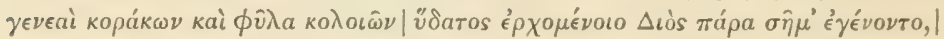

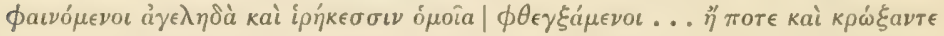

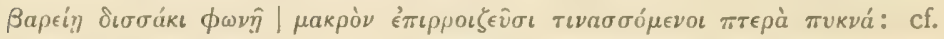

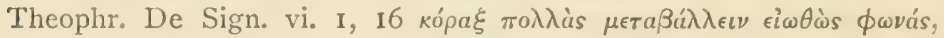

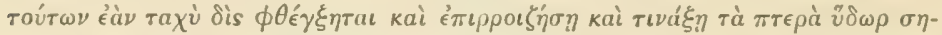

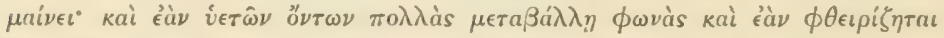

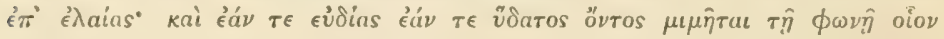

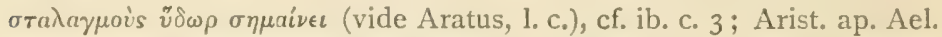

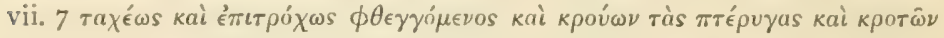

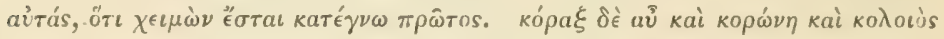

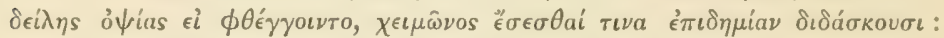
Plut. Sol. Anim. ii. I29 A, Nic. Ther. 406 and Schol., \&c. A sign of

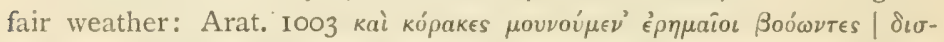

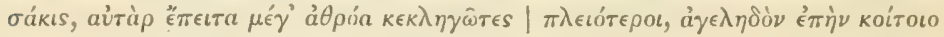

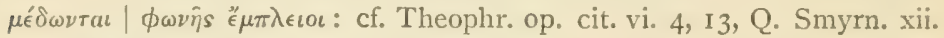
513, Geopon. i. 2, 6; i. 3, 8, Plin. xviii. 87, Virg. G. i. 382,410 . In the Georgics, the allusion is evidently to rooks, as is perhaps also the case, though more doubtfully, in Aratus; cf. W. W. Fowler, 'A Year with the Birds' (3rd ed.), p. 234.

Varieties.-White ravens, Arist. H. A. iii. 12, 519: cf. De Color.

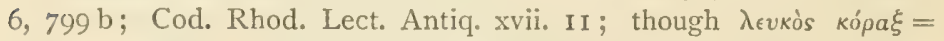
cygmus niger, an unheard-of thing, Anth. Pal. xi. 417 (Jac. iv. 130)

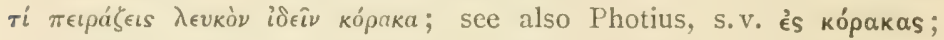

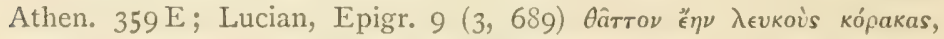

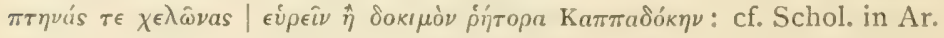

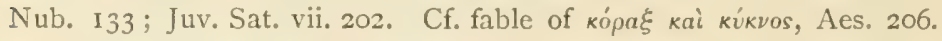
According to Boios and Simmias, ap. Anton. Lib. c. $\mathrm{xx}$, Lycias, son of Cleinis, was metamorphosed into a white Raven. The ravens in Egypt are smaller than in Greece, Arist. H. A. viii. 28, 606.

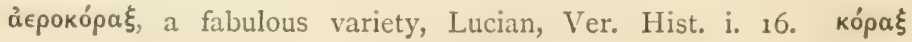


KOPAE (continued).

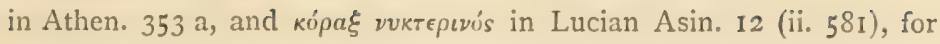
vикткко́ра乡, q.v.

On talking Ravens, Porph. De Abst. iii. 4, Plin. x. (43) 6o, \&c.

Fables.-Fable of the pitcher and the stones, Bianor iv, in Gk. Anthol. ii. 142; Ael. ii. 48, vii. 7. Fox and Crow, Babr. 77, Aes. (ed. Halm), 204: cf. Hor. Sat. ii. 5, 56. The Sick Raven, Babr. 78, Aes.

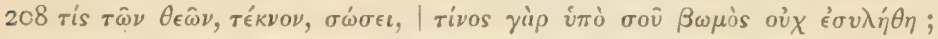
Daw and Raven, Aes. 201. Raven and Serpent, Aes. 207: cf. Gk.

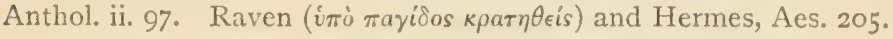

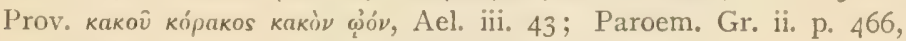
ed. Leutsch : cf. W. H. Thompson's Phaedrus, p. I32.

KO'PAE. $\beta$. A Cormorant, Phalacrocorax carbo, L., and P. graculus,

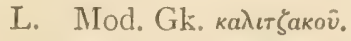

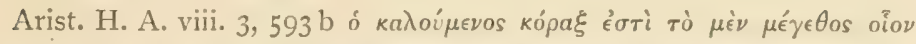

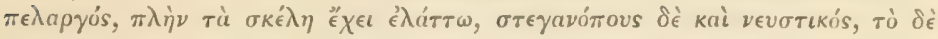

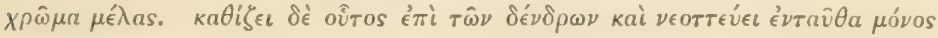

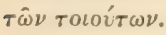

The Cormorant appears in various Italian dialects as cormoran, corvo marin, corvastro, \&c., the Little Cormorant (vide S.v. koגoós) as corvo marin piccolo, and in Venetia, corvéto marin, i. e. Sea-Jackdaw (Giglioli).

The corvus aquaticus of Plin. xi. (37) 47, mentioned as bald (quibus apud Graecos nomen est inde), and therefore presumably identical with the fhalacrocorax, ib. x. (48) 68, must have been a different bird.

Ko'PAфOs. An unknown bird, Hesych. According to Schn., for кópuфos, whence $\mu \in \lambda a \gamma$ кópuфos.

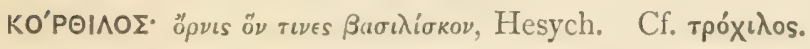

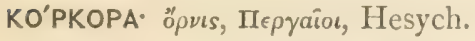

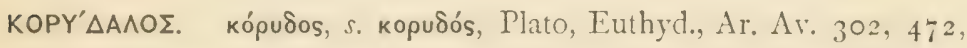
\&c., Anaxandrides ap. Athen. iv. I3 I, Arist. H. A. \&c., Theocr. vii. I 4I, Plut. De Is., \&c., Galen, \&c. ; кори $\alpha \alpha \lambda \lambda \eta ́$, Epich. 25

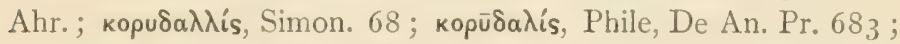

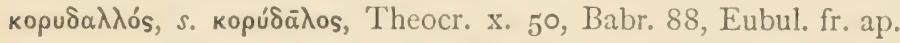

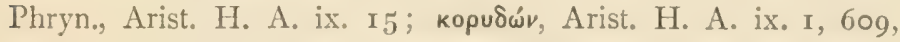
cf. Schol. ad Ar. Av. $3 \circ 3$; kópuӨos, Hesych. (a doubtful word,

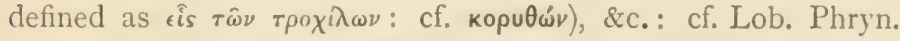
338 ; Rutherford, New Phryn. p. 426. On the gender, cf.

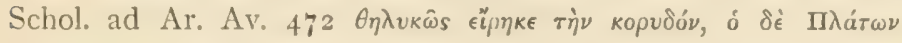
(Euthyd. 29I D) rois kopvooús. 


\section{KOPY $\triangle A \wedge O \Sigma$ (continued).}

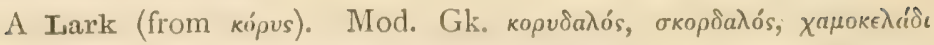

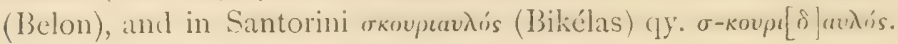

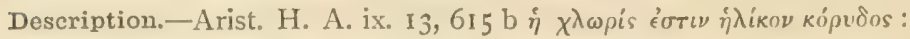

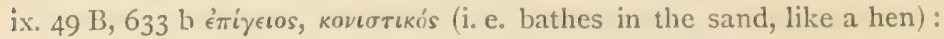

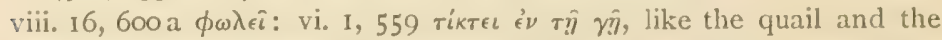

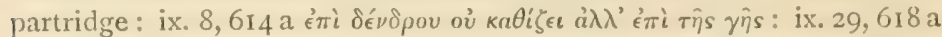
the cuckoo lays in its nest, which is placed on the ground, cf. Ael. iii. 30. Is caught with bird-lime, Dion. De Avib. iii. 2, or by help of the owl, ib. iii. I7. The crest referred to proverbially, Simon. fr. 68

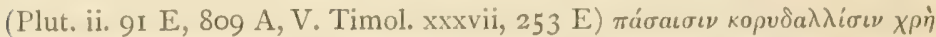
$\lambda$ ó $\phi \circ \nu^{\prime} \gamma \gamma$ i $\nu \in \sigma \theta a$. Arist. mentions neither the singing nor the soaring

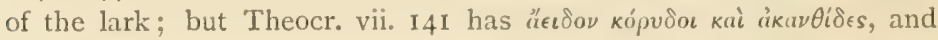

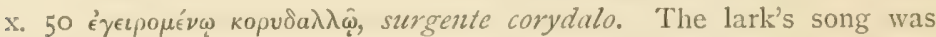

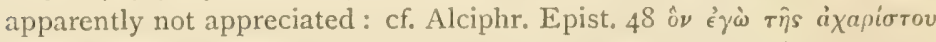

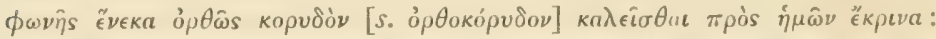

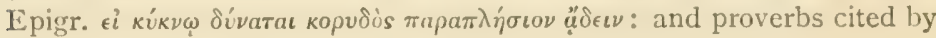
Schneider in Arist. vol. iv. p. 128.

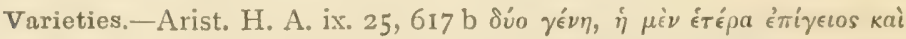

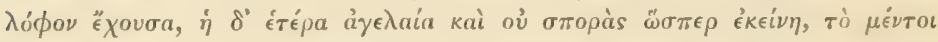

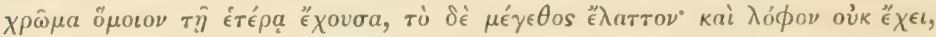

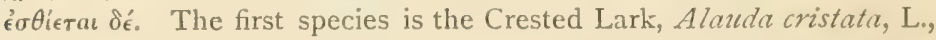
a permanent resident in Greece; the other is the Common Lark, Alauda arvensis, L., a winter migrant (v.d. Mühle, p. 36, Lindermayer,

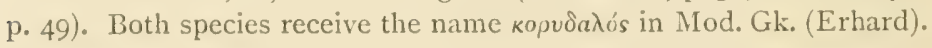

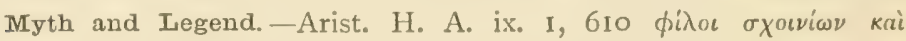

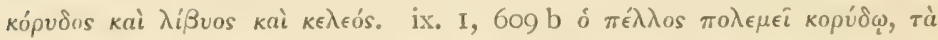

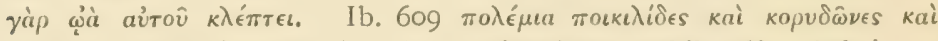

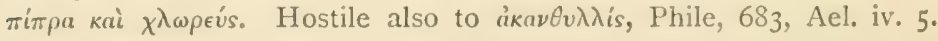
Uses the grass "̈ $\gamma \rho \omega \sigma \tau \iota s$ as an amulet or protection, Ael. i. 35, as does the Hoopoe, Phile, 724; whence the proverb év kopvoov

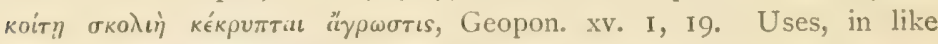
manner, oak-leaves, Phile, 725. Is killed by mustard-seed, vímvos

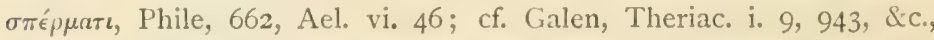
Diosc. ii. 59, 796. How the lark led an Attic colony to Corone in Messenia, and how Apollo, under the name Kópvosos, had a temple and cured diseases there, Paus. iv. 34, 8. How the Lemnians honoured

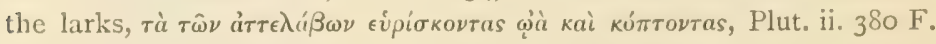
The story of the Lark and his Father, Aesop ap. Ar. Av. 47 I kopviò

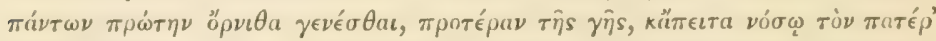

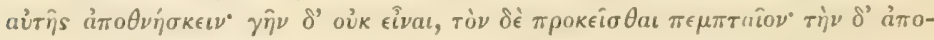

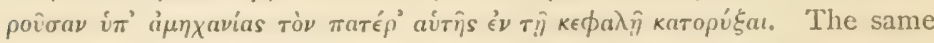

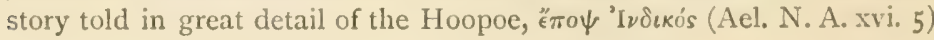


KOPY $\triangle A \wedge O \Sigma$ (continued).

with the statement that the Greeks probably transferred the legend to the lark; vide s.v. є̈ $\pi \circ \psi$. The legend, which probably includes a solar myth,

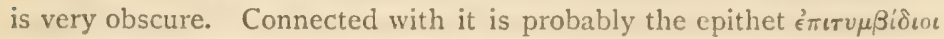

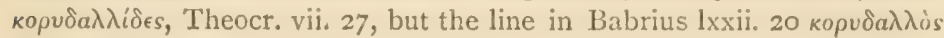

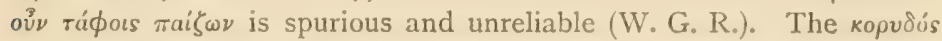
and $\epsilon_{\pi \circ} \psi$ (both crested birds) are frequently confused: the very word Alauda is possibly an Eastern word for the Hoopoe, Arab. al hudhud. Cf. Plin. xi. 37 galerita appellata quondam, postea gallico (?) vocabulo alauda.

Associated with the name Philoclees, Ar. Av. 1295.

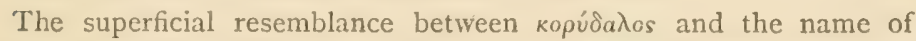

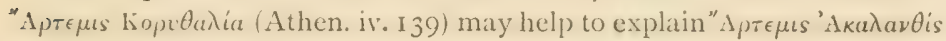
and the other similar epithets in Ar. Av. 870-877.

A fabled metamorphosis, Boios ap. Anton. Lib. c. 7, where Hippo-

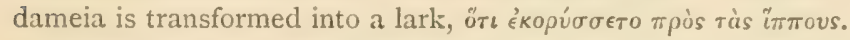

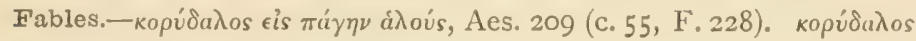
kui yewpyós, Ib. 210 (F. 379, C. 42I, B. 88).

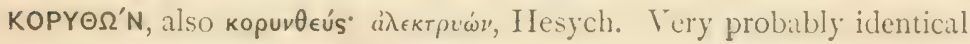

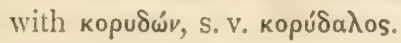

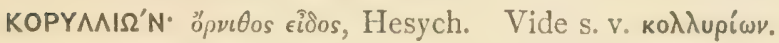

KOP $\Omega^{\prime} N H$. The Crow, Corrus corone, L., including also the Hooded Crow, C. cornix, L. Mod. Gk. корติva (Erh.), коvроîva (v. d. M.). Sometimes the Rook, which only appears in Greece during the winter, and appears to have received no special name: vide s.v.

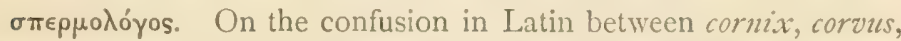
\&c., v. Wedgwood, Tr. Philol. Soc., I854, p. Io7; also W. W. Fowler, 'A Year with the Birds,' c. vii. Dim. kopwvıseús, Cratin. $\Pi v \lambda$, IO.

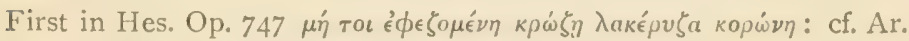
Av. 609 ; Apoll. Rhod. iii. 928 ; Arat. 950.

Described as frequenting cities, Arist. H. A. ix. 23, 6I 7 b, not a migrant, ib. (cf. Fab. Aes. 4I 5). No bigger in Egypt than in Greece, ib. viii. 28, 606 ; alimentary canal as in the Raven, ib. ii. 17, 504 ; frequent the seashore, to feed on jettisoned carcases, being omnivorous, ib. viii. 3, 593 b;

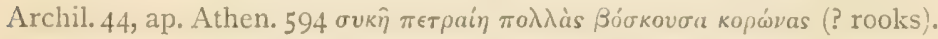

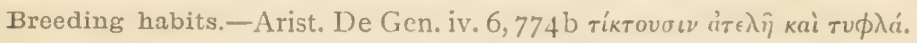

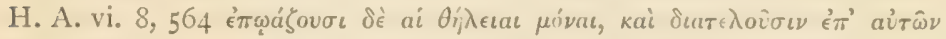

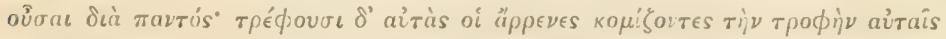

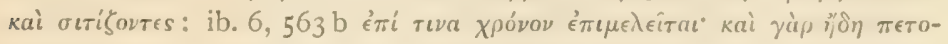

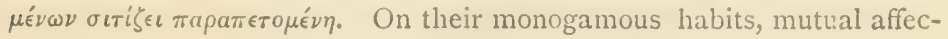




\section{KOP $\Omega$ NH (continued).}

tion and constancy, whence their invocation at weddings, vide Ael. iii. 9 (infra cit.).

Myth and Legend,-Its proverbial longevity. Hes. in Plut. De Orac.

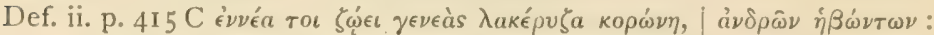

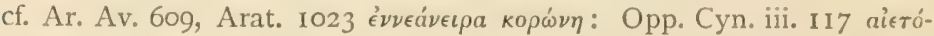

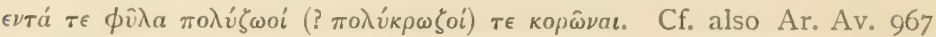

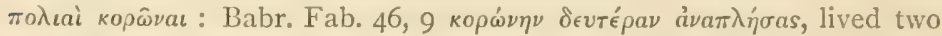

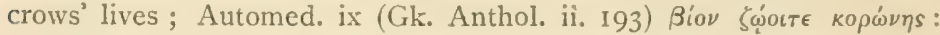

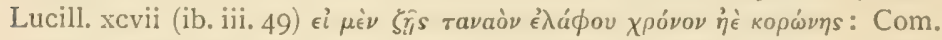

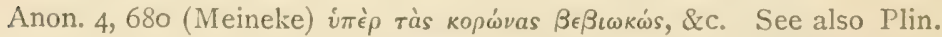
vii. 48, Horat. Car. iii. I7, I6 annosa cornix; Martial, x. 67 cornicibus omnibus superstes, \&c.; Lucret. v. I083, Juv. x. 247, Ovid, Amor. ii. 6, 36. Auson. Id. xviii.

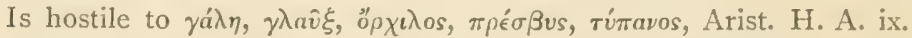

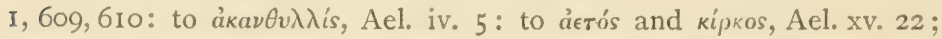

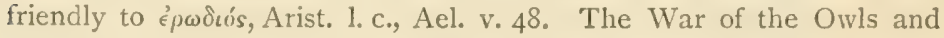

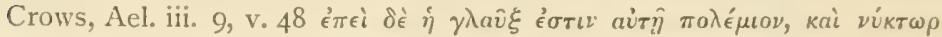

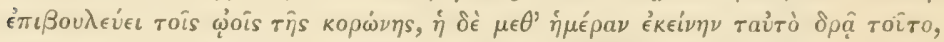

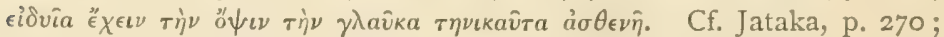
Ind. Antiq., I882, p. 87; De Gubern. Zool. Myth., \&c. Vide S. v. $\gamma \lambda \alpha \hat{u} \xi$ for a discussion of the moon-symbolism of the latter bird, and compare the Chinese expression of the Golden Crow and the Jewelled Hare to signify the Sun and Moon. The same legend may account for Athene's supposed enmity to the Crow, cf. Ovid, Amor. ii. 6, 35 cornix invisa Minervae.

Uses ảp $\iota \tau \epsilon \rho \hat{\omega} \nu$ as a charm, Ael. i. 35 ; also pá $\mu \nu o v$, Phile, De Am. Pr.

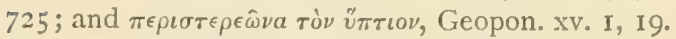

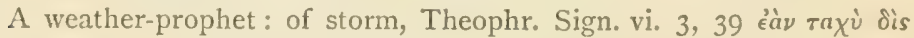

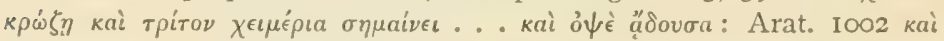

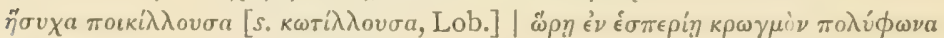

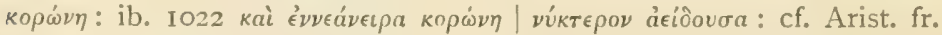
24I, I 522 b, ap. Ael. vii. 7, Plut. ii. 674 B, Virg. G. i. 388, Hor. C. iii. I7, 13, Lucan V. 556; a sign of fair weather, Theophr. vi. 4, 53 kai

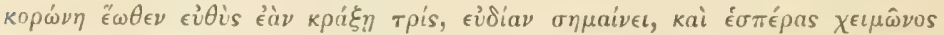

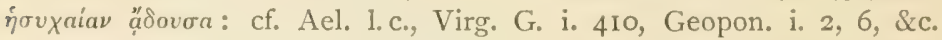
A bad summer is portended when the fig-leaves are shaped like a crow's foot, Plut. ii. 4 Io E.

The Crow in augury, seldom mentioned in Greek, save in Ar. Aves; see also Ael. iii. 9, where a solitary crow is mentioned as an evil omen; according to Porph. De Abst. iii. 4, the Arabs understood the language of crows. A crow on the left-hand is unlucky, Virg. Ecl. ix. I5, Cic. De Div. i. 39, Plaut. Asin. ii. I, I2, \&c. ; cf. Hopf, Orakelthiere, p. I 5. According to Bent, Cyclades, 1885, p. 394, the inhabitants of Anti- 
KOPSNH (continued).

paros are called knvpov́va by their neighbours in Paros, the reason assigned being that if the former see a crow on the south side of a tree, they are in terror.

How a crow never enters the Acropolis at Athens, Arist. fr. 324 , 1532 b, Ael. v. 8, Apollon. viii, Plin. x. (12) 14. (This statement is believed by some modern travellers, cf. Dr. Chandler, Trav. in Greece, c. xi. p. 54 ; and may have a foundation in fact, due simply to the height of the hill.) How a crow in Egypt used to carry messages for King Marres, and was honoured with a sepulchre, Ael. vi. 7. How a crow dies if it falls in with the leavings of a wolf's dinner (!), Ael. vi. 46, Phile, 671. How a brazen crow was found in the foundation of Coronea, Paus. iv. 34, 5. How the crows showed the grave of Hesiod, Paus. ix. 38, 3. How the young crow leaves the egg feet first, Dion. De Avib. i. Io. The heart eaten, to secure prophetic powers, Porph. De Abst. ii. 48 (cf.

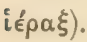

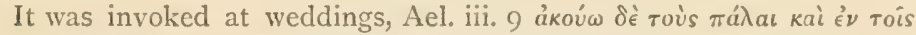

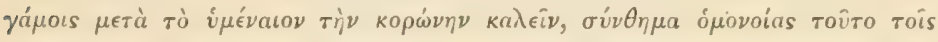

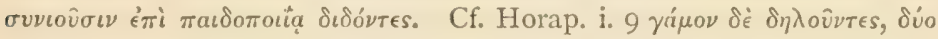

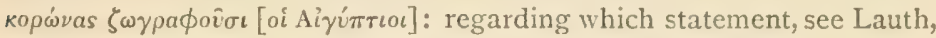

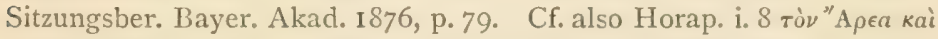

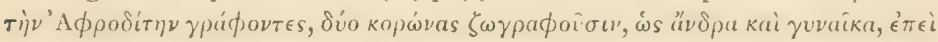

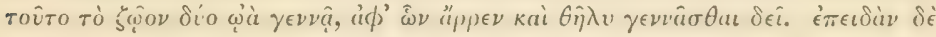

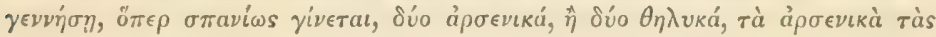

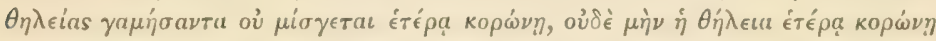

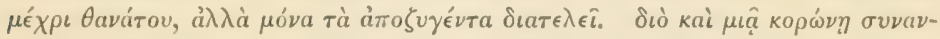

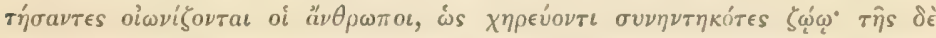

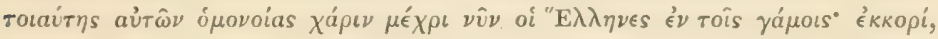

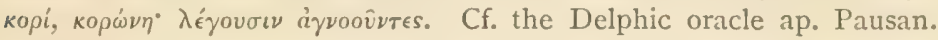

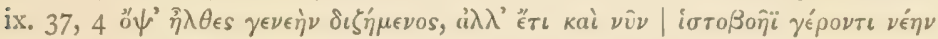
$\pi \circ \tau i \beta a \lambda \lambda \epsilon \kappa o \rho \dot{\omega} \nu \nu$.

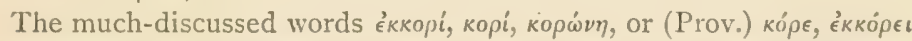

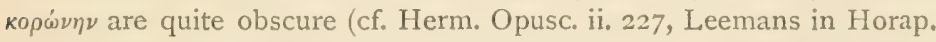
p. I 56, various commentators on Pind. P. iii. 19, \&c.). They are probably part of a 'Crow-song', and very likely involve a corruption of foreign words: IJKOpI (which word includes the article) is said to be

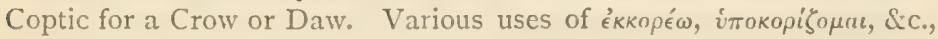
are perhaps involved in the same corruption ; $\mathrm{cf}$. also the word-play on

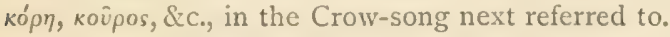

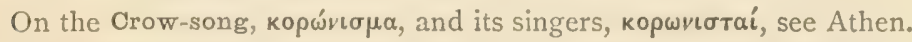

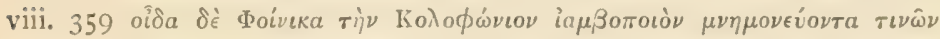

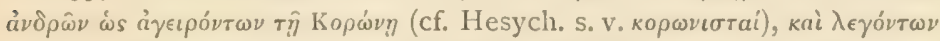

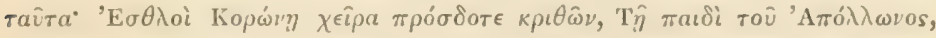
$\hat{\eta} \lambda \epsilon_{\chi} \chi \sigma^{\prime} \pi p \hat{\omega} \nu, \kappa . \tau . \lambda$. Ilgen, Poet. Gr. Mendicorum Spec., in Opusc. 
KOP $\Omega$ NH (continued).

Var. Phil., i. p. 169; Fauriel, Chants de la Gr. Mod., i. p. cix. See also

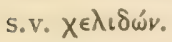

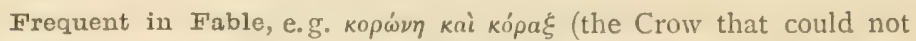
prophesy), Fab. Aes. 202 ; кор

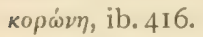

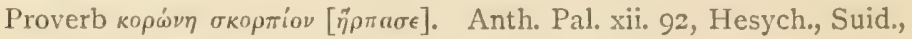
cf. Ael. vii. 7, Zenob. iv. 6o, p. IoI.

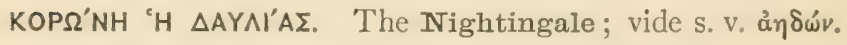

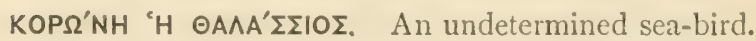

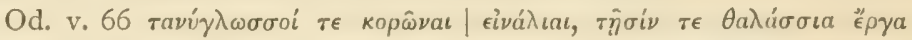

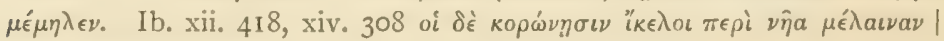

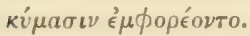

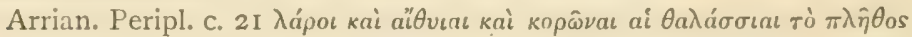

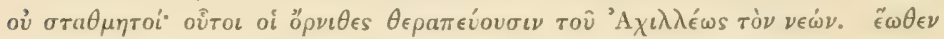

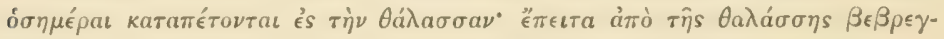

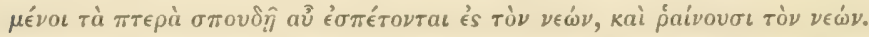

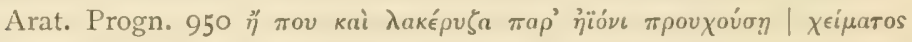

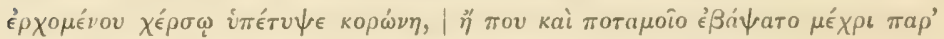

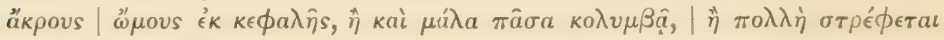

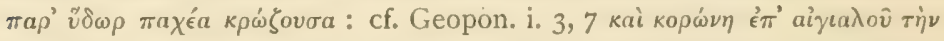

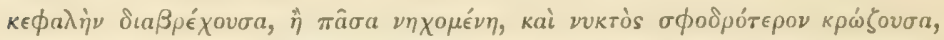

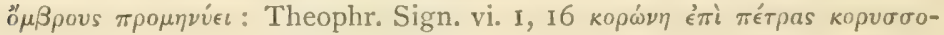

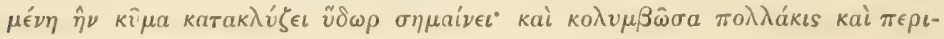

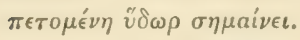

These passages, with which compare Arist. H. A. viii. 3, $593 \mathrm{~b}$, and Ael. xv. 22, denote a different bird altogether from kop心 a swimming and diving bird, and not merely one frequenting the seashore as the Carrion Crow and Hooded Crow do. It is neither a Aápos nor an aitvia (Arrian, 1. c.) though identified with them by the Scholiast

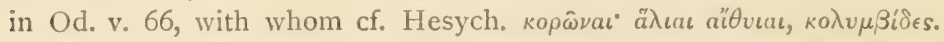
It may be another name for the Cormorant (vide s.v. кópa $\xi, \beta$ ): but it is not safely identifiable.

It is apparently such passages which are imitated in Virg. G. i. 388 Tum cornix plena pluviam vocat improba voce, Et sola in sicca secum spatiatur arena; cf. Claud. De Bell. Gild. 492 Heu nimium segnes, cauta qui mente notatis, Si revolant mergi, graditur si littore cornix. Cf. however the weather-prophecies S. v. koגoเós. It is at least pretty clear that in such passages the Latin poets were thinking more of what they had read than of what they had seen.

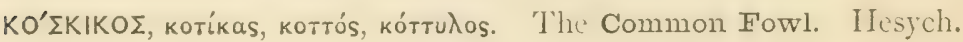

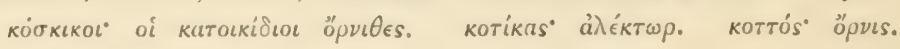

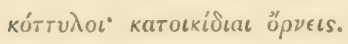




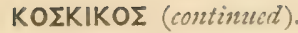

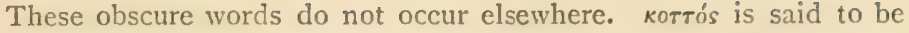
connected with коттís, for a crest or top-knot, cf. Hesych. s. v. троко́тта :

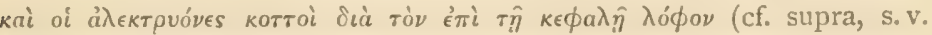

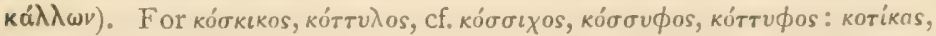
on the other hand, suggests a corruption of katoıxís. Cf. Lob. Proll. 327 ; Schmidt ad Hesych. 3758, 3790.

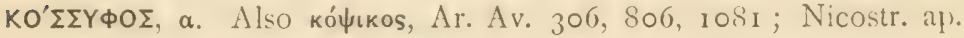
Athen. ii. $6_{5}$ D, \&c.; ко́ұukos, Suid.

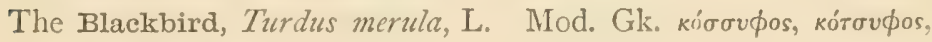

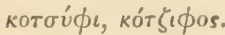

Description.-Its size compared with the Woodpecker, Arist. H. A.

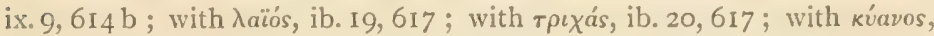

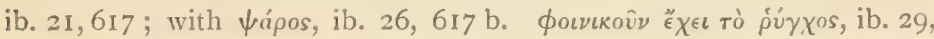

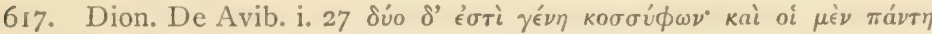

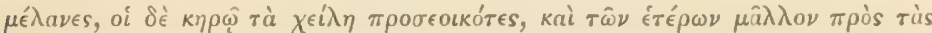
$\omega \dot{\delta} a \dot{s} \dot{\epsilon} \pi \imath \tau^{\prime} \delta \epsilon \iota \iota \iota:$ this is plainly the sexual difference.

Migration, Arist. H.A. viii. 16, 6oo, $\phi \omega \lambda \epsilon \hat{\imath}$. Change of plumage, ib.

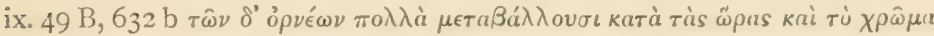

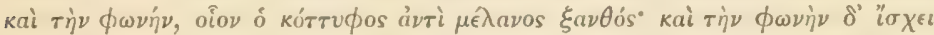

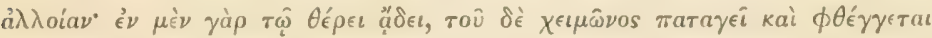
$\theta o \rho v \beta \omega \delta \epsilon s$. Cf. Arist. fr. 273, I527 b; Ael. xii. 28. Eustath. Hexaem.

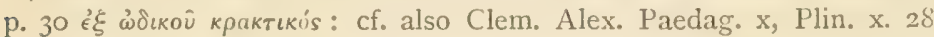
Merula ex nigrâ rufescit, canit aestate, hyeme balbutit, circa solstitium mutat. Song referred to also, Ael. vi. 19; Theocr. Ep. iv. 10 eiapıขoi

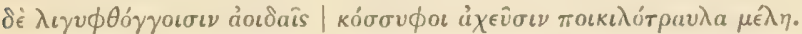

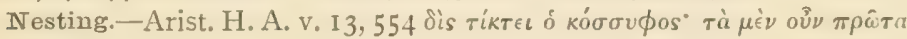

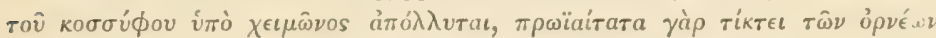

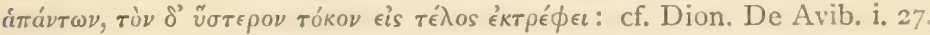
Arist. H.A. ix. 13, 616, builds a nest lined with hair and wool like $\chi^{\lambda \omega}$ pis.

White Blackbirds on Cyllene.-Arist. H. A. ix. 19, 617, De Mirab. I5, 83 I b, Pausan. viii. I7, 3, Sostrat. ap. Ael. v. 27, Plin. x. 30, Steph. Byz. S. v. $\kappa v \lambda \lambda \eta \dot{\eta} \eta$, \&c.; according to Lindermayer (p. 30) white or albino blackbirds are still remarkably common on Cyllene, but in Aristotle the fact is mixed with fable.

Mode of capture.-Dion. De Avib. iii. I3. Frequently mentioned, together with $\kappa^{i} \chi \lambda \eta$, in the Anthology; Rhian. vi (Gk. Anth. Jac. i. 23I)

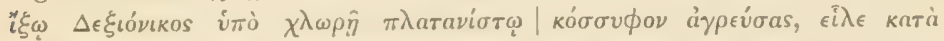

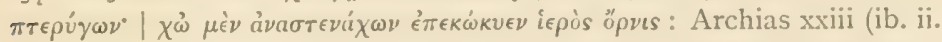

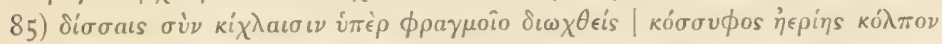

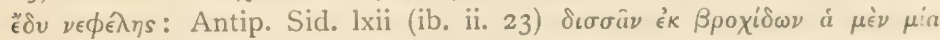

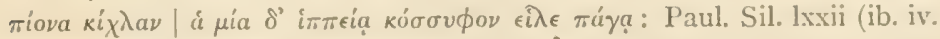

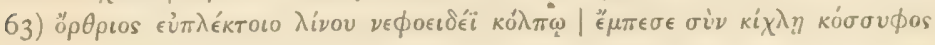




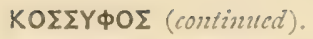

ịoußóas. Mentioned as a destructive bird, Anon. 416 (ib. iv. 206)

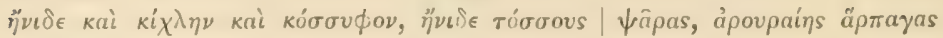
ยข่mopins.

MIyth and Legend.-Arist. H. A. ix. I, 608 b, hostile to $\kappa \rho \epsilon ́ \xi$, friendly with $\tau \rho v \gamma \dot{\omega} \nu$ : cf. Ael. vi. 46 . Is killed by pomegranate, cf. Phile, De An. Pr. 657.

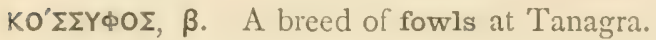

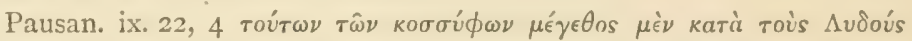

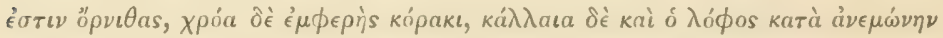

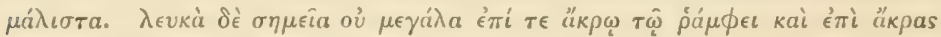

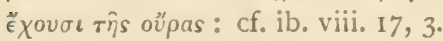

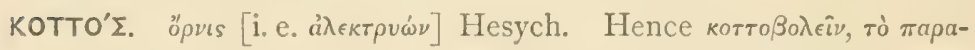

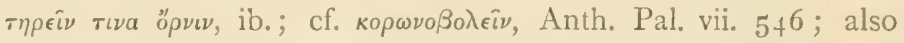

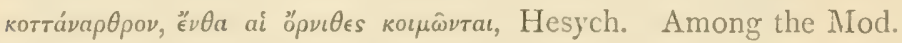

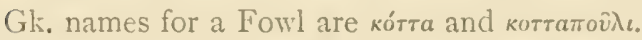

KoYkoY'фA, s. коukoúфas, s. koúkouфos. The Fgyptian name for the

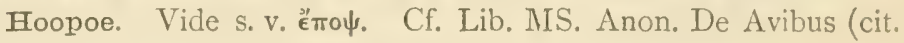
Ducange in Gloss. Med. et Inf. Gr., s. v. koúkouфos, Leemans

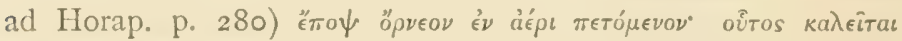
кои́коขфоs, ксі亡 тоиิтоs.

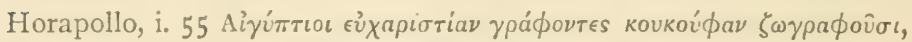

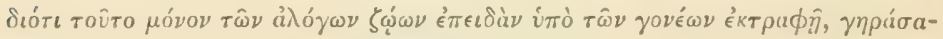

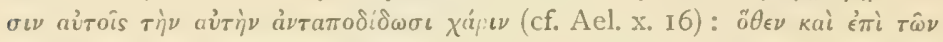

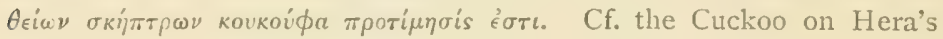
sceptre at Mycenae, s.v. kókкuł. On the Hoopoe on Egyptian sceptres or staves, see Creuzer's Symbolik, ii. 64, 280, pl. iv. I7; Denon, Pl. cxix. 8, \&c., \&c. For an account of the hieroglyphic symbol of the Hoopoe, and an explanation of the statements of Horapollo, vide Lauth, in Sitzungsb. d. Bayer. Akad. 1876, p. 106. To the Egyptian

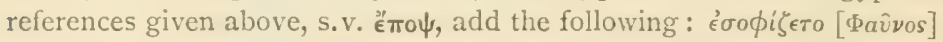

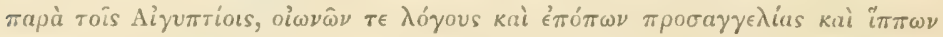
$\chi \rho \epsilon \mu \epsilon \tau \iota \sigma \mu o \dot{s} \mu a \theta \dot{\omega} \nu$, Exc. Gr. Barbari, Chron. Min., ed. Fick, 1893, p. 239.

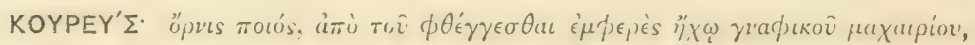
Hesych.

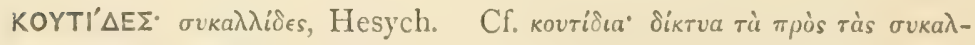
$\lambda i \delta a s, H e s y c h$.

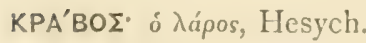

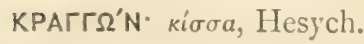




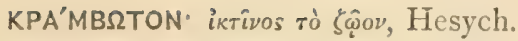

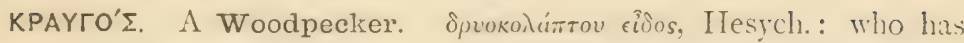
also кpazyóv moı̀s öpvis. Von Edlinger cites Lith. kraki: cf.

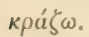

KPE'三, also керкás (Hesych.). A very doubtful bird, usually identified, by Sundevall and others, with the Corn-crake or Land-rail,

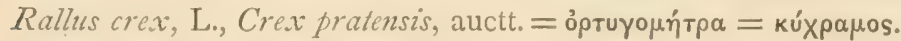
The name is lost in Mod. Gk.

Herod. ii. 76, compared in size with the Ibis.

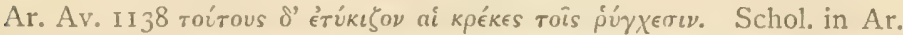

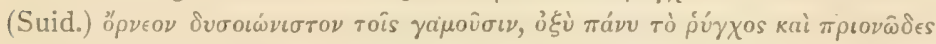

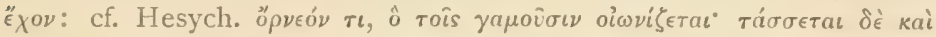

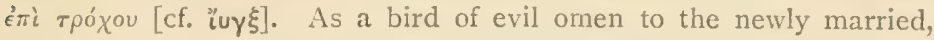

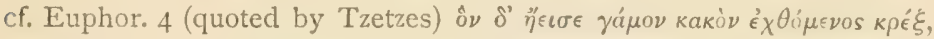

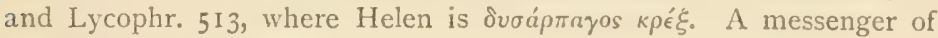
Athene, Porph. De Abst. iii. 5.

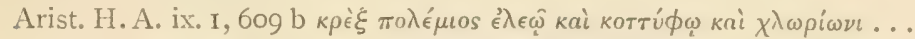

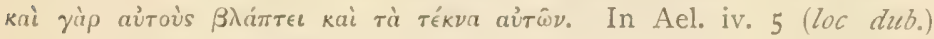
$\kappa \rho \xi \xi \xi$ is hostile to aitvia: aiso Phile, De An. Pr. 68I, with epithet

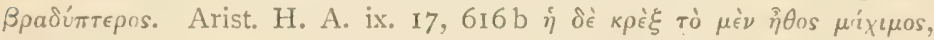

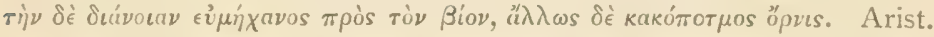
De Part. iv. 12, 695, mentioned among the long-legrged birds with a short hind-toe.

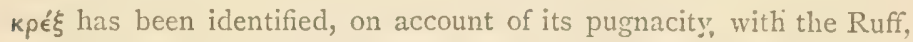
Machetes pugnax, L.; but the Ruffs fight with one anotiner (cf. $\mu \mu_{\mu \nu \omega \nu),}$ and, moreover, all the accounts of mutual hostilities between birds are unreliable, and in the main mythological. From the size, and the rudimentary hind-toe, the Black-winged Stilt, Himantopus mefpes, Bechst. was suggested first by Belon: its use by Herodotus as a standard of comparison with the Ibis is somewhat in favour of this bird, which is common in Egypt. The identification with the Corn-crake rests mainly on the assumption that the name is onomatopoeic. The facts that the Scholiasts knew little or nothing about the bird, and that the name is lost in Mod. Gk., suggest that the word was perhaps an exotic, and that its meaning was early lost.

KPIГH'• $\dot{\eta} \gamma \lambda a \hat{\xi} \xi$, Hesych.

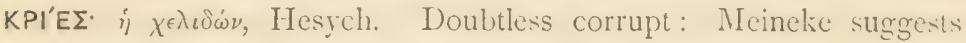
$\kappa \rho i[\delta o \nu] \epsilon s ;$ or $\kappa \rho i[\kappa] \epsilon s, \kappa \rho i \xi$.

KY'ANOE. Probably the Wall-Creeper, Tichodroma muraria, L.

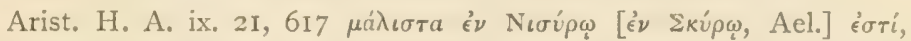

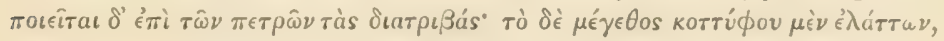




\section{KYANOE (continued).}

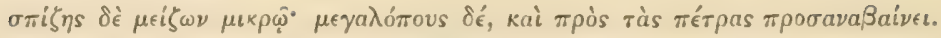

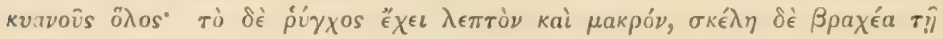

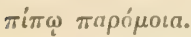

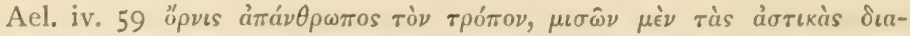

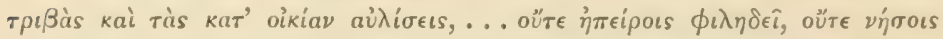

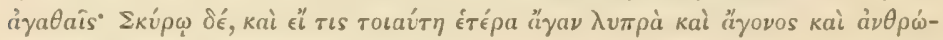

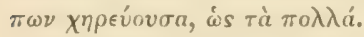

The description in Aristotle accords very perfectly with the WallCreeper (with which bird Gloger, Sundevall, and Heldreich identify it) as regards habitat, size, feet, and bill, as does Aelian's account of its solitary nature: but the bird is not kvavoûs ồos, nor is Aelian's account of its habitat satisfactory. Aubert and Wimmer on the other hand, following Belun, Gesner, and other older commentators, identify kíayos

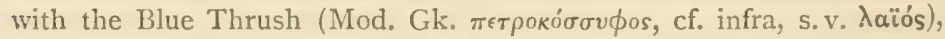
which agrees with the description in colour, but in little else, and is a very common bird, whereas kúavos is mentioned as scarce and local.

KYKNI'As. An Eagle, white like a swan, at Sipylus near Lake Tantalus, Pausan. viii. I 7,3 .

That Pausanias is here in error is rendered the more probable by the existence in Med. Gk. of the words $\tau \zeta$ rテเหขiâs, meaning a White Heron or Egret.

The White Eagle of Pythagoras (Iambl. Vit. Pythag. $\$ 132$, Ael. V. H. iv. I7) is supposed to be an allegory for the town of Croton, on whose coins an eagle is represented; cf. O. Keller, op. cit., pp. 238, 431.

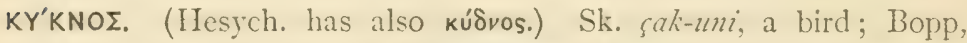
ii. p. 379, cf. Fick in Herzenberger's Beitr. z. I. Gr. Spr., vii. p. 94, 1883: cf. the Gk. use of oppvıs for the constellation Cygnus (Arat. 275, 599, 628, \&c.).

A Swan. Mod. Gk. kúkvos, víàua (Heldr.), and in the Cyclades коî̀os (Erh.). The Mute Swan, Cygmus olor, Gm., breeds in Greece; the Hooper or Whistling Swan, C. musicus, Bechst., is probably only a winter migrant; cf. Heldr., op. cit., p. 56 .

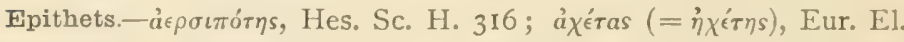

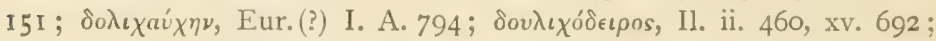

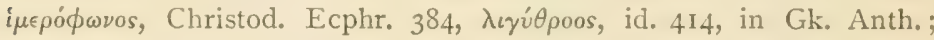

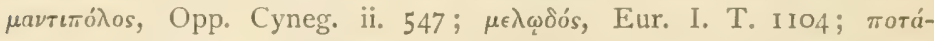

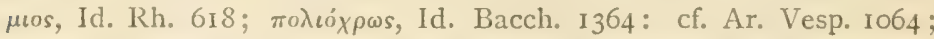

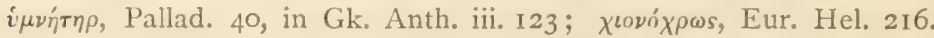
A frequent emblem of whiteness: cf. Eur. Rh. $618 \sigma \tau i \lambda \beta o v \sigma \iota \delta^{3} \tilde{\omega} \sigma \tau \epsilon$

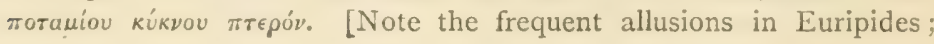


KYKNOE (continued).

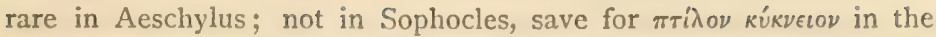
dubious fr. 708, ap. Clem. Alex. Strom. 716.]

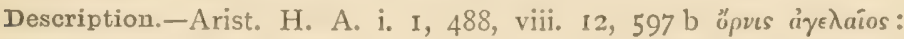

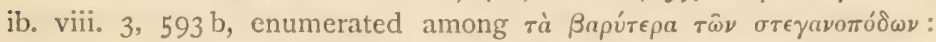

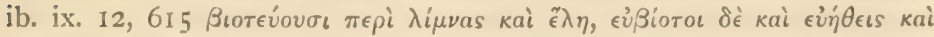

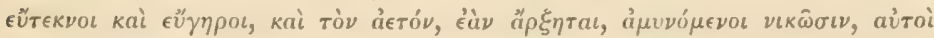

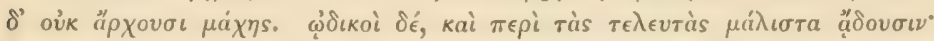

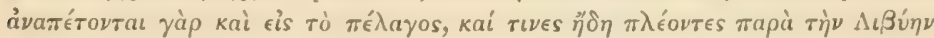

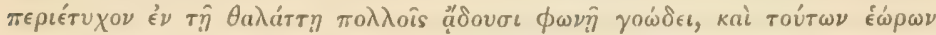

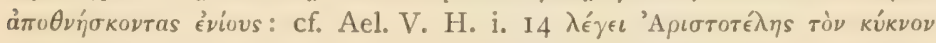

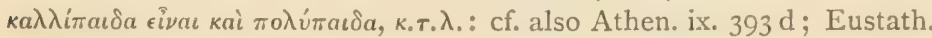
ad Hom. Il. p. 193; Dion. De Avib. ii. 19. Arist. H. A. ii. 17, 509 है $\chi \epsilon \iota$

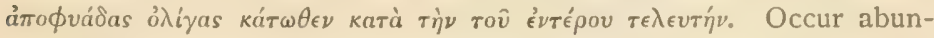

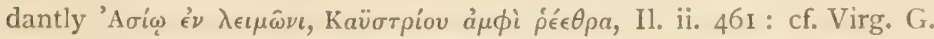
i. 383 , Aen. vii. 699; on the river Hebrus, Ar. Av. 768; on Lake Aornos, in the spot called Pyriphlegethon, near Cumae, Arist. De Mirab. 102, 839. Its flight described, Plin. x. (23) 32. The swan as food, Athen. ix. 393, Plut. De Esu Carn. 2, \&c.

Myth and Legend.-On the combat with the Eagle, vide S. v. ảetós, and compare also the story of Leda; cf. also Ael. v. 34, xvii. 24 ; Dion.

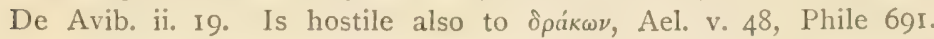

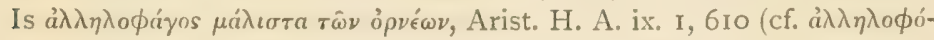

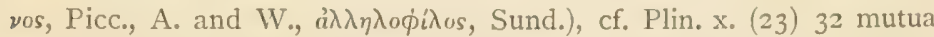

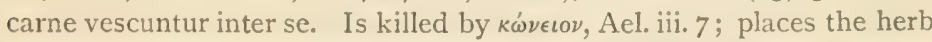
Avyaia in its nest as a charm, Boios ap. Athen. ix. 393 E. How the Indians do not favour the swan, from its want of filial affection, Ael. xiv. I3; yet the swan bewails its dead parent in Eur. El. 151, cf. Bacch. 1364 öpvis

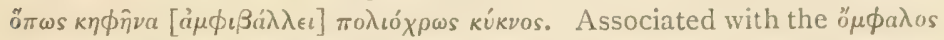
at Delphi, Plut. De Orac. i. 409; vide s.v. ảerós. A good omen to sailors, Virg. Aen. i. 393, Aemil. Macer in Ornithogr. Anthol. Vet. Lat. Epigr. et Poem. i. I16 (cf. Serv. in Aen. 1. c.) Cygnus in auspiciis semper laetissimus ales, Hunc optant nautae, quia se non mergit in undas: see also Stat. Theb. iii. 524 ; cf. the Sivan as a figure-head, Nicostr. iii. 282 , \&c. : cf. also the mythological (and astronomical) association of the Swan with Castor and Pollux (Hopf, Orakelthiere, p. 177) : see also Drummond in Class. Journal, xvi. p. 94. The Sivan-maidens,

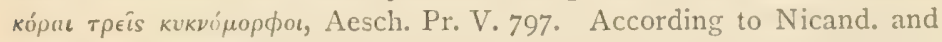
Areus ap. Anton. Lib. c. xii, a certain Cycnus, and his mother Thuria,

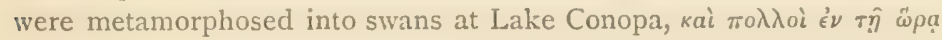

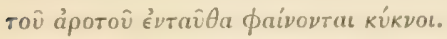

On the Swan as the bird of Apollo, cf. Hymn. Hom. xxi, Callim. Hymn. Apoll. 5, id. Hymn. Del. 249, Ar. Av. 772,870 , Ael. xi. 1, Nonn.

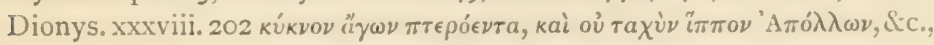




\section{KYKNOE (continued).}

\&c.; represented on coins of Clazomenae. With the Greek association of the Swan with Apollo, cf. the Hindoo connexion of the same bird with Brahma. Associated with Venus, in Latin only, Hor. C. iv. 1, 9, Sil. Ital. Punic. vii. 44I, Stat. Silv. iii. 4, 22 ; cf. the Cilix of Aphrodite and the Swan in the British Museum : vide Kalkmann, Jahrb.d. k. d. Inst., I886, i. 4I, Collignon, Gk. Mythol.p. I32, fig. 56; see also Guignat, pl. C. 393, Creuzer, pl. liii. 2.

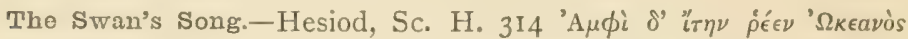

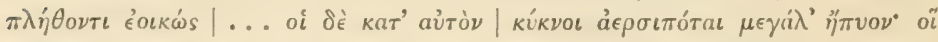

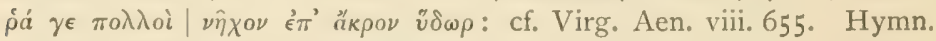

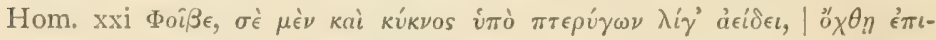

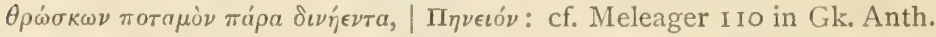

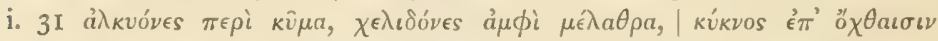

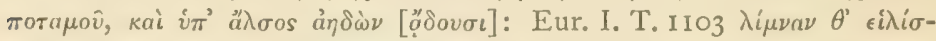

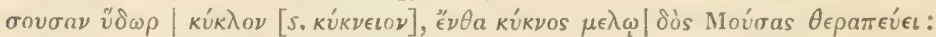

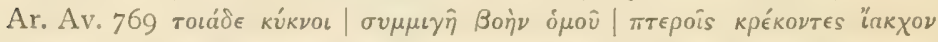

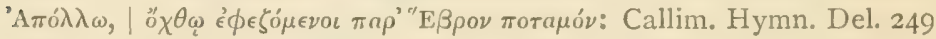

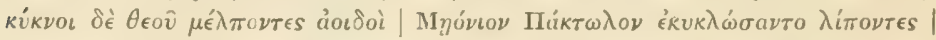

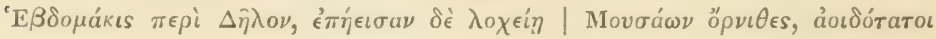

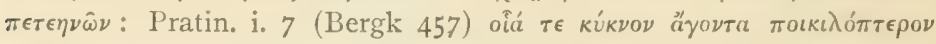

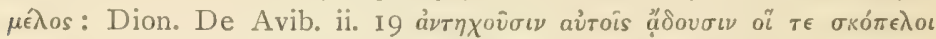

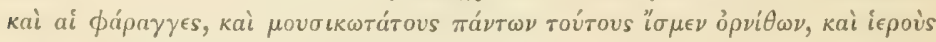

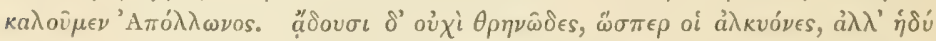

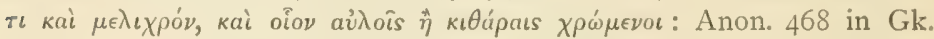

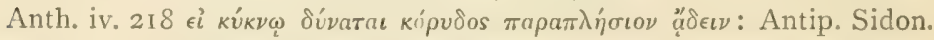

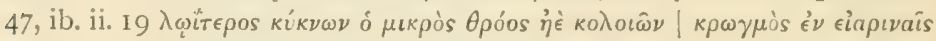

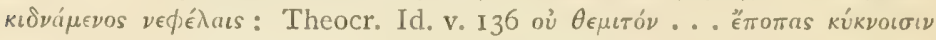

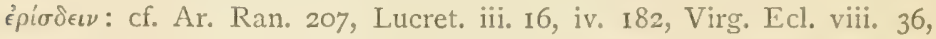

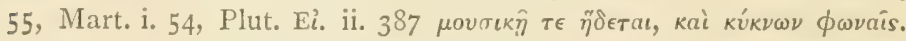

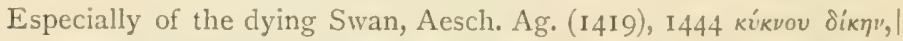

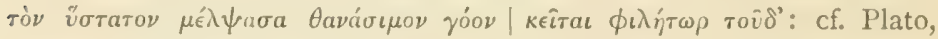

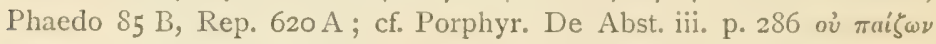

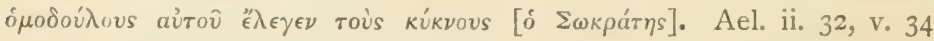

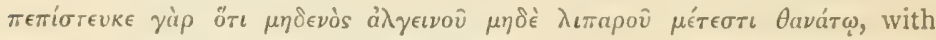

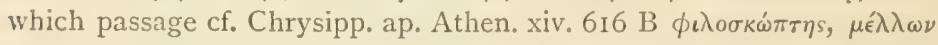

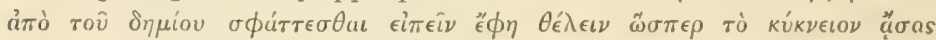

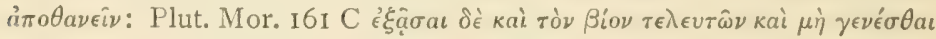

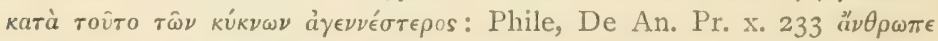

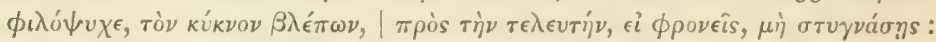
cf. Cic. De Orat. iii. I, I; see also Ael. x. 36, xi. I; Fab. Aes. 215 , 216, 416 b; Apoll. Rhod. iv. I30I; Polyb. xxx. 4, 7, xxxi. 20, I ;

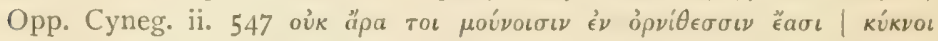

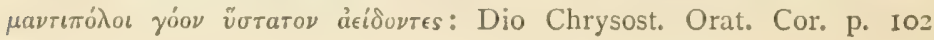


KYKNOE (continued).

(Reiske) ; cf. Hor. C. ii. 20, Ovid, Her. vii. I, Met, xiv. 430, Mart. xiii. 77, Stat. Silv. ii. 4, Io, \&c., \&c. The singing swan a portent of death, Artemid. Oneirocr. ii. 20. Modern allusions are innumerable; $c f$. Chaucer, P. of Fowles, 342, Tennyson, 'The Dying Swan,' \&c. ; see also for numerous references, Douce's Illustr. of Shakspeare, i. 262, Lenz, Zool. d. Gr. u. R., pp. 384-400, \&c.

The Swan's song was discredited by some, e.g. Alex. Mynd. ap. Athen. ix. 393 d; Lucian, De Electro seu Cycnis; Cic. Tusc. Quaest. i ; Philostr. V. Apollon. iii. c. 23 ; Plin. x. (23) 32 ; cf. Greg. Nazianz. Ep. i.

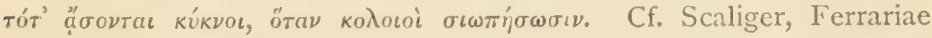
multos cygnos vidimus, sed cantores sane malos, neque melius ansere canere; cf. also Aldrov. Ornith. iii. 19, 5 ; Wormius in Mus. Worm. iii. c. 19; Mauduit ap. Plin. ed. Panckoucke, vii. 385 ; Voss. De Idol. ii. p. 1212; Pierius, De Cycnis, p. 254; Brown's Vulg. Errours, iii. p. 27 ; the curious conjectures of Bryant, Anc. Mythol. ii. 353-384; Pallas, Zoogr. ross.-asiat., ii. p. 212 , and recent writers. Modern naturalists accept the story of the singing swans, asserting that though the Common Swan cannot sing, yet the Whooper or Whistling Swan does so. It is certain that the Whooper sings, for many ornithologists state the fact, but I do not think it can sing very well; at the very best, dant sonitum rauci per stagna loquacia cygni. This concrete explanation is quite inadequate ; it is beyond a doubt that the Swan's Song (like the Halcyon's) veiled, and still hides, some mystical allusion.

Applied as an epithet to a poet, especially an old poet; Eur. H. F.

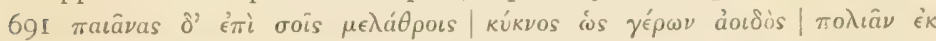
$\gamma \in \nu v^{\prime} \omega \nu \mid \kappa \epsilon \lambda a \delta r_{j} \sigma \omega$, Id. Bacch. 136I ; Posidipp. xi in Gk. Anth. ii. 48

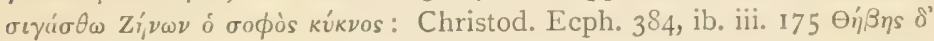

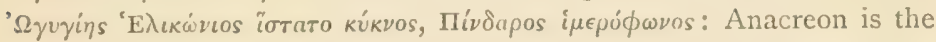
'Swan of Teos,' Antip. i. 26, cf. Hor. C. iv. 2, 25. Cf. Horap. ii. 39

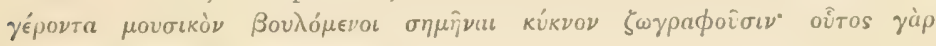

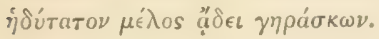

The Swan of Leda.-Cf. Eur. I. T. 794, I IO4, Hel. I9, \&c., Herc. F. 690 , Orest. I388; also various passages in the Anthology, e.g. Pallad. 40, in Gk. Anth. iii. 123, Anon. ib. iv. I 1 8, 128, \&c. ; cf. Lucian, De Deor. 20, I4 (I. 264). For mythographic references, see Hygin. Fab. 77, P. Astron. ii. 8, German. c. 24, Eratosth. c. 25, Theon. p. I36, \&c. According to these latter authors, the mythology of the Swan is inseparable from the phenomena attending the constellation Cygnus. The stellar Swan lies in the Milky Way, 'the river of heaven'; it is adjacent to the constellation Lyra; it rose a little in advance of the Eagle, but, lying more to the north, it only set some time after the Eagle had gone down: that is to say, it was attacked by the Eagle, but in turn defeated it, cf. Arist. H. A. ix. 12, 615 b, Ael. xvii. 24, \&c. ; 
KYKNOI (continued).

it stood in mid-heaven at the rising of the Pleiad; at its own rising, the Virgin (Leda) was in mid-heaven, and the twins Castor and Pollux were just setting in the west. The stories of Cycnus, son of Mars (Hesiod, Anton. Lib. 12, Philochor. ap. Athen., Ovid, Met., \&c.), of Cycnus, King of Liguria (Hygin. Fab. 144), Cycnus, brother of Phaethon (Lucian, De Electro, Virg. Aen. x. 189), and others, which are also similarly connected with astronomical myths, lie outside the scope of this book. Cf. (int. al.), Dupuis, Orig. de tous les cultes, iii. p. 813, vii. p. 367 .

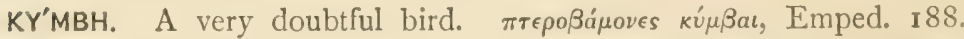
Supposed by L. and S. to be a Tumbler-pigeon; but cf. кó $\beta \beta \alpha$,

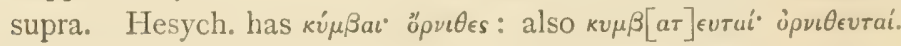

$K Y^{\prime} M I N \Delta I \Sigma=x a \lambda k i s=(?) \pi \tau u ́ \gamma \xi, q . v . \quad k \dot{\beta} \beta \iota \nu \delta \iota s$ in some MISS., both of Hom. and Arist., cf. J. G. Schneider in Arist., vol. iv. p. 92.

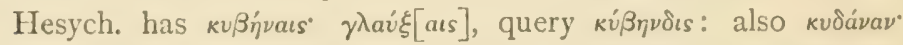

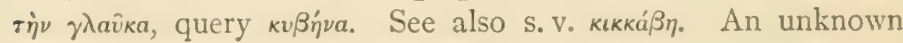
or fabulous bird; perhaps an Owl.

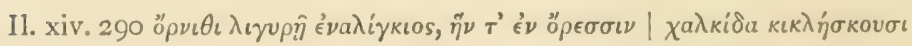

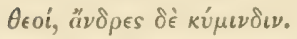

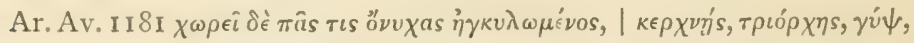

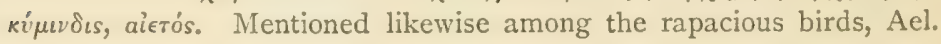
xii. 4 .

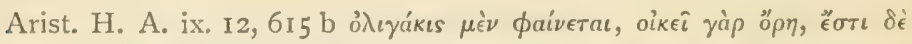

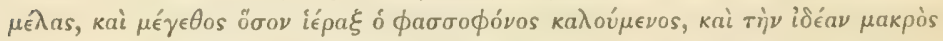

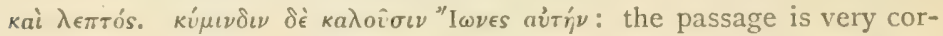
rupt, and according to some texts (followed apparently by Pliny, x. 8 , and by Eustath. in Hom.), the next clause concerning i $\beta \rho$ is or $\pi \tau \dot{\gamma} \gamma \xi$

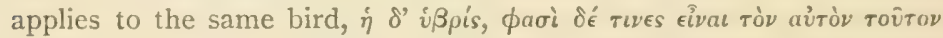

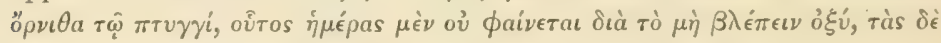

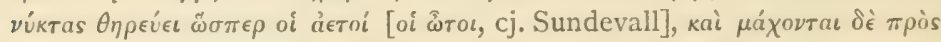

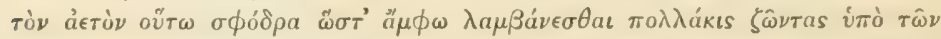

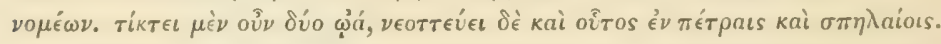

Conjectured by Sundevall to be the Black or Glossy Ibis, from the suggestion of metallic colouring in $\chi^{a \lambda}$ кis, and from Mod. Gk. $\chi^{a \lambda \kappa o ́ к о т а . ~}$ Erh.; but this is certainly not a bird of the mountains, and the supposed derivation from $\chi^{a \lambda k o ́ s ~ i s ~ i m a g i n a r y . ~ B y ~ A u b . ~ a n d ~ W i m m e r, ~}$ and others, ascribed to the Capercailzie, Tetrao urogallus, L.

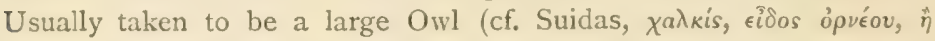

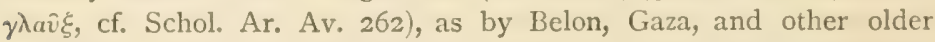
naturalists. Cuvier (Grandsaigne's Pliny, I. v. II, pp. 374, 375) identifies it with the Hawk Owl, Strix uralensis, Pall., and Netolicka agrees. 


\section{KYMIN $\Delta I \Sigma$ (continued).}

The bird being, in Homer, that in whose shape " $\Upsilon \pi \nu 0 s$ appears, is an additional point in favour of identifying it with a nocturnal species : and this relation of $\tilde{v} \pi \nu$ os to the bird $\chi a \lambda k i$ suggests a connexion with the phrase $\chi a$ áкео $\tilde{\pi} \pi \nu$ os. $\chi a \lambda \kappa i s$ belongs to the language of the gods, that is to say, is probably a foreign word; it is not likely to be a simple

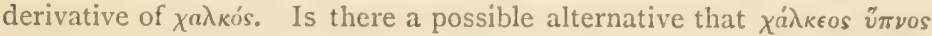
is wrongly translated by ferreus sommes?

For an account of various Scholia relating to this bird, cf. J. G. Schneider, l.c. In some, if not all, of the names of this bird, we are undoubtedly confronted with foreign words.

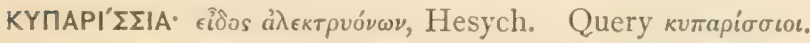

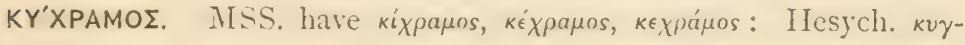

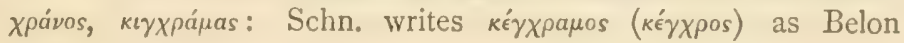
translates miliarius.

An unknown bird: probably (as Sundevall takes it) identical with

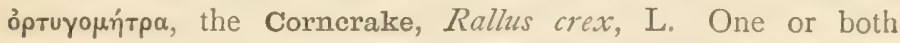
names doubtless apply also to the Water-rail, Rallus aquaticus, L., which is very abundant in Greece, and according to Von der Mühle abandons its usual haunts in Autumn and frequently associates with the quails (op. cit., p. 92).

Arist. H. A. viii. I2, 597 b. A bird which accompanies the quails, каi ả

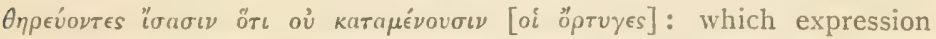
Sundevall translates 'delay not their coming,' and A. and W. 'remain no longer.' Cf. Plin. x. (23) 33.

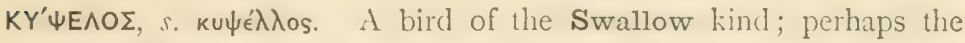

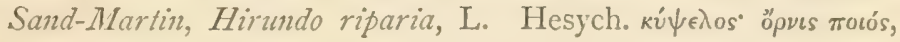

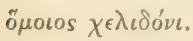

Arist. H. A. ix. 30, 680, mentioned as synonymous with a้mous, q. v.,

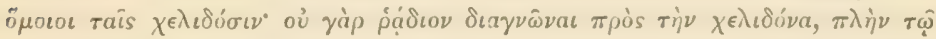

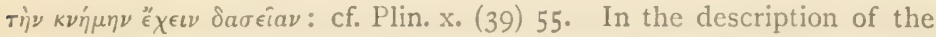
nest (loc. cit.), though $k \dot{\psi} \psi \in \lambda_{\text {cs }}$ (a box, or beehive) would rather suggest the nest of the House-Martin (H. urbica, L.), yet the epithet paкpós would certainly not apply: moreover the House-Martin was certainly included in $\chi € \lambda \iota \delta \omega \nu$. Accordingly the evidence leans to identifying $\kappa \dot{\psi} \psi \in \lambda$ os with the Sand-Martin, H. riparia, L. ; this identification is followed by Sundevall, while A. and W., on the contrary, identify the bird with the House-Martin. There was doubtless a confusion of species. If the passage in Pliny suggests one more than another, it would seem to be the Swift; yet in the Aristotelian reference the 


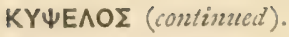

hypothesis of the Sand-Martin, advocated by Sundevall, has stroner claims.

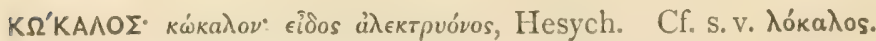

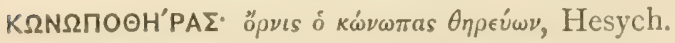

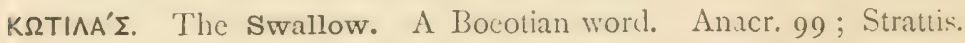
Фoเv. 3 ; cf. Simonid. 243.

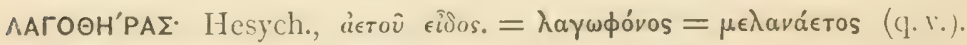
An epithet of the Fagle.

Arist. H. A. ix. 32,618 b. The Eagle in combat with the hare is frequent on gems, and on coins of Agrigentum, Messana, Elis, \&c. : cf. Imhoof-Blum. and Keller, passim; Keller, Th. d. cl. Alterth., p. 449. The wide occurrence of this subject (cf. Layard, Nineveh, ii. pl. 62) indicates a lost mythological significance, in which one is tempted

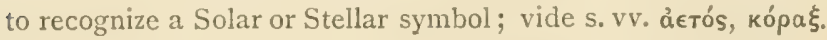

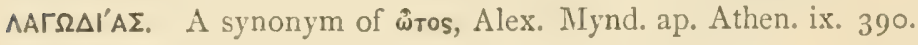

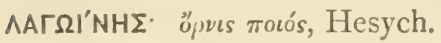

\section{$\Lambda$ AГ $\Omega^{\prime} \Pi$ กY. A Ptarmigan.}

Plin. x. (48) 68 praecipuo sapore lagopus : pedes leporino villo nomen ei hoc dedere, cetero candidae, columbarum magnitudine, \&c. The lagois, s. logois of Hor. Sat. ii. 2, 22, is possibly akin. In Mart. vii. 87, an old reading was Si meus aurita gaudet lagopode Flaccus, altered by Scaliger to gluucopide.

$\wedge A \Gamma \Omega^{\prime} \Sigma$. A bird-name, mentioned with the Swallow, in Artemid.

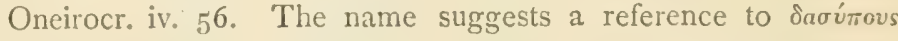
$\chi \in \lambda \iota \delta o ́ v \epsilon \iota s$, Diph. s. Calliad. ap. Athen. ix. 40 I a. According to Boios ap. Anton. Lib. c. xx a certain Oreius was metamor-

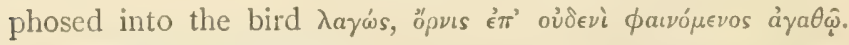

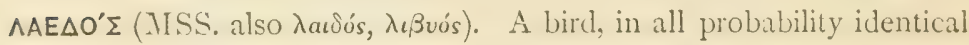

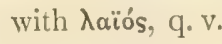

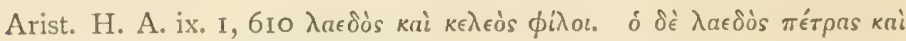

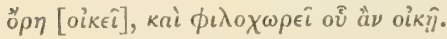

We may connect the reputed friendship of $k \in \lambda \epsilon o ́ s$ and $\lambda a \epsilon \delta$ ós with the association of $\kappa \epsilon \lambda \epsilon$ s $_{\text {s }}$ and $\lambda$ aiós together, in the obscure story of the metamorphosis of those impious persons who entered the forbidden cave in Crete where Jupiter was born; Boios ap. Anton. Lib. c. xix.

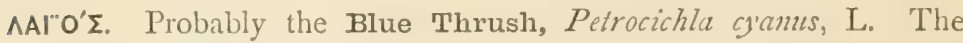
Stone-thrush, $P$. saxatitis, L., is less common in Greece, and 
AAIOS (continued).

is chiefly found in the northern and more mountainous parts.

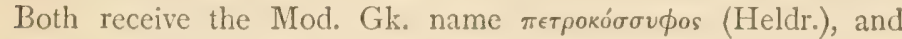
were probably confused under the ancient name also.

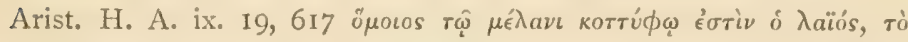

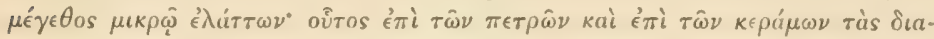
$\tau \rho \iota \beta$ ìs толєітаı. A fabled metamorphosis, Boios ap. Anton. Lib. c. xix.

It seems all but certain that $\lambda \alpha \epsilon \delta$ ós and $\lambda$ riós refer to the same bird. The correct reading of the name, or names, is unknown. In Arist. H. A. ix. I9, edd. have also ßaios and puios (cf. Camus, i. 747, Schneider, ii. 120). The name גaïós is taken from the passage in Anton. Lib., the supposed derivation from $\lambda$ âas helping to gain it acceptance. Schn. and Picc. read $\lambda$ aiós also for $\lambda a \in \delta o ́ s, q . v$.

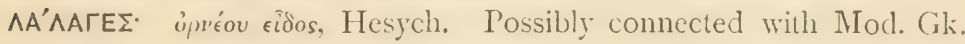
$\lambda \epsilon \hat{\lambda} \in \kappa \ell$, a Stork; vide s.v. $\pi \in \lambda \alpha \rho \gamma o ́ s$.

$\triangle A^{\prime} P O \Sigma$, a. A Sea-Gull. In Mod. (and doubtless also in Ancient) Gls. ydápos includes both the Gulls and the Terns.

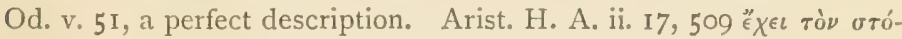

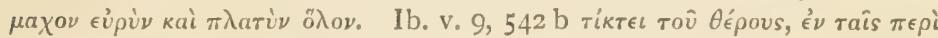

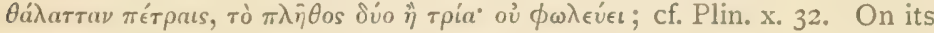
breeding habits, see also Dion. De Avib. ii. 4 .

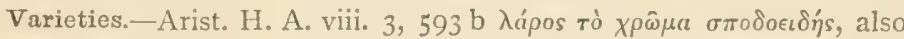
$\lambda$ ápos o $\lambda \in v$ kós. The former is, according to Aub. and Wimmer, one of the darker Terns, e.g. Sterna nigra, Briss.; but the epithet seems more descriptive of the ashy grey of the 'Black-backed' Gulls: cf.

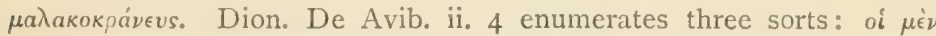

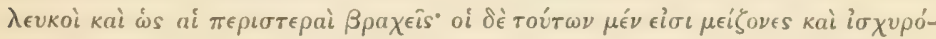

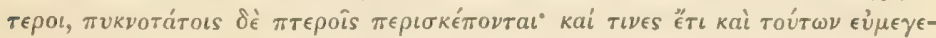

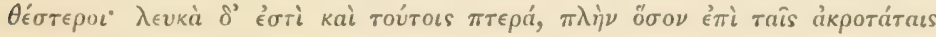

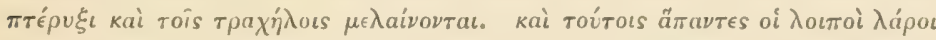

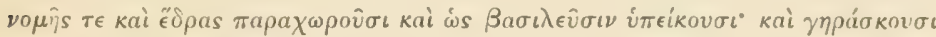

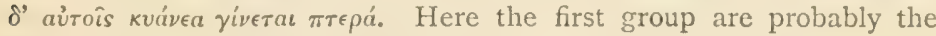
Terns, the last the Black-backed Gulls.

A bye-word for greediness, Ar. Eq. 959, Nub. 59r, Av. 567. Devour dolphins stranded on the beach, Ael. xv. 23. Open shell-fish by dropping them from a height, Ael. iii. 20.

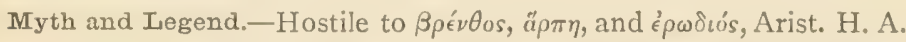
viii. 3, 593 b, Ael. iv. 5, Phile 682; friendly to koגotós, Ael. v. 48. Killed by pomegranate-seed, Ael. vi. 46, Phile 657. Associated with Hercules, Ar. Av. 567. The Gulls are souls of disembodied fishermen, hence their gentle and peaceable disposition, Dion. 1.c. A gull's feather was tied to a fishing-line as a kind of float, Ael. xv. Io.

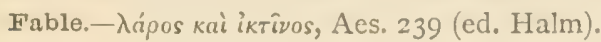




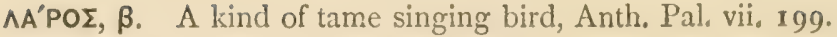

$\Lambda E I^{\circ} O \Sigma$, vide S. v. é̀teı́s.

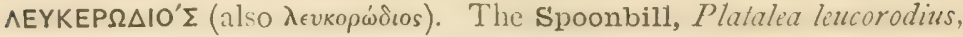

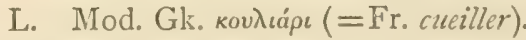

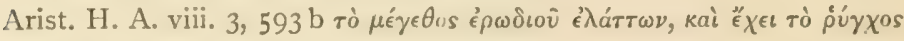

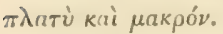

The description of the bill easily identifies the bird in this passage (Belon, Sundevall, \&c.), but the name would probably be likewise applied to the other White Herons or Egrets.

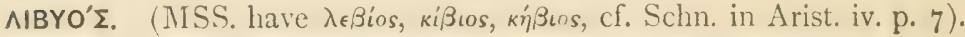

An unknown bird: possibly to be compared with $\Lambda$ ı Ar. Av. 65 .

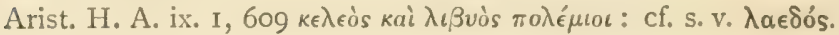

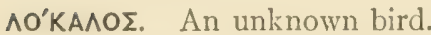

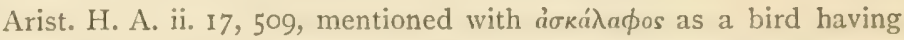
colic coeca. Omitted in Cod. Venetus and others. Gesner supposes the word to be Italian (?= aluco, an Owl), and to have come in as

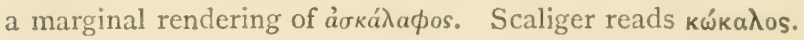

$\Lambda Y^{\prime} K O \Sigma$. A sort of Jackdaw (Arist. H. A. ix. 24, 610 b); probably

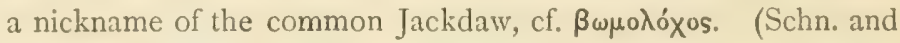

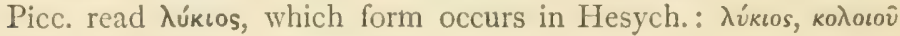
єi̊ons). See also s. v. kípкos.

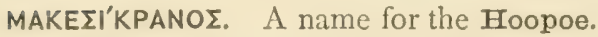

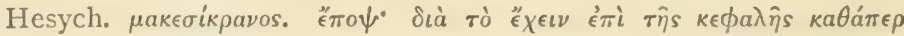

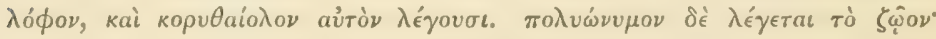

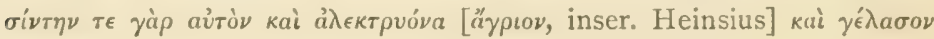
$\lambda \epsilon ́ \gamma 0 \nu \sigma \iota$.

MAAAKOKPANEY' $\Sigma$. An unknown bird.

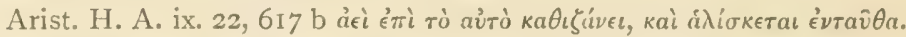

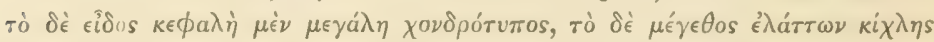

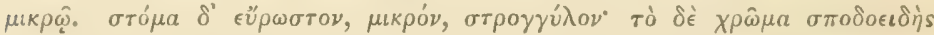

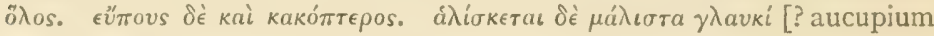
per noctuam].

Identified by Sundevall with the Lesser Grey Shrike, Lanizes minor,

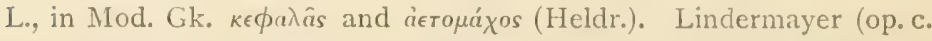
p. 114) states that this bird is extremely common in Greece, and sings all day long 'auf der äussersten Spitze eines Baumes oder Strauches sitzend.' This identification is more plausible than the many others that have been suggested, such as the Jay, the Bullfinch, and even the Snipe 


\section{MAAAKOKPANEY $\Sigma$ (continued).}

(Belon, Schneider, Brisson, \&c.). It must, however, be remembered that the bird is mentioned once only, and in a portion of the Historia Animalium that is full of difficulties and incongruities: the epithets

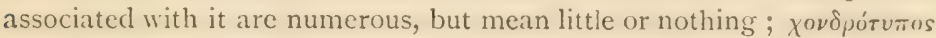

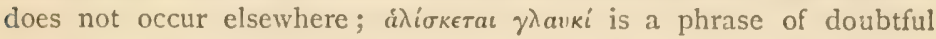
meaning and questionable construction. The Aristotelian description seems at first sight copious and adequate, but in the words of Camus, 'autant qu'il semblerait devoir être facile de reconnoître le Crane-mol,

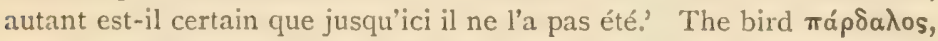
q. v., is next mentioned, and is in like manner impossible to identify.

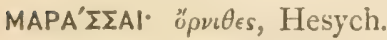

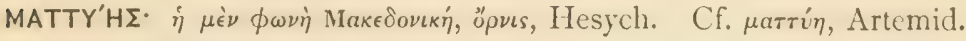
ap. Athen. xiv. $663 \mathrm{D}, \& \mathrm{c}$.

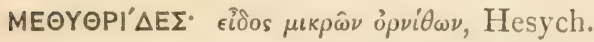

menarko'pyфos. Probably the Marsh Tit, Parus palustris, L.; in which identification Sundevall and Aub. and Wimm. agree. But there was a confusion between this bird and the Blackeap Warbler, Motacilla atricapilla, L., Sylvia atricapilla, auctt. The verb

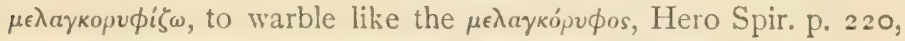
suggests the latter of these two. See also s.v. oukaגis.

Mentioned in Ar. Av. 887.

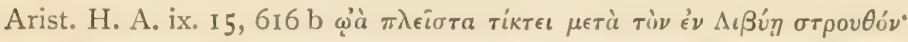

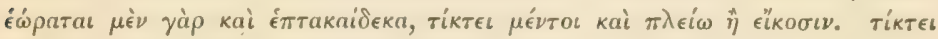

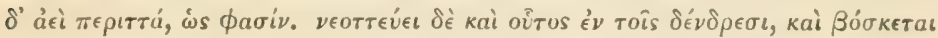

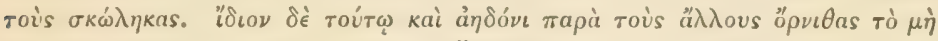

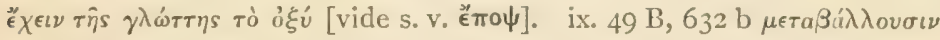

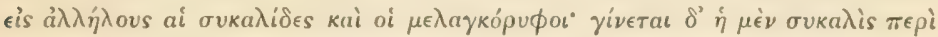

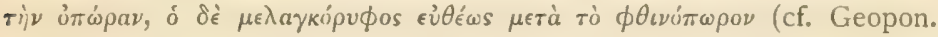

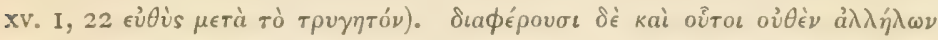

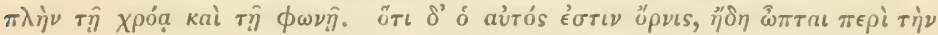

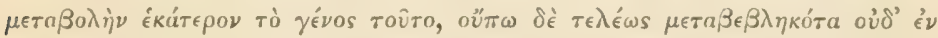

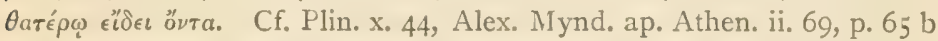

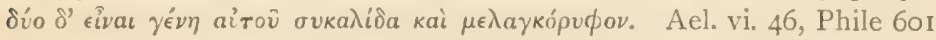

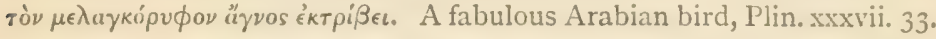

MEAA'MTYTOz. A word applied to the Eagle in the Fable of the Fox and the Eagle, Archil. fr. I Io (86). Schol. Venet. Il. xxiv. 3 I5

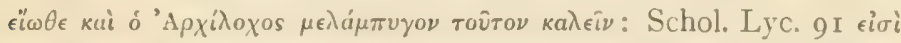

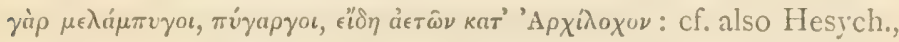
and Gaisford's note. Cf, also Schneidewin; Farnell, Gk. Lyr. Poets, p. 300 , \&c. 


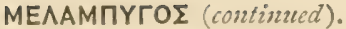

A solar symbolism probably underlies this name and its correlative

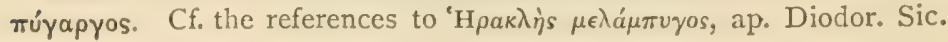
iv. $3 \mathbf{I}$, \&C.

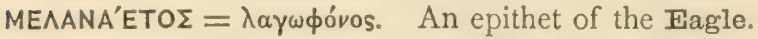

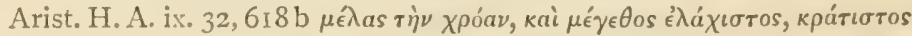

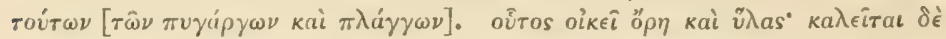

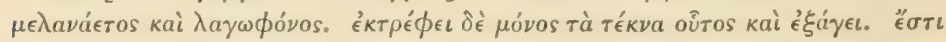

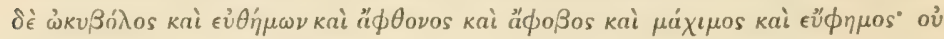

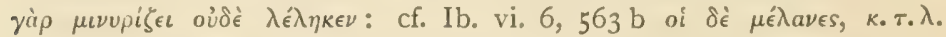
Plin. x. 3 Melanaetus a Graecis dicta, eademque Valeria [MSS. in Valeriâ], minimâ magnitudine, viribus praecipua, colore nigricans, Scc.

Aubert and Wimmer suppose a small species of Eagle, e. g. Aquila minutu, Brehm, to be meant ; Sundevall sugrests the Peregrine Falcon.

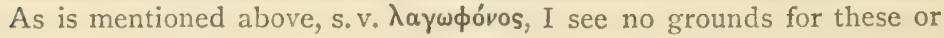
any other concrete interpretations : the passage is mystical and probably foreign. Aubert and Wimmer have already called attention to the want of meaning and irrational order of the six epithets $\omega$ kvßónos, є่ं $\dot{\eta} \mu \omega \nu, \& c$.

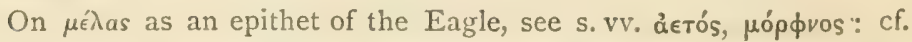

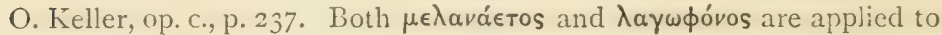
the constellation Aquila in the Comm. Alfrag. p. I06; and I am inclined to think that the 'Black Eagle' had originally a mystical and astronomical meaning. Cf. s. v. $\mu \in \lambda a ́ \mu \pi u \gamma o s$.

MEAA'N

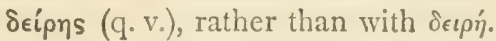

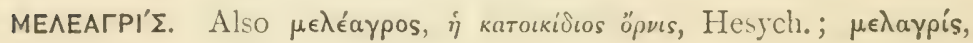
Salmas. ad Plin. p. 6 I 2.

A foreign.word, connected with Sem. Melek; as in Melkart, Meleager, Melicertes, \&c. (cf. Keller, Volksetym. p. 236, Lat. Etym. p. 180).

The Guinea-Fowl, Numida sp.

First mentioned by Soph. Meleag. fr. ap. Plin. xxxvii. (2) II, the birds weeping tears of amber for the death of the hero. Mentioned in connexion with amber also by Mnaseas ap. Plin. 1. c.

A full description in Clytus Miles. ap. Athen. xiv. $655 \mathrm{C}-\mathrm{f}$ ä $\sigma \tau$ ropyov

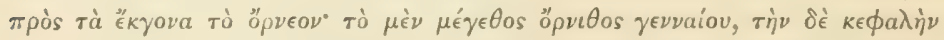

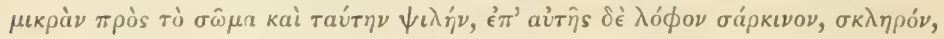

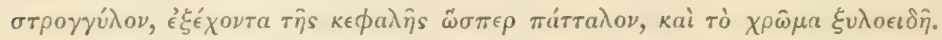

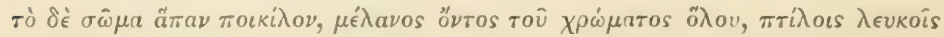

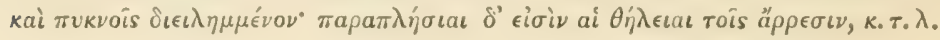


MEAEATPIE (continued).

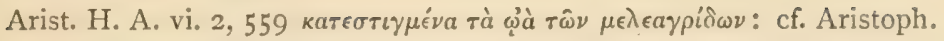

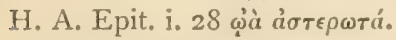

See also the description given by Columella, viii. 8, 2 Africana est quam plerique Numidicam dicunt, meleagridi similis, nisi quod rutilam galeam (paleam, emend. Newton) ct cristam capite gerit, quac utraque sunt in meleagride coerulea. This passage from Columella is very interesting as showing that the Greek $\mu \epsilon \lambda \epsilon a \gamma p$ is and the Roman Gallint africana or mumitica were different from one another, the latter having a red wattle, the former a blue. This would look as though the $\mu \epsilon \lambda \epsilon a-$ rois had sprung from what is now called Numida ptilorhyncha, an Abyssinian species, and had been brought to Athens by way of Egypt ; while the Afra avis originated in the Numida meleagris of W. Africa. See Newton, Dict. of Birds, p. 399, footnote.

The $\mu \epsilon \lambda \epsilon a \gamma p i \delta \in s$ mentioned, however, by Scylax, Periplus, were seen beyond the Pillars of Hercules, in N.W. Africa, as were those mentioned by Mnaseas; and these were doubtless, therefore, of the redwattled species. Strabo and Diodorus report the birds as inhabiting an island in the Red Sea; Sophocles (1.c.), speaks of them poetically as Indian.

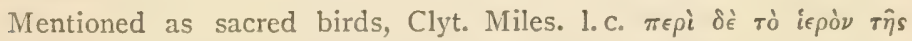

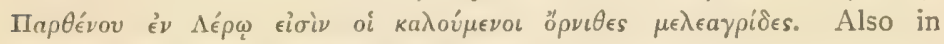
Aetolia, Menodot. ap. Athen. xiv. 655 a.

Ael. iv. 42: the metamorphosis of the sisters of Meleager; ס̋ $\sigma 0$

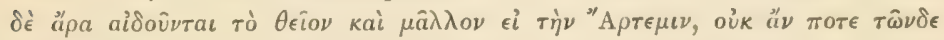

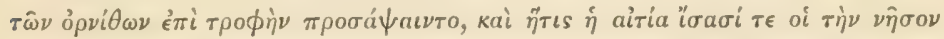

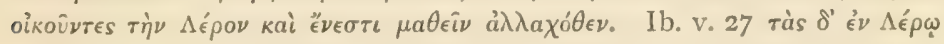

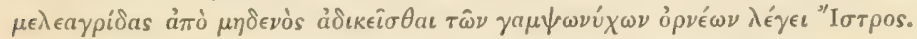

Sacrificed at the temple of Isis in Tithorea (Phocis), Pausan. x. 3 I (x. 32, 9, ed. Teubn.).

Were kept also in the Acropolis : $\mu \epsilon \lambda \epsilon a \gamma p i \delta \in s^{\circ}$ of $\rho \nu \epsilon \varsigma$ a

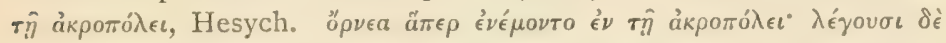

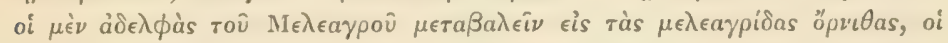

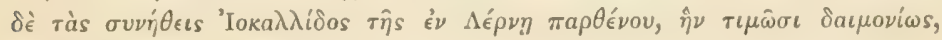
Suid., Phot.

On the story of the metamorphosis, cf. Nicand. ap. Anton. Lib. c. I, Hygin. Fab. I74, Ovid, Met. viii. 534, Mart. iii. 58, I 5, Lactant. viii. 4 .

How the Meleagrides fought around the tomb of Meleager (cf. s. v. $\mu \in \dot{\mu} \mu \nu \omega v)$ Plin. x. (26) 38, \&c.

For other references, see Antig. Caryst. xi ; Juv. xi. 142 ; Hor. Epod. ii. 53 Afrae aves; Mart. iii. 58, 15 Numidicae guttatae; xiii. 45 Libycae volucres; xiii.75; Stat. Silv. i. 6, 78, ii. 4, 28 ; Suet. Calig. 22 (vide s.v. reтрáwv); Petron. 93; Varro, De R. R. iii. 9, I8, \&.c. 


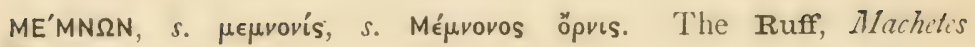
pugnax, L.

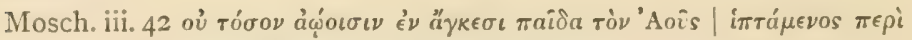

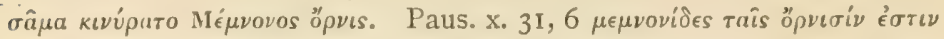

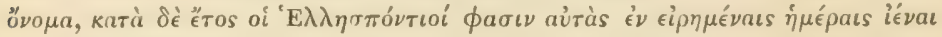

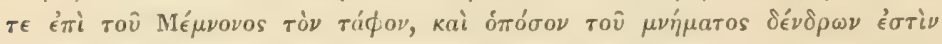

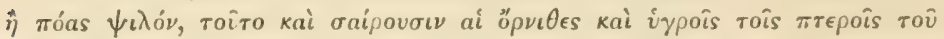

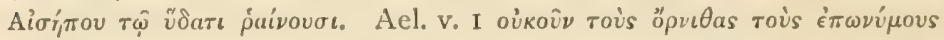
тоû $\ddot{\eta} \rho \omega o s$ ả

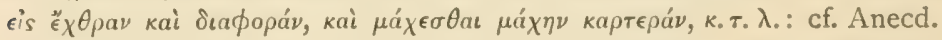
Paris. Bekk. ii. p. 25. See also Dion. De Avib. i. 8 ; Quint. Smyrn. Posthomer. ii. 645, et seq.; Plin. x. (26) 37 ; Ovid, Met. xiii. 607, Amor. i. 13, 3; Solin. c. 40.

The identification, first suggested by Cuvier (Grandidier's Pliny, loc. cit.), is certain, the combats or 'hilling' of Ruffs being unmistakeably described: for modern descriptions, see Montagu, quoted in Yarrell, 4th ed. vol. iii. p. 428. At the same time, it is evident that the myth is a very ancient one, and its connexion with this particular species of bird and its peculiar annual combats may be a late version of an old and mysterious story: cf. Creuzer, Symb. ii. I $8 \mathrm{I}, \& c$. In other words, though Pausanias and Aelian undoubtedly alluded to the Ruff, I do not for a moment believe that Moschus did so. Vide s.v. ảvtíuxor.

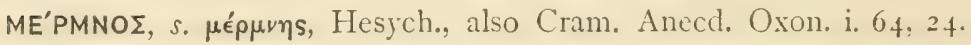
A kind of hawk, sacred to Cybele, Ael. xii. 4; according to Hesych., identical with трเópxๆs.

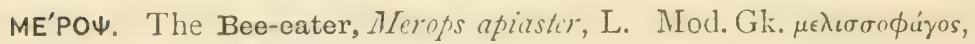

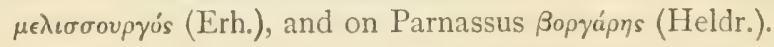

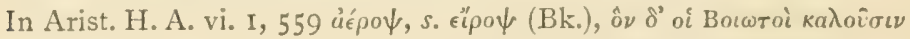

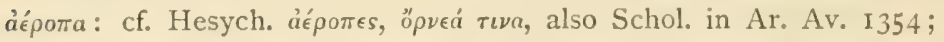

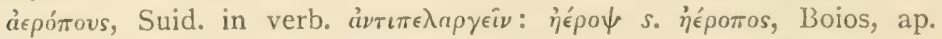

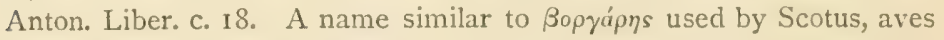
quae dicuntur Graece Boareia, ovant in foraminibus terrae, and by Albertus M., quam obarcham Graeci vocant : cf. Schneider in Arist. 1. c. According to Bent (Cyclades, 1885, p. 325), $\mu \in$ poitras now means in Syra simply a bird, ö $\rho v \iota s$.

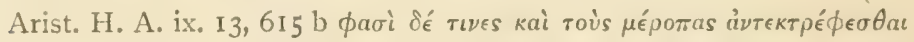

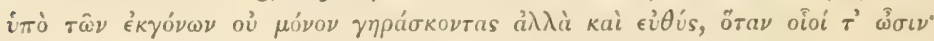

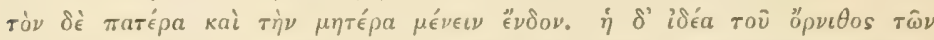

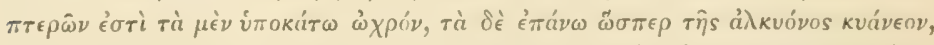

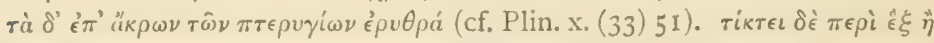

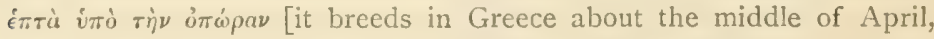

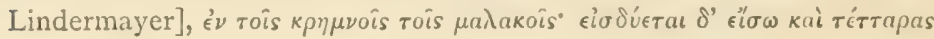




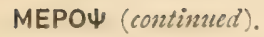

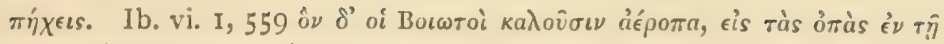

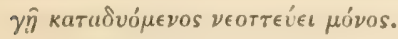

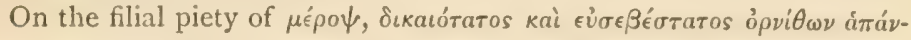
$\tau \omega \nu$, see Ael. xi. 30, Plin. x. (33) 5 I ; cf. Boch. Hieroz. ii. p. 302.

Is destructive to bees, Arist. H. A. x. 40, 626, Ael. v. I I, vii. 6, Plut. Mor. $976 \mathrm{C}$, Geopon. xv. 2, Phile 650, Virg. Georg. iv. I4.

Is said to fly backwards, Ael. i. 49.

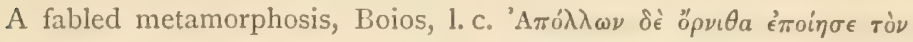

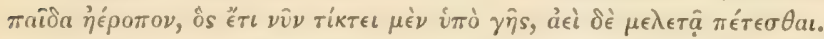

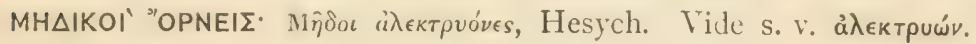

Cf. also Plin. x. 2 I, Colum. viii. 2, Varr. R. R. iii. 9, and Festus.

In Latin a common reading is Melicae gallinae; cf. Colum. 1. c.

The term 'Median bird' is applied also to the Peacock.

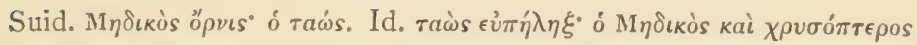

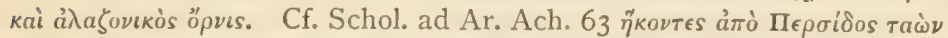

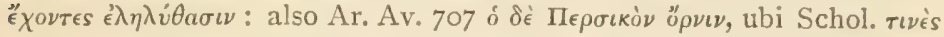

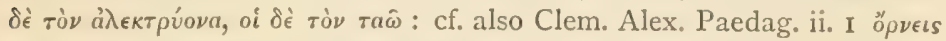

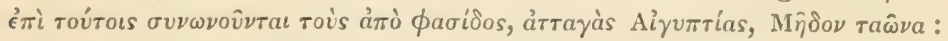

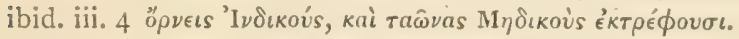

MONO'乏IPOI. A breed of fowls in Egypt.

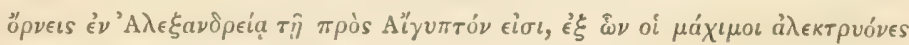

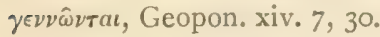

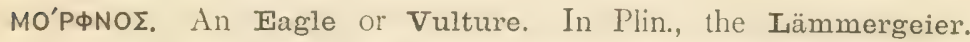

Supposed to be connected with the idea of dark or black; cf. ö $\phi \nu \eta$, Russ. mrachnoe, Eng. murky. ( but $=\xi a \nu \theta o ́ s$, Hesych.).

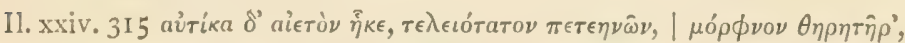

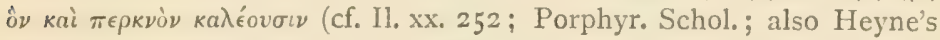

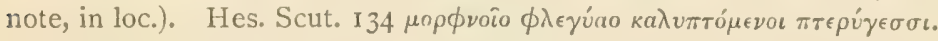

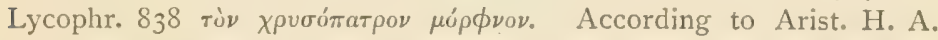

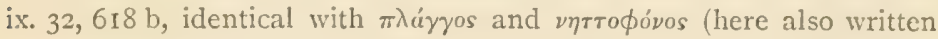

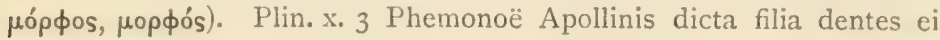
esse prodidit, mutae alias, carentique lingua: eandem aquilarum nigerrimam, prominentiore cauda. Ingenium est ei testudines raptas frangere e sublimi iaciendo, \&c. Cf. Suid,, who definitely applies the

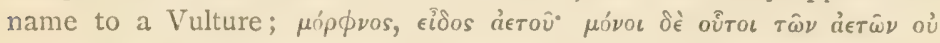

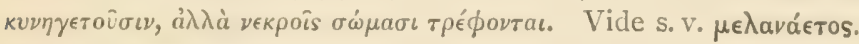

MY'TTHE: öpvis troเós, Hesych.

NE'BPA

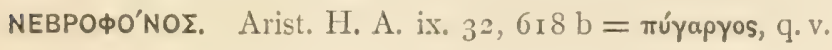




\section{NE'PTOs. A Vulture.}

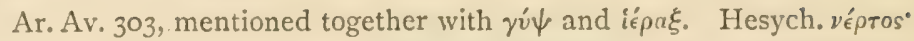

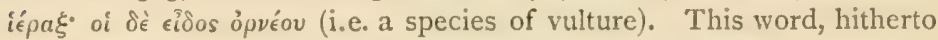

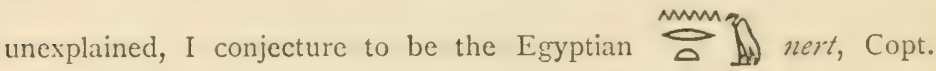

rorpI, a Vulture: cf. Chaeremon, fr. 9, and Lauth, in Horap. i. 3, Sitzungsber. Bayer. Akad., 1876, p. 73.

NH'TTA, Boeot. vâơa (Ar. Ach. 875). A Duck. Cf. Lat. anat-is, Lith. antis, A. S. ened, Ger. Ente. Dim. virrápıov (a term of endearment), Ar. Pl. Io I I, Menand. Inc. 422 (4, 3 I6); vírтเov,

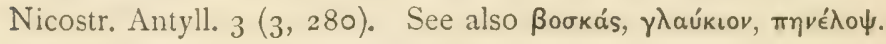

Description.-Arist. H. A. viii. 3, 593 b included among rà ßapúrepa

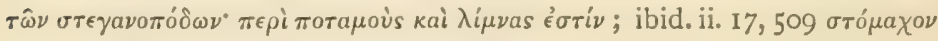

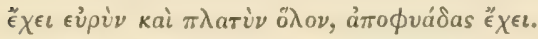

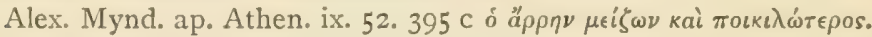

An allusion to the particoloured plumage of the Common Drake, or else of some wild Duck, in Ar. Av. I 148.

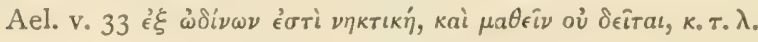

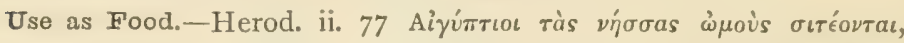

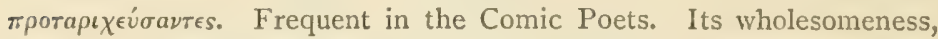

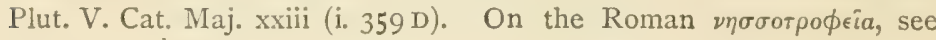
Varro, De R. R. iii. I I, Colum. viii. I5. Mode of capture, Dion. De Avib. iii. 23.

Brought as tribute to Indian kings, Ael. xiii. 25.

Myth and Legend.-Sacred to Poseidon, Ar. Av. 566. According to Nicand.ap. Anton. Lib. c. ix, one of the Emathides, daughters of Pierus, was metamorphosed into the bird $\nu \hat{\eta} \sigma \sigma a$.

Its defence against the eagle, cf. Phile, De An. Pr. xiv.

Use the herb sideritis as a remedy, Plin. viii. 27.

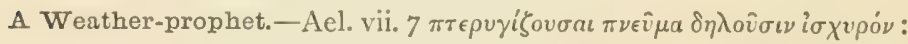
cf. Arist. fr. 24I, 1522 b; Theophr. De Sign. fr. vi. 18, 28; Arat. 918, 970.

NHTTOKTónOs, s. virtoфóvos. A kind of Eagle, the Anataria of

Plin. x. 3. Supposed, by Sundevall, to be the Spotted Eagle,

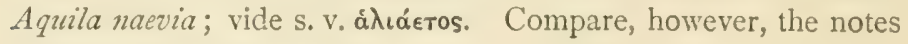

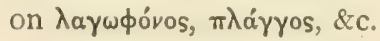

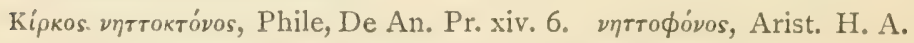
ix. 32, $618 \mathrm{~b}=\mu$ ópфvos and $\pi \lambda a ́ \gamma \gamma o s, q . v$. Cf. Ael. v. 33.

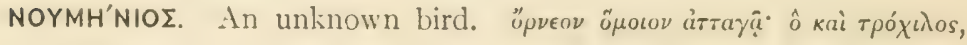
Hesych.

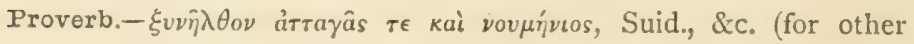




\section{NOYMHNIOE (contimued).}

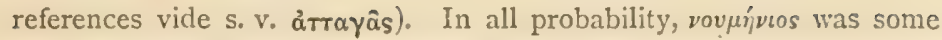
bird associated with moon-worship; we have an obscure indication of a kindred symbolism in the case of àrrayas, in the statement that that bird is hostile to the Cock (Ael. vi. 45). That árтayâs had some mystical signification seems plain, though the precise allusion is obscure: the frequent reference to the bird as moikinos, and the statement of its friendship with the Stag, may in time furnish a clue to the mystery. For my part, I imagine I discern a stellar attribute in the one bird, and a lunar in the other. Tradition, of doubtful antiquity, associates the name Numenius with the Curlew, and it may well have this or some similar bird with a decurved or crescentic bill.

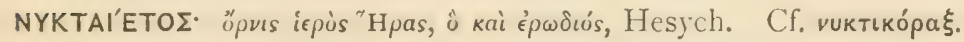

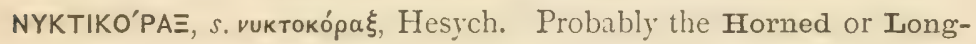
eared Owl, Strix otus, L.; but perhaps also applied to the Night-Heron.

Arist. H. A. viii. 12, 597 b ๕̌vı

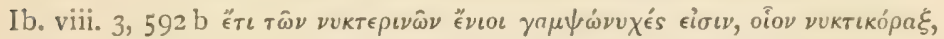

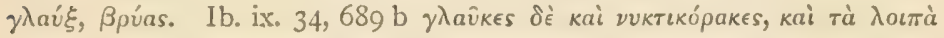

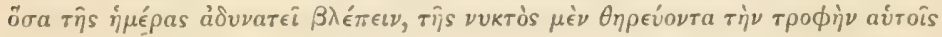

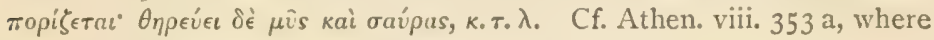

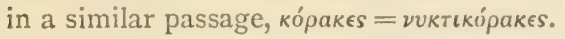

Arist. H. A. ii. 17, 509 ảmoфváóas $\ddot{\epsilon} \chi \epsilon \iota$. [The caeca are rudimentary or absent altogether in the Herons; they are large and conspicuous in

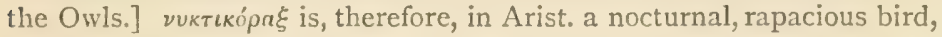

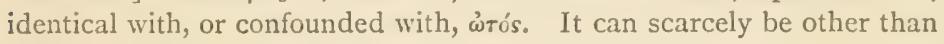
the Long-Eared Owl.

It corresponds to Heb. כוס, an Owl, in Ps. I02. 6 (LXX).

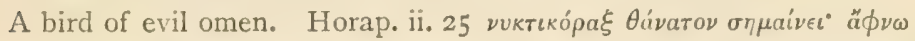

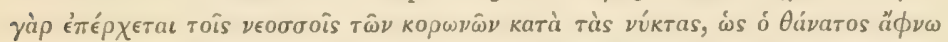

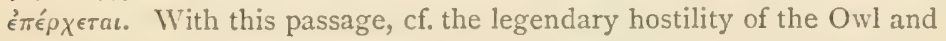

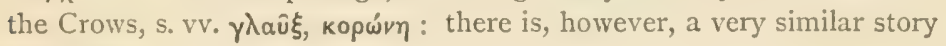

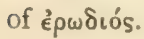

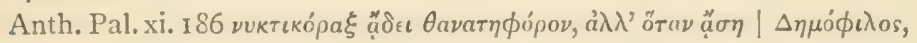

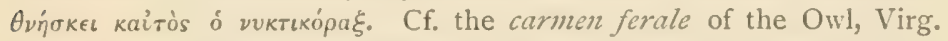
Aen. iv. 462 : vide also s. v. ßúas. Cf. also Spenser's 'hoarse nightraven, trompe of doleful drere,' \&c.

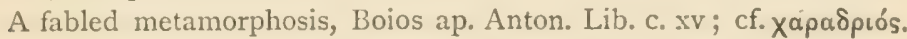

There is an old confusion between this bird and the Night-Heron, Ardea nycticorax, L. Gesner (ed. cit., p. 357), discussing the discrepant opinions regarding $\nu$ vктко́pa $\xi$, figures the Night-Heron, and adds, "Wir haben hierbey die Figur des Vogels gesetzt, welcher zu Strasburg ein Nachtram anderswo ein Nachtrabe geheissen wird, welcher doch 


\section{NYKTIKOPAE (continued).}

meines Bedenckens weder ein Caprimulgus noch Nycticorax ist.' And the confusion thus introduced seems to have been aided by Gaza

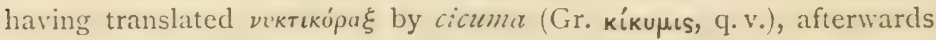
misspelt cicunia, ciconia (vide Belon, ii. c. 36, Camus, ii. p. 250).

Nevertheless, although the above-cited passages all appear to apply to an Owl, yet Ardea purpurea, nycticorax, and other Herons are said

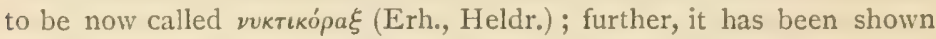
above that the attributes of é $\rho \omega \delta$ เós are in part nocturnal. Lastly, it must be noted that there are evidences of Egyptian influence in the

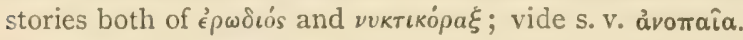

OI'NA'NOH. An unknown bird.

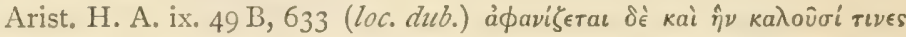

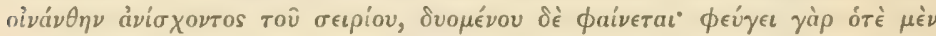

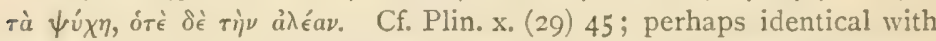
parra, ib. xviii. 69, or vitiparra, ib. x. (33) 50. Vide infra, s. v. oivás.

Belon (Nat. des Oiseaux, vii. I2) first applied the name to the Wheatear, which (Saxicola oenanthe, L.) still retains it.

OI'NA' $\Sigma$. A kind of Pigeon: probably the wild Rock-Pigeon, Columba livia, L. Also oivías, Poll. vi. 22 oivias dè kaì oivás,

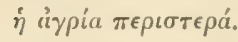

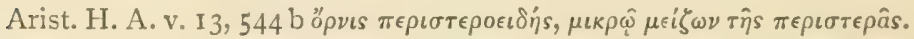

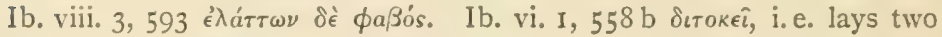
eggs ; cf. De Gen. iv. 77, iii. 9, Plin. x. 79 (58). Arist. H. A. viii. 3.593 тoû

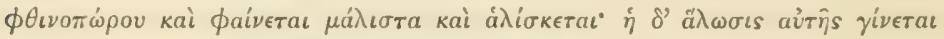

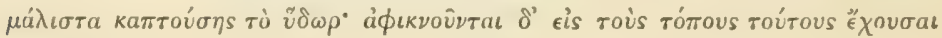
veotroús.

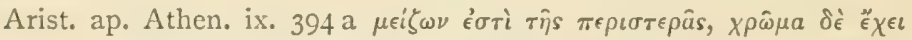

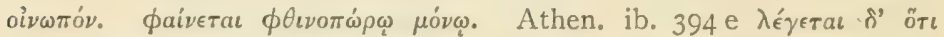

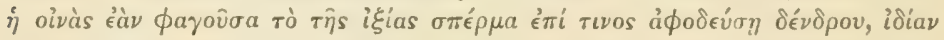

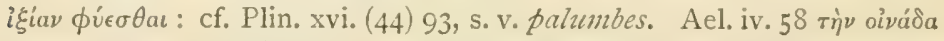

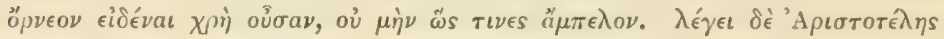

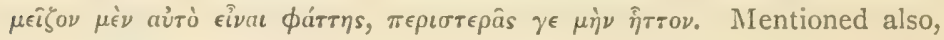
Lyc. 358 .

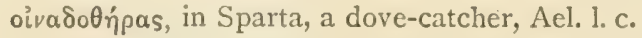

The passage in Aelian, and the discrepancy between the accounts of the bird's size, indicate that oivás was a little-known word. The later Greeks and early commentators derived it from oivos, with reference to the colour of the bird (Athen. 1. c., Eustath. ad Odyss. p. 475, ed. Basil.)

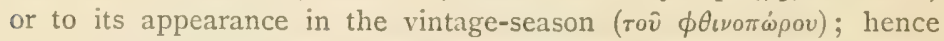
Gaza translates it Vinago; and most moderns have identified it with the Stock-dove, $C$. oenas, L., whose breast is purple-red. But the word is more probably identical with the Hebrew $\mathrm{n}$ ', jonah, as has been suggested by Casaubon in Athen. p. 6I7, and Bochart, Hieroz. ii. 


\section{OINAI (continued).}

2. Cf. 'Í́vas, Hesych., also Tzetz. Chiliad. vii. 126. [The same word is supposed by some to give its name to the island of S. Columba.] It was then probably either a sacred name, introduced with a foreign cult, or else a Phoenician sailor's name, especially for the wild Rockpigeons of the coast; and on this latter interpretation the passage in Arist. viii. 3, 593 would refer naturally to an autumn flight inland from the sea-board breeding-places.

The Оivórроло, who were turned into doves, Lyc. 570, cf. Simon. fr. 24 (39), ap. Schol. Hom. Od. iv. 164, Serv. Virg. Aen. iii. 8, Ovid, Met. xiii. 674, \&c., may derive their name from the same root, and the story of their turning water into wine may then be due to a case of 'Volksetymologie.'

By this word, and its Semitic root, I would seek to explain the curious 'canting heraldry' which represents the constellation of the

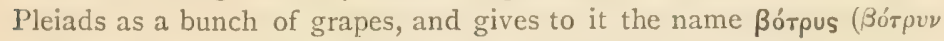

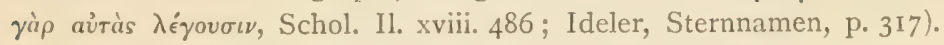
On coins of Mallos in Cilicia, we have Doves represented, whose bodies are formed by bunches of grapes, and in other cases the dove is lost and replaced simply by the grapes: on the relation of these figures and their other associated symbols to the constellation of the Pleiad, see M. J. Svoronos, Bull. de Corresp. Hellen., I894, p. 107, \&c. I imagine that an old confusion, intentional or unintentional, between oivás and oivos may have been the cause of this strange and unwonted prefigurement of the constellation. The association of the dove with the bunch of grapes survives in early Christian symbolism; cf. Gorius, Diss. XIII. De Gemmis Astrif. Christian. (vol. iii. p. 249) 1750.

The symbolic meaning here assigned to oivás tends to suggest a similar derivation and interpretation in the case of oivóv $\theta \eta$.

OINIA'三. According to Hesych. a kind of Raven, but probably = oivás, which latter word Hesych. interprets yévos kópakos" oi $\delta \dot{e}$

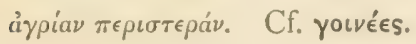

OI ${ }^{\boldsymbol{\beta}} \Sigma T P O \Sigma . \quad A n$ unknown small bird.

Arist. H. A. viii. 3, $592 \mathrm{~b}$, mentioned as a small insect-eating bird

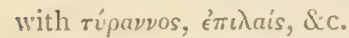

On the assumption that oirrpos (the Gad-fly) must denote some very small bird, Sundevall follows the mediaeval naturalists in identifying it with the Willow-wren, Sylvia trochilus, L., our smallest bird next to the Gold-crests.

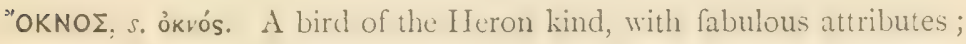
in Arist. H. A. ix. I, 609 b, I8, 6 I 7 , Ael. v. $3^{6=a ̉ o r e p i a s, ~ q . v . ~}$

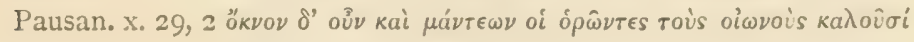


OKNOI (continucd).

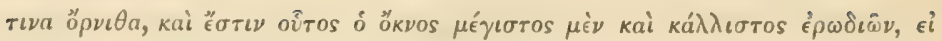

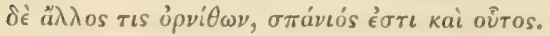

According to Boios ap. Anton. Lib. c. vii, Autonous was metamor-

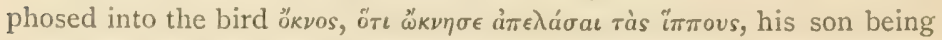
turned into an épwótós. On Ocnus as a mythological character, cf. Diodor. i. 97, p. 109, Pausan. 1. c., \&c.

Probably a foreign word, and perhaps Egyptian (cf. Ael., Diod. 1. c.). Bearing in mind the close connexion of the Heron with Athene, I am

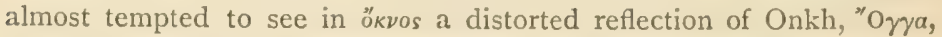
"O

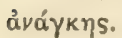

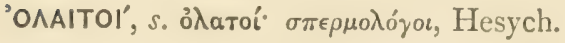

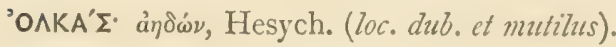

'ONOKPO'TA^OE. A Pelican.

Plin. x. (47) 66, Mart. xi. 21, Hieron. in Lev. xi. I8, \&c. ; cf. Boch. Hieroz. ii. 276.

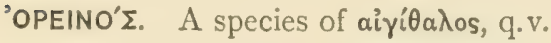

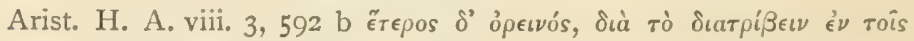

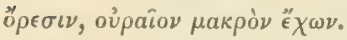

Also a name or epithet, like ỏpeír Amat. iv. 9.

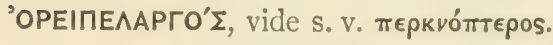

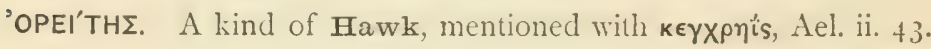

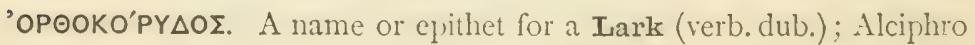
iii. 48.

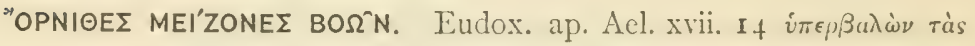

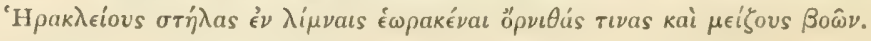

'opo'smizos. The Blue-throat, Cyanecula suecica, L.

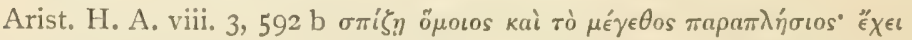

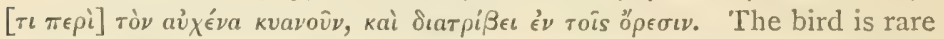
in Greece (Lindermayer, p. I04), nevertheless its identity is unmistakeable. The MSS. have several variants in the name.

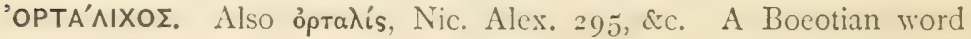
(Stratt. $\Phi_{\circ \nu .2} ; 78 \mathrm{I}$ ) for a Chick.

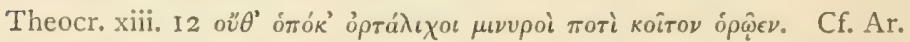
Ach. 87I and Schol.; Aesch. Ag. 54. Applied to Swallow-chicks, Opp. Hal. v. 579. 
'OРтYгомн'тPA. The Corn-crake or Land-rail, Rallus crex, I.,

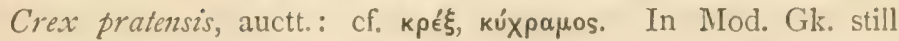

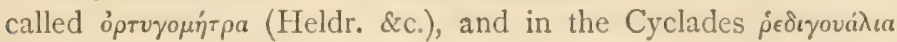
(Erh.), It. Re di quaglie.

Arist. H. A. viii. I2, $597 \mathrm{~b}$; a bird which accompanies the quails

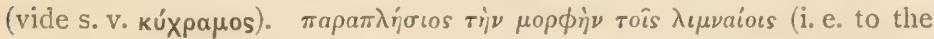
wading birds): cf. Plin. x. 33; Frider. ii De Arte Venandi, i. 9 et modus rallorum terrestrium, quae dicuntur duces coturnicum. Alex.

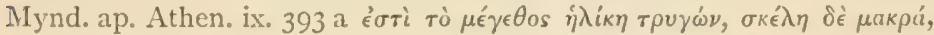
$\delta v \sigma \theta a \lambda \dot{s}$ kai $\delta \epsilon i \lambda \eta$.

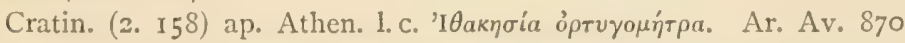

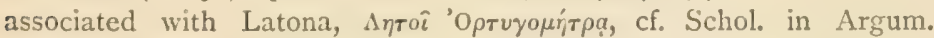
Pythiorum Pindari.

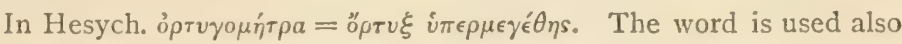
by the LXX, and by the Fathers, for ö $\rho \tau v \xi$ (Ex.xvi. 13; Numb. xi. 3I, 32 ; Ps. cv. 40) : according to Bochart (Hieroz. ii. 94) qua tamen voce libentius usi sunt, quam simplici oprvyes, ne crederetur Deus gresrarias coturnices Israelitis immisisse, sed earum nobilissimas!

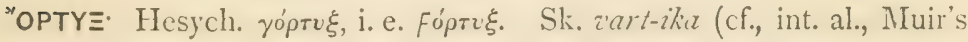

Sk. Texts, i. I I2. 8), cf. Lat. vertere, Lit. the dancer (?), or more probably and simply, the one who returns. The Quail, Colurnix vulgaris, auctt. Mod. Gk. öртикє, óрти́кเор. Dim. óртúyıо, Eupolis and Antiph. ap. Athen. ix. 392 e. On the quantity of

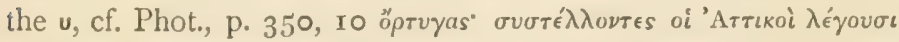

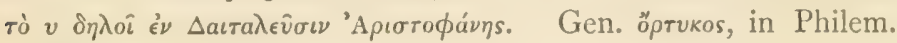
ap. Chaerob. i. 82 .

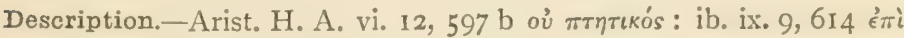

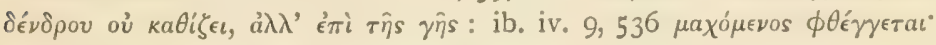

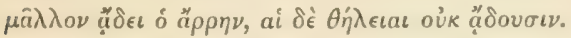

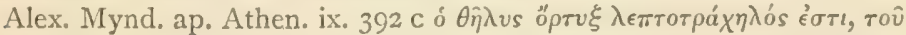

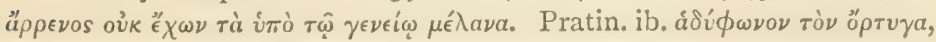

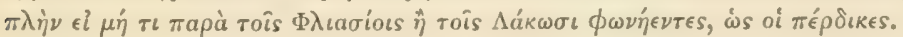

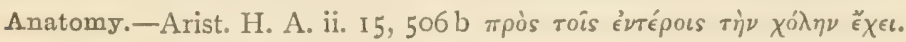

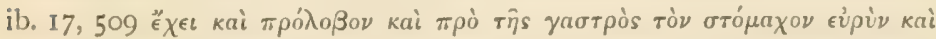

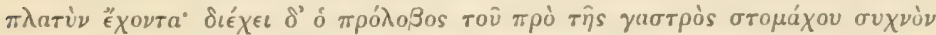

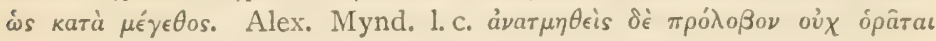

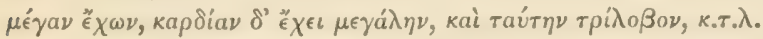

Nest and Breeding-habits.-A full description, together with $\pi \epsilon ́ \rho \delta \iota \xi$, Arist. H. A. ix. 8, 6I3 b, 6I 4 : cf. ib. vi. I, 559. Cf. Xen. Memor. ii. 1,4 .

Migrations.-Arist. H. A. viii. 12, 597. Migrate in September, rov

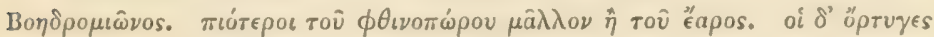




\section{OPTYE (continued).}

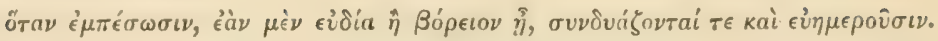

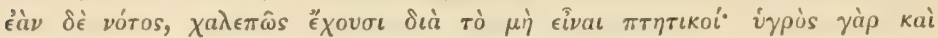

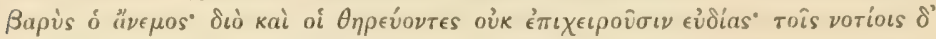

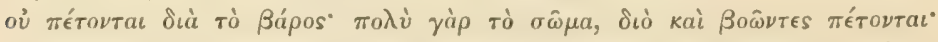

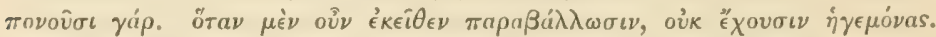

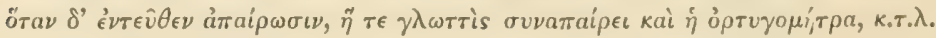
Cf. Dion. De Avib. i. 30 ; Plin. x. 33 (23) ; Varro, De Re Rust. iii. 5, 7 . The connexion between the quails' flight and the wind is well known: cf. Numb. xi. 3 I ; Joseph. Ant. iii. I, 5.

Modes of capture.-With a mirror, Clearci. Sol. ap. Athen. ix. 393

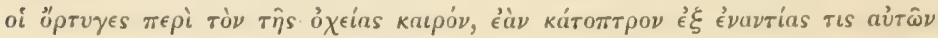

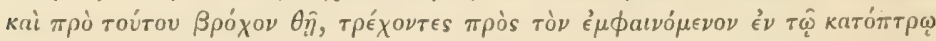

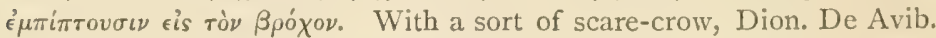
iii. 9. With nets simply, on the coast of Egypt, Diodor. i. 6o. A quailcatcher, ópruyotípas, Plat. Euthyd. 290 D. Cf. Arist. H. A. ix. 8, 614

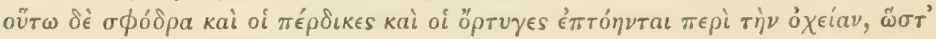

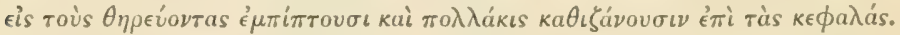

Abundance and cheapness: cf. Antiph. ap. Athen. ix. 397 Theiovs $\delta^{\prime}$

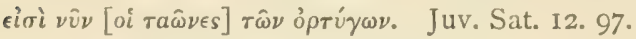

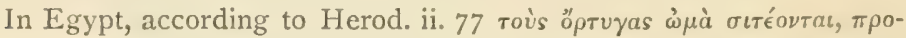

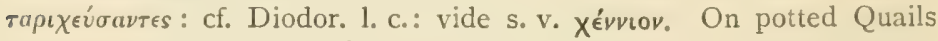
in the Morea, cf. G. St. Hilaire ap. Bory de St. Vincent, Morée, Oiseaux, p. 35 .

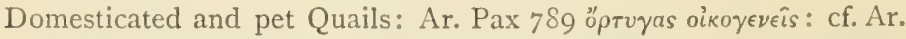
Fr. 36; Arist. Probl. x. 12, I; Plut. V. Alcib. i. 195 E, Mor. ii. 799 D ; Varro, iii. 5, 2 ; M. Anton. i. 6. A lover's gift, Ar. Av. 707, Plat. Lys. 2 II E: cf. Plaut. Capt. v. 4, 5 ; vide Jacobs ad Anthol. x. p. I3.

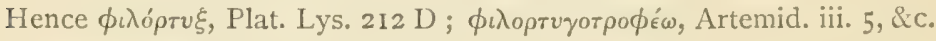

Quail-fights. Lucian, Anach. 37 (2, 9I8); Plat. Lys. 2 I I E; Plut. i. 930 E, cock and quail-fights between Antony and Caesar (cf. Ant. and Cl. ii. 4 ' and his quails ever Beat mine, inhoop'd at odds'); ibid.ii. 207 B how in Egypt a procurator of Augustus killed and ate a victorious quail, and how retribution fell on him; Ovid, Amor. ii. 6, 27, \&c. This sport, still common among the Chinese, Malays, \&c., was practised in Italy in Aldrovandi's time (Ornith. ii. p. 74 : cf. Voss., De Idol. c. 86, p. 596). For a Chinese picture of a quail-fight, showing the 'hoop' or $\tau \eta \lambda i a$ (cf. supra, p. 22, s.v. $\dot{\alpha} \lambda \in \kappa \tau \rho u \omega ́ v$ ), see Douce's Illustr. of Shakspeare, p. 367 ; cf. also Bell's Travels in China, i. p. 404 (8vo ed.). See also Becker's Charicles. The birds are said to have been

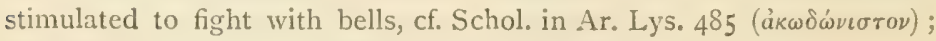
see also Aristarch. ap. Harpocrat. S. v. $\delta \iota \epsilon \kappa \omega \delta \omega ́ v \iota \sigma \epsilon$.

Quail-striking, ортууокотік, Jul. Pollux, ix. 107. The player was

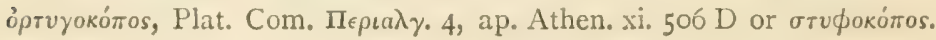


OPTY $\equiv$ (continued).

Ar. Av. 1299 and Schol. Cf. Plut. ii. 34 D. See also Meursius, De Ludis Graecorum, in Gronov. Thes. Ant. Gr. vii. p. 979.

Immunity from poison.-Arist. De Plant. 5, 820 b iorkúaros kai

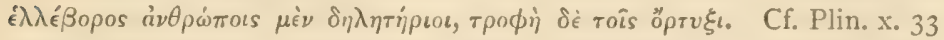
(23), Geopon. xiv, 24, Galen. De Ther. ad Pison. i. 4, De Alim. Fac. ii. 6, De Temper. iii. 4, Basil. Hexaem. v. p. 59 (ed. Paris), Eustath. Hexaem. p. 9, Ambros. Hexaem. iii. 9, \&c., Lucret. iv. 64I. For similar oriental reff., see Bochart, ii. 97, 98.

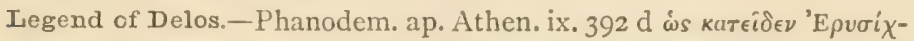

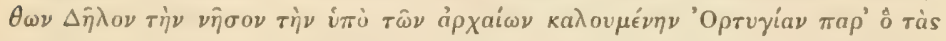

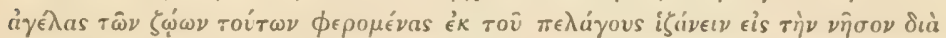

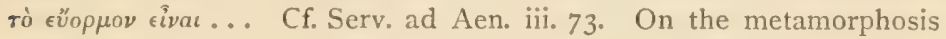
of Artemis, Leto, and Asteria into Quails, see Apollod. i. 4, I, Schol. Apoll. Rhod. i. 308, Hygin. Fab. 53, Tatian, Adv. Graec. c. xvi, \&c. In yet another version it is Zeus himself who appears as a Quail : Argum. Pyth. Pindari, ed. Böckh, ii. p. 297.

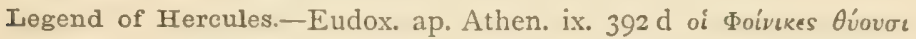

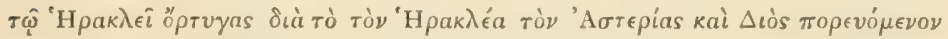

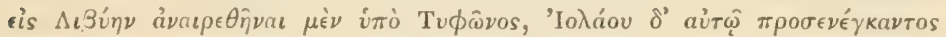

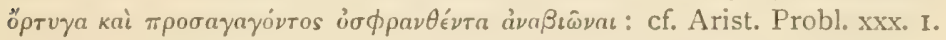

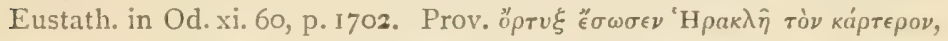
Zenob.v. 56; Ding. vii. 10; Apostol. xiii. 1; Eutecnius in Cram. Anecd. Paris., i. p. 31 ; Paroemiogr. Gr. i. p. I43. In this passage various commentators read öpvya for öprvya, the Gazelle being sacred to Typhon; cf. Jablonski, Panth. I97; Dupuis, Orig. de tous les Cultes, ii. 350, Creuzer, Symb. ii. I00, Boch., l. c.; but the emendation is not justified, cf. Stark, op. infra cit. The Quail's brain was a specific for epilepsy, the morbus comitialis or herculeus, Galen, Parat. Facil. iii. I55, Plin. x. (23) 33. Vartikâ, the Quail, is said to be a solar ernblem among the Hindoos: it is as the emblem of the returning Sun, that it figures in the legend of Delos, the birthplace of Phoebus, and in that of Hercules, the slayer of Typhon.

The principal allusions to the Island of Ortygia are collated and discussed by Hermann, De Apoll. et Diana, Opusc. vii. p. 310 (I 839). See also, for a still more elaborate investigation, Stark, Die Wachtel, Sterneninsel und der Oelbaum im Bereiche phoinikischer und griechischer Mythen, Ber. K. Sächs. Ges. d. Wiss., 1856, pp. 32-120. It seems clear to me that in the superstitions regarding the Quail, and in the sacred reputation of Ortygia, the main point is with reference to

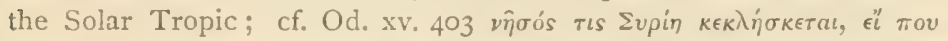

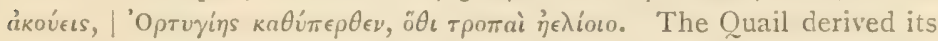
sanctity, and perhaps its name, from the circumstance that it returned with the returning Sun, and Ortygia was some spot where the $\tau$ pomai 


\section{OPTY $\equiv$ (continued).}

iं $\lambda$ ioto were observed and their festivals celebrated, as of old in Delos. Cf. (int. al.) Pind. Nem. i.

The word OPTYTOөнPA, on coins of Tarsus (Mionnet, Suppl. vii. p. 258 , \&c.) is supposed to refer to a similar symbolic festival (Stark, op. c., p. 44).

Hostile to $\pi \epsilon \lambda \epsilon \kappa a ́ v$, Ael. vi. 45, Phile, 684. A prey to hawks, Ael.

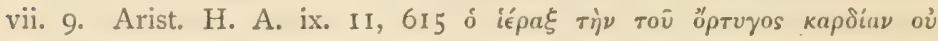

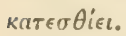

How the Quails, migrating, carry each three stones, to hear by dropping them whether they be over the sea, Dion. De Avib. i. 30: cf. Plin. x. 33 (sand for ballast) ; cf. s.v. yépavos.

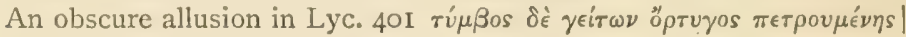

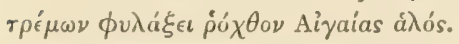

Proverbial References.-Philostr. V. Sophist., p. 253 (ed. Kayser)

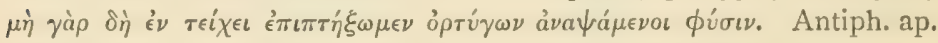

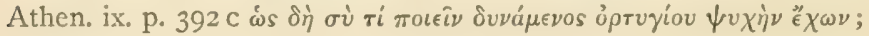

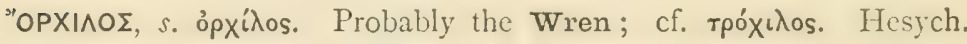

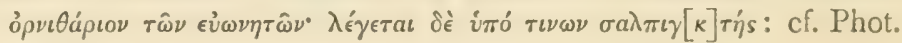
35 I. I 2 .

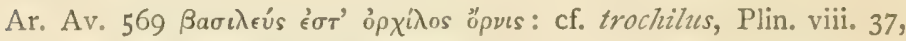
x. 95. Mentioned also Ar. Vesp. 1513.

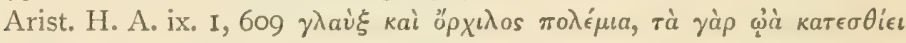

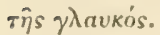

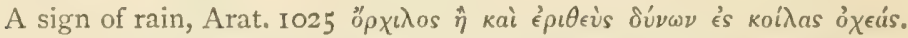
Cf. Theophr. De Sign. vi. 3. 39, 4. 53. According to Nicand. ap. Anton. Lib. c. xiv, Alcander, son of Munychus, was metamorphosed into the bird óp

An evil omen at weddings: Avienus in Arat. 1. c. infestus floricomis hymenaeis orchilus. Cf. Euphor. ap. Tzetz. ad Lycophr. p. 83 (cit.

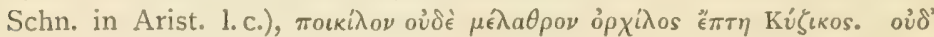

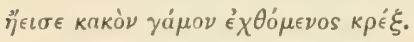

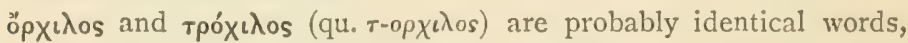
and of foreign origin. kóp $\theta \iota \alpha_{\text {os }}$ (q. v.) may be yet another corrupt form. Lauth (in Horap. i. 57, Sitzungsber. d. Bayer. Akad. 1876, p. I07), comparing Copt. orp\& avis, and orpo rex, affords a hint which may explain, by referring to an Egyptian source, the origin both of

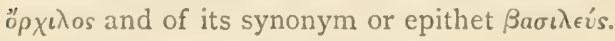

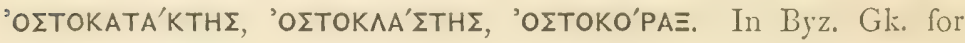
ossifragus.

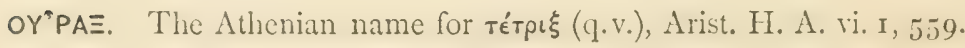


OY'PI'A. A kind of water-bird.

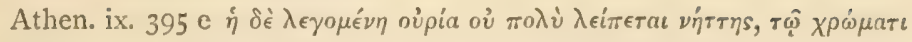

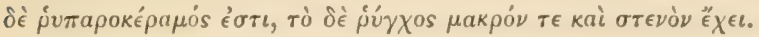

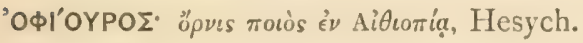

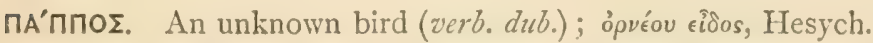

Mentioned Ael. iii. 30, in a somewhat doubtful passage, as a bird in whose nest the Cuckoo lays her egg. Sometimes supposed to be

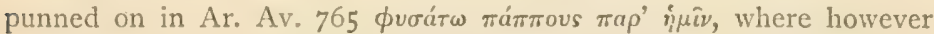
$\pi a ́ \pi \pi 0 \iota$ are more probably young downy feathers (vide Kock, \&c.).

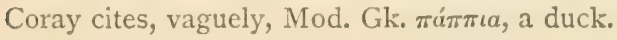

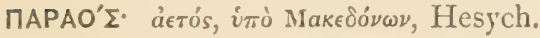

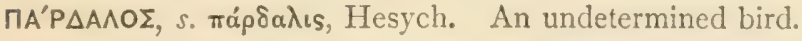

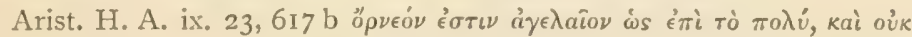

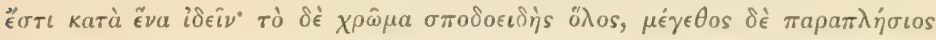

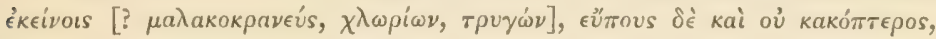

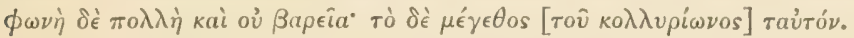

A very doubtful passage, cf. Billerbeck, De loc. nonnull. Arist. H. A. difficilior., Hildesh. I8o6. Sundevall, following Turner, Gesner, \&c., identifies ráp $\delta a \lambda o s$ with the Golden Plover, Charadrius pluvialis, L., which is frequent in flocks in Greece, and has a constant cry, and is about as large as $\tau \rho v \gamma \dot{\omega} \nu$ : in the name he sees a suggestion of the

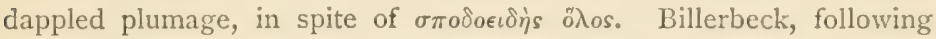
Aldrovandi, \&c., identifies it with the Starling, for similar and equaily

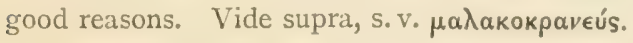

MEAAPTO' $\Sigma$. (Said to be derived from $\pi \epsilon \lambda o ́ s$, apyós: lit. black-andwhite; vide Suid. S.v. $\pi \epsilon \lambda a \rho \gamma \iota \delta \in i s$, ed. Bernhardy; Zonarus, p. I 528 ;

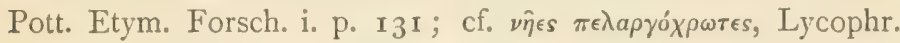

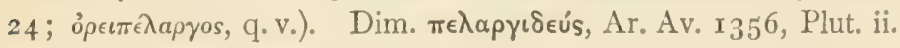

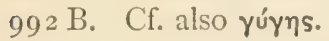

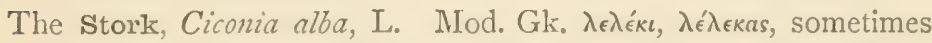
said to be a Turkish word; but Byzantios ingeniously compares

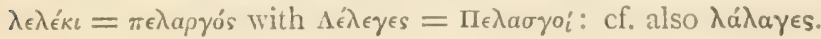

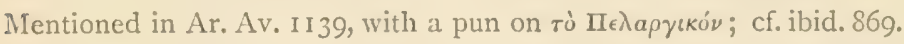

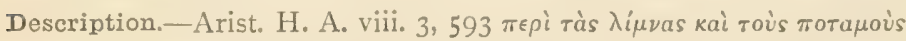

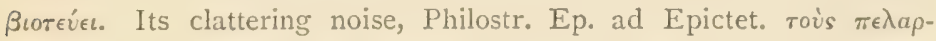

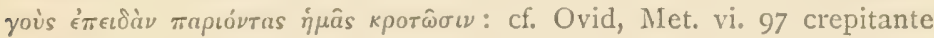
ciconia rostro.

Migrations.-Arist. H. A. viii. 16, 600, $\phi \omega \lambda \in \hat{\imath}$. Cf. Plin. x. 23 (3I) Ciconiae quonam e loco veniant aut quo se referant, incompertum adhuc est. Nemo videt agmen discedentium, cum discessurum appareat, nec 


\section{MEAAPTOE (continued).}

venire sed venisse cernimus: utrumque nocturnis fit temporibus. Cf. Dionys. De Avib. i. 3r. (Its departure is scarcely noticed; Lindermayer,

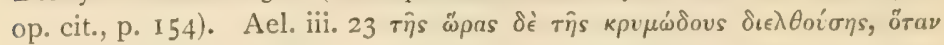

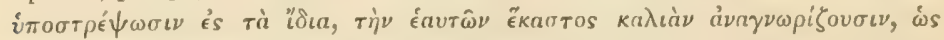

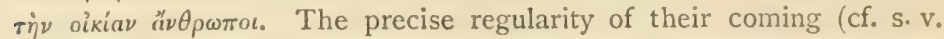

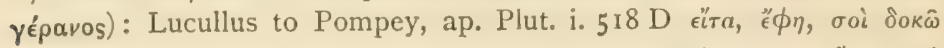

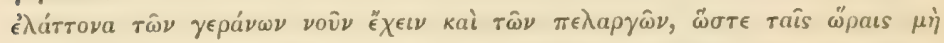

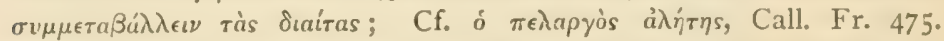
Accorling to Strabo, 22I, 397, connected with $\Pi \epsilon \lambda a \sigma \gamma o i$, a nomad race; cf. Dion. Hal. i. 28.

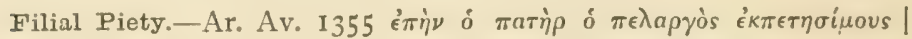

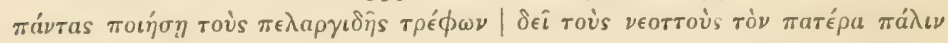

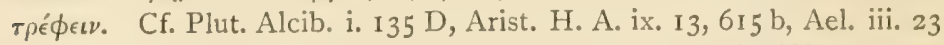

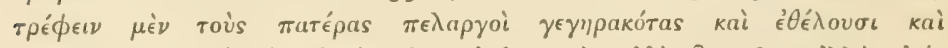

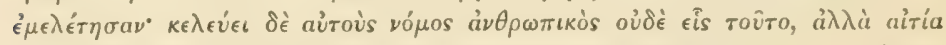

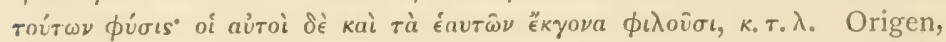

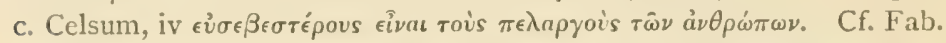

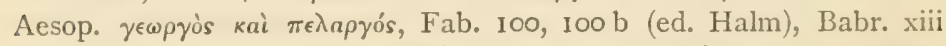

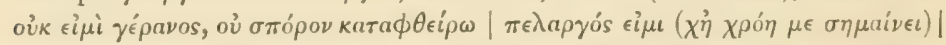

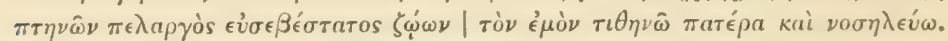

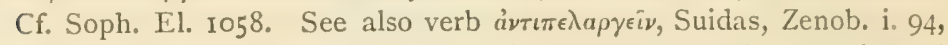

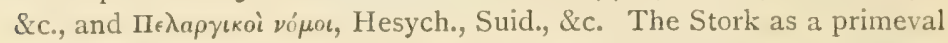
law-maker is alluded to in Ar. Av. 1353, perhaps also ibid. 1213. Hence the Stork was honoured by the Egyptians, as an emblem of piety : Ael.

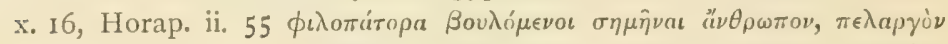
$\zeta \omega \gamma \rho$ ¿

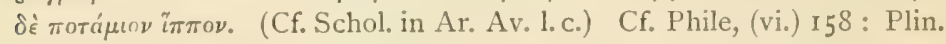
x. (23) 33; Juv. Sat. i. I16 ; Porph. De Abst. iii. II ; Publius ap. Petron. Sat. 55 ciconia etiam grata, peregrina, hospita, Pietaticultrix, gracilipes, crotalistria.

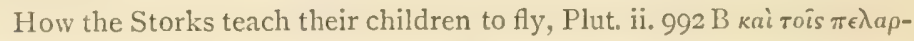

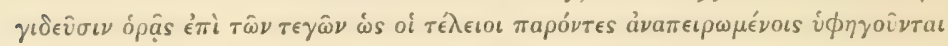
$\tau \dot{\nu} \nu \pi \tau \hat{\eta} \sigma \iota \nu$.

Destroys serpents, and hence honoured by the Thessalians. Arist.

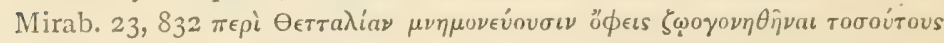

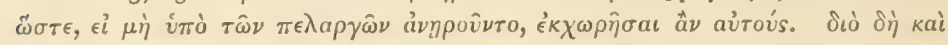

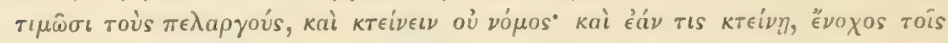

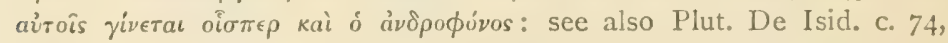
Symp. viii. 7, Plin. x. (23) 33, Solin. De Thessal. Cf. Juv. Sat. xiv. 74 serpente ciconia pullos, Nutrit et inventa per devia rura lacerta; Virg. G. ii. 320 .

The Stork as food, Hor. Sat. ii. 2, 5o, and Scholia; cf. Corn. Nepos, ap. Plin. x. (23) 30, Mart. Ep. xiii. 


\section{MEAAPTOS (contimed).}

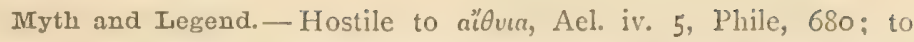

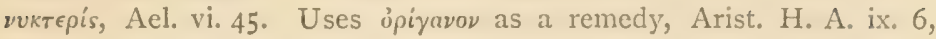

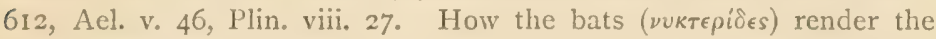
Stork's eggs unfruitful, and how the Stork defeats them with a leaf of Tháravos, Ael. i. 37, Geopon. xiii. 13, xv. I, 18 ; according to Anatol. p. 298, a tortoise-bone is equally efficacious. A Stork's stomach is a specific for the murrain of sheep and goats, Geopon. xviii. II ; cf. l'lin. xxix. 33 .

A young Stork, a prophylactic against ophthalmia, Plin. xxix. 38.

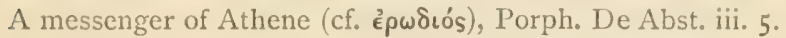

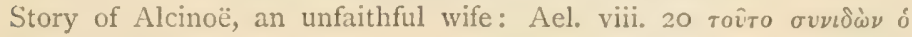

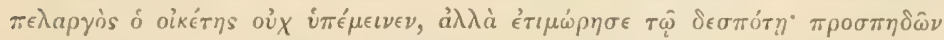

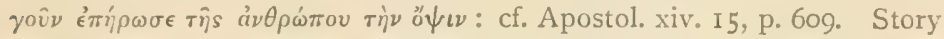
of Heracleïs, to whom the Stork, healed of a broken leg, brought next

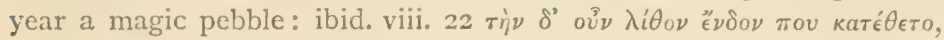

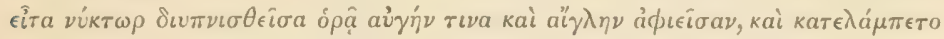

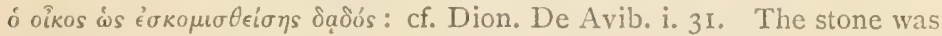
probably the stone $\lambda u ́ x v t s$ or $\lambda v \chi v i \tau \eta s$, cf. Plin. xxxvii. (17) 103, and

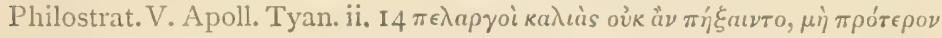

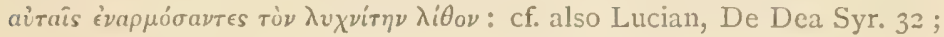
Orph. Lith. 268.

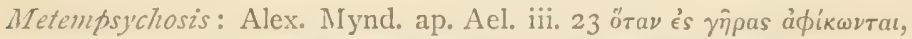

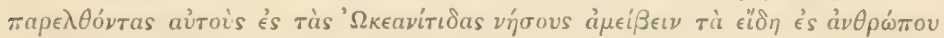

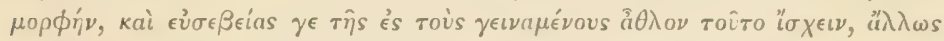

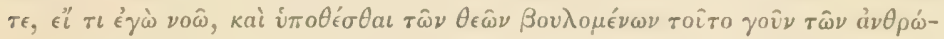

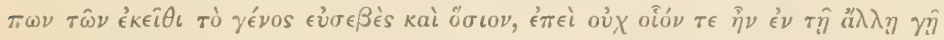

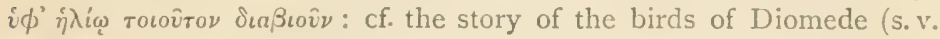

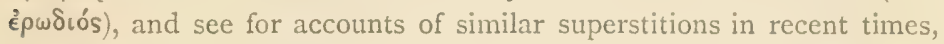
Schwenk, Slav. Mythol. p. 129; cf. also August Marx, Griech. Märchen, pp. 50-55, Stuttgart, I889.

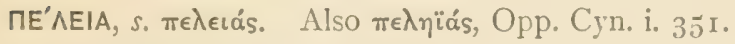

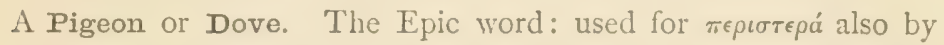
the Dorians (Sophron. ap. Athen. ix. 394 D), and by the Ionians (Hipp. 638. 8, 667.3: cf. Lat. pal-umba. Commonly said to be

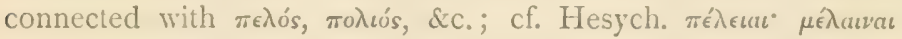

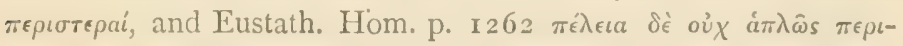

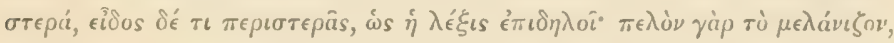

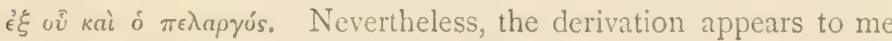
somewhat dubious; for all the wild pigeons, the Turtle-dove excepted, are very much of a colour, and I do not think the Greeks would have spoken of black pigeons until they had got 
MEAEIA (continued).

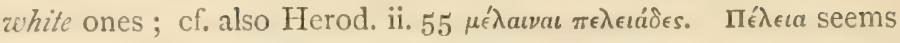
lost as a current word in Mod. Gk. : it does not occur in Aristophanes, save in the Homeric parody in Ar. Av. 575.

In Hom. frequent; the only Homeric word for pigeon, save for the

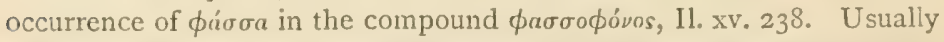
with epithet $\tau \rho \dot{p} \rho \omega v$ q.v., a word of equally doubtful etymology, the received derivation from $\tau \rho \epsilon$ é appearing dubious in the light of such pigeon-

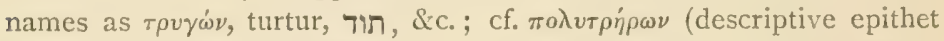
of the towns Thisbe and Messe), Il.ii. 502, 582, and Lyc. 87, 423, where $\tau \rho \eta \dot{\rho} \rho \nu=\pi \epsilon^{\prime} \epsilon \epsilon a$ : see also Eustath. Hom. Il. pp. 1262, 1712, Athen. xi. 490 D. A prey to i $\eta \xi$, Il. xxi. 493, to кiркos, Il. xxii. 139; cf. Aesch. Pr. V. 858. Messengers of Zeus, when Rhea protected him from

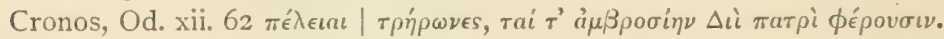

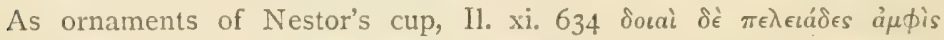

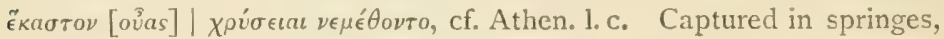

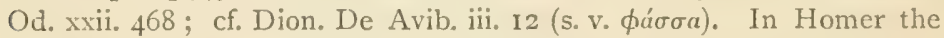
pigeon is never spoken of as a domesticated bird, and is definitely a wild one in II. xxi. I39, and Od. xxii. 468 . Il. xxi. 495 suggests the

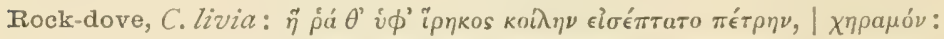

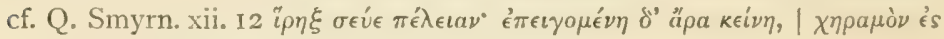

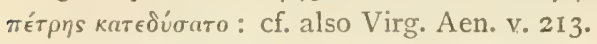

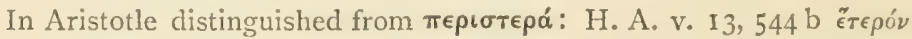

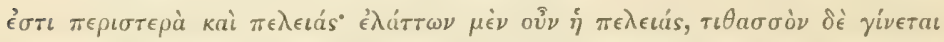

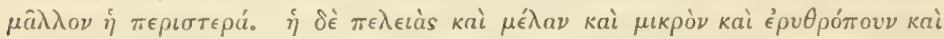

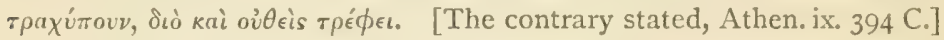

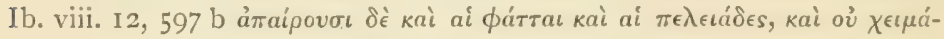

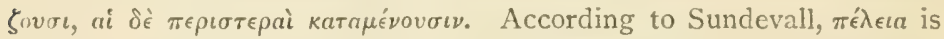
here in Aristotle the Stock-dove, C.oenas, oivás being the Rock-pigeon,

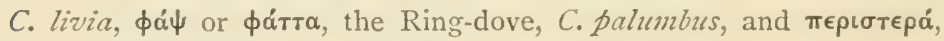
the Domestic Pigeon. Aubert and Wimmer, on the other hand, take oivís as the Stock-dove, and leave $\pi \epsilon \in \epsilon \iota a$ in doubt. For my part, I do not think the Stock-dove was recognized as a distinct species, but was

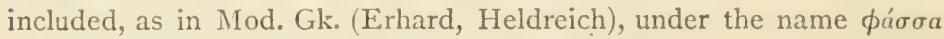
with the Ring-dove. Excluding the Turtle-doves, there then only

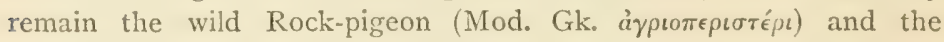
domestic variety; and I imagine that both oivás (q.v.) and $\pi \epsilon \epsilon \iota a$ refer, in Aristotle, to the wild Rock-pigeon, and $\pi \epsilon \rho \iota \tau \tau \rho a$ especially to

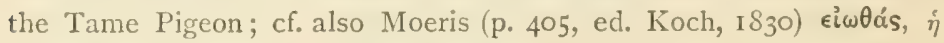

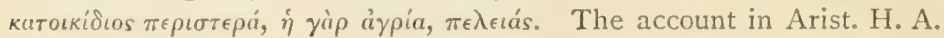
v. 13 is corrupt and not to be too much depended on, especially in view of the discrepant quotation in Athenaeus. The chief difficulty in the whole interpretation is the passage $H$. A. viii. 12, where it

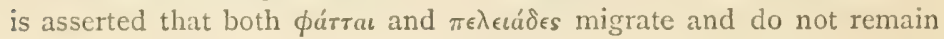




\section{MEAEIA (continued).}

over the winter, whereas all the Pigeons occur more or less in Greece in winter-time, and it is in summer that the Ring-dove and Stockdove, which breed elsewhere, are seldom found. The passage can hardly have been written in Attica; it would appear more consonant with the truth did we suppose it written, for instance, in Macedonia. Except in the doubtful case of Aristotle, $\pi \epsilon \operatorname{tela}$ is in no sense a specific term: we have seen it applied in Homer to the Rock-pigeon, and on the other hand the $\pi \epsilon$ ' been either Ring-doves or Stock-doves (vide infra). In Opp. Cyn. i. $35 \mathrm{I}$, where pigeon-fanciers are said to cause the pigeons by a display of purple stuff to bring forth young of a like colour, $\pi \epsilon \lambda$ riás and also rpíp $\rho \nu$ are used of tame pigeons.

On the Latin usage of columba, palumbes, \&c., cf. W. W. Fowler, A Year with the Birds (3rd ed.), p. 218.

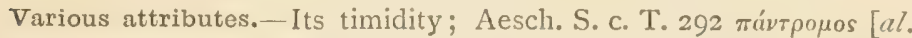

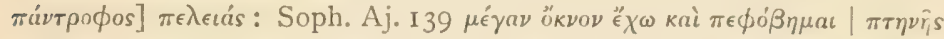

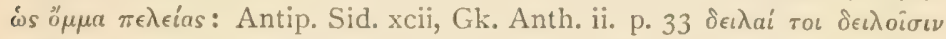

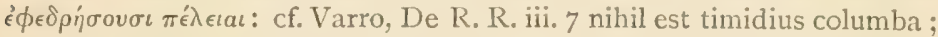
Ovid, A. Amat. i. 117 , ii. 363 , \&c., \&c. Its swiftness: Soph. Oed. Col.

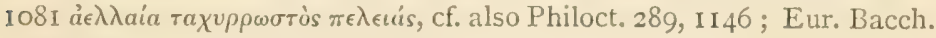

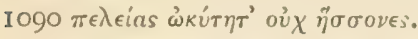

The Dove pursued by the Hawk or Eagle, a type of swiftness and of timidity: I1. xxi. 493, xxii. I39, Q. Smyrn. xii. I2; Aesch. Pr. V. 858

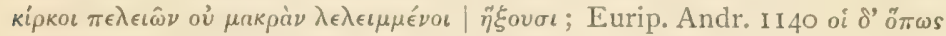

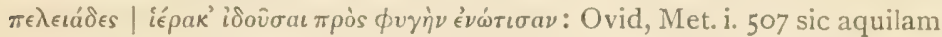
penna fugiunt trepidante columbae ; cf. ibid.v. 605, Trist. i. I, 75 ; Virg. Ecl. ix. II; Lucret. iii. 75I ; Phaedr. Fab. i. 3I, 3, \&c. Thus Medea comes to Jason, as a Dove seeking shelter from the Hawk, Val. Flacc. Argon. viii. 32 .

The Dove in the clutches of the Eagle or Hawk, as an omen, Od. xx. 243 , xv. 525, Sil. Ital. Pun. iv. 104 ; cf. Virg. Aen. xi. 721.

Hera and Athena, coming to the aid of the Argives, compared to

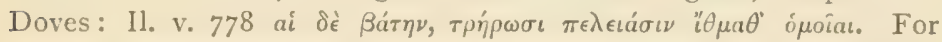
various interpretations of this simile, see the Scholia, also Ameis and other commentators; but the allusion is probably neither to swiftness nor to dainty tread, but to the ancient and widespread prefigurement of the deity as a dove (cf. int. al., F. L. W. Schwartze, Urspr. d. Mythologie, p. 218); in the Homeric Delian Hymn, v. 114, Iris and

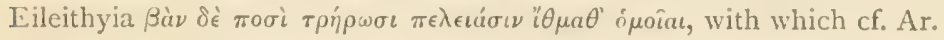

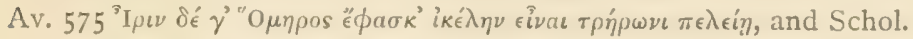

The story of the Dove bound by Achilles to the mast as a mark for the archers, Il. xxiii. 850 et seq. : it was shot by Meriones, $\tilde{u} \psi \iota$

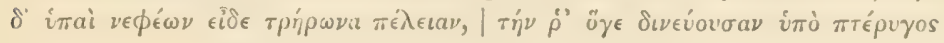


MEAEIA (continued).

$\beta a ́ \lambda \epsilon \mu \epsilon_{\sigma \sigma \eta \nu}$ : the same story transferred to Aeneas and Eurytion, Virg. Aen. v. 485-544.

On the pigeons that brought ambrosia to the infant Zeus, see Od. xii. 60 ; Moero Byz. ap. Athen. xi. 490 e; Ptolem. Hephaest. ap. Phot. i. p. 474 .

The Dove that flew between the clashing rocks in the passage of

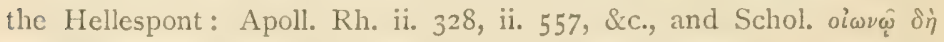

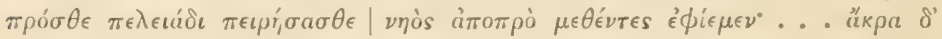

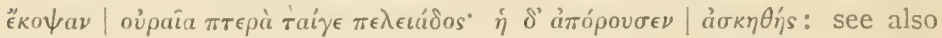
Apollod. i. 9, 22, Hygin. Fab. xix, Propert. ii. 26, 39 cum rudis Argûs Dux erat ignoto missa columba mari, \&c.; cf. the account of the

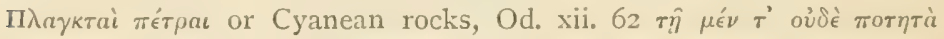

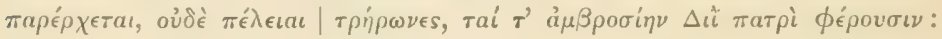
cf. Plut. ii. $156 \mathrm{~F}$. The Dove in the story of the Argonauts again,

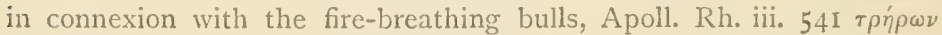

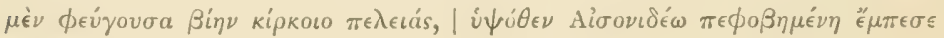
кóर $\pi$ oเs.

In the above legends there are numerous traces of the mythical astronomy of the Pleiads. This view is a very ancient one; cf. Athen.

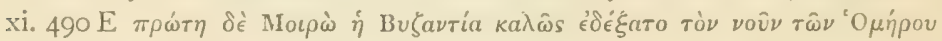

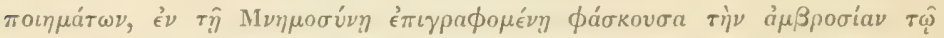

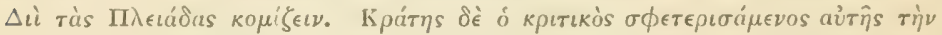

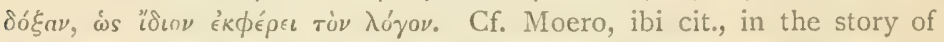

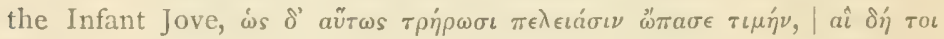

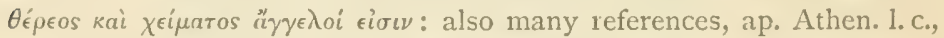
from Pindar, Simonides, Simmias, Lamprocles, \&rc., where the $\pi \lambda \in a$ ádes

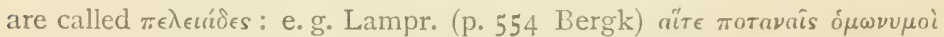

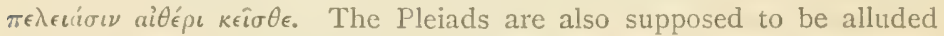

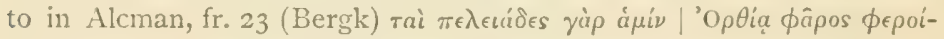

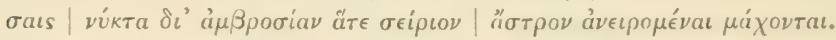

The coincidences on which rests the foundation for an astronomical interpretation of the above myths are chiefly the following. As has

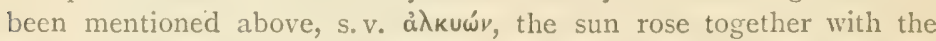
Pleiads in the sign of the Bull, at the vernal equinox, the ancient opening of the year. If the Cretan Jupiter was a Sun-god, he might be said to be nursed by the $\pi[\epsilon] \lambda \epsilon \iota a ́ \delta \epsilon s:$ the sign Taurus may have been the Cretan Bull; and a transit through that sign may have been the celestial Bófropos of the Argonautic voyage. The Dove as an attribute of Venus is similarly explained, the domus Veneris being in the sign Taurus, the sign of the Pleiad.

The Doves of Nestor's cup, 11. xvi. 634, are also supposed to have reference to the Pleiades, Athen. xi. 490-492.

On the Dove of Deucalion: cf. Plut. Mor. 968, i185. On the dove in 
MEAEIA (continued).

the Chaldaean deluge-myth, cf. Euseb. Chron. Armen. i. p. 5o, \&c., \&c. ; see also the representation on coins of Apamea, Eckhel, Doctr. Numm. iii. 132, Friedländer, Kgl. Münzkab. pl. ix, \&c., \&c.

A similar explanation is given of the Dove of the deluge-myth.

The Pleiades (as doves?) fleeing before the hunter Orion, Hes. Op. et D. 6ig.

For references to the copious (and often unreliable) literature of Pleiad-symbolism, see int. al., Pluche, Hist. du ciel, Dupuis, Orig. de tous les cultes, Haliburton, New Materials for the Hist. of Man, 1863, von Bunsen, Plejaden und Thierkreis, 1879, Nitzsch in Od. v. 272, \&c., \&c.

How the soul of Ctesylla departed as a dove; Nicand. ap. Anton. Lib. i ; cf. Ovid, Met. vii. 370.

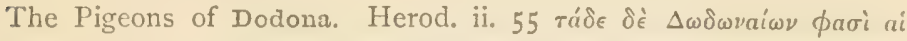

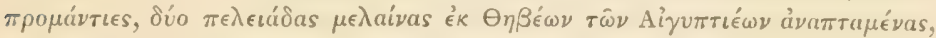

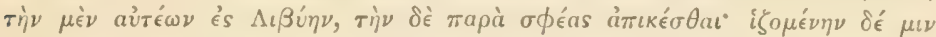

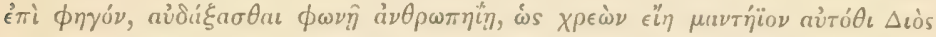

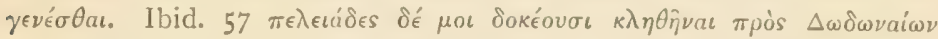

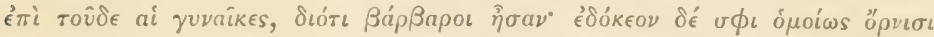

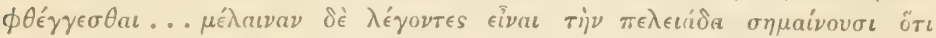

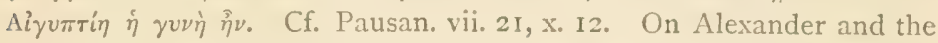
doves at Ammon, cf. Curtius, iv. c. 7, Strabo, xvii. See also J. Arneth. Ueber das Taubenorakel von Dodona, Wien, 1841; Perthes, Die Peleiaden von Dodona, Progr. d. Progymn. zu Mörs, I869; H. D. Mïller, Philol. Anz. ii. p. 95, 1870; Lorenz, op. cit., p. 35; Creuzer, Symb. iii. pp. $183,217$.

According to Thrasybulus and Acestodorus, ap. Schol. Il. xvi. 233, a dove had founded the oracle in the time of Deucalion. On the

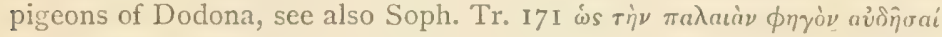

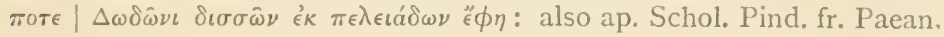
58 (30) ; Diod. i. 13, iii. 7I ; Sil. Ital. iii. 678; Serv. in Aen. iii. 466, Ecl. ix. 13. According to Strabo, ap. Eustath. in Od., p. 1760, and

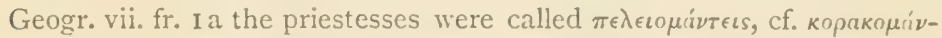
$\tau \in \iota$. According to Philostr. Imagg. ii. $33(387 \mathrm{k})$, a choir of priestesses danced round an oak, on which sat a golden dove. Dion. Halic. Ant. Rom. i. I4, 41 compares with the Dodonaean dove the mixos or

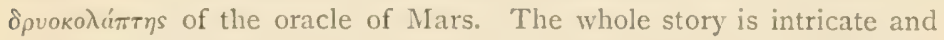
confused. It seems clear that the priestesses were called té $\lambda \epsilon \iota \iota$ (cf. Paley, Aesch. Suppl. ed. 2, p. xiv) or $\pi \epsilon \lambda \epsilon \iota \mu^{\prime}{ }^{\nu} \tau \epsilon \iota s ;$ and also that the oracle was not essentially an augury or bird-oracle, but one in which tree-worship, river-worship (cf. Macrob. v. I8), and thunderworship (cf. Mommsen, Gr. Jahresz. p. 432, \&c.) were alike involved. The doves of Dodona link on to the story of Deucalion, to the doves 
MEAEIA (continued).

that fed the infant Zeus, to the dove in other Zeus-myths (cf. Athen. ix. 395 a, Ael. V. H. i. I5) and to the doves of Dione. If we seek to get further back, we enter the mist of Pleiad-symbolism.

It has been suggested by Landseer, Sabaean Researches, p. I86, from the study of an Assyrian symbolic monument, that the stars which Conon converted into the Coma Berenices (Hygin. P. A. ii. 24, cf. Ideler, Sternnamen, p. 295) and which lie in Leo opposite to the Pleiades in Taurus, were originally constellated as a Dove; and that this constellation, whose first stars rise with the latest of those of Argo, and whose last rise simultaneously with the hand of the Husbandman, links better than the Pleiad into the astronomical Delugemyth. The case rests on very little evidence, and indeed is an illustration of the conflicting difficulties of such hypotheses: but it is deserving of investigation were it only for the reason that the Coma Berenices contains seven visible stars (Hygin.), and the Pleiad six, a faint hint at a possible explanation of the lost Pleiad.

$\pi \epsilon \lambda \epsilon \iota \theta \rho \epsilon \dot{\mu} \mu \omega \nu$, an epithet of Salamis (according to the Schol. and Hesych., but see Paley and other commentators), Aesch. Pers. 309 ; cf.

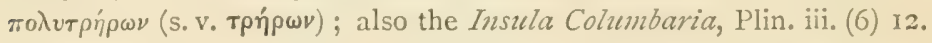

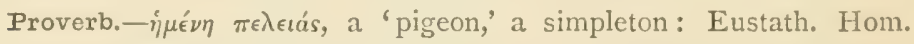

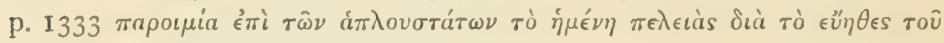

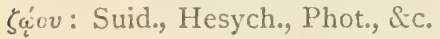

In preparing this article on $\pi \epsilon \lambda_{\epsilon} a$, and the other cognate articles on the various Pigeon-names, I have drawn much from the learned pamphlet of Dr. Lorentz, Die Taube im Alterthume, Wurzen, I886, as well as from the earlier compilation of Hehn, in his Culturptanzen und Hausthiere.

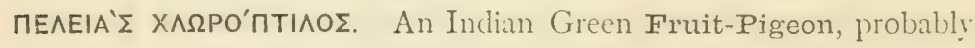
Crocopus chlorogaster, Blyth, cf. Val. Ball, Ind. Antiq., xiv. p. 305,1885 .

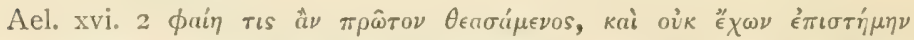

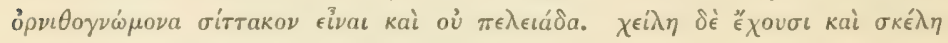

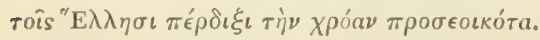

nEAEKA'N. The Pelican, Pelecanus crispus, Bruch., and P. onocrotalus, L., which latter is rare in Greece (Von der Mühle).

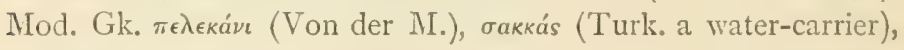

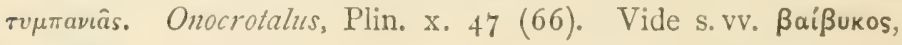
$\beta a เ \dot{\theta} \theta$.

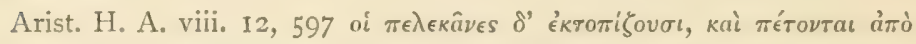

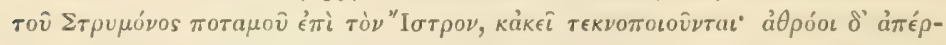

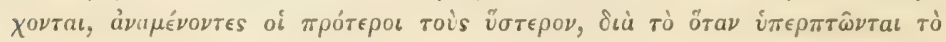


TEAEKAN (continued).

öpos åônj

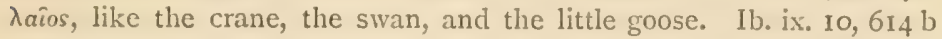

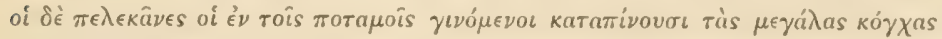

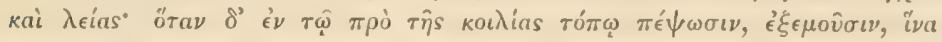

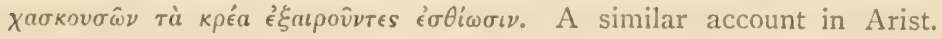
De Mirab. I4, 83I b ; Antig. Hist. Mirab. 4I (47); Ael. iii. 20, 23, v. 35 ; Apostol. Cent. I5; Phile, De An. (9), 215; Dion. De Avib. ii. 6

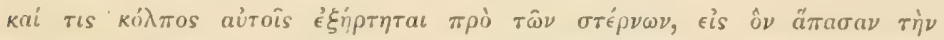

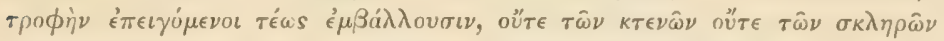

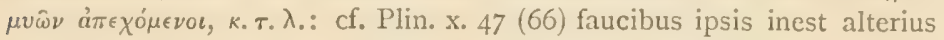
uteri genus. That the Pelican can render up its food from its 'pouch' was much commented on by the ancients: hence the Hebr. name kaath, lit. 'to vomit.' But the Pelican feeds on fish, not (?) on shell-fish: and moreover P. crispus is common in Greece and is not limited to the north. Hence various writers have doubted the common interpretation, e. g. Gesner, Brandt (Descr. Animal. Rusticorum, 1836, p. 53), Van der Hoeven (Handb. d. Zool., ii. p. 396) and especially Aubert and Wimmer (op. cit., i. p. 104), who suppose a species of Heron to be meant. But the passage in Dionysius (s. v. $\pi \in \lambda \in \kappa(v o s)$ is only applicable to the Pelican, and the latter is distinguished from épwótós in Ael. v. 35, Phile, c. ix, \&c.; the Heron and the Pelican seem however to be confounded by Plutarch, $1 . \mathrm{c}$.

Cicero (De Nat. D. ii. (49) 124) repeats the story under the name Platalea, and Plin. (x. (40) 56) under that of Platea, names which rather suggest the Spoonbill, to which the account may have been transferred, the Pelican not occurring in Italy (Gallia hos septentrionali proxima Oceano reddit, Plin. x. 47).

The Pelican and its 'piety,' Ael. iii. 23. Cf. Horap. i. $54 \pi \epsilon \lambda \epsilon k a ̂ \nu a ~ \delta \epsilon$

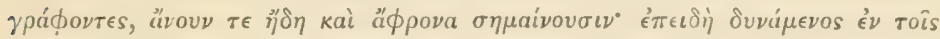

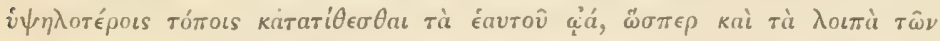

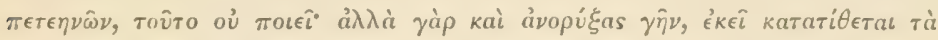

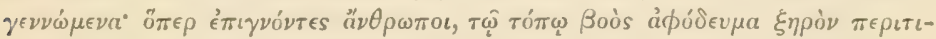

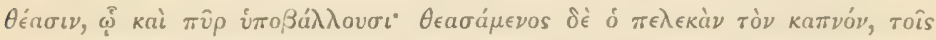

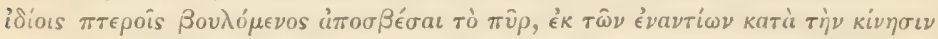

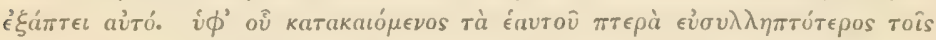

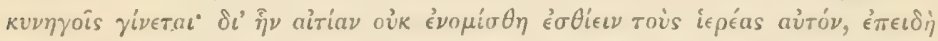

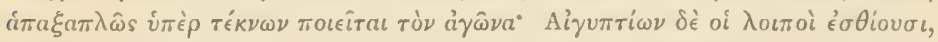

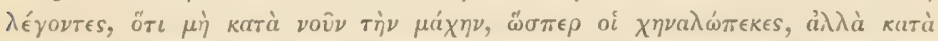

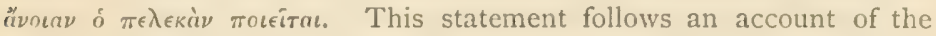
parental affection of $\chi \eta \nu a \lambda \omega \imath \eta \xi$; Lauth (Sitzungsb. Bayer. Akad., I 876 , p. I05) shows that it is in part based on a confusion between two Egyptian words, chemi, 'a pelican,' and chemi, 'ignorant.' The parental affection of the Pelican is frequently referred to by the Fathers: cf. 
TEAEKAN (iontimuct).

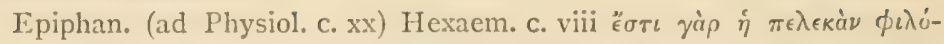

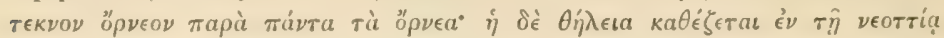

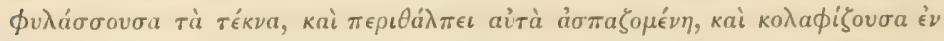

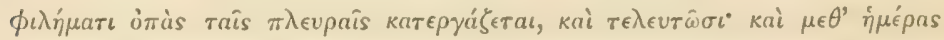

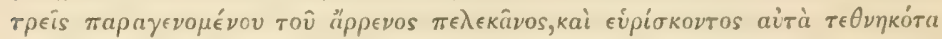

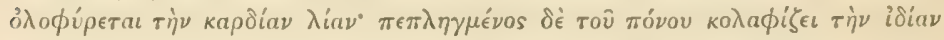

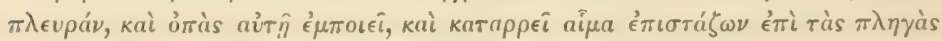

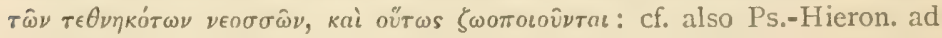
Praes. de Cer. Pasch. v. p. I 49 (ed. I693), Isid. Orig. xii. c. 7, Glycas, Annal. i. p. 44, S. August. in Ps. cii, \&c., \&c. A confusion with certain Woodpecker-myths (cf. $\pi \epsilon \lambda \epsilon \kappa \hat{s}$ ) may be one of the various sources of these corrupt but popular stories.

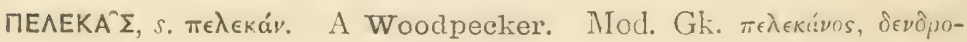

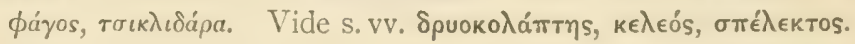

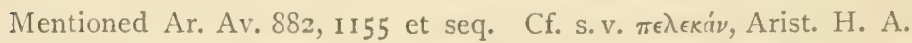

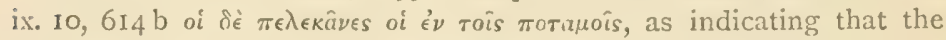
same word applied to the two different birds. Cf. Suid. (verb. q. del.

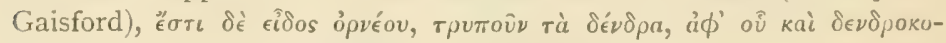

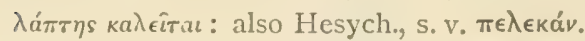

In the version of the Itylus-myth, given by Boios ap. Anton. Lib. c. xi, Polytechnus, the husband of Aëdon, is metamorphosed into the bird $\pi \epsilon \lambda \epsilon \kappa a ́ \nu$, the brother of Aëdon being transmuted at the same time

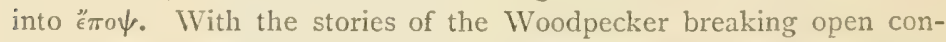

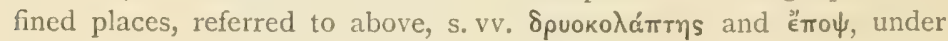

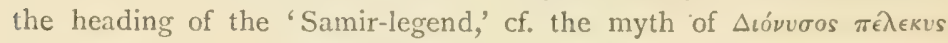
(R. Brown, Dionysiac Myth, i. p. 332, ii. p. 81).

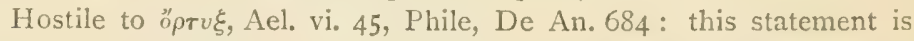
generally referred to the Pelican, but it more probably refers to the Woodpecker, that bird and the Quail being both alike associated with solar myths.

\section{MEAEKINNOE.}

In Dion. De Avib. ii. 6, and probably therefore also in Ar. Av. S82, a Pelican.

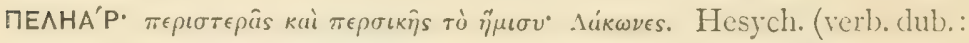
cf. Schmidt in Hesych.).

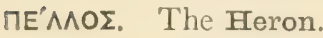

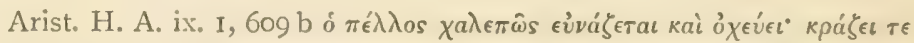

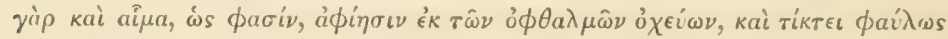

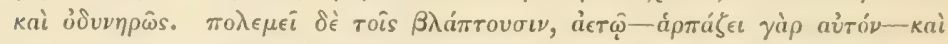

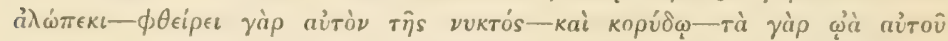

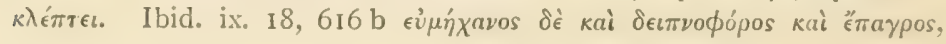




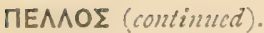

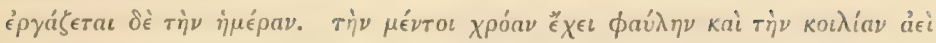
ípáv. Cf. Plin. x. (60) 79.

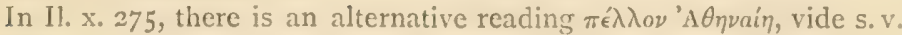

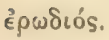

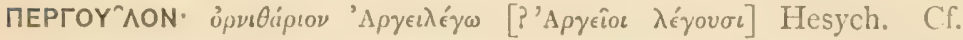

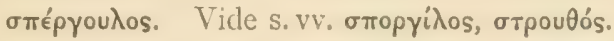

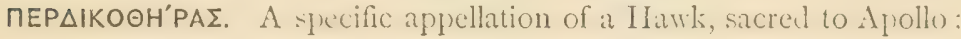
Ael. xii. 4 .

$\Pi E^{\prime} P \triangle I \equiv$. (On the guantity of the, vide Athen, ix. \& $\mathrm{I}, 383$, and Soph. fi: 300 , ibi cit.).

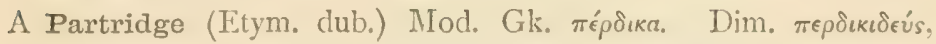

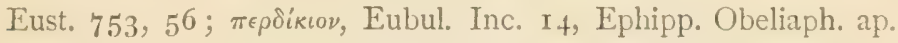
Athen. ix. 359 b, \&c. The species commonly referred to is Perdix graeca $=P$. saxatitis, auctt., the Common Partridge, $P$. cinerea, being distinguished from it chiefly by its note.

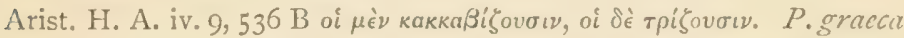
cries cacabis, $P$. cinerea on the other hand girrah or ripipri. The latter bird, our common Partridge, is now confined to the north of Greece. Cf. Athen. ix. 390 a, b : Theophr. ap. Athen. 1. c. of ' $\Delta \theta \dot{\eta} \nu \eta \sigma \iota$

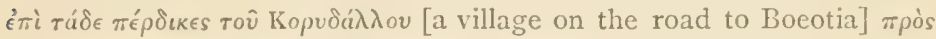

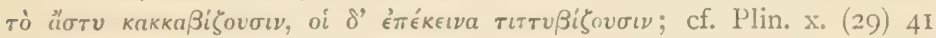
Perdices non transvolant Boeotiae fines in Atticam; Solin. vii. 23.

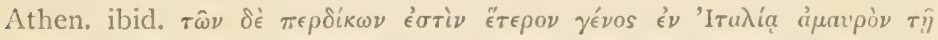

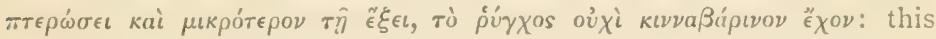
seems to be again the common Partridge. The red legs of the Greek

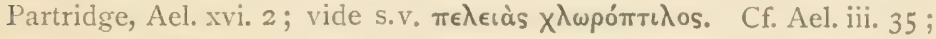

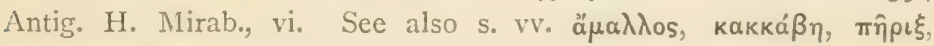

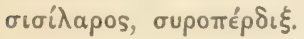

Description. - An epitomized account, mostly after Arist. (fr. 270), in

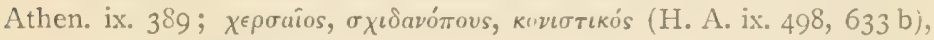

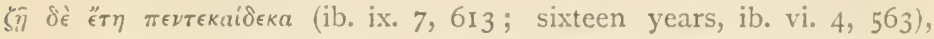

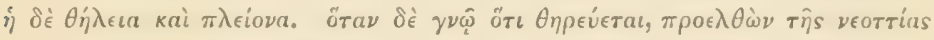

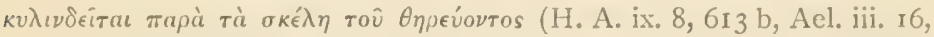
Plut. ii. 992 B, Antig. H. Mirab. 39 (45), Plin. x. (33) 5I; cf. verb.

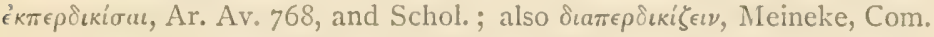

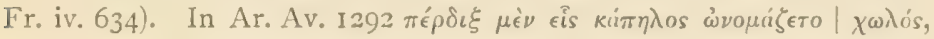
the allusion is rather to its supposed habit of feigning lameness, than mercly, in a general way, to the bird as a proverbial deceiver; $\mathrm{cf}$. Prov.

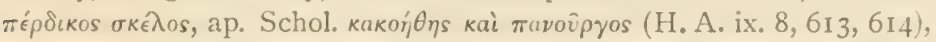

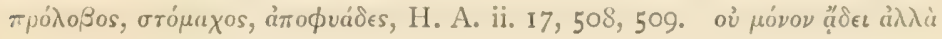




\section{MEP $\triangle I$ (continued).}

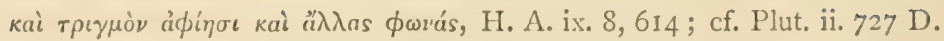
$\mu \in \tau a \beta a ́ \lambda \lambda \epsilon \iota$ тò $\chi p \hat{\omega} \mu a$, De Color. 6. 798 ; albino variety, De Gen. v. 785 b.

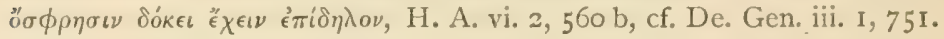

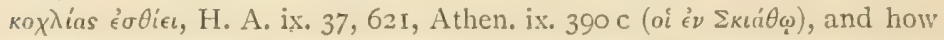
the snails (oi $\kappa a \lambda$. a $\rho$ eioves) to elude them leave their shells behind, Ael. x. 5. ó $\dot{\eta} \gamma \epsilon \mu \grave{\omega} \nu \tau \hat{\omega} \nu$ à $\gamma \rho \hat{i} \omega \nu$, of $\chi \hat{\eta} p o \iota$, Athen. 1. c., Arist. H. A. ix. 8, 6I 4.

Nest and Breeding Habits.-Lays ten to sixteen eggs (Arist. H. A.

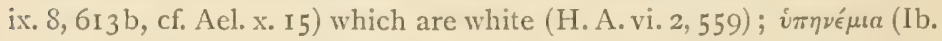

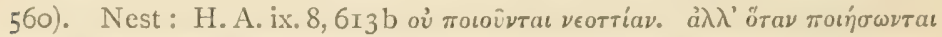

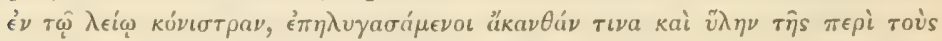

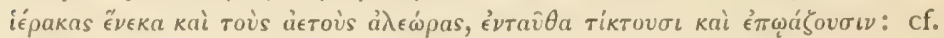
Ael.iii. 16, x. I5 ; Plin. x. (33) 5 I ; Ovid, Met. viii. 258. Arist. H. A. vi. 8,

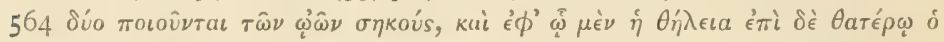

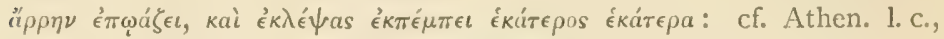
Antig. H. Mirab. IOI (IIO). Hence, perhaps, the allusion in Ar. Av.

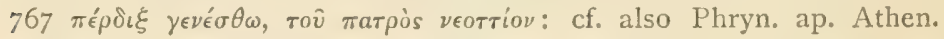

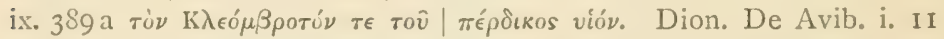

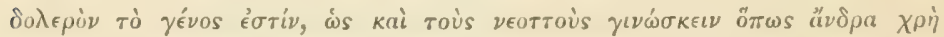

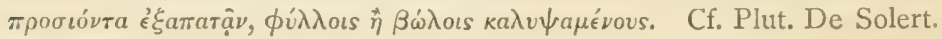
An. p. 971 .

Its salacity. De Gen. ii. 746 b, iii. 749 b, Ael. iv. I, vii. I9, \&c., \&c.

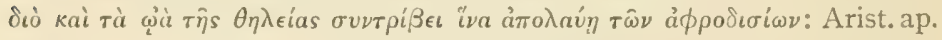
Athen. 1. c., Ael.iii. 5. (With this and similar fables, cf. Jerem. xvii. II).

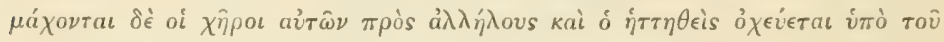

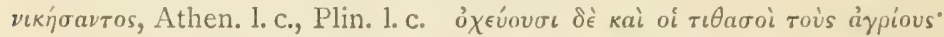

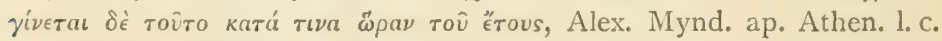

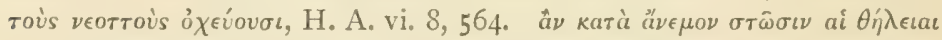

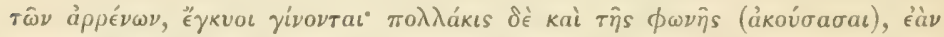

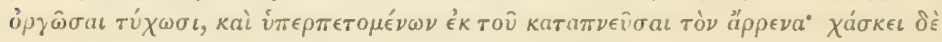

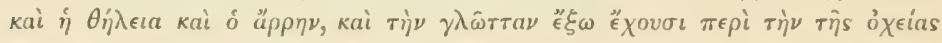
$\pi \circ i \eta \sigma \iota$, H. A.v. 5, 54I; cf. De Gen. iii. i, 75I, Ael. xvii. 15, Antig. H. Mirab. 8I (87), Athen. 1. c., Plin. l. c., \&c.

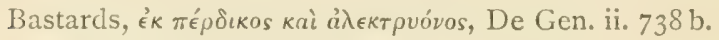

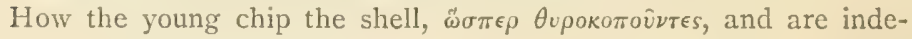
pendent from the first: Ael. iv. I2.

Capture and Domestication.-Decoy partridges, Arist. H. A. ix. \&, 6i4, vi. 2, 560 b, Ael. iv. I6, Xen. Mem. ii. I. 4. Various modes of capture, Dion. De Avib. iii. 7 ; cf. Simm. Rh. iv, Gk. Anthol. i. p. 137

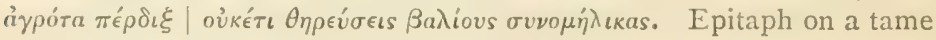

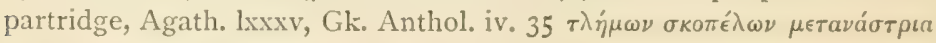
$\pi \epsilon ́ \rho \delta \_\xi$ (also others by Democharis, \&c.).

The sport of partridge-fighting (still practised in the Greek Islands), and how the females are kept at hand to stimulate the courage of the 


\section{MEPAI (contimuci).}

combatants, Ael.iv. I. How the Cirrhaean (Phocian) Partridges, which can neither fight nor sing, deliberately starve themselves in order to be unfit for food also: but the singing and fighting birds deliver themselves up rather than be slain: Ael. iv. 13; cf. Athen. ix. 390. An Egyptian dwarf who imitated partridges in their cages, Philostorg. $x$. II (cf. J. E. B. Mayor in Juv. viii. 33).

The Partridge as food, Mart. Ep. iii. 58, 15, xiii. 65, 76, \&c.

Myth and Legend.-(Besides the stories already told under the head of Brecding-habits, supra).

On tépótkes in the wars of the Cranes and Pygmies; Basilis and Menecles, ap. Athen. ix. $39 \mathrm{cb}$.

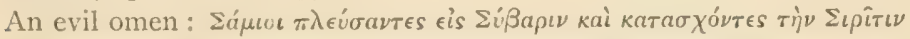

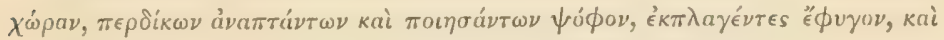

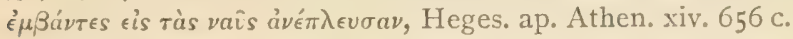

A fabled metamorphosis of Perdix, son of Daedalus, Hygin. Fab. 274, Ovid, Met. viii. 236-260. This subject is discussed in a curious essay by Gerland, Ueber die Perdixsage, Halle a. S., I87I. The writer identifies Perdix with the Lapwing.

Sacred to Zeus and Latona, Ael. x. 35 .

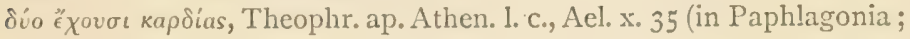
cf. Plin. xi. 70).

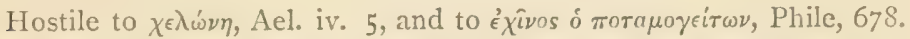
Friendly to $\epsilon \lambda a \phi o s$ (hence a stag's head used as a decoy), Dion. De Avib. i. II; to фátra, Ael.v. 48.

Use кá $\lambda a \mu u s$ as a remedy, Ael. i. 35, Phile, 723, Geopon. xv. I ; also opífavov, Ael. v. 46, or a leaf of laurel, Plin. viii. 27 , or the herb variously known as perdicium, helxine, sideritis or parthenium, Plin. xxi. (I6) 62 ; xxii. (17) 19.

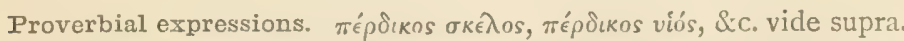

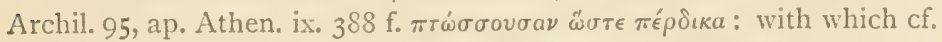

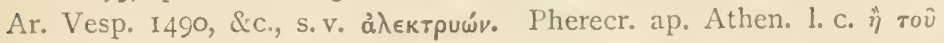

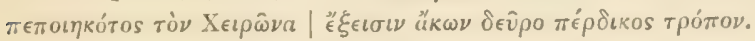

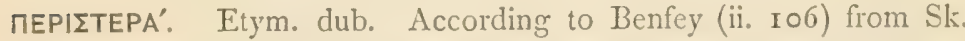
prî, 'to love'; a derivation not much more convincing than

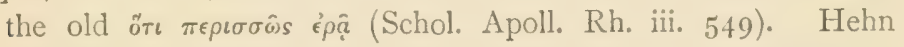
(Wandering of Plants, \&c., Eng. ed. p. 484), and others compare O. Slav. pero, 'a feather,' prati, pariti, 'to fly.'

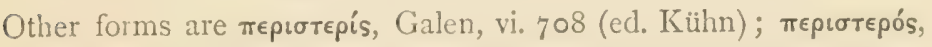

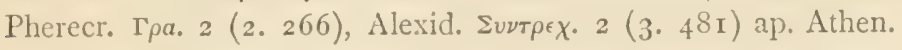
ix. 395 a, b; Eustath. Hom. p. I 7 I 2 ; a form censured by Lucian, Soloec. 7 ; cf. Lat. columbus, Varro, De L. L. ix. 38. Dim. 


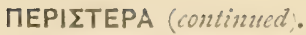

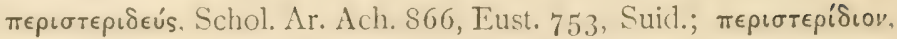

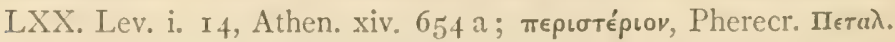

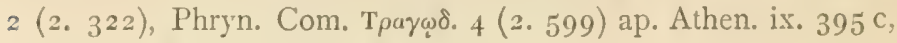
xiv. $65+$ b, \&c. (vide Meineke).

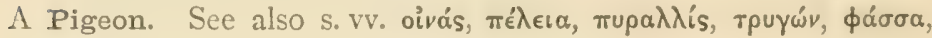
фáł.

First mentioned in Charon ap. Athen. ix. 394 c, and Herod. i. I38; in Attic, first in Sophocles, then in the Comic Poets and Plato.

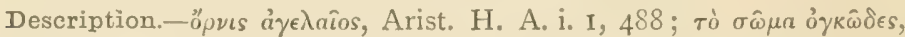

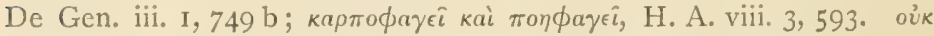

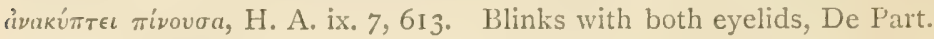

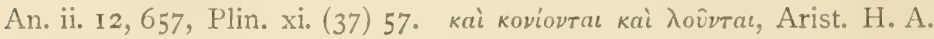
ix. $49 \mathrm{~B}, 633 \mathrm{~b}$; does not migrate, Ib. viii. 3, 593, $597 \mathrm{~b}$. Lives to eight years old (when blinded as a decoy) Ib. ix. 7,613 , Plin. x.

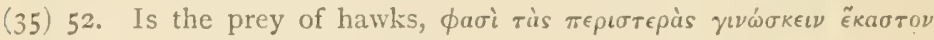

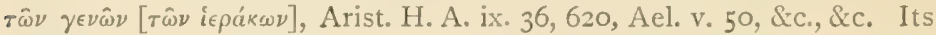

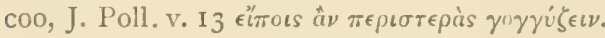

How pigeons purge themselves with the herb helxine, Plin. viii.

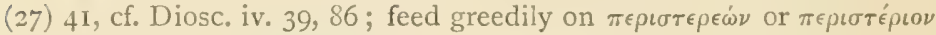
(verbena), Plin. xxv (I0) 78, Diosc. iv. 60, Nic. Ther. 860 and Schol.; and on the white seeds of Helioscopium, Plin. xxvi. (8) 42.

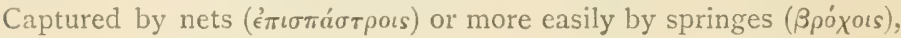
Dion. De Avib. iii. I2.

Anatomical particulars.-Arist. H. A. ii. I5, $506 \mu \iota \kappa \rho \dot{\nu} \nu ~ " ̈ \chi \epsilon \iota ~ \tau \dot{\partial \nu ~}$

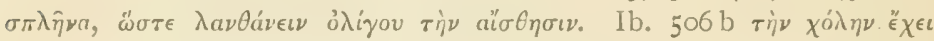

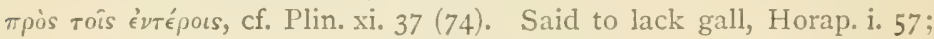
see also Clem. Alex., Paedag. i. 15, Isidor. Orig. xii. 7, 6r, and many mediaeval naturalists and poets, e. g. Walther v.d. Vogelıv. xix. I 3 rôs âne dorn, ein tûbe sunder gallen; cf. Hamlet, ii. 2. Galen, De Atra Bile 9, states correctly that the Pigeon possesses gall and merely lacks

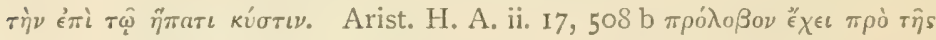

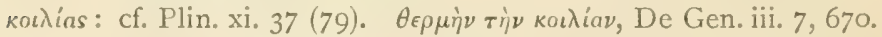

Her wings are covered with silver, and her feathers with yellow

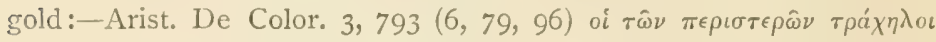

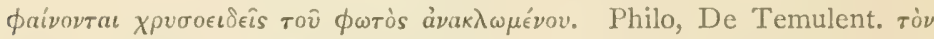

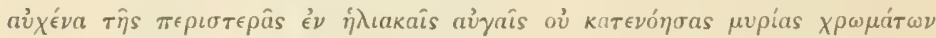

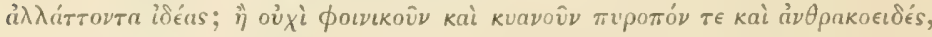

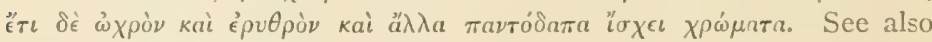
Ael. Promot., 480 a, cit. Rhein. Mus. xxviii. p. 277, 1873. Cf. Lucret. ii. Sor Pluma columbarum quo pacto in sole videtur, Quae sita cervices circum collumque coronat; et seq. See also Cic. Acad. Pr. ii. 25 in columba plures videri colores, nec esse plus uno; Nero ap. Senec. Q. 
MEPISTEPA (continued).

Nat., i. 5, 6 colla Cytheriacae splendent agitata columbae; Plin. x. (36) 52 nosse credas suos colores varietatemque dispositam; id. xxxvii. 5 (I8); Auson. Epist. iii. 15. The young birds are plainer and darker in colour, Arist. De Gen. v. 6, 785 b.

Nesting and Breeding Habits. - Arist. H. A. vi. 2, $560 \mathrm{~b}$ kuvov̂ơ

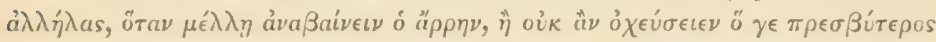

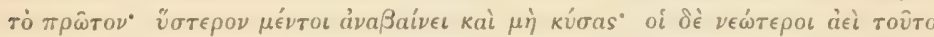

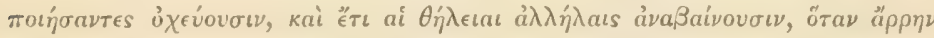

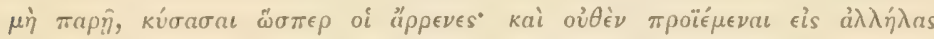

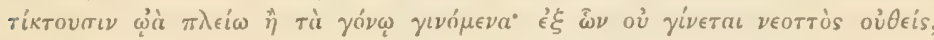

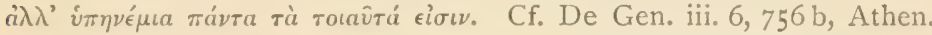
ix. 394 d, Ael. V. H. i. 15, Dion. De Avib. i. 25, Plin. x. 58 (79); Ovid, Am. ii. 6, 56 oscula dat cupido blanda columba mari.

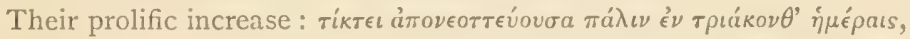

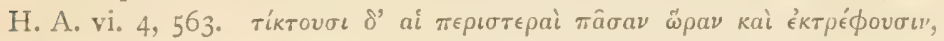

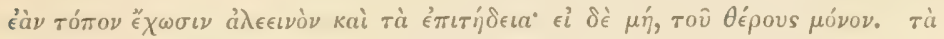

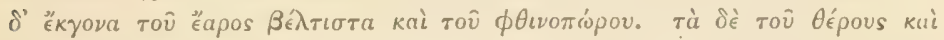

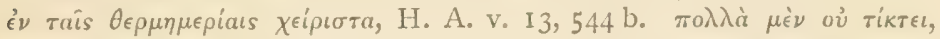

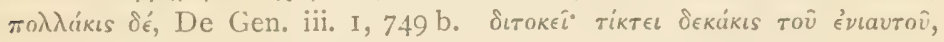

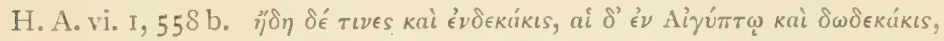

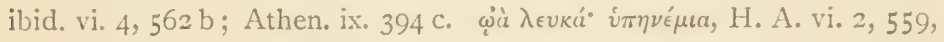

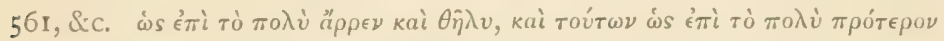

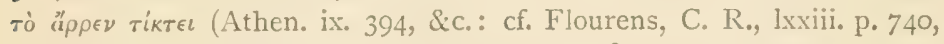

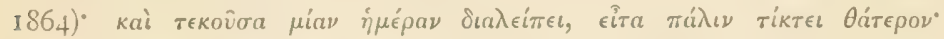

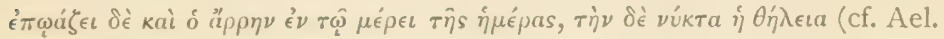

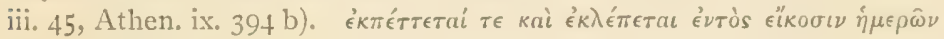

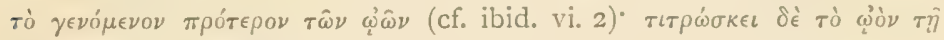

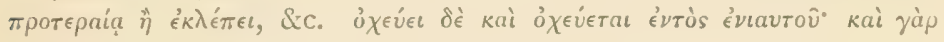
$\tilde{\epsilon} \kappa \mu \eta \nu o s$, H. A. vi. 4, 562 b : cf. Arist. fr. 27 I, 1527.

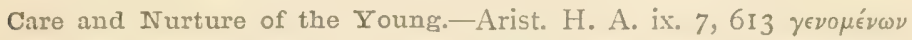

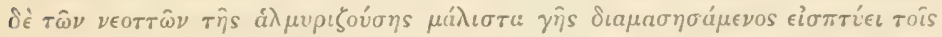

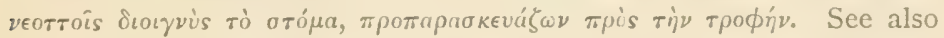
Ael. iii. 45, Athen. ix. 394 f, Plin. x (34) 52 ; hence the variant in Athen.

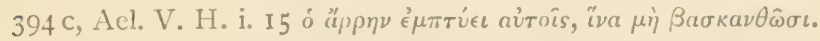

For other particulars regarding nesting, incubation, care of the young, \&.c., see Arist. H. A. vi. I, 558, 2, 560, 8, 564, ix. 7, 612: De Gen. iii. 6, 756 b, iv. 6, 774; Athen. ix. 39t; Geoponic. xiv. I, 2, xvi. I, 3 ; Plin. $x$ (53) 75, (58) 79, (6o) So ; Varro, De R. R. iii. 7, 9, \&.c. ; Colum. R. R. viii. 8 , 5 ; Eustath. p. I7I2, \&c., \&c.

Conjugal Affection and Chastity.-Arist. H. A. ix. 7, 612 b oút $\epsilon$ jå $\rho$

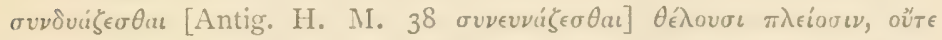

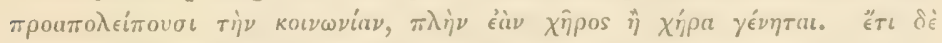

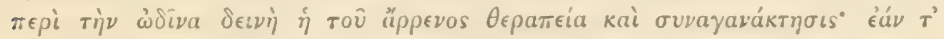




\section{MEPIITEPA (continued).}

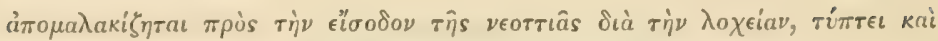

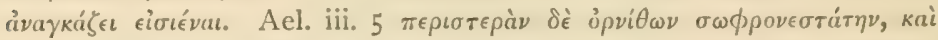

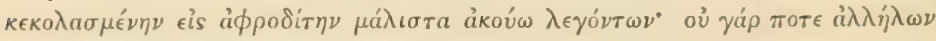

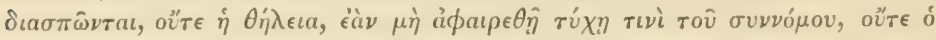

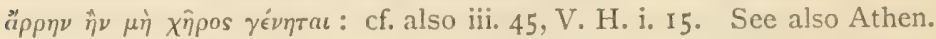
ix. 394, Antig. H. M. 38 (44), Dion. De Avib. i. 25, Porphyr. De Abst. iii. 10, Plin. x. (34) 52, Propert. ii. I5, 27, \&c., \&c. Hence, in Egypt, a black dove a symbol of perpetual widowhood, Horap. ii. 30 .

Its simplicity and harmlessness (ákepaıoúv $)$ Matt. x. I6; cf. Cyrill.

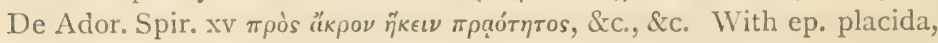
Ovid, Met. vii. 369, cf. Hor. Epist. i. Io, 4, \&c., \&c.

As Epithets, $\pi \epsilon \rho \iota \sigma \tau \rho a ́$ and $\phi a ́ \sigma \sigma \alpha$ are applied to a wife and mistress, Artemid. Oneir. ii. 20 ; similarly Lycophron calls Helen $\tau \rho \eta \dot{\eta} \rho \nu$ (Cass.

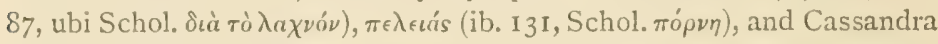
(ib. 357) фí $\sigma \sigma a$. In Lat. Columba is very frequent as a term of endearment, Plaut. Cas. i. 50, Asin. iii. 3, I03, \&c., \&c., while palumbes, Id. Bacch. i. I, I7 appears in the sense of lover, and turtur, Bacch. i. I, 35 in that of mistress.

Varieties.-Aristotle enumerates the following names or varieties

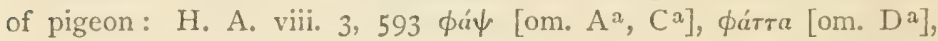

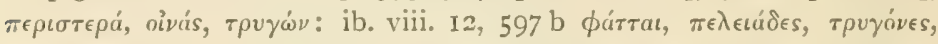

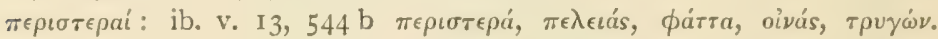

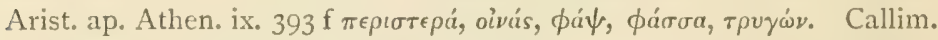

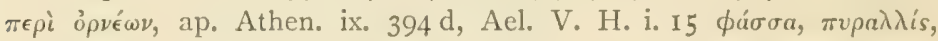

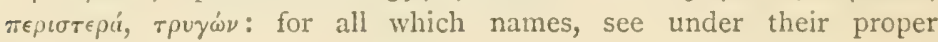
headings.

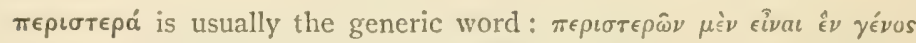

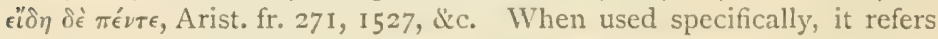
to the Domestic Pigeon, Columba livia, var. domestica: Arist. H. A.

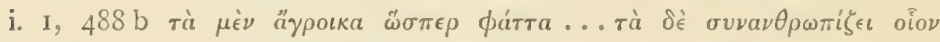

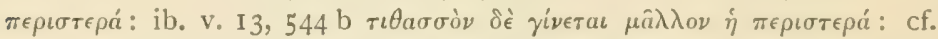

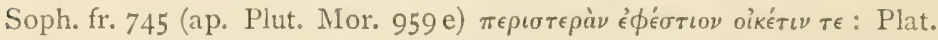

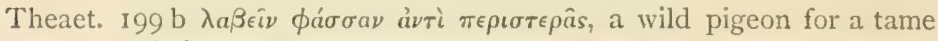

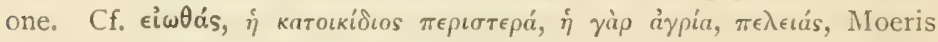
(p. 405, ed. Koch, 1830); with which cf. Themist. Or. xxii. p. $273 \mathrm{C}$ ou

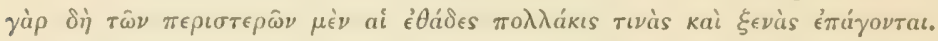
In its generic use it appears, e.g., in the statement that in cities $\pi \epsilon \rho t \sigma \tau \epsilon \rho a i$ are tame, in country districts very wild, Ael. iii. $15 \pi \epsilon \rho \sigma \tau \tau \rho a i$

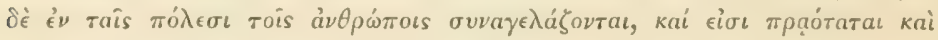

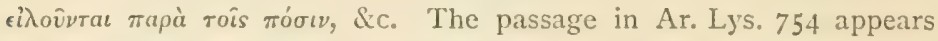
to refer to the extreme familiarity of the city-pigeons.

White pigeons : first seen in Greece near Athos, during the Persian War, Charon ap. Athen. ix. 394 d, Ael. V. H. i. I5; though white 
ПEPIITEPA (continuce).

pigcons were not honoured in Persia, being deemed hostile to the Sun, Herod. i. I38; the white doves had probably been the property of Phoenician, Cilician, or Cypriote sailors (Hehn). On white pigeons,

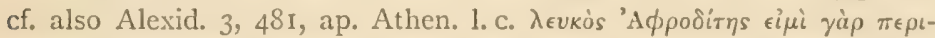
otepós: see also Varro, De R. R. iii. 7, Ovid, F. i. 452, Ep. xv. 37, Met. ii. 537, xiii. 674, xv. 715, Martial, \&c. The white pigeons were apparently the sacred race of Babylon, which afterwards spread to Syria and to Europe: cf. Hehn, Culturpf. p. 279, Engl. ed. p. 258; they are still numerous in Damascus (cf. Thomson, Land and Book, p. 27I). Galen distinguishes between the кaтoเкíoto

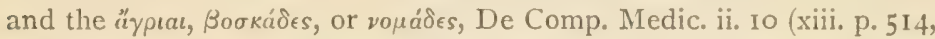
ed. Kühn), cf. De Simpl. Med. Temp. x. 25 (xii. p. 302); for the latter, dove-cotes were built in the fields near Pergamus. Varro, De R. R. iii. 7 gives a similar account: agrestes maxime sequuntur turres, in quas ex agro evolant, suapte sponte, et remeant. Alterum genus illud columbarum est clementius, quod cibo domestico contentum intra limina ianuae solet pasci. Hoc genus maxime est colore albo. There

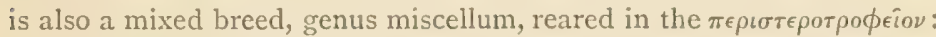
cf. Ovid, Heroid. xv. 37 et varis albae iunguntur saepe columbae. See also on the care of domesticated and half-domesticated pigeons, Colum. De R. R. viii. 8, Pallad. i. 24, Geopon. xx.

Homing or Carrier-Pigeons.-Pherecr. fr., ap. Athen. ix. 395 b ảtó-

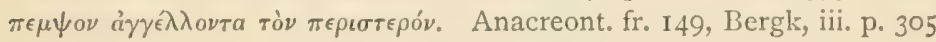
(ed. 4) 'А

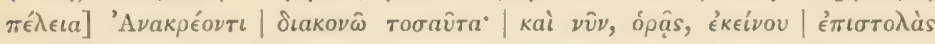
$\kappa о \mu i \zeta \omega$. A message sent from Pisa to Aegina, by Taurosthenes, a victor in the Olympian games, to his father, Ael. V. H. ix. 2. Cf. Varro, De R. R. iii. 7, 7 columbas redire solere ad locum licet animadvertere, quod multi in theatro e sinu missas faciunt. Pigeons sent into the Consuls' camp by Dec. Brutus at the siege of Mutina, Plin. $x$. (53) 37 ; cf. Frontin. Strategem. iii. 13, 8. See also Mart. Epigr. viii. 32 , \&c., \&c.

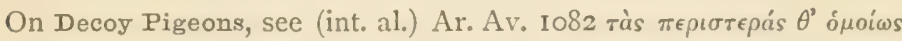

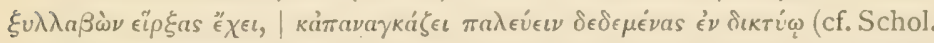

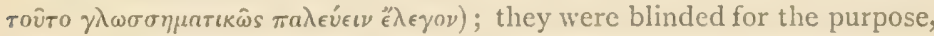

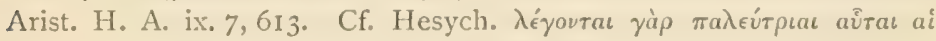

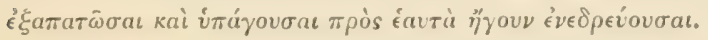

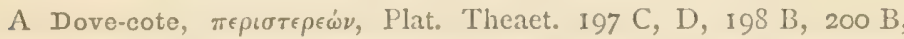

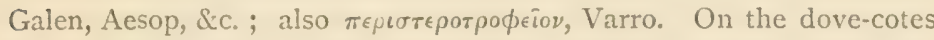
in Herod's garden at Jerusalem, $\pi \dot{v} \rho \gamma o \iota \pi \epsilon \lambda \epsilon \iota \dot{\delta} \delta \omega \nu$ ij $\mu \dot{\epsilon} \rho \omega \nu$, Joseph. De Bell. Jud.v. 4, 4. Great dove-cotes are still conspicuous objects in many parts of the East; they are very numerous and large, for instance, in Tenos, the modern site of the Panhellenic shrine and festival (cf. Bent, 


\section{MEPIITEPA (continued).}

Cyclades, 1885, p. 253). On the construction of dove-cotes, their internal niches (

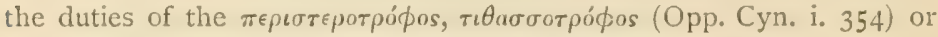
pastor columbarius, on charms to keep the birds from straying, \&.c., \&c., see Varro, Columella, Palladius, and Geoponica, loc. citt. For references to dove-cotes, see also Ovid, Met. iv. 48 albis in turribus; id. Tr. i. 4.7 aspicis, ut veniant ad candida tecta columbae, Accipiat nullas sordida turris aves; Mart. xiii. 3 I quaeque gerit similes candida turris aves.

According to Varro, a pair of full-grown pigeons was worth from 200-1000 sesterces; and L. Axius had purchased a pair of a dealer for 500 denarii.

The Sacred Doves of Venus or Astarte. Pigeons were sacred in the eyes of the Syrians, like the fishes of the river Chalos, Xen. Exp. Cyr. i. 4, 9; they were kept in great numbers at Ascalon, Ctes. ap. Diodor. ii. 4, Philo ap. Euseb. Prep. Evang. viii. 14, 64 (cf. the Dove on coins of Ascalon, Eckhel, Doctr. Numm. iii. p.445); and at Hierapolis, Lucian, De Syr. Dea, c. 14, where the statue of Atargatis had a gold dove on her head, Lucian, ibid. c. 33. On Venus' doves, see also Virg. Aen. vi. 190, Ovid, Met. xiv. 597, Fulgent. Mythol. ii, \&c., \&c.

On the doves in Palestine, cf. Tibull. i. 7, I7 Quid referam, ut volitet crebras intacta per urbes Alba Palaestino sancta columba Syro? cf. Hygin. Fab. I97, Lucian, De Syr. p. 9I2, Joseph. loc. cit., Clem. Alex.

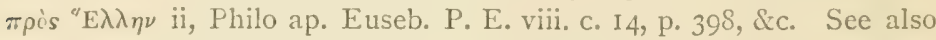
the account given above of the introduction of white pigreons into Greece, and compare the sanctity of the bird in modern times at Mecca, Constantinople, Venice, Moscow, \&c. On the cult of Doves in Syria, cf. Broeckhuis, ad Tibull. 1. c.

The cult of the goddess, carried from Ascalon to Cyprus (Herod. i. 105, Pausan. i. 14, 7), brought thither the sacred doves; cf. Antiphon.

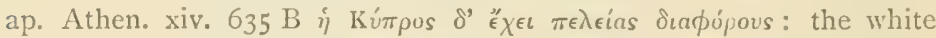
Paphian doves, Martial, viii. 28, I3, cf. Nemes. fr. De Aucup. 22 ; see also Eustath. Hom. I1. p. I035. See also Fr. Münter, Die himmlische Göttin zu Paphos, p. 25.

As evidences of the cult in islands of the Aegean, ct. the Dove on coins of Seriphos and Siphnos, and the ancient dove-cotes still standing on the latter island. On figures of Astarte with the Dove, see (int. al.) Lenormant, Gaz. Archéol. 1876, p. 133; de Longpérier, Mus. Napol. iii. pl. xxvi. 2, \&ec., \&c.

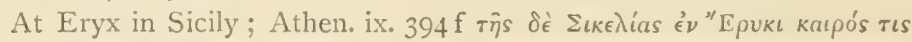

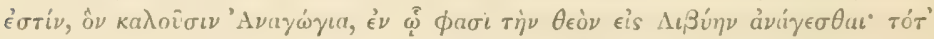

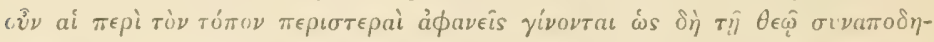

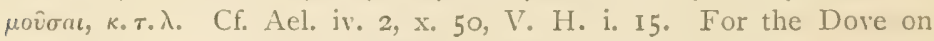
a silver coin of Eryx, see Du Mersan, Méd. inédites, Paris, 1832, p. 57. 
MEPIITEPA (continued).

Sicilian doves mentioned, Alexis and Nicander, frr. ap. Athen. ix. 395 b, c, Philemon, ibid. xiv. 658 b.

The story of Semiramis, forsaken as an infant by her mother Derceto, and fed by Doves in the wilderness, Ctes. ap. Diodor. ii. 4, 4, Ctes. fr. ed. Bühr, p. 393. Cf. Lucian, De Syr. Dea, ii. p. 885, Athenag. Leg. pro Christ. p. 156 (ed. Otto), Ovid, Met. iv. 47. Cf. Phornutus,

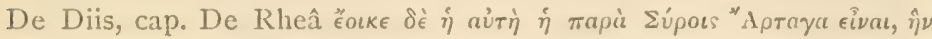

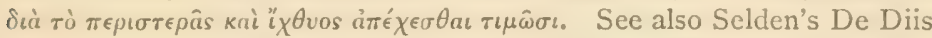

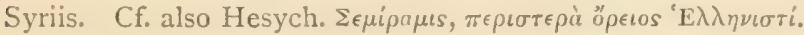

The Dove sacred also to Dione: Sil. Ital. iv. Io6 Dilectas Veneri notasque $\mathrm{ab}$ honore Diones Turbabat violentus [accipiter] aves.

The Dove in connexion with the Cyprian 'A $\delta$ 'sva, Diogen. ap. Gaisford, Paroem. i. Pref. p. 5. On the Dove in connexion with Aphrodite, see also Apollod. ap. Schol. Apollon. iii. 593.

How Doves hatched the egg from which Venus sprang, Hygin. Fab. I97; Theon, ad Arat. I31.

The Dove is not associated with Aphrodite in early Greek, unless, as is not likely, the obscure fragment of Sappho (Bergk 16 (8), Schol. Pind. Pyth. i. ro) indicate such an allusion. In later authors, the

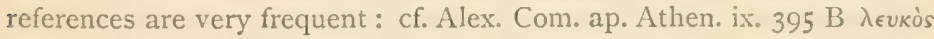

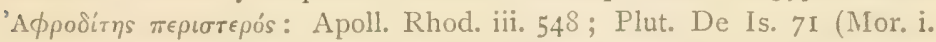
463), \&c., \&c. Cf. also Virg. Aen. vi. 192 tum maximus heros Maternas agnoscit aves; Sil. Ital. iii. 683 Cythereïus ales; cf. Nero ap. Senec. 1. c. On Venus' car with its team of Doves, cf. Ovid, Met. xiv. 597 ; Apuleius, Met. vi. 6, 393 ; Claudian, Epithalam. I04.

Venus and her Dove are associated with the month of April on the cylindrical Zodiac of the Louvre, \&c.: and the sign Taurus was the domus Veneris. This fact also has a direct reference to Pleiadsymbolism.

The Dove on the mystical monument of the 'Black Demeter' at Phigaleia, Paus. viii. 42, 3 .

As an instance of the Syrian Dove adopted into Christian worship, cf. Hefele, Concil. ii. 77 I : how the clergy of Antioch, A. D. 518, complained that Servius had removed the gold and silver doves that hung over the altars and font [note the apparent confusion of ideas in $\left.\kappa o \lambda v \mu \beta \eta \theta_{\rho} a\right]$, on the ground that the symbolism was unfitting. On the $\pi \epsilon \rho \iota \tau \dot{p}$ iov, or receptacle in the form of a dove for the Blessed Sacrament, cf. Chardon, Hist. des Sacram. ii. 242. On the sacred. symbolism of the dove, cf. also Euseb. H. E. vi. 29.

Various Legends.-How Zeus pursued the virgin Phthia in Aegium in the form of a Dove, Athen. ix. 395 a.

How Doves led the Chalcidians to Cumae, Philostr. Icon. ii. 8. 
MEPIITEPA (continued).

How a Pigeon caused a war between Chaonians and Illyrians, Ael. xi. 27.

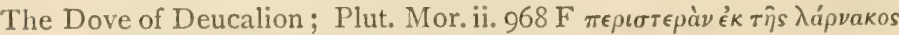

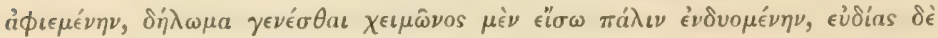

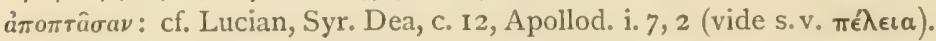

The Pigeon in Medicine.-For references to the therapeutic value of Pigeons' dung, flesh, blood, feathers, and other parts in cases of poisoning, burns. ulcers, jaundice, and most other ailments, sce Galen, De Simpl. Med. Temp. x, also Plin. iii. (6) 12, xxii. (25) 58, xxix. (6) 39, and $\mathrm{xxx}$, passim.

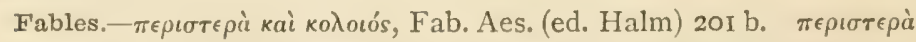

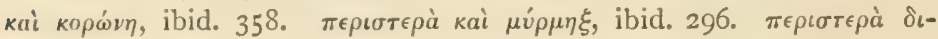
$\psi \omega \hat{\omega} \sigma a$, ibid. 357.

See also, in addition to articles cited S.v. $\pi \epsilon \epsilon \epsilon \iota, T$. Watters, Chinese Notions about Pigeons and Doves, N. China Br., R. As. Soc., iv. pp. 225-242, 1867. In this paper various resemblances are shown to exist between classical superstitions and Chinese popular notions, an important subject concerning which too little information is accessible. Among other points, the writer states that in Chinese legend the Dove is often confused with the Cuckoo, that the former as well as the latter bird is said to metamorphose into the Hawk, and that the Dove is said to lay in the Magpie's nest: these facts may have some bearing on

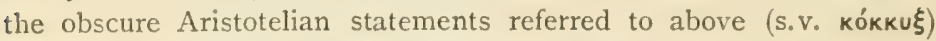
concerning the nesting of the Cuckoo in the nest of $\phi a \dot{\psi}$.

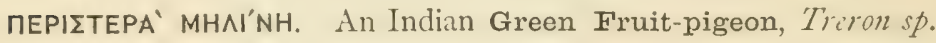

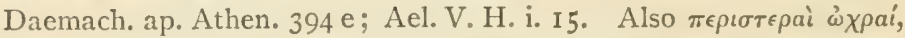

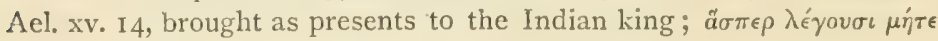

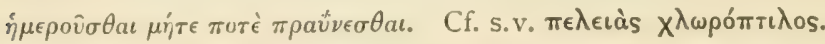

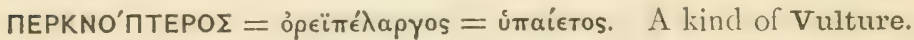

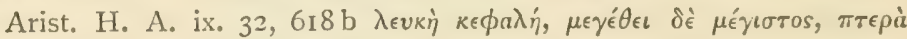

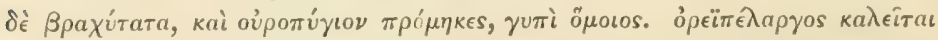

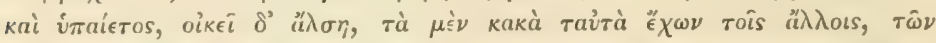

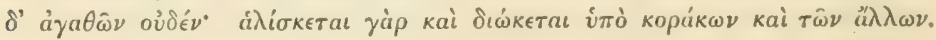

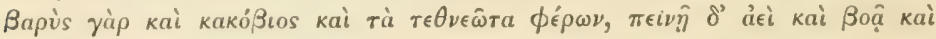

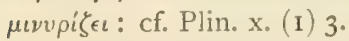

Of the three names, not one occurs elsewhere, save imaítos, Boios ap. Anton. Lib. c. 20 (loc. corr.). The description is insufficient, but agrees fairly, except as regards size, with the Egyptian Vulture; in which case the black and white plumage may explain $\pi \epsilon \rho \kappa \nu o ́ \pi \tau \epsilon \rho o s$, and, together perhaps with the stork-like nest, ópєïrє̇apyos.

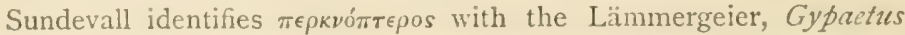

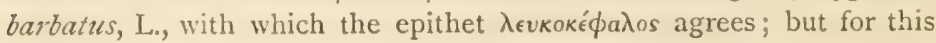


REPKNOMTEPOI (continued).

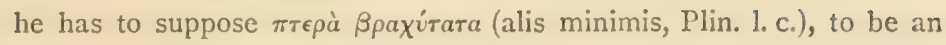

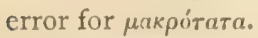

The Egyptian Vulture, Neophron percnopterus, L., Sav., though the black-and-white of its plumage might be associated with the name ó $\rho \ddot{\imath} \pi \epsilon \operatorname{\lambda a\rho \gamma os}$, and though a comparison might also be drawn with the Stork in connexion with the Egyptian stories of its parental

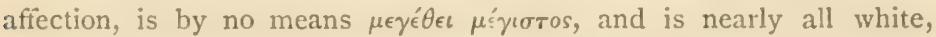
instead of merely on the head. In short, the bird is not to be clearly identified, and the passage, like much of its immediate context, is altogether obscure.

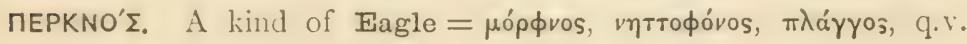
( $\pi \epsilon \rho к \nu o ́ s=\mu \epsilon ́ \lambda a s$, Suid.).

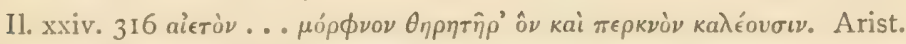

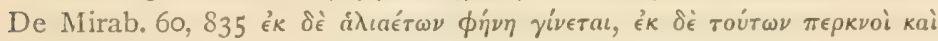
yîtes. Cf. Plin. x. (I) 3 ; Lyc. 260.

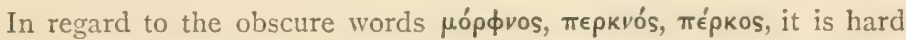
to be content with the Scholiastic explanations which treat them as mere colour-epithets: such an interpretation may or may not be true, and various facts suggest that there is more to be learned regarding

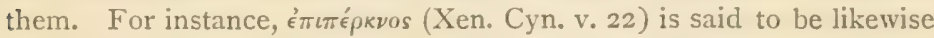
a mere colour-epithet (J. Poll. v. 67), but the relations between $\pi \epsilon \rho \kappa \nu$ s,

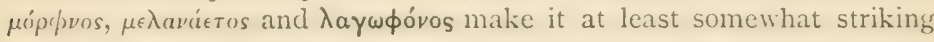

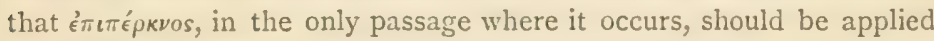
to the Hare.

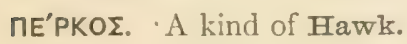

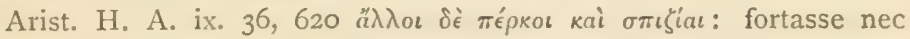

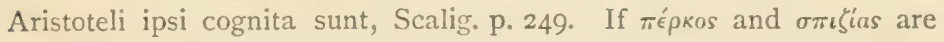
identical, the former, if it mean dark-coloured, agrees as an epithet with the traditional identification of the latter with the Sparrow-hawk.

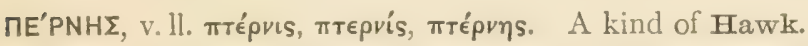

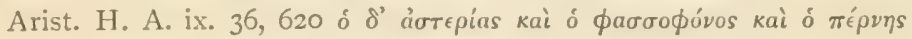

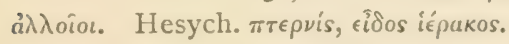

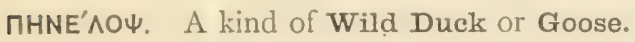

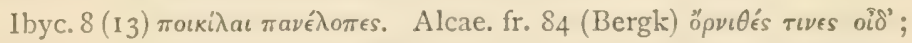

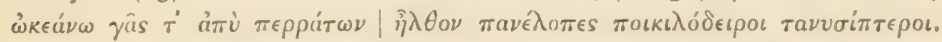

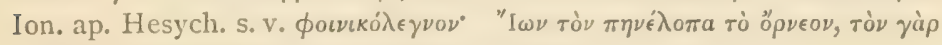

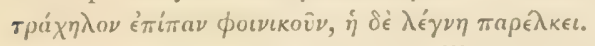

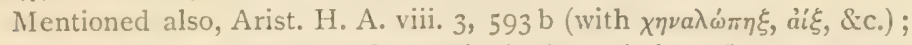

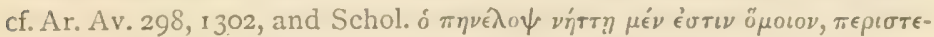

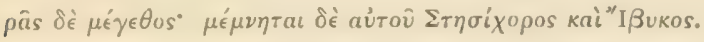

From the superficial resemblance of the name to $\chi \eta \nu a \lambda \omega \operatorname{\omega } \eta \xi, \chi \eta \nu a ́ \lambda a \psi$ 


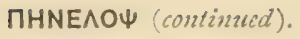

Hesych, and from its occurrence in some MSS. for the latter in Plin. x. (22) 29, it seems probable that both names are identical, and possible that both are corruptions of a foreign (Egyptian ?) word. The

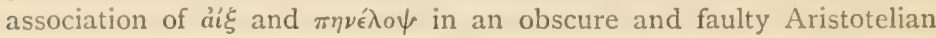
passage, may be a mere confusion arising out of the story of Hermes visiting Penelope in the form of a goat (cf. Creuzer, Symb. iii. p. 502); in which case ải should disappear from the list of bird-names.

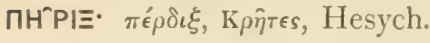

MIKos. A Woodpecker. Lat. picus; said to be an Oscan word.

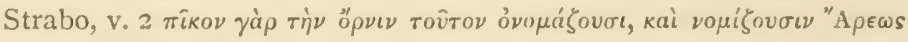
iepóv. See also Dion. Halic. i. 14. Cf. Ovid, F. iii. 37, \&c. Cf. also Grimm's D. Myth. p. 388, Creuzer's Symb. iii. 676, iv. 368.

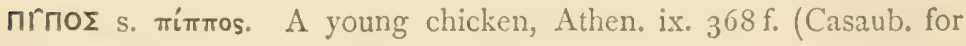
iтrovs).

$\Pi I \Pi \Omega^{\prime}$ (MISS. have also $\pi i \pi \alpha, \pi i \pi o s, \pi i \pi p a$. Some editors read " $\pi \pi \omega$, cf. ' $\pi \pi \eta)$. The Greater and Lesser Spotted Woodpeckers, Picus major and minor, L.

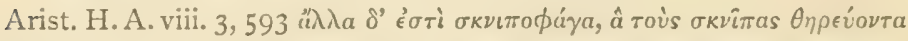

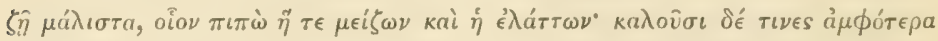

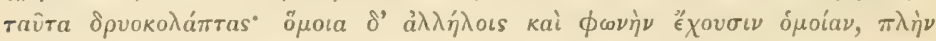

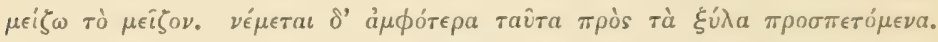

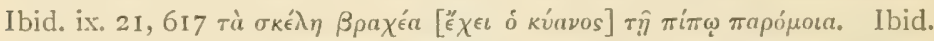

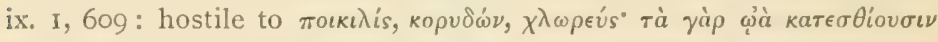

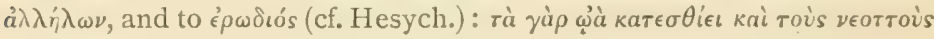

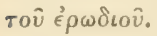

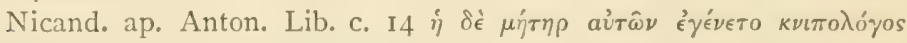

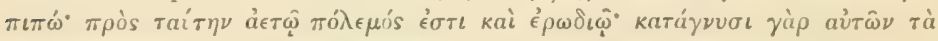

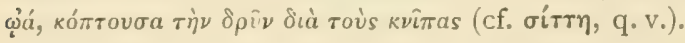

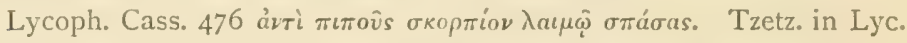

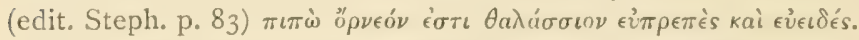

The above identification, setting aside the statement of Tzetzes, depends solely on the existence of two species of Spotted Woodpecker, similar in appearance, but unequal in size.

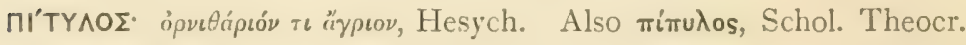
X. 50 .

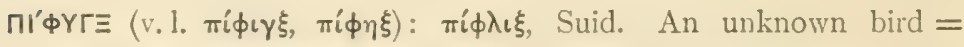

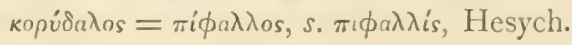

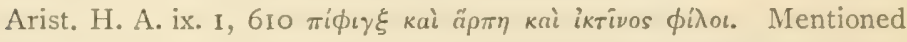
also by Boios ap. Anton. Lib. c. $\mathrm{xx}$, in a fabled metamorphosis, together

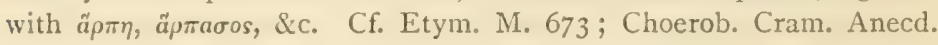


ПIфYГE (continued).

Oxon. ii. p. 245 ; Lob. Proll. p. 96. I cannot help thinking that the word is akin to $\phi \hat{\omega} \cup \xi$, and its allies.

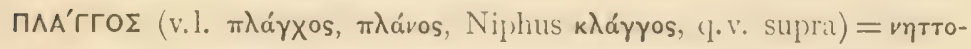
фóvos $=\mu$ ópфvos (Arist.).

$\Lambda$ kind of Eagle.

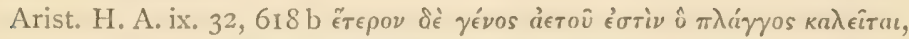

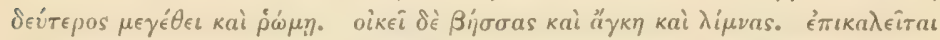

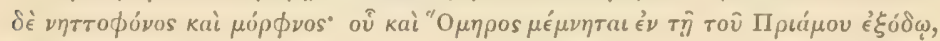
Il. xxiv. 316.

Plin. x. I Tertii generis morphnus, quam Homerus et percnon vocat, aliqui et plancum et anatariam, secunda magnitudine et vi : huicque vita circa lacus, Sc.

Commentators have given innumerable interpretations of this word. If it be really a concrete specific appellation, then the Spotted Eagle, Aquila naevia, fulfils the conditions best: it is large and powerful, but less so than the Golden Eagle; it frequents water, feeding partly on fish (especially on pieces of decomposing fish, cf. Shelley, Birds of Egypt, p. 206), and partly on waterfowl and sea-birds (cf. Buffon,

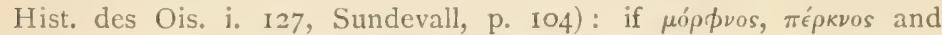
(?) $\kappa$ גáryos are to be taken as descriptive epithets (as they are by some), it is dusky, mottled, and noisy.

The passage quoted from Pliny is full of fables, and includes the story of the death of Aeschylus, which suggests rather the habits of the Lämmergeier (cf. s.v. ả€tós, Ael. vii. I6).

חOIKIAI' $\Sigma$. An unknown bird: taken by mediaeval writers (Belon, Aldrovandi, \&c.) for the Goldfinch, from the statement that it

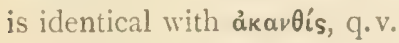

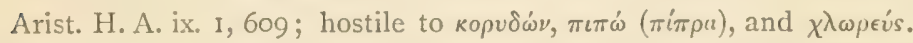
Schol. ad Theocr. vii. I I I (cit. Schn. in Arist. vol. ii. p. 5) ảka $\theta$ is $\delta \dot{\epsilon}$

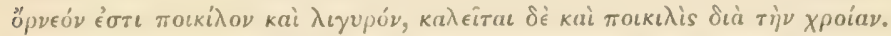

Поккіגos öpris was also an expression for the Peacock. Cf. Athen. ix. 397 C 'А

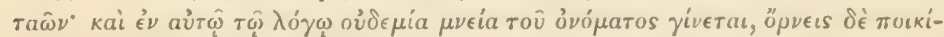

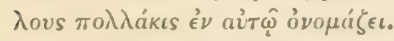

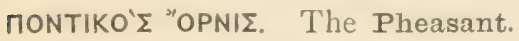

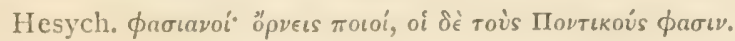

поРфүРІ' $\Sigma$. An unknown bird $=\lambda a \theta$ เторфupis.

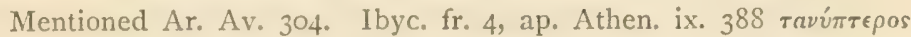

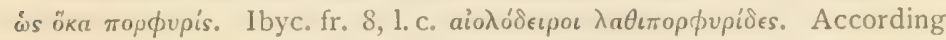

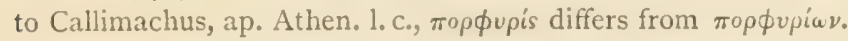


порфүрі'sN. The Purple Gallinule, P'orphyrio hyacinthus, Temm.

Mentioned Ar. Av. 707, 88I, 1249. Arist. fr. 272, ap. Athen. ix.

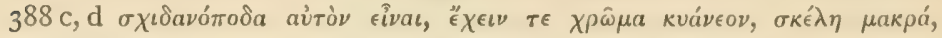

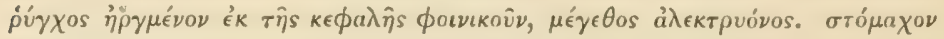

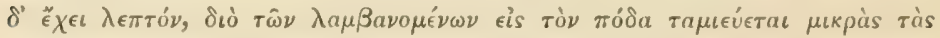

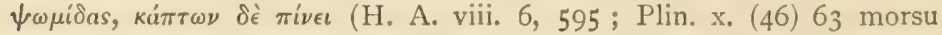

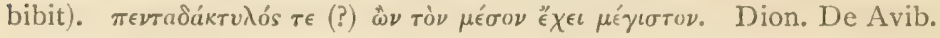

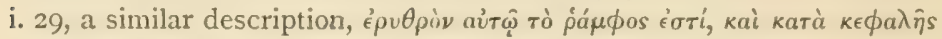

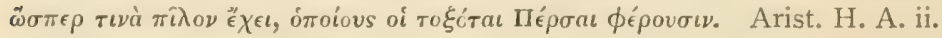

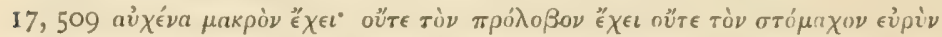

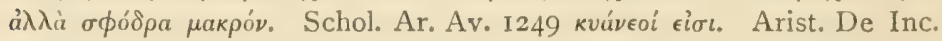

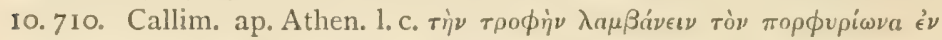

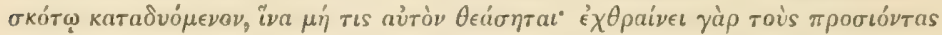

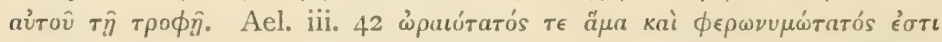

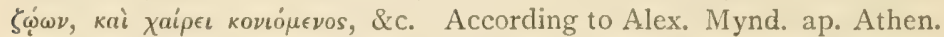
1.c., it inhabits Libya and is there held sacred. According to Plin. x. 63, it inhabits Commagene (Asia Min.) and a yet nobler sort (x.69) the Balearic Islands.

A bird of lofty morals and great vigilance, Polemon ap. Athen. 1. c., Ael. iii. 42, v. 28, vii. 25, viii. 20, xi. 15, Dion. De Avib. i. 29.

An easy mode of capture, Dion. De Avib. iii. 2 I.

The descriptions in Arist. fr. 272 and Dionysius clearly refer to the Purple Gallinule: that in Arist. H. A. ii. I7 is supposed by some (I think needlessly) to apply to the Flamingo, the Gallinule not having a very long neck. The bird occurs in Egypt and neighbouring countries: it is rare in Greece, but inhabits Lake Copaïs and Lake Dystos in Euboea (Erhard, 1.c., also Naumannia, I858, p. 21), though, according to other authorities (Von der Mühle, Heldreich, Krüper), nothing is known of its occurrence in Greece in recent times.

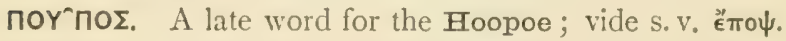

Anon. De Avibus et earum Virtutibus in Medicina (MS. cit. Du

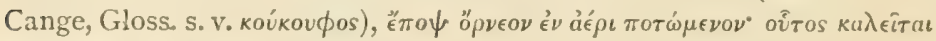

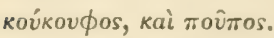

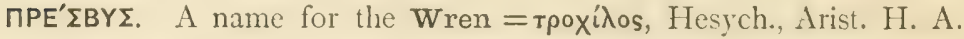
ix. I I, 6r5. In this word one is much tempted to suspect a transposition of letters, and to suggest, as a conjectural emendation,

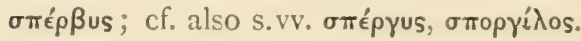

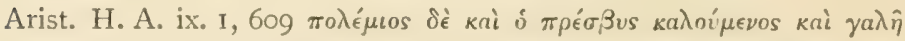

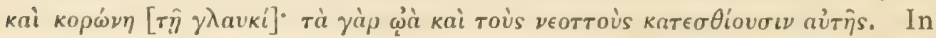

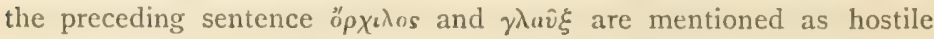
to one another. (Here Sundevall supposes the Jackdaw to be meant, on account of its egg-eating propensities, but the passage is mythological, not prosaic.) 


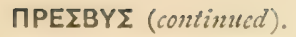

Cf. Plin. viii. 25 ; Munk, ad Anton. Lib. p. 100; Lob. Path. p. 132 .

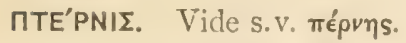

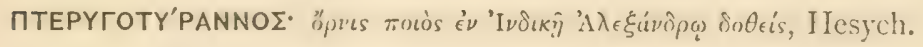

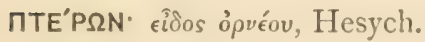

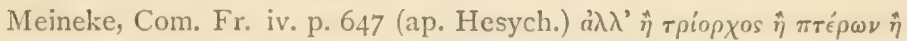
orpovtias. Cf. Etym. M. 226, 37, Theognost. 36. I9.

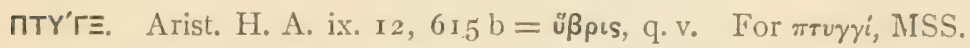

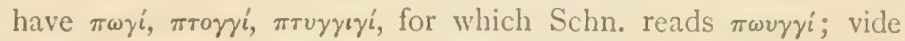

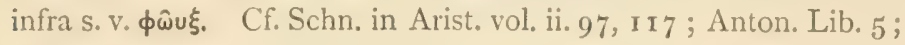
Etym. MI. 699, Io; Lob. Phryn. 72.

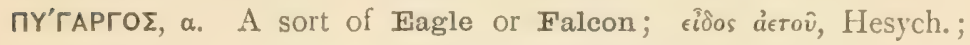
vide infra.

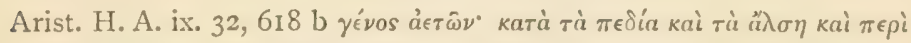

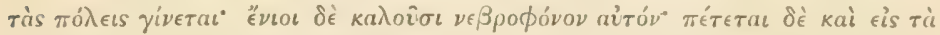

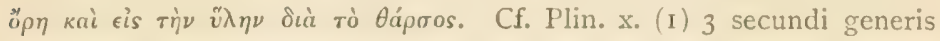
Pygargus, in oppidis mansitat et in campis, albicante cauda. Arist.

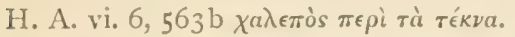

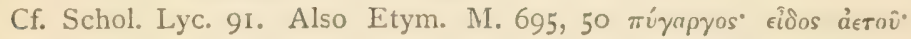

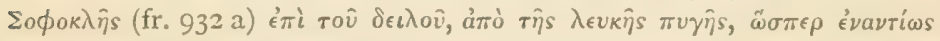
$\mu \in \lambda a \mu \pi \dot{\gamma} \eta \bar{s}$ àmò $\tau \hat{\eta} s$ í $\chi$ vpâs.

Note.-Circus cyaneus, L. ( $~(=$ Falco pygargus, L.), the Hen-harrier or Ring-tail, is now called ríyapyos in the Cyclades (Erhard, op. cit. p. 47). To it much of the description given is applicable, but certainly

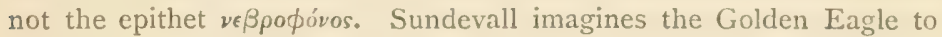
be meant, Gloger and others the White-tailed Eagle or Erne, Halicretus

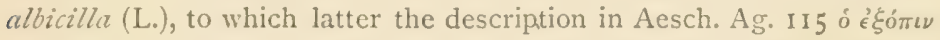
apyias, seems to apply: but these are surely excluded by the evidence as to size (cf. Pliny, l. c.), frequency, and affection for cities and plains. I incline to identify the bird with the Short-toed Eagle, Circaëtus gallicus, which in French, as perhaps also here, seems to share its popular name (Jean-le-Blanc) with $C$. cyanens. But the name was originally mystical (cf. s.v. $\mu \in \lambda a ́ \mu \pi u \gamma o s)$, however it may in later times have been specifically applied to a particular bird.

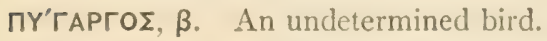

Arist. H. A. viii. 3, 593 b. A water-bird, mentioned with oxotvíos

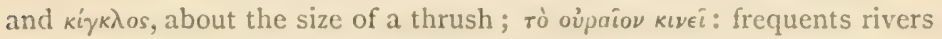
and streams.

The size agrees with Sunderall's suggestion of a Sandpiper. Aubert 


\section{MYTAPTOE (continucd).}

and Wimmer take the three birds to be different species of Wagtail (Motacilla). The name more strongly suggests to me the Dipper,

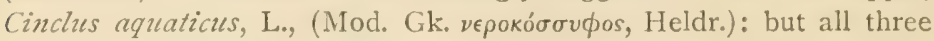
birds are quite doubtful.

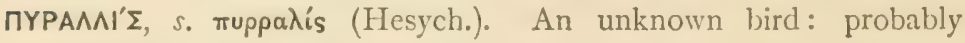
a kind of Pigeon.

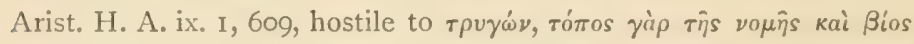
ó aírós. Cf. Ael. iv. 48.

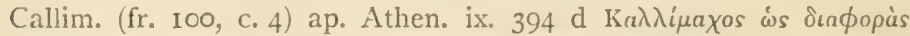

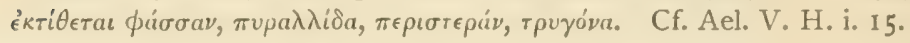

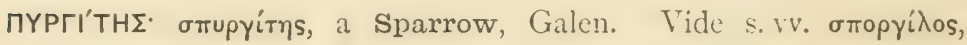

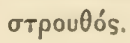

חY'PPA. A bird, hostile to r $\rho v \operatorname{cov}^{\prime}$ Ael. iv. 5, Phile, 685. Perhaps identical with mupa $\lambda \lambda$ is.

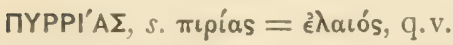

חYPPOKO'PAミ. 'The Alpine Chough, Corvus pyrrhocorax, L.

Plin. x. (48) 68 Alpium pyrrhocorax, luteo rostro, niger.

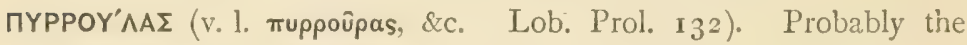
Bullfinch, Pyrrhula vulgaris.

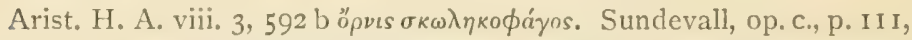
identifies ruppoúdas with the Robin, the Bullfinch being a seed-eater, and confined to the mountainous parts of Northern Greece: but Heldreich quotes the same word as the name for the Bullfinch in Mod. Gk.

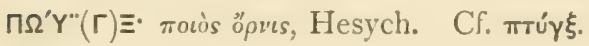

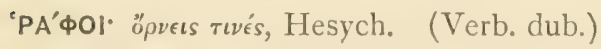

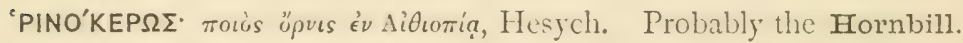

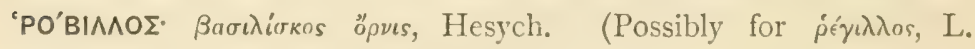

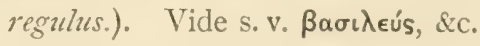

'PYN $\triangle A^{\prime} K H$. Supposed to be akin to Pers. $\mu$; (Rund) nomen avis, quae frequenter in oryzetis invenitur (J. Albertus in Hesych., \&c.). An Indian bird, of the size of a pigeon, Ctes. Pers. 6I ; also Hesych. In Plut. Vit. Artax. I9, p. I020, ค́uvтákךs.

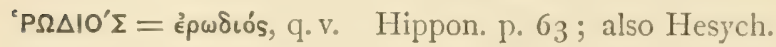

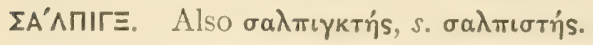

A synonym of öpxı 


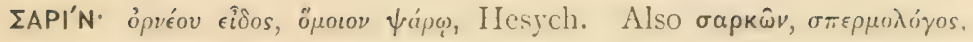
Hesych.

In both cases it has been suggested to read oapiov, quasi wapiov.

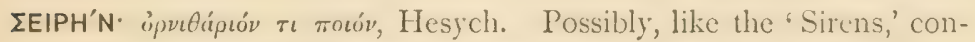
nected with the Heb. sir, to sing.

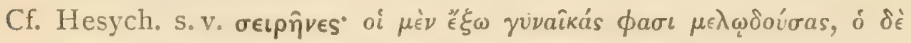

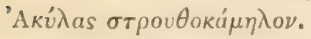

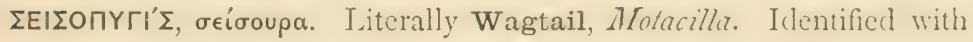

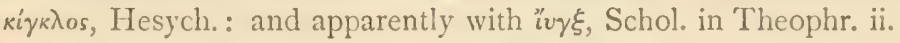

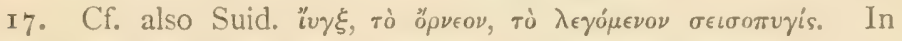

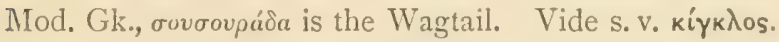

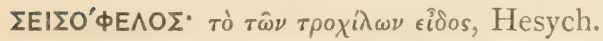

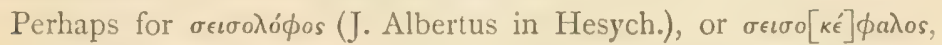

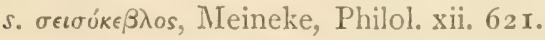

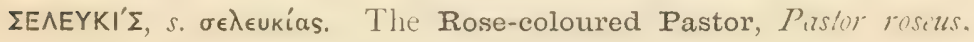
Temm.

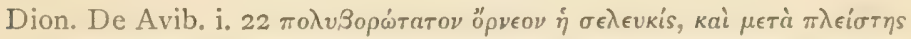

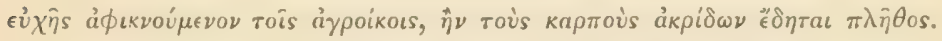

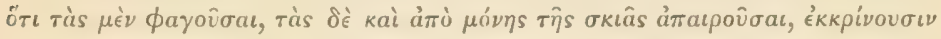

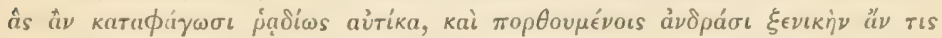

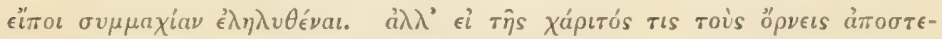

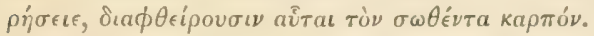

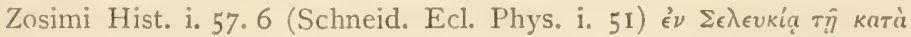

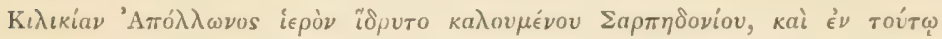

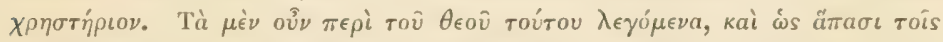

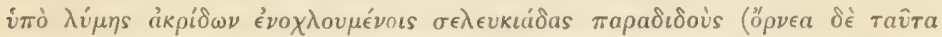

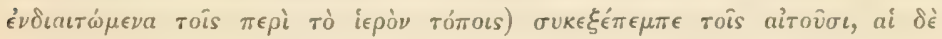

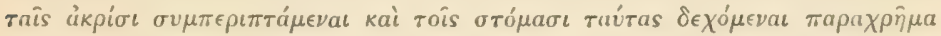

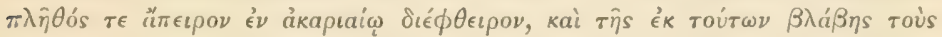

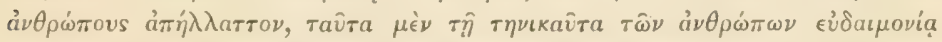

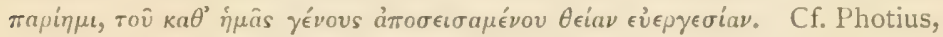
Cod. ccxxiii. p. 68I (teste Bernhardy, ed. Suid.).

Plin. x. (27) 39 Seleucides aves vocantur quarum adventum ab Iove precibus impetrant Casii montis incolae, fruges eorum locustis vastantibus. Nec unde veniant, quove abeant, compertum, nunquam conspectis nisi cum praesidio indigetur.

Cf. Ael. xvii. I9; Galen, De Loc. Affect. vi. 3 ; Hesych., \&c.

The bird, under the name Samammog or Samarmar is in like manner reverenced to this day by the Arabs; cf. Niebuhr, Beschreib.v. Arabiens, p. I74. In Mod. Gk, it is called áyı rovi $\lambda_{\iota}$ on its Spring migration,

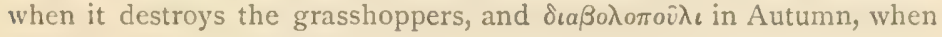
it devours the grapes (Heldr.). 


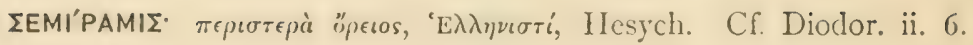

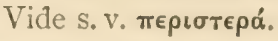

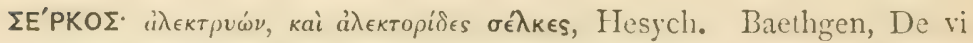
et signif. Galli, Diss. Inaug., Gotting. I887, p. Io, collates Fé $\lambda_{\kappa \circ}$ s, a word inscribed together with the image of a Cock on a Cretan vase (Roulez, Choix de vases de Leide, p. 40, nr. I3), and this in

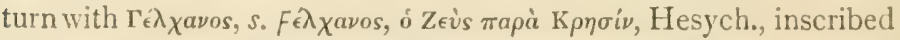
also on a coin of Phaestus (Bull. Inst. Arch., I 84 I, p. I74); further

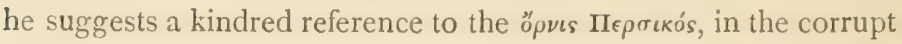

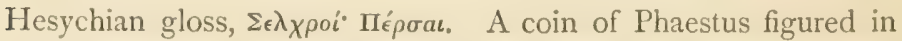
the Brit. Mus. Cat. Coins (Crete, p. 63, pl. xv. Io), bears the same inscription and shows the god seated holding a Cock on his knee.

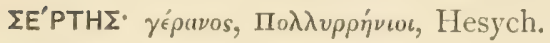

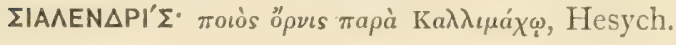

Schn. in Arist. H. A. viii. 3 (vol. ii. p. 596) suspects this bird to be

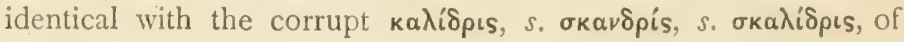

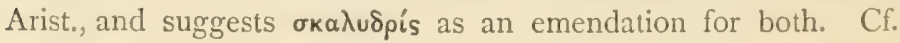
also oıa入ís.

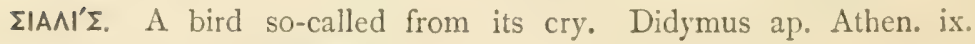
392 f. Also Hesych.

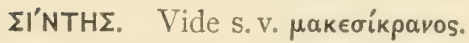

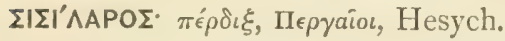

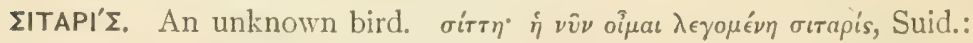
cf. Zonar. I 645, Lob. Proll. p. 30.

IITTA'KH, Philostorg. H. E. iii. I I. oเттакós, Ael. xvi. I5, Arrian. Ind. i. 8, \&c. Vide s.v. ४ıттакós.

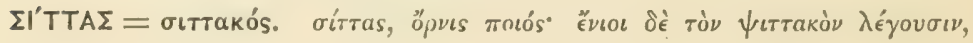
Hesych.

II'TTH. (Some MSS, have $\sigma i \pi \pi \eta$ in Arist. H. A. ix. I.) With $\sigma i \pi \pi \eta$

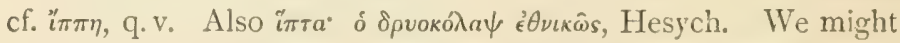

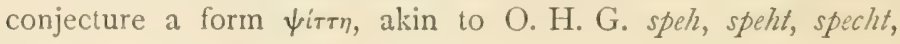
Lith. spakas, Sk. pika, \&c.

A bird with fabulous attributes, allied to the Woodpecker; ö $\rho$ เs

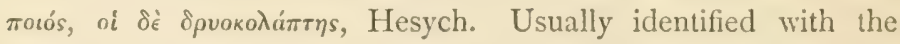
Nuthatch, Sitta europaea or S. syriaca, which latter very similar species is commoner in Greece (Von der Mühle, Lindermayer); 


\section{IITTH (continued).}

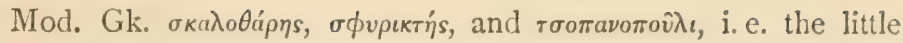
shepherd (Heldr.).

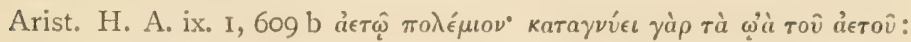

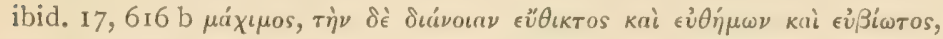

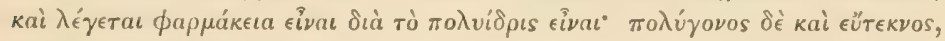

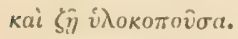

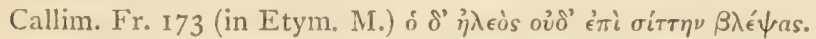

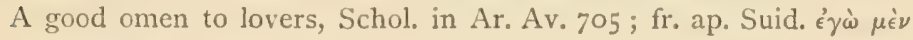

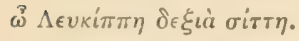

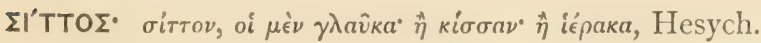

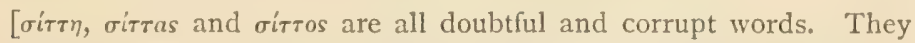
are probably akin to the equally corrupt and obscure $\pi \iota \pi \omega$, which bird, like $\sigma i r \tau \eta$, is allied to the woodpeckers and hostile to the eagle.]

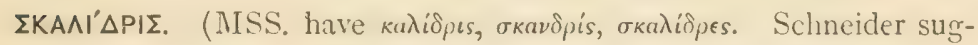

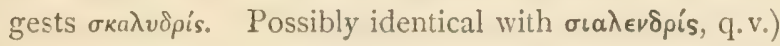

An unknown bird; taken by Belon and later writers for a species of Sandpiper, e.g. Totanus calidris, auctt., the Redshank: but any one whom it pleases may interpret it as a Wagtail, whose

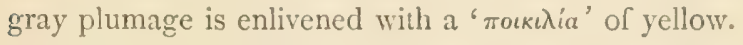

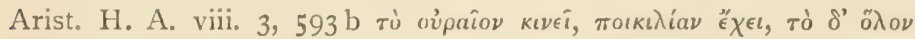

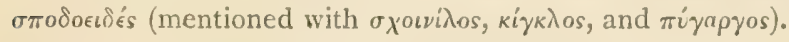

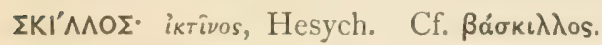

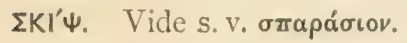

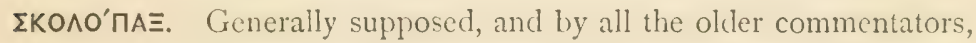

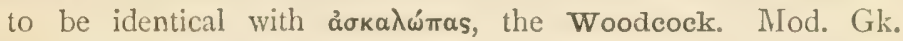

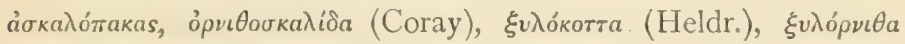

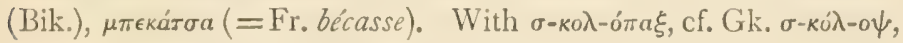

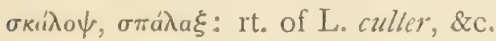

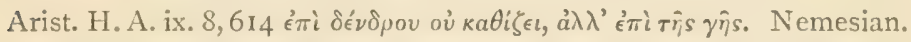
Aucup. fr. 2 I (in Wernsdorf's Poet. Lat. Min.) praeda est facilis et amoena Scolopax.

[ ${ }_{\pi} a \dot{\lambda} a \xi$ or $\sigma \kappa i ́ \lambda o \psi$ in Theophr. De Sign. Temp. p. 439, ed. Heinsii, is sometimes taken to apply not to the mole but to this bird: cf. J. G. Schneider, in Arist., vol. iv. p. 131.]

$\Sigma K \Omega^{\prime} \Psi$. Etym. doubtful. The derivation from $\sigma \kappa \epsilon \pi \tau \omega$ is not more certain than the older one from $\sigma \kappa \omega \pi \tau \omega$ (Athen. and Aelian). The $\sigma$ may be a late prefix, from the false analogy with $\sigma \kappa \omega i \pi \tau \epsilon \nu$. According to Alex. Myndius, ap. Athen. ix. 39 I b, Homer wrote 


\section{$\Sigma K \Omega \Psi$ (continued).}

$\kappa \hat{\omega} \pi a s$ for $\sigma \kappa \hat{\omega} \pi \alpha s$, and Aristotle likewise: so also Speusippus; cf. Acl.xv. 28 , and Cobet's note [falso dixit hoc Alexander, Casaubon in Athen. ii. 358]. Doederlein, Hom. Gloss. § 2359, finds the

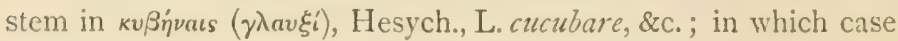

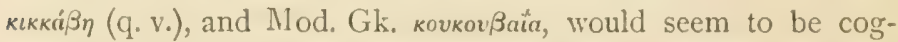
nate. Hesych. has also oxórtes. The name resembles the cry of the bird, and is in part at least onomatopoeic: cf. It. jacopo. In Switzerland it is called Todtenvogel, and cries Tod, Tod, Tod, Hopf. Orakelthiere, p. Ioz.

The Little Horned Owl or Scops Owl, Ephinaltis siofs, L. MIod. Gk. $k \lambda \hat{\omega} \sigma \sigma o s, \chi \iota \hat{\omega} \nu \iota$ (Erh.).

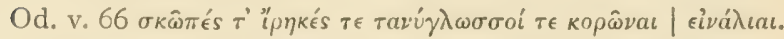

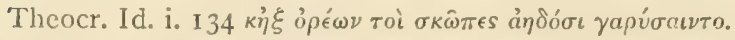

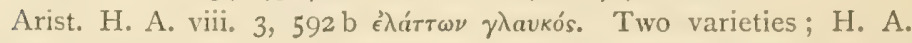

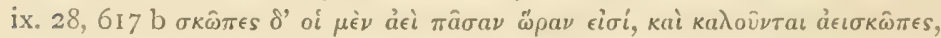

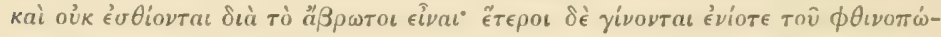

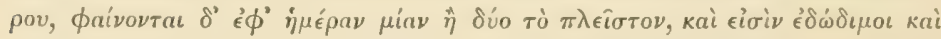

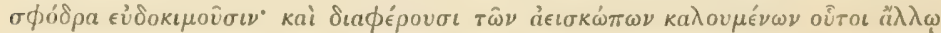

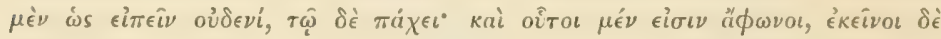
$\phi \theta \dot{\gamma} \gamma \gamma$

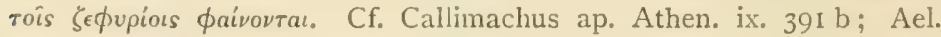

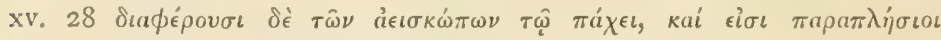

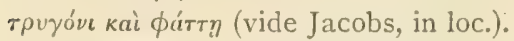

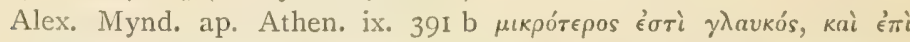

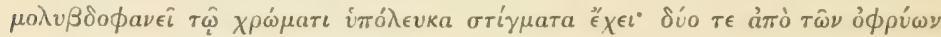

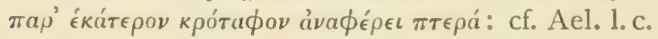

The account given of the size of the bird and the descriptions in Athenaeus and Aelian agree perfectly with the Scops Owl; this is a noisy bird, repeating its cry with monotonous persistence. But it appears to spend the summer only in S. Europe, migrating to Africa in winter. The passage in Aristotle is perhaps faulty in this connexion, owing to misinterpretation of the name a $\epsilon^{i} \sigma \kappa \omega \psi$ as though from a $a i$. Sundevall supposes the other variety to be the Short-eared Owl, Strix brachyotus, a somewhat larger species, which appears merely to pass through Greece on its migrations : vide infra, s.v. ẇrós. The bird $\sigma \kappa \dot{\omega} \psi$ was quite unknown to Pliny, x. (49) 70; as apparently

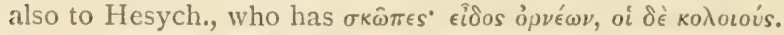

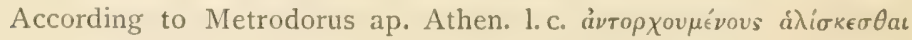
roìs $\sigma \kappa \hat{\omega} \pi a s$. Hence $\sigma \kappa \dot{\omega} \psi$ and $\sigma \kappa \omega \pi \epsilon \dot{\mu} \mu$ as the name of a dance, Ael. xv. 28, Athen. ix. 391 a, xiv. $629 \mathrm{f}$, where there is a confusion

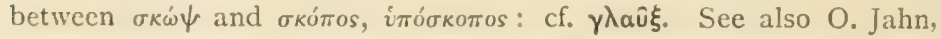
Vasenbilder, p. 24 ; Rochett, J. des savans, 1837, pp. 5I4-5I7. 


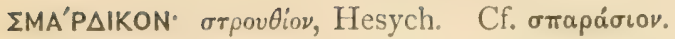

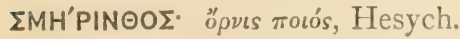

$\Sigma O Y \Sigma \phi A$, s. $\sigma 0 \hat{\imath} \phi \phi$. Indian birds which indicated to the mariner proximity to land, Cosmas, Indopl. ii. p. r82. Schneider, Lex.

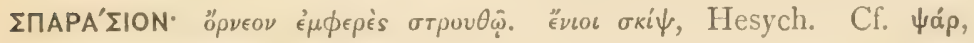

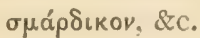

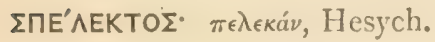

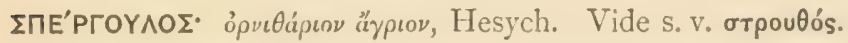

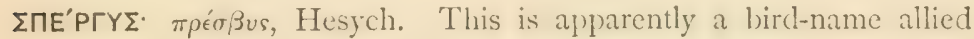

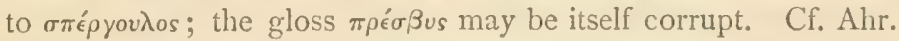

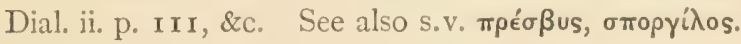

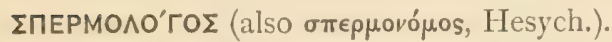

Although commentators now take this word adjectivally (as it is in Athen. ix. 387 b) or generically, I have no doubt that it applies specifically to the Rook, Corvus frugilegus, L., in Ar. Av. 232

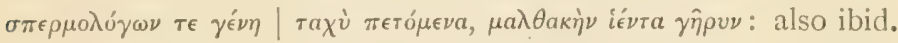
579; and accordingly also in Arist. H. A. viii. 3, 592 b. Cf.

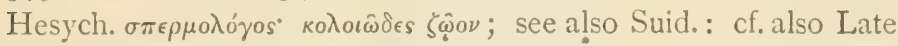
Lat. frugilega. It is so interpreted by older writers, e.g. Caius, De Rarior. Anim. Hist. Libellus, p. Ioo. In Mod. Gk. the Rook

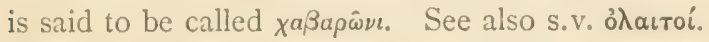

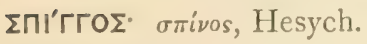

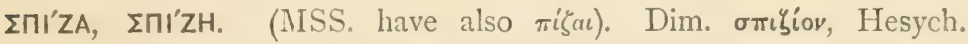

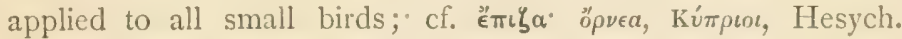
Perhaps from rt. ping, to paint, connected with Germ. fink, finch, \&c. Cf. Eng. bunt-ing.

The Chaffinch, Fringilla coelebs, L. Mod. Gk. orivos, and, on

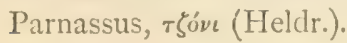

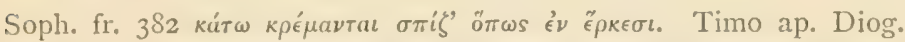

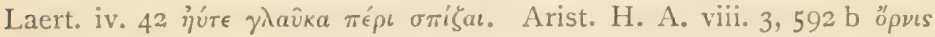

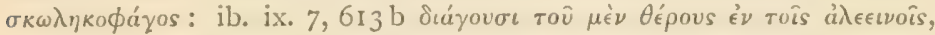

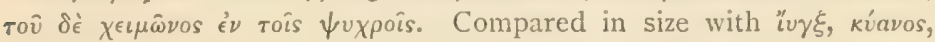

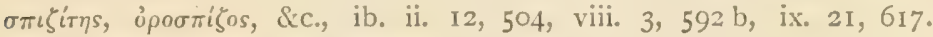

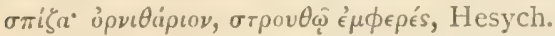

Evidently some very common bird, from its use as a standard of comparison. I follow Sundevall (in spite of Aubert and Wimmer's scepticism) in identifying it with the Chaffinch, on the ground of 
IMIZA (contiuned).

tradition, and on the ground of the resemblance of the name to the various forms of the word orivos, which is still the Mod. Gk. name of the bird: partly also because the other common birds which might be meant (Goldfinch, Greenfinch, and Linnet) are fairly well identified under other names.

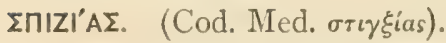

Mentioned (by name only) in Arist. H. A. viii. $3,59^{2}$ b, ix. $3^{6}$,

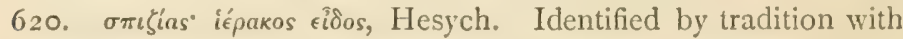
the Sparrow-hawk, Accipiter nisus, L.; vide S.v. те́pкos.

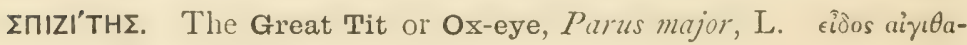

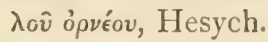

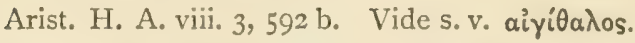

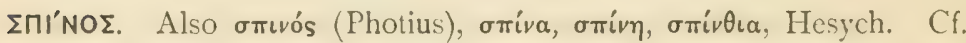

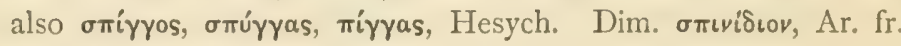
344: orıviov, Eubul. Incert. I 4.

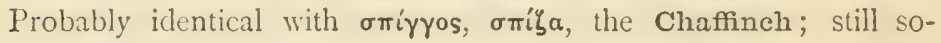
called (Heldr.).

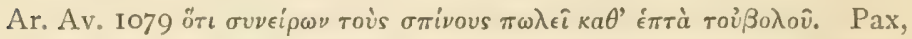

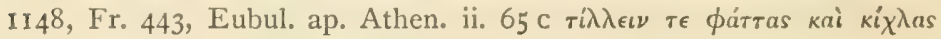

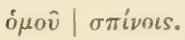

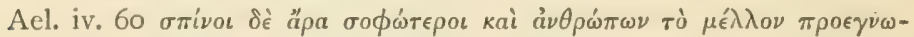

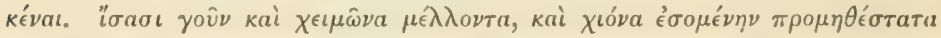

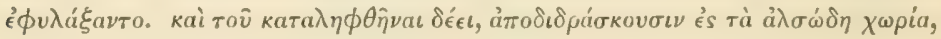

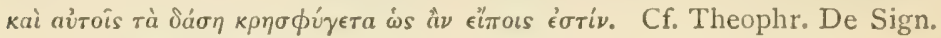
vi. I, 3 ; Arat. 1024 .

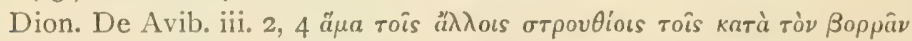

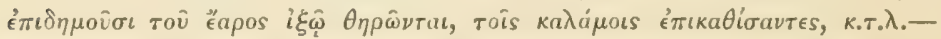

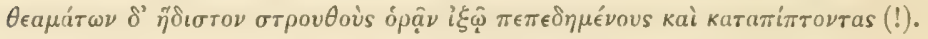

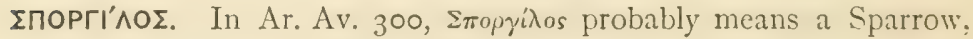
and the usual reference to Sporgilos, a barber, if justified at all, makes the joke a double-barrelled one. The word is

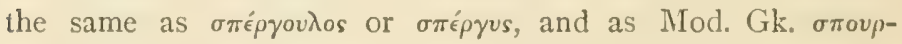

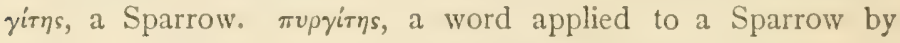
Galen, \&c., is rendered in the dictionaries turritis, as if from

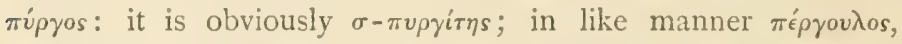

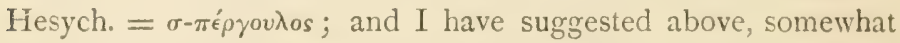
less confidently, that $\pi \rho \dot{\epsilon} \sigma \beta u s$ as a bird-name should perhaps read $\sigma \pi \hat{\epsilon} \rho \beta u s=\sigma \pi \epsilon ́ \rho \gamma v s$. These words form a parallel series, with $\pi$ 


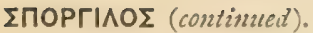

for $\tau$, to oтpovtós, \&c.; they have a near ally in Eng. Sparrow, and a still nearer in sprug.

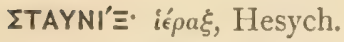

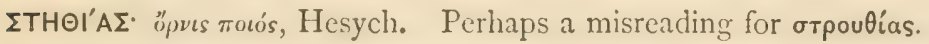

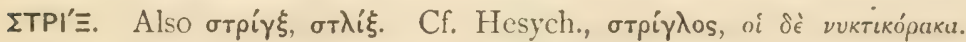

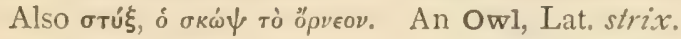

Boios ap. Anton. Lib. c. 2I. Cf. Hygin. Fab. 28. Theognost. in Anecd. Oxon. ii. 4I, I32.

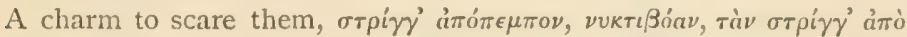

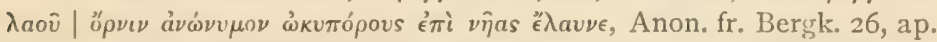
Festus, p. 3I 4. Cf. Plin. xi. (39) 95 quae sit avium constare non arbitror; Isidor. xii. 7, \&c.

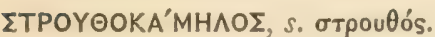

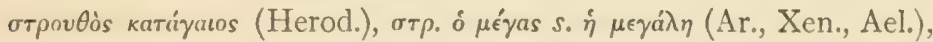

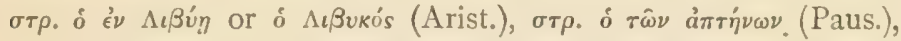

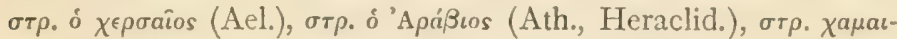

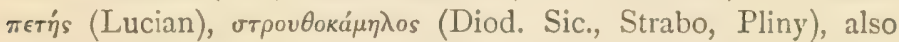

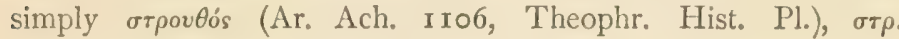

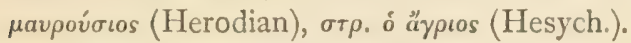

The Ostrich, Struthio Camelus, L.

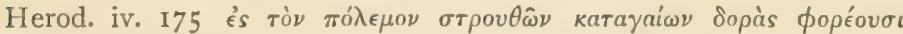

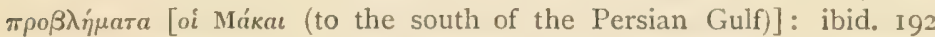

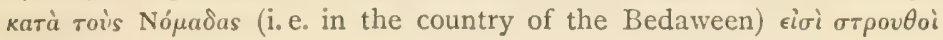

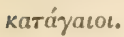

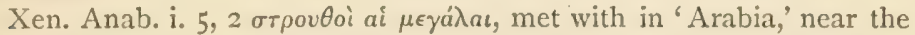

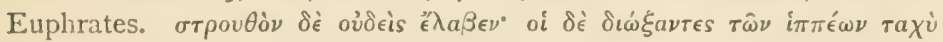

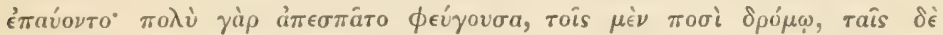

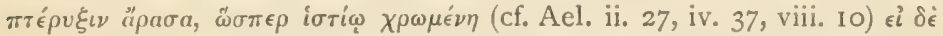

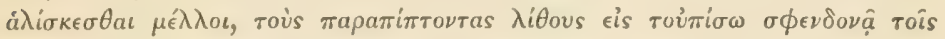

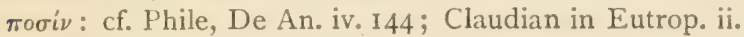

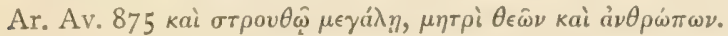

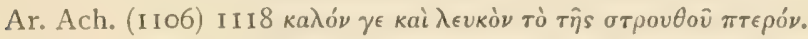

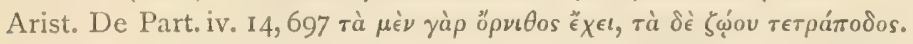

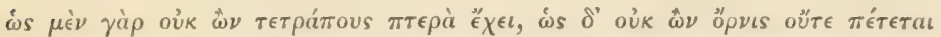

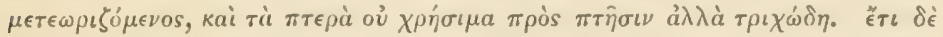

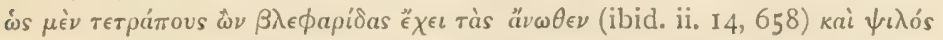

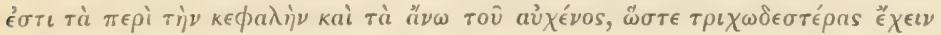

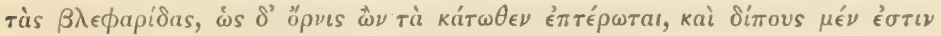

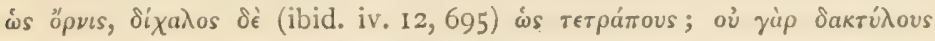




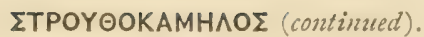

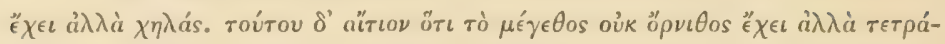

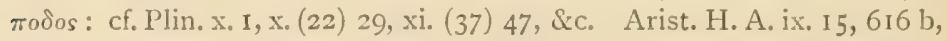
lays more eggs than any other bird (the fact being that several lay in one nest), cf. De Gen. iii. I, 749 b, and Ael. iv. 37. On the number of eggs ( $\dot{v} \pi \dot{\epsilon} \rho \tau \dot{\alpha}$ ỏ $\left.\gamma \delta r_{i} k o \nu \tau a !\right)$, on the construction of the nest, and on its maternal affection, v. Ael. xiv. 7, Phile, 1. c.

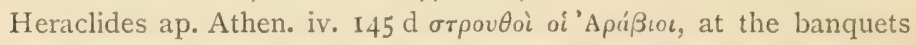

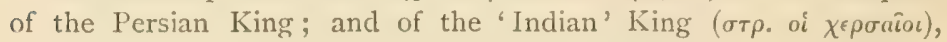
Ael. xiv. I3; also of Heliogabalus, Ael. Lampridius, De Heliog. 28.

On the capture of the Ostrich see also Diod. Sic. ii. 50, Ael. xiv. 7. Opp. De Ven. iii. 487. The interesting account in Strabo, xvi. 4, II, doubtless refers to the Ostrich.

How the Ostrich swallows stones, which are a medicine for the eyes, and how its fat and sinews are a useful tonic, Acl. xiv. 7, Phile, 1.c. The price of Ostrich-fat, Plin. xxix. 30.

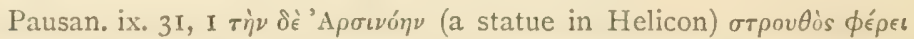

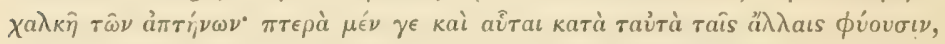

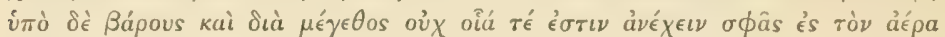
$\tau \dot{a} \pi \tau \epsilon \rho \dot{.}$. Cf. the ales equos of Cat. Ixvi. 54, and Ellis's note thereon; cf. also Flav. Vop. Firm. c. 6 sedentem ingentibus struthionibus vectum esse ut quasi volitasset.

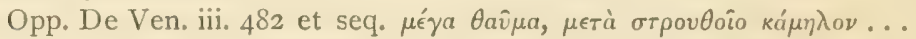

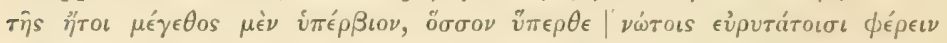

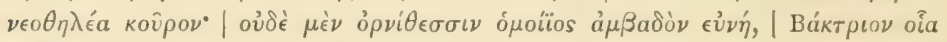

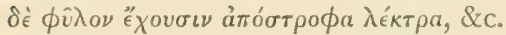

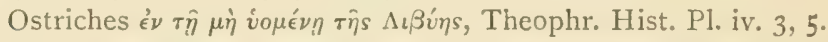

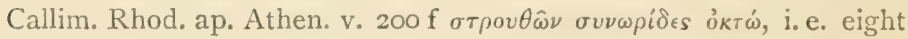
yoke of ostriches (drawing chariots?) in a procession of Ptolemy Philadelphus at Alexandria. Cf. Plautus, Pers. ii. 2, 17 Vola curriculo. Isthuc marinus passer per circum solet. Ostriches harnessed to the coach of the Emperor Firmus, Flav. Vopisc. Firm. c. 6.

Ostrich plumes mentioned, ibid. iv. 4, 5, ix. I2, 5 .

How the eggs are eaten by the Garamantes (in the Libyan Desert), Lucian, Dipsad. 235, but are of inferior quality, Galen, De Ovis, xxii.

How the Ostrich hides its head in the sand, Oppian, Halieut. iv.

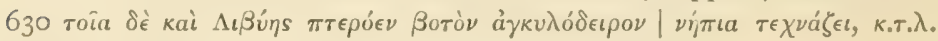
Cf. Plin. x. I.

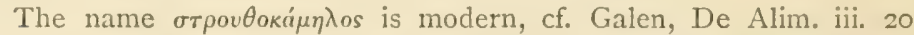

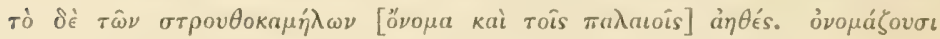

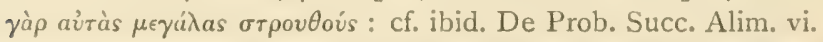

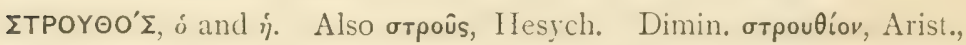

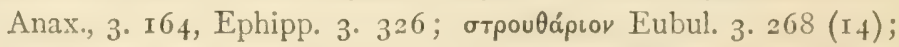
orpoutias, Com. Anon. 4.647 (I 72 ); orpoutis, Eust. Opusc. 3 I2, 


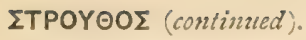

cf. Alexid. 3. 449, and Meineke's note; orpoutíros, Theod.

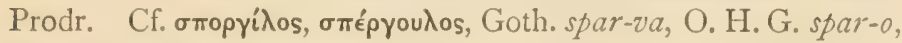
Eng. sprug, sparrow, \&c.

A Sparrow, Passer domesticus, L., in Greece, as here, the commonest of birds (Von der Mühle, \&c.) : in Elis, called also $\delta \epsilon i p \eta s$,

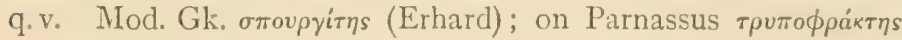

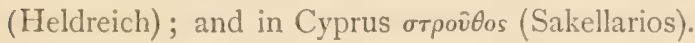

Very often used generically, like Lat. passer, Heb. רפנ, of any

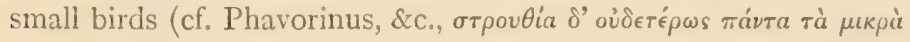

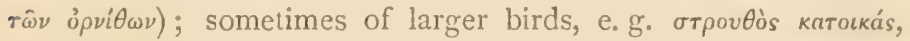
Nic. Alex. 60. 535; transferred to the Ostrich (vide s. v. orpouto-

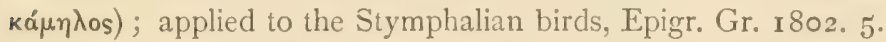

Farly and Poetic References.-The story of the serpent and the brood of sparrows, 11. ii. 308-332: this is an instance where the name is used vaguely and not specifically (as is 793 in Deut. xxii. 6); the Homeric account of the nest is reflected in Ael. iv. 38 , and the statement as to the number of eggs reappears in Arist. fr. 1527, ap. Athen. ix. $391 \mathrm{f}$.

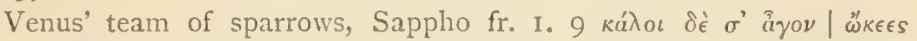

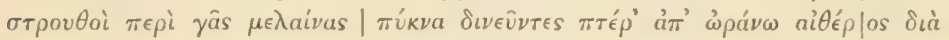
$\mu \epsilon^{\prime} \sigma \sigma \omega$. On the connexion between this image and the lascivious propensities of the sparrow, cf. Athen. 1. c.

The story of Aristodicus and the sparrows' nests in the temple, Herod. i. 159.

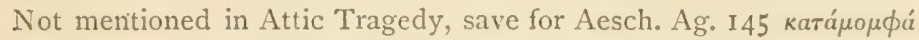

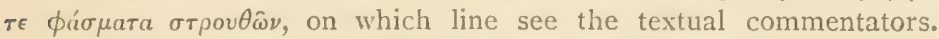
Frequent in Aristophanes: Vesp. 207, Lys. 723, Ach. I106, \&c.

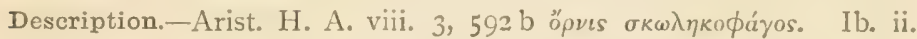

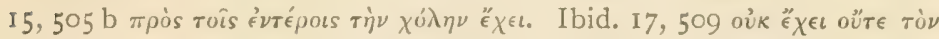

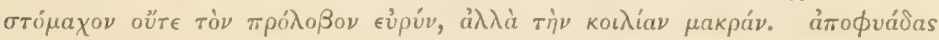

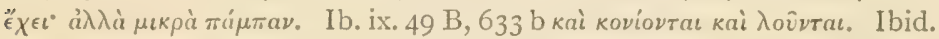

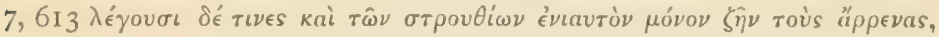

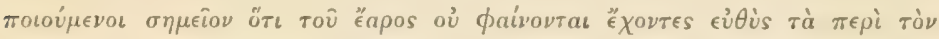

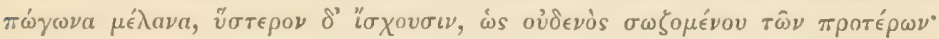

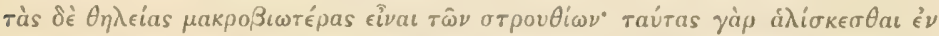

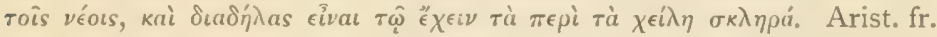
273. 1527 (ap. Athen. 392 a) $\mu \epsilon \tau a \beta a ́ \lambda \lambda \epsilon \iota$. On albino varieties, cf. H. A. iii. I2, 519 ; De Gen. v. 6,785 b.

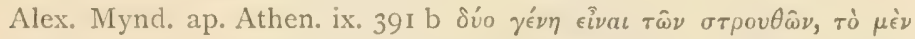

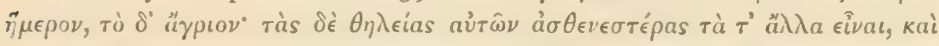

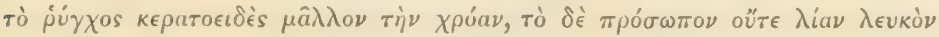

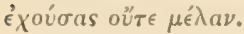




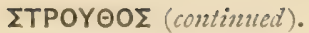

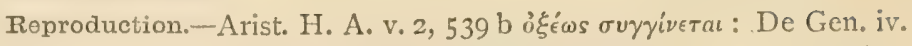

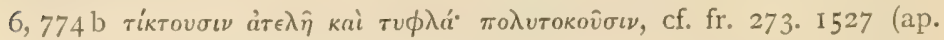
Athen. $39 \mathrm{I} \mathrm{b)} \mathrm{\tau ík \tau є \iota} \mathrm{\mu є́ \chi \rho} \mathrm{ók \tau \omega ́.} \mathrm{Athen.} \mathrm{ix.} \mathrm{391} \mathrm{e} \mathrm{ỏ \chi}$ used as an aphrodisiac, Terpsicles, ap. Athen. 1.c. The crotic symbolism of the sparrow is alluded to by Festus, s.v. strutheum.

Whatever Lesbia's 'sparrow' may have been, I am pretty sure in my own mind, pace Professor Robinson Ellis, that it was not Passer domesticus, the most intractable and least amiable of cage-birds (experto crede; cf. also Bechstein's 'Cage-birds'; on the point at

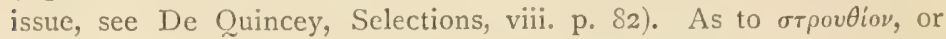
passer, used (non-specifically) of a cage-bird, cf. Job xl. $24 \pi a i \xi \eta \delta \dot{~}$

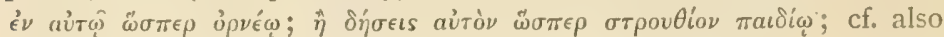
Boch. Hieroz. ii. I 52.

A Weather-prophet.-Theophr. Sign. vi. $3 \sigma \tau p o v \theta \grave{s} \sigma \pi i \zeta \omega \nu \tilde{\epsilon} \omega \theta \epsilon \nu$ $\chi \epsilon \iota \mu \epsilon^{-}$

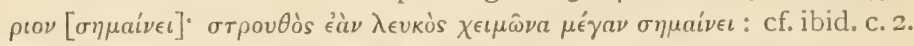

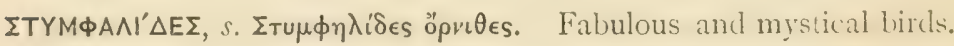

They were met with by the Argonauts at the Island of Dia; they shot forth their feathers like arrows, and were put to flight by the beating of spears on shields, ex more Curetum, Apoll. Rhod. ii. 1054 and Schol., Q. Smyrn. vi. 227, Hygin. Fab. xx, Claud. Idyll. ii. They were shot by Hercules in his fifth labour, in insula Martis, Hygin. Fab. xxx, or at Lake Stymphalus, Paus. viii. 22, 4; or terrified by him with a brazen drum, Strab. viii. 371, 389: cf. Pisand. ap. Paus. 1. c., \&c. They inhabited Arabia, and had migrated thence; they were as large as cranes, and resembled the Ibis, but had stronger beaks; they pierced through iron and brass. but were held by reed-

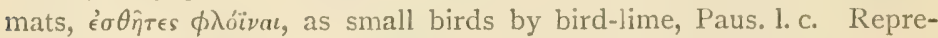
sented, three in number, on the metopes of the temple of Zeus at Olympia (now in the Louvre) Paus. v. 10, 9; cf. Expéd. de la Morée, i. pl. 77, \&c., \&c. Also, together with female figures having birds' legs, on the temple of Artemis Stymphalia at Lake Stymphalus, Paus. 1. c. Also on medals, cf. Méd. du Card. Alban. ii. p. 7o, \&c.; on an amphora in the Brit. Mus., J. de Witte, Gaz. Archéolog. 1876, pl. iii ; on coins, as crested water-birds (B. C. 431-370), B. M. Cat. Coins, Peloponnese, p. I99.

According to Dupuis (Orig. de tous les cultes, ii. p. 260, 8vo, l'an iii), the Stymphalian birds are the constellations of Aquila, Cygnus and Vultur or Lyra, which rise together with, that is to say are paranatellons of, the sign Sagittarius (cf. Hygin., Columella, \&.c.). Starting from the Lion (with which the labours of Hercules began) the sign of the Archer is the fifth in order: it was moreover the domicile of Diana, to whom belonged the temple at Stymphalus. A similar explanation possibly underlies the story of the Birds of Diomede. 
$\Sigma T Y^{\prime} \equiv$. A bird-name, mentioned, in connexion with a fabled meta-

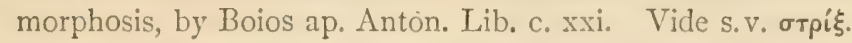

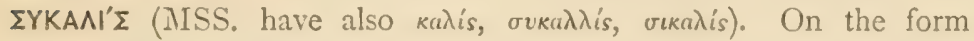

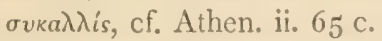

Probably the Black-cap Warbler, Sylvia alricapilla, auctt. Lat.

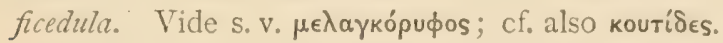

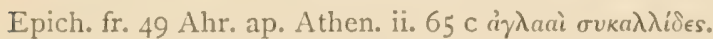

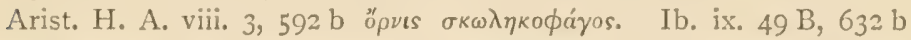

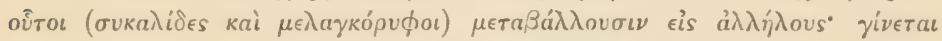

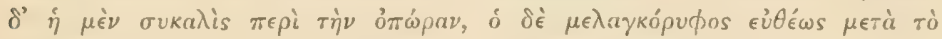
$\phi \theta \iota v o ́ \pi \omega p o v$. Cf. Plin. x. (29) 44, Geopon. xv. I, 22, Festus.

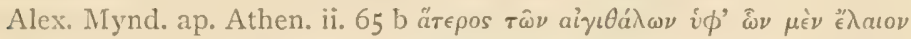

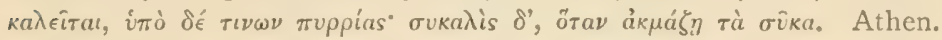

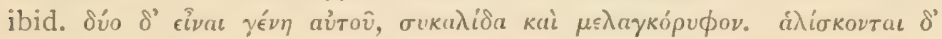

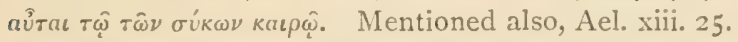

Aubert and Wimmer suppose the Marsh Tit, Pames palustris, L., $P$. atricapillus, Gmel., to be meant. Sundevall supposes a confusion between that bird ( $\mu \in \lambda a \gamma$ кópuфos) and the Black-headed or Pied

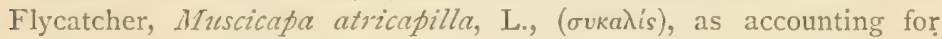
the imaginary metamorphosis. But the Black-headed Flycatcher is probably chosen incorrectly, and should be the Black-cap Warbler or true Beccafico, Sylvia atricapilla. It is the latter and not the former bird which comes down into the plains in autumn and is caught in multitudes on the fig-trees (Krüper, p. 24I, \&c.). The former is a comparatively scarce bird in Greece (Krüper, Lindermayer). Coray, on the other hand, identifies $\sigma u k a \lambda$ is with the Golden Oriole, in MIod. Gk. Gukoфíyos. The Golden Oriole is also known now-a-days as

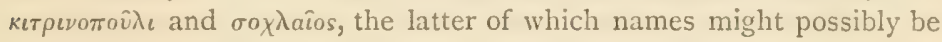
a corruption of $\sigma u k a \lambda i s$.

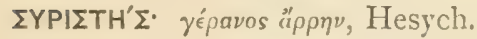

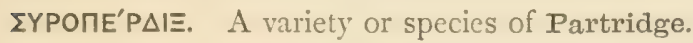

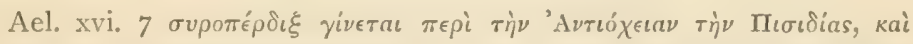

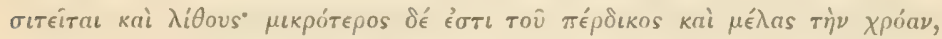

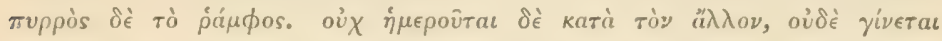

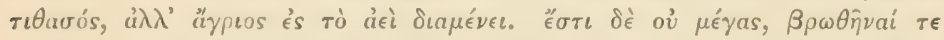

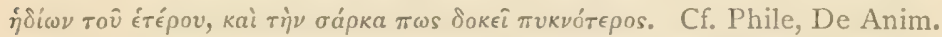
330. The species cannot be certainly identified from this account.

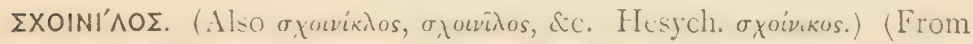
бXoivos, iuncus.)

Probably a Wagtail, Motacilla sp.

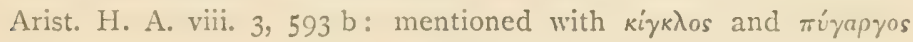




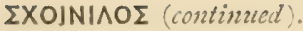

as a small bird, smaller than a thrush, which moves its tail and frequents rivers and ponds.

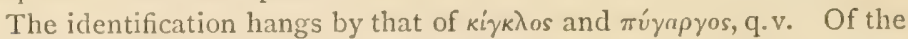
three bird-names, not one is to be identified with any certainty; I am somewhat inclined to interpret $\pi \dot{v}$ yapyos, the largest of the three, as a Sandpiper, and to suppose the other two to be both Wagtails; at any rate, $\sigma$ Xouvi $\lambda$ os, in its derivation, rather suggests a Wagtail than a Sandpiper. The same bird appears elsewhere under such names as кi $\lambda \lambda \lambda_{\text {ov }}$ pos,

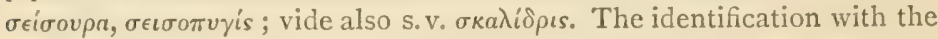
Reed Bunting, Emberiza schoeniclus, adopted by Turner, Gaza, \&c., \&c., is based purely on the derivation of the word, and is contradicted by the fact that the Reed Bunting does not flick its tail as the others do.

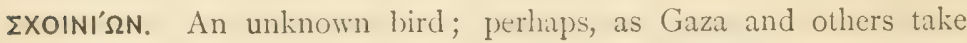
it, identical with oxowínos.

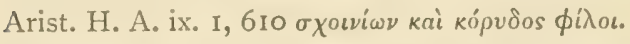

$\Sigma \Omega \triangle E \Sigma$, ai. An unknown small bird, caught with bird-lime: Dion. De Avib. iii. 2.

TATH'N, TATHNA'PION. Apparently names for ảrtayás (q. v.), Suid. raynvâpe is given by Tournefort (Voy. ii. p. III), as Mod. Gk. for the Francolin.

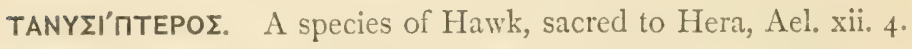

TATY'PAI. Vide S.V. тÉtapos.

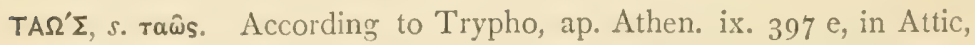

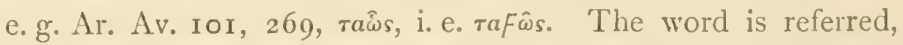
with Hebr. tukkiyim, Arab. tâzuns, Pers. tâuis, to Tamil tôgai, ns such Sk. çikkî (v. Edl., \&c.). Cf. Lat. pavo, A. S. pawa, Ger. pfau, \&c. On the change of Semitic $t$ into $p$ see Hehn, Wanderings of Plants, \&c., pp. 208, 266.

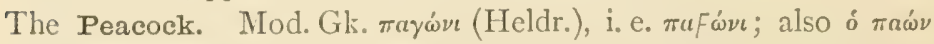

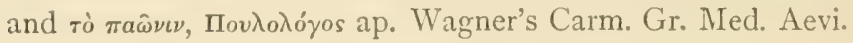

History and Mythology.-Menodot. ap. Athen. xiv. 655 a oi taoi

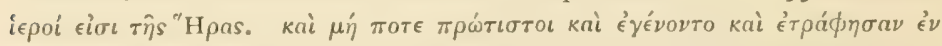

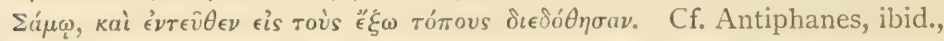

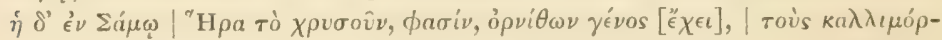

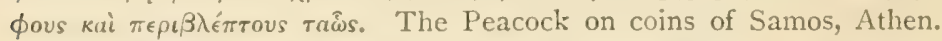
1. c., cf. Eckhel, Doctr. Numm. ii. p. 568; Imhoof-Blumer and Keller, pl. v. 49. Samos was, according to this evidence, the original home of the Peacock in Greece. The bird was sacred to Hera (as also at 
$T A \Omega \Sigma$ (continued).

Tiryns, Paus. ii. 17, 6) as Queen of Heaven (cf. Eur. Hel. 1096) from its starry tail (Hehn): cf. Ovid, Met. xv. 385 Iunonis volucrem, quae caudâ sidera portat; ibid. i. 723 ; Juv. vii. 32 ; Stat. Silv. ii. 4, 26 ; Claudian, Eutrop. ii. 330. Cf. also Joh. Lydus, De Menss. p. 66 кai

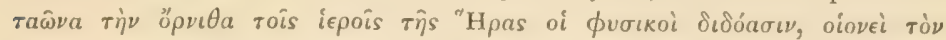

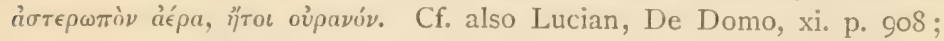
Hemsterh. ad Nigr. i. p. 247. The Peacock is associated with Hera on coins also of Cos, Halicarnassus, \&c. On a Roman zodiac (Millin, Galér. Mythol. pl. xxix. fig. 86) a Peacock comes after Capricorn, coinciding with the Athenian month Gamelion, the month (Hesych.) of Hera ; cf. Boetticher, Philologus xxii. p. 399, I865, Pyl, Der Zwölfgötterkreis im Louvre, Greifswald, 1857 , \&c. [The association of Hera with the month Gamelion (Jan.-Feb.) is due to the fact that this was the month of the sign Aquarius; and the connexion in turn between Hera and Aquarius is connected with the fact that the Full Moon stood in that sign when the Sun was in Leo, in the month of Zeus, at the season of the Olympic festival.]

The story of Argus, Mosch. Id. ii. 58, Ovid, Met. i. 720, Dion. De

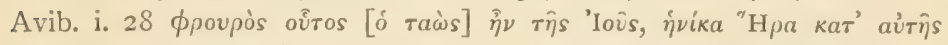

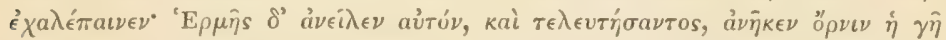

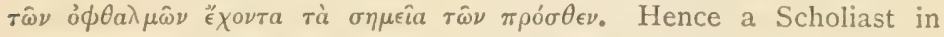
Ar. Av. 102 suggests (sed hyeme gallica frigidior est haec coniectura,

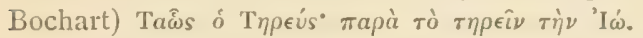

On Peacocks in Athens, in the time of the Persian Wars, Antiphon

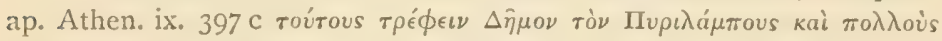

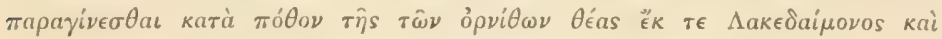

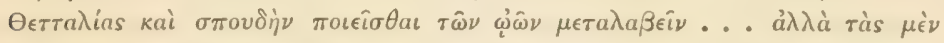

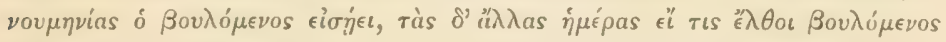

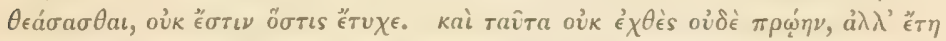

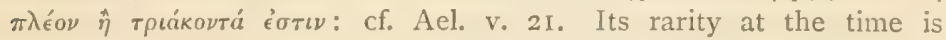
suggested in Ar. Av. 102, 270: but already a nickname in Ar. Ach.

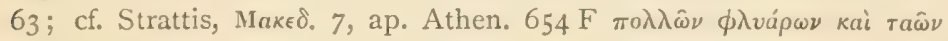
àvтর́६ıน.

Its former rarity and subsequent abundance, Antiph. ap. Athen. ix.

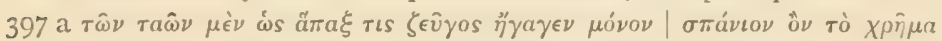

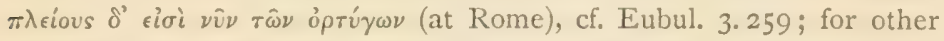

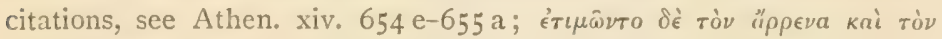
$\theta \ddot{\eta} \lambda v \nu \delta \rho a \chi \mu \omega \hat{\omega} \nu \mu v \rho i \omega \nu$, Antiph. ap. Ael. v. 21 ; cf. also Plut. i. I6o d, Plin. x. (20) 22, Varro, R. R. iii. 6, Macrob. Sat. iii. I 3, \&c.

On the probably independent introduction of Peacocks into Rome, cf. Hehn, op. c.

The Peacock is an Indian bird, Aelian passim, Lucian, Navig., \&c.;

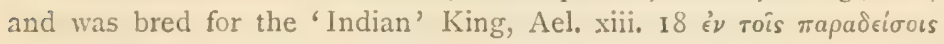




\section{$\mathrm{TA} \Omega \Sigma$ (contimued).}

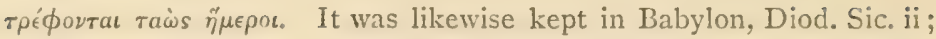
and the passage in Ar. Ach. 63 may imply that the I'ersian ambassador was bringing a present of peacocks to the City. How Alexander protected the Indian Peacocks on account of their beauty, under pain of a heavy penalty, Ael. v.2I. An Indian Peacock presented to the Egyptian King, Ael. xi. 33. The Indian Peacocks larger than elsewhere, ibid. xvi. 2. The Peacock throne at Babylon (as to this day, according to report, at Teheran), Philostr. $386 \mathrm{k}$.

The Peacock, like the Cock, was also called the Persian Bird.

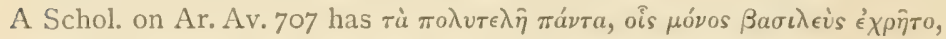

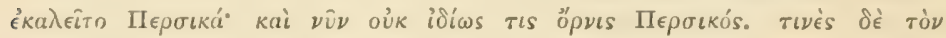

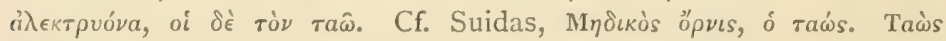

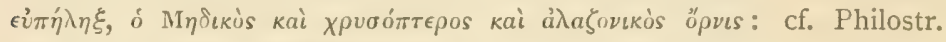

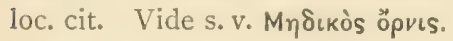

The Peacock as food, Ael. iii. 42 ; first so used by Hortensius, ibid. v. 21, Plin. x. (20) 23; cf. Hor. Sat. ii. 2. 28, Juv. Sat. ii. 143, vii. 32, Varro, De R. R. iii. 6, Columella, viii. II, and innumerable other Lat. references.

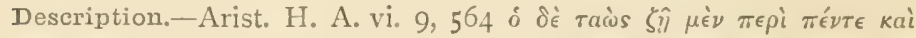

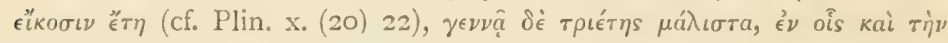

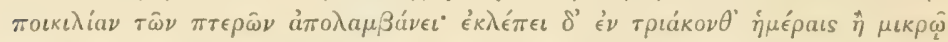

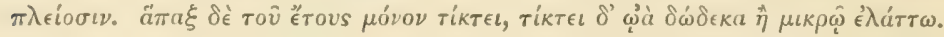

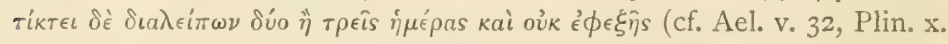

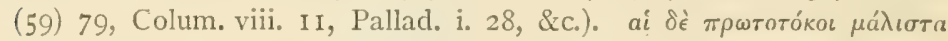

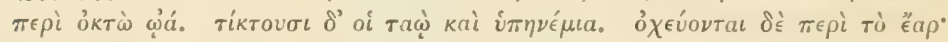

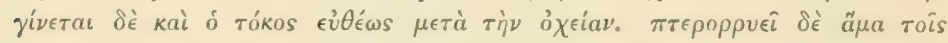

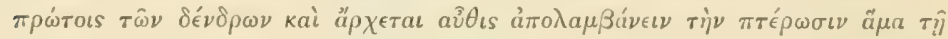

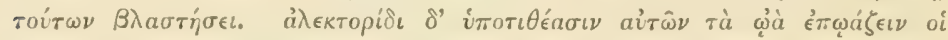

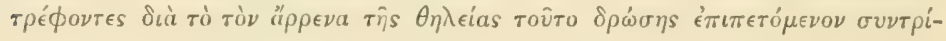
$\beta \epsilon \iota \nu$ : cf. Arist. fr. 274. I 527 b, ap. Athen. ix. 397 b.

Its plumage and its 'pride,' Mosch. Id. ii. 59 ópvis à

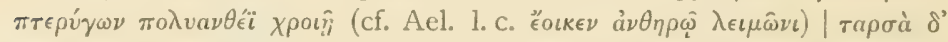

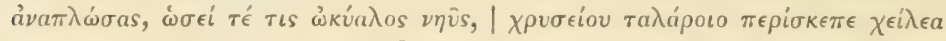

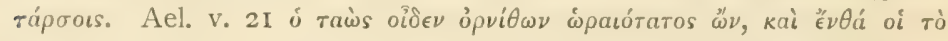

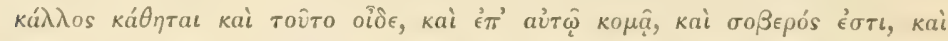

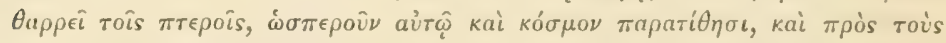

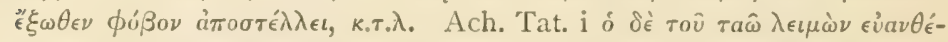

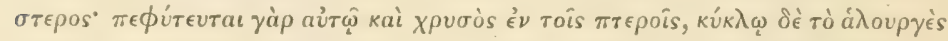

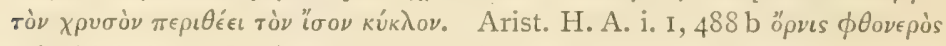

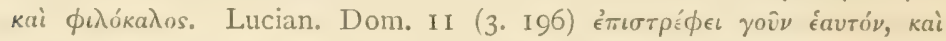

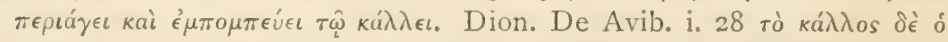

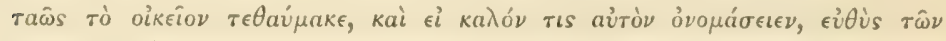

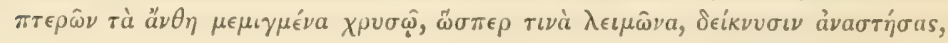




\section{$\operatorname{TA} \Omega \Sigma($ continued).}

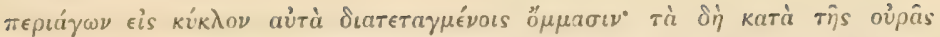

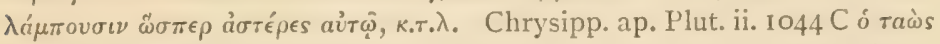

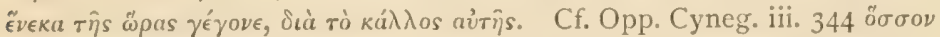

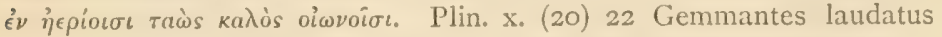
expandit colores adverso maxime sole, quia sic fulgentius radiant : ... omnesque in acervum contrahit pennarum, quos spectari gaudet oculos. Colum. R. R. ix. I I Semetipsum, veluti mirantem, caudae gemmantibus pennis protegit, idque cum facit, rotare dicitur. Ovid, Art. Amor. i. 627 Laudatas ostendit aves Iunonia pennas; Si tacitus spectes, illa recondit opes : cf. id. De Medic. Fac. 33, Met. xiii. So2. Cf. also Hor. Sat. ii. 2, 24, Lucret. ii. 806, Stat. Silv. ii. 3, 26, Mart. xiii. 70, Propert. ii. 24, I I ; Phaedr. iii. 57, \&c., \&c. It is, however, much ashamed of its ugly feet :

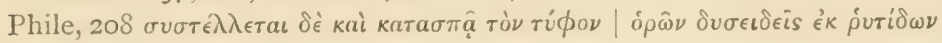
roùs móóas.

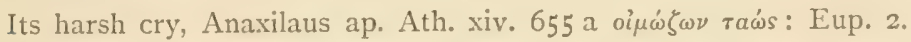

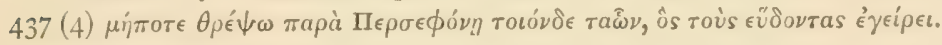

Various legends.

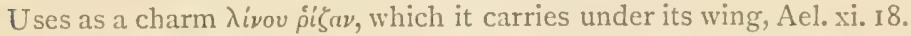
How the peacock swallows its excrement, lest we should use it in medicine, Plin. xxix. 38 .

A peacock enamoured of a maid, Clearch. ap. Athen. xiii. Co5 c.

Fable.-The Crane and the Peacock, Babr. lxv, cxlii (ed. Rutherford)

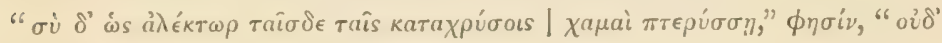

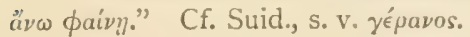

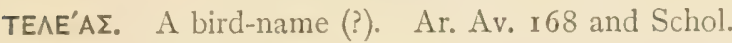

TE'TAPOs. A Pheasant. A Median word, whence Pers. tedyrut, adopted into Old Scl. tetravi, tetria, \&c.; also Lith. teterva, teterwas, teltera, whence Finn. tetri; adopted further into Sw. tjäder, Dan. tuir, and possibly incorporated (Hehn) into Eng. turkey. Cf. Hind. tittiri, a Partridge or Francolin; Lat. tetrao, Gk. те́тра乡, төтра́wv. Cf. Pott, Etym. Forsch. i. p. Ixxx.

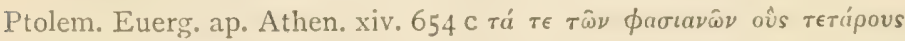

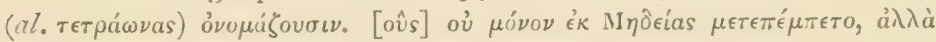

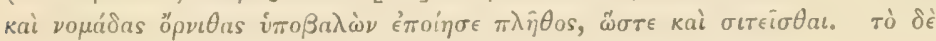

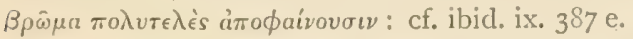

Also ratúpas, Epaenetus, Artemid. and Pamph. ap. Athen. ix. $387 \mathrm{~d}$

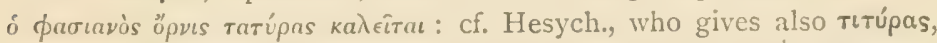

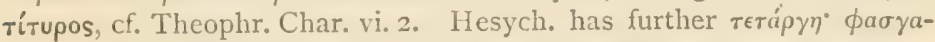

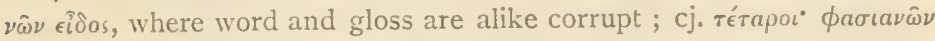

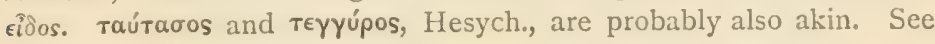

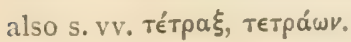




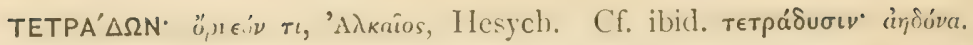
See Schmidt in loc., and Bergk, P. Lyr. Gr. iii. p. I92, fr. I 54 (I I 6).

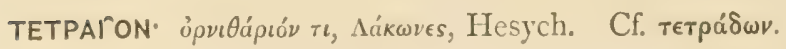

TE'TPA E. A doubtful word, applied to the Guinea-fowl.

Ar. Av. 885, Eust. 1205, 27.

A discussion concerning the identity of this bird in Athen. ix. (c. 58).

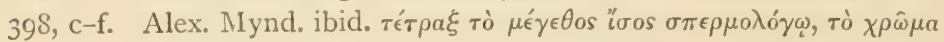

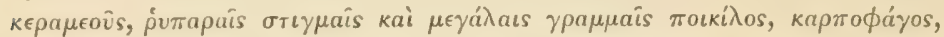

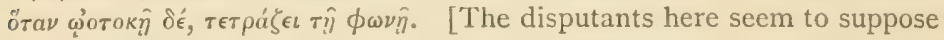

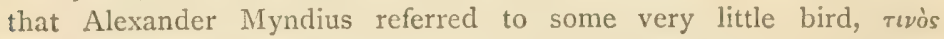

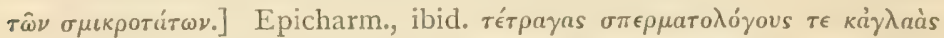

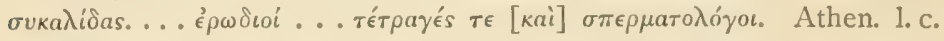

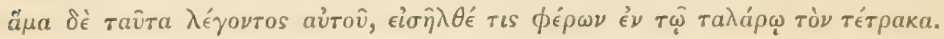

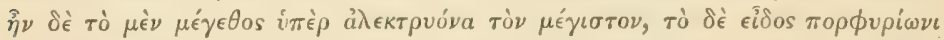

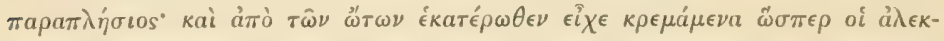

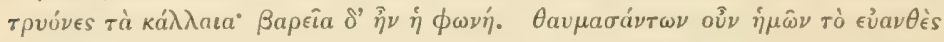

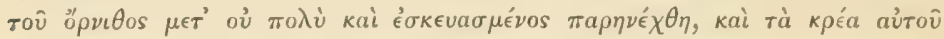

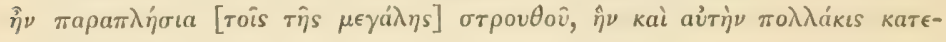
$\delta a \iota \sigma a ́ \mu \epsilon \theta$.

According to Larensius (ap. Athen. 1.c.), he had seen the bird and heard the name in Mysia and Paeonia: he probably alluded to some one of the Grouse family; cf. tetraon in Plin. x. (22) 29. The bird brought into the banquet was evidently a Guinea-fowl, the description given of the colour, wattles, \&c. being characteristic. The account in Alex. Mynd, is not capable of identification : it also may possibly refer to the Guinea-fowl, which is not mentioned under the name $\mu \in \lambda \epsilon a \gamma p i$ by this author. Sundevall supposes that Alex. Mynd. alluded to some small bird, perhaps the Whinchat, Pratincola mbetra, L.,

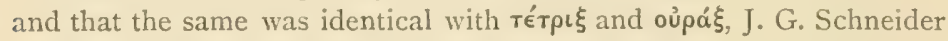
(Anmerk. z.d. Ecl. Phys. p. 45) conjectures the Little Bustard, Otis tetrax, L., on whose cry at breeding-time, cf. Buffon, iv. p. 55 .

The name occurs also in Nemesian, i. I28, Anthol. Lat. 883 (ed. Riese), in a passage, however, which adds nothing definite to our knowledge: Tetracem Romae quem nunc vocitare taracem Coeperunt, avium est multo stultissima; namque Cum pedicas necti sibi contemplaverit adstans, Immemor ipse sui tamen in dispendia currit... Hic prope Pentinum radicibus Apennini Nidificat, patulis quae se sol obiicit agris, Persimilis cineri dorsum, maculosaque terga Inficiunt pullae cacabantis imagine notae.

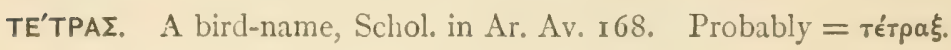




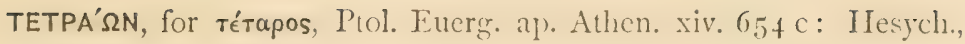

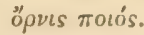

In Sueton. Calig. xxii tetraones numidicae were probably Guineafowl. In Plin. x. (22) 29 tetrao is the Black Grouse, Tetrao tetrix: decet tetraonas suus nitor, absolutaque nigritia, in superciliis cocci rubor. The larger variety mentioned next is the Capercaillie, T. urogallus : alterum eorum genus vulturum magnitudinem excedit, quorum et colorem reddit; nec ulla ales, excepto Struthiocamelo, maius corpore implens pondus, \&c.

TE'TPIE. An unidentified bird.

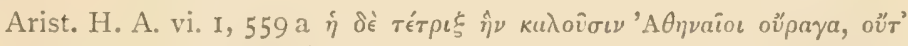

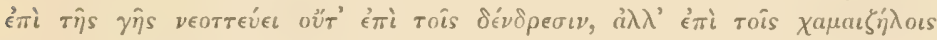
фuтoîs. A few lines before it is mentioned with the lark as nesting on the ground.

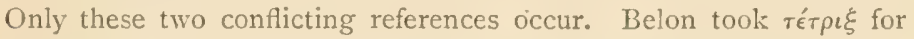
the Black Grouse, Camus and Buffon for the Capercaillie, neither of which occur in Attica. Sundevall identifies it with the Whinchat, vide S. v. те́тра乡.

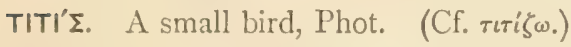

To'pros. A Vulture.

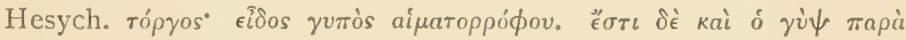

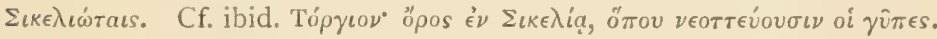
ảф’ oủ kaì aủroì tópyou.

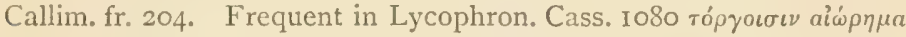

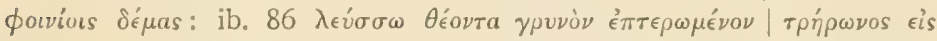

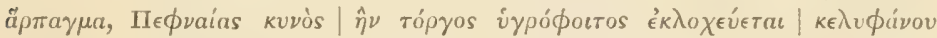

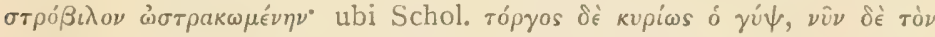

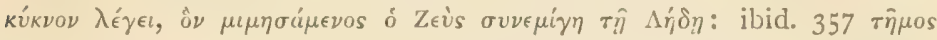

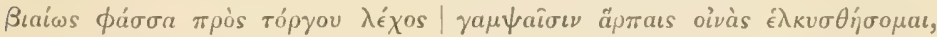
where the Scholiast is in doubt whether to translate oivás by ä $\mu \pi \in \lambda o s$, or

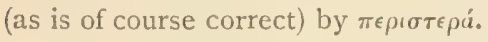

The word rópyos comes to us through Alexandrine writers (latebrasque Lycophronis atri !). I take it (in spite of Hesychius) to be an Egyptian word, and to be connected with the root of opp $p$ เ $\lambda_{\text {os }}(q . v$.$) and$

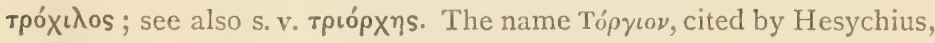
is at least more likely to be derived from tópyos, than the latter from it.

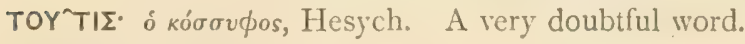

TPH'PSN. A Pigeon or Dove.

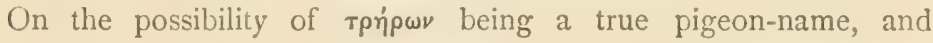
not merely an epithet derived from $\tau \rho \epsilon$ '́ $\pi \dot{\lambda} \lambda \epsilon \iota$. 
TPHP $\Omega N$ (continued).

Moero, ap. Athen. xi. 49 I $\mathrm{B}$ of the doves that fed the Infant Jupiter

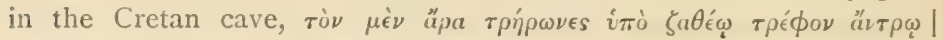

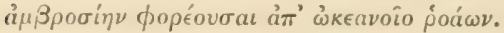

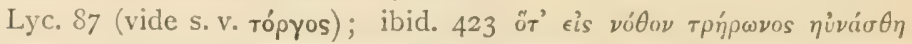

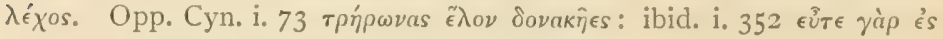

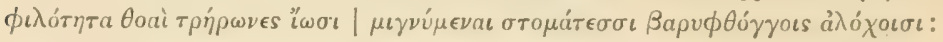

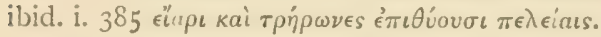

Hence $\pi \circ \lambda v \tau \rho \dot{\eta} \rho \omega \nu$, an epithet of Laconian Messe, and Boeotian Thisbe, I1. ii. 502, 582 ; cf. Stat. Theb. vii. 26r Dionaeis avibus circumsona Thisbe. There is a curious apparent coincidence between the association with doves of the town Thisbe, and the connexion of Thisbe in the story of Pyramus and Thisbe (Ovid, Met. iv) with Babylon, urbs Semiramidis: on the dove-myth of Semiramis, vide S.v. $\pi \epsilon \rho \iota \sigma \tau \epsilon \rho \dot{.}$.

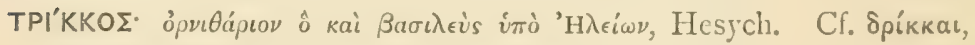

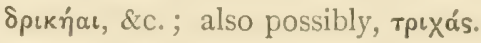

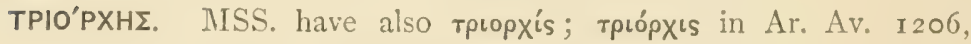

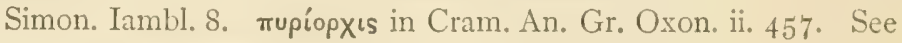

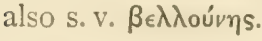

\section{A Buzzard (?), Buteo vulgaris, auctt. Mlod. Gk. Bapßaxiva.}

Ar. Av. II81, I206; also in Ar. Vesp. 1532, where the Buzzards are called the children of Poseidon.

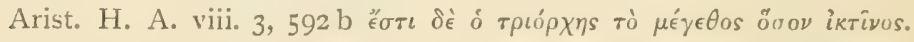

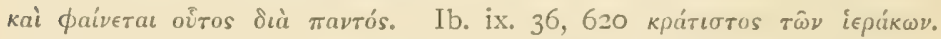

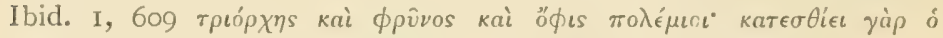

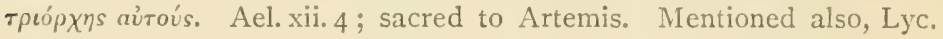
I 47 ; Plin. x. (8) 9 Triorchem a numero testium. Buteonem hunc appellant Romani.

Tradition interprets $\tau \rho \iota \rho^{\prime} \chi \eta s$ as the Buzzard, with which the descrip-

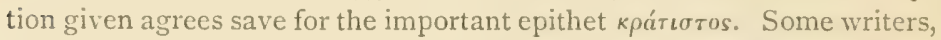
e.g. Thuanus, De Re Accip., 16 12, pp. 22, 100, repudiate the identification.

The mediaeval anatomists, Aldrovandi, Gesner, \&c., sought and found (!) the abnormality from which the bird apparently derives its name: but the derivation is probably quite false, and the word corrupted by Volksetymologie. Is it possible that its origin lies hid under the name rópyos, (q. v.)?

According to Nicander, ap. Anton. Lib. c. xiv, Munychus was metamorphosed into the bird $\tau \rho \iota \rho^{\rho} \chi \eta s$, and his son Alcander into " $\rho \chi \chi \imath$ s other two sons becoming i $\chi \nu \epsilon \dot{\nu} \mu \omega \nu$ and $\kappa \dot{\omega} \omega \nu$, both of which are here spoken of as birds. There is, to my mind, an Egyptian look about the whole story. 


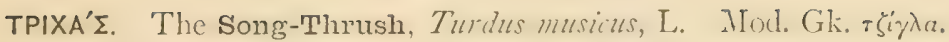

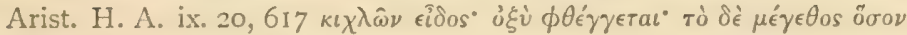

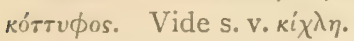

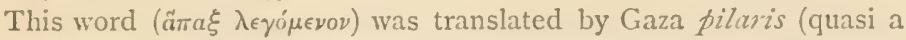

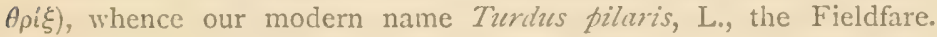
The word survives in Mod. Gk. as $\tau \sigma i \chi \lambda \alpha, \tau \zeta i \gamma \lambda \alpha, \tau \zeta i \gamma \lambda \alpha a$, and is possibly the same as трíkкоs, q.v.; it is a parallel form to кíx $\lambda \eta$, and is the same as our thrush. [Cf. Lith. s-trazd-as (Nessl. p. 506), Russ. drosd", Icel. trast, L. turdus, \&c.]

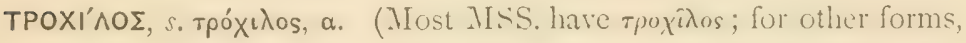
v. Lob. Par. I 5. ) Derived, in my opinion, from the root of ö $\rho \times \imath \lambda o s(q . v$.$) , and not connected with \tau \rho \epsilon ́ \chi \omega$.

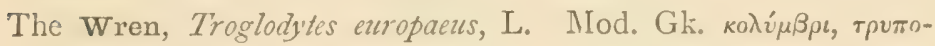
карúoa (Erhard, Bikélas).

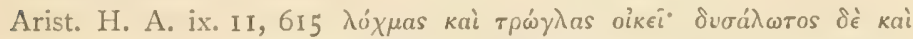

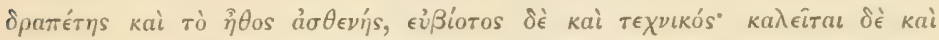

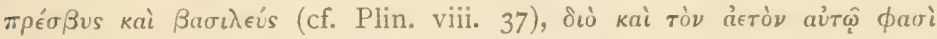
$\pi 0 \lambda \epsilon \mu \epsilon i \nu$ : cf. ibid. ix. I, 609 b. Mentioned as an oracular bird, Plut.

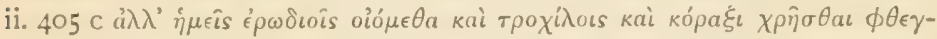

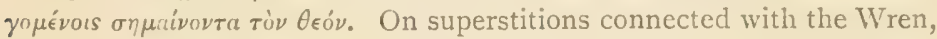
'The king of all birds,' \&c., Dyer, Brit. Pop. Customs, I876, p. 497 ; id. Engl. Folk-lore, I880, p. 67; Croker, Researches in S. Ireland, I\&24, p. 233 ; N. and Q. (6), xi. p. 297, I885, \&c., \&..

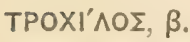

The Egyptian Plover or Ziczac, Pluviamus aegyptius = Hyas aeguptiacus $=$ Charadrius melanocephalus. Also called $\kappa \lambda a \delta$ apópvy $\chi^{o s .}$ This identification, due in the first instance to Geoffroy St. Hilaire, is generally accepted: a recent writer, however, states that the true 'Crocodile-bird' is a somewhat larger species, the spur-winged Plover, Hoploplerus spinosus (Ibis, I 893, p. 277).

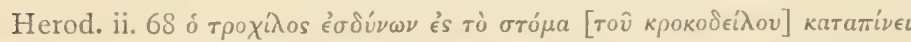

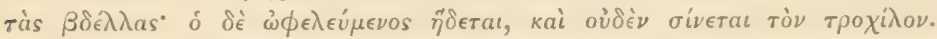

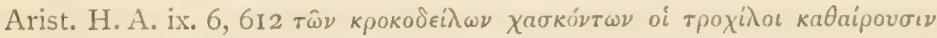

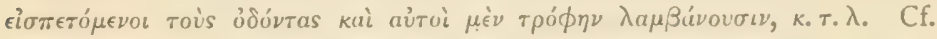
Arist. Nirab. 7, 831 a ; Ammian, xxii. 15, 19; Antig. Car. c. 33; Ael. iii. I I, viii. 25, xii. I 5 ; Plut. De Sol. Anim. ii. 980 d; Phile, De An.

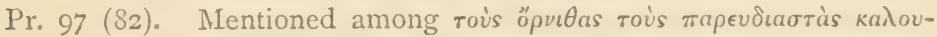
$\mu^{\prime}$ vovs, Athen. x. 332 e. In Dion. De Avib. ii. 3, the name is apparently applied to various sandpipers. Mentioned also Ar. Av. 79 ("̌б

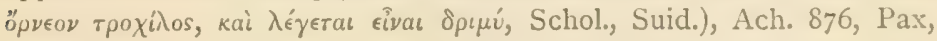
$1004, \& c$. 


\section{TPOXINOE (continued).}

Pliny confuses it with the foregoing: Parva avis quae trochilos ibi vocatur, rex avium in Italia, H. N. viii. (25) 37.

Cf. G. St. Hilaire, Descr. de l'Égypte, (2) xxiv. p. 440, Mém. du Mus. xv. p. 466 ; Curzon, Monast. of the Levant, c. xii ; Brehm, Thierleben, Vögel, iii. p. 216 (2nd edit.); Newton, Dict. of Birds, pp. 442, 733, \&c.

TPY'rTAz. In some MISS. and editions (Ald. Schn. Ec.) for míyupros, Arist. H. A. viii. 3, 593 b.

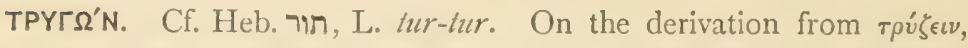
cf. Eust. Hom. Il. (xi. 3I I), p.75 I, Od. pp. 229, I95I ; Schol. ad Theocr. Id. vii. I40, \&c.; cf. Isid. Orig. I 2, I 7 turtur de voce vocatur. I am inclined to think that $\tau \rho v \gamma \dot{\omega} \nu$ cannot be directly derived from $\tau \rho \dot{v} \zeta \epsilon \iota$, but that the verb was applied to the dove's note from mere coincidence of sound: and further that the root

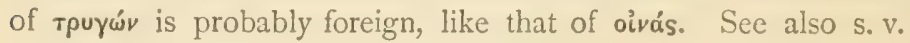
три́р

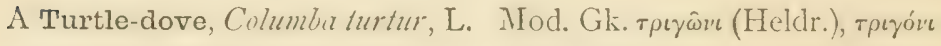

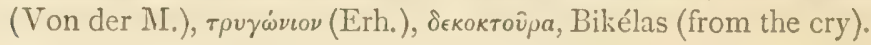

Mentioned Ar. Av. 302, 979, \&c.

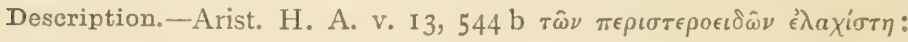

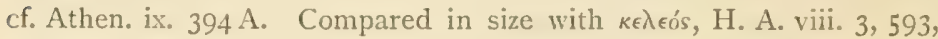

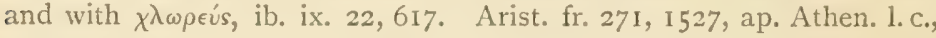

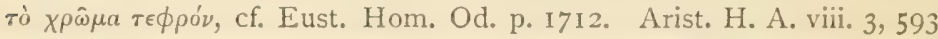

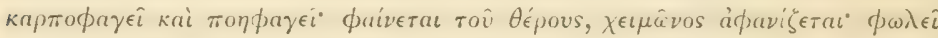

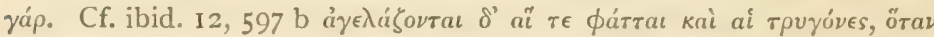

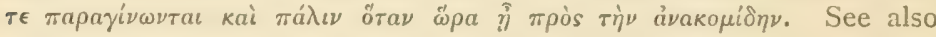

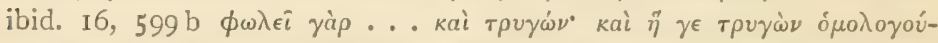

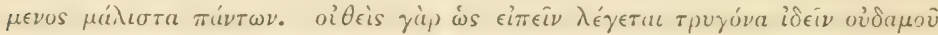

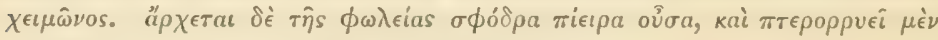

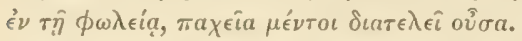

Cf. Plin. x. (24) 35 verius turtur occultatur, pennasque amittit. On its migration, see also Varro, De R. R. iii. 5, 7, \&c. Arist. H. A. ix. 7,

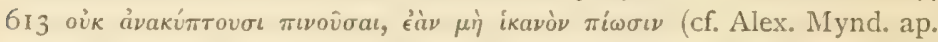

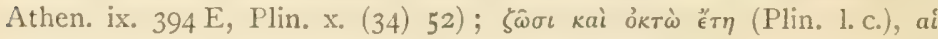

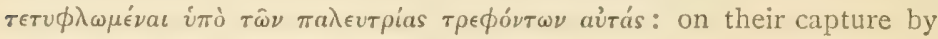
decoys, see also Dion. De Avib. iii. 4, 16.

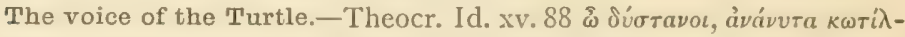

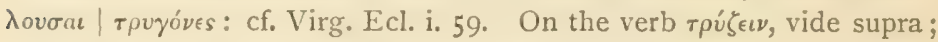

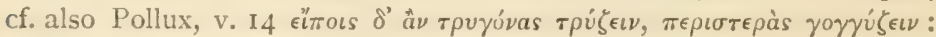

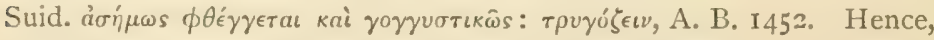

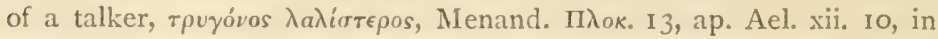
which passage a 'double entendre' is expatiated on by Aelian, Suidas, 
TPY $\Omega N$ (continued).

\&c. ; see also Demetr. Sic., ap. Ael. l. c., Arist. H. A. ix. 49 B, 633 b,

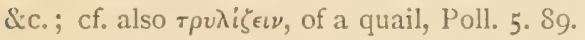

Reproduction, Nesting, \&c.-Arist. H. A. vi. I, $55^{8}$ b

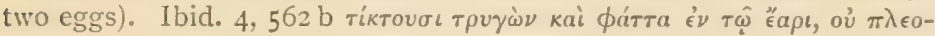

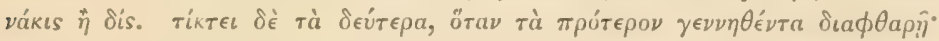

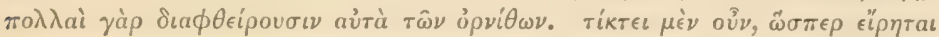

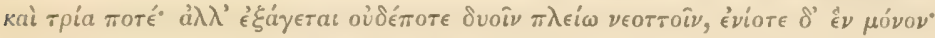
тò $\delta$ '

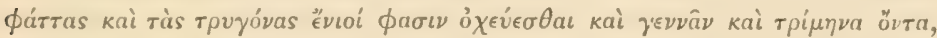

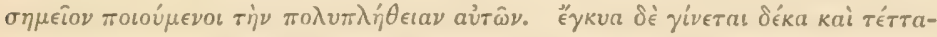

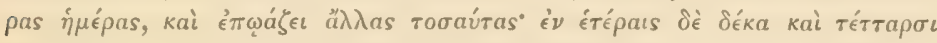

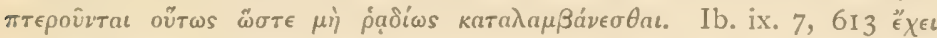

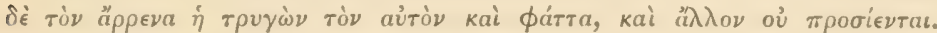
(Concerning its chastity, see also Ael. iii. 44, x. 33, Dion. De Avib.,

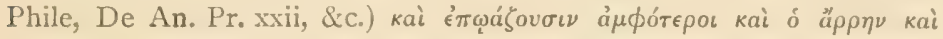

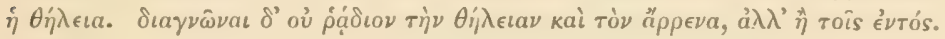

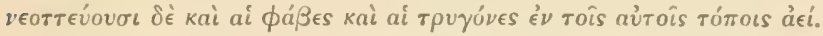

The Cuckoo builds in its nest, Arist. De Mirab. 3, 830 b.

On White Turtle-doves, which are sacred not only to Aphrodite and to Demeter, but also to the Fates and the Furies, Ael. x. 33 .

How Turtle-doves were brought as tribute to the Indian king; Ael. xiii. 25. How the Turtle-dove is slain by $\chi \lambda \omega \rho \epsilon u ́ s$, Arist. H. A. ix. 1, 609, Phile, De An. Pr. 69o ; is hostile to $\pi v \rho a \lambda \lambda$ is, Arist. l. c., and to

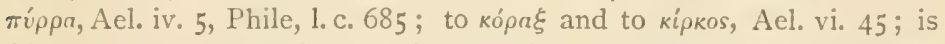

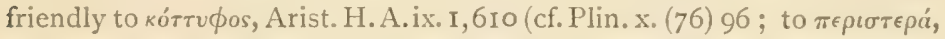
Ael. v. 48, and to the Parrot, Plin. x. (76) 96, cf. Ovid, Heroid. xv. 38 et niger a viridi turtur amatur ave; id. Amor. ii. 6, 12 tu tamen ante alias, turtur amice, dole. Plena fuit vobis omni concordia vita, \&c. These last references probably allude to the practice of keeping Turtledoves together with Parrots in aviaries. On Turtle-doves in captivity, see Varro, iii. 8, Columella viii. 9, Geopon. xiv. 24, \&c. Mentioned as a delicacy, Juven. vi. 39, Martial. xiii. 53, \&c. Is killed by pomegranate seed, Ael. vi. 46, Phile, 1. c. 657, and uses the fruit of the Iris as a charm, Ael. i. 35, Phile, 1. c. 727. Possibly identical with the trigon or try'gon that is said to issue tail first from the egg, Hylas ap. Plin. x. (I6) I8.

They are captured by the aid of decoys, at their drinking-places, Dion. De Avib. iii. 12; or with bird-lime, ibid. 2. An incredible story of their being beguiled by dancing and music (sometimes referred to $\tau$ pvý́ $\nu=$ pastinaca) Ael. i. 39, Phile, De An. Pr. 22 (2I), 464.

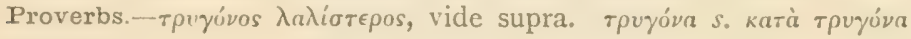

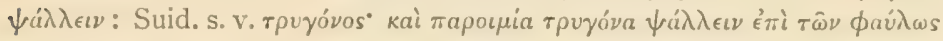

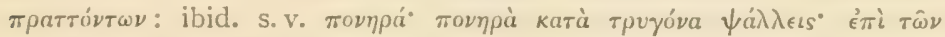

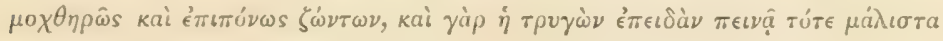

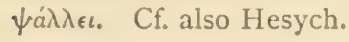




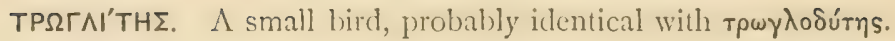

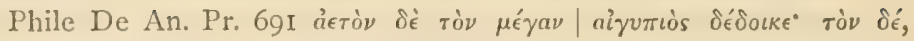

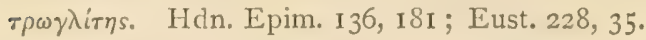

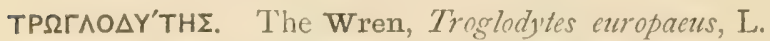

Philagr. Med. ap. Aët. xi. II (cit. Schn. in Arist. vol. iv. p. 85) $\sigma \tau$ pov-

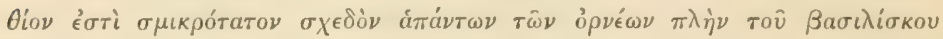

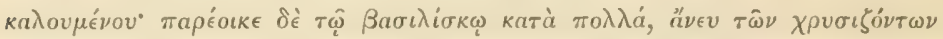

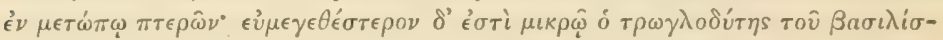

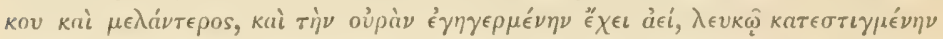

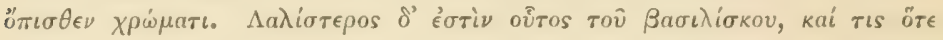

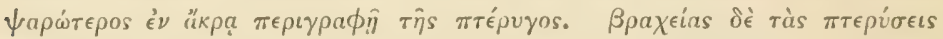

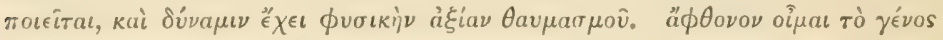

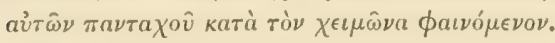

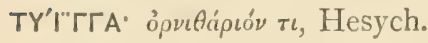

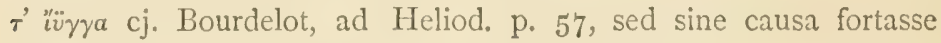
(M. Schmidt, ad Hesych.).

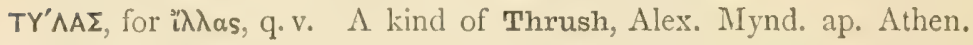
ii. 65 a.

TY'MANOS. An unknown bird.

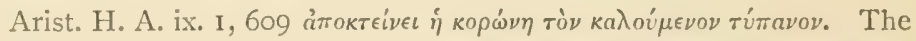
fact that the Crow is also said to be hostile to ö $\rho \chi \iota \lambda o s$ and to $\pi \rho \epsilon \epsilon \beta \nu s$,

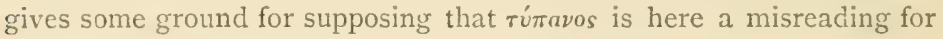
тúpayvos.

TY'PANNos. The Gold-crested Wren, Rogulus cristatus and ignicapillus. (Both species occur in Greece, Von der Mühle, p. 68,

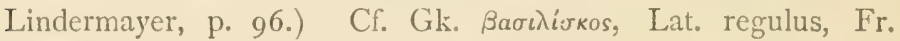
roitelet, Germ. Zaunkönig, \&c.

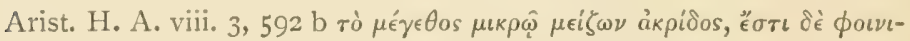

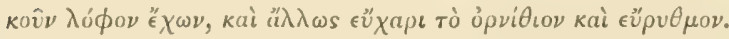

TYT $\Omega^{\prime} \cdot \dot{\eta} \gamma \lambda a \imath \hat{\xi}$, Hesych.

Cf. Plaut. Menaechm. iv. 2, 90 Vim afferri noctuam, quae tutu usque dicat tibi? Cf. O. Keller, Lat. Etym., I893, p. I I I.

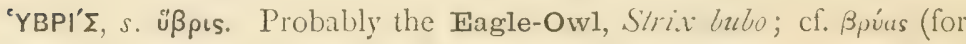
$\beta$ úas), of which word ispis is perhaps a corrupt form.

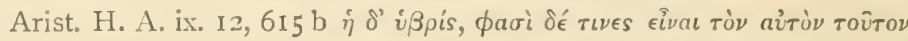

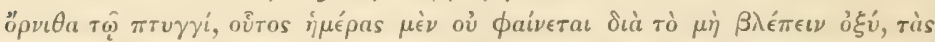

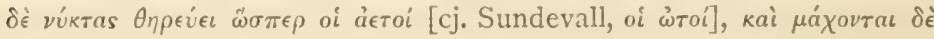

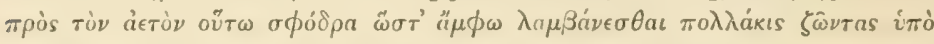

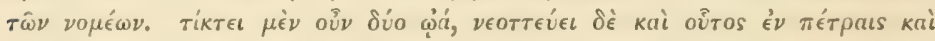

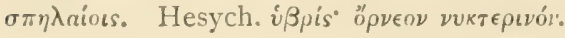




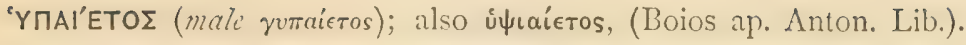
An obscure name for an Eagle or Vulture.

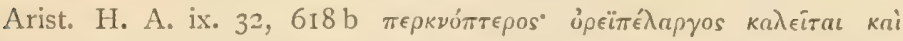

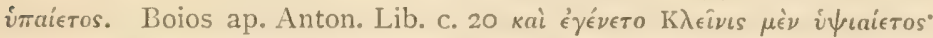

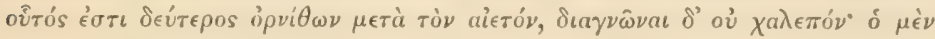

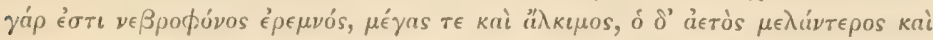

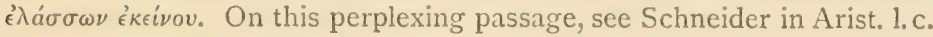

'YחO $\triangle E \Delta I \Omega$ ' . A Libyan bird-name, Ar. Av. 65.

The word is commonly taken as a Comic derivative of $i \pi n \delta \in i \delta \omega$ (cf. Soph. Aj. 169). The five bird-names beginning with the syllable $i \pi-$ are all obscure, and what little is said about them is replete with signs of foreign influence. I am pretty certain that in none of these cases does imo- mean sub, and for my own part I suspect it to be a corruption of a foreign, and probably Egyptian, word or prefix.

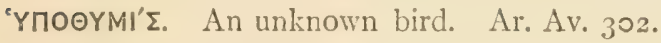

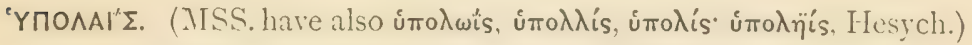
An indeterminate small bird. Perhaps the Wheatear, Saxicola sp. The Cuckoo lays her eggs in its nest, which is on the ground, Arist. H. A. viii. 7, 564, ix. 29, 618, Antig. H. Mir. Ioo (109), Theophr. De

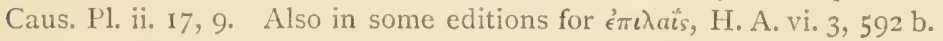
Sundevall suggests the Wheatear, which makes its nest under a stone, from a supposed connection with $\lambda$ âas ; and the conjecture is supported to some extent by the circumstance that the Cuckoo is known sometimes to use the Wheatear's nest in Greece (Krüper, p. I84); but the derivation is very doubtful. The Orphean Warbler is the bird in whose nest the Cuckoo in Greece usually lays its egg, and further the statements in Aristotie as to the birds in whose nest the Cuckoo lays are very untrustworthy.

\section{'YПОТРІО'РXН乏. A kind of Hawk.}

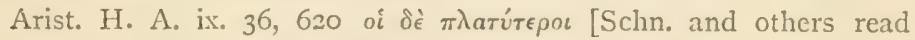

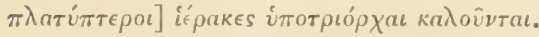

There is nothing by which to identify the name, which indeed seems to be to some extent generic. The name subbuteo is traditionally applied to the Hobby, which if $\pi \lambda a \tau$ intepos means broad-winged, is, as Sundevall remarks, excluded by the epithet.

фАвотү'пог, s. фаßокто́ros, Ilesych. A kind of Hawk. Cl. фаббoфóvos, q. V.

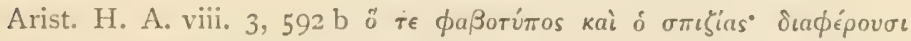

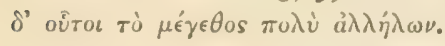


QA^AKPOKO'PAE. A bird, commonly identified, on the strength

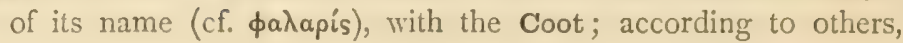
the Cormorant. See also s. v. кópa $\xi, \boldsymbol{\beta}$.

Plin. x. (48) 68 Iam et in Gallia Hispaniaque capitur [attagen], et per Alpes etiam, ubi et phalacrocoraces, aves Balearium insularum peculiares. Cf. ib. xi. 47 quaedam animalium naturaliter calvent, sicut ... corvi aquatici, quibus apud Graecos nomen est inde.

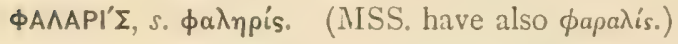

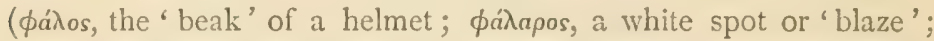

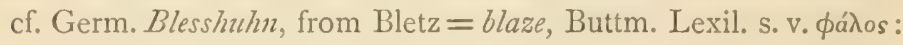
the Engl. bald-coot is analogous.)

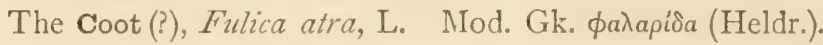

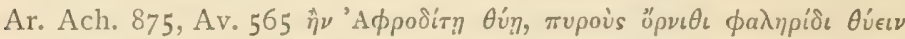

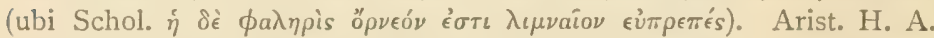

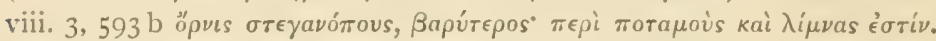

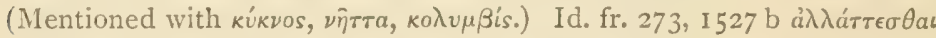

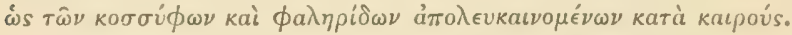

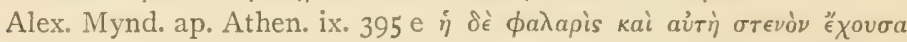

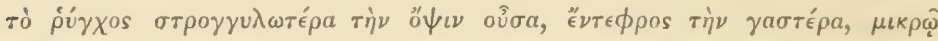

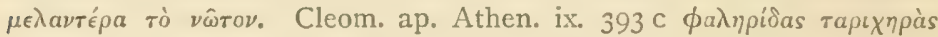

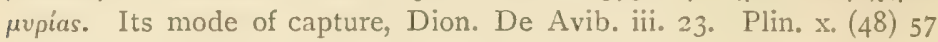
Phalerides in Seleucia Parthorum et in Asia, aquaticarum laudatissimae; Colum. viii. 15, I ; Varro, R. R. iii. I I, 4.

The identification rests mainly on the modern name, of which Sundevall and Aubert and Wimmer seem to have been unaware, and is supported by the derivation of the word. Sundevall suggests Mergus albellus, and Aubert and Wimmer also suppose a species of Mergus. Gesner, Camus, and other older commentators agree in the identification of Coot. At best the identification is doubtful, and the various references perhaps refer to more birds than one. The allusion in Athenaeus to ten thousand salted $\phi a \lambda \eta p i \delta a s$ is especially puzzling. The connexion with Aphrodite in Ar. Av. 565, where we might rather have expected some such word as $\pi \epsilon \rho \iota \sigma \tau \epsilon \rho \hat{a}$, is not explained.

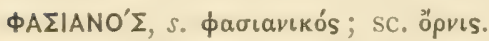

A Pheasant, Phasianus colchicus, L. Vide also s. v. tétapos.

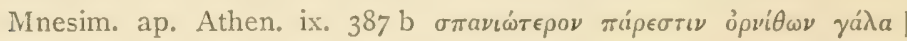

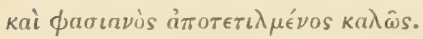

Ar. Av. 69; Nub. 109 (sometimes supposed to refer, in the latter passage, to a Phasian horse, cf. Suidas, Lob. Phryn. 460, but not so according to Athen. ix. 387 a).

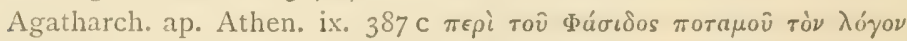

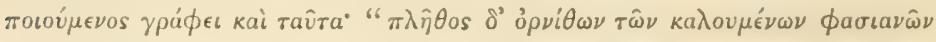




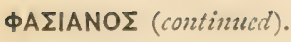

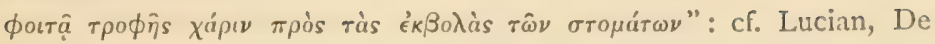
Merc. Cond. 17, Navig. 23. Callix. Rhod. ap. Athen. 1.c. (describing

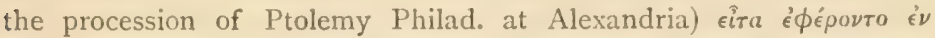

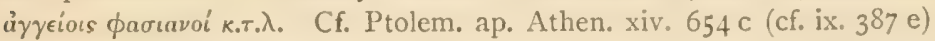

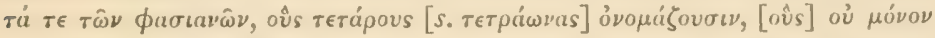

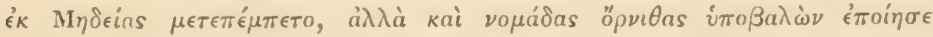

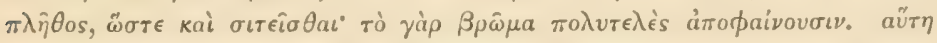

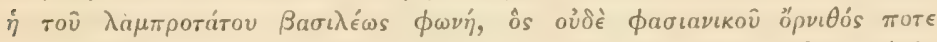

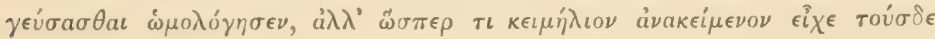

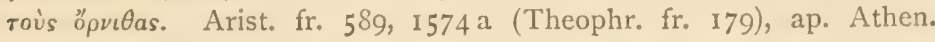

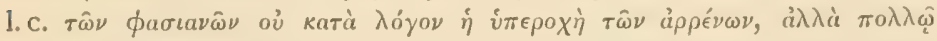

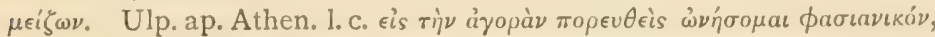

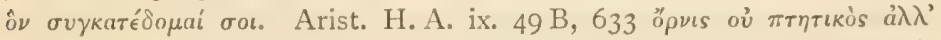

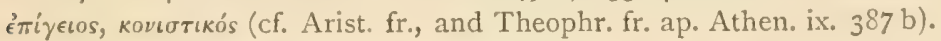

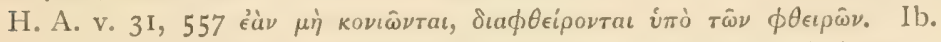

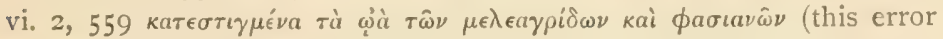
is repeated by Buffon, Hist. Ois. iv. 78).

On Pheasants reared by the Indian kings, Ael. xiii. I8. On the breeding and rearing of Pheasants, see Pallad. R. R. i. 29, Colum. viii. $8,10$.

For Latin references to the Pheasant as a dainty, cf. Juv. xi. I39 Scythicae volucres; Mart. xiii. 45, 72, \&c. ; Stat. Silv. i. 6, 77, ii. 4, 27 ; Manil. Astron. v. 376 ; Suet. Cal. 22 ; Lampr. Alex. Sev. 37 Iovis epulo et Saturnalibus et huiusmodi festis diebus phasianus; Capitol. Pert. 12 phasianum nunquam privato convivio comedit aut alicui misit ; Amm. xvi. 5, 3 phasianum et vulvam et sumen exigi vetuit (Iulianus) et inferri, munificis militis vili et fortuito cibo contentus; Ambr. Hexaem. vi. 5 exquisitum illud et accuratum opipare convivium, in quo phasiani aut turturis species apponitur.

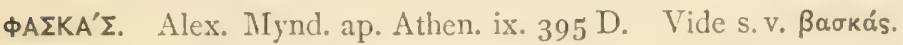

$\phi A^{\prime} \Sigma \Sigma A, A t t . \phi a ́ t \tau \alpha$.

A Ringdove or Woodpigeon, Columba palumbus, L. Mod. Gk.

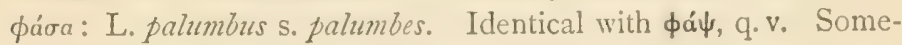
times applied also to the Domestic Pigeon, v. infra. Dim. фа́ттьо, Ar. Pl. ror I, Ephipp. 3, 334 (Mein.). An artificial masc. form фárтos in Luc. Soloec. 7. Used as an illustration of the interchange of $\sigma \sigma$ and $\tau \tau$, Luc. Jud. Voc. 8. [On the

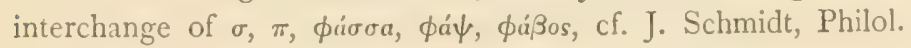
Anz. xxv. p. I39, I881.]

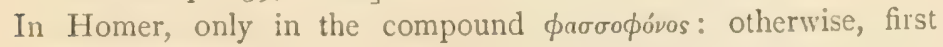
in Aristophanes. 


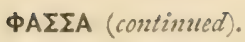

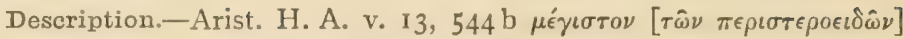

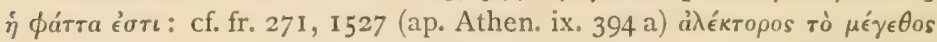

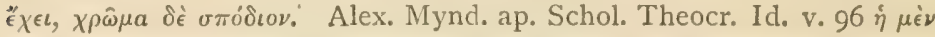

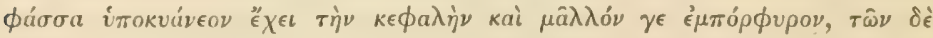

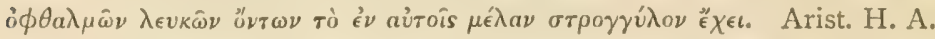

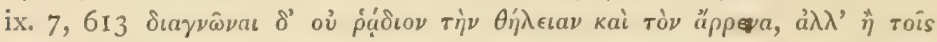

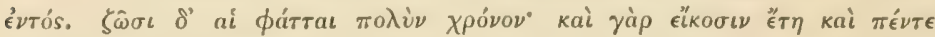

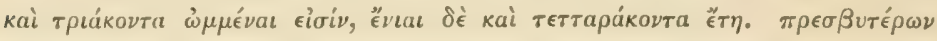

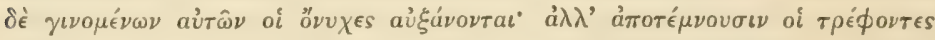

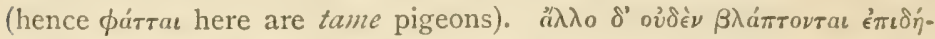

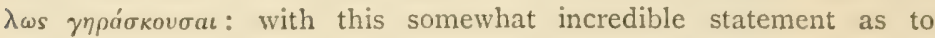
length of life, cf. ib. vi. 4, 563, Athen. ix. 394 b, Plin. x (32) 52. Arist.

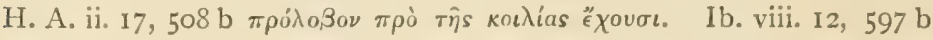

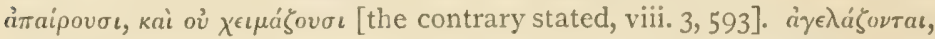

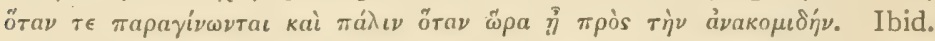

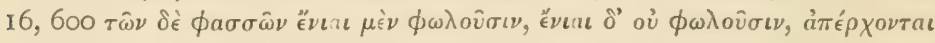

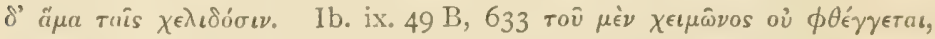

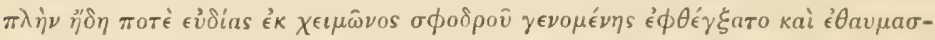

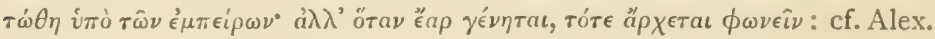
Mynd. ap. Athen. 394 e. Arist. H. A. viii. I8, 60I oi aủ $\chi \mu$ oi $\sigma u \mu \phi \epsilon ́ p o v \sigma \iota$

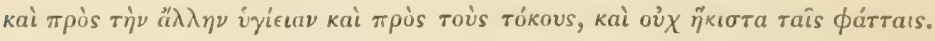

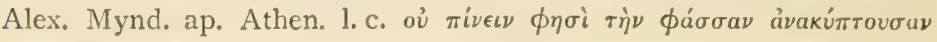

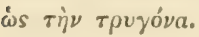

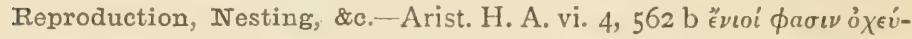

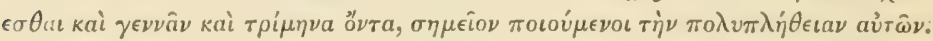

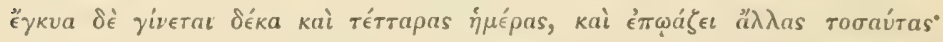

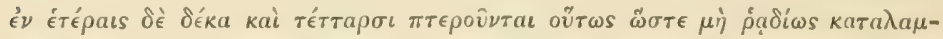

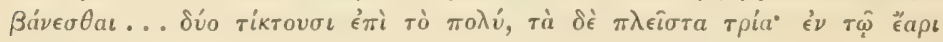

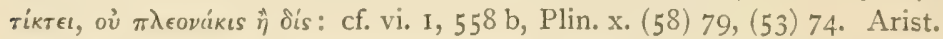

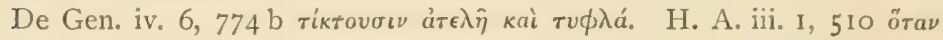

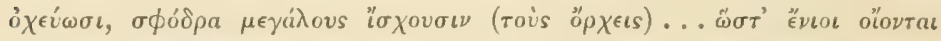

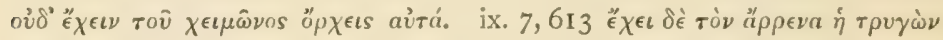

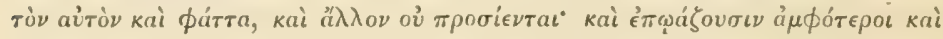

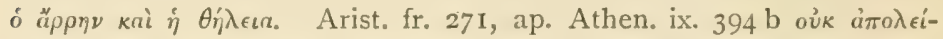

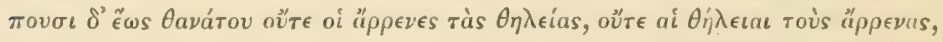

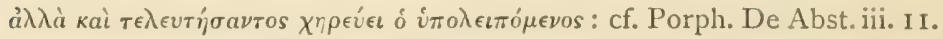
How it places a branch of laurel, $\delta a ́ \phi \nu \eta$, in its nest for a charm, Ael. i. 35, Phile, 722, Geopon. xv. I, cf. Plin. viii. (27) 41. How the Cuckoo builds in its nest, and the young Cuckoo, assisted by their parents, casts out its foster-brothers, Arist. De Mirab. 3, 830 b, Ael. iii. 30.

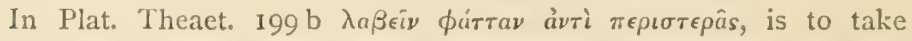
a wild pigeon for a tame one. Its flesh is mentioned as a dainty,

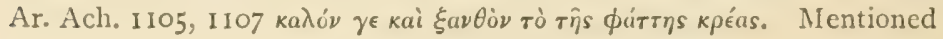




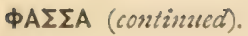

as coming from Boeotia, Ar. Pax II04. In Anth. Pal. ix. 7I the oak

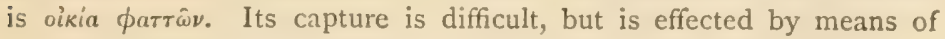
nets and by the aid of blinded decoy-birds, Dion. De Avib. iii. 12.

A lover's gift, Theocr. v. 133. The Dim. фártıv, used as a term

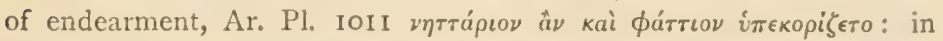
Philip. Obel. fr. ap. Athen. viii. 359 b, a little pigeon, a skinny one.

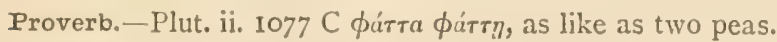

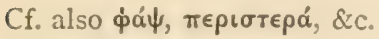

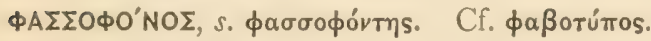

A species of Hawk.

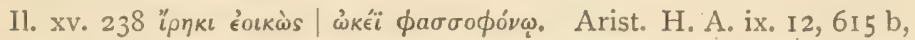

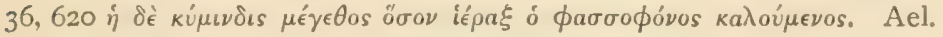

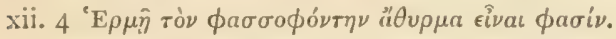

Commonly translated Goshawk, i. e. Astur palumbarius, L., which has moreover a reputation for extreme swiftness: but the Goshawk is rare in Greece (Lindermayer, Von der Mühle), and there is no definite tradition in regard to the name (Scaliger, in Arist. p. 249 certe periculosum sententiam suam dicere). The above references are all mystical; cf. S. v. $\pi \epsilon ́ \lambda \epsilon \iota \alpha$.

$\phi A^{\prime} \Psi$. A Wild Pigeon; almost certainly identical with фároa, the Ringdove. Cf. фаßотúros, фaбooфóvos.

Apparently distinguished from фú $\sigma \sigma a$ in Arist. H. A. viii. 3, 593 a, I5, where however, in the catalogue of pigeon-names, some

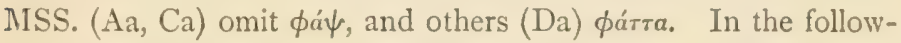

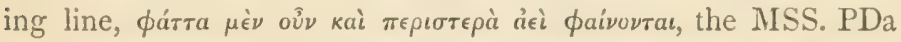
read фá $\psi$, as in Arist. fr. 27 I, I527, Athen. ix. 394 a. In Arist. ap. Athen. 1.c. there is further confusion in the statements as to their size, $\phi \dot{\sigma} \sigma \sigma a$ and $\phi i \dot{\psi}$ being apparently cited as different, but the passage is corrupt.

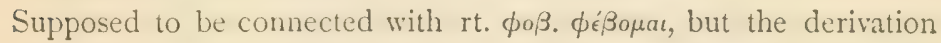
is as doubtful as its supposed parallel, $\tau \rho \dot{\eta} \rho \omega \nu, \tau \rho \epsilon$ é. As zar. $l l$. $\phi \lambda a ́ \beta \epsilon s$, and $\phi \lambda c i \beta \omega \nu$ occur in Arist. passim; $\phi a \beta \omega \nu$ is specially cited in Aesch. Philoct. (fr. 232) ap. Athen. ix. 394 a.

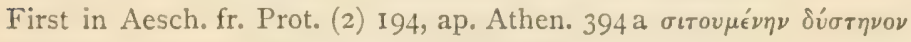

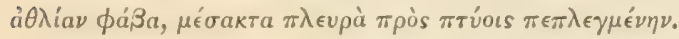

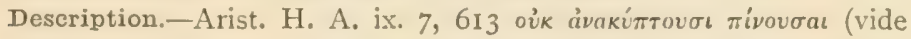

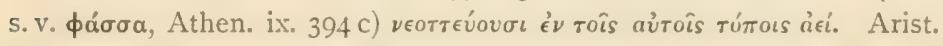

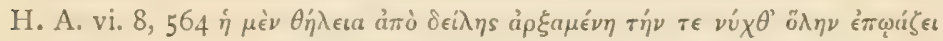

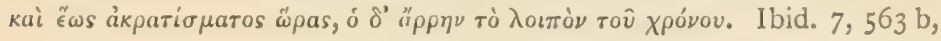




\section{ФA $\Psi$ (continued $)$.}

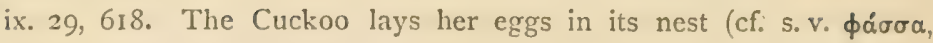
Arist. De Mirab. 3, 830 b).

Mentioned also Lyc. 580.

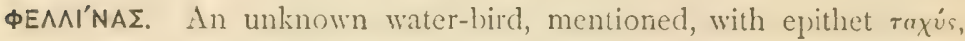
as being captured in nets, Dion. De Avib. iii. 23.

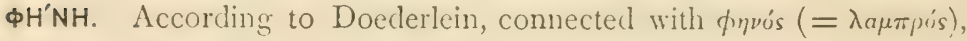

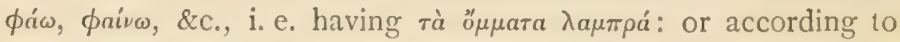
Von Edlinger and others, from root $b h a-n=\phi \omega \nu \epsilon \hat{\imath}$. I incline to think the word is an exotic, and probably Egyptian, connected with 申oiv $\xi, \mathrm{Eg}$. benmu.

\section{A kind of Vulture.}

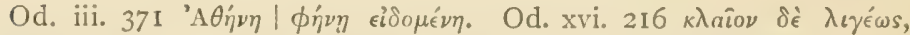

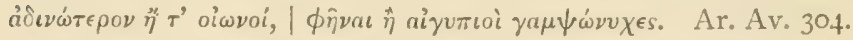

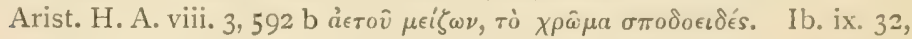

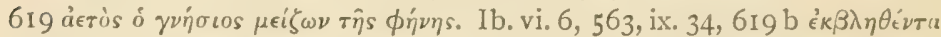

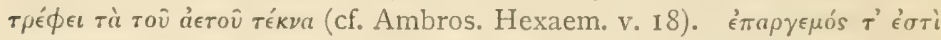

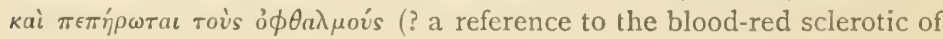
the eye). Its maternal affection referred to (cf. aiyumı́s, \& c.), Opp.

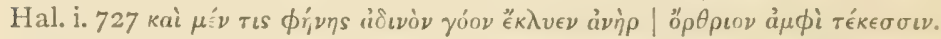

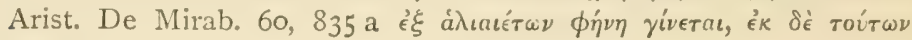

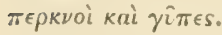

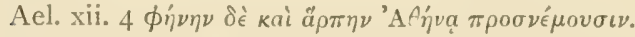

According to Boios ap. Anton. Lib. c. vi, Zeus metamorphoses the

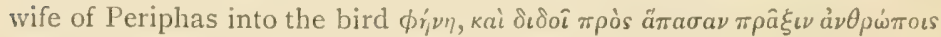

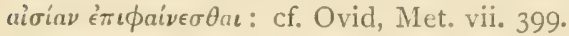

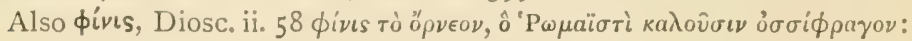
cf. Plin. x. 3 .

Identified by A:drovandi, Gaza, and by most moderns, with the Aquila barbata of Pliny, N. H. x. 3, that is to say with our Lämmergeier, Gypaëtus barbatus, L., which is accurately described by Dion. De Avib. i. 4 under the name åp $\pi$. The Lämmergeier is also identical with Lat. ossifraga (Plin. 1.c.), a name accurately descriptive of its habits, and Lat. sanqualis (Festus, 316, 317). The brief description in Arist. H. A. viii, inclines Sundevall, Aubert, and Wimmer, to identify $\phi \dot{\eta} \eta$ with Vultur monachus. The references are in the main poetical or mythical, and both the name and the stories of the bird's maternal affection seem to me to point to an Egyptian origin. With the stories of the Eagle's bastard brood, cf. the Mod. Gk. name $\mu \eta \lambda a \delta \varepsilon \lambda \phi \iota=$

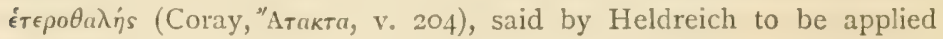
to Aquila Bonellii. 


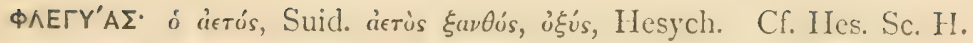
I 34 (vide infra).

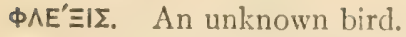

Ar. Av. 882. Perhaps connected with $\phi \lambda \in$ yúas, a name or ep. of

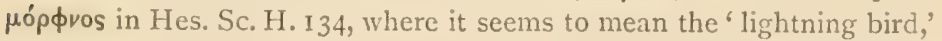
from $\phi \lambda \epsilon \gamma^{-} \omega$, fulg-eo, Sk. bharg, to shine. Cf. Steinthal, app. to Goldzieher, Myth. of the Hebrews, p. 384 (ed. London, 1877).

\$OINIKo'ntepor. The Flamingo, Phoiniofinus antipuorum, L.

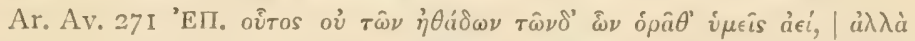

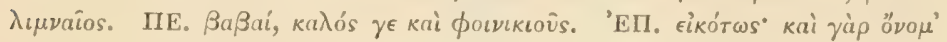

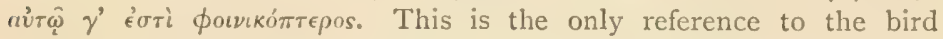
in classical Greek, and the identification here is at best doubtful. The succeeding reference to the Cock might lead one to suspect that under the name Phoenicopterus some bird less unlike the Cock than the Flamingo is, was here alluded to: such a bird, for example,

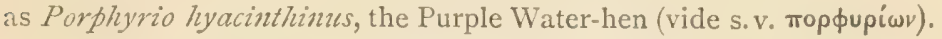
The question, however, is not capable of settlement. The Flamingo occurs in Greece only as a rare straggler, though abundant on the opposite coast of Asia Minor (Von der Mühle, p. II8; Lindermayer, p. 155, \&r.). Cf. Gesner, H. Anim. lib. iii Mirum est huius tam pulchrae et eximiae avis nomen ab Aristoteli taceri, cum Aristophanes, qui vixit eadem aetate, meminerit; sed Graecis etiam raram esse hanc avem puto. Flamingos were seen, however, by Bory de St. Vincent, in the marshes of Osman Aga near Navarino.

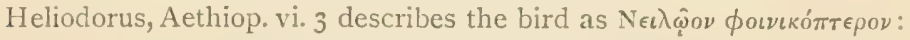
and the Scholiast ad Juv. xi. I39 states in like manner, abundans est in Africa : it, apparently, is also mentioned as a dainty, by Philostr.

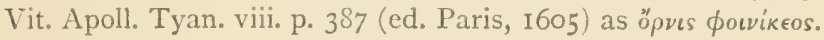

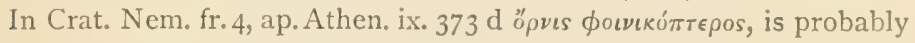
the Cock.

It has been stated above, s. v. $\gamma \lambda \omega \tau$ tis, that Belon (Hist. des Oyseaux, viii. 8) identified that bird with the Flamingo; so also did Aldrovandi (Ornithol. iii. 20,4), with as little reason. To the opinion there ascribed to Linnaeus, the following words of Gesner should have been subjoined: ego vero iis quas Gallinulas aquaticas nostri vocant avibus Glottidem adnumero, quae omnes fissipedes sunt; cf, also Scaliger (in loc. Aristot.) Glottis autem quae sit nondum mihi constat; ridiculum quod quidam de Phoenicoptero ausus est pronuntiare.

In Latin, references to the Flamingo are frequent and free from doubt. Cf. Juv. xi. I39 et Scythiae volucres et phoenicopterus ingens; Martial, Ep. iii. 58, I4 nomenque debet quae rubentibus pennis; ib. xiii. 71 dat mihi penna rubens nomen; Suet. Cal. 22, \&c., \&c.

'That the Tongue of this Volatile was much commended, and in 


\section{\$OINIKOTTEPOI (continued).}

great Esteem, for its excellent Taste and most delicious Relish, will appear from the following Ouotations' (Douglass, op. infra cit.) : Plin. x. (48) 68 Phoenicopteri linguam praecipui saporis esse, Apicius docuit; Martial, xiii. II sed lingua gulosis Nostra sapit: quid si garrula lingua foret? cf. also Sueton. Vitell. xiii. The brain was also a tid-bit, and Heliogabalus (Lamprid. 20, p. I08) exhibuit Palatinis dapes extis et cerebellis Phoenicopterorum refertas. Receipts for the cookery of Flamingos are given (without mention of the tongue) by Apic. (?) De Re Coquin. vi. 7. I am inclined to believe that such costly indulgences of the palate were often determined by obscure superstitious motives (as are many Chinese luxuries) rather than by real or imaginary refinements of taste. Nevertheless the Flamingo's tongue is said to be still appreciated: cf. Von der Mühle, Ornithol. Griechenlands, p. 118 Ein französischer Schiffscapitain brachte mir einige von Smyrna, wo sic sehr häufig sind, und von den Jägern den Engländern zum Verkaufe angeboten werden, welche die dicke fleischige Zunge als Leckerbissen verzehren. Cf. (int. al.) the interesting paper by Dr. J. Douglass in Phil. Trans. v. p. 63, 1721.

фOINI'KOYPOE. The Redstart, Luscinia fhocnicums, L., and L. tithy's

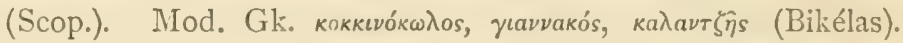
Arist. H. A. ix. 49 B, 632 b; Plin. x. (29) 44; vide s.v. épíakos. Cf. also Geop. Xv. I, 22.

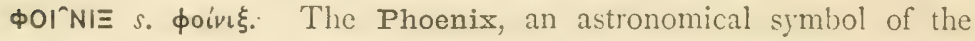
Egyptians. Eg. bemm.

First in Hes. Fr. 50, 4.

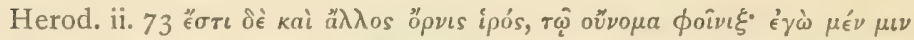

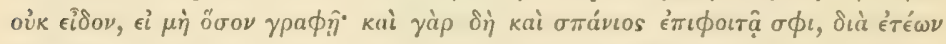

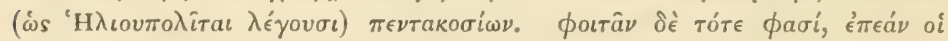

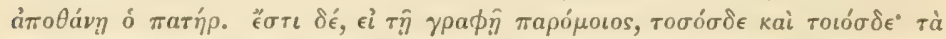

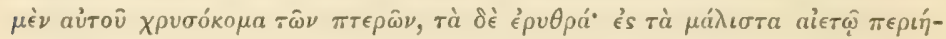

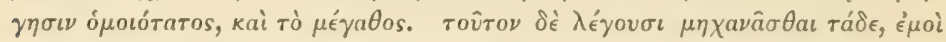

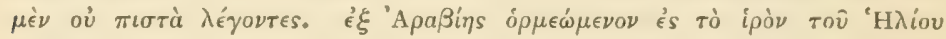

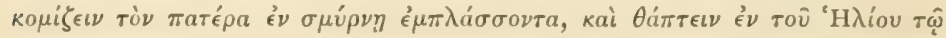

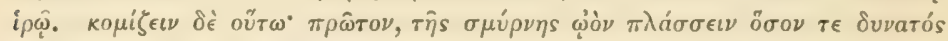

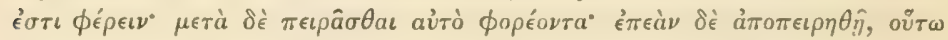

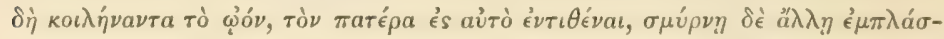

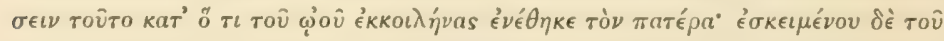

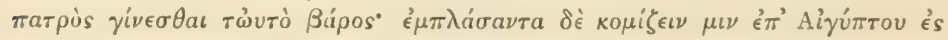
rov̂ 'H $\lambda$ íou tò ipóv. Cf. Ael. vi. 58, Philostr. Vit. Apollon. Tyan. iii. 49,

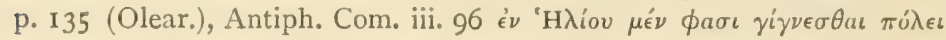

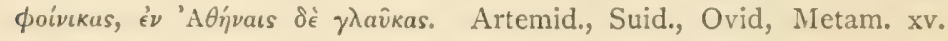
392, \&c. 
ФOINIE (continued).

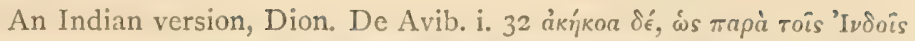

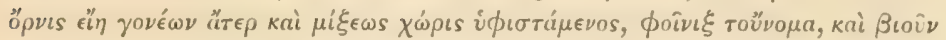

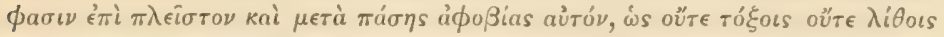

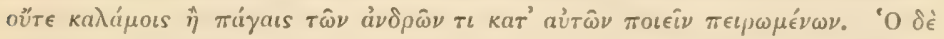

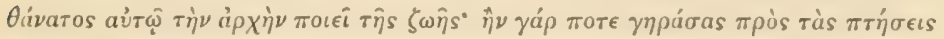

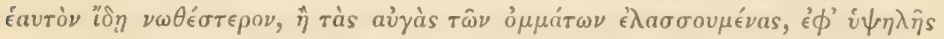

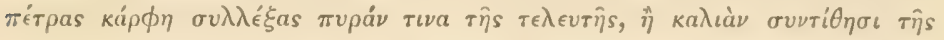

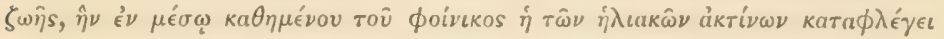

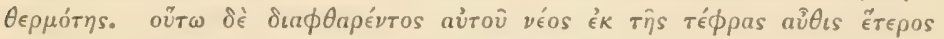

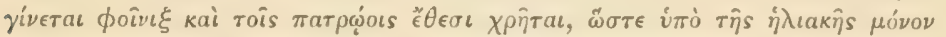

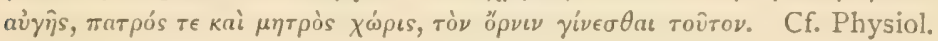
Syr., c. xvi (who adds that the Phoenix builds its nest in the month Pamnuth, s. Faminoth, a Coptic word); Epiphan. in Physiol. c. xi, Eustath. Ant., p. 29 (ed. Lugd. 1677), Pseudo-Hieronym., p. 219 (ed. Venet. 1772).

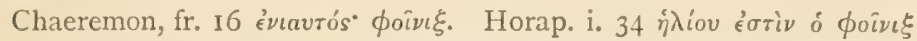

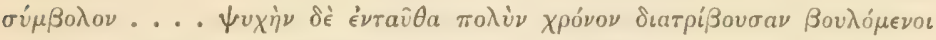

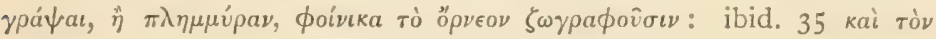

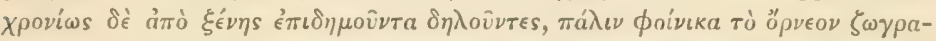

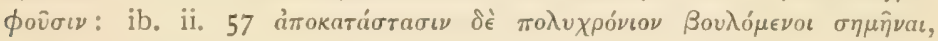

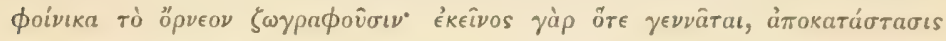

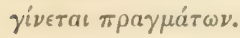

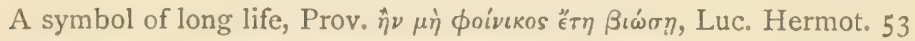
(I, 793) ; cf. Job xxix. 18, where for sand read Phoenix.

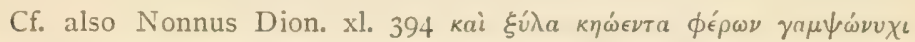

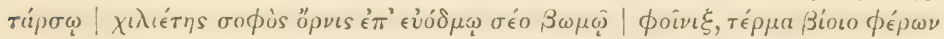

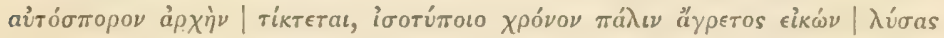

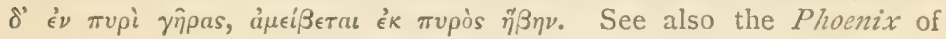
Claudian; Auson. Id. xi ; Ovid, Met.xv. 402 ; Senec. Ep. xlii ; Pompon. Mela, iii. 9 ; Lactant. (?) Carm. Phoenice; Lucian, iii. 27, 276, 350; Solin. Polyhistor. c. 36 ; Clem. Rom. Ep. i ad Corinth. c. 24, p. I20, \& c.

Late apparitions of the Phoenix, Plin.x. 2 ; Tacit.vi. 28; Dio C. Ivii; Suidas; Tzetz. Chiliad. v. 6. A new Phoenix-period is said to have commenced A.D. I39, in the reign of Antoninus Pius; and a recrudescence of astronomical symbolism associated therewith is manifested on the coins of that Emperor.

Various remedies were to be obtained from its nest, Plin. xxix. 9 (Irridere est vitae remedia post millesimum annum reditura monstrare).

For further references, oriental and classical, see Bochart, Hieroz. ii. coll. 8 I 8,849 .

On the Phoenix as an astronomical symbol of a cyclic period, see (int. al.) Marsham, Canon. Chron. p. 9, 387 ; Creuzer's Symb.i. p. 438, ii. p. 163 ; Lewis, Astr. of Anc., p. 283; Kenrick's Egypt of Herod., 
QOINIE (continued).

p. I00; Larcher's Herod. ii. p. 320 ; Encycl. Metrop., Art. Herodotus (8vo ed.), p. 249; Drummond in Class. Journal, xiv. 319; Ideler, Enchir. Chron. Math. i. p. 186. See the Bhagavad Gita, viii, for an account of the similar cyclical 'day and night of Brahma.' For a corresponding Chinese tradition, see Martini, Histor. Sinica, cit. Coray ad Heliod. p. 201 ; Creuzer, Symb. ii. 164; on the Persian account, cf. Dalberg, 'Simorg, der Persische Phönix,' in Von Hammer's Fundgruben des Orients, i. p. I99. See also Henrichsen, De Phoenicis fabula apud Graecos, Romanos, et populos orientales, Hafniae, 1825, 1827.

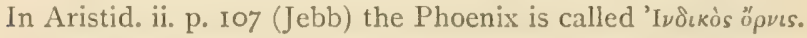

For representations of the Phoenix, see Jomard's Descr. de l'Ég. Antiq. i. c. 5 .

The Phoenix has been taken by Cuvier, Lenz, and others, for the Golden Pheasant, - a coarse materialising of a mythic symbol (Hehn). On the study and interpretation of such sacred enigmas of the ancients, see Grote's Hist. i. c. I6.

The subject deserves to be studied under many heads; for example, the varying terms assigned to the Phoenix-period, and the various astronomical cycles thereby indicated; the relation of the Phoenix to

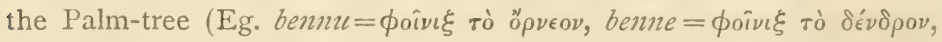
Lauth, Sitzungsber. Bayer. Akad., I876, p. 94) in connexion with the whole symbolic imagery of the latter; the relation of the Phoenix to the Heron (Lauth, 1.c.; cf. supra s.v. $\beta a \iota \eta \dot{\theta}$ ), involving also the depicting of the Soul as the Phoenix and the question of the term assigned to the Soul's wanderings. The whole subject is of great complexity, and lies beyond the scope of this book.

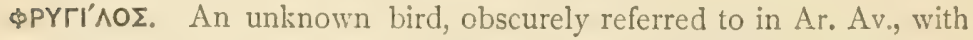

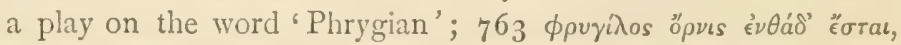

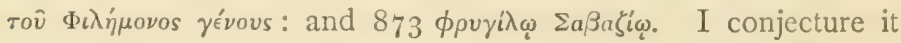
to be a form cognate to $\pi \epsilon p \gamma o u \hat{\lambda o v, ~ \sigma \pi \epsilon ́ p \gamma o u \lambda o s, ~ \& c ., ~ a n d ~ t o ~ m e a n ~}$

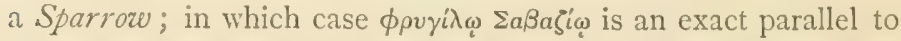

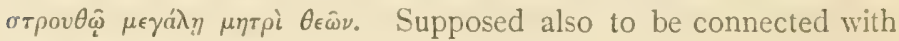
Lat. fringilla.

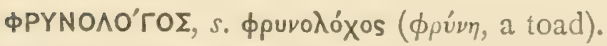

A kind of Hawk, probably a species of Harrier, Circus sp.

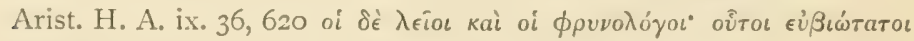

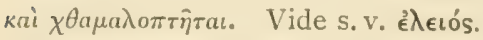

Of the various hawks that feed on reptiles, the epithet 'low-flying' seems best applicable to the Harriers.

$\phi \Omega \mathrm{KI} \Omega \mathrm{N} \cdot$ öp 
$\phi \Omega \Upsilon Y \equiv . \quad$ (MSS. have $\phi \dot{\omega} v \xi, \theta \hat{\omega} v \xi$, Ald. and Camus $\phi \dot{\omega} \iota \xi$, Schn. $\pi \dot{\omega} v \xi$. $\pi \dot{\omega} v \gamma \xi$ in Anton. Lib. c. 5 ; Et. M.)

A bird of the Heron kind; supposed to be a name for the Bittern, but equally applicable to the Common Heron.

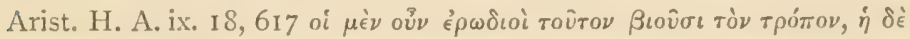
кà

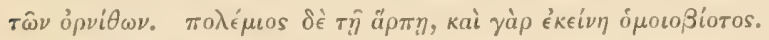

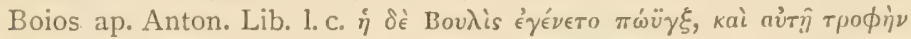
є̋ $\delta \omega \kappa \in \nu$ ó Z Z

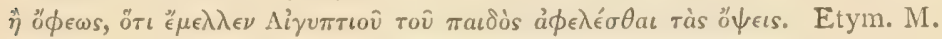

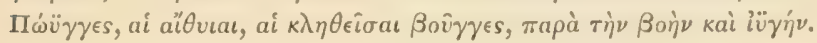

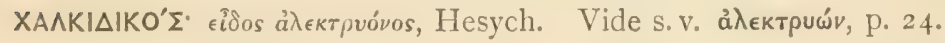

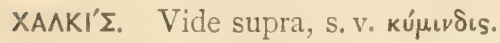

XAPA $\triangle P I O ' \Sigma$. A bird conjectured to be the Thick-knee or Norfolk Plover, Charadrius oedicnemus, L., Oedicnemus crepitans, auctt.; so identified by Gesner, followed by Sundevall, Aubert and Wimmer, \&c.. Mod. Gk. тoup $i \delta a$ (Erh.). Applied by the

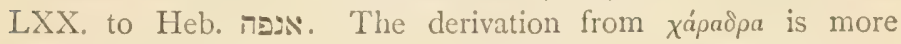
than doubtful.

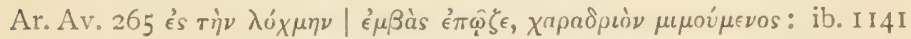

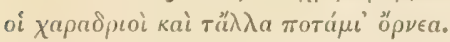

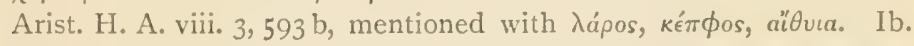

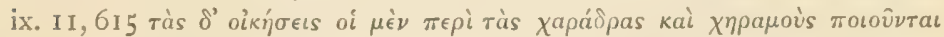

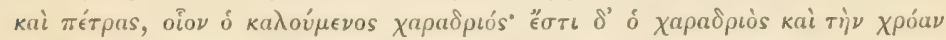

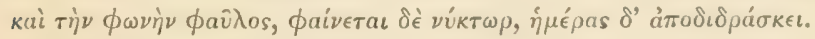

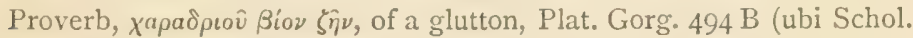

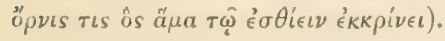

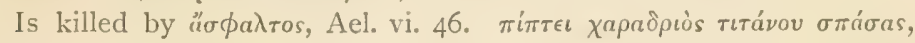
Phile, De An. Pr. 673.

According to Boios ap. Anton. Lib. c. xv, Agron is metamorphosed into the bird xapaopés, the other characters in the story turning into various other nocturnal birds.

The sight of it is said to cure the jaundice, the bird catching it itself

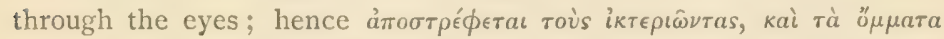
$\sigma v \gamma k \lambda \epsilon i \sigma a s \ddot{\epsilon}^{\prime} \chi \imath$. [From which we may conjecture that the experiment has never been fairly tried. W. H. T.] Plut. Symp. ii. 68I c, Ael. xvii. 13. See also Suidas (and Schol. in Ar. Av. 267) Xapaópiós.

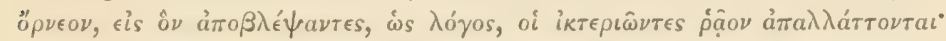

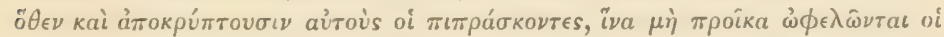

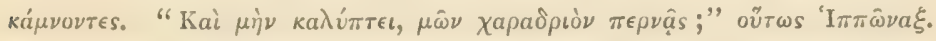

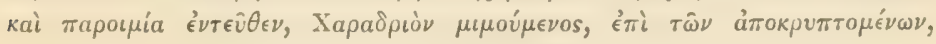




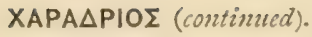

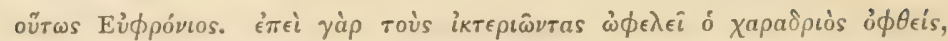

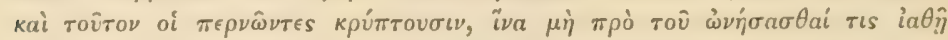

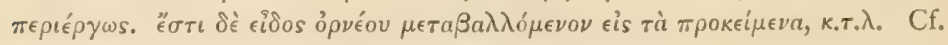
íkTepos.

In these mythical stories, with which compare Physiol. Syr. xv (volucris tota alba, nec ulla in ea nigredo est: reperitur in regum palatiis), Epiphan. in Physiol. xxiii, Eust. Hex. p. 32, Bochart, ii. p. 340, we have to do with eastern tales of the Stork, Heb. chasad (Lev. xi. I9, Deut. xiv. I8) arising from a confusion of names.

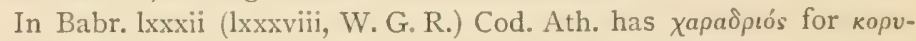
$\delta a \lambda \lambda$ ós: the word is here perhaps a corrupt connexion of $\kappa a \dot{\lambda} a \nu \delta \rho o s$, It. calandra, which occurs in Dion. De Avib. iii. I5. Cf. W. H. Thompson's note on Plat. Gorg. l.c.

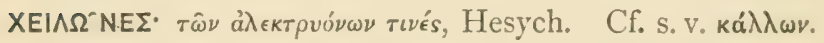

XEAI $\triangle \Omega^{\prime} N$. Etymology very doubtful. Cf. Lat. Mirunfo, Sp. srolundrina, \&c. Supposed by some to be from Sk. rt. har, 'to catch or seize,'cf. Lat. hir-udo, a view somewhat akin to one much older, Isid. Orig. xii. 7 hirundo dicta est, quod cibos non sumat residens, sed in aëre rapiat escas et edat.

A swallow. The Chimney Swallow, Hirundo rustica, and the

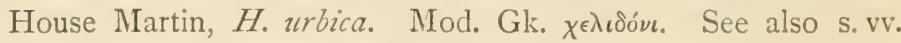

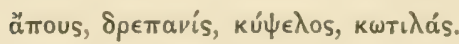

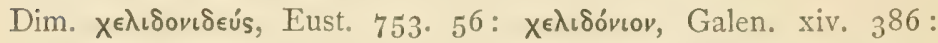

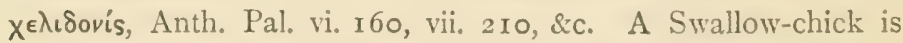

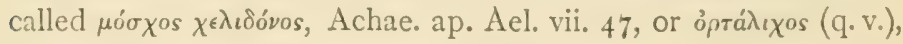
Opp. Hal. v. 579 .

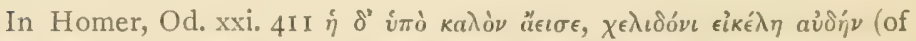

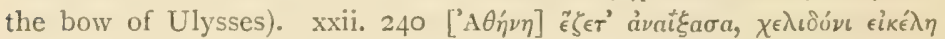
ä $v \tau \nu$ : cf. Plut. Is. and Osir. xvi, ii. $357 \mathrm{C}$, where Isis turns by night into a Swallow.

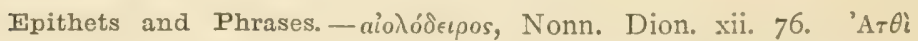

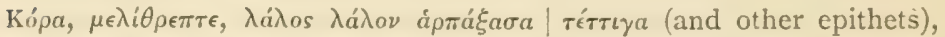

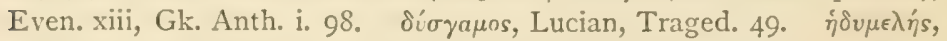
$\chi a \rho i \epsilon \sigma \sigma a \chi^{\epsilon} \lambda_{\iota} \delta \circ \hat{\imath}$, Anacr. fr. 57 ap. Hephaest. vii. 39. 4, p. 22. $\chi \epsilon i \lambda \epsilon \sigma \iota \nu$

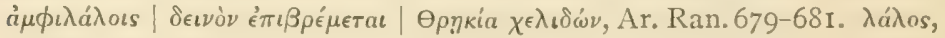

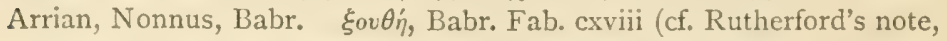

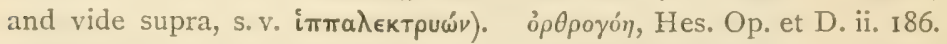

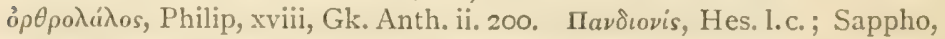

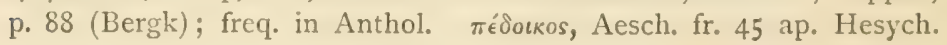


XEAI $\triangle \Omega N($ continued).

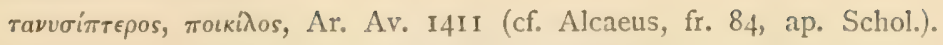

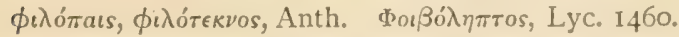

Description.-Arist. H. A. vi. 5, 563, viii. 3, 592 b öpvis бapкoфáyos.

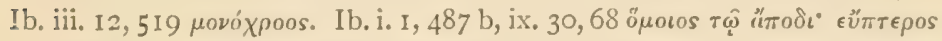

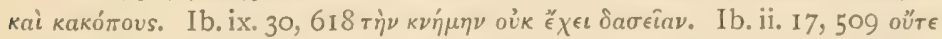

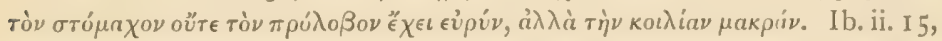

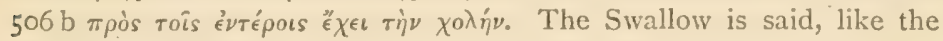
Nightingale, to have no tongue, Aes. Fab. 416, \&c.

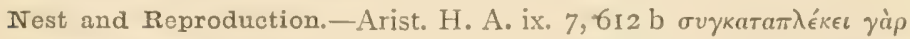

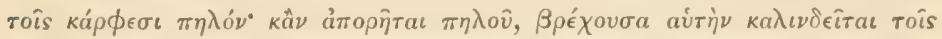

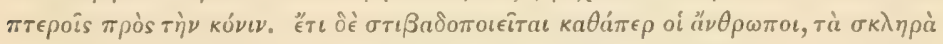

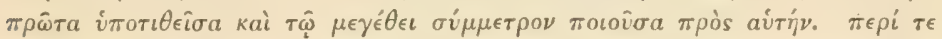

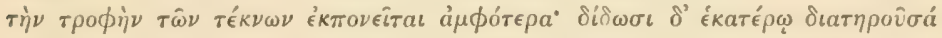

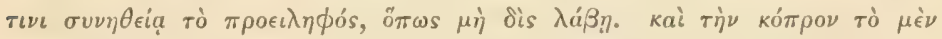

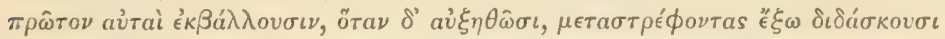

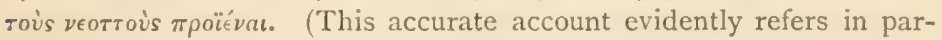
ticular to the House Martin.) Cf. Ael. iii. 24, 25, Antig. Mirab. 37 (43),

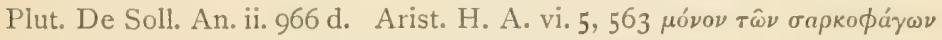
Sis $\nu \in \circ \tau \epsilon \dot{v} \epsilon$. The nests of the Swallow, House Martin and Sand Martin are adequately described by Plin. x. (33) 44.

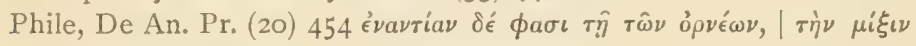

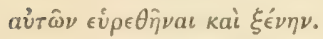

For poetic references see (int.al.) Ar. Av. 1151 (which quotation is, however, by a recent emendation, no longer apt : cf. Rutherford, Class.

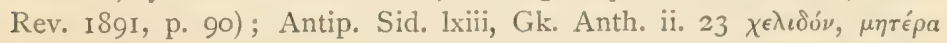

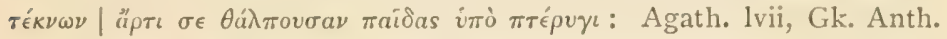

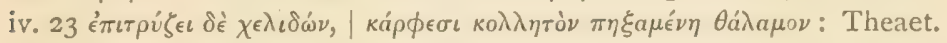

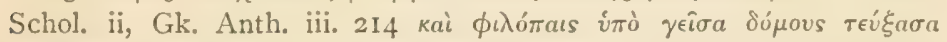

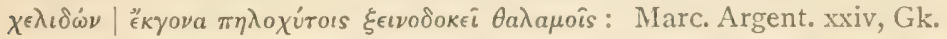

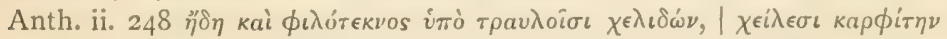

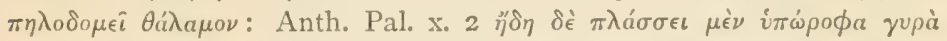

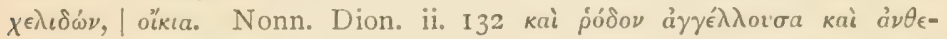

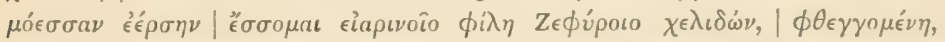

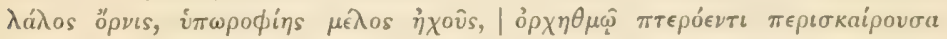

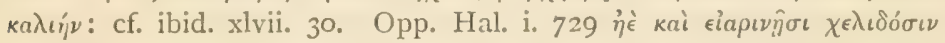

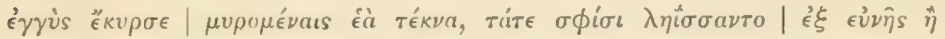

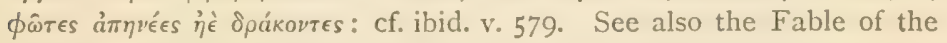
Nightingale and the Swallow, Babr. xii (ed. Rutherford).

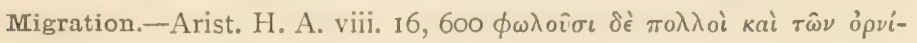

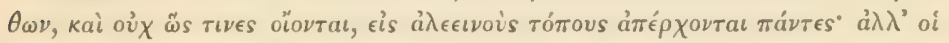

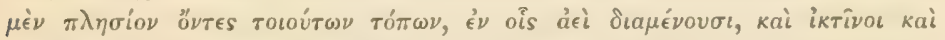

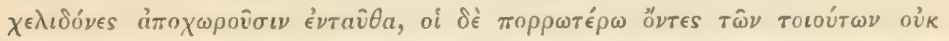

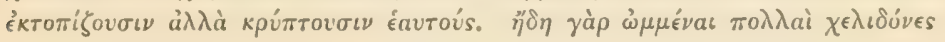


$X E \wedge \mid \triangle \Omega N$ (continued).

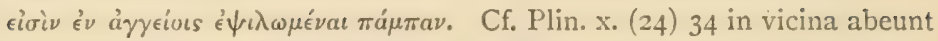
apricos secutae montium recessus, inventaeque iam sunt ibi nudae atque deplumes; Claudian, Eutrop. i. II 8 Vel qualis gelidis pluma labente pruinis Arboris immoritur trunco brumalis hirundo. In reference to

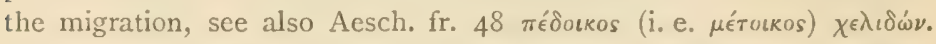

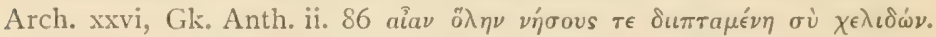
The Swallow as the bird of returning Spring: Hes. Op. et D. 568 (ii.

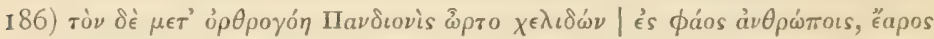

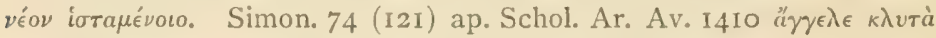

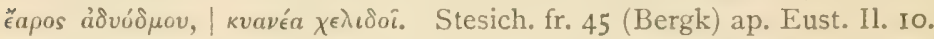

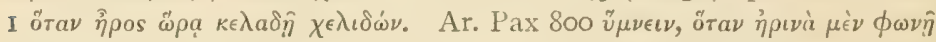

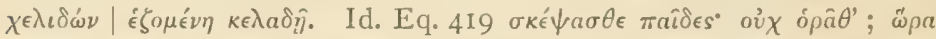
$\nu^{\prime} a, \chi \in \lambda \iota \delta \dot{\omega}$. Id. Av. 714, \&c. Ael. i. 52. Babr. 131. Cf. Ovid, Fasti, ii. 853 Fallimur an veris praenuntia venit hirundo: Hor. Ep. i. 7, I3, \&c. Cf. also a well-known vase (first figured in Mon. Inst. Corr.

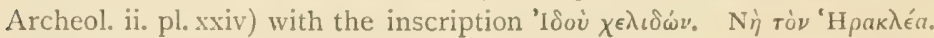

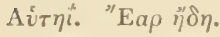

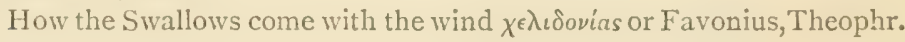
H. P. vii. I5, I, Plin. ii. 47.

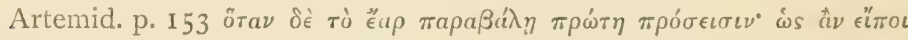

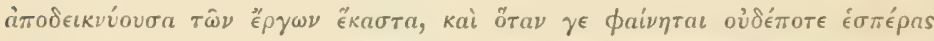

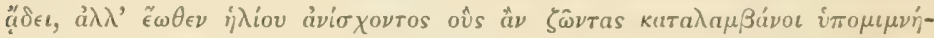

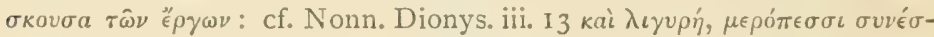

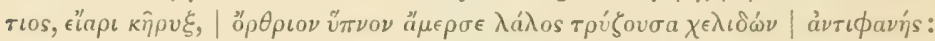
Apul. Florid. ii. I 3 cantum hirundinibus matutinum ; \&c., \&c.

Hence invoked at the Spring festival of the Thesmophoria: Ar. Thesm. I $\hat{\omega} Z \epsilon \hat{v}, \chi \epsilon \lambda \iota \delta \dot{\nu} \nu$ åpá $\pi o \tau \epsilon \phi a \nu \eta ் \sigma \epsilon \tau a \iota:$ cf. Ar. fr. $499 \pi v \theta 0 \hat{v} \chi \epsilon \lambda \iota \delta \dot{\omega} \nu$

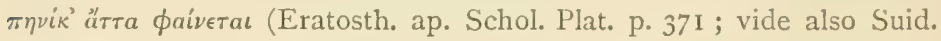

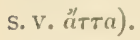

How the Swallow is visible in Egypt all the year, Herod. ii. 22, Pausan. X. 4, 9; but never stays to nest in Daulis, the country of Tereus, Pausan. 1. c. Neither does it visit Thebes, quoniam urbs illa saepius capta sit; nor Bizya, in Thrace, propter scelera Terei, Plin. iv. (II) I8,

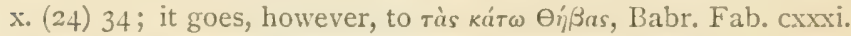

On Swallows used as messengers, Plin. x. (24) 34 .

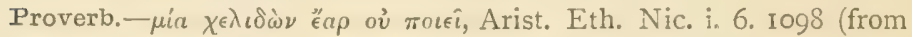
Cratin., according to Cramer, An. Par. i. 182) ; cf. Ar. Av. 1417.

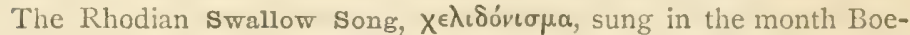

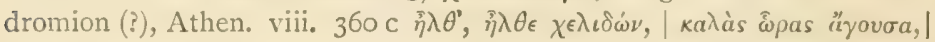

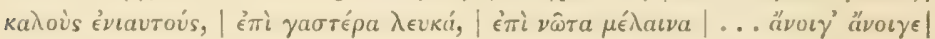

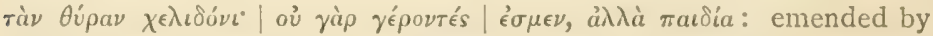
Ilgen, Opusc. Phil. i. p. I65, Bergk, P. Lyr. iii. p. 67I. Cf. Eustath. 1914,45 . 


\section{$\mathrm{XEAI} \triangle \Omega \mathrm{N}$ (continued).}

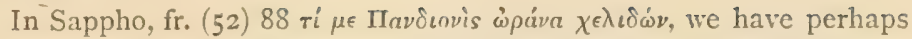
a fragment of a 'Swallow-song.' This difficult line is variously read

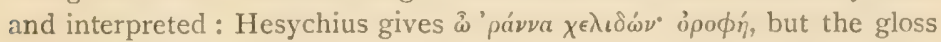
is, in my opinion, fragmentary and meaningless: Bergk, after Is.

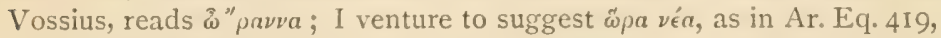
which latter line is itself probably a fragment of a Swallow-song. Another fragment of a Swallow-song perhaps exists in Hom. Carm.

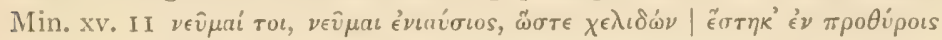
$\psi i \lambda \dot{\eta} \pi$ ó $\delta$ as. In the Rhodian Swallow-song already referred to, two very curious features are the alternate balance or 'parallelism' of successive lines and the apparent influence of accent on rhythm: the text has been much emended by commentators, in order to obtain a more accurate scansion than the song ever, perhaps, possessed. It is easy to

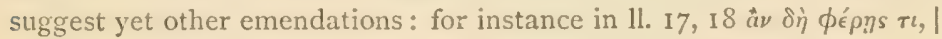

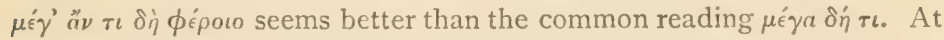
the very best some of the lines (in their present state) seem to have little rhythm and not much sense.

A modern $\chi € \lambda_{\iota}$ ióvı $\sigma \mu a$, Fauriel, Chants de la Grèce mod., i. p. xxviii

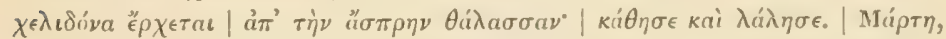

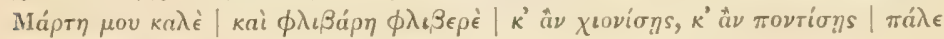

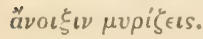

According to Bent (Cyclades, 1885, p. 434) the Swallow-song is still sung in Kythnos (Thermia) and in Macedonia, on March I. Cf. Grimm, D. Myth. p. 723; Swainson, Prov. Names of British Birds,

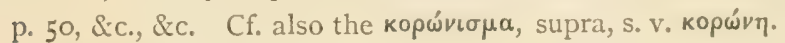

A Melancholy Bird.-The myth of Itylus. Agath. xii, Gk. Anth.

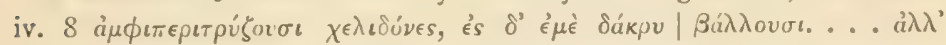

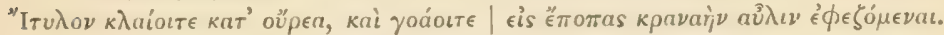

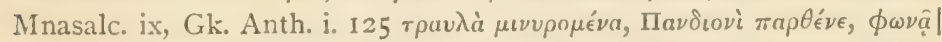

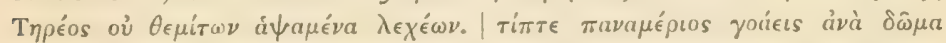

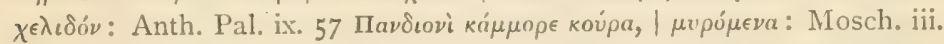

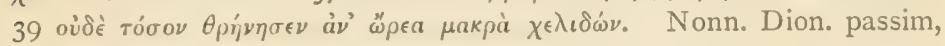
\&c., \&c.

The Itylus-myth has been already discussed s. vv. åๆ $\delta \omega \omega v$ and In the association together of the Swallow and the Nightingale, a curious feature is the similarity of the poetical epithets applied to both. The

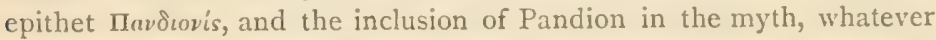
they may exactly mean, seem to me to have something to do with

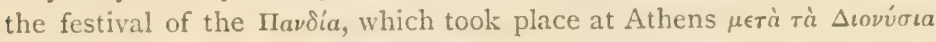
(Photius); that is to say, at or near the Vernal Equinox, and not far from the time when the $\chi € \lambda \iota \delta o ́ v \iota r \mu$ is still sung. The statement of Photius that Iavoia is a name for the Moon, is also of great interest, 
$\mathrm{XEAI} \triangle \Omega N$ (continued).

especially in connexion with the Swallow's relation towards the un-

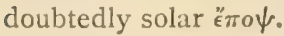

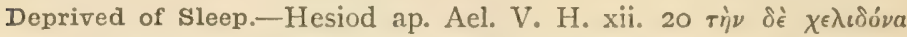

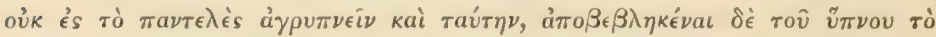

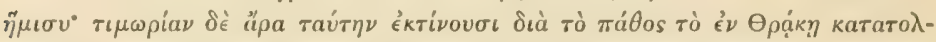

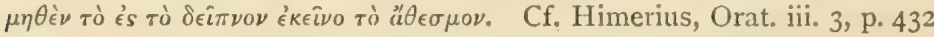

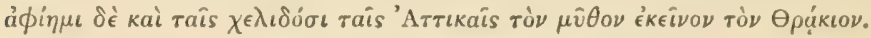

Other Myths and Legendary Allusions.-How the mother brings to her young, being blind at first, sight by means of a certain herb

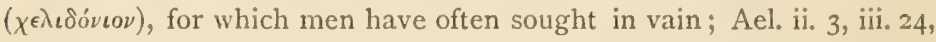

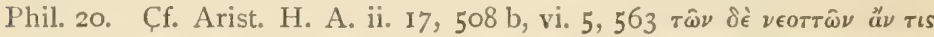
"ૅ

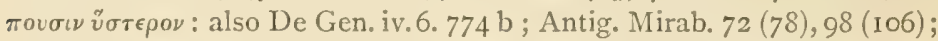

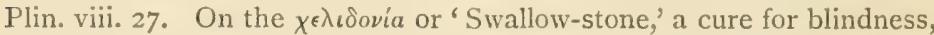
epilepsy, \&c., see Theoph. Nonn. 36, Diosc. ii de hirundine, Plin. xi. 79, xxxvii. 56; cf. Evangeline, I. ii. I 33 'the wondrous stone which the Swallow Brings from the shore of the sea to restore the sight of its fledglings'; Baring-Gould, Myths of the M. Ages; Lebour, Zoologist, xxiv. p. 523, 1866, \&c. Hence the ashes of Swallows are a remedy for cataract, Plin. xxix. 38 ; Galen, De Fac. Simpl. Med. Ch. Boiled swallow, a remedy for the bite of a mad dog, Plin. xxviii. (10) 43.

How the mother immolates herself over the bodies of her dead

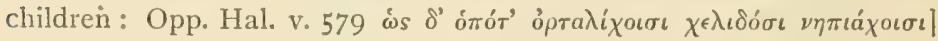

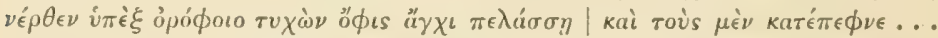

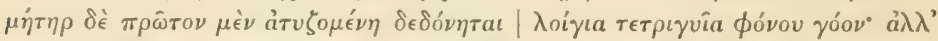

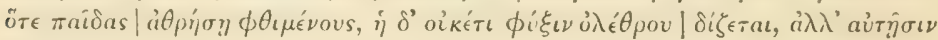

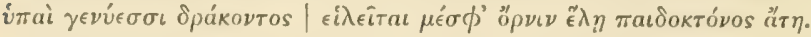

The twittering of Swallows likened to the speech of barbarous

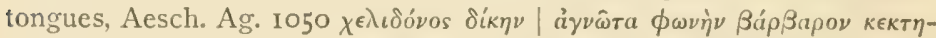

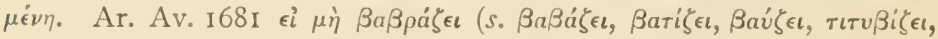

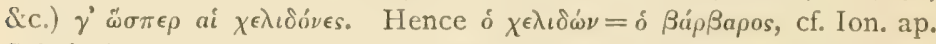
Schol. Ar. Av. I680; Ar. Ran. 680. Similarly, Eur. Alcmen. fr. 9 I

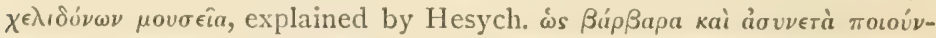

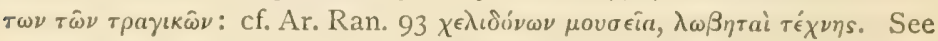

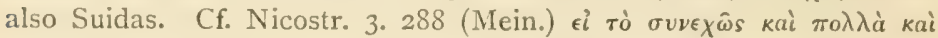

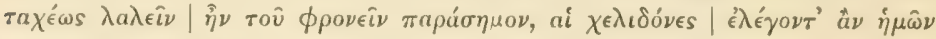

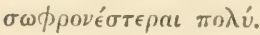

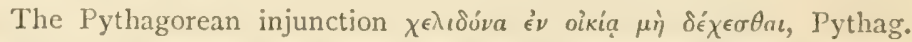
ap. Iambl. Adhort., xxi, may be thus understood of foreigners:

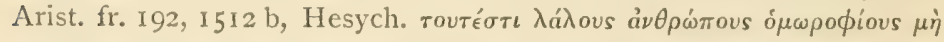

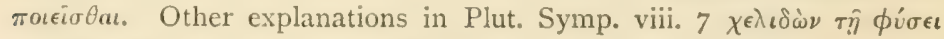

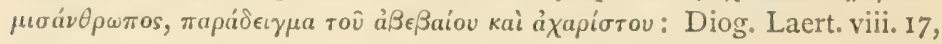




\section{$\mathrm{XEAI} \triangle \Omega \mathrm{N}$ (continued).}

p. 578, Clem. Alex. Strom. v. p. 238, \&c. Vide Class. Rev. I891, pp. I, 230 .

On Swallows commonly building within the house, consult Darnel, Tour through Greece, p. 40, I819, and recent travellers: on their entering ancient temples, cf. Clem. Alex. Protrept. iv. 52.

How the Swallows restrain the overflow of the Nile: Thrasyllus in

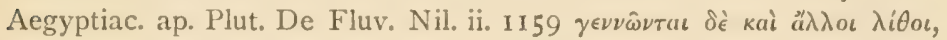

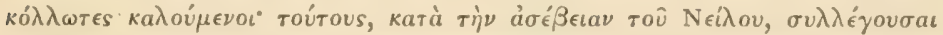

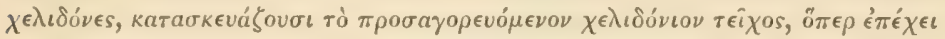

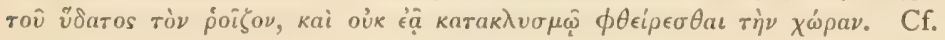
Plin. x. (33) 49. Cf. also Ogilby's Fables of Aesop, 165 I, p. 54, cit. N. and Q. (7) v. p. 346.

There is perhaps an allusion to this legend in the story of the building of the $\tau \epsilon \hat{i} \chi 0 s$ in Ar. Aves, in which account we may note the references not only to the Swallow but to Egypt and Egyptian birds. This conjecture is partly based on Rutherford's demonstration (supra cit.) that there is no distinct reference to mud-nest-building on the part of the Swallow in v. I I 5 I.

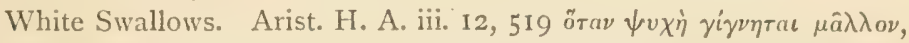
$\lambda$ evkòs yiveruı. Cf. De Color. vi. 798, Theophr. De Sign. vi. 2, Alex. Mynd. ap. Ael. x. 34. A White Swallow in Samos (connected with the story of recovered sight), Arist. ap. Ael. xvii. 20, Antig. Mirab. I2O (132).

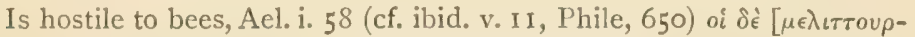

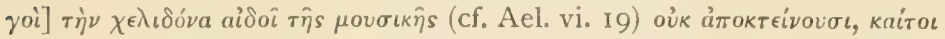

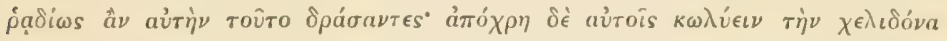

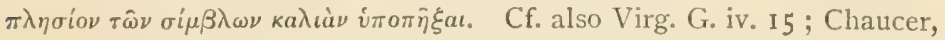
P. of Fowles, 353, 'the swalow, mordrer of the beës small,' \&c. Cap-

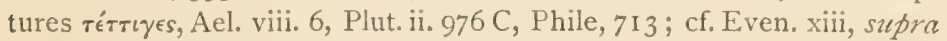

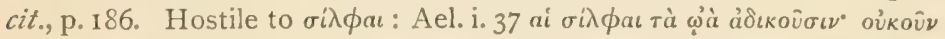

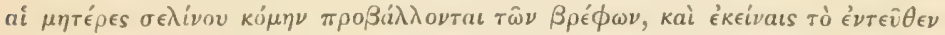

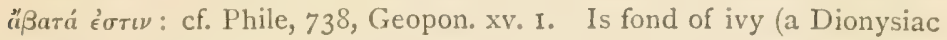

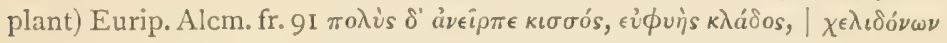
$\mu \circ v \sigma \in i o \nu$.

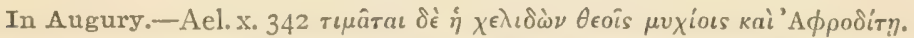
Swallows nesting in the general's tent were (very naturally) an evil omen, as in the cases of Alexander, son of Pyrrhus and Antiochus, Ael. 1. c. : but by returning to the citadel foretold the safe home-coming of

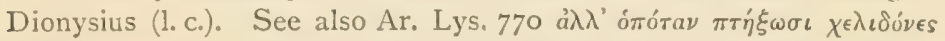

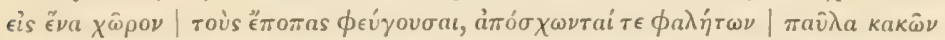

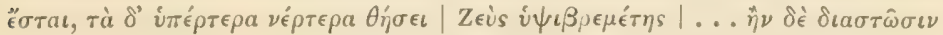

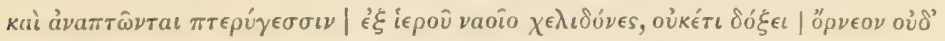

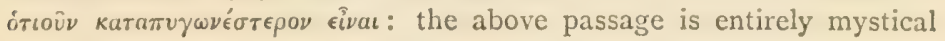


$X E \wedge \mid \triangle \Omega N$ (continued).

and obscure. How Swallows that had built in Cleopatra's galley were expelled by others before Actium, Plut. Anton. Ix, i. 944 a ; cf. Ant. and Cl., 'Swallows in Cleopatra's sails Have built their nests.' The Sivallow that fluttered round Alexander's head as an omen of treachery, Arr.

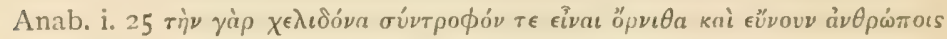

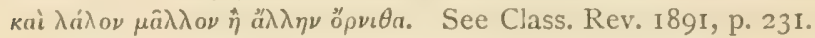

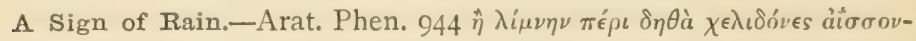

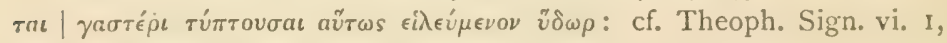
Virg. G. i. 377 .

Fables.-The Swallow and the Nightingale, vide s.v. ån $\delta \dot{\omega} v$. The Swallow and Eagle, Plut. ii. 223 F. The Wise Swallow and the Hen,

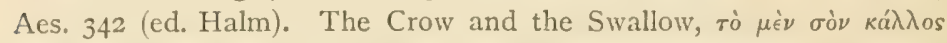

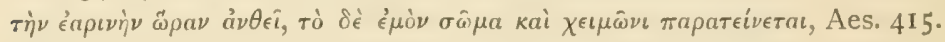

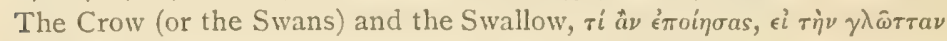

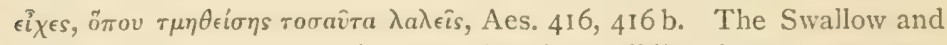
other Birds, Aes. 417, 4I7 b. The Swallow building in the Law-court,

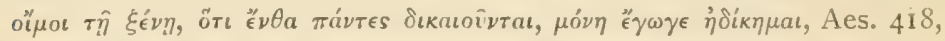
418 b : cf. Babr. I 8 . The Swallow out of due season, Babr. I3I.

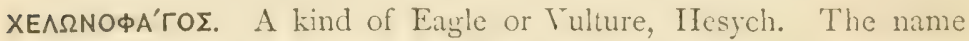

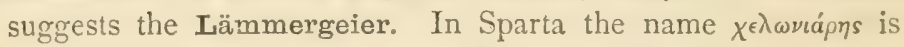
said to be now applied to Aquila imperialis, but surely not to the exclusion of the Lämmergeier.

The Lämmergeier does indeed eat tortoises, as has been mentioned above; and it may accordingly be held that the name $\chi \in \lambda \omega \nu$ óáos is manifestly so simple a descriptive term as to throw doubt on my astronomical interpretation of the Eagle that slew the Serpent or the Swan. But it is curious to note that the constellation of the Tortoise is placed in very much the same relation to that of the Eagle as is that of the Swan: moreover the Tortoise forms part of the constellation Lyra, another name for which is the Vulture, and to the latter 'bird' the Eagle is said also to be hostile. It is only natural that those astronomical 'hostilities' should be the most commented on, which are somewhat akin to zoological fact or possibility.

\section{XE'NNION, s. XEvvíw.}

A kind of Quail, eaten pickled by the Egyptians.

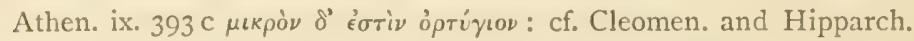

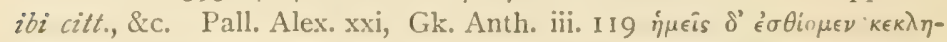

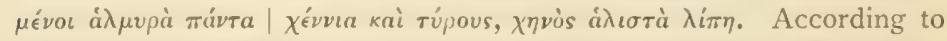
Bent (C)clades, 1885 , p. 12S) potted or pickled quails are still eaten in 


\section{XENNION (continued).}

Santorini. Jablonsky, De Toc. Esypt, ap. Steph. Thes., suspects xévveny to have been a locust, Eg. sche. See also Hercher in Jahn's Annal. I 856 , Suppl. i. p. 285.

XH'N. A Goose.

Sk. hansa, hamsa, L. (h)anser. $\chi \eta \nu=\chi$ avs or $\chi \in \nu s$ (cf. $\mu \eta \nu=\mu \epsilon \nu s$ ); Ger. Gans. Lat. ganta (the small wild northern species, Plin. x. (22) 27 ; also Venant. Fortunat., Miscell. vii. 4, I I, teste Keller) is a borrowed word; cf. O. H. G. ganzo (Keller), Engl. gannet. The connexion with $\chi$ aiv Gk. Anth. iv. $25^{8}$ (A. P. vii. 546)

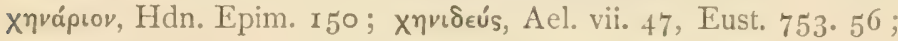

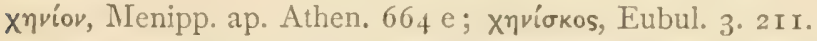

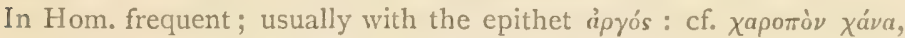
Antip. Sid. lxxxviii, Gk. Anth. ii. 31. The Geese in the Odyssey are tame birds, Od. xv. I61, 174, xix. 536, in the Iliad always wild, Il. ii. 460, xv. 69o. Remains of the bird are not known from ancient Troy or Mycenae (Schliemann and Virchow, teste Keller, Th. d. cl. Alt., p. 288).

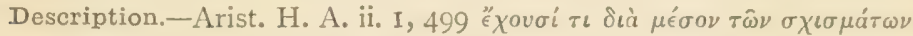

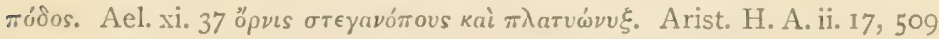

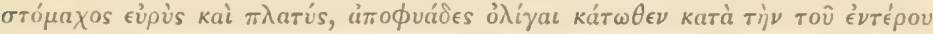

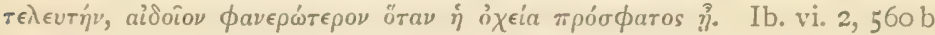

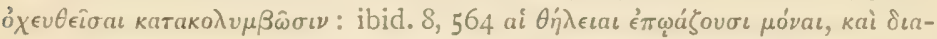

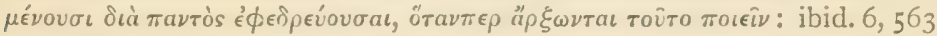

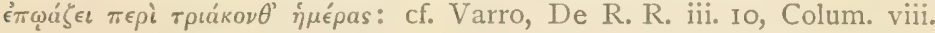
7, I. Their splay feet alluded to, Ar. Av. Ir45. The goose's cackle is expressed by $\chi \eta \nu i \zeta \epsilon \iota \nu$, Diphil. 4. 413, $\pi a \pi \pi a ́(\zeta \epsilon \iota$, J. Pollux, Lat. gingrire, Festus; its splashing movements in the water by $\pi \lambda a \tau v \gamma i \zeta \in \iota v$, Eubul. 3. 260 .

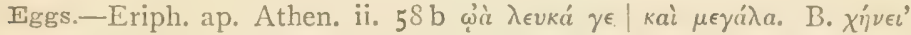

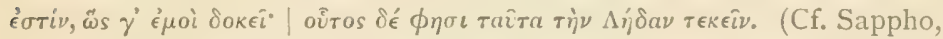
fr. 56 B, ap. Athen. 1. c., Clem. Alex. Homil. v. I4.) Simon. fr. I I B

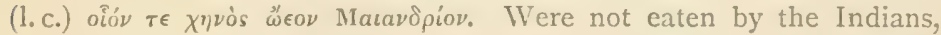
Ael. xiv. 13. The Fable of the Golden Egg, Aesop, ed. Halm 343 b; cf. Keller, Gesch. d. Gr. Fab. p. 346 et seq.

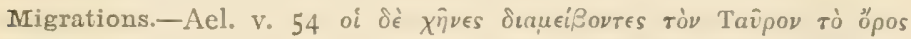

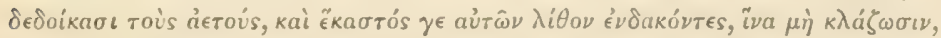

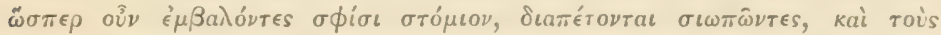

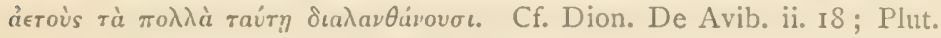
De Soll. Anim. p. 967 B ; Phile, De An. Pr.xv.

Sacred to Osiris and Isis, Pausan. x. 32, 16; cf. Juv. vi. 540; see

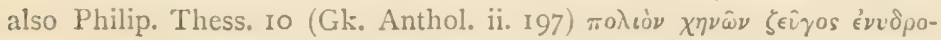




\section{XHN (continued).}

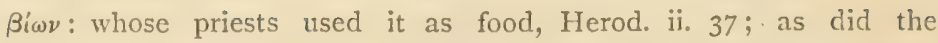
Pharaohs, Diod. Sic. i. 70, and the sacred cats, ibid. i. 84.

The Geese of the Capitol, sacred to Juno, Diod. Sic. xiv. II6 ; Ael. xii. 32 ; cf. Liv. v. 47, Cicero pro Roscio, 20, Virg. Aen. viii. 655, Plin. x. 26, xxix. I4, Ovid, Fasti, i. 453. Cf. ref. to the bird's watchfulness, Arist.

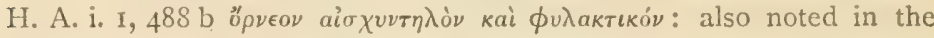
Vedas (Zimmer, Alt.-ind. Leben, p. 90, cit. Keller) ; cf. also Chaucer, 'the waker goose.' Its wisdom, Ael. v. 29, cf. Ovid, Met. viii. 684, xi. 599 canibus sagacior anser.

Sacred to Venus in Cyprus (Cesnola, Cyprus, pl. vi) and to Priapus, Petron. Sat. 136, 137.

The Goose was sacrificed to Isis and Osiris in Autumn (Paus. 1.c.), as by the ancient Germans to Woden at Michaelmas (Keller, op. c. p. 30I).

An erotic bird; a goose enamoured of a boy, Ael. v. 29; of a musician, ibid. i. 6 ; and of a philosopher, ibid. vii. 41. Cf. Ael. iv. 54; Athen. xiii. $606 \mathrm{c}$; Plut. Mor. $972 \mathrm{~F}$. A lover's gift, Ar. Av. 707.

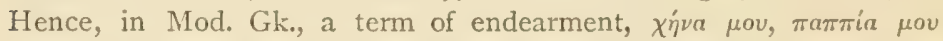

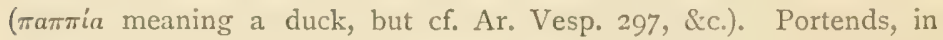
dream-prophecy, the birth of a wanton maid, Artemid. Oneirocr. iv. 83. Goose-fat as an aphrodisiac, Plin. xxviii. (19) 8o, \&c. On sacrifices of the Goose vide Gust. Wolff, Porphyr. De Phil., Ex Orac. Haur. Libr. Reliq., Berlin, 1856; cf. Philologus xxviii. p. I89, I869. On the erotic symbolism of the Goose, see (int. al.) Creuzer, Symb. iv. p. 423.

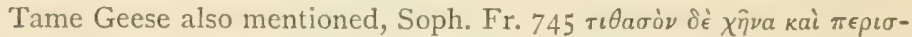

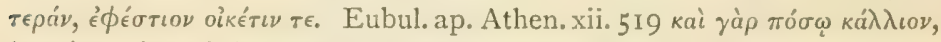

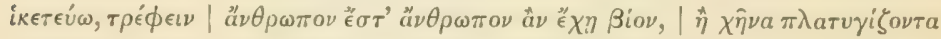

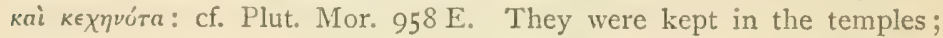

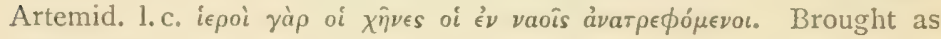
gifts to the Indian king, Ael. xiii. 25.

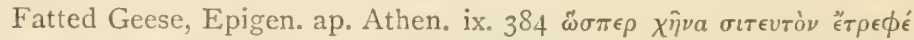

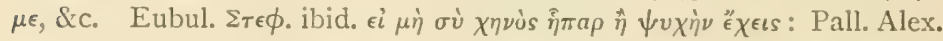

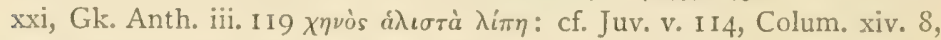
\&c. A favourite food of the younger Cyrus, Xen. Anab. i. 9, 26. Given by the Egyptians to Agesilaus, Athen. 1.c. Brought from Boeotia to the Athenian market, Ar. Ach. 878, Pax 1004; kept likewise in Macedonia and in Thessaly, Plat. Gorg. 47 I C, Polit. 264 C. Cf. Plut. ii. 2 roc, Plin. x. (22) 27, \&c.

They were kept, but not eaten, by the Celtic inhabitants of Britain, Caes. Bell. Gall. v. 12 ; very much as at the present day.

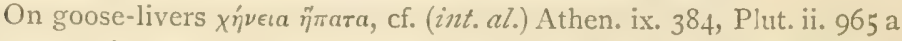
Geopon. xiv. 22, Plin. x. 52, Hor. Sat. ii. 8, 88, Juv. v. II4, Mart.

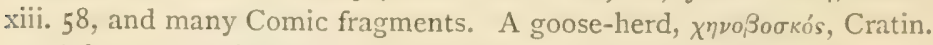

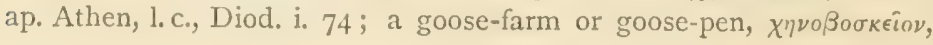


XHN (continued).

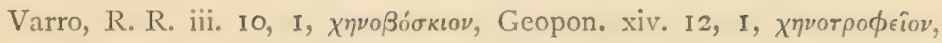

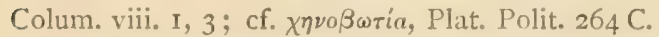

On goose-fat, or goose-flesh, in medicine, Plin. xxix. 38 , Nicand. Alex. 228, Celsus, ii. I8, \&c. ; the blood, in medicine, ibid. xxix. 33, cf. Diosc. Alexiph. c. 30, Galen, Comp. Medic. xi. r. On the use and value of the

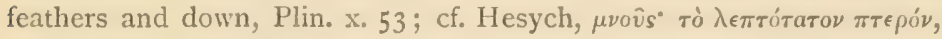

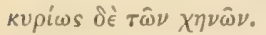

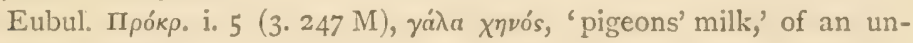
known luxury.

Destructive to the crops, Babr. I3, Aesop, 76.

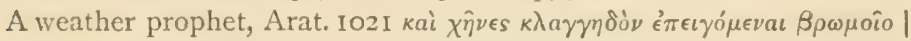
$\chi \epsilon \iota \mu \hat{\omega} \nu$ os $\mu \epsilon \operatorname{\gamma a} \sigma \hat{\eta} \mu a$. Cf. Theophr. Sign. vi. 3; Geopon. i. 3, 9 ; Avien. Aratea, 432 ; Suid.

Capture by decoys, Dion. De Avib. iii. 23: see also Nemes. Cyn. 314.

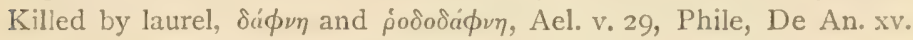
Use the herb sideritis as a remedy, Plin. viii. 27.

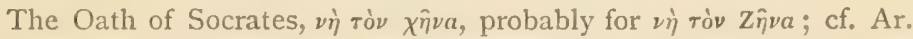
Av. 521 ; an oath prescribed by Rhadamanthus (Suid.). Cf. Philostr.

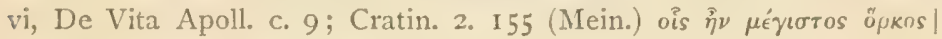

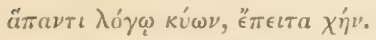

Associated with Aquarius, in a representation of the month of

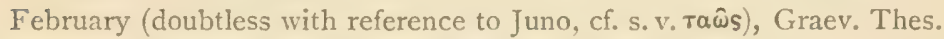
Ant. Rom. viii. 97 ; cf. Creuzer, Symb. iii. p. 626.

See for a further account of the Goose in classical art and mythology, O. Keller, Thiere d. Cl. Alterth., pp. 286-303.

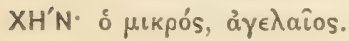

A wild species, unidentifiable, mentioned in Arist. H. A. viii. 3, 593 b, I 2, 597 b.

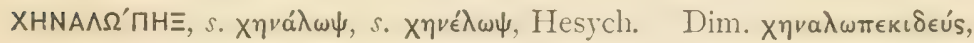
Ael. vii. 47 .

The Egyptian Goose, Chunalofex atgythinca, Steph. This and $\pi \eta \nu \dot{\lambda} \circ \psi$ are both probably renderings of an Egyptian word, corrupted by false etymology.

Arist. H. A. viii. 3, $593 \mathrm{~b}$, mentioned among the heavier web-footed

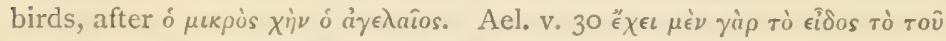

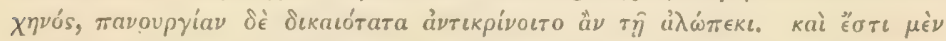

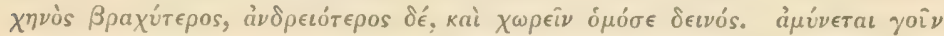

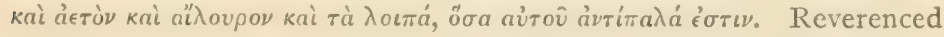

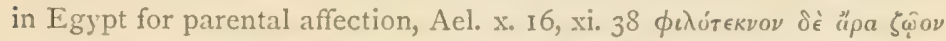

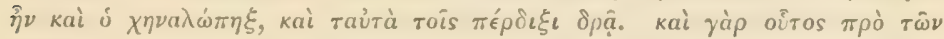

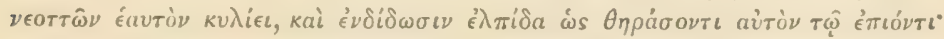

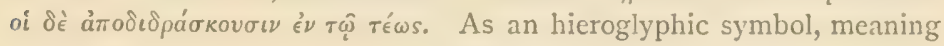




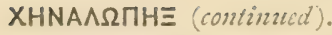

'son,' Horap. i. 53 ; cf. Bailey in Class. Journ. xvi. p. 320, and especially Lauth, Sitzungsber. Bayer. Akad., 1876, p. 105, who cites from the Rosetta stone $2 \odot$ su-rit=vius 'HAiov. Sacred to the Nile, Herod.

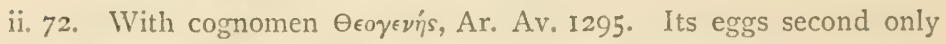

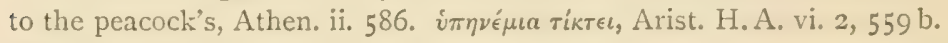
Mentioned also Plin. x. (22) 29.

XHNE'PSE. A small kind of Goose, Plin. x. (22) 29 et quibus lautiores epulas non novit Britannia, chenerotes, fere ansere minores.

XHNozko'mos. Name of an Eagle, Phile, De An. Pr. (I 5 ) 376. Cf. vๆтroфóvos.

$X \wedge \Omega P E Y ' \Sigma$. An unknown bird, the statements regarding which are all fabulous.

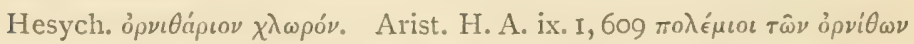

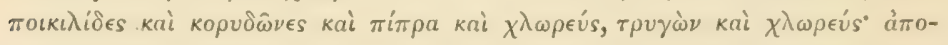

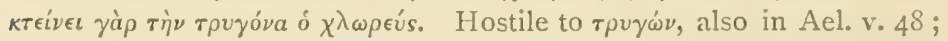

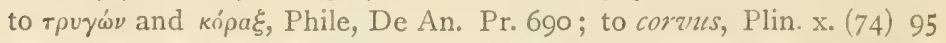
noctu invicem ova exquirentes. Supposed by Gesner and Sundevall to be identical with $X^{\lambda \omega}$ pi $\omega v$, and by Gaza with $X^{\lambda \omega \rho i s, ~ q . ~ v . ~}$

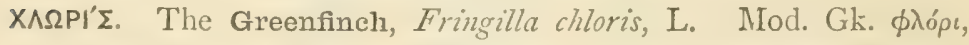
$\phi \iota \dot{p} \iota$ (Erh. p. 4. Ton ler Mïihle, p. 47), in Attica $\sigma \pi \iota \gamma \gamma$ cip Cf. It. verdone, \&c.

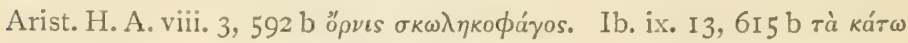

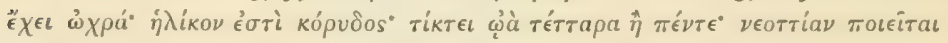

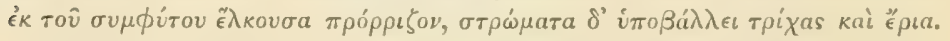
The cuckoo lays in its nest, which is placed in a tree, ibid. 29,618 .

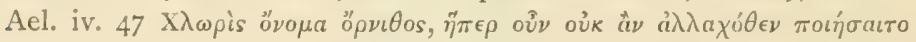

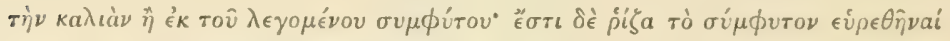

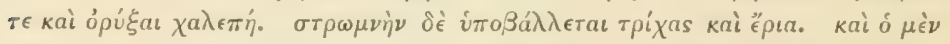

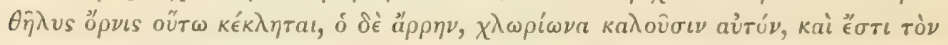

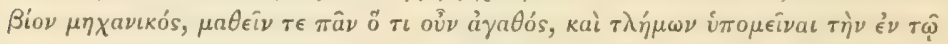

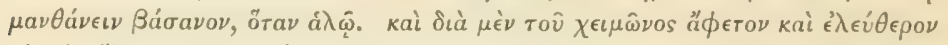

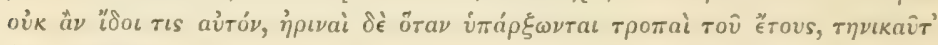

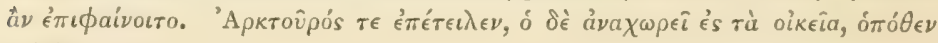
каi $\delta \epsilon \hat{v} \rho \circ \epsilon^{\epsilon} \sigma \tau a \dot{\lambda} \eta$.

According to Nicand. ap. Anton. Lib. c. ix, one of the Emathides, daughters of Pierus, was metamorphosed into the bird $\chi \lambda \omega$ pis.

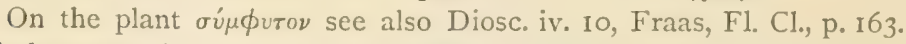
Lindermayer, 1.c., p. 62, says that the Greenfinch builds abundantly in the olive-groves of Attica, making its nest always of the same material, 


\section{$\mathrm{X} \Lambda \Omega P I \Sigma$ (continued).}

the roots of a species of Symplyytum (?), lined with black goats' hair. In Ael. 1. c. the bird is confused with the Golden Oriole, $\chi \lambda \omega$ pi $\omega$ ", which migrates in winter, while the Greenfinch does not.

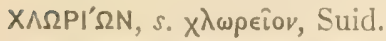

Cf. Lat. galbula (galbus $=$ gelb $=$ yellow): oriolus qu. aureolus; It. rigogolo, from auri-galbulus (Diez, p. $\mathbf{r}_{52}$ ).

The Golden Oriole, Oriolus galbula, L. Mod. Gk. бvкофáyos

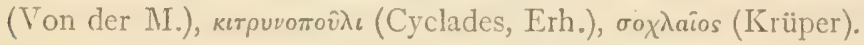

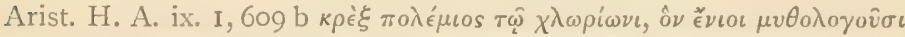

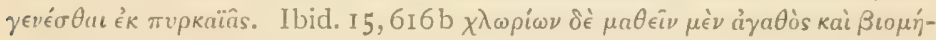

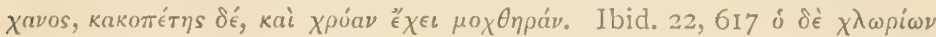

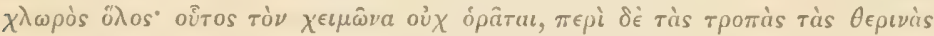

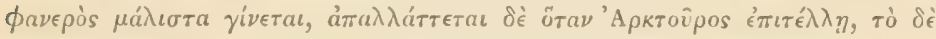

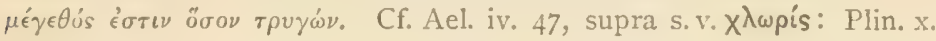
(29) 45 .

The Oriole arrives in Greece in April, and appears in great numbers among the figs in August (Von der Mühle, \&c.). Of the above accounts in Aristotle, the first is clearly mythical, and contains a suggestion of the Phoenix myth: the second is equally obscure, though Aubert and

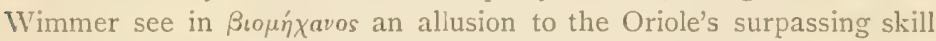
in nest-building; while the third, though undoubtedly referring to the Golden Oriole, is far from accurate: cf. Buffon, M. des Ois. v. 35I 'Je me contenterai de dire ici que, selon toute apparence, Aristote n'a connu le loriot que par ouï-dire.'

xpyzA'Etos. The 'Golden Eagle, a mystical name, already discussed s. v. ảetós.

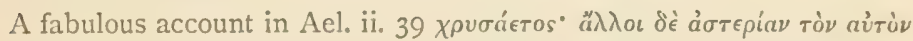

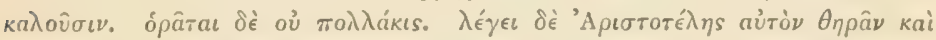

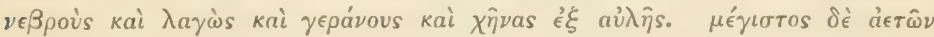

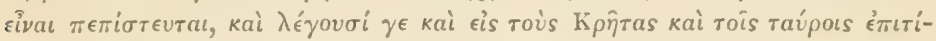

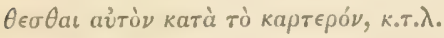

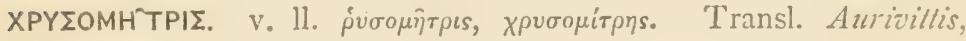
Gaza.

The Goldfinch, Fringilla carduetis, L.

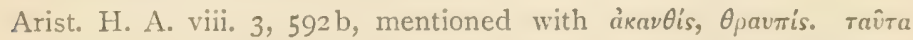

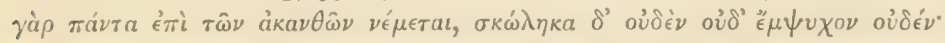

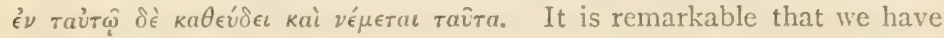
so little definite record of the Goldfinch, which in Greece is now, according to Lindermayer, next to the Sparrow the commonest of birds.

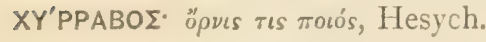




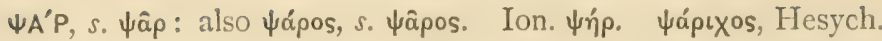

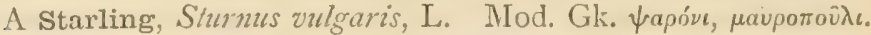

The Etymology is confused and doubtful. Von Edlinger (op.c.

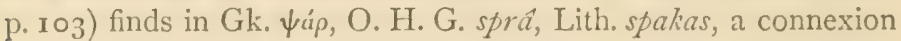

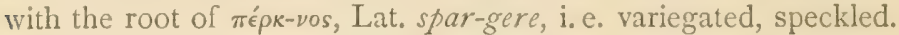
But there also seems to be a connexion of Gk. $\psi$ á $\rho$ or $\sigma \pi a \rho-$ with the various names for sparrow, Goth. sparwa, O. Pr. sperglo, \&c., as Engl. starling, stare. Ger. Staar, L. sturnus, form another series together with $\sigma \tau \rho$-ovtós. The Hebr. sippor is perplexingly similar.

In Hom. always coupled with the Jackdaw, Il. xvi. 583 ip

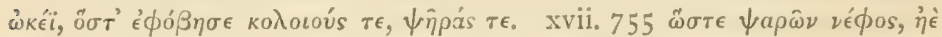

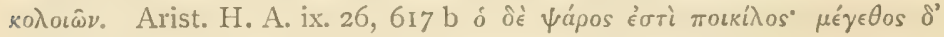

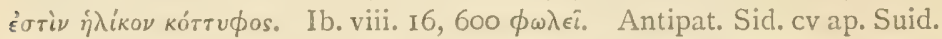

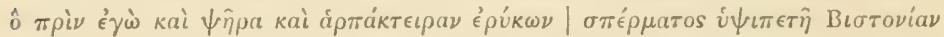

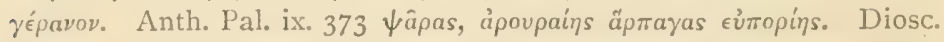

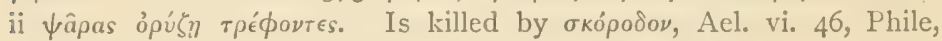
De An. Pr. 66o. Used as food, Antiph. ap. Athen. ii. 65 e.

On talking starlings, Plut. ii. 972 F, Plin. x. 59 (43), Aul. Gell. xiii. 20. Stat. Silv. ii. 4,18 auditasque memor penitus demittere voces, Sturnus, \&c.

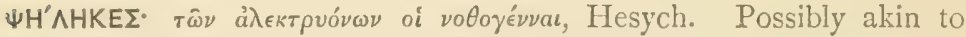

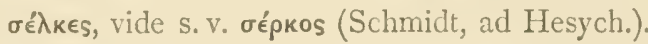

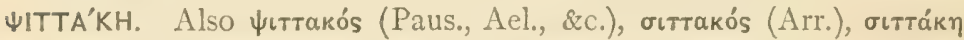
(Philost.), Biтrakos (Ctes.). A Parrot.

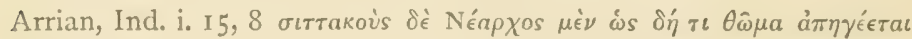

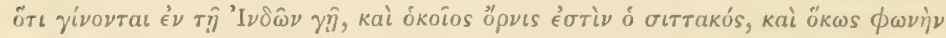

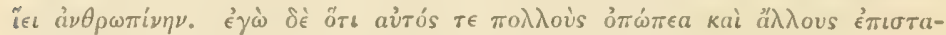

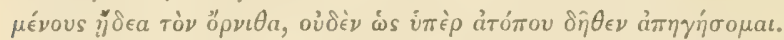

Arist. H. A. viii. 12, $597 \mathrm{~b}$ (spurious passage, A. and W.) ó $\lambda \omega s \delta \grave{\epsilon} \tau \dot{a}$

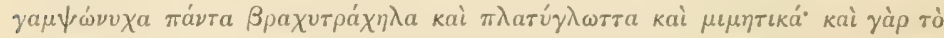

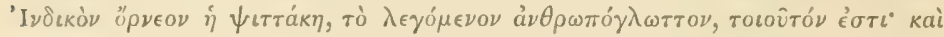

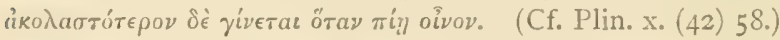

Pausan. ii. 28, (on animals of restricted geographical range), mapà $\delta$ ' 'I

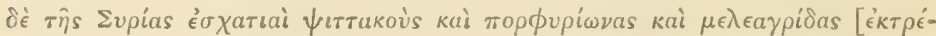

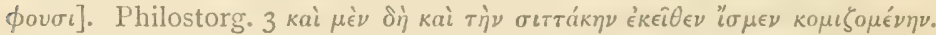

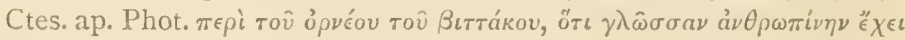

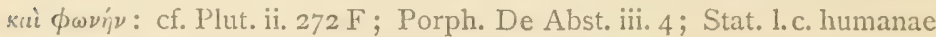
solers imitator, Psittace, linguae.

Athen. ix. $387 \mathrm{~d}$, parrots carried in Ptolemy's procession at Alexandria ; ibid. $39 \mathrm{I}$ b, mentioned as a mimic, with кiтra and $\sigma \kappa \hat{\omega} \psi$. 
WITTAKH (continucd).

Ael. vi. I9, xvi. 2, 15, its wisdom and vocal powers; xiii. 18, is reckoned sacred among the Brahmins; xvi. 2 , is of three species.

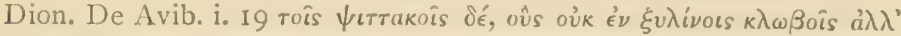

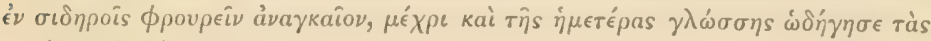
$\mu \iota \mu \dot{\eta} \sigma \epsilon \iota s \dot{\eta} \phi \dot{v} \sigma \iota s$.

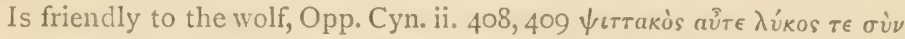

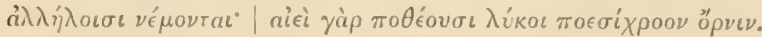

The Indian parrots above alluded to are the common parrots of Northern India, Psittacus (Palaeornis) Alexandri, L. (Cf. Val. Ball, Ind. Antiq. xiv. p. 304, I885.) The parrots seen by Nero's army at Meroë (Plin. vi. (29) 35) must have been another species, $P$. cubicularis, Hass, and probably all the parrots described by Roman writers (Ovid, Amor. ii. 6, Statius, Silv. ii. 4, Apul. Florid. 12, Persius Prologue, and even Plin. x. (42) 58) came from Alexandria and belonged to that species. They are described as green by Stat., ille plagae viridis regnator Eoae; Ovid, Tu poteras virides pennis hebetare smaragdos, Tincta gerens rubro Punica rostra croco, \&c. Cf. Sundevall, op. cit., pp. 126, 127.

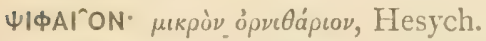

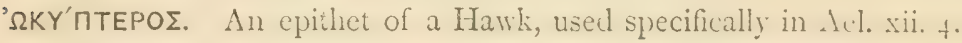
Cf. Il. xiii. 62, \&c.

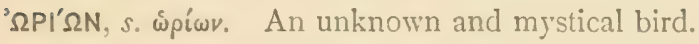

Clit. ap. Ael. xvii. 22: an Indian bird, like a Heron, red-legged,

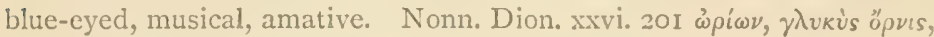

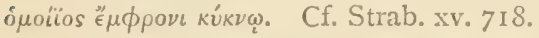

This bird, always associated with the equally mysterious katpeús, is evidently a poetic and allegorical creation, but what it signifies is unknown.

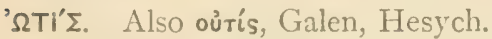

The Bustard, Otis tarda, L.; including also the Houbara, $O$.

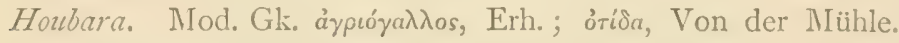

Lat. tarda, whence Bustard, i. e. avis Tarda, Plin. x. (22) 29

Proximae eis (tetraonibus) sunt quae Hispania aves tardas appellat,

Graecia otidas.

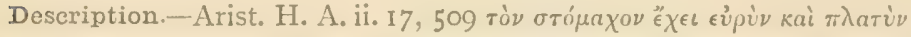

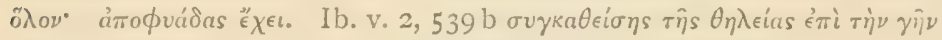

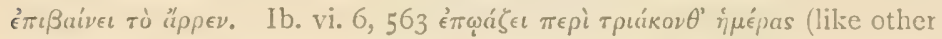
large birds, e.g. goose and eagle). Arist. Fr. 275, 1527 b, ap. Athen. ix.

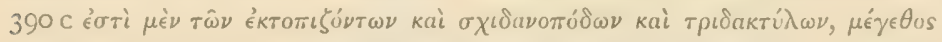

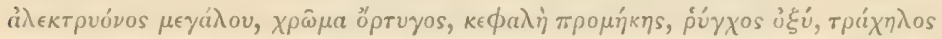

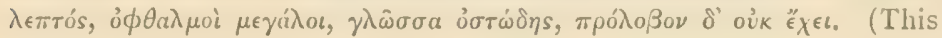




\section{$\Omega T I \Sigma($ continued).}

last description is perhaps taken from the Iittle Bustard, O. tetrax,

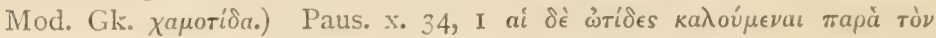

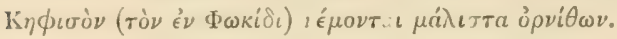

Capture by Coursing, with horse and dog. Xen. Anab. i. 5, 3 tàs $\delta \dot{\epsilon}$

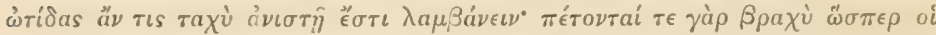

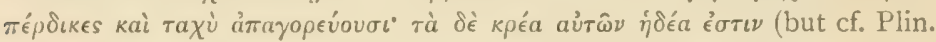
1. c.). Athen. ix. 393 d, quoting Xenophon, adds from Plutarch, ả $\eta \theta \hat{\eta}$

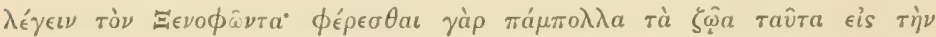

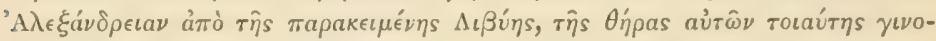

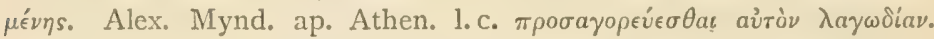

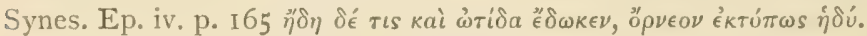

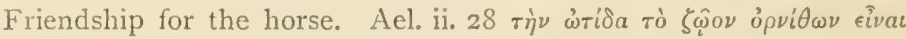

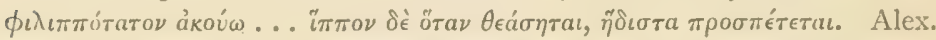

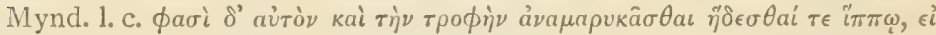

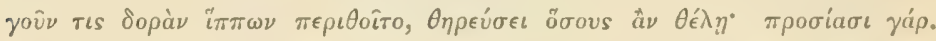
Cf. Plut. Sol. Anim. xxxi. 7 (ii. 98 r B); Opp. Cyn. ii. 406; Dion. De Avib. iii. 8.

Hostile to the dog, Ael. v. 24, and grossly deceived by the fox, ib. vi. 24 .

Buffon and others have supposed from the namie wris that the Houbara (which is very rare in Greece) is chiefly meant: but the etymology is doubtful; the 'ears' are not mentioned save by Oppian,

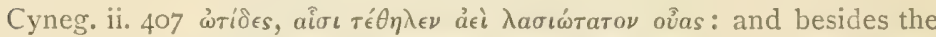
cheek-tufts of the Common Bustard might suggest ears as well as the crest of the Houbara. It is however the Houbara, as the common African species, which is alluded to in Plutarch ap. Athen. 1.c.

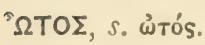

A Ilorned Owl, especially the Short-eared Owl, Striv brachyous or Asio accipitrinus.

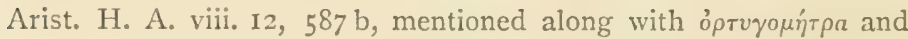

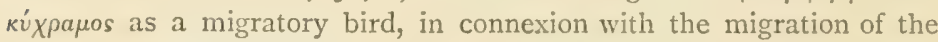

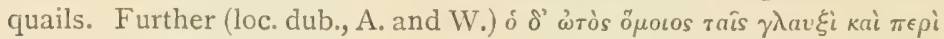

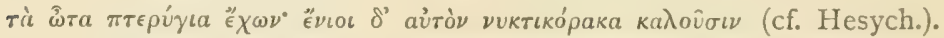

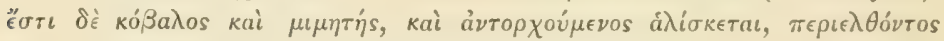

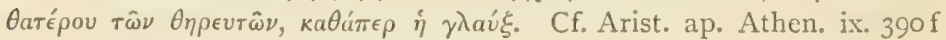

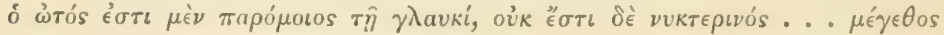
$\pi \epsilon \rho \iota \sigma \tau \epsilon \rho \hat{s} s, \kappa . \tau . \lambda$.

In Athen. ix. $390 \mathrm{~d}$, a ridiculous story of its capture by mimicry:

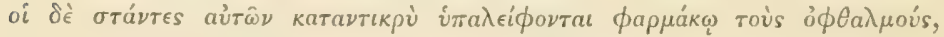

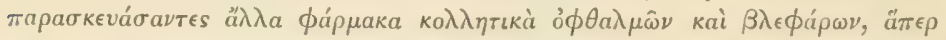

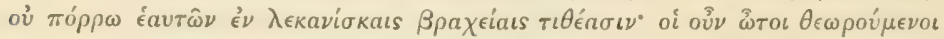

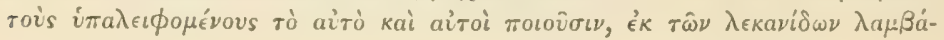


$\Omega T O \Sigma$ (contimed').

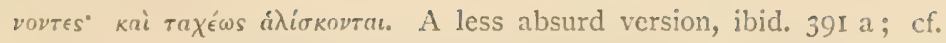
Plut. Mor. ii. 96r E. Hence w่tós, one easily taken in, a 'gull.'

Plin. x. (23) 33 Otus bubone minor est, noctuis maior, auribus plumeis eminentibus, unde et nomen illi; quidam Latine asionem vocant : imitatrix avis ac parasita, et quodam genere saltatrix, \&c.

Casaubon and others, followed by Lidd. and Sc., state that Athenaeus confounds âtos with $\omega$ 'is. There is indeed a confusion in the text, due

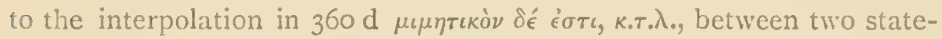
ments referring to $\dot{\omega}$ is ; but the respective statements as to $\omega^{5} \tau$ s and wंis are correct.

The Short-eared Owl is indicated in the following statements: (I) as a migratory bird; (2) as associated with the quails, i.e. a bird of the open country; (3) as being diurnal and not nocturnal. The commentators have often fallen into error from ignorance of the habits of the Short-eared Owl: e.g. Gesner, in gallinis, de otide, "nocturnam avem aut noctuae similem nullam migrare arbitror.' (Certain other species are, at least, partially migratory; cf. (int. al.) Giglioli, Avif. Ital., I 886, pp. 227, 228, \&c.)

In Arist. H. A. viii. I2, and in Plin. 1. c. there appears to be some confusion with the Long-eared or Common Horned Owl, Strix otus, L. 



\section{ADDITIONAL NOTES}

\section{'AETO' $\Sigma$.}

Add the following references, concerning the Eagle in connexion

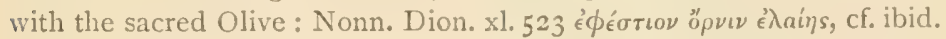

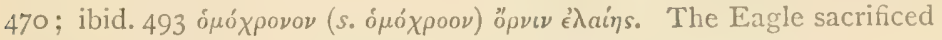
to Neptune, ibid. 494. Add also the epithet $\chi u ́ p \omega \nu$, Lyc. 260.

\section{'AH $\triangle \Omega$ 'N.}

Hesychius states that 'A $\eta \delta \dot{\omega} \nu$ was a surname or epithet of Athene among the Pamphylians. The connexion between Athene and the Nightingale or the Adonis-myth, lies perhaps in the fact that Athene or Minerva was associated, as for instance in the cylindrical zodiac of the Louvre, with the sign and month of the vernal equinox. Just as Adonis or Attis was, in like manner, a Spring-god and god of the opening flowers; Porph. ap. Euseb. P. E. iii. I I, p. I Io et seq.

While I am still convinced of a connexion between the attributes of an $\delta \omega_{\nu}$ and the veiled allusions to the mysteries of Adonis, I am inclined to admit that some of the minor arguments adduced by me in support of this hypothesis are overstrained: in particular the interpretation given (pp. 13, 14) of Thuc. ii. 29, and the suggested connexion between

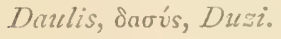

\section{'A^EKTPY $\Omega$ 'N.}

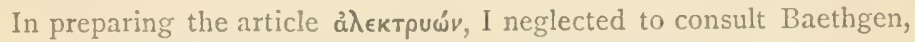
De Vi et Signific. Galli in Relig. et Art. Gr. et Romanorum, Diss. Inaug., Gotting. 1887, in which paper will be found (among other matters) a valuable account of monumental and numismatic representations of the Cock.

The Cock on coins of Himera (vide supra, p. 26) is traced by Baethgen (p. 35) to an association with Aesculapius; cf. C. I. Gr.

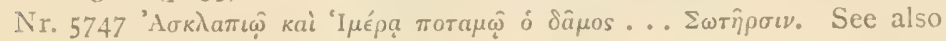
Head, Hist. Numorum, p. 125.

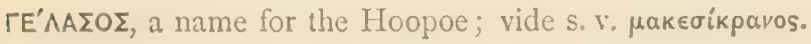


$\Gamma \gamma^{\prime} \Psi$.

The Bapкaí (vide supra, p. 49) are probably the Bapkávı (? Parsees) of Ctes. xi, Tzetz. Chil. i. I, 82 ; cf. J. Macquart, Philologus, Supplement-bd. vi. p. 609, 1893.

\section{$\triangle P Y O K O \wedge A^{\prime} \Pi T H \Sigma$.}

The eastern legend of the Woodpecker's imprisoned young is so suggestive of the walled-up nest of the Hornbill, that one is almost tempted to suspect a dim tradition, far-travelled from Africa or India, concerning the extraordinary nesting-habits of the latter bird. 


\section{BIBLIOGRAPHICAL REFERENCES}

The following works, in addition to the Natural Histories of Pliny, Aelian, and Phile, are referred to merely under their authors' names:-

Aubert und Wimmer. Aristoteles' Thierkunde, 2 vols. Leipzig, 1868 (especially Thierverzeichniss, vol. I., pp. 77-1 I3).

Bikélas, O. La nomenclature de la Faune Grecque. Paris, I879.

ERHARD, DR. Fauna der Cykladen. Leipzig, I 858.

KRÜPER, DR. Zeiten des Gehens und Kommens und des Brütens der Vögel in Griechenland und Ionien; in Mommsen's Griechische Jahreszeiten, 1875 (mit Citaten und Zusätzen von Dr. Hartlaub).

Lindermayer, DR. A. Die Vögel Griechenlands. Passau, I860.

MÜHLE, H. VON DER. Beiträge zur Ornithologie Griechenlands. Leipzig, I 844 .

Sundevall, C. J. Thierarten des Aristoteles. Stockholm, 1863.

It is perhaps desirable that I should point out that I have several times in this book, quite with my eyes open, quoted authors whom scholars now look upon with distrust or even altogether reject. The student who is not ashamed to consult Creuzer, nor afraid to peep now and then even into Bryant, will not only find there a great useless mass of theories now deservedly repudiated, but will also find a great store of curious learning and will be guided to many obscure sources of useful knowledge. 


\section{ERRATA}

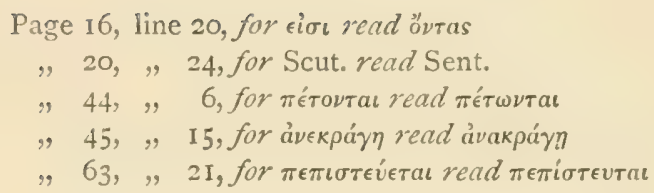

For the detection of most of the above errors, and for infinite kindness in reading the final proofs of the whole book, I am indebted to my friend Mr. W. Wyse. I must record my debt also, for the like scholarly services, to Mr. P. Molyneux of the Clarendon Press. Lastly, I must pay a debt which should have been acknowledged more prominently than here, to Mrs. W. R. H. Valentine, of Dundee, for three beautiful wood-cuts, the work of her hands. 


\section{Orfors}

PRINTED AT THE CLARENDON PRESS

BY HORACE HART, PRINTER TO THE UNIVERSITY 



\section{SELECT LIST \\ () $\mathrm{F}$}

\section{Etandard EBeological Dorkis}

PRINTED $A T$

The Clarendon Press, Oxford.

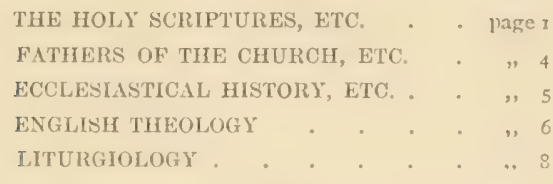

\section{THE HOLY SCRIPTURES, FTC.}

HEBREW, otc. Notes on the Hebrevo Text of the Book of Genesis. By G. J. Spurrell, M.A. Crown 8ro. IOS. $6 d$.

Notes on the Hebrew Text of the Books of Samuel. By S. R. Driver, D.D. Svo. I 4 s.

Treatise on the use of the Tenses in Hebrew. By S. R. Driver, D.D. Thiral Edition. Crown 8vo. 7s. $6 \mathrm{~d}$.

The Psalms in Hebrew without points. Stiff covers, $2 s$.

A Commentary on the Book of Proverbs. Attributed to Abraham Ibn Ezra. Edited from a MS. in the Bodleian Library by S. R. Driver, D.D. Crown 8vo. paper covers, $3 s .6 d$.

- The Book of Tobit. A Chaldee 'Text, from a unique MS. in the Bodleian Library ; with other Rabbinieal Texts, English 'Transla. tions, and the Itala. Edited by $\mathrm{Ad}$. Neubauer, M.A. Crown 8vo. 6s. A Hebrew and English Lexicon of the Otd Testament, with an Appendix containing the Biblical
Aramaic, based on the Thesaurus and Lexicon of Gesenius, by Francis Brown, D.D., S. R. Driver, D.D., and C. A. Briggs, D.D. Parts I and II. Small 4 to. 2s. 6d. each. Part III, In the Press.

HEBREW, etc.-Hebrew Accentuation of Psalmes, Proverbs, and Job. By William Wickes, D.D. Svo. $5 s$. Hebrew Prose Accentuation. By the same Author. 8ro. ros. 6 d.

- The Book of Helrew Roots, by Abu 'l-Walìd Marwân ibn Janâh, otherwise called Rabbî Yônâh. Now first edited, with an appendix, by Ad. Neubauer. 4to. 2l. 7 s. $6 a$.

EтHIOPIC. The Book of Enoch. 'Translated from Dillmann's Ethiopic Text (emended and revised), and edited by R. H. Charles, M.A. 8vo. $16 s$.

GREEK. OLd Testament. Vetus Testamentum ex Versione Septuaginte Interpretum secundum exemplar Vuticanum Pomale editum. Accedit potior varietas Codicis Alexandrini. Tomi III. $18 \mathrm{mo}$. I $8 \mathrm{~s}$. 
GREFK. A Concortance to the Septuagint and the other Greet Versions of the Old Testament, including the Apocryphal Books. By the late Edwin Hatch, MI.A., and H. A. Redpath, NI.A. Parts I and II. 4to. 2 Is. each. Part III, Immediately.

Essays in Biblical Greek. By Edvin Hateh, M. A., D.D. Svo. Ios. 6 t.

Origenis Hexaplorum quace supersumt; sice, Veterum Interprehum Graconm in totum Vetus Testa. mentum Fragmenta. Edidit Fridericus Field, A.M. 2 vols. 4to. 5l. 5 s.

New'lestanent. Novum Testamentum Graece. Antiquissimorum Codieum Textus in ordine parallelo dispositi. Accedit collatio Codicis Sinaitici. Edidit E. H. Hansell, S.I.B. Tomi III. 8vo. $24 s$.

\section{Novum T'estamentum}

Graece. Accedunt parallela S. Scripturae loca, ete. Edidit Carolus Lloyd, S.T.P.R. I8mo. $3 s$.

On writing paper, with wislo margin, $7 s, 6 l$.

\section{Appendices ad Novum}

Testamentum Stephanicum, jam inde a Millii temporibus Oxoniensium manibus tritum; curante Gulmo. Sanday, A.M., S.T.P., LL.D. I. Collatio textusWesteottio-Hortiani(jure permisso) eum textu Stephanico anni MDL. II. Delectus lectionum notatu dignissimarum. III. Lectiones quaedam ex codicibus versionum Memphiticae Armeniacae Aethiopicaefusius illustratae. Extra fcap. 8vo, cloth. 3s. $6 d$.

\section{Novum I'estamentum}

Graece juxta Exemplar Millianum. I8mo. 2s. 6d. On writing paper, with wide margin, $7 s$. $6 d$.
GREEK. The Greek'T'estament, with the Readings adopted by the Revisers of the Authorised Version:-

(I) Pica type, with Marginal References. Demy Svo. 10s. $6 d$.

(2) Long Primer type. Feap. 8vo. 4s. $6 a$.

(3) The same, on writing paper, with wide margin, ${ }_{5} 5$.

The Parallel New Testament, Greek and English; being the Authorised Version, I6 I ; the Revised Version, I88I ; and the Greek Text followed in the Revised Version. 8vo, I2s. 6 d.

Outlines of TextualCriticism applied to the New Testament. By C. E. Hammond, MI.A. Fifth Edition. Crown 8vo. $45.6 d$.

\section{A Greek Testament Pri-} mer. An Easy Grammar and Reading Book for the use of Students beginning Greek. By E. Miller, M.A. Extra feap. 8vo. 3s. $6 d$.

LATIN. Libri Psalmorum Versio antiqua Latina, cum Paraphrasi Anglo-Saxonica. Edidit 33. Thorpe, F.A.S. Svo, Ios. 6d.

\section{Old-Latin Biblical}

Texts: No. I. The Gospel according to St. Matthew, from the St. Germain MS. $\left(g_{1}\right)$. Edited with Introduction and Appendices by Jolnn Wordsworth, D.D. Small 4 to, stiff covers, 6s.

\section{Old-Latin Biblical}

Texts: No.II. Portions of the Gospels according to St. Mark and St. Matthew, from the Bobbio MS. (k), etc. Edited by John Wordsworth, D.D., W. Sanday, M.A., D.D., and H. J. White, M.A. Small $4^{\text {to, }}$ stiff covers, $21 S$, 
IATIN. Old-Latin Biblical Texts: No. III. The Four Gospels, from the Munich MS. (q), now numbered Lat. 6224 in the Royal Library at Munich. With a Fragment from St. John in the Hof-Bibliothek at Vienna (Cod. Lat. 502). Edited, with the aid of Tisehendorf's transeript (under the direction of the Bishop of Salisbury), by H. J. White, M.A. Small 4to. stiff' covers, I2s. $6 c_{\text {. }}$

\section{INouum Testamentum Domini} Nostri Iesu Christi Latine, se. cundum Editionem S. Hieronymi. Ad Codicum Manuscriptorum fidem recensuit Iohannes Wordsworth, S.'I.P., Episcopus Sarisburiensis. In operis societatem adsumto Henrico Iuliano White, A.M. 4to.

Fasc. I. Euangelium secunctum Mattherm. I2s.6e.

Fasc. II. Euangelium secunchum IIarcum. 7s. 6d.

Fasc. III. Euangelizm secundum Lucam. I2s. 6d.

\section{OLD-FRENCH. Libri Psal-} monum Versio antique Gallica e Cod. ms. in Bibl. Bodleiana adserrato, una cum Versione Mretrica aliisque Monmentis peretustis. Nune primum deseripsit et edidit Franciscus Michel, Phil. Doc. Svo. Ios. Gu.

\section{ENGLISH. The Holy Bible}

in the Earliest English Versions, made from the Latin Vulgate by John Wycliffe and his followers: edited by Forshall and Madden. 4 vols. Royal 4to. 3l. $3 s$.

Also reprinted from the above, with Introduction and Glossary by W. W. Skeat, Litt. D.

The Boolis of Job, Psalms, Proverbs, Ecclesiastes, and the Song of Solomon. 3s. 6 .

The New Testament. 68 .
ENGLISH. The Holy Bille, Revisen Version *.

Cheap Editions for School Use.

Revised Bible. Pearl I Gmo, cloth boards, is. $6 d$.

Revised Now 'Testament. Nonpareil $32 \mathrm{mo}$, 6d.; Brevier I6mo, Is. ; Long Primer 8vo, Is. Ga.

* The llevised Version is the joint property of the Universities of Oxford and Cambridge.

The Oxford Bible for Teachers, containing the Holy Seriptures, together with a new, enlarged, and illustrated edition of the Oxford Helps to the Study of the Bible, comprising Introductions to the several Books, the History and Antiquities of the Jews, the results of Modern Discoveries, and the NaturalHistory of Palestine, with copious Tables, Concordance and Indices, and a series of Maps. Prices in various sizes and bindings from $7 s .6 u$. to 2l. $2 s$.

\section{Helps to the Study of the}

Bible, taken from the Oxford Bille for Teachers. Crown Svo. $4^{\text {s. } 6 \text { d. }}$

The Psalter, or Psalms of Darid, and certain Canticles, with a Translation and Exposition in English, by Richard Rolle of Hampole. Edited by H. R. Bramley, M.A. With an Introduction and Glossary. Demy 8 vo. Il. Is.

Studia Biblica et Ecclesiastica. Essays in Biblical and Patristic Criticism, and kindred subjects. By Members of the University of Oxford.

Vol. I. Svo, Ios. Gd.

Vol. II. 8ro. 12s. 6a.

Vol. III. Sro. I6s. 
ENGIISH. The Book of Wisdom: the Greek 'lext, the Latin Vulgate, and the Authorised English Version; with an Introduction, Critical Apparatus, and a Commentary. By W. J. Deane, M.A. 4to. I2s. $6 d$.
GOTHIC. The Gospel of St. Mark in Gothic, according to the translation made by Wulfila in the Fourth Century. Edited, with a Grammatical Introduction and Glossarial Index, by W. W. Skeat, Litt. D. Extra feap. 8vo. 4 s.

\section{FATHERS OF THE CHURCH, ETC.}

\section{St. Athanasius : Orations} against the Arians. With an account of his Life by William Bright, D.D. Crown 8vo. 9s.

Historical Writings, according to the Benedictine Text. With an Introduction by W. Bright, D.D. Crown 8vo. ros. 6 d.

St. Augustine: Select AntiPelagian Treatises, and the Acts of the Second Council of Orange. With an Introduction by William Bright, D.D. Crown 8vo. 9s.

St. Basil: The Book of St. Basil on the Holy Spirit. A Revised Text, with Notes and Introduction by C. F, H. Johnston, M.A. Crown 8vo. 7s. $6 d$.

Canons of the First Four General Councils of Nicaea, Constantinople, Ephesus, and Chalcedon. With Notes by W. Bright, D.D. Second Edition. Crown 8vo. 7s. 6 d.

Catenae Graecorum Patrum in Novem Testamentum. Edidit J. A. Cramer, S.T.P. Tomi VIII. 8vo. 2l. 4 s.

Clementis Alexandrini Opera, ex recensione Guil. Dindorfii. 'Tomi IV. 8vo. 3l.
Cyrilli Archiepiscopi Alexundrini in XII Prophetas. Edidit P.E. Pusey, A.M. Tomi II. 8vo. 2l. 2s. in D. Joannis Evangelium. Accedunt Fragmenta Varia neenon 'Tractatus ad Tiberium Diaconum Duo. Edidit post Aubertum P. E. Pusey, A.M. Tomi LII. 8ro. 2l. 5 s.

Commentarii in Lucue Evangelizm quae supersunt Syriace. E mss. apud Mus. Britan. edidit R. Payne Smith, A.MI. 4to. Il.2S.

The same, translated by R. Payne Smith, M.A. 2 vols. 8 vo. I 4 s.

Ephraemi Syri, Rabulae Episcopi Edesseni, Balaei, alionmque Opera Selecta. E Codd. Syriacis mss. in Museo Britannico et Bibliotheca Bodleiana asservatis primus edidit J. J. Overbeck. 8vo, Il. Is.

Eusebii Pamphili Evangelicae Praeparationis Libri $X V$. Ad Codd. mss. recensuit T. Gaisford, S.T.P. Tomi IV. 8vo. Il. 10s.

Evangelicae Demonstrationis Libri X. Recensuit T. Gaisford, S.T.P. Tomi II. 8vo. I5s.

contra Hieroclem et Marcellum Libri. Recensuit T. Gaisford, S.T.P. 8 vo. 7 s. 
Eusobius' Ecclesiastical History, according to the text of Burton, with an Introduction by W. Bright, D.D. Crown 8vo. Ss. Gel.

Evagrii Historia Ecclesiastica, ex recensione H. Valesii. 8vo. 4 .

Irenaeus: The Thired Book of St. Irenaeus, Bisltop of Lyons, against Heresies. With short Notes and a Glossary by H. Deane, B.D. Crown 8 vo. $5 s, 6 c$.

Patrum Apostolicorum, S. Clementis Romani, S. Iynatii, S. Polycarni, quae supersunt. Edidit Guil. Jacobson, S.'I.P.R. Tomi II. Fourth Edition. Svo. Il. Is.

Reliquiae Sacrae secundi tertiique saeculi. Recensuit MI. J. Routh, S.I'P. 'Tomi V. Second Edition. Sro, Il. 5 s.
Scriptorum Ecclesiasticorum Omiscula. Recensuit M. J. Routh, S.'T.P. Tomi II. 8vo. Ios.

Socrates' Eiclesiastical History, according to the 'Text of Hussey, with an Introduction by William Bright, D.D. Crown 8vo. 7s. 6 d.

Sozomeni Historia Eeclesiastica. Edidit R. Hussey, S.I'.B. Tomi III. Svo. I5s.

Tertulliani Apologeticus adversus Gentes mo Christianis. Edited, with Introduction and Notes, by 'T. Herbert Bindley, B.D. Crown 8 vo. $6 s$.

de Praeseriptione Haereticorum ad IIartyras: ad Scapulam. Edited, with Introduction and Notes, by 'T'. Herbert Bindley, B.D. Immediately.

Theodoreti Ecclesiasticue Historiae Libri V. Recensuit 'T'. Gaisford, S.T.P. Svo. 7s. 6d.

\section{ECCLESIASTICAL HISTORY, ETC.}

Baedae Historia Ecclesiastica. Edited, with Euglish Notes, by G. H. Moberly, M.A. New edition in the Press.

Bigg. The Christian Platonists of Alexandria; being the Bampton Lectures for 1886. By Charles Bigg, D.D. Svo. 10s. 6d.

Bingham's Antiquities of the Christian Church, and other Works. Io vols. Svo. 3l. $3 \mathrm{~s}$.

Bright. Chapters of Early English Church History. By W. Bright, D. D. Second Edition。 8vo. I2s.

Burnot's History of the Reformation of the Church of England. A new Edition. Carefully revised, and the Records collated with the ori- ginals, by N. Pocock, M.A. 7 rols. 8vo, Il. IOs.

Cardwell's Documentary Annals of the Reformed Church of England; being a Collection of Injunctions, Declarations, Orders, Articles of Inquiry, etc. from 1546 to $17 \mathrm{I} 6$. 2 vols, $8 \mathrm{vo}, 18 \mathrm{~s}$.

Councils and Ecclesiastical Documents relating to Great Britain and Ireland. Edited, after Spelman and Wilkins, by A. W. Haddan, B.D., and W. Stubbs, D.D. Vols, I and III. Medium $8 v o$, each Il. Is.

Vol. II, Part I. Medium Svo, I0.s. 6d.

Vol. II, Part II. Church of Ireland ; Memorials of St. Patrick. Stiff covers, 3s. $6 d$. 
Fuller's Church History of Britain. Edited by J. S. Brewer, M.A. 6 vols. 8vo. Il. Igs.

Gibson's Synodus Anglicana. Edited by E. Cardwell, D.D. 8 vo. $6 s$.

Hamilton's (Archbishop John) Catechism, 1552. Edited, with Introduction and Glossary, by Thomas Graves Law, Librarian of the Signet Library, Edinburgh. With a Preface by the Right Hon. W. E. Gladstone. Demy 8ro. I2s. 6 d.

Hussey. Rise of the Papal Poucer, traced in three Lectures. By Robert Hussey, B.D. Second Edilion. Feap. 8vo. 4s. 6d.

John, Bishop of Ephesus. The Third Part of his Ecclesiastical History. [In Syriac.] Now first edited by William Cureton, M.A. 4to. Il. I2S.

The same, translated by R. Payne Smith, M.A. Svo. IOS.

Lo Neve's Fasti Ecclesicie Anglicanae. Corrected and continued from 1715 to $x 853$ by T. Duffus Hardy. 3 vols. Svo. Il. Is.

Noelli (A.) Catechismus sive prima institutio disciplinaque Pietatis
Christianae Latine explicala. Editio nova cura Guil. Jacobson, A.MI. 8vo. 5s. $6 d$.

\section{Records of the Reformation.} The Dirorce, I527-I533. Mostly now for the first time printed from MSS. in the British Afuseum and other Libraries. Collected and arranged by N. Pocock, M.A. 2 vols. 8 vo. It. I6s.

Reformatio Leguni Ecclesiasticarum. The Reformation of Ecclesiastical Laws, as attempted in the reigns of Henry VIII, Edward VI, and Elizabeth. Edited by E. Cardwell, D.D. 8 vo. $6 s .6 a$.

Shirley. Some Account of the Church in the Apostolic Age. By W.W. Shirley, D.D. Second Edition. Feap. 8vo. 3s, $6 d$.

Stillingfleet's Origines Britannicae, with Lloyd's Historical Account of Church Government. Edited by T. P. Pantin, M.A. 2 vols. 8vo, IOS.

Stubbs. Registrum Sacrum Anglicanum. An attempt to exhibit the course of Episcopal Succession in England. By W. Stubbs, D.D. Small 4 to. $8 s_{0} 6 d_{\text {. }}$

\section{ENGLISH THEOLOGY.}

Bradley. Lectures on the Book of Job. By George Granville Bradley, D.D., Dean of Westminster. Crown Svo. 7s. 6d.

Lectures on Ecclesiastes. By G. G. Bradley, D.D., Dean of Westminster. Crown 8vo. 4s. $6 d$.
Bull's Works, with Nelson's Life. Edited by E. Burton, D.D. 8 vols. Svo. 2l. 9 s.

Burnet's Exposition of the IXXIX Articles. 8vo. $7 s$.

Butler's Works. 2 vols. 8vo. I IS. 
Comber's Companion to the Temple; or a Help to Devotion in the use of the Common Prayer. 7 vols. Svo, Il, IIs. $6 l_{\text {. }}$

Cranmer's Works.. Collected and arranged by H. Jenkyns, M.A., Fellow of Oriel College. \& vols. Svo, rl. ros.

\section{Enchiridion}

\section{Theologicum}

Anti-Romanum.

Vol. I. Jeremy Taylor's Dissuasive from Popery, and 'Treatise on the Real Presence. 8vo. $8 s$.

Vol. II. Barrow on the Supremacy of the Pope, with his Discourse on the Unity of the Church. Svo. 7 s. 6d.

Vol. III. Tracts selected from Wake, Patrick, Stillingfleet, Clagett, and others. 8vo. IIs.

Groswell's Harmonia Evangelica. Fifth Elition. 8vo. 9s. 6al.

Hall's Worles. Edited by P. Wynter, D.D. Io vols. 8vo. 3l. 3s.

Heurtley. Hamonia Symbolica: Creeds of the Westem Church. By C. Heurtley, D.D. Svo. $6 s, 6 d$.

Homilies appointed to be read in Churches. Edited by J. Griffiths, M.A. Sro. 7s. 6d.

Hooker's Works, with his Life by Walton, arranged by John Keble, M.A. Serenth Edition. Revised by R. W. Chureh, M.A., Dean of St. Paul's, and F. Paget, D.D. 3 vols. medium 8ro. Il. I6s.

the T'ext as arranged by J. Keble, M.A. 2 vols. Sro. IIS.
Jackson's (Dr. Thomas) Worlis. I2 vols. 8vo. 3l. $6 \mathrm{~s}$.

Jewel's Works. Edited by R. IV. Jelf, D.D. 8 vols. 8 vo. Il. Ios.

Martineau. A Study of Religion: its Sources and Contents. By James Martineau, D.D. Second Edition. 2 vols. Crown 8vo, $15 \mathrm{~s}$.

Patrick's 'Theological Worlis. 9 vols. Svo. Il. Is.

Pearson's Exposition of the Creed. Revised and corrected by E. Burton, D.D. Sixth Edition. Svo. IOS. 6 d.

_- MinorTheological Works. Edited with a Memoir, by Edward Churton, MI.A. 2 vols. Svo. IOS.

Sanderson's Worles. Edited by IV. Jacobson, D.D. 6 rols. 8 vo. Il. Ios.

Stillingfleet's Origines Sucrue. 2 vols. Svo. $9^{s .}$

Rational Account of the Grounds of Protestant Religioin; being a vindication of Archbishop Laud's Relation of a Conference, etc. 2 vols. 8vo. IOS.

Wall's History of Infant Baptism. Edited by H. Cotton, D.C.L. 2 vols. 8vo. Il. 1 s.

Waterland's Works, with Life, by Bp. Van Mildert. A nero Edition, with copious Indexes. 6 vols. 8vo. 2l. IIS.

Review of the Doctrine of the Eucharist, with a Prefince by the late Bishop of London. Crown Svo. 6s. 6d. 
Wheatly's Illustration of the Buok of Common Prayer. Svo. 5 s.

Wyclif. A Catalogue of the Original Works of John Wryclif. By W. W. Shirley, D. D. 8vo. 3s. 6d.
Wyclif. Select English Works. By 'T. Arnold, M.A. 3 vols. 8 vo. Il. Is.

-. Trialogus. With the Supplement now first edited. By Gotthard Lechler. 8vo. $7 \mathrm{~s}$.

\section{LITURGIOLOGY.}

Cardwell's Two Books of Common Prayer, set forth by authority in the Reign of King Edward VI, compared with each other. Third Edition. 8vo. 7 s.

\section{History of Conferences} on the Book of Common Prayer from I55I to I690. Third Edition. 8vo. 7 s. $6 d$.

Hammond. Liturgies, Eastenn and Western. Edited, with Introduction, Notes, and a Liturgical Glossary, by C. E. Hammond, M.A. New edition, by F. E. Brightman, M.A., In the Press.

An Appendix to the above, crown $8 v 0$, paper covers, Js. $6 d$.

Helps to the Study of the Book of Common Prayer. Being a Companion to Church Worship. Crown 8vo. 3s. 6d.

Leofric Missal, The, as used in the Cathedral of Exeter during the Episeopate of its first Bishop, A.D. IO50-1072 ; together with some
Account of the Red Book of Derby, the Missal of Robert of Jumièges, and a few other early MS. Service Books of the English Church. Edited, with Introduction and Notes, by F. E. Warren, B.D., F.S.A.

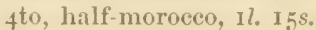

Maskell. Ancient Liturgy of the Church of England, according to the uses of Sarum, York, Hereford, and Bangor, and the Roman Liturgy arranged in parallel columns, with preface and notes. By W. Maskell, AI.A. Third Edtition. 8vo. I5s.

Monumenta Ritualia.

Ecclesiae Anglicanae. The occasional Offices of the Church of England according to the old use of Salisbury, the Prymer in English, and other prayers and forms, with dissertations and notes. Second Erlition. 3 vols. 8 vo. $2 l$. IOS.

Warren. The Liturgy and Ritual of the Celtic Church. By F. E. Warren, B.D. Svo. I. 4 s.

\section{Oxford}

AT THE CLARENDON PRESS

LONDON : HENRY FROWDE

OXFORD UNIVERSITY PRESS WAREHOUSE, AMEN CORNER, E.C. 



